\author{
A XXV. FIATAL MÜSZAKIAK \\ TUDOMÁNYOS ÜLÉSSZAK ELŐADÁSAI
}

PROCEEDINGS OF THE XXV ${ }^{\text {TH }}$ INTERNATIONAL SCIENTIFIC CONFERENCE OF YOUNG ENGINEERS 


\section{MÜSZAKI TUDOMÁNYOS KÖZLEMÉNYEK}

PAPERS ON TECHNICAL SCIENCE

13.

ISSN $2393-1280$

Erdélyi Múzeum-Egyesület Műszaki Tudományok Szakosztálya Transylvanian Museum Society - Department of Technical Sciences 
MÜSZAKI TUDOMÁNYOS KÖZLEMÉNYEK

PAPERS ON TECHNICAL SCIENCE

13.

\section{A XXV. FIATAL MÜSZAKIAK TUDOMÁNYOS ÜLÉSSZAK ELŐADÁSAI}

\section{PROCEEDINGS OF THE XXV ${ }^{\mathrm{TH}}$ INTERNATIONAL SCIENTIFIC CONFERENCE OF YOUNG ENGINEERS}

Szerkesztette / Edited by

BITAY ENIKŐ

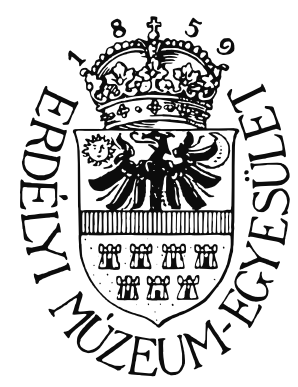

ERDÉLYI MÚZEUM-EGYESÜLET

Kolozsvár

2020 
A kötet megjelenését támogatta Kolozsvár Polgármesteri Hivatala és Városi Tanácsa, a Magyar Tudományos Akadémia, a Bethlen Gábor Alapkezelő Zrt. és az EME Műszaki Tudományok Szakosztálya

The publication of this volume was supported by the Cluj Town Hall and Local Council, the Hungarian Academy of Sciences, the Bethlen Gábor Fund and the TMS - Department of Engineering Sciences

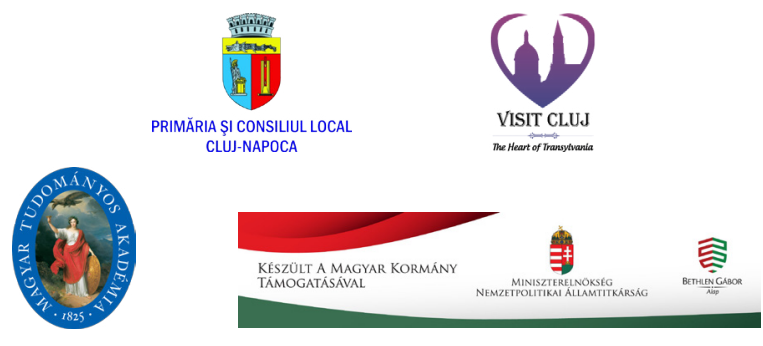

Copyright @ a szerzők / the authors, EME/ TMS 2020

Minden jog a kiadvány kivonatos utánnyomására, kivonatos vagy teljes másolására (foto-kópia, mikrokópia) és fordítására fenntartva.

All rights reserved. No part of this publication may be reproduced or transmitted in any means, electronic, mechanical, photocopying, recording or otherwise, without the prior written permission of the publisher.

Kiadó / Publisher: Erdélyi Múzeum-Egyesület

Felelős kiadó / Responsible Publisher: Biró Annamária

Szerkesztette / Edited by: Bitay Enikő

Olvasószerkesztők: András Zselyke (magyar). David Speight (angol)

Műszaki szerkesztő / DTP: Szilágyi Júlia

Borítóterv / Cover: Könczey Elemér

Nyomdai munkálatok / Printing-work F\&F International Kft. Kiadó és Nyomda, Gyergyószentmiklós

Ügyvezető igazgató / Manager: Ambrus Enikő

Tel./Fax: +40-266-364171

online elérhető / online available at:

https://eme.ro/publication-hu/mtk/mtk-main.html

DOI: $10.33895 /$ mtk-2020.13 


\section{A XXV. FIATAL MÜSZAKIAK TUDOMÁNYOS ÜLÉSSZAK ELŐADÁSAI (KOLOZSVÁR, 2020. MÁRCIUS 26.)}

\section{PROCEEDINGS OF THE XXV ${ }^{\text {TH }}$ INTERNATIONAL SCIENTIFIC CONFERENCE OF YOUNG ENGINEERS}

(CLUJ, MARCH 26. 2020)

FŐVÉDNÖK / PATRON:

Bokor József, a Magyar Tudományos Akadémia alelnöke

TISZTELETBELI VÉDNÖK / HONORARY PROTECTOR:

Gyulai József, a Novofer Alapítvány kuratóriumának volt elnöke

SZERVEZŐ / ORGANIZED BY:

Az Erdélyi Múzeum-Egyesület Műszaki Tudományok Szakosztálya Transylvanian Museum Society - Department of Technical Sciences

\section{TÁRSSZERVEZŐ / CO-ORGANIZER:}

Sapientia Erdélyi Magyar Tudományegyetem, Marosvásárhelyi Kar Sapientia Hungarian University of Transylvania, Faculty of Technical and Human Sciences, Tîrgu Mureș 


\section{PROGRAMBIZOTTSÁG / ORGANIZATION BOARD Gyenge Csaba, Máté Márton, Réger Mihály, Talpas János}

\section{TUDOMÁNYOS BIZOTTSÁG / LEKTOROK SCIENTIFIC ADVISORY BOARD / PEER REVIEWERS}

Dr. Bagyinszki Gyula (Budapest)

Dr. Bitay Enikő (Kolozsvár)

Dr. Czigány Tibor (Budapest)

Dr. Danyi József (Kecskemét)

Dr. Darvay Zsolt (Kolozsvár)

Dr. Dávid László (Marosvásárhely)

Dr. Dezső Gergely (Nyíregyháza)

Dr. Dudás Illés (Miskolc)

Dr. Dusza János (Kassa)

Dr. Forgó Zoltán (Marosvásárhely)

Dr. Gobesz Ferdinánd-Zsongor (Kolozsvár)

Dr. Gyenge Csaba (Kolozsvár)

Dr. Hajdú Sándor (Debrecen)

Dr. Hollanda Dénes (Marosvásárhely)

Dr. Imecs Mária (Kolozsvár)

Dr. Kakucs András (Marosvásárhely)

Dr. Kántor József (Marosvásárhely)

Dr. Kelemen András (Marosvásárhely)

Dr. Kerekes László (Kolozsvár)

Dr. Kocsis Imre (Debrecen)

Dr. Kovács Szilveszter (Miskolc)

Dr. Kovács Tibor (Budapest)

Dr. Kovács Tünde (Budapest)

Dr. Lovas Tamás (Budapest)
Dr. Márton László (Gyergyószentmiklós)

Dr. Máté Márton (Marosvásárhely)

Dr. Nagy Zsolt (Kolozsvár)

Dr. Papp Sándor (Marosvásárhely)

Dr. Patyi Szabolcs (Pécs)

Dr. Pinke Péter (Nagyszombat)

Dr. Pokorádi László (Budapest)

Dr. Rácz Pál (Budapest)

Dr. Rajnai Zoltán (Budapest)

Dr. Réger Mihály (Budapest)

Dr. Réti Tamás (Budapest)

Dr. Roósz András (Miskolc)

Dr. Samad Dadvandipour (Miskolc)

Dr. Szántó Attila (Debrecen)

Dr. Szigeti Ferenc (Nyíregyháza)

Dr. Szlancsik Attila (Budapest)

Dr. Török Ádám (Budapest)

Dr. Tóth László (Debrecen)

Dr. Tóth Rudolf (Budapest)

Dr. Truzsi Alexandra (Debrecen)

Dr. Üveges Andrea (Debrecen)

Dr. Varga Zoltán (Veszprém)

Dr. Végvári Ferenc (Kecskemét) 


\section{TARTALOM}

Dávid László, György Katalin, Galaczi László-Alpár

Az optimális és modell prediktív irányitások áttekintése és valós idejü alkalmazása, különös tekintettel az állapotbecslők használatára.

\section{Bagyinszki Gyula, Bitay Enikő}

Mérnökképzés oktatási módszerei

Beke Éva

Az Ipar 4.0 és az oktatás kapcsolata és kölcsönhatása

\section{Csongvai Roland, Torkos Zoltán}

Innováció tervezése biztonságos termékekért.

\section{Debreceni Attila, Erdei Timotei István,Tóth Szabolcs, Husi Géza}

Termopolimer darálóegység rekonstrukciója és IOT-irányítástechnikai rendszer tervezése Linux-alapon.

\section{Fábián Hunor, Gergely Attila Levente}

Müanyagok szakítószilárdságának vizsgálatára alkalmas berendezés tervezése és kivitelezése

Faragó István, Erdei Timotei István, Zolnai Sándor, Husi Géza

IoT alapú Smart Meteorológiai állomás adatgyüjtő rendszerének tervezése és mérések elvégzése kiber-fizikai robotlaborban

\section{Felvári Bálint, Dunavölgyi Dávid, Kuti János}

Korrózióálló vastag lemez egy oldalról történő hegesztése.

\section{Géresi Zoltán Gergő, Gábora András}

Öntészeti szerszám tervezése és számítógéppel segített gyártása.

\section{Haraszti Ferenc}

A termográfia méréstechnikai nehézségeinek elemzése

\section{Hodgyai Norbert, Gergely Attila Levente, Farmos Rudolf-László}

Tárcsás elektrosztatikus szálképző-berendezés tervezése és kivitelezése

\section{Horváth Lajos}

Az árvízvédelmi feladatok ellátásához a KÖTIVIZIG-nél rendelkezésre álló és a külső szervezetektől bevonható gépi eröforrások. 
Hrámcov István, Erdei Timotei István, Décsei Roland,Husi Géza

Elektroncsöves és félvezetős feszültségstabilizált erősítő áramkörök kivitelezése

\section{Hronyecz Erika}

A V4-ek biztonság- és védelempolitikája - nemzeti és szövetségesi kihívások a tagországokban

Kelemen Orsolya, Izbékiné Szabolcsik Andrea, Bodnár Ildikó

Háztartási mosóvizek mint alternatív vízforrások elemzése

Kiss Gábor József, Szigeti Ferenc, Gergely Dezső

Öves légrugótermékek gyártásának fejlesztése

Kovács Márk, Agg Péter, Johanyák Zsolt Csaba

SDMN-architektúra az 5G-ben

Laki Márk, Kuti János

A Rapid Weld-technológia költséghatékony konfigurációjának kutatása

Leveles Borbála, Kemény Alexandra, Orbulov Imre Norbert

Kerámia gömbhéjjal töltött, alumíniummátrixú bimodális fémhabok vizsgálata.

Lós Réka, Izbékiné Szabolcsik Andrea, Bodnár Ildikó

Szürkevizek hatékony kezelését támogató detergens- és fémanalitikai vizsgálatok......114

Lukács Norbert László, Ficzere Péter, Szebényi Gábor

A gyártás közben alkalmazott hütés hatása hőálló PLA-alapanyagra

Máder Patrik Márk, Szilágyi Dorottya, Rák Olivér, Háber István Ervin

Lézeres felméröeszköz és felmérési módszertan közvetlen építészeti tervezőszoftver

kapcsolattal.

Márton László, Szigeti Ferenc, Gergely Dezső

Szövettekercselő egység tervezése.

Máté Péter, Szekrényes András

Vékonylemez hengerítési folyamatának numerikus modellezése.

Mihály Krisztián, Kulcsár Gyula

Kiterjesztett projektütemezési feladatok megoldása

Molnár Eszter, Borsos Ágnes

Az otthonteremtés jövőjének katalógusa.

Muhi Kristóf, Johanyák Zsolt Csaba

Gépi tanulásban alkalmazott dimenziószám-csökkentő módszerek 148

Nagy Andor-Csongor, Hajdó Harmat, Kis Ádám, Moldovan Dorin-Vasile

Tömörítési együttható befolyása a háromtengelyü georácsokkal megerősített útszerkezetek tartóképességére. 
Nagy Roland, Hartyányi Máté, Nagy Bianka, Varga Csilla

Szabad dietanol-amin-tartalom meghatározása

Novák János

A hatékony környezettudatos nevelés kritériumai. 162

Szántó Attila, Szántó András, Sziki Gusztáv Áron

Soros gerjesztésű egyenáramú motor modellezési eljárásainak áttekintése. 166

Tóth László, Nyikes Zoltán, Mhatre Umesh

Szerszámacélok felületi kopásállóságának növelése felületkezeléssel. 170

\section{Asadi Soodabeh Dezaki, Vogel Manfred}

Tanulásiráta-módszer full-batch gradiens-tanulásra. 174

SZERZŐK JEGYZÉKE 178 



\section{CONTENT}

FOREWORD

\section{Dávid, K. György, L.-A. Galaczi}

Survey of Optimal Control and Model Predictive Control with State Estimation and a Real-Time Applications

\section{Gy. Bagyinszki, E. Bitay}

Educational Methods of Engineering Training................................................................... 31

É. Beke

The Relatonship and Interaction Between Industry 4.0 and Education

R. Csongvai, Z. Torkos

Innovation Design for Safe Products

A. Debreceni, T. I. Erdei, Sz. Tóth, G. Husi

Reconstruction of Grinding Machine Intended for Thermo-Polymers, and Design of Linux Based IOT Control System

H. Fábián, A. L. Gergely

Design and Implementation of a Tensile Testing Machine 50

I. Faragó, T. I. Erdei, S. Zolnai, G. Husi

Design of an IoT Smart Meteorological Station Complete with Data Acquisition and Realising Test Measurements in Cyber-Physical Robotics Lab.

B. Felvári, D. Dunavölgyi, J. Kuti

Stainless Steel Plate One Side Welding.

Z. G. Géresi, A. Gábora

Casting Tool Design and Computer-Aided Manufacturing.

F. Haraszti

A Review of Difficulties in the Measuring Technologies of Thermography 68

\section{N. Hodgyai, A. L. Gergely, R. L. Farmos}

The Design and Implementation of a Disk Electrospinning Device 72

\section{Horváth}

Mechanical Resources Available at Middle Tisza District Water Directorate for

External Flood Protection and Outsourcing. 
I. Hrámcov, T. I. Erdei, R. Décsei, G. Husi

Design of Electron Tube and Semiconductor-Based and Voltage-Stabilised

Amplifier Circuits

E. Hronyecz

V4 Security and Defense Policy - National and Allied Challenges in Member States....... 86

O. Kelemen, A. Izbékiné Szabolcsik, I. Bodnár

Investigation of Household Laundry Water as an Alternative Water Source

91

G. J. Kiss, F. Szigeti, D, Gergely

Development of the Production of Belted Air Spring

M. Kovács, P. Agg, Z. Cs. Johanyák

SDMN Architecture in $5 G$

\section{Laki, J. Kuti}

Research on Cost-Effective Configuration of Rapid Weld Technology 105

B. Leveles, A. Kemény, I. N. Orbulov

Investigation of Bimodal Aluminum Matrix Syntactic Foams Filled with Ceramic Hollow Spheres

R. Lós, A. Izbékiné Szabolcsik, I. Bodnár

Investigations of Detergents and Metal Components for Supporting the Effective Treatment of Greywater .....

\section{N. L. Lukács, P. Ficzere, G. Szebényi}

The Impact of Active Cooling on Heat Resistant PLA

P. M. Máder, D. Szilágyi, O. Rák, I. E. Háber

Laser Survey Tool and Survey Methodology for Direct Architectural CAD Software Connection

L. Márton, F. Szigeti, D. Gergely

Design of a Fabric Winding-up Unit...

P. Máté, A. Szekrényes

Numerical Modelling of the Three-Roll Bending Process of a Thin Plate.

\section{K. Mihály, Gy. Kulcsár}

Solving of Extended Project Scheduling Problems.

\section{E. Molnár, Á. Borsos}

The Catalog for Our Future Homes. 
K. Muhi, Zs. Cs. Johanyák

Dimensionality Reduction Methods Used in Machine Learning.

A.-Cs. Nagy, H. Hajdó, Á. Kis, D. V. Moldovan

Influence of the Degree of Compaction on the Bearing Capacity of a Road Structure Reinforced with Triaxial Geogrids

R. Nagy, M. Hartyányi, B. Nagy, Cs. Varga

Determination of Free Diethanolamine Content. 158

J. Novák

Criteria for an Effective Environmental Education 162

A. Szántó, A. Szántó, G. Á. Sziki

Review of Modelling Methods of Series Wound DC Motors. 166

L. Tóth, Z. Nyikes, Mhatre Umesh

Tool Steels Surface Wear Resistance Increasing by Surface Treatment. 170

S. D. Asadi, M. Vogel

A Learning Rate Method for Full-Batch Gradient Descent 174

LIST OF AUTHORS. 178 



\section{ELőSZÓ}

Egy folyamatosan változó világban élünk, melyhez csakis úgy érdemes hozzáállnunk, hogy a tudásunk, törekvésünk a társadalom életének jobbítását szolgálja. A választott tudományágunk egyik jellegzetessége a közvetlen, gyakorlati hasznosság. A mérnök munkájának nyomán fejlődik a technológia, hatékonyabbak, olcsóbbak és eredményesebbek a gyártási folyamatok, ami az egész társadalom fejlődésére kihat. Ezért a műszaki tudományok mögött mindig óriási motiváció, hajtóerő áll. Informatizált, technologizált, folyamatosan gazdagodó (műszaki) világunk arra késztet bennünket, hogy lépést tartsunk az állandó fejlődéssel, s hogy a megszerzett új információkat adjuk is tovább, emellett pedig ösztönözzük és serkentsük az erre kíváncsi fiatalok érdeklődését, lehetőségeinkhez mérten járuljunk hozzá szakmai fejlődésükhöz.

Ezért szervezzük immáron huszonöt éve a Fiatal Müszakiak Tudományos Ülésszakát, fórumot teremtve a szakmai tapasztalatcserére, az új kutatási eredmények bemutatására. Külön cél, hogy az eredményeket magyar nyelven tárhassuk a nagyközönség elé, ezáltal ápolva a müszaki tudományos szaknyelvet. Kutatásaink eredményeit azonban nem csupán magyarul, a magyar közönség számára kívánjuk népszerüsíteni, azt is nagyon fontosnak tartjuk, hogy mindezek a globális tudósközösség számára is elérhetők legyenek.

Az Erdélyi Múzeum-Egyesület Műszaki Tudományok Szakosztálya idei, 25. jubileumi nemzetközi tudományos rendezvénye a virtuális térbe szorult, és az egyesület első videókonferenciájaként zajlott. A rendkívüli eseményt az EME és a Sapientia EMTE közösen szervezték. A nagy érdeklődésnek örvendő, a Kárpát-medence müszaki kutatásait megjelenítő fórumon ezúttal 108 szerző 48 tanulmány keretében mutatta be, illetve ajánlotta közlésre kutatási eredményeit.

A konferenciánkon elhangzott előadások tanulmányait mind magyar, mind angol nyelven közzétesszük a Müszaki Tudományos Közlemények sorozatkötet (https:// www.eme.ro/publication-hu/mtk/mtk-main.htm) 13. számában. Az anyagtudomány szakterületéről beérkező tanulmányok, a tudományos bizottság javaslatának megfelelően, az Acta Materialia Transylvanica folyóirat 3. évfolyama (2020) számaiban kerülnek közlésre (https://www.eme.ro/publication-hu/acta-mat/mat-main.htm).

Az angol nyelvü tanulmányokat a De Gruyter Open, Sciendo népszerüsíti (https:// content.sciendo.com/view/journals/mtk/mtk-overview.xml, illetve https://content.sciendo.com/view/journals/amt/amt-overview.xml). Ezek indexelve lesznek a nemzetközi szakmai adatbázisokban és a szakmai online könyvkereskedésekben is.

A jelen kiadvány a Müszaki Tudományos Közlemények sorozat tizenharmadik száma (MTK, 2020. 13. szám). A kötet a 2020. március 26-i XXV. Fiatal Műszakiak Tudományos Ülésszakán elhangzott negyvennyolc előadás közül válogatott, harminchárom írást tartalmaz, melyek 75 szerző munkái. 
A kiadvány lefedi a műszaki tudományok valamennyi területét (anyagtudomány, anyagtechnológia, gépészet- és gyártástudomány, mechatronika, biztonságtudomány, alkalmazott informatikai, környezetvédelem, vegyészet, építészet), a műszaki oktatást, amely az interdiszciplináris kutatások eredményeivel is kiegészül. A publikáló szerzők között egyetemeken, kutatóintézetekben működő szakembereket találunk, ugyanakkor a versenyszférából is megtalálni az ipar(ágak) képviselőit.

Köszönetet mondunk mindazoknak, akik a tudományos ülésszakon vállalták az aktív részvételt négy országból, s érdekfeszítő, nívós videó-előadásukkal, értékes tanulmányukkal hozzájárultak a rendezvény színvonalának növeléséhez s a kiadvány megvalósításához, szakmai nívójához.

Idén a konferencia megszervezésekor váratlan helyzet előtt álltunk, amely meggátolta a személyes részvételt/találkozást, viszont közös gondolkodással, erővel és hozzáállással a jubileumi rendezvényt valóban ünnepivé, a legmodernebb eszközöket felhasználva hatékonnyá, a kitűzött célt szolgálóvá tudtuk tenni, mely nem más, mint „a kutatás ösztönzése, a tudományos kapcsolatok kialakítása/megtartása, valamint a magyar müszaki nyelv művelése”!

Reméljük, hogy kötetünkkel felkeltjük azok érdeklődését is, akik nem vehettek részt konferenciánkon, és esetleg ösztönözhetjük őket arra, hogy a jövőben bekapcsolódjanak rendezvényünkbe, de addig is jelen kötet számukra is értékes szakmai információkat, hasznos adatokat nyújthat.

Kolozsvárt, 2020 márciusában

Bitay Enikö

akadémikus, az MTA külső tagja,

az Erdélyi Múzeum-Egyesület

Műszaki Tudományok Szakosztályának elnöke 


\section{FOREWORD}

We live in a constantly changing world and the only worthy way to approach it is with a desire to improve the life of our society through our knowledge and ambitions. A specific of our chosen branch of science is its immediate, practical usefulness. The work of an engineer brings technological development, efficiency, improved results and lower costs for the industry, which in turn is beneficial for the development of society as a whole. Therefore, there is always an enormous motivation and driving force behind technical sciences. Our computerized, technologically advancing world, being continuously enriched with new knowledge and results, pushes us to follow these changes, to pass on newly acquired knowledge, to motivate and stir the interest of young people who have a predisposition for these sciences and to contribute to their professional development.

This is why, for the past twenty-five years, we have organised, the Young Engineers' Scientific Conference, creating a forum for professional exchange and the presentation of new research results. A special goal is to provide the opportunity to present results in the Hungarian language to our audience, in the hope that we can preserve the Hungarian technical scientific language. Yet we do not limit ourselves to presenting our research for a Hungarian language audience, we think that it is also important to make the results available to the global scientific community.

This year the $25^{\text {th }}$ - jubilee - international scientific conference of the Transylvanian Museum Society's Department of Technical Sciences had to be held in the virtual space - the first video conference of the Society. This extraordinary event was the joint organization of the Transylvanian Museum Society and the Sapientia Hungarian University of Transylvania. The forum presents results of technical sciences achieved in the Carpathian basin and always enjoys wide popularity, This year 108 authors were able to present and communicate their research results in 48 studies.

The presentations given in our conference are published both in Hungarian and in English in the $13^{\text {th }}$ volume of the Müszaki Tudományos Közlemények (Technical Scientific Communications) series (https://www.eme.ro/ publication-hu/mtk/Mtk-main. $\mathrm{htm})$. Studies that come from the specific fields of material sciences are published according to the recommendations of the scientific committee and after the necessary completions in the 2020 ( $3^{\text {rd }}$ volume) numbers of the Acta Materialia Transylvanica periodical (https://www.eme.ro/publicationhu/acta-mat/mat-main.htm).

English language publications are popularized by the De Gruyter Open, Sciendo (https://content.sciendo.com/view/journals/mtk/mtk-overview.xml, respectively https:// content.sciendo.com/view/journals/amt/amt-overview.xml). These will be indexed in the international scientific databases and in the professional online bookstores. 
The present publication is the $13^{\text {th }}$ issue of Müszaki Tudományos Közlemények (Technical Scientific Communications). The volume contains 33 papers of 75 authors selected from the 48 presentations displayed at the $25^{\text {th }}$ Scientific Conference of Young Engineers on 26 March 2020.

All fields of technical sciences (Material Science and Technology, Mechanical Engineering and Manufacturing, Mechatronics, Security Science, Applied Informatics, Environmental Science, Chemistry and Construction), as well as Technical Education are represented and results from inter-disciplinary research are added. Among the authors we find not only professionals from universities and research institutes, but also representatives of the different branches of industry.

We would like to thank all those who willingly and actively participated in our scientific conference from four different countries, with their interesting highly professional video presentations and valuable studies which contributed to the overall high scientific level of our event and the publication of the volume.

Organizing the conference we faced an unexpected new situation that prevented us from participating and meeting personally. However, we put our thoughts, forces and approach together by taking advantage of state-of-the art technology and were able to make this jubilee event truly festive - serving the goals that we have set forth: „to motivate research, to forge and preserve scientific relationships and to cultivate the Hungarian technical language"!

We hope that the present volume arouses the interest of those who could not participate in our conference and that it encourages them to join our future events. As for the present, they can find valuable scientific information and useful data in the volume.

Cluj-Napoca, March 2020

\section{Bitay Enikő}

academician, external member

of the Hungarian Academy of Sciences, president of the Transylvanian Museum-Society's

Department of Technical Sciences 


\title{
AZ OPTIMÁLIS ÉS MODELL PREDIKTÍV IRÁNYÍTÁSOK ÁTTEKINTÉSE ÉS VALÓS IDEJƯ ALKALMAZÁSA, KÜLÖNÖS TEKINTETTEL AZ ÁLLAPOTBECSLŐK HASZNÁLATÁRA
}

\section{SURVEY OF OPTIMAL CONTROL AND MODEL PREDICTIVE CONTROL WITH STATE ESTIMATION AND A REAL TIME APPLICATION}

\author{
Dávid László, ${ }^{1}$ György Katalin, ${ }^{2}$ Galaczi László-Alpár ${ }^{3}$ \\ Sapientia-Erdélyi Magyar Tudományegyetem, Marosvásárhelyi Kar, Villamosmérnöki Tanszék, \\ Marosvásárhely, Románia \\ ${ }^{1}$ ldavid@ms.sapientia.ro, \\ ${ }^{2}$ kgyorgy@ms.sapientia.ro \\ 3alaczil@yahoo.com
}

\begin{abstract}
The optimal control and its limited version namely the model predictive control represent one of the most important nonlinear control alternatives nowadays. The success of them are also proven in many practical applications. These can provide for several industrial applications the optimal trajectory calculation as well as calculation of the real-time control signal. One successful version of this is Generalized Predictive Control (GPC). A big advantage of these control algorithms is that they solutions are able to take into account the limitations of the inputs, and the states. In some cases, it is important to know the mathematical model chosen and the complete state information. Otherwise, the model can be estimated during the operation. Our study shows through the control of the cathode heating of a high power electron beam device the self-tuning adaptive control thus constructed. Using a suitable dynamic model and an extended Kalman estimator, we determine the estimated temperature of the two cathodes during operation and the saturation electron current, which ensures the maximum cathode life. The practical application was tested on a CTW 5/60 type electron gun.
\end{abstract}

Keywords: optimal control, Kalman filter, model predictive control, optimal trajectory.

\section{Összefoglalás}

Az optimális irányítás és ennek korlátos változata a modellprediktív irányítás napjaink egyik legfontosabb nemlineáris irányítási alternatíváját jelenti, melynek gyakorlati alkalmazásokban bizonyított sikerei is jelzik fontosságát. Ezek biztosíthatják egy-egy ipari alkalmazásnak az optimális pályaszámítást, valamint a valós idejű vezérlőjel-szekvencia számítását. Egyik sikeres változata ennek az általánosított prediktív irányítás (GPC). Nagy előnyük ezeknek az irányítási algoritmusoknak az, hogy a megoldásnál képesek figyelembe venni a bemenetek, valamint az állapotok korlátozásait is. Bizonyos esetekben fontos a választott matematikai modell és a teljes állapotinformáció ismerete. Ellenkező esetben a modellt működés közben lehet megbecsülni. A tanulmányunk egy nagy teljesítményü elektronsugaras berendezés katódfütésének szabályozása kapcsán mutatja be az így felépített önhangoló adaptív irányítást. Egy megfelelő dinamikus modell és Kálmán-becslő segítségével határozzuk meg működés közben a két katód becsült hőmérsékletét, illetve a maximális katódélettartamot biztosító szaturációs elektronáramot. A gyakorlati alkalmazást egy CTW 5/60-típusú elektronágyún teszteltük.

Kulcsszavak: optimális szabályozó, Kálmán szürő, modell prediktív szabályozó, optimális pályatervezés. 


\section{Bevezetés}

Ismert tény, hogy napjainkban - a digitális beágyazott rendszer elterjedésének köszönhetően - bár nagyon gyakran alkalmazunk numerikus irányítási algoritmusokat, mégis a működő szabályozások jelentős része a klasszikus PID- vagy ennek megfelelő algoritmussal müködik. Megfigyelhető az is, hogy nagyon divatosak lettek az ún. adaptív PID-algoritmusok, amelyek implementációja könnyü, és nagyon egyszerűen áttekinthető. Igen ám, de igényes szabályozások esetében a PID által biztosított maximum egylépéses predikció a gyakorlatban nem megfelelő. És ekkor jöhetnek képbe az ún. minimális szórású, illetve modellalapú prediktív irányítások, amelyek horizontját a tervező választja meg. Ezek keretében a PID-irányítás megfelelője a GPC-irányítás, amely a gyakorlatban könnyen megvalósítható és a predikciós horizontnak, valamint annak, hogy egy paraméterbecslővel kiegészítve adaptív algoritmust kaphatunk, bizonyosan jó alternatívája lehet az említett szabályozásoknak. Tehát egy GPC-algoritmus, és egy legkisebb négyzetes paraméterbecslő gyakorlatban már adaptív irányítást biztosít, mert a paraméterbecslő megadja az aktuális munkapontnak megfelelő regressziós paramétereket, és ennek alapján a GPC-irányítás megfelelő vezérlőjelet számol. Persze itt a kérdés az, hogy van-e olyan algoritmusunk, amely mindkét feladatot el tudja végezni adott mintavételezési idő alatt, amely sokszor milliszekundum nagyságrendü. Nos, vannak olyan folyamatok ahol ezt képtelen egy adaptív GPC-algoritmus elvégezni, sőt nemlineáris rendszereknél - mivel a becsült paraméterek csak a munkapont egy szűk környezetében érvényesek - és ezért minden mintavételben el kell végezni a becslést, mely fokozottan érzékeny lehet a számítási időkre. Vajon milyen lenne az az algoritmus, amely akár nemlineáris rendszereknél is a teljes működési tartományban képes lenne elvégezni a becslést, és így nem kellene működés közben erre pocsékolni a drága számítási időt. Nos, ilyen algoritmus a GPC-irányítás egyik változata, a neurális GPC-irányítás, amely a regressziós becslést nem ARMAX-, ARIMAX-, CARIMAX-modellekkel végzi, hanem egy neuronhálóval. Természetesen ez is egy regressziós becslés, a szakirodalom a NARMAX-becslés néven ismeri, és így egy előzetes becslés alapján lehet a GPC-irányításnak megfelelő vezérlőjelet számítani. És bár sokan foglalkoztak ezzel, sőt Norgaard professzor úr programcsomagot is fejlesztett, mégis az alkalmazások jelentős része csak lineá- ris folyamatokra alkalmazza a módszert. Célunk egy erősen nemlineáris folyamat esetében tanulmányozni az esetleges előnyöket, hátrányokat. $\mathrm{Ez}$ a folyamat egy nagy teljesítményü elektronsugaras megmunkálóberendezés katódfütésének a teljesítményszabályozója, amely eredetileg PID-szabályozóval volt megvalósítva, és ennek eredményeként maximum 80-90 W teljesítményig lehetett stabil üzemmódban szabályozni, ami nem volt elég sok esetben a maximális elektronáram eléréséhez. Az irányítási algoritmusok fejlődésének egy nagyon lényeges fejezete az adaptív algoritmusok közé sorolható, ilyen például az önhangoló irányítási algoritmus. Ezt - eredetileg SISO-rendszerekre - Åström és Wittenmark javasolták [1], mint egy paraméterbecsléssel kiegészített minimális varianciájú (MVC) irányítási algoritmust, amelyet többváltozós MIMO-rendszerekre mások mellett Keviczky László, Hetthéssy Jenő, Hilger Miklós és Kolostori János dolgoztak ki [2]. Azt már Clarke és Gawthrop, a GPC-irányítás kifejlesztői is megjegyezték, hogy ezekben az esetekben a holtidő pontos ismerete mellett, a célfüggvény vezérlőjelkorlátjának a nullától különböző értéke szükséges. Sőt, azt is észrevették, hogy amennyiben a használt regressziós modell vezérlőjelét meghatározó polinomot a tervezésnél elhanyagoljuk, akkor a tervezett zártkörü irányítás instabil lesz, amennyiben ennek a polinomnak instabil gyökei vannak. Ekkor ők egy segédkimenet bevezetését javasolták, amely módosítja a használt regressziós modell struktúráját [3]. Sajnos ez a módszer sem vezetett eredményre, mert az itt alkalmazott egylépéses becslés - a holtidőt itt nem számítjuk külön horizontnak - jelentősen korlátozza a következőkben predikciónak nevezett becslés minőségét, jóságát. Erre alapozva, könnyen megérthető a Grimble által 2002-ben megfogalmazott vélemény. „A klasszikus MVC irányítás széles sávszélességet, nagy erősítési tényezőt, és ezért valószínűtlenül nagy vezérlőjel változást eredményez.” Egyébként a szerzők is gyakran találkoztak ezzel a jelenséggel, és többé-kevésbé empirikus módon próbáltuk ezt az elfogadhatatlanul nagy vezérlőjel-változást korlátozni. Igen ám, de ezek után felmerült az irányítási algoritmus tervezésében elhanyagolt korlátozás által okozott kezelhetetlen minőségi romlás, illetve az empirikus hangolás kiküszöbölése. Ezért is tűnt annak idején nagyon hasznosnak a Bitmead, Graves és Wertz (1990) valamint a Clarke és Mohtadi (1989) által javasolt módosítás, amelyet az ún. általánosított minimális varianciájú algoritmus (GMVC) néven ismer a szakirodalom, és amely az 
eredeti célfüggvényt kiegészítette a vezérlőjelkorlátokkal, valamint az előírt pályával. Természetesen ez a módszer is megtartotta az egylépéses horizontú predikciót, tehát a jelzett nagy vezérlőjel-változás csökkentésére csak a vezérlőjelnek vagy a vezérlőjel változásának, a célfüggvényben történő jelentős súlyozása jelenthetett megoldást. Ez viszont összességében csökkenti a vezérlőjel nagyságát mind a korlátokon kívül, mind azok keretén belül, és ezzel ugyancsak minőségi romlást eredményeznek. Erre a jelenségre jelent hatékony megoldást, a Clarke és Gawthrop által kifejlesztett, általánosított prediktív irányítási algoritmus, rövidített nevén GPC. Ez önmagában éppen úgy biztosítja az önhangoló adaptív irányítást, mint az MVC, valamint a GMVC, de emellett, hatékony korlátkezelési algoritmusa, valamint a predikciós horizontjának tetszőleges kiterjesztése révén hatékony megoldást jelent a felsorolt hiányosságokra is, azaz kezeli a nem minimálfázisú és nyílt hurokban instabil folyamatokat, valamint az ismeretlen vagy változó holtidőt. Nos, mielőtt levonnánk azt a felületes következtetést, hogy megvan az ideális irányítási algoritmus, hisz a regressziós ARX-modell működés közbeni becslése minden mintavételben lehetőséget teremt az irányítási algoritmus számítására, nézzük meg a gyakorlati tapasztalatokat. Abban az esetben, ha lineáris vagy közel lineáris folyamatokra alkalmazzuk, természetesen igazak az állítások, de akkor, ha erősen nemlineáris folyamatot szeretnénk irányítani, a lineáris ARX-becslés nem lesz mindig megfelelő, főként, ha a munkaponttól jelentős távolságra lévő horizontra van szükségünk. Ezt a helyzetet oldja meg a neurális regressziós becslés, amelyet az elmúlt két évtizedben viszont hatékonyan használtak számos gyakorlati irányítási folyamatnál. A következőkben ennek a nagyon közkedvelt általánosított prediktív irányításnak egy gyakorlati megvalósítását tanulmányozzuk részletesen.

\section{A katódegyüttes termikus modell- jének meghatározása és az MVC, illetve GPC irányításának összeha- sonlítása}

\subsection{A katódfütés dinamikus modellezése}

A feladatunk az, hogy valósítsunk meg azt a minimális varianciájú (minimális szórású) adaptív irányítási algoritmust, amely egy nagy teljesítményü elektronsugaras megmunkálóberendezés közvetett fütésű masszív katódfütési teljesítmé- nyét állandó értékre szabályozza. Nos, mindenekelőtt lássuk, mit is jelent ez a feladat. Ismert tény, hogy a nagy teljesítményü elektronsugaras megmunkálóberendezésekben n x 100 mA elektronnyalábot, általában közvetett fütésű, termoemissziós katódot használnak elektronforrásként (1. ábra). Egy tipikus, ilyen felépítésű elektronforrás két részből áll. A megmunkálóáramot biztosító ún. „masszív katódból”, illetve az ezt közvetve melegítő spirál alakú primer katódból. Amennyiben a masszív katódot állandó teljesítménnyel melegítjük, amelyet a primer katód által kibocsátott - telített tartományban működő - elektronok biztosítanak, úgy jó közelítéssel megvalósítható az, hogy az aktív áramot biztosító katód emiszsziós felületén lévő hőmérséklet állandó legyen. Ekkor a primer katódon áthaladó $I_{p k}$-vezérlőjelnek tekintett áram $T_{p}$-hőmérsékletre melegíti fel a prieér katódot, amely ennek következtében egy $J_{s}$-áramsűrűségü elektronnyalábot bocsát ki. Az így kilépett szabad elektronok - az $U_{S}$ állandó, a primer, illetve masszív katód között kialakított potenciál hatására - felgyorsulnak, a masszív katódot $T_{S}$-hőmérsékletre melegítik fel. A hatékony működés, azaz minél kisebb hőveszteség érdekében, a masszív katód felépítése egy termikus csapdát is tartalmaz, azaz a katód átmérője a felfogás irányában elszükül, 0,6...0,7 mm, az 1,4 mm átmérőjű emissziós felülettel szemben. Ez a megoldás a hővezetés csökkenéséhez vezet, amely a megfelelő hőveszteségek csökkentését is eredményezi.

Természetesen ezt az ún. hőcsapdát a primer katód rögzítési irányában kell elképzelnünk, így csökken a masszív katód hővezetés révén elvesztett teljesítménye. Továbbá ez nemlinearitást eredményez a katódegyüttes szerkezetének a karakterisztikájában. Mindezeket figyelembe véve a feladatunk az, hogy tervezzünk meg egy a minimális szórású (varianciájú) MVC-szabályozó algoritmust, majd egy általánosított minimális varianciájú (GMVC) és végül egy általánosított prediktív

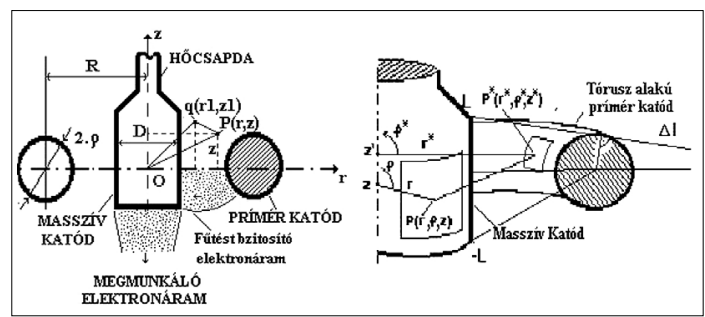

1. ábra. Közvetett fütésü katódegyüttes keresztmetszete, illetve radiációs hőátadás a primer, illetve masszív katód között 
irányítást GPC), amely a masszív katód fütési teljesítményét tekinti kimenetnek. Mindenek előtt, írjuk fel a katód együttes szerkezetének müködését leíró matematikai modellt, majd a megvalósítjuk az MVC-, GMVC-, illetve GPC-algoritmusokat.

A „masszív katód” fütési teljesítmény eloszlásának a meghatározásához szükségünk van először a tórusz alakú primer katód $(\mathrm{R}=2.74 \mathrm{~mm}$ tóruszátmérő, illetve $\mathrm{r}=0.15 \mathrm{~mm}$ drótátmérő) és s a masszív katód (henger alakú a következő méretekkel: $1=6,6 \mathrm{~mm}$ és $0,7 \mathrm{~mm}$ ) közötti potenciál eloszlásának ismeretére. Az elektronok mozgásából meghatározhatjuk a töltéssűrűség eloszlását a masszív katód felületén, mely egyenesen arányos a bejövő teljesítménysűrüséggel.

A masszív katód melegítését biztosító elektromos áram - a primer- és masszív katód közti áram - az elektromos térerősség erővonalai mentén mozog, és a stacionárius üzemmód modellezése érdekében - állandó katódáram, illetve ütközési feszültség esetében - meghatározzuk a masszív katód felületén az áramsűrűséget, illetve a fütési teljesítmény eloszlását. Természetesen iteratív módon több ciklusban megközelítjük egymás után az áram hatását a létrehozott elektromos potenciálra is. Mindezek alapján az elektromos térerősség eloszlása és az elektromos áramsűrűség megközelítésének a lépéseinek a mellőzésével egy globális melegedési modellt használtunk. Ezt a globális hőmérsékletét teljesítmények egyensúlyi képletei alapján határozhatjuk meg. A primer katód által kibocsátott és a katódok közötti stacionárius elektromos tér által felgyorsított elektronok ütközéséből eredő fütési teljesítmény a masszív katód belsejét (térfogatát) felmelegíti. Itt radiáción és hővezetésen keresztül a felületen hőveszteség jelentkezik. A radiáción keresztüli a hőveszteség korlátozva van bizonyos henger alakú viszszaverő felületek elhelyezésével a katódegyüttes szerkezetének a külső részén. Ezek használata, a primer katód felületének hőmérséklet-csökkenése mellett egyfajta stabilitástartalékot is képez az emissziós áram hirtelen változásának a kiküszöbölésével. A kísérleti eredmények bebizonyították egy pozitív visszacsatolás létezését a radiáció miatt. A masszív katód felülete radiáció segítségével melegíti a primer katódot, ez telített üzemmódban dolgozik, és egy nagyobb áramsürüségű elektronáramot bocsát ki, mely arányos a fütési teljesítménnyel. A dinamikus állapotmodell meghatározásához szükséges a fütési teljesítmény és a radiáció által elvesztett hőmennyiség. Kiszámolva a radiációfolyamatnál a hőátadási felületeket, a termikus üzemmód egyenletei a következő egyszerűsítő feltételek mellett kerültek megoldásra:

- A primer és a masszív katód felületeken a hőmérséklet eloszlása egyenletes;

-A primer katódot elektromos és radiációval is melegítjük, a hőmérséklet felületi eloszlása egyenletes. A hőveszteségek radiáción keresztül keletkeznek, a termikus hőelvezetés és a konvekciós hőveszteségek pedig csak mint ismeretlen perturbáció jelennek meg;

- A masszív katód melegítése a primer katód által kibocsájtott és a $800 \mathrm{~V}$ feszültséggel gyorsított elektronok ütközése által történik, a veszteségek a radiáció, valamint a termikus csapda - elvékonyított keresztmetszet - felé hőelvezetésen keresztül jelentkeznek. Tekintettel az ágyúban lévő vákuumra, a konvekciós veszteségekkel nem számolunk, pontosabban ezt a tagot egy ismeretlen perturbációs tagnak tekintjük;

- A radiáción keresztül a hőcsere csak a primer katód és masszív katód, illetve a primer katód és termikus védő, valamint a masszív katód és termikus védőszerkezet-együtteseknél lényeges;

- A henger alakú koncentrikus termikus védő, amely a radiáció hatását részben visszaveri, így a védőfelület is felmelegszik. Amennyiben ennek a termikus védőnek a fala vékony, akkor a külső és a belső falak közötti hőmérséklet-különbség elhanyagolható.

A radiáció által létrehozott kölcsönhatás a leglényegesebb elem a hőátadási folyamatban. A primer és masszív katódok közötti kölcsönhatási felületek meghatározásához és azon felületek meghatározásához, melyek teljesen elveszítik a hőt a radiáció során. A primer katód a szabályozott $I_{p k}$-vezérlőjelnek tekintett áram hatására felmelegszik, sőt pozitív visszacsatolásként, a masszív katód által kibocsátott radiációs hőteljesítmény egy része, amely megfelel a masszív katódot elérő térszögnek, ugyancsak a primer katódot melegíti. Ez a kölcsönhatás követhető az 1. ábrán.

Ezek alapján a primer katód hőmennyiséget veszít radiáción keresztül, amely így befolyásolja a felmelegítéséhez szükséges energiát. A masszív katódon számolnunk kell a termikus hőelvezetéssel. Ilyen hipotézisek mellett a hővezetés miatt elveszett egy $P \lambda(T)$-hőteljesítmény, amely a következő összefüggéssel adható meg:

$$
P \lambda(T)=\lambda \cdot \pi \cdot \frac{d^{2}}{4}\left[8 \frac{\sigma r_{0}}{\left(\alpha r_{0}+1\right) \cdot \lambda \cdot d} T^{\alpha r_{0}+1}\right]^{\frac{1}{2}}
$$


Ekkor a melegítési folyamat dinamikus matematikai modellje a következő differenciálegyenletekkel adható meg:

$$
\begin{aligned}
& \frac{d}{d t} \underline{x}=f(\underline{x}, u, t)=\frac{d}{d t}\left[\begin{array}{c}
T p \\
T s
\end{array}\right]= \\
& {\left[\begin{array}{l}
\frac{1}{C p}\left[\operatorname{Pr}(T s) \cdot S_{01} \cdot \varepsilon(T p)+2 R \frac{\rho 0 \cdot T p^{\alpha}}{r^{2}} I_{p k}{ }^{2}-\operatorname{Pr}(T p) \cdot S_{00}\right] \\
\frac{1}{C s}\left[\operatorname{Pr}(T p) \cdot S_{10} \cdot \varepsilon(T s)+P e(T p, U s)-\operatorname{Pr}(T s) \cdot S_{11}-P \lambda(T s)\right]
\end{array}\right]}
\end{aligned}
$$

ahol:

- $C_{p}$ és $C_{s}$ a primer illetve a masszív katód hőkapacitása,

$-P_{r}$ radiációval leadott hőmennyiség és a katódok által visszatükrözött mennyiség, mely függ a hőmérséklettől:

$P_{r}(T)=\alpha \cdot r_{0} \cdot T^{\alpha r 0}$, ahol, a visszavert teljesítményt meghatározó visszaverődési tényező: $\varepsilon(T)=P_{r}(T) /\left(\sigma \cdot T^{4}\right)$,

$-j_{s}\left(T_{p}, R(R-r)\right)$ a primer katód - amelyet az $I_{p k}$-árammal melegítünk - által kibocsájtott telített áramsürüség.

$\left.-P_{e}\left(T_{p}, T_{s}\right)\right)$ a teljes elektromos teljesítmény, amellyel a masszív katódot melegítjük, jelenti a mért kimenetet:

$P_{e}\left(T_{p}, U_{s}\right)=4 \cdot \pi \cdot R \cdot 10^{4} \cdot v_{j} \cdot j_{s}\left(T_{p}, E(R-r)\right) \cdot U_{s}$

$-P \lambda(T)$ a masszív katód termikus hőelvezetésen alapuló vesztesége.

$-2 \cdot R \cdot r_{0} \cdot T_{p}{ }^{\alpha} \cdot r^{-2} I^{2}$ a vezéráram által létrehozott fütési teljesítmény a primer katódnál.

Természetesen a melegítés a Joule-effektuson keresztül történik, ahol a katód hőmérsékletfüggő ellenállásának változása miatt bizonyos korrekciókat figyelembe kell venni.

\subsection{Az általános minimális varianciájú (GMC) illetve az általánosított prediktív irányítás (GPC)}

Amennyiben az időállandók és a megvalósított interfészek lehetővé tesznek egy állandó előírt teljesítményre való számítógépes szabályozást, akkor fontos az $I_{p k}$ és $I_{s}$ áramok korlátozása. Így a szabályozási tömb az $I_{p k}$, $U_{s}$ és $I_{s}$ mérésére szükséges erősítőkből, illetve a primer katódot tápláló tirisztorok fázisvezéregységéből áll. A $P_{M K}$-teljesítmény mérése, illetve az $I_{p k}$ és $I_{s}$-áramok korlátozását a numerikus algoritmuson belül lehet megoldani. A következőben egy összehasonlító tanulmányt valósítottunk meg egy mintavételezett pályakövető szabályozó (előírt $T_{s}$-hőmérséklet) és egy minimális szórású adaptív szabályozó dinamikus jellemzőire hivatkozva.
Egy sor becslési módszer létezik a lineáris regressziós modellparaméterek meghatározásához. Ezek a módszerek képesek megszürni a folyamaton mért zajos jeleket, megbecsülik a rendszerek fokszámát, és megbecsülik a modellparamétereket. Ezeket lehet offline üzemmódban, illetve online (ciklikus, rekurzív) üzemmódban is alkalmazni. Az így kapott modelleket felhasználhatjuk a szabályozó paramétereinek az önhangolására, minimalizálva egy adott kritériumfüggvényt. Feltételezzük, hogy a becslés után a következő ARMA-modelltípushoz jutottunk:

$$
P_{M K}\langle k\rangle=\frac{B\left(z^{-1}\right)}{A\left(z^{-1}\right)} I_{p k}\langle k-\mu\rangle+\alpha \frac{C\left(z^{-1}\right)}{A\left(z^{-1}\right)} e_{k}
$$

ahol

$-P_{M K}$ a kimeneti jel,

$-I_{p k}$ a szabályozójel,

- $\mu$ a holtidőnek mintavételezési idő többszörösében kifejezett megfelelő késleltetés,

$-B\left(z^{-1}\right) / A\left(z^{-1}\right)$-arány a folyamat átviteli függvénye,

$-C\left(z^{-1}\right)$ polinom a zaj természetét jellemzik. Amennyiben a zaj fehérzaj akkor $C\left(z^{-1}\right)=1$. Az $e_{k}$ zajvektor egy normál eloszlású, nulla középértékű jel. A minimális szórású szabályozó a következő kritérium minimalizálásán alapszik:

$$
J(u)=E\left\{\left(P_{M K}{ }^{\langle k+\mu+1\rangle}-P_{M K p r}\right)^{2}+\lambda \cdot\left(I_{p k}{ }^{\langle k\rangle}-I_{p k p r}\right)^{2}\right\}
$$

ahol

$-P_{M K}$ a szabályozott kimenet,

$-P_{M K p r}$ az előírt kimenet (ez az érték módosul az elektronnyaláb maximális előírt áram és a becsült maximális áram közötti különbségértéke függvényében),

$-I_{p k}$ a vezérlőáram értéke,

$-I_{p k p r}$ az előírt érték.

Ha a modell holtideje $\mu=1$ valamint a paraméterei ismertek, és az $A\left(z^{-1}\right), B\left(z^{-1}\right)$, illetve $C\left(z^{-1}\right)$ polinomok adottak (a holtidő és a polinomok fokszámának a megválasztása kísérleti úton történt meg azaz a legkisebb fokszám, amely még megfelelő pontosságot biztosít):

$$
\begin{aligned}
& A\left(z^{-1}\right)=1+a_{1} z^{-1}+a_{2} z^{-2}+a_{3} z^{-3} \\
& B\left(z^{-1}\right)=b_{0}+b_{1} z^{-1}+b_{2} z^{-2} \\
& C\left(z^{-1}\right)=1
\end{aligned}
$$

akkor következik a szabályzójel meghatározása az alábbi összefüggés szerint: 


$$
\begin{aligned}
& C\left(z^{-1}\right)=A\left(z^{-1}\right) F\left(z^{-1}\right)+z^{-\mu} G\left(z^{-1}\right) \\
& F\left(z^{-1}\right)=1, G\left(z^{-1}\right)=g_{0}+g_{1} \cdot z^{-1}+g_{2} \cdot z^{-2} \\
& 1=\left(1+a_{1} \cdot z^{-1}+a_{2} \cdot z^{-2}+a_{3} \cdot z^{-3}\right) \cdot 1+z^{-1}\left(g_{0}+g_{1} \cdot z^{-1}+g_{2} \cdot z^{-2}\right)
\end{aligned}
$$

Meghatározzuk az F(.) és G(.)-polinomok együtthatóit ennek az összefüggésnek megfelelően. A szabályozó jelet pedig a következő képlettel számoljuk ki:

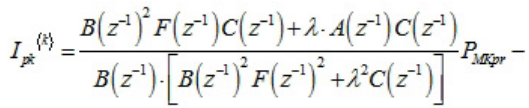

$$
\begin{aligned}
& -\frac{B\left(z^{-1}\right) F\left(z^{-1}\right) G\left(z^{-1}\right)}{B\left(z^{-1}\right)^{2} F\left(z^{-1}\right)^{2}+\lambda^{2} C\left(z^{-1}\right)} P_{M K}^{(z)} \\
& I_{p k}{ }^{k(\rangle)}=\frac{B\left(z^{-1}\right)^{2}+\lambda \cdot A\left(z^{-1}\right)}{B\left(z^{-1}\right) \cdot\left[B\left(z^{-1}\right)^{2}+\lambda^{2}\right]^{M K p r}} P- \\
& \frac{B\left(z^{-1}\right) G\left(z^{-1}\right)}{B\left(z^{-1}\right)^{2}+\lambda^{2}} P_{M K}^{\langle k\rangle} \\
& B\left(z^{-1}\right) \cdot\left[B\left(z^{-1}\right)^{2}+\lambda^{2}\right] I_{p k}{ }^{k 3}= \\
& =\left[B\left(z^{-1}\right)^{2}+\lambda \cdot A\left(z^{-1}\right)\right] P_{M K p r}-B\left(z^{-1}\right)^{2} G\left(z^{-1}\right) P_{M K}\langle k\rangle
\end{aligned}
$$

Amennyiben nem korlátozzuk a vezérlőjelet $\lambda \rightarrow 0$, akkor az előbbi egyenlet:

$$
B\left(z^{-1}\right) \cdot I_{p k}^{\langle k\rangle}=P_{M K p r}-G\left(z^{-1}\right) P_{M K}\langle k\rangle
$$

Vagy behelyettesítve megkapjuk az MVC-algoritmusnak megfelelő irányítási törvényt, mint:

$$
\left(b_{0}+b_{1} z^{-1}+b_{2} z^{-2}\right) \cdot I_{p k}^{\langle k\rangle}=P_{M K q r}-\left(g_{0}+g_{1} z^{-1}+g_{2} z^{-2}\right) P_{M K}
$$

$I_{p k}\langle k\rangle=\left[\begin{array}{l}P_{M K p r}-b_{1} I_{p k}{ }^{\langle k-1\rangle}-b_{2} I_{p k}^{\langle k-2\rangle}- \\ -g_{0} P_{M K}^{\langle k\rangle}-g_{1} P_{M K}^{\langle k-1\rangle}-g_{2} P_{M K}^{\langle k-2\rangle}\end{array}\right] / b_{0}$

A gyakorlatban fontos tény, hogy a számítógépes irányítási rendszer vezérlőjelét meghatározó DAC átalakítójának a kerekítési hibáit, egy additív fehérzajjal lehet a legjobban modellezni, amelynek a korrelációja a hasznos jellel elhanyagolhatóan kicsi [4], [5]. Ezért a szimuláció kétfajta zajt tartalmaz. Egy korlátos fehérzajt a kimeneten, amely a kvantizálási hibákat modellezi, illetve egy, a bemeneti mérésekre ható, normál eloszlású zajt. A 2. ábrán ennek az GMVC-irányításnak az eredményeit lehet követni.

Megfigyelhető, hogy a klasszikus GMVC, amely nem tartalmazza sem a vezérlőjel, sem a vezérlőjel változásának a korlátozását, olyan nagy ve-
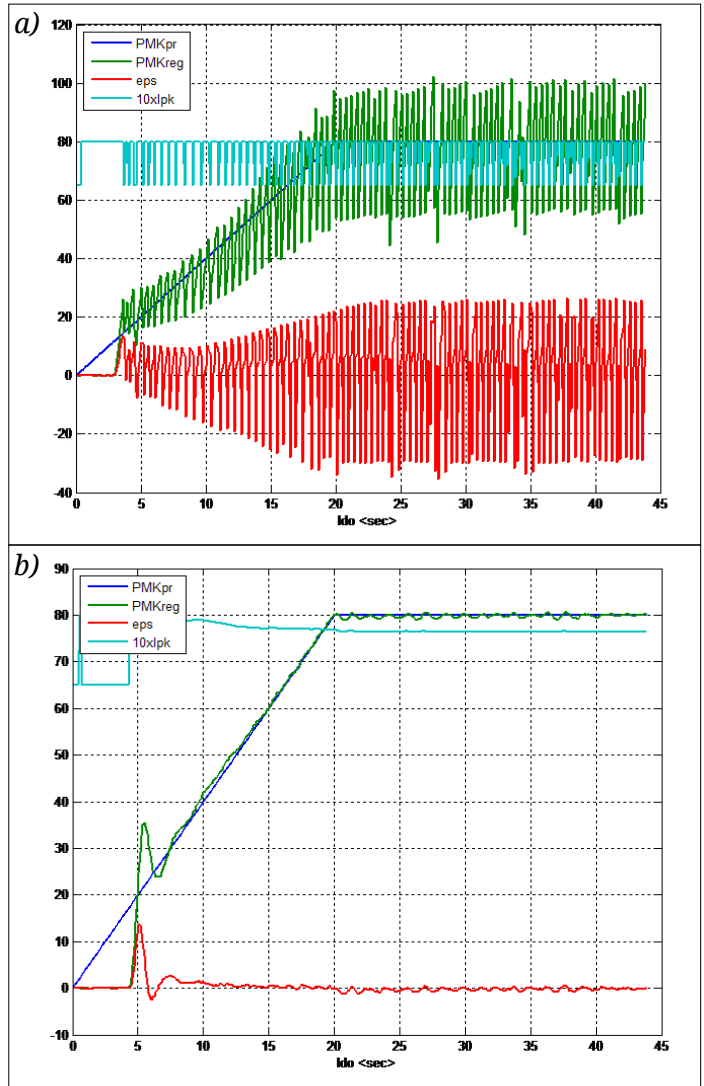

2. ábra. GMVC-irányítás kimeneti szürö nélkül (a) illetve kimeneti szürővel (b)

zérlőjelet generál, amely belengeti a rendszert, főként a fütésteljesítmény nagy értékeire, ahol a folyamat karakterisztikája nagyon meredek. Ekkor a vezérlőjel $1 \mathrm{~mA}$-változása már jelentős teljesítményváltozást eredményez. Bevezetünk egy empirikus vezérlőjel-korlátozást, amelyet egy szűrő végez el. Látható, hogy ez valamennyire stabilizálja a folyamatot, bár a felfutási követési hiba és az állandósult állapot sem teljesen hibamentes. Ezért hasznos lehet a korlátozást már a célfüggvényben megfogalmazni. Ugyanakkor jól követhető a folyamat az ARMAX modelljének a becslési hibája is. Egyébként ez az összefüggés ismert, és gyakran használt az adaptív szabályozásoknál, az ún. önhangoló irányítási algoritmusoknál.

A katódfütés GPC-irányítása esetében több horizontra vetítjük előre a predikciót. Egyébként láttuk, hogy a GMVC-algoritmus csak akkor alkalmazható sikerrel, ha valamilyen módszerrel korlátozzuk a vezérlőjel változását. A fenti esetben ezt egy empirikusan bevezetett szűrő tette. Avezérlőjelabszolútértékénekgyengekorlátozása 
pedig nem jó ötlet, mert a stabil állapothoz tartozó 7-8 a vezérlőáramot bünteti, és nem ennek a változását. Ezért ennek megvalósításával nem foglalkozunk. A vezérlőjel változását korlátozó GMVC algoritmusa viszont teljesen azonos kellene, hogy legyen a csupán egy mintavételnyi horizontú, erős korlát nélküli GPC-irányítás algoritmusával. A matematikai modell, melyet használunk itt is, a (3) összefüggéssel írható le, itt viszont a következő jelölést vezetjük be:

$$
\begin{aligned}
& A_{\Delta}\left(z^{-1}\right)=\left(1-z^{-1}\right)\left(1+a_{1} z^{-1}+a_{2} z^{-2}+a_{3} z^{-3}\right)= \\
& =1+\left(a_{1}-1\right) z^{-1}+\left(a_{2}-a_{1}\right) z^{-2}+\left(a_{3}-a_{2}\right) z^{-3}-a_{3} z^{-4}
\end{aligned}
$$

Azért, hogy felírhassuk a GPC-hez, szükséges következő egyenletet:

$$
\hat{y}_{k+p / k}=G_{p}\left(z^{-1}\right) \cdot y_{k}+F_{p}\left(z^{-1}\right) \cdot B_{\mu}\left(z^{-1}\right) \cdot \Delta u_{k+p-1}
$$

Meg kell határoznunk az $F\left(z^{-1}\right)$ és $G\left(z^{-1}\right)$-polinomokat, különböző $p$ horizontértékekre, mint:

$$
\begin{aligned}
& A_{\Delta}\left(z^{-1}\right) F\left(z^{-1}\right)=1-z^{-p} G\left(z^{-1}\right) \Rightarrow \\
& \left(1+\left(a_{1}-1\right) z^{-1}+\left(a_{2}-a_{1}\right) z^{-2}+\left(a_{3}-a_{2}\right) z^{-3}-a_{3} z^{-4}\right) . \\
& \cdot F\left(z^{-1}\right)+z^{-p} G\left(z^{-1}\right)=1
\end{aligned}
$$

1. Eset: $\mathrm{p}=1, \mathrm{n}=3$

$$
\begin{aligned}
& F_{1}\left(z^{-1}\right)=1+f_{1} z^{-1}+f_{2} z^{-2}+\ldots+f_{\mu-1} z^{-p+1}=1 \\
& G_{1}\left(z^{-1}\right)=g_{0}+g_{1} z^{-1}+\ldots+g_{n-1} z^{-n}=g_{0}^{1}+g_{1}^{1} z^{-1}+g_{2}^{1} z^{-2}+g_{3}^{1} z^{-3} \\
& g_{0}^{1}=1-a_{1}, g_{1}^{1}=a_{1}-a_{2}, g_{2}^{1}=a_{2}-a_{3}, g_{3}^{1}=a_{3}
\end{aligned}
$$

2. Eset: $p=2, n=3$

$$
\begin{aligned}
& F_{2}\left(z^{-1}\right)=1+f_{1} z^{-1}+f_{2} z^{-2}+\ldots+f_{\mu-1} z^{-p+1}=1+f_{1}^{2} z^{-1} \\
& G_{2}\left(z^{-1}\right)=g_{0}+g_{1} z^{-1}+\ldots+g_{n-1} z^{-n}=g_{0}^{2}+g_{1}^{2} z^{-1}+g_{2}^{2} z^{-2}+g_{3}^{2} z^{-3} \\
& f_{1}^{2}=1-a_{1}, \\
& g_{0}^{1}=f_{1}^{2} \cdot\left(1-a_{1}\right)+a_{1}-a_{2}, \\
& g_{1}^{2}=f_{1}^{2} \cdot\left(a_{1}-a_{2}\right)+a_{2}-a_{3}, \\
& g_{2}^{2}=f_{1} \cdot\left(a_{2}-a_{3}\right)+a_{3}, g_{3}^{2}=f_{1} \cdot a_{3}
\end{aligned}
$$

3. Eset: $p=3, n=3$

$$
\begin{aligned}
& F_{3}\left(z^{-1}\right)=1+f_{1} z^{-1}+f_{2} z^{-2}+\ldots+f_{\mu-1} z^{-p+1}=1+f_{1}^{3} z^{-1}+f_{2}^{3} z^{-2} \\
& G_{3}\left(z^{-1}\right)=g_{0}+g_{1} z^{-1}+\ldots+g_{n-1} z^{-n}=g_{0}^{3}+g_{1}^{3} z^{-1}+g_{2}^{3} z^{-2}+g_{3}^{3} z^{-3} \\
& f_{1}^{3}=1-a_{1}, \\
& f_{2}^{3}=f_{1}^{3} \cdot\left(1-a_{1}\right)+a_{1}-a_{2}, \\
& g_{0}^{3}=f_{1}^{3} \cdot\left(a_{1}-a_{2}\right)+f_{2}^{3} \cdot\left(1-a_{1}\right)+a_{2}-a_{3}, \\
& g_{1}^{3}=f_{1}^{3} \cdot\left(a_{2}-a_{3}\right)+f_{2}^{3} \cdot\left(a_{1}-a_{2}\right)+a_{3}, \\
& g_{2}^{3}=f_{1}^{3} \cdot a_{3}+f_{2}^{3} \cdot\left(a_{2}-a_{3}\right), \\
& g_{3}^{3}=f_{2}^{3} \cdot a_{3}
\end{aligned}
$$

4. Eset: $\mathrm{p}=4, \mathrm{n}=3$

$$
\begin{aligned}
& F_{3}\left(z^{-1}\right)=1+f_{1} z^{-1}+f_{2} z^{-2}+\ldots+f_{\mu-1} z^{-p+1}=1+f_{1}^{4} z^{-1}+f_{2}^{4} z^{-2}+f_{3}^{4} z^{-3} \\
& G_{3}\left(z^{-1}\right)=g_{0}+g_{1} z^{-1}+\ldots+g_{n-1} z^{-n}=g_{0}^{4}+g_{1}^{4} z^{-1}+g_{2}^{4} z^{-2}+g_{3}^{4} z^{-3} \\
& f_{1}^{4}=1-a_{1}, \\
& f_{2}^{4}=f_{1}^{4} \cdot\left(1-a_{1}\right)+a_{1}-a_{2}, \\
& f_{3}^{4}=f_{1}^{4}\left(a_{1}-a_{2}\right)+f_{2}^{4}\left(1-a_{1}\right)+a_{2}-a_{3} \\
& g_{0}^{4}=f_{3}^{4} \cdot\left(1-a_{1}\right)+f_{2}^{4} \cdot\left(a_{1}-a_{2}\right)+f_{1}^{4}\left(a_{2}-a_{3}\right)+a_{3}, \\
& g_{1}^{4}=f_{3}^{4} \cdot\left(a_{1}-a_{2}\right)+f_{2}^{4} \cdot\left(a_{2}-a_{3}\right)+f_{1}^{4} a_{3}, \\
& g_{2}^{4}=f_{2}^{4} \cdot a_{3}+f_{3}^{4} \cdot\left(a_{2}-a_{3}\right), \\
& g_{3}^{4}=f_{3}^{4} \cdot a_{3}
\end{aligned}
$$

Természetesen, amennyiben ezt folytathatjuk, fokozatosan kiterjesztjük a horizont értékét. A (11) összefüggésnek megfelelően felírhatjuk a különböző $\mathrm{p}=1$, 2, 3, 4 horizont paraméterértékére, mint:

$$
\begin{aligned}
\hat{y}_{k+1 / k}= & \left(1-a_{1}+\left(a_{1}-a_{2}\right) z^{-1}+\left(a_{2}-a_{3}\right) z^{-2}+a_{3} z^{-3}\right) \cdot y_{k}+ \\
1 & \cdot\left(b_{0} z^{-1}+b_{1} z^{-2}+b_{2} z^{-3}\right) \cdot \Delta u_{k} \\
\hat{y}_{k+2 / k}= & \left(\begin{array}{l}
\left.f_{1}^{2}\left(1-a_{1}\right)+a_{1}-a_{2}+\left(f_{1}^{2}\left(a_{1}-a_{2}\right)+a_{2}-a_{3}\right) z^{-1}+\right) \cdot y_{k}+ \\
\left(f_{1}^{2}\left(a_{2}-a_{3}\right)+a_{3}\right) z^{-2}+f_{1}^{2} a_{3} z^{-3}
\end{array}\right. \\
& +\left(1+\left(1-a_{1}\right) z^{-1}\right) \cdot\left(b_{0} z^{-1}+b_{1} z^{-2}+b_{2} z^{-3}\right) \cdot \Delta u_{k+1} \\
\hat{y}_{k+3 / k}= & \left(\begin{array}{l}
f_{1}^{3}\left(a_{1}-a_{2}\right)+f_{2}^{3}\left(1-a_{1}\right)+a_{2}-a_{3}+ \\
\left(f_{1}^{3}\left(a_{2}-a_{3}\right)+f_{2}^{3}\left(a_{1}-a_{2}\right)+a_{3}\right) z^{-1}+ \\
+\left(f_{1}^{3} a_{3}+f_{2}^{3}\left(a_{2}-a_{3}\right)\right) z^{-2}+f_{2}^{3} a_{3} z^{-3}
\end{array}\right) \cdot y_{k}+ \\
& +\left(1+\left(1-a_{1}\right) z^{-1}+\left(f_{1}^{3}\left(1-a_{1}\right)+a_{1}-a_{2}\right) z^{-2}\right) . \\
& \left(b_{0} z^{-1}+b_{1} z^{-2}+b_{2} z^{-3}\right) \cdot \Delta u_{k+2} \\
\hat{y}_{k+4 / k}= & \left(\begin{array}{l}
f_{3}^{4}\left(1-a_{1}\right)+f_{2}^{4}\left(a_{1}-a_{2}\right)+f_{1}^{4}\left(a_{2}-a_{3}\right)+a_{3}+ \\
+\left(f_{3}^{4}\left(a_{1}-a_{2}\right)+f_{2}^{4}\left(a_{2}-a_{3}\right)+f_{1}^{4} a_{3}\right) z^{-1}+ \\
\left(f_{2}^{4} a_{3}+f_{3}^{4}\left(a_{2}-a_{3}\right)\right) z^{-2}+f_{3}^{4} a_{3} z^{-3}
\end{array}\right) \cdot y_{k}+ \\
& +\left(\begin{array}{l}
1+\left(1-a_{1}\right) z^{-1}+ \\
\left(f_{1}^{4}\left(1-a_{1}\right)+a_{1}-a_{2}\right) z^{-2}+ \\
\left(f_{1}^{4}\left(a_{1}-a_{2}\right)+f_{2}^{4}\left(1-a_{1}\right)+a_{2}-a_{3}\right) z^{-3}
\end{array}\right) .
\end{aligned}
$$

Ezt átírva, kapjuk:

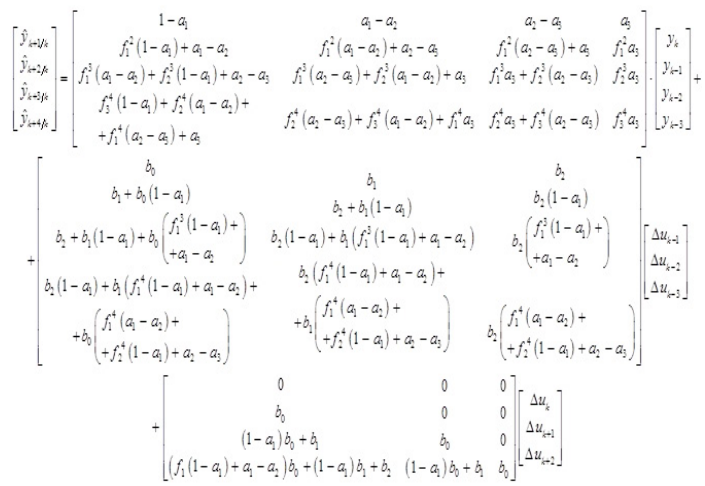


Észrevehető, hogy az első egyenlet, a várható módon, a holtidő miatt nem használható, tehát elhagyva az első sort, és ebben az esetben felhasználva a $G_{p}-, F B^{<0>}$-, valamint $F B$-jelöléseket, a szabad válasznak, illetve az optimális irányításnak megfelelő releváns egyenletek:

$\hat{Y}_{k}^{0}=\left[\begin{array}{c}\hat{y}_{k+2 / k} \\ \hat{y}_{k+3 / k} \\ \hat{y}_{k+4 / k}\end{array}\right]=G_{\mathbf{P}} \cdot\left[\begin{array}{c}y_{k} \\ y_{k-1} \\ y_{k-2} \\ y_{k-3}\end{array}\right]+F B\langle 0\rangle \cdot\left[\begin{array}{c}\Delta u_{k-1} \\ \Delta u_{k-2} \\ \Delta u_{k-3}\end{array}\right]$

És a vezérlőjel értékét nem korlátos esetben így megkapjuk, mint:

$$
\left[\begin{array}{c}
\Delta u_{k}^{*} \\
\Delta u_{k+1}^{*} \\
\Delta u_{k+2}^{*}
\end{array}\right]=\left(F_{B}{ }^{T} \cdot F_{B}+\lambda I\right)^{-1} \cdot F_{B}{ }^{T}\left(R_{k}-\hat{Y}_{k}^{0}\right)
$$

ahol:

$$
F_{B}=\left[\begin{array}{ccc}
b_{0} & 0 & 0 \\
\left(1-a_{1}\right) b_{0}+b_{1} & b_{0} & 0 \\
\left(f_{1}\left(1-a_{1}\right)+a_{1}-a_{2}\right) b_{0}+\left(1-a_{1}\right) b_{1}+b_{2} & \left(1-a_{1}\right) b_{0}+b_{1} & b_{0}
\end{array}\right]
$$

A 3. ábrán követhető az erős korlát nélküli GPC működése $\mathrm{p}=1$, 2, 3 horizontértékekre, amennyiben a vezérlőjel értékét korlátozó súlyzó értékét lehetőleg úgy választjuk meg, hogy a fűtőáram mint vezérlőjel ne érje el a kijelölt korlátot. Ekkor $\lambda=10$.

Látható, hogy már az egylépéses horizont is stabil működést tud biztosítani, de a két-, háromlépéses horizont teljesen kielégítő müködést eredményez.

Viszont az, hogy adott állandó teljesítményt tudunk szabályozni, nem elég. Van egy másik feltétel is, nevezetesen az, hogy a felfütött katód képes vagy sem biztosítani a megmunkálási áramot. Ez gyakorlatilag két tényezőtől függ. Elsősorban azt a kérdést kell feltennünk, hogy a masszív katód hőmérséklete elég nagy-e ahhoz, hogy a szaturációs árama nagyobb legyen, mint az igényelt megmunkálási áram. Ez azt jelenti, hogy a tértöltés által meghatározott tartományban müködik a berendezés. Persze, az sem jelent megoldást, ha a katód hőmérséklete túl nagy, mert ekkor igaz, hogy biztosítani tudjuk az igényelt áramot, de a túlfütés miatt a katód élettartama jelentősen lecsökken (ami gazdaságosság szempontjából
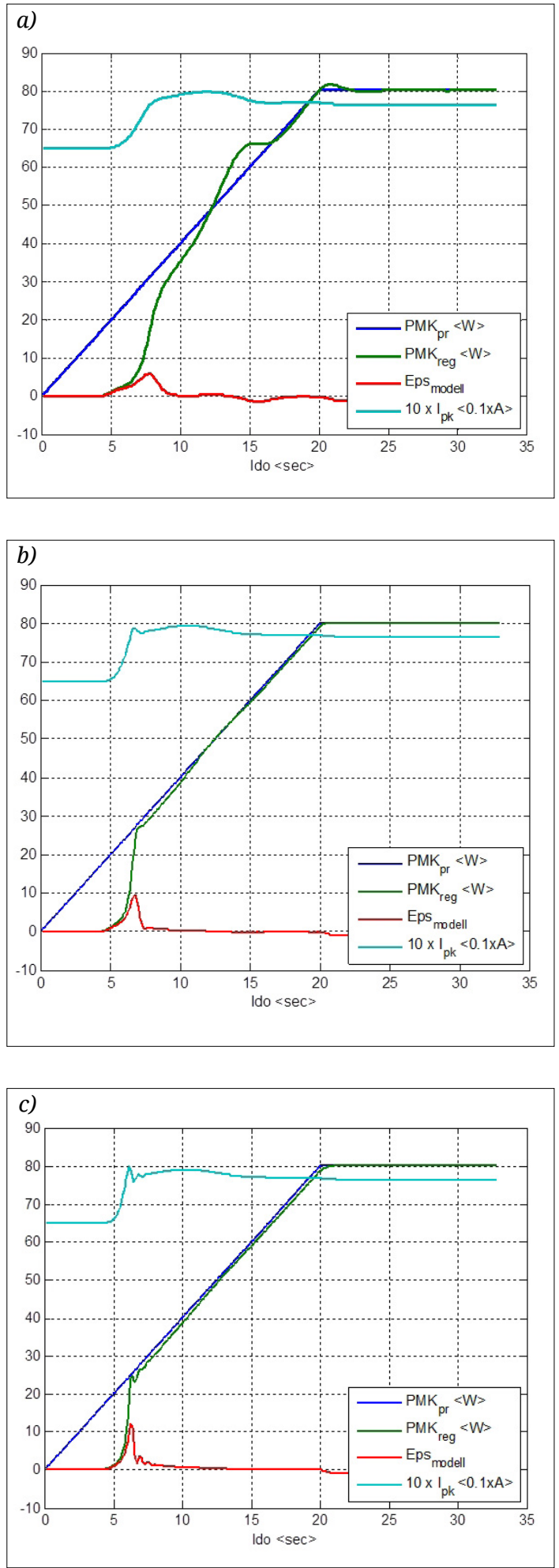

3. ábra. Katódfütés GPC-adaptív szabályozása $p=1,2,3$ lépésü horizontértékekre 
gondot okoz). Nem mindegy, hogy havonta vagy naponta kell katódot cserélnünk. Másodsorban a katód helyzete jelentheti a gondot. Túl mélyen behelyezett katód nagyon kis Wehnelt-feszültség esetében már lezárja a sugáráramot, így a teljes nyitás esetében a Wehnelt-feszültség túl alacsony ahhoz, hogy biztosítsa a „cross-over” fókuszpont kialakulását, tehát magát a megmunkálást sem tudjuk elvégezni, mert a megmunkálás síkjában fókuszált sugár a „cross-over” leképzését jelenti.

Alkalmazva a modern irányítástechnika eredményeit, mindkét jelenséget könnyedén tudjuk kezelni.

\subsection{A kibővített Kálmán-szürő alkalmazása}

Elsősorban nézzük a szaturációs áram becslését. Ez két lépésből áll. Először megbecsüljük az emissziós felület hőmérsékletét, majd feltételezve, hogy az emissziót az ún. Schottky-termoemiszszió biztosítja, kiszámítjuk az elérhető maximális megmunkálási áramot. A hőmérsékletek gyakorlati becslését a kibővített Kálmán-szűrő klasszikus módszerével végezhetjük el:

1. Minden mintavételben mérjük az $I_{P K k}$-vezérlőjel illetve $P_{M K}$-kimeneti jelszekvenciát.

2. Meghatározzuk az adott lépésben érvényes szakaszos, szaggatott rendszer $\Phi_{k}$-állapot, illetve $\Gamma_{k}$-bemenő vezérlőjelmátrixait. Ezt a nemlineáris egyenlet sorba fejtése alapján kapjuk.

3. Meghatározzuk az adott ciklusban érvényes ún. determinisztikus, azaz a korrekció nélküli becslést, valamilyen differenciálegyenleteknél alkalmazott módszerrel, mint az Euler- vagy a Runge-Kutta-módszerek, például:

$$
\underline{x}_{k+1 / k}=\underline{x}_{k / k}+\delta t \cdot \underline{f}\left(\underline{x}_{k / k}, \underline{u}_{k}\right)
$$

Ekkor viszont a számítási hibák is becslési hibaként jelennek meg, viszont sokkal gyorsabb lesz a számítás.

4. Kiszámítjuk az extrapolált szórásnégyzet mátrixértékét:

$$
P_{k+1 / k}=\Phi_{k} \cdot P_{k / k} \cdot \Phi_{k}{ }^{T}+Q_{k}
$$

5. Kiszámítjuk a minimális szórásnégyzetet biztosító visszacsatolási erősítővektor értékét:

$$
K_{k+1}=P_{k+1 / k} H_{k}{ }^{T}\left(H_{k} P_{k+1 / k} H_{k}{ }^{T}+R_{k}\right)^{-1}
$$

6. Kiszámítjuk a visszacsatolással pontosított becsült állapotvektort:

$$
x_{k+1 / k+1}=x_{k+1 / k}+K_{k} \cdot\left(y_{k+1}-H_{k+1} \cdot x_{k+1 / k}\right)
$$
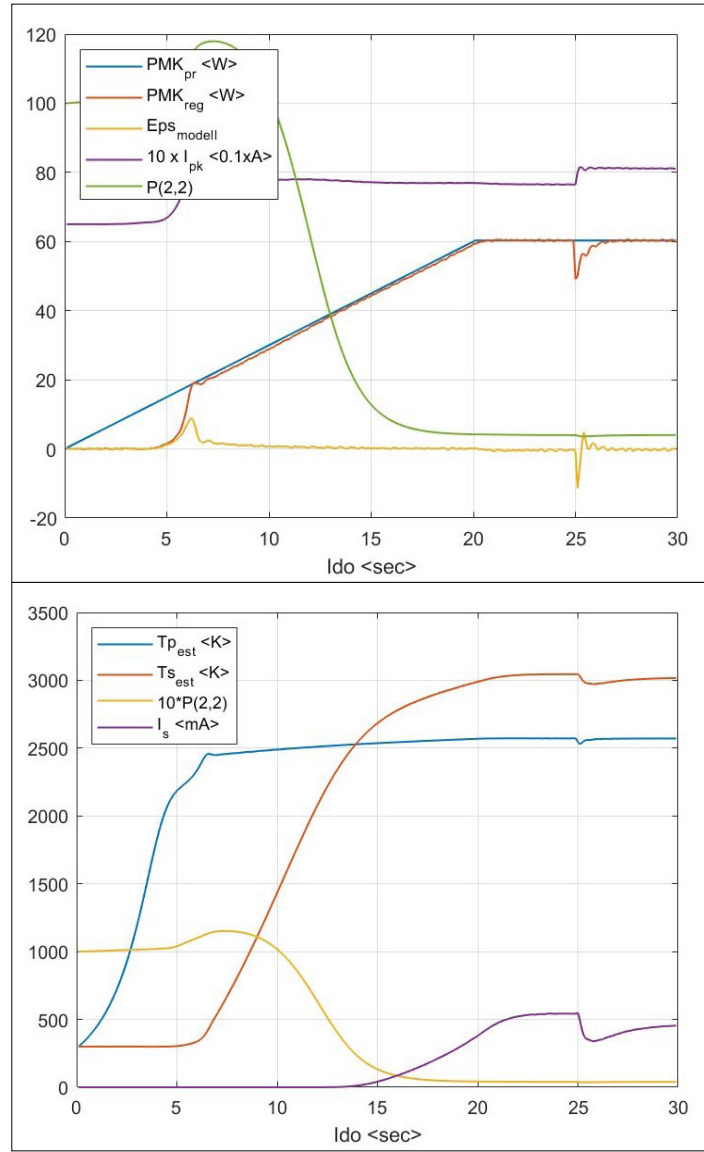

4. ábra. Katódfütés, GPC-irányítás és kibővített Kálmán-szürős hőmérséklet, illetve szaturációs árambecslés

7. Végül pedig kiszámítjuk a visszacsatolással javított szórásnégyzet mátrixértékét.

$$
P_{k+1 / k+1}=\left[I-K_{k} \cdot H_{k}\right] P_{k+1 / k}
$$

8. Növeljük a ciklusszámot $k \rightarrow k+1$ majd visszatérünk az 1-es lépéshez.

A fenti elektronsugaras berendezés katódfűtésének esetében a 4. ábrán követhető ez a folyamat:

Látható a két hőmérséklet becslése, a masszív katód becslésének a szórása, valamint a becsült Is-szaturációsáram becslése, amelyet jó közelítéssel biztosít a Schottky-katódelmélet [6], [7]. A becslésnek a bizalmi tényezője pont a szórásmátrix nyomának a változása. A viszonylag nagy kezdeti érték $\left(\mathrm{P}_{11}=\mathrm{P}_{22}=100\right)$ csökkenése jelzi a helyes becslést. Valójában két tényező is szerepel, mint bizonytalanság a fenti feladatban. Elsősorban a használt modell bizonytalansága. Hisz a 
katód hőmérséklet-eloszlása helyett egy egyszerűsített modellt használtunk, ahol a két katód hőmérséklete esetében egyenletes hőmérsékletet feltételeztünk. Másodsorban a becslő algoritmus esetében nem a nagyon időigényes numerikus integrálási algoritmusokat (Runge-Kutta, Adams stb) használtunk, hanem a jóval egyszerübb és gyorsabb Euler-módszert, ahol a numerikus pontatlanságokat is a Kálmán-szűrő kompenzálja. Továbbá nagyon lényeges a $t=25$ sec időpillanatban előálló helyzet. Az elektronágyú, illetve megmunkálókamra közti szelep nyitása azt eredményezi, hogy a felfütött katód környékén a csökkenő vákuum miatt megjelenik a konvekciós hőtranszfer jelensége, amely hűti a katódot. Ezért az elérhető maximális szaturációs áram értéke jelentősen csökkenni kezd, amit valamennyire kompenzál a GPC által megvalósított teljesítményszabályozó, de természetesen nem teljesen. Sőt, az így kialakuló melegítés, majd hűtési ciklusok a katód élettartamára is hatással vannak. Ezért az lenne helyes, ha úgy terveznénk meg a melegítési-felfutási előírt pályát, hogy az magát a katód élettartamát is megnyújtja. Ez az optimális pályatervezés alapján valósítható meg, amelynek megfogalmazását, illetve példáját a következőkben mutatjuk be.

\subsection{Az optimális pálya tervezése}

Abban az esetben, ha magát a követendő optimális pályát szeretnénk megtervezni - amely teljesen más feladat, mint az előírt pálya valós időben való követése - a linearizálás módszere értelmét veszti. Hisz ez a feladat a teljes pálya alapján dönti el azt az előírt pályát, amely a választott célfüggvény alapján a legjobb, tehát nem tudunk olyan pontot rögzíteni, amely környezetében érdemes lenne alkalmazni a linearizálás módszerét. Persze, ez már teljesen más feladat, mint maga az irányítás, de legalább annyira fontos, mert megadja a megfogalmazott célnak a legjobb előírt pályát. Amennyiben a folyamat matematikai modellje ismert, akkor könnyen megfogalmazhatók és matematikailag is leírhatók az optimalitást biztosító szükséges feltételek, mint a Hamilton-Jacobi- vagy a Hamilton-Jacobi-Bellman-egyenletek, amelyek megoldására ma már számos numerikus módszer létezik. Mivel az alkalmazott tudományok számos területén növekvő komplexitással találunk nemlineáris, dinamikus, optimális irányítási feladatokat, így az elméleti alapokat követően az utóbbi pár évtizedben számos numerikus algoritmust is kidolgoztak és alkalmaznak, sőt ez ma úgy is tekinthető, mint egy különálló tudo- mányterület. Az 5. ábra szemlélteti a pályaszámítási algoritmusok típusait.

Ezek alapján látható, hogy jelenleg az optimális irányítás mint témakör olyan szoftverek alkalmazását jelenti, amelyek a folytonos idejü, nemlineáris optimális irányítási feladatokat alakítják át numerikusan megoldható feladattá. Kezdve az 1980-as évektől, ezek fő trendje egy nemlineáris programozási feladattá (NLP) való átalakítás, amelyet viszonylag jól tanulmányozott módszerekkel lehetett megoldani. Példaként említhetjük a SNOPT [11], IPOPT [12], valamint KNITRO [13] programkörnyezeteket. Eredetileg ezeknél a csoportosítási módszereknél úgy határozták meg a megoldások időskáláját, hogy azok minden egyenletnél (állapotegyenletek, vezérlőjel-, valamint segédállapot-egyenletek) azonosak legyenek. A konvergencia ezeknek a pontoknak a sürítésével oldható meg. [14], [15]. Újabb kutatások azt bizonyították, hogy a közvetlen ortogonális Gauss-kvadratúra segítségével pedig jó eredmények születnek. Ennek lényege, hogy mi magunk válasszuk meg nemcsak a súlyokat, hanem az abszcisszákat is, ahol egy függvényt meg szeretnénk közelíteni. A Gauss-kvadratúrák előnye az, hogy egy adott egész szám esetében, amely a közelítési tagok számát jelöli, mindig találunk egy rendsúlyzót, valamint ortogonális függvényt úgy, hogy az optimális pálya célfüggvényét megközelítő integrál lehetőleg minél pontosabb legyen.

$$
\int_{-1}^{1} f(x) \cdot d x=\sum_{i=1}^{n} w_{i} \cdot f_{i}(x)
$$

Ezt a módszert használják a Legendre-Gauss, a Legendre-Gauss-Radau, valamint a LegendreGauss-Lobatto elnevezések alatt ismert „pszeudospektrum” név elnevezésű módszere [16]. Természetesen ezeknek a módszereknek akkor van értelme, ha a meghatározandó optimális pálya és a rendszert leíró differenciálegyenletek ezt szükségessé teszik.

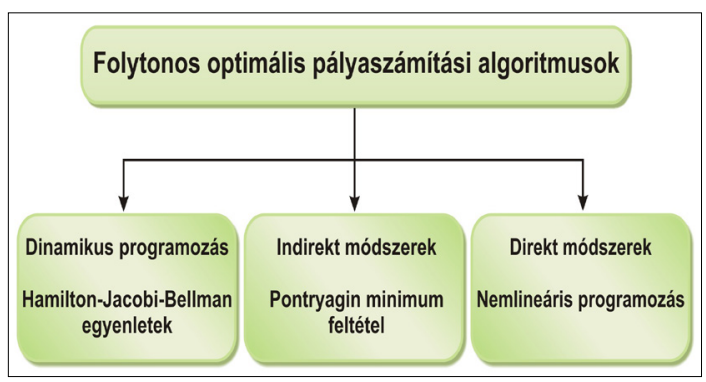

5. ábra. Pályaszámítási algoritmusok 
Az irányítási feladat megfogalmazásához általában a folytonos rendszerekre felírt ismert általános állapotmodellt használunk.

$$
\begin{aligned}
& \frac{d}{d t} \underline{x}(t)=f(\underline{x}(t), \underline{u}(t), t) \\
& \underline{y}(t)=h(\underline{x}(t), \underline{u}(t), t)
\end{aligned}
$$

ahol $\underline{x}(t) \in \Re^{n}$ az állapotok vektora, az $y(t) \in \Re^{p}$ a kimenet, illetve az $\underline{u}(t) \in \Re^{m}$ a vezérlőjel vektora. Azt is fontos kiemelnünk, hogy ezt az optimális irányítást, illetve a megfelelő optimálispálya-kiszámítást arra is lehet használni, hogy az adott rendszer előírt pályáját generáljuk, amely mentén bizonyos előírt feltételeknek felel meg az irányított rendszer. Az általánosan érvényes szabályozási algoritmus kiszámítása csak a nemlineáris karakterisztika közvetlen figyelembevételével lehetséges. A következőkben bemutatunk egy ilyen módszert, amelyek többé-kevésbé iteratív módon meghatározzák a teljes tartományban érvényes vezérlőjelet.

Mindezeket arra alapozzuk, hogy a tanulmányozott dinamikus rendszer optimális irányítása azt jelenti, hogv ez biztosítia a következő

$$
J(\underline{u})=\lambda(\underline{x}(t f))+\int_{t o}^{t f} L(\underline{x}(t), \underline{u}(t), t) d t
$$

célfüggvény minimumát, úgy, hogy a rendszer $\underline{x}(t)$ állapotai, valamint $\underline{u}(t)$ vezérlőjelei egyelőre nincsenek korlátozva, a szabályozási feladat $t_{f}$-időhorizontja pedig le van rögzítve, és a rendszer $\underline{x}\left(t_{f}\right)$ célállapota szabad. Az ismert módszert követve, meghatározzuk a feladathoz rendelt $H(\underline{x}, \underline{u}, \underline{p}, t)$ Hamilton-függvényt, mint:

$H(\underline{x}(t), \underline{u}(t), \underline{p}(t), t)=$

$=L(\underline{x}(t), \underline{u}(t), \underline{p}(t), t)+\underline{p}^{T}(t) \cdot f(\underline{x}(t), \underline{u}(t), t)$

A módszer algoritmusa a következő:

1. A $t \in\left[t_{0}, t_{f}\right]$ intervallumban megválasztunk egy kezdeti közelítést az $u_{0}(t)$ vezérlőjelnek.

2. Használva ezt, kiszámítjuk az állapotegyenletek egy pályáját a $t \epsilon\left[t_{0}, t_{f}\right]$ időintervallumra.

3. Használva a segédállapot-vektor peremfeltételét,

$$
\underline{p}(t f)=\frac{\partial \lambda(\underline{x}(t f))}{\partial \underline{x}}
$$

meghatározzuk a segédállapot egy közelítését időben visszafele integrálva a HJ-egyenleteket.

4. Vizsgáljuk a következő feltétel teljesülését:

$$
\left\|\frac{\partial H}{\partial \underline{u}}\right\|=\int_{0}^{t f}\left[\frac{\partial H}{\partial \underline{u}}\right]^{T}\left[\frac{\partial H}{\partial \underline{u}}\right] d t \leq \varepsilon
$$

5. Amennyiben ez teljesül, akkor megkaptuk az optimális pályát, amennyiben nem, úgy minden időpillanatban elvégezzük a következő korrekciót:

$$
\underline{u}(t)^{\langle k+1\rangle}=\underline{u}(t)^{<k>}-S^{*} \cdot \frac{\partial H(x, p, u, t)}{\partial \underline{u}}
$$

Az iterációt a 2.-es lépéstől folytatjuk.

Ezután az egyetlen kérdés az, hogy milyen célfüggvényt tudunk választani. Gyakorlati megfigyelések bizonyítják, hogy az indirekt fütésű katód élettartamát a primer katód élettartama határozza meg. Amennyiben nem áll elő valamilyen váratlan esemény, úgy ennek a párolgása miatti tömeg-, illetve átmérővesztése alapján lehet ezt az élettartamot számítani. Amennyiben ezt a tömegvesztési értéket $M_{w}<\mathrm{g} / \mathrm{cm}^{2} \cdot s>$ jelöljük, akkor [6] és [9] alapján a becsült $\Delta t$ élettartamot úgy számíthatjuk, mint az az időintervallum, amely alatt $\Delta m$ tömeget veszít a katód. Ekkor felírhatjuk:

$$
\Delta t=\frac{\Delta m}{M_{w}(T) \cdot S_{P K}}=\frac{\gamma_{w} \cdot \Delta V}{M_{w}(T) \cdot \pi \cdot \eta_{i} \cdot(2 r) \cdot l_{P K}}
$$

Ahol $\gamma_{w}=19.5 \mathrm{~g} / \mathrm{cm}^{3}$ a wolfram katódsűrüsége, $l_{P K}<c m>$ a primer katód spirális hossza, illetve feltételezve, hogy a primer katód átmérője $\eta_{i} \cdot(2 r)$ értékről, $\eta_{i+1} \cdot(2 r)$ értékre csökken, akkor:

$$
\Delta V=\frac{\pi}{4} l_{P K} \cdot(2 r)^{2} \cdot\left(\eta_{i}^{2}-\eta_{i+1}^{2}\right)
$$

következik

$$
\Delta t=\frac{\gamma_{w} \cdot(2 r) \cdot\left(\eta_{i}^{2}-\eta_{i+1}^{2}\right)}{4 M_{w}(T) \cdot \eta_{i}}
$$

Mivel az $M_{w}$-tömegvesztés erősen hőmérsékletfüggő (lásd 6. ábra), ezért egyik megoldás az

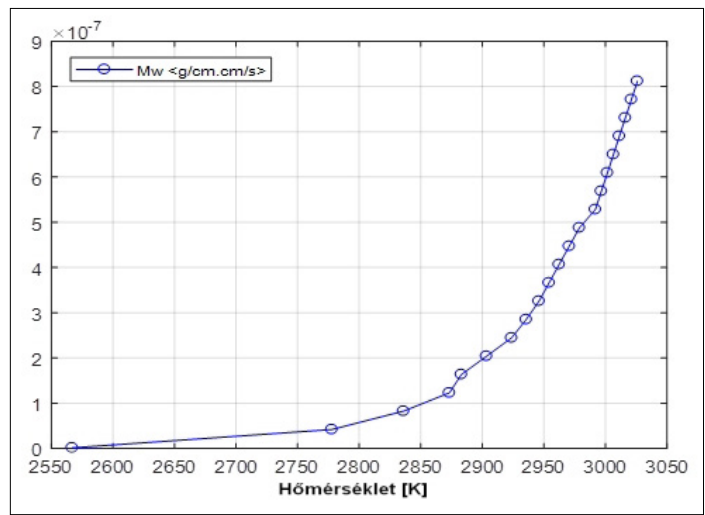

6. ábra. Tömegvesztés a hömérséklet függvényében 
lenne, hogy minden bekapcsolás, megmunkálás esetében egy állandó szabályozott hőmérsékleten kiszámítjuk, hogy hány százaléka párolog el a katódnak, majd ezek összege egy adott időintervallumra kivetítve legyen a legkisebb. Ebből természetesen az a feltétel adódik, hogy lehetőleg tartsuk a legkisebb értéken a katód hőmérsékletét, de úgy, hogy egy adott alsó érték alá ne essen ez.

Egyébként majdnem ugyanezt az eredményt kapjuk feltételezve a következő empirikus eredményt (6. ábra) [8]. Wolfram-direktfütésű hőemissziós katód teljesítménye az $U$-tápfeszültség U1.6-hatványával arányos, a fényerő-kibocsátás U.4-hatványával, illetve az élettartama az U-16-hatványával [10].

\section{Következtetések}

A dolgozat napjaink ismereteinek megfelelően kezel egy az iparban bevált technológiát biztosító megmunkálóberendezést, amely komoly alternatíváját jelenti a lézeres megmunkálásnak. Tekintettel arra, hogy maga a megmunkálás vákuum alatt történik, maga a megmunkálás pontosabb, homogénebb, ellenállóbb, mint a lézeres megmunkálás. Ez az elektronsugaras megmunkálás, amely az elmúlt fél évszázadban bizonyította alkalmasságát a hegesztés, a felületi hőkezelés, a párologtatás, az olvasztás területén, jelenleg az additív anyaggal való 3D-nyomtatás területén hozott jelentős áttörést. Mindezt viszont csak úgy lehet elérni, ha sikerül magát a folyamat paramétereit megfelelően ellenőrizni. Ilyen a katódegyüttes, amely magát a sugáráramot biztosítja. Fontos a megfelelő biztonságos és pontos emissziós felületi hőmérséklet szabályozása, valamint a szaturációs (maximális) sugáráram ismerete, valamint egy olyan üzemmód biztosítása, amely maximális élettartamot biztosít ennek az együttesnek. Adott létező konfiguráció esetében bizonyítottuk, hogy egy adaptív GPC-irányítás, stabil működést tud biztosítani, míg egy kibővített Kálmán-szűrő megfelelő módon tudja biztosítani a katódfelületek hőmérsékletének, valamint a szaturációs sugáráram előzetes becslését, amely biztonságossá teszi a technológiát. A dolgozatban mindezt kiegészítettük egy maximális élettartamot biztosító optimális pályaszámítással, amely az előírt teljesítmény segítségével fejti ki hatását. Mindezt egy CTW 5/60-típusú elektronágyú működésének a javítása érdekében fejlesztettük, amelyet a Sapientia Egyetem keretében újítunk fel.

\section{Szakirodalomi hivatkozások}

[1] Åström K. J., Wittenmark B.: On self-tuning regulators. Automatica, 9. (1973) 185-199.

[2] Keviczky L., Hetthéssy J., Hilger M., Kolostori J.: Self-tuning adaptive control of cement raw material blending. Automatica, 1978.

[3] Methods of Model Based Process Control in Proceedings of the NATO Advanced Study Institute on Methods of Model Based Process Control. Antalya, Turkey, August 7-17, 1994.

[4] Bennett W. R.: Spectra of Quantized Signals. Bell System Technical Journal, 27. (1948) 446-472.

[5] Gray R. M., Neuhoff D. L.: Quantization. IEEE Transactions on Information Theory, IT-44/6. (1998) 2325-2383.

[6] Hinrics C. H., Mackie W. A., Pincosy P. A., Poulsen P.: The Extended Schottky Cathode. IEEE Transactions on Electron Devices, 37/2. (1990) 2575-2580.

[7] Hartman W., Kirkman G., Dominic V., Gundersen M. A.: Super Emissive Self-Heated Cathode for High Power Applications. IEEE Transactions on Electron Devices, 36/4. (1989) 825-826.

[8] Plante E. R., Sessoms A. B.: Vapor Pressure and Heat of Sublimation of Tungsten. Journal of Research of the National Bureau of Standards, Physics and Chemistry, 77A/2. March-April, 1973.

[9] Virag M., Murín J.: Thermal Field Simulation of a Tungsten Filament Lamp Referring to its Lifetime. Journal of Electrical Engineering, 56/ 9-10. (2005) 252-257.

[10] Özbek H., Çil C., Rodoplu A.: Effect of Architecture and Operating Conditions of Vehicle Bulb Lifetime in Automotive. International Journal of Mechanical and Mechatronics Engineering, 13/6. (2019)

[11] Gill P. E., Murray W., Saunders M. A.: SNOPT: An SQP Algorithm for Large Scale Optimization. SIAM Review, 47/1. (2005) 99-131.

[12] Wächter A., Biegler L.T.: On the Implementation of a Primal-Dual Interior Point Filter Line Search Algorithm for Large-Scale Nonlinear Programming. Mathematical Programming, 106. (2006) 25-57. https://doi.org/10.1007/s10107-004-0559-y

[13] Byrd R. H., Nocedal J., Waltz R. A.: Knitro: An Integrated Package for Nonlinear Optimization. In: Di Pillo G., Roma M. (Eds.): Large Scale Optimization, Nonconvex Optimization and Its Applications, 83. (2006) 35-59.

[14] Betts J. T.: Practical methods for optimal control and estimation using nonlinear programming. $2^{\text {nd }}$ edition, 2010, SIAM.

[15] Zhao Y., Tsiotras P.: Density Functions for Mesh Refinement in Numerical Optimal Control. Journal of Guidance, Control and Dynamics, 34/1. (2011). https://doi.org/10.2514/1.45852

[16] Garg D., Patterson M. A., Hager W. W., Rao A. V., Benson D., Huntington G. T.: An overview of three pseudospectral methods for numerical Solution of Optimal Control. Advances in the Astronautical Sciences, 135. 2009. 


\title{
A MÉRNÖKKÉPZÉS OKTATÁSI MÓDSZEREI
}

\section{EDUCATIONAL METHODS OF ENGINEERING TRAINING}

\author{
Bagyinszki Gyula, ${ }^{1}$ Bitay Enikő ${ }^{2}$ \\ ${ }^{1}$ Óbudai Egyetem, Bánki Donát Gépész és Biztonságtechnikai Mérnöki Kar, Budapest, Magyarország, \\ bagyinszki.gyula@bgk.uni-obuda.hu \\ ${ }^{2}$ Sapientia Erdélyi Magyar Tudományegyetem, Marosvásárhelyi Kar, Marosvásárhely, Románia, \\ ebitay@ms.sapientia.ro
}

\begin{abstract}
The choice and the appropriate combination of methods used in the teaching-learning (education - knowledge-acquisition) process in technical higher education depends to a large extent on the personality of the lecturer, his/her pedagogical culture, personal competences and of course, the technical possibilities at his/ her disposal. This study provides a concise overview of the methods as tried-and-tested systems of consciously implemented operations and means that are systematically used by the lecturer to achieve the objectives of training in practical cooperation with the students.
\end{abstract}

Keywords: education, method, lecturer, student.

\section{Összefoglalás}

A műszaki felsőoktatás tanítási-tanulási (képzési-ismeretelsajátítási) folyamatában alkalmazható módszerek megválasztása és célszerű kombinálása nagy mértében függ az oktató személyiségétől, pedagógiai kulturáltságától, személyes kompetenciáitól és természetesen a rendelkezésére álló technikai lehetőségektől. Jelen közlemény a módszerek - mint tudatosan megvalósított műveletek és eszközök kipróbált rendszerei - választékáról nyújt tömör áttekintést, amelyeket az oktató a képzési célok elérése érdekében szisztematikusan alkalmaz(hat), célszerű kooperációban a hallgatókkal.

Kulcsszavak: oktatás, módszer, oktató, hallgató.

\section{Bevezetés}

Ha az oktatók és a hallgatók tevékenységét tekintjük az oktatási folyamatban, a „műveleteik” négy fő csoportját, fajtáját különböztethetjük meg [1]:

a) az oktatók részéről:

- a kész információk szóbeli közlését és/vagy írásos formában való hozzáférhetővé tételét,

- a megismerési problémák megoldási folyamatának irányítását,

- a tudományos, társadalmi, etikai és esztétikai értékek kiemelését,

-a hallgatók gyakorlati tevékenységének szervezését.

b) a hallgatók részéről a felsoroltaknak megfelelően:

- a „kész” tartalmak tanulását és az ismeretek elsajátítását, -a problémák megoldását, az összefüggések feltárását és az itt szerzett ismeretek elsajátítását, - az értékek megismerését és átgondolását,

- a tárgyak alakítását.

\section{Módszerek csoportosítása}

A tanítási-tanulási (képzési-ismeretelsajátítási) folyamatban alkalmazható módszerek egy lehetséges csoportosítása az [1, 2] alapulvételével a következő:

\section{Közlő (szövegen alapuló) módszerek:}

1. előadás

2. tankönyv-, ill. jegyzetfeldolgozás

3. szakirodalom-kutatás

4. vitatkozó módszer

5. kérdező módszer

6. konzultáció 


\section{Szemléltető (megfigyelésen alapuló) mód- szerek:}

1. modellezés

2. szimuláció

3. poszteres, ill. prezentációs feldolgozás

4. vetítés

5. tanulmányi kirándulások, üzem- vagy céglátogatások, ill. szakkiállítások megtekintése

\section{Gyakorlati (tevékenységen alapuló) mód- szerek:}

1. kísérletezés

2. laboratóriumi mérés

3. begyakorlás

4. szakmai, üzemi gyakorlatok

\section{Komplexebb (szintetizáló) módszerek:}

1. programozott (táv)oktatás

2. problémafelvető (projektalapú) oktatás

3. algoritmusoktatás

\section{A felsorolt módszerek jellemzői}

Az előadásra jellemző az oktató kiemelt szerepe és határozottan aktív magatartása az oktatási folyamat megszervezésében és lebonyolításában, a hallgatók „fogyasztói” magatartása mellett.

A tankönyv, illetve jegyzet - mint bemutatással (ábrák, fotók, diagramok, táblázatok) kiegészített „nyomtatott előadás” - kész formában közli a hallgatókkal az elsajátítandó ismereteket. Itt a hallgató a közölt ismeretek „passzív” befogadója.

A szakirodalom-kutatás fontos tényezője az egyre bővülő ismeretanyag adott tanórakeretbe már be nem építhető része feldolgozásának és az önálló tudományos munkára való nevelésnek. A tudományok specializáltsága miatt ennek legjobb lehetőségei az intézményi és online könyvtárakban vannak meg. Például egy jól szervezett szakfolyóirat-gyüjtemény révén a szakterületi információk naprakészen áll(hat)nak az irodalomkutatók rendelkezésére.

A vitatkozó módszer lényege, hogy az oktató felveti a megoldásra váró problémát, és a hallgatók megfogalmazzák azzal kapcsolatos nézeteiket. Az oktató - aki a vita egyik egyenrangú résztvevőjeként kapcsolódik be a foglalkozásba - csak irányító szerepet tölt be. Ez a módszer főként a szemináriumok jellemzője, de más keretek között is alkalmazható.

A kérdező módszer esetében a foglalkozásokat egy megfelelően összeállított kérdéssor segítségével bonyolítják le. A „moderátori” kérdéssor bevezető vagy előkészítő, rávezető és összegző, vagyis a feldolgozott téma összefoglaló és szintetizáló kérdésekből áll(hat).

A konzultációk a hallgatók munkájában való segítségnyújtás tanrenden kívüli formái, az adott tantárgy tanulásával, illetve a tudományág alaposabb megismerésével kapcsolatos tanácsok formájában valósulnak meg. A konzultációk köre és jellege nagyon differenciált lehet. Az alsóbb évfolyamokon a nehezebb tananyagrészek megértéséhez, a felsőbb évfolyamokon viszont már tudományos feladatok (pl. TDK, szakdolgozat, diplomaterv) megoldásához is kérik a hallgatók a konzultációs segítséget.

A modellezés, modellalkotás a tananyag-feldolgozás fontos eszköze, ami tulajdonképpen a kapcsolódó tudományágnak is fő jellemzője. Bonyolult szerkezetek, (szub)mikroszkopikus objektumok és folyamatok, rendkívül rövid ideig tartó jelenségek stb. csak így válhatnak jól követhetőkké, érthetőkké. Természetesen a modellt kellő kritika alá kell vetni „bevezetése” előtt, és meg kell állapítani a valósággal való korrelációjának mértékét. Az ilyen modellek nagy része tárgyiasult formában is megjeleníthető, mint szemléltetőeszköz. A makettek is idesorolhatók, amelyek azonban nem egyszerüsítik, hanem kicsinyített változatban többé-kevésbé leképezik a valóságot.

Példának okáért a geometriai krisztallográfia szemléltetési lehetőségei lehetnek [3]:

- A síkbeli grafikus modellek, amelyek a kristályrácselemeket leggyakrabban kétdimenziós axonometrikus drótváz, húrcsomópont vagy golyóábrákkal szemléltetik. Előnyük az olcsó „előállítás”, a kis helyigény és a nagyfokú mobilitás. De bármilyen szépek és térhatásúak is ezek az ábrák, főleg az összetettebb celláknál és rácsoknál nem áttekinthetőek, és nem mindig adnak egyértelmű választ a térbeli felépítésre, az allotróp átalakulások lehetőségére.

- A térbeli épített modellek (makettek), amelyek az előbbi csoport továbbfejlesztett térbeli változatai. Például ilyenek a gyárilag előállított (rendszerint műanyagból készült) demonstrációs modellek és építőkészletek. Ezek helyettesíthetők „házilag barkácsolt” golyó-drótváz (általában fém, müanyag és fa alapanyagú) vagy ragasztott ping-pong-labda-modellekkel. Előnyük az igényes megjelenés és az, hogy a hallgatók fizikailag is megfoghatják, közelről megnézhetik. Hátrányuk a sérülékenység, a költségesség és az, hogy a hallgató nem tud bármikor hozzáférni.

-A háromdimenziós számítógépes statikus modellek, amelyek ötvözik az előző két csoport tulajdonságait, és a kétdimenziós monitoron 
háromdimenziós objektumokként, felületekként jelennek meg. Nem megfoghatók ugyan, de térben elforgathatók, kicsinyíthetők, nagyíthatók. Nagy előnyük, hogy tetszőleges beállítású kétdimenziós kép menthető el róluk, így az első csoport létrehozásához is felhasználhatók. Adathordozón korlátlanul sokszorosíthatók, hálózaton keresztül is eljuttathatók bárhová, ami nagyfokú „mobilitást” biztosít. Viszonylag kis helyet foglalnak és prezentációkban is felhasználhatók, remek lehetőségeket nyújtva az oktatásban. Hátrányuk, hogy a sok felületelemből álló objektumok renderelése (az a funkció, amikor a megszerkesztett médiát vágásokkal, effektekkel, feliratokkal stb. a kívánt formátumban elkészíti, vagyis kiszámolja a program, majd menti a „végterméket”) esetenként igen erős hardvert igényel.

- A háromdimenziós számítógépes animációk, amelyek a leglátványosabbak, de a legfejlettebb hardver- és szoftverhátteret igénylik. Segítségükkel a legbonyolultabb rácsátalakulások és torzulások is szemléletesen bemutathatók. Szintén „hordozhatók” (pl. pendrive-on, memóriakártyán), bár több tárhelyet foglalnak, mint a statikus modellek.

A szimuláció is egyfajta modell, de tipikusan folyamatokat, tehát nem kiragadott pillanatnyi állapotokat szemléltet. Különösen népszerűek és sokoldalúak a számítógépi szimulációk, melyeknek főbb lépései [4]:

- probléma megfogalmazása, újrafogalmazása (figyelembe veendő tényezők meghatározása, szűkítése-bővítése);

- modellépítés és -fejlesztés (egyszerübbtől haladva a bonyolultabb felé);

- szükséges adatok összegyűjtése (befolyásoló hatásuk mértékének figyelembevételével);

- rendszermodell elkészítése, kódolása (algoritmizálás, programozás);

- ellenőrzés (lépésről lépésre), stabilitásvizsgálat (szélsőséges, illetve gerjesztő paraméterekkel is), értékelés (érvényességi kör, pontosság);

- szimulációs kísérleti vizsgálatsor megtervezése; - szimulációs modell használata, „futtatása”;

- eredmények elemzése, értékelése;

- eredmények dokumentálása, felhasználása.

A poszteres, illetve prezentációs feldolgozás egyegy tananyagegység tömören összefoglalt változata. Szemléltetőerejét az esztétikus, logikus felépítés és a beleszerkesztett ábrák, fotók, diagramok, táblázatok adják. A korszerű témát feldolgozó poszterek (tablók) nemcsak egyszerű szemléltetőeszközök lehetnek a foglalkozások keretében, ha- nem tanszéki dekorációs, illetve kiállítási célokat is szolgálhatnak.

A vetítés módszere magában foglalja a vizuális szemléltetés, illetve a megfelelő eszközök legnagyobb részét. Régebben eszközparkjához az írásvetítő, a diavetítő, a mozgófilmvetítő, a videomagnetofon tartozott. Ezeket együttesen felváltotta a számítógép-projektor kombináció. Ezen módszerrel - célszerúen elkészített médiafájlokkal - lehet a legsokoldalúbb és egyben legnagyobb információsűrűségű szemléltetést (adott időkeretben) biztosítani. Éppen ezért használatakor figyelembe kell venni azt is, hogy ezt a nagy mennyiségü információt nem lehet teljes egészében elsajátítandó tananyagnak tekinteni, hanem célszerű szempontokat adni a lényeg megragadásához.

A tanulmányi kirándulások, üzem- vagy céglátogatások, illetve a szakkiállítások megtekintése is az oktatás szervezeti formái közé tartoznak, és éppen ezért teljes értékű tanulmányi munkának tekintendők. Nem szoríthatók ki teljesen videófelvételek „bevetésével”, hiszen az üzemi légkörről, a térbeli valóságról a legjobb felvételek sem nyújtanak teljesen reális képet, nem beszélve az időbeli tömörítettségükről.

Az [5] közlemény egy olyan - elsősorban hegesztés iránt érdeklődő hallgatóknak, szponzori támogatásokkal szervezett - 15 napos, 6 országot érintő, autóbuszos, nyugat-európai szakmai körútról számol be, amelynek keretében 11 elismert céget (Fronius, Audi, SLV, Oerlikon, Castolin, TWI, Soudometal, RWTH, Cloos, Voest-Alpine, Interweld), illetve azok tevékenységét sikerült „testközelből” megismerni. A sok értékes tapasztalaton és prospektuson kívül kulturális élményekben is gazdagodtak a résztvevők, ugyanis a szakmai programok mellett városnéző túrákra is maradt idő, többek között Salzburg, Ulm, Zürich, Lausanne, Párizs, Versailles, Cambridge, London, Brüszszel, Köln, Frankfurt am Main, Nürnberg, Linz nevezetességeit felkeresve.

A begyakorló foglalkozások és a szakmai, üzemi gyakorlatok főként a manuális készségek (rajzolás, berendezések kezelése, valamilyen tárgyak előállítása, illetve vizsgálata stb.) fejlesztését szolgálják. Amíg a begyakorló foglalkozások iskolai tanmühelyekben (laborokban) kerülnek lebonyolításra, addig a szakmai gyakorlatok vállalatoknál, tehát „élesben” mennek. A műszaki felsőoktatásban különös fontossággal bírnak a tantermi és a laboratóriumi gyakorlati foglalkozások. Egy korábbi [6] közleményünkben ezek szerepéről, funkcióiról, formáiról és tartalmi szerkezetéről már áttekintést adtunk. 
A programozott és a problémafelvető oktatás legfontosabb sajátosságait - összehasonlítva a közlő oktatás jellemzőivel - az 1. táblázat foglalja össze [1, 2].

A programozott (táv)oktatás módszerének célja az oktatási folyamat individualizálása és automatizálása. Lényege maga a távoktatási tananyag, amely egymással logikai és tartalmi összefüggésben álló információadagok sora, amelyet a hallgatóknak el kell sajátítaniuk a megfelelően összeállított, számítógépen futó „tankönyv” segítségével.

A problémafelvető (projektalapú) oktatás a kooperatív, kollaboratív és autonóm tanulás, illetve a tanulói motivációra épülő pedagógiai irányzatok, módszerek szintézise és a tanulási folyamatban a tanulói aktivitás kulcsszerepet játszik, illetve az elsődleges oktatói (tanári) szerepkör is módosul. Az oktató a tradicionális tanári szerepet a koordináló, moderátori szerepre cseréli fel. A megoldandó projektfeladatok (felvetett prob- lémák) megközelítését az interdiszciplinaritás jellemzi.

A tanítás algoritmusa olyan módszeres tanítási eljárás, mely szerint minden egyes lépésnek az egész rendszeren belül olyan meghatározott helye van, hogy bármelyik pontból egy meghatározott döntés alapján minden esetben el lehet jutni a következő oktatási lépéshez.

$\mathrm{Az}$ algoritmusok oktatásának ott van jelentősége, ahol a tanulóknak nagyszámú (gyakran ismeretlen végeredményü) feladatot kell megoldani, és ezen feladatok jó megoldási algoritmusait nem könnyű felfedezni, illetve annak következtében komoly nehézségek támadhatnak az ismeretek elsajátításában.

\section{Következtetés}

A felsőoktatás, azonbelül a mérnökképzés didaktikai, módszertani folyamatát úgy célszerű

\begin{tabular}{|c|c|c|c|}
\hline & $\begin{array}{c}\text { Közlö } \\
\text { oktatás }\end{array}$ & $\begin{array}{l}\text { Programozott } \\
\text { (táv)oktatás }\end{array}$ & $\begin{array}{c}\text { Problémafelvetö (projektalapú) } \\
\text { oktatás }\end{array}$ \\
\hline 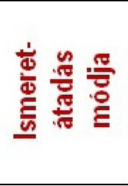 & $\begin{array}{l}\text { A tananyagot az oktató kész } \\
\text { formában adja át. } \\
\text { Elsôsorban a tantervre, ill. a } \\
\text { tematikára figyel és ez „elfedi } \\
\text { szeme elöl" a hallgatókat. }\end{array}$ & $\begin{array}{c}\text { A tananyag közlésének módja } \\
\text { állandó aktivitásra kényszeríti a } \\
\text { hallgatókat. } \\
\text { Maguk a hallgatók állnak az } \\
\text { oktatás középpontjában. }\end{array}$ & $\begin{array}{l}\text { A hallgatók elméleti és gyakorlati } \\
\text { problémák megoldása útján } \\
\text { szerzik az új ismereteket. }\end{array}$ \\
\hline 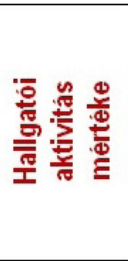 & $\begin{array}{l}\text { A verbális vagy a tankönyv útján } \\
\text { történô közlésben hiányok, } \\
\text { akadályok és nehézségek } \\
\text { merülnek fel, aminek oka többek } \\
\text { között a hallgatók „átmeneti } \\
\text { kikapcsolása” az oktatási } \\
\text { folyamatból. }\end{array}$ & $\begin{array}{c}\text { A tananyag programozása olyan, } \\
\text { hogy nincsenek benne hiányok } \\
\text { és nehézségek. } \\
\text { Az elörehaladáshoz a } \\
\text { hallgatóknak minden akadályt le } \\
\text { kell küzdeniük. }\end{array}$ & $\begin{array}{l}\text { A probléma megoldása során a } \\
\text { hallgatóknak minden akadályt le } \\
\text { kell küzdeniük, aktivitásuk és } \\
\text { önállóságuk itt a legnagyobb. }\end{array}$ \\
\hline 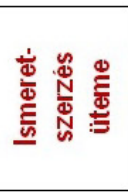 & $\begin{array}{l}\text { A közlés ütemének a jobb, } \\
\text { közepes vagy gyengébb } \\
\text { hallgatókhoz egyaránt } \\
\text { alkalmazkodnia kell. }\end{array}$ & $\begin{array}{l}\text { A tanulás üteme kizárólag a } \\
\text { hallgatóktól függ, hiszen } \\
\text { egyénileg dolgoznak. }\end{array}$ & $\begin{array}{l}\text { A tanulás üteme az egyes } \\
\text { tanulóktól, vagy azok } \\
\text { csoportjaitól (team) függ. } \\
\text { A gyengébb hallgatóknak } \\
\text { elönyös a csoportmunka. }\end{array}$ \\
\hline 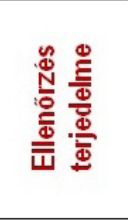 & $\begin{array}{l}\text { Az oktatási eredmények } \\
\text { ellenörzése részleges, nem } \\
\text { szerves része az ismeretek } \\
\text { átadásának. }\end{array}$ & $\begin{array}{c}\text { Az ellenörzés teljes és a tanulás } \\
\text { szerves része. } \\
\text { A hallgatók nem léphetnek } \\
\text { elöbbre anélkül, hogy ne } \\
\text { ellenöriznék, tudják-e a } \\
\text { tananyagot. }\end{array}$ & $\begin{array}{l}\text { A hallgatók nagyobb fokú } \\
\text { aktivitása és a tanulás pozitiv } \\
\text { motivumainak fejlödése } \\
\text { csökkenti a teljes körü ellenörzés } \\
\text { szülkségességét. }\end{array}$ \\
\hline 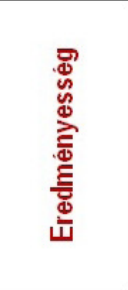 & $\begin{array}{c}\text { Nem lehet százszázalékos } \\
\text { oktatási eredményt biztositani } \\
\text { valamennyi hallgató számára, de } \\
\text { az így szerzett ismereteket a } \\
\text { hallgatók rendszerint } \\
\text { könnyebben alkalmazzák, mint a } \\
\text { programozott (táv)oktatás } \\
\text { esetében. }\end{array}$ & $\begin{array}{c}\text { Tekintettel a rendszeres } \\
\text { ellenörzésre, az oktatás } \\
\text { eredményei jobbak, mint a közlö } \\
\text { oktatásnál, az ismeretek } \\
\text { alkalmazásának képessége } \\
\text { azonban kevésbé jó. }\end{array}$ & $\begin{array}{c}\text { Az oktatás eredményei } \\
\text { viszonylag jók. } \\
\text { A hallgatók sok ismeretet } \\
\text { szereznek, könnyen alkalmazzák } \\
\text { öket új helyzetekben. } \\
\text { Egyúttal fejlödik megismerō } \\
\text { készségük, szakmai } \\
\text { érdeklödésük is. }\end{array}$ \\
\hline
\end{tabular}


irányítani, hogy a hallgatók értsék a képzés célját és saját felelősségüket azok megvalósításában, kialakuljon bennük a pozitív motiváció és az önellenőrzés, illetve ne legyenek a kész ismeretek paszszív fogyasztói, hanem annak aktív teremtőivé is váljanak. Ezért fontos a módszertani eszköztár ismerete és azonbelül a hallgatói aktivitásra alapozó módszerek előtérbe helyezése.

\section{Szakirodalmi hivatkozások}

[1]Okoň W.: Felsőoktatási didaktika. Felsőoktatási Pedagógiai Kutatóközpont, Budapest, 1973.

[2] Kietliňskja Z:: A müszaki felsőoktatás pedagógiája. Felsőoktatási Pedagógiai Kutatóközpont, Budapest, 1974.
[3] Bagyinszki Gy., Tar A.: Anyagok szubmikroszkópikus és makroszkópikus krisztallográfiája. Anyagok Világa (Materials World) - Független Elektronikus Szakmai Folyóirat, 7/2. (2007).

[4] Bagyinszki Gy., Bitay E.: Bevezetés az anyagtechnológiák informatikájába. Erdélyi Múzeum-Egyesület, Kolozsvár, 2007. https://doi.org/10.36242/mtf-03

[5] Bagyinszki Gy.: Fiatal szakemberjelöltek NyugatEurópában. Gép 40/1. (1992) Február, 19-21.

[6] Bagyinszki Gy., Bitay E.: Anyagtudományi gyakorlat-modulok a gépész- és mechatronikai mérnök képzésben. In: Fiatal műszakiak tudományos ülésszaka XVI., Kolozsvár, Románia, Műszaki Tudományos Füzetek 2011. 5-16.

https://doi.org/10.36243/fmtu-2011.04 


\title{
AZ IPAR 4.0 ÉS AZ OKTATÁS KAPCSOLATA ÉS KÖLCSÖNHATÁSA
}

\section{THE RELATIONSHIP AND INTERACTION BETWEEN INDUSTRY 4.0 AND EDUCATION}

\author{
Beke Éva \\ Óbudai Egyetem, Biztonságtudományi Doktori Iskola, Budapest, Magyarország \\ beke.eva@bgk.uni-obuda.hu
}

\begin{abstract}
The effects and results of Industry 4.0 are ubiquitous: in mobile applications and laptops, in sensor-driven technologies, in communication capabilities, in intelligent robots, in smart offices and in cyberspace. In the future, the most sought after skills will not only be technology-related, but there will be a huge demand for creativity, emotional intelligence, critical thinking, and interpersonal skills.

Based on this knowledge, a whole new economic model and a change to the old system will be needed.
\end{abstract}

Keywords: competencies, Industry 4.0, industry expectations.

\section{Összefoglalás}

Az Ipar 4.0 hatásai és eredményei mindenhol jelen vannak: mobilalkalmazásokban és szuperszámítógépekben, szenzorvezérelt technológiákban, kommunikációs képességeikben, intelligens robotokban, okosirodákban és kibertérben. A jövő cégében a leginkább keresett készségek nemcsak a technológiával lesznek kapcsolatosak, hanem hatalmas kereslet lesz a kreativitás, az érzelmi intelligencia, a kritikus gondolkodás és az interperszonális készségekkel rendelkezők iránt.

Ezen ismeretek alapján egy teljesen új gazdasági modellre és a régi rendszer megváltoztatására lesz szükség

Kulcsszavak: készségek, Ipar 4.0, ipari elvárások.

\section{Bevezetés}

A negyedik ipari forradalom érkeztével mindennapossá váltak a robotikai alkalmazások, a felhőalapú számolás, a mesterséges intelligencia, a 3D-nyomtatás és a mindent behálózó szenzorok. Az Ipar 4.0 teremti meg az okos városok és mezőgazdaság alapjait, kiszámíthatóvá teszi a közlekedést, feltárja az eddig ismeretlen vagy veszélyes területeket drónok segítségével [1]. Kialakult egy új szektor: a kibertér, és ezzel együtt törékennyé vált a személyes adatok biztonsága. Felértékelődött a szellemi-intellektuális munkaerő, míg leértékelődött a fizikai erő az iparban. A jelenkori fogyasztói társadalom legfőbb jellemzői közül elsőként kell megemlítenünk, hogy ez - azaz a ne- gyedik - az első olyan ipari-technikai forradalom, amely a nagy tömegek jólétéhez, gazdasági és kulturális felemelkedéséhez vezethet [2]. A polgári demokrácia érvényesülése olyan alapvető emberi jogokban manifesztálódik, mint a választójog, a magasabb képzettség megszerzésének joga és lehetősége és a szociális juttatások. Míg korábban kizárólag a nyersanyagok birtoklása jelentette a gazdasági hatalmat, addig mára általánossá vált a szellemi tőke fölénye és annak felértékelődése, valamint a tanuláshoz-kutatáshoz kapcsolódó ipari előnyök megszerzése. Ehhez társult a határok nélküli áru-, pénz- és munkaerőmozgás, amely az egyes államok gazdasági szuverenitása helyett, mára alapvetően politikait jelent csupán, 
egy globálisan változó és alakuló gazdasági piac mellett [3].

Mint minden új rendszer, az Ipar 4.0 azt is tanította, hogy az emberek, rendszerek és tárgyak közötti kapcsolat bonyolultabb, dinamikusabb és egy valós idejű optimalizált hálózat lesz. Ennek köszönhetően az összeköttetés egy információs struktúrát hoz létre, és az ott gyüjtött adatokat tárolja, csoportosítja egy intelligens, felhőalapú rendszerben, amelyet aztán egy prediktív és automatizált döntéshozatalhoz felhasznál mesterséges intelligencia segítségével. A vállalatok, a gyártási egységek, a kutatási szektorok és a kormányok számos, különböző szinten megvalósítható biztonsági gyakorlatot vezetnek be, például a kiber- és a számítógépes támadások kivédésére, valamint a létesítmények és a személyzet védelmére.

Az ebből, az eredően egyedülálló paradigmából következően nemcsak fejlesztések és vívmányok, hanem zavarok is keletkezhetnek, ami azt jelenti, hogy egy nagy ígéret és nagy veszély kettősségében élünk [4].

\section{Az oktatás feladatai és kihívásai}

A változások elkerülhetetlenné váltak az oktatásban is. A hagyományos, formális oktatási rendszerek nem képesek többé választ adni az okos városok és a kapcsolódó társadalmak legfontosabb elvárásaira. A jelen oktatási rendszerek többsége a 20. századi rendszeren alapul, és figyelmen kí- vül hagyja a 21. századi ipari és munkatrendeket és elvárásokat [5]. Új kompetenciák oktatása, új oktatási modellek és struktúrák bevezetése elkerülhetetlenné vált. Ennek eredményeként a ma használatos készségek és kompetenciák 35\%-a szintén cserélődik, mert ezeknek összhangban kell lennie a mindenkori munkaerő piaci követelményekkel ahhoz, hogy müködő, hatékony gazdaságról beszélhessünk.

A legmodernebb robotikai újítások, a vezető nélküli járművek, az infokommunikációs eszközök és hálózatok jelenléte, a közlekedés megújulása olyan versenyhelyzetet teremt, amelyben a tudásmegszerzésre irányuló törekvéseket is újra kell tervezni. Tanulókat és hallgatókat nem lehet többé a kizárólag lineáristudás-alapú oktatással a jövőre felkészíteni, még kevésbé arra, hogy a robotokkal versenyezzenek [6]. Ezért olyan készségek és kompetenciák előtérbe helyezése és fejlesztése válik szükségessé, amelyre a robotok még nem képesek. Ezek közül a legfontosabbak a kreativitás, a kritikus gondolkodás, valamint az alternatív problémamegoldások és -mérlegelések kérdésköre. A kutatásomban megkeresett vállalatoktól egyebek mellett fontosnak tartottam megkérdezni, hogy milyen javaslataik lennének, hogy még hatékonyabb legyen az ipari-akadémiai oldal együttműködése, valamint arról is, hogy milyen javaslatokat fogalmaznak meg az oktatási struktúra átalakítására. A másik fontos téma az ipar által elvárt és hasznosítható készségek kérdésköre volt. A kérdőíves, feltáró kutatással az a célom,

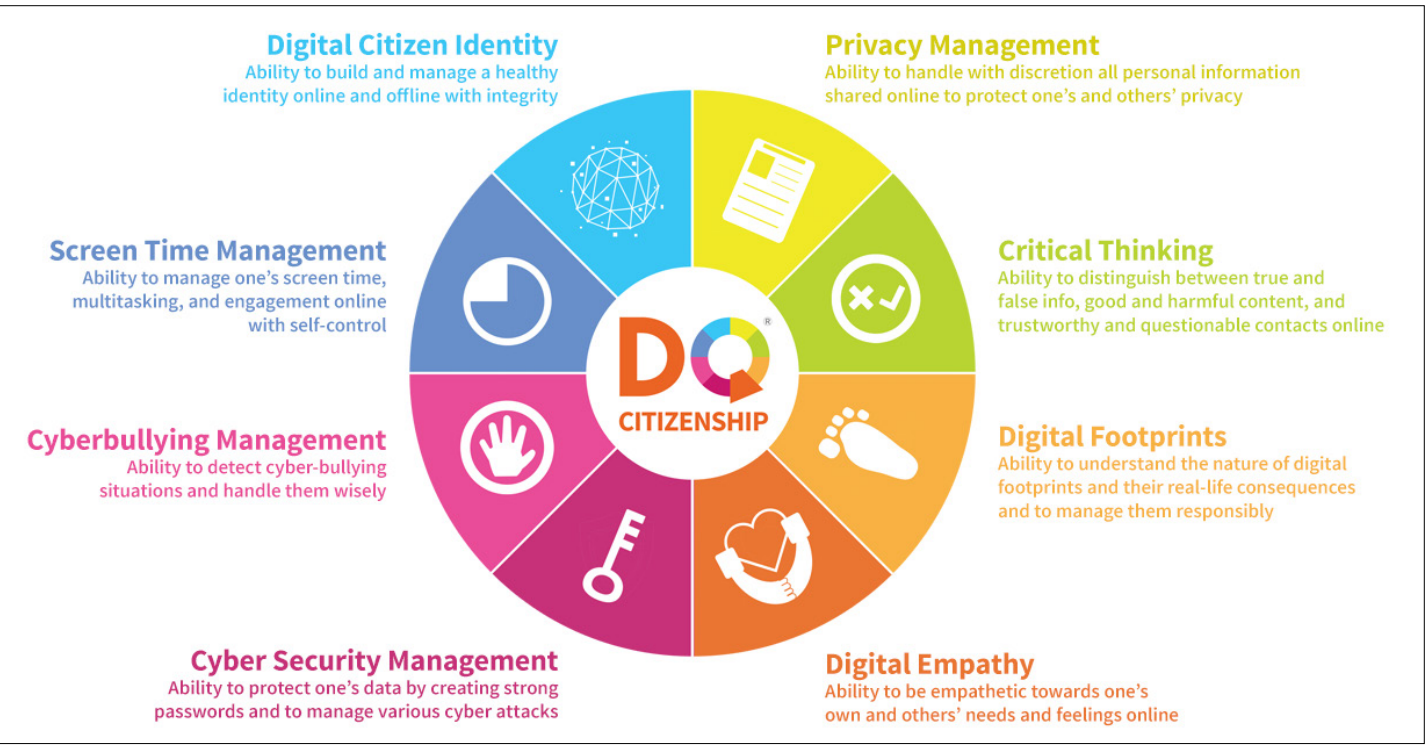

1. ábra. Digitális intelligencia az Oktatás 4.0. korában (World Economic Forum, február, 2020.) 
hogy viszonylag kis elemszámú minta mellett árnyaltabb, mélyebb ismereteket gyüjtsek össze a megkérdezettek véleménye alapján [7]. A résztvevők munkahelyi profiljukat tekintve két csoportra oszthatók: az egyikbe azok tartoznak, akik a cégeiket az Ipar 4.0 jegyében fejlesztik a robotizáció, innováció, a folyamatszervezés modernizálása vagy a leginnovatívabb gépsorok beszerzésével, míg a másik csoport a biztosításhoz kapcsolódik: egyfelől informatikai részről a biztosítási ügyletek ügyviteli és értékesítési folyamatainak támogatására szakosodott vállalkozás, valamint egy biztosítótársaság alkotja. Az első csoport a ma Magyarországon leghúzóbb és befolyását tekintve a legtöbb munkaerőt alkalmazó ipari szektorhoz, a gépiparhoz köthető, akár alkatrészek gyártása, akár a tervezés területéhez kapcsolódóan [8]. A megkérdezettek között 4 nemzetközi cég, míg két közepes méretű, magyar vállalkozás szerepelt.

$\mathrm{Az}$ open-ended question-methodot használtam fel a válaszok kiértékelésére. A válaszadók közül öt „több gyakorlati képzést” vezetne be a felsőoktatási intézményekben, míg három javasolta „céges szakemberek bevonását az oktatásba”. Ketten jelezték, hogy a kikerülő hallgatóknál hiányzik a kommunikációs és prezentációs készség, míg egy-egy esetben került szóba, hogy az „oktatókat kellene kihelyezett projektmunkára” meghívni, bevezetni a „müszaki-matematikai képzést minden területen”, az „elavult képzési tervek” helyett „közös projektmunkákat” és “esettanulmányi versenyeket” hirdetni.

\section{3. Új vállalati-szervezeti modellek}

Nemcsak az akadémiai oldalnak és a kormányoknak, hanem természetesen a vállalatoknak is rugalmasan kell alkalmazkodniuk a 21. századi kihívásokhoz. Gyártási és technológiai szinten éppúgy, mint humán erőforrások tekintetében. A vállalatoknak át kell képezniük a munkavállalóikat, új munka- és szervezeti modelleket kell elfogadniuk, az Ipar 4.0 vívmányait szem előtt tartva, új stratégiai munkaerő-tervezéssel kell foglalkozniuk [9].

Az Ipar 4.0 új típusú kölcsönhatásokat eredményez az emberek és a gépek között - olyanokat, amelyek jelentős hatással lesznek a munka és a szervezeti struktúrák természetére. A gyártási ütemezések növekvő változékonyságának kielégítése érdekében a vállalatoknak olyan új munkamodelleket kell figyelembe venniük, amelyek rugalmas irodai időbeosztást tartalmaznak. Annak érdekében, hogy sikeres legyen az Ipar 4.0, a vállalatoknak új megközelítéseket kell figyelem- be venniük a munkaerő-toborzás és -megtartás területein is [10]. Képességekre és kompetenciákra összpontosító toborzás szükséges, nem pedig fokozatokra és titulusokra épített képesítésekre. Mivel a munkavállalók az alapképzésükhöz nem kapcsolódó feladatok szélesebb körén fognak dolgozni, a toborzóknak gyakran a formális képzés adta tudáson túli készségeket is figyelembe kell venniük, hogy olyan munkaerőt találjanak, akik az adott feladatokhoz szükséges készségekkel rendelkeznek. „Radikálisan eltérő gondolkodásra és platformokra van szükségünk, hogy a képesítések helyett inkább a képességekre összpontosítsunk - az új munkaerőpiacon...” - jegyzi meg Alexander Spermann.

A fenti kutatásokat is figyelembe véve arról is megkérdeztem a cégeket, hogy ők milyen készségek alapján választanak munkaerőt. A válaszadók közül ketten nagyon specifikusan a „gépiparhoz kapcsolódó tudás” alapján, míg másik kettő a „hatékony problémamegoldás” szempontját figyelembe véve választ munkaerőt [11]. A megkérdezettek fele, azaz három cég vallotta, hogy a “csapatmunka”, “kreativitás” és a „változás-menedzsmentkezelés” befolyásolja döntően a választásukat. Ketten érezték fontosnak, hogy a jelentkező rendelkezzen a munkához szükséges lelkesültséggel („drive”), míg egy-egy megkérdezett jelezte, hogy a „lelki kiegyensúlyozottság”, az „alkalmazkodókészség” és a „kritikai gondolkodásmód” játszik abban szerepet, hogy ki lesz a sikeres jelölt. Figyelembe véve a generációk közötti különbségeket, egy válaszadó fontosnak ítélte meg a „vegyes életkort”, míg egy másik ugyanilyen megfontolások alapján az „alkalmazkodóképességet” [12].

\section{Következtetések}

A megváltozott piaci elvárások közepette egyre fontosabbá válik, hogy mind a munkáltatók, mind a piac, illetve a munkahelyek felismerjék az egyén saját legjobb képességeit, és az egységes, szigorúan kötött tanulási folyamatok és rangsorok helyett biztosítsák a nonlineáris oktatási formákat. A régebben megszerzett és fontosnak számító kompetenciákat nem elvetve, hanem azokat beépítve egy új szisztéma bevezetése várható, amely ezeket a régi gyakorlatokat felhasználva újakat tanít, alkalmazkodva a mindenkori, gyorsan változó piaci normatívákhoz. Számos kutatás tárgya a digitális bennszülöttek és a digitális bevándorlók közötti különbségek feltárása. Mára egyre nyilvánvalóbbá válik, hogy a digitális 
bennszülöttek jó része tudja, hogy hogyan használja a legújabb technológiákat, de nem tudják, hogy ezek hogyan támogathatják a tanulási folyamataikat [13]. Távolról sem rendelkeznek annyi tudással és gyakorlattal, mint azt első körben feltételezték, így a legújabb tendenciák igyekeznek a kombinálni és utat engedni a formális és nem formális tanulásnak, e kettő között olyan átmenetet teremteni, amely jövő generációs technikai felkészültséggel rendelkező, ugyanakkor sajátosan emberi készségekkel is ellátott polgárokat neveljen [14].

\section{Köszönetnyilvánítás}

$\mathrm{Az}$ Innovációs és Technológiai Minisztérium ÚNKP-19-1415/38 kódszámú Új Nemzeti Kiválóság Programjának szakmai támogatásával készült.

\section{Szakirodalmi hivatkozások}

[1] Beke É.: Industry 4.0 and its risks in the state administration, corporate and medical sectors. National security review: periodical of the military national security service, 1. (2018) 98-110.

[2] Beke É., Kolnhofer-Derecskei A.: Talent management at Óbuda University focusing on teachers' and students' roles. In: Konferenciaközlemény (FIKUSZ) 2018.

[3] Erol Selim et al: Tangible Industry 4.0: a scenario-based approach to learning for the future of production. Procedia CIRP, 54. (2016) 13-18. https://doi.org/10.1016/j.prcir.2016.05.102

[4] Kopátsy S.: Új Közgazdaságtan. A minöség társadalma. Akadémiai Kiadó, Budapest, 2011.

[5] Dobbins M., Knill C: Higher Education Policies in Central and Eastern Europe: Convergence toward a Common Model. Governance, 22/3. (2009) 397-430.
[6] Benesova A., Tupa J.: Requirements for Education and Qualification of People in Indusrty 4.0. Procedia Manufacturing, 11. (2017) 2195-2200. https://doi.org/10.1016/j.promfg.2017.07.366

[7] Hatum A.: Next-generation talent management. Palgrave MacMillan Publication, Basingstoke, United Kingdom, 2016.

[8] Hecklau F. et al: Requirements for Education and Qualification of People in Indusrty 4.0 - Holistic approach for human resource management in Indusrty 4.0. Procedia CIRP, 54. (2016) 1-6.

[9] Jakab L., Sallai Gy., Kovács K.: A smart city megoldások technológiai háttere és fenntartható komplex modellje. Magyar tudomány, 8. (2017) https://doi.org/10.1556/2065.179.2018.9.4

[10] Kiss D.: A szellemi tőke szerepe a posztindusztriális társadalomban. Journal of Economy and Society, 2-3. (2013) 16-18.

[11] Hartmann E., Bovenschulte M.: Skills Needs Analysis for Industry 4.0 based on roadmaps for smart systems. In: SKOLKOVO Moscow School of Management \& International Labour Organization Global Workshop Proceedings, 2013.

[12] Mulder M.: Conception of professional competence. In: Billett S., Harteis C., Gruber H. (Eds.): International Handbook of Research in Professional and Practice-based Learning. Dordrecht, Springer, 2014. 107-137.

[13] Schwab K.: The Fourth Industrial Revolution. 1. ed. Crown Business, New York, USA, 2018.

[14] Varga J.: A készségek és az oktatás követelményrendszere a tudásalapú társadalomban. Magyar Tudomány, 1. 2018.

https://doi.org/10.1556/2065.179.2018.1.8 


\title{
INNOVÁCIÓ TERVEZÉSE BIZTONSÁGOS TERMÉKEKÉRT
}

\section{INNOVATION DESIGN FOR SAFE PRODUCTS}

\author{
Csongvai Roland, ${ }^{1}$ Torkos Zoltán ${ }^{2}$ \\ Erdélyi Múzeum-Egyesület, Kolozsvár, Románia \\ ${ }^{1}$ csongvai.roland@gmail.com \\ 2z.torkos@upcmail.hu
}

\begin{abstract}
Innovation \& product safety in the case of the EC \& Hungarian SMEs is a top priority, where product safety is also a legal obligation. Despite this, innovation design is dealt with inadequately by the majority of companies, and this is due to lack of knowledge or competency, especially considering the processes related to the design of safe products. Improper behaviour in the design stages results in losses for the companies - losses due to the inadequacy of otherwise innovative products. Inadequate or poorly applied directives/policies, especially when coded into processes influence not only the safety of the products but can result in delays to market access, significantly increasing costs \& development time, as well jeopardising the product's acceptance on the future market.
\end{abstract}

Keywords: innovation, product design, product safety, design, regulation.

\section{Összefoglalás}

Az innováció és termékbiztonság az EU és a Magyar KKV-k esetében kiemelt prioritás, a termékbiztonság pedig még jogszabályi kötelezettség is. Ennek ellenére a cégek nagy része tudáshiány, vagy a megfelelő kompetencia hiánya miatt nem megfelelően kezeli az innováció tervezését, különös tekintettel a biztonságos termékek fejlesztéséhez kapcsolódó folyamataikat, hatalmas károkat okozva ezzel saját maguknak, az egyébként innovatív termékeik hiányosságai miatt. A nem megfelelő, vagy nem jól alkalmazott irányelvek, pláne folyamatokba kódolva, nemcsak a termékek biztonságát befolyásolják, hanem azok piacra jutását is késleltetik, nagymértékben megnövelve a költségeket, a fejlesztési időt, valamint a termékek jövőbeni piaci elfogadottságát alááshatja.

Kulcsszavak: innováció, terméktervezés, termékbiztonság, tervezés, szabályozás.

\section{Bevezetés}

Napjainkban az egyik legfontosabb stratégiai kihívása az Európai Uniónak és hazánknak is az innováció felgyorsítása, hogy az egyes területeken jelentkező lemaradásunkat a világ többi gazdasági szereplőivel szemben le tudjuk dolgozni. Ennek egyik fontos része a KKV-k innovációs képességeinek a javítása, és bővítése. Sajnos a tapasztalatok azt mutatják, hogy a KKV-k nem rendelkeznek a megfelelő tudással az innováció és termékbiztonság területén, és ezáltal hátrányba kerülnek a többnyire nagy nemzetközi cégekkel szemben. Ennek következtében a cégek nagy része tudáshiány vagy a megfelelő kompetencia hiánya miatt nem megfelelően kezeli az innováció tervezését, különös tekintettel a biztonságos termékek fejlesztéséhez kapcsolódó folyamataikat, hatalmas károkat okozva ezzel saját maguknak, az egyébként innovatív termékeik hiányosságai miatt. A nem megfelelő vagy nem jól alkalmazott irányelvek, pláne folyamatokba kódolva, nem csak a termékek biztonságát befolyásolják, hanem azok piacra jutását is késleltetik, nagymértékben meg- 
növelve a költségeket, a fejlesztési időt, valamint a termékek jövőbeni piaci elfogadottságát is alááshatja. Napjainkra nagyon felgyorsultak az innovációs és termékfejlesztési folyamatok, és ennek köszönhetően a hagyományos üzleti folyamatok kiegészültek különböző gyorsító fázisokkal, mint az innováció előtti előkészítő fázis, valamint az ötleteket felismerő/megoldó, előtervezési fázisokkal, amelyeket Peter Koen elsők közt felismert és megfogalmazott, vizualizált (1. ábra).

\section{Az Innováció és termékfejlesztés ha- tékony felépítése, szakaszai és folya- matai}

Az innováció teljes folyamata napjainkra három fő csoportra tagozódott, melyek azonos fontossággal is bírnak egymáshoz képest. Nagyon fontos lett kiváltképp a nem folyamatos fejlesztési ciklussal rendelkező cégek életében az első szakasz az ún. innováció előtti fázis (IEF), mert ennek jó működése teszi igazán hatékonnyá az innovációs folyamat beindulását és sikerét, amit pl. sok start-up sikeresen is alkalmaz rugalmasságuknak köszönhetően. Természetesen hatékony második (termékfejlesztés) és harmadik (piacra juttatás) fázis nélkül sem lesz piacképes és sikeres egy termék. Ebben a tanulmányban az IEF- és a termékfejlesztési fázist szeretnénk áttekinteni a termékbiztonság kontextusában, de nézzük előbb, hogy hogyan épül fel ez a két fázis generalizált formában.

\subsection{FEI Front End of Innovation, avagy Inno- váció Előtti Fázis IEF}

Lássuk mi is az a FEI vagy másképp IEF. A már korábban is említett Peter Koen [1] szerint a legtöbben ezt a Stage Gate ${ }^{\mathrm{TM}}$ 3. kapuja előtti résznek tekintik, ami a PACE [2] szerint az 1-es kapunak

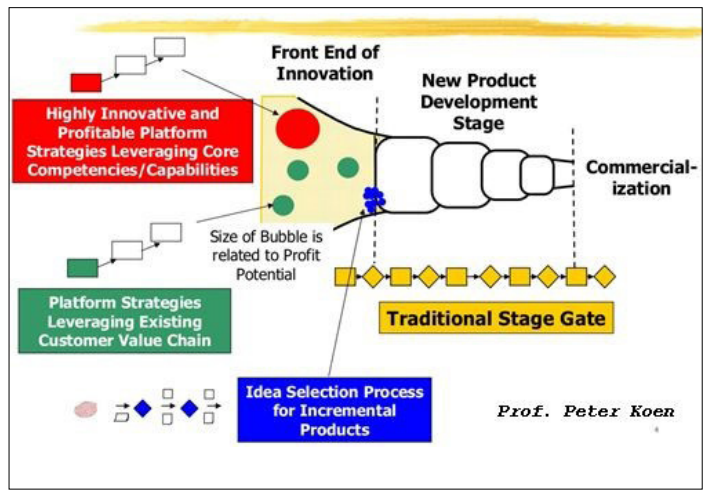

1. ábra. Az innováció teljes folyamata, Peter Koen felel meg, és amelyeket egy kapuval már korábbra sorolnánk mára a felgyorsult fejlesztési és újabb ötletvalidálási megoldások miatt. A IEF magában foglalja az összes olyan folyamatot, amelynek következtében új piacképes (vagy sem) ötleteket lehet generálni. Amely megvalósulhat különböző ötletgeneráló szoftverek, kreatív egyének, (dedikált) K+F csapatok, start-upok inkubációs/akcelerációs fázisának, speciális csoportok, különböző technikák, szakmai csoportok, felhasználói értékelések, úgynevezett konverterek, egyetemek és kutatóintézetek, klaszterek stb. segítségével. (2. ábra) Az IEF bármilyen kreatív lehetőséget magában foglalhat, ami arra ösztönzi az embert, hogy valami újat hozzon létre; a lényege, hogy megragadja a pillanatot, és tudja materializálni az ötletet. Manapság több olyan technika létezik, amely segíti a problémamegoldást, mint a hagyományos csoportos brainstorming vagy az újabb design sprintek készítése, a Design Thinking [3], Lean Start-Up [4], Biomimicry, Platform design, Business Innovation Design Framework stb. A fenti különböző technikák alkalmazása sokat segít az új innovatív ötletek felismerésében és a megoldások keresésében, megvalósításában.

A napjaink sikeres fejlesztései akkor tudnak igazán gyorsak és átütőek lenni, ha az első kapuig sikerül a problémát felismerni, a Perszónát sikeresen azonosítani, és a megoldást is körvonalazni olyan szintig, hogy az első kapu után a PACE szerinti termékfejlesztési folyamat valós koncepció alapján felállt projektcsapattal és kész megvalósítási tervvel indulhasson. Célszerű már ebben a fázisban is figyelembe venni a fejlesztendő termék termékbiztonsági megvalósíthatóságát és ennek kivitelezési lehetőségeit.

\subsection{Termékfejlesztés}

A sikeres cégek többsége a termékfejlesztés klasszikus PACE- [5] vagy a Stage Gate ${ }^{\mathrm{TM}}$ rendszerét illesztik a cég struktúrájához, és ennek segítségével végzik az inkrementális és az inno-

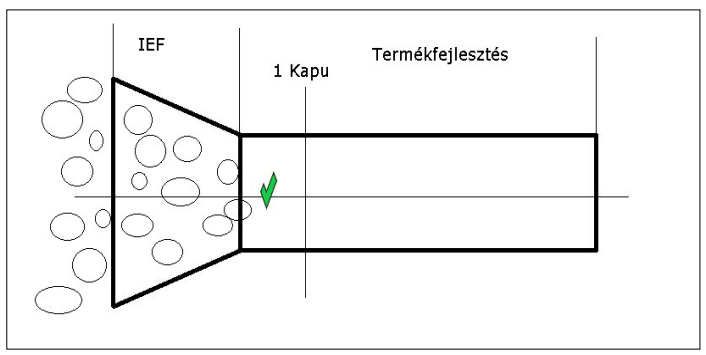

2. ábra. Az innováció első két folyamata, 
vatív termékfejlesztést. Röviden ismertetném a PACE-rendszer lényegét, hogy tisztábban lássuk annak a lehetséges kapcsolódási pontjait a termékbiztonsághoz a fejlesztés korai szakaszában.

A PACE jelentése (Product And Cycle-time Excellence) „Termék- és ciklusidő-kiválóság”, amely a teljes termékfejlesztést fázisokra bontott fejlesztési folyamatokra szakaszolja, minden szakaszt egy kapu bírálattal validálva lásd 3. ábra. A PACE-t használva a cégek nagyon sok felesleges időpazarlástól és költségtől tudják megkímélni magukat, felgyorsítva ezáltal a fejlesztés hatékonyságát és gazdaságosságát. A rendszer hatékony működésének részét kell, hogy képezze a felső vezetés hatékony és elkötelezett részvétele a kapubírálatokon a halaszthatatlan döntéshozás megvalósulása érdekében.

\section{Az innováció és a termékbiztonság korai összefonódása}

Akármilyen furcsa is, de az innovációs folyamat elején a 0 . kapunál egy döntést meg kell meghozni, azaz kategorizálni kell a terméket, hogy az pl. fogyasztási cikk, mint a gépjárművek, mobiltelefonok, stb. Ez nem mond ellent egyik agilis módszertannak sem, sőt azok köztudott magasabb integritásigényükre példa. Az integritáshoz köthető azon tény is, hogy egy terméknek az egyéb attribútumai mellett biztonságosnak kell lennie, erre vonatkozó információval bír a termék kategorizálása.

Maradva példánknál, a biztonság kapcsán kétirányú megközelítés képezi a mindennapi gyakorlatot, hisz a termékhasználók egészségének, biztonságának és gazdasági érdekeinek védelmén túl a termék környezetvédelme is elvárt. [6], [7]

A felhasználók szempontjából ez szükségszerüen nem azt jelenti, hogy a termék használata nem bír(hat) semmilyen kockázattal a felhasználókat illetően. Inkább azt, hogy a termékkel kapcsolatos kockázatok ismertek, és erről a felhasználókat tájékoztatták. Ezen elvárás viszont csak akkor teljesíthető maradéktalanul, ha folyamatosan dokumentált kockázatelemzés zajlik az innovációs tevékenység első lépéseitől. Nyilván ez annak az

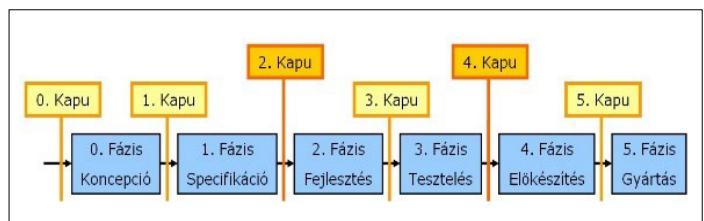

3. ábra. A PACE termékfejlesztési rendszer folyamata egyszerű kérdésnek a megválaszolását jelenti a legeslegelején, hogy a kívánt újítás/fejlődés (innováció) képez-e bármiféle kockázatot az egészségre, biztonságra, gazdasági érdekekre, illetve a környezetvédelemre tekintettel. Erre bináris válasz adható, igen, vagy nem. A „nem tudható” válasz is ,igen”, hisz az annyit tesz, hogy nem ismert egy veszély súlyossága vagy a kitettség mértéke, ami miatt a kockázatelemzés elkerülhetetlen. Azonban a kockázatelemzés szisztematikus kell, hogy legyen, így egyfajta úgynevezett előzetes, kockázatorientált, robusztus rendszertervezési koncepció metamodelljének megalkotása elkerülhetetlen. (4. ábra)

\subsection{Szisztematikus megközelítés}

Az agilis módszertanok, keretrendszerek mindegyike rendelkezik egy metamodellel, amely az abban megjelenő információk, lépések kapcsolatát, ok-okozati struktúráját írja le. Ez az információ az esetek többségében viszont nem publikus, oktatásokon keresztül lehet részben hozzáférni, a kapcsolódó üzleti modell végett.

Ez a fentebb említett tény, azonban óriási kihívást jelent már az első lépések megtételét követően, hisz kezelni kell egy információ-/tudáshiányos állapotot és annak már kezdetben is nagymértékű komplexitását.

Ehhez jön számtalan kezdeti feltételezés a termékkel kapcsolatban, ami majd, ha egyáltalán, a későbbiekben nyer megerősítést. Amelyek valamilyen módon, direkt vagy többszörös áttéten keresztül, de összefüggenek az előzőekkel.

Mindezek mellett a biztonságos termék nem más, mint jól végzett rendszermérnöki munka, ami a terméket felölelő kontextus minden aspektusát kezeli dinamikus módon, tehát nem csak a

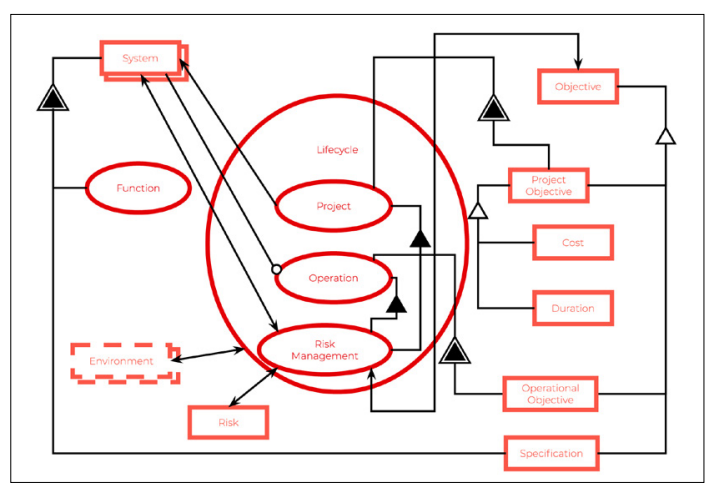

4. ábra. Elózetes kockázatorientált robosztus rendszer tervezési koncepció egy lehetséges metamodellje 
műszaki tartalomra koncentrál. Egyszerű következtetés, hogy a tudáshiány és komplexitás ellenére szükség van a kapcsolati viszonyok, egyszerűen, közérthető nyelven történő feltérképezésére attribútumokon átívelően, amely technikai és nem technikai szempontból is kellően informatív. Ilyen módszert ír le az ISO/PAS 19450:2015 szabvány. [8]

Ennek hiánya csak biztonságtechnikai lencsén keresztül szemlélve is erős kétséget ébreszt a minimális relatív biztonság elvárásait tekintve, illetve egy jól felépített, pl. PACE termékfejlesztési folyamatot feltételezve az új információk kontextusbeli beágyazottságának hiánya, ellentmondás-elemzés nélkül, a projekt megállítását eredményezi.

\section{A Termékbiztonság}

Ez a fajta komplex megközelítés (5., 6. ábra) nem túlzó, hanem minimálisan elvárható, ennek igazolásául tekintsük át az alábbi példát. Egy KKV elektromosjármű-fejlesztése kapcsán a jogi keretrendszerből fakadóan (7. ábra) egyebek mellett az alábbi követelményeket kell, hogy figyelembe vegye.

A piros keretes részek két dologról tájékoztatnak;

(I) „5. cikk”; megfordítja a gépjármű egészére vonatkozó típusmegfelelőség bizonyítási kényszerét, így bármely kétely az engedélyező hatóság részéről a típusjóváhagyás elmaradását eredményezheti [9].

(II) „8. cikk; A szerződésszerűség objektív követelményei

(1) A digitális tartalomnak, illetve a digitális szolgáltatásnak a szerződésszerűség szubjektív követelményei mellett az alábbi követelményeknek is meg kell felelnie:

(a) alkalmasnak kell lennie arra a célra, amelyre az azonos típusú digitális tartalom vagy szolgáltatás szokásosan használatos lenne, figyelembe véve adott esetben a hatályos uniós és tagállami jogszabályokat és múszaki szabványokat, illetve ilyen műszaki szabványok hiányában az alkalmazandó ágazatspecifikus magatartási kódexeket.” [10].

Ez magyarul annyit tesz, hogy a gyártónak az összes elérhető, a tudomány állása szerint innovatív megoldást, tudást alkalmaznia és dokumentálnia kell a termékfejlesztés során, hogy egyebek mellett a biztonságot szavatolja, és ezen erőfeszítéseit igazolni tudja, egy esetleges későbbi jogorvoslati eljárás során is.

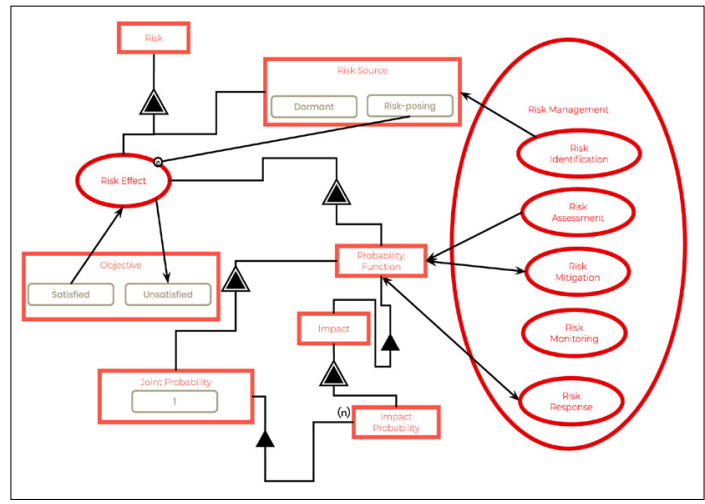

5. ábra. Kockázatkezelés egy lehetséges modellje

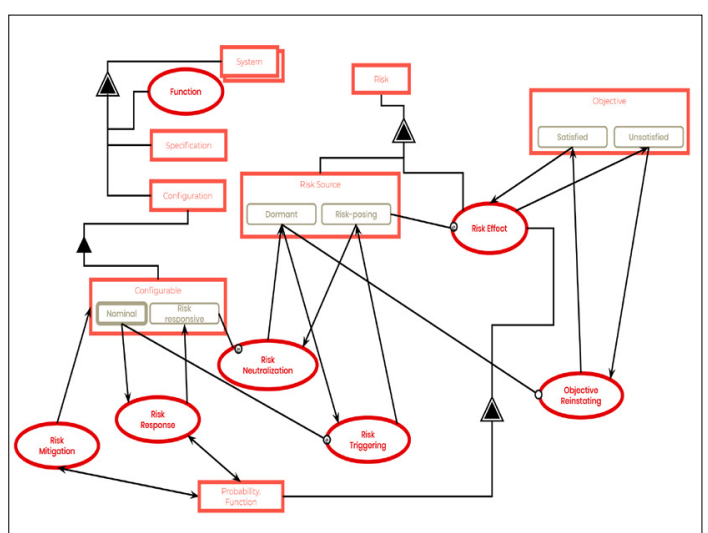

6. ábra. Kockázatkezelés egy lehetséges kifejtett modellje

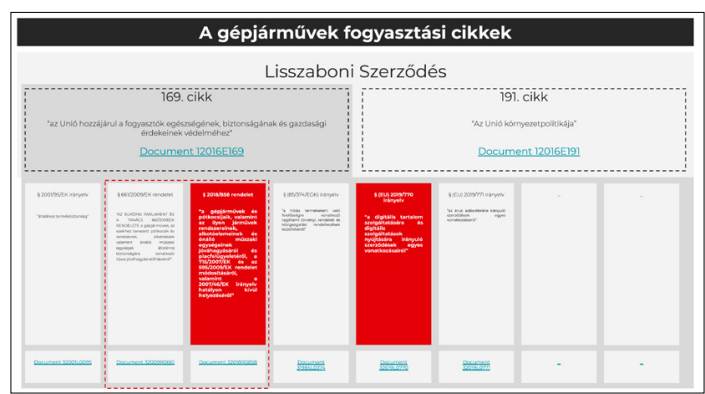

7. ábra. A jogi keretrendszerből fakadó követelmények

Ezen elvárás olyan komplexitással bír, hogy a legnagyobb autómárkák is nehezen birkóznak meg a feladattal, amennyiben ez nem része a kezdetektől a szisztematikus innovációs folyamataiknak, így könnyen belátható, hogy a KKV-k számára pedig csak az az egyetlen út, hogy a kezdetektől pl. a cikkünkben részlegesen bemutatott könnyüszerkezetes, de rendszerezett módon kezeljék az innovációs folyamataikat. 


\section{Következtetések}

Következtetésként levonható, hogy egy KKV csak akkor tud hatékony innovatív termékfejlesztést sikeresen működtetni, ha rendelkezik vagy hajlandó kiépíteni a következő stratégiai tudást a cégen belül:

- termékfejlesztés és termékbiztonság ismerete és cégen belüli szabályozása;

- a termék felhasználási környezetének alapos ismerete;

- vállalaton belüli közös nyelv kialakítása és tudásbázis felépítése;

- alkalmazottak innováció iránti elkötelezettsége és komplexitáskezelési képessége.

\section{Szakirodalmi hivatkozások}

[1] P. Koen P., A. Ajamian, G., Boyce, S., Clamen, A., Fisher, E., Fountoulakis, S., Johnson A., Puri. P., Seibert, R.: Fuzzy-Front End: Effective Methods, Tools and Techniques, PDMA Toolbook for New Product Development, P. Belliveau, A Griffen, S. Sorermeyer, John Wiley and Sons. 2002, 2-35.

[2] McGrath E. M., Anthony T. M., Saphiro R. A.: Product Development: Sucesss Through Product And Cycle-Time Excellence, Butterworth-Heinemann, Newton, 1992, 1-260.

[3] Luchs G. M., Swan K. S., Griffin A.: Design Thinking: new product development essentials from the $P D M A$, John Wiley \& Sons, Hoboken, New Jersey, 2016, 1-431.
[4] Eric Ries: The Lean Statup, Crown Publishing Group, USA, 2011, ISBN 0307887898

[5] McGrath E. M., (revised edition), Setting the PACE in product development: a guide to product and cycle-time excellence, Butterworth-Heinemann, Newton, 1996, 1-184.

[6] Consolidated version of the Treaty on the Functioning of the European Union, Part 3 - Union Policies And Internal Actions Title XV - Consumer Protection, Article 169

http://data.europa.eu/eli/treaty/tfeu_2016/ art_169/oj

[7] Consolidated version of the Treaty on the Functioning of the European Union PART THREE - UNION POLICIES AND INTERNAL ACTIONS TITLE XX - ENVIRONMENT Article 191

http://data.europa.eu/eli/treaty/tfeu_2016/ art_191/oj

[8] ISO/PAS 19450:2015 Automation systems and integration - Object-Process Methodology.

[9] Regulation (EU) 2018/858 of the European Parliament and of the Council of 30 May 2018 on the approval and market surveillance of motor vehicles and their trailers, and of systems, components and separate technical units intended for such vehicles, amending Regulations (EC) No 715/2007 and (EC) No 595/2009 and repealing Directive 2007/46/EC.

http://data.europa.eu/eli/reg/2018/858/oj

[10] Directive (EU) 2019/770 of the European Parliament and of the Council of 20 May 2019 on certain aspects concerning contracts for the supply of digital content and digital services. http://data.europa.eu/eli/dir/2019/770/oj 


\title{
TERMOPOLIMER DARÁLÓEGYSÉG REKONSTRUKCIÓJA ÉS IOT-IRÁNYÍTÁSTECHNIKAI RENDSZER TERVEZÉSE LINUX-ALAPON
}

\section{RECONSTRUCTION OF A GRINDING MACHINE INTENDED FOR THERMO-POLYMERS, AND DESIGN OF A LINUX BASED IOT CONTROL SYSTEM}

\author{
Debreceni Attila, ${ }^{1}$ Erdei Timotei István, ${ }^{2}$ Tóth Szabolcs, ${ }^{3}$ Husi Géza ${ }^{4}$ \\ Debreceni Egyetem, Müszaki Kar, Debrecen, Magyarország \\ 1 adebreceni93@gmail.com \\ 2timoteierdei@eng.unideb.hu \\ ${ }^{3}$ szabolcs978@gmail.com \\ ${ }^{4}$ husigeza@eng.unideb.hu
}

\begin{abstract}
With the increasing use of 3D printing technology, a closely related problem is that of spreading. This problem is the presence of the polymer waste created by faulty prints, and support material used during printing. To create filament from this waste, it must first be chopped into fine pieces. In this project, an original polymer grinder was designed and built, adopting the innovations of Industry 4.0. Remote control and supervision were achieved using a Raspberry Pi I. type B and an Arduino Nano. The finished project can be seen in the faculty of engineering at the University of Debrecen.
\end{abstract}

Keywords: SketchUp make, 3D modelling, gripper, robot.

\section{Összefoglalás}

A 3D-nyomtatás terjedésével párhuzamosan terjed egy probléma, amely a technológiával szoros összefüggésben áll. A probléma nem más, mint a nagy mennyiségű polimer hulladék, amelyek forrása többek között a sérült modellek és a support-anyagok. Ahhoz, hogy a hulladékból szálat lehessen húzni, elsőnek apróbb darabokra kell őket aprítani. A projektben egy egyedi kivitelezésű polimeraprító lett megtervezve és megépítve, amely adaptálja magába a 4. ipari forradalom követelményeit. A távvezérlést és a távfelügyeletet egy Raspberry Pi I. type B és egy Arduino Nano segítségével került megvalósításra. Az elkészült projekt megtalálható a Debreceni Egyetem Müszaki Kar Mechatronika Tanszékén.

Kulcsszavak: ABS, távfelügyelet, távvezérlés, Raspberry Pi, Arduino, Linux, IoT, Industry 4.0.

\section{Bevezetés}

A XXI. század iparát jelentős mértékben befolyásolja az Ipar 4.0 vívmányai. Ezen vívmányok közé tartozik a távvezérlési és a távfelügyeleti rendszerek, melyek legfőbb csatornája az internet.
Az üzembiztos technológiák alkalmazásával kiforrott, az ipar számára is használható távvezérlés és távfelügyeleti rendszert került kidolgozásra, a Debreceni Egyetem Mechatronikai Tanszék, Cyber-Physical \& Intelligent Robot Systems Laboratory-ban [1]. 


\section{A megfelelő technológia kiválasztása}

A Cyber-Physical \& Intelligent Robot Systems Laboratoryban korábban megépítésre került FDM 3D-nyomtató, rendszeres használata során jelentős mennyiségű hulladék keletkezik. Ezek jelentős része a „support”-támaszelemek, de nem elhanyagolható a hibás modellek száma sem, melyek jelentős mennyiségű polimerből épülnek fel. Ezek a meghibásodások több tényezőre is visszavezethetőek, mint például az a tény, hogy az ABS-rétegekből felépített modelleknél gyakori jelenség, hogy jelentős magasságok esetén előfordul a rétegek elválása-repedése. Problémát okozhat a nem megfelelő szálhúzásra vonatkozó beállítások (túl lassú vagy túl gyors). Illetve a heatbed és az extruder rossz hőmérséklet-tartomány megadása.

A hulladékok megjelenésével számításba került egy újrahasznosító rendszer kidolgozása. Az újrahasznosítás két részre bontható. Az első a hulladékok felaprítása, míg a második a már feldarabolt polimerből a szálhúzás. A projekt során az első rész megvalósítása élvezett prioritást.

Az első feladat a megfelelő aprítási technika kiválasztása volt. A választás egy kalapácsos aprítóra [2] esett a következő okokból:

- Az eszköz eredetileg hasonló szakítószilárdságú anyagok zúzására lett tervezve.

- A munkát végző kalapácsok beszerezhetők.

-A motor cserélhető.

- Gép könnyen javítható, bővíthető.

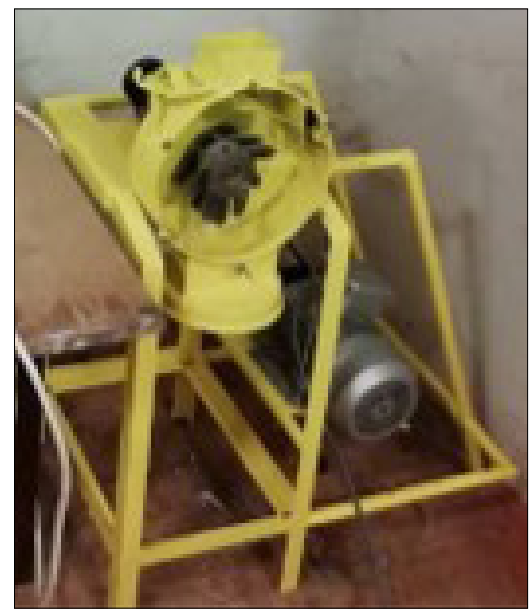

1. ábra. A rekonstruált darálóegység

\section{Az aprító müködésének ismertetése és rekonstrukciója}

A darálótérben a darabolandó anyag a nagy fordulatszámú kalapácsokhoz, majd törőfelülethez, végül a rostafelülethez ütközve aprózódnak fel. A rosta szerepe, hogy csak azok a darabok juthassanak ki a darálótérből, amelyek mérete kisebb, mint a rosta átmérője. Miután a technológia megválasztásra került és a darálóegység beszerzése megtörtént, szükséges volt annak felújítása. Mivel az eszközt korábban már alkalmazták termény darálására és a célból, hogy megfeleljünk a tisztasági követelményeknek a ledarált termopolimer esetén elvégeztük a kötelező tisztítási folyamatokat. A felújított berendezés az 1. ábrán látható.

A polimerdarálóhoz ki kellett választani a megfelelő meghajtást is. A rendelkezésre álló eszközök közül egy Agisys MS 803-4 típusú 3 fázisú 400 [V] feszültségen működő, 1,1 [kW] teljesítményü, 50 [Hz] hálózati frekvencián $1390 \mathrm{~min}^{-1}$ fordulatszámú aszinkron motort [3] lett választva.

\section{A megépített áramkör}

Az áramkörhöz a következő eszközök kerültek kiválasztásra: Raspberry Pi 1 Arduino Nano, 1 kontaktor, 1 TRIAC, 1 optoizolátor, 3 fázisú AC motor, MPU6050 giroszkóp és gyorsulásmérő szenzor.

A 2. ábrán látható áramkör KiCAD-ben került megtervezésre. A kapcsoláson látható hogy a motor vezérlését egy Arduino Nano [4] végzi, amely egy Raspberry Pi 1-re [5] van kötve USB-porton keresztül. A két eszköz soros kommunikáción keresztül küld és kap adatot egymástól. Ezen

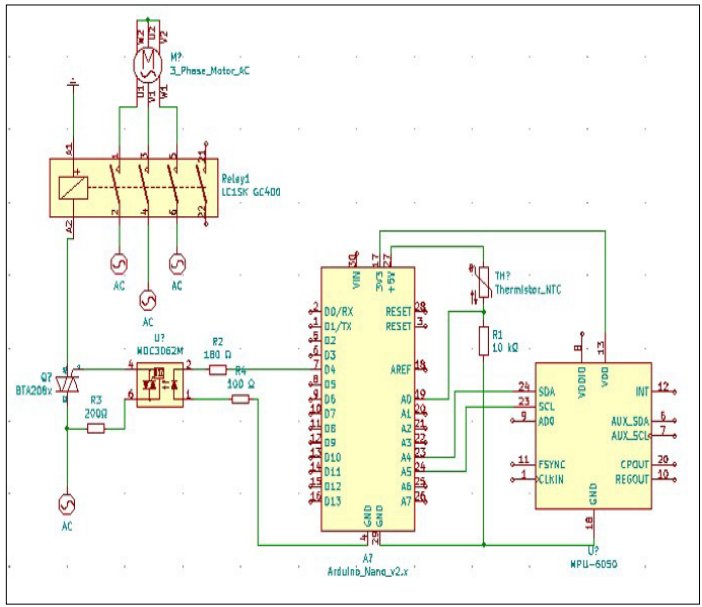

2. ábra. A motort vezérlö elektronika 
kommunikációk révén a jelenlegi gépet lehetséges távolról irányítani, illetve a megvalósított felügyeleti rendszerek esetrén is ezen a porton kommunikál a 2 eszköz. Az Arduino 7-es kimenete MOC3062-jelzésű optoizolátor LED-jét bekapcsolja ezáltal az integrált áramkörön keresztül folyhat a hálózati áram, amely egy TRIAC gate bemenetére van kötve, így a kimenetét a BTA208X TRIAC gate csatlakozójára kötve biztosítja, hogy a „main” termináljain keresztül biztosítani lehessen a kontaktornak a szükséges vezérlőfeszültséget, melyen keresztül a motor megkapja a 3 fázisú 400 V feszültséget közvetlenül a hálózatról.

A motorban található NTC termisztor segítségével lehetséges megállapítani, hogy a motor nem melegedett-e túl, a motor hőmérsékletének az állapotát megjeleníti a weblapon. A kapcsoláson látható még egy MPU6050 gyorsulásmérő és giroszkóp szenzor. A szenzort felhasználva képesek lehetséges rezgéselemzést végezni.

\section{A programozás előkészítése és a táv- vezérlés megvalósítása}

A programozás során öt különböző programnyelvet lett felhasználva, annak érdekében, hogy a lentebb látható folyamatábra kivitelezésre kerülhessen.

A programnyelvek közül PHP-t és a HTML-t, JavaScript könyvtárat, a Python 3, és $\mathrm{C}++$ program-

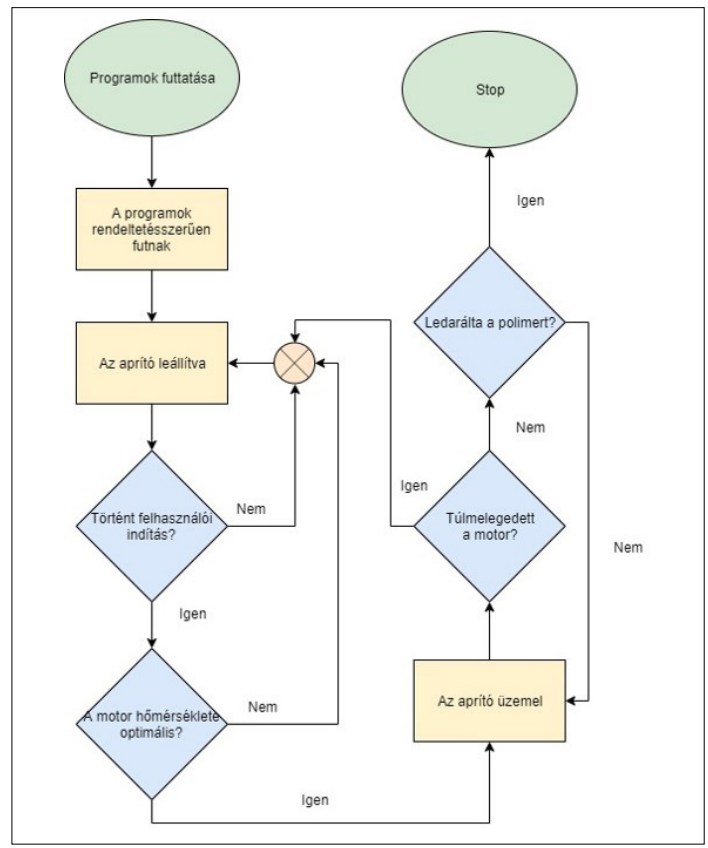

3. ábra. Aprítás folyamatábrája nyelvek kerültek felhasználásra. A PHP és a Python 3 a Raspberryn futó terminál szövegszerkesztőjében a GNU Nano [6] környezetében lett megírva, míg a C++ kódot az Arduino IDE szoftverben.

Mielőtt a programozást elkezdődhetett volna, szükséges volt elvégezni a konfigurációs műveletet a Raspberry Pi eszközön. Az eszközre a Raspbian Lite [7] verzió került feltelepítésre. Az Apache 2 [8] amely egy nyílt forráskódú http webserver. Ahhoz, hogy a php-program kommunikálni tudjon az Arduinóval, szükségünk volt a PhpSerial nevű könyvtár letöltésére. Az MPU6050-szenzor I2C-kommunikációt folytat az Arduinóval, ahol az Arduino a master és az MPU6050 a slave eszköz, az I2C kommunikációt a wire.h library tartalmazza. A programok működésének áttekintését a 3. ábra segíti.

Az elsőnek megvalósított funkció a távoli elérés volt, melynek programja a 4. ábrán látható. Az ezt vezérlő program a Raspberry Pi-on a következő. Elsőnek hozzáadásra került a PhpSerial könyvtár a programhoz, majd megadásra került, hogy melyik porton és milyen baud rate-beállítással csatlakoztattuk az Arduinót. A deviceOpen() parancs indítja a kommunikációt. A weblap tartalmaz két 2 nyomógombot, ezek a nyomógombok küldenek egy „Start” vagy „Stop” parancsot command néven.

Start utasítás esetén soros porton keresztül egy üzenetet küld az Arduinónak, amely tartalma a

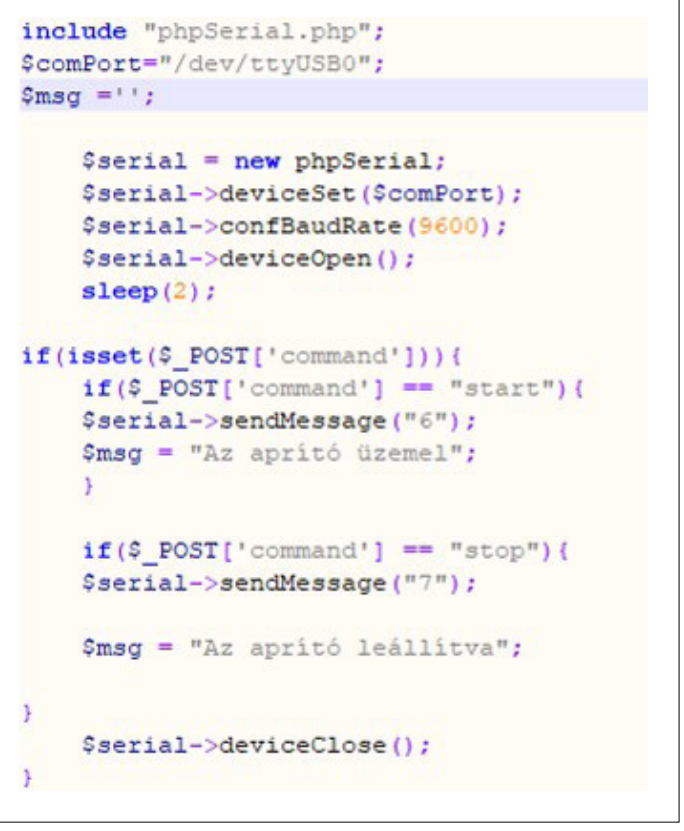

4. ábra. A weblap távvezérlését irányító kód részlet 
„6” és a \$msg változót tartalmát átírja „Az aprító üzemel” üzenetre amely megjelenik a weblapon. Stop utasítás esetén „„” üzenetet küld a soros porton, és a weblapon „Az aprító leállítva” üzenet jelenik meg.

Az Arduino kód Void Loop szakaszában, ha a soros porton információ érkezik az Arduinóhoz, azt az információt hozzárendeljük az incoming_state változóhoz, ha "6" érkezik a pint HIGH állapotba kerül, ami miatt a triacon keresztül a szükséges vezérlőáram eljut a nagy teljesítményű kontaktor tekercséhez, amely így húzni kezd, és így az AC-motor hálózatra lesz kötve, ha nincs túlmelegedve.

$\mathrm{Az}$ indexfájlban került szintén létrehozásra a csúszka, mely 1 és 5 között tud felvenni értékeket 1 egység lépésenként. A felvett értékek továbbításra kerül MotValue néven. A MotValue érték határozza meg, hogy hány percig legyen bekapcsolva a motor. Ez az Arduino kódban a millis függvény segítségével lett megvalósítva, a gombnyomáskor lévő millis érték rögzítésével, melyet követően relatív időmérés valósulhat meg.

\section{A termisztor és a MPU 6050 kezelése}

A motor védelme érdekében elhelyezésre került egy NTC MF52B2 termisztor [9]. Ezen termisztor -50 és +125 Celsius fok közötti tartományban képes a valóságra megközelítőleg igaz adatokkal szolgálni.

Ahogyan az 5. ábrán is megfigyelhető, a termisztor szobahőmérsékleten $100 \mathrm{k} \Omega$ ellenállással rendelkezik. A feszültségosztó kapcsolásban található még egy $10 \mathrm{k} \Omega$-os ellenállás, ezzel a megoldással az analóg 0 csatlakozót felhasználva, mérhető a motor pillanatnyi hőmérséklete.

A feszültségosztóra $5 \mathrm{~V}$ feszültség lett kapcsolva, így az Arduino a mért feszültséget automatikusan egy 0 - 1023 tartományra bontva értelmezi. Ezután a hőmérsékletet a szintén a programban látható Steinhart-Hart-egyenlettel számíthatjuk ki.

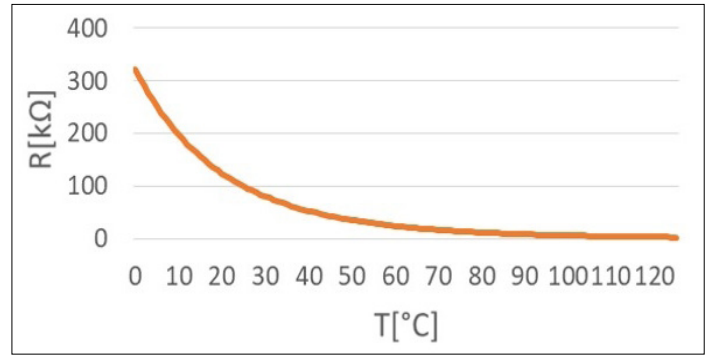

5. ábra. NTC-termisztor ellenállás-hőmérséklet görbéje
Lekérdezésre kerülnek a gyorsulásmérő adatai. Az MPU 6050 egy MEMS-szenzort használ, a mért gyorsulási adatokat mg/LSB formában adja meg. A szenzornak be lehet állítani a mérési tartomány nagyságát, melyek a következők: $\pm 2 \mathrm{~g}, \pm 4 \mathrm{~g}, \pm 8 \mathrm{~g}$, $\pm 16 \mathrm{~g}$. A jelen esetben a $\pm 8 \mathrm{~g}$ tartomány lett használva, ami azt jelenti, hogy összesen 16000 [mg] széles tartományban mér a szenzor, a kimenet 16 bites, így összesen 216 különböző értéket tud felvenni. A mért feszültségértéket és a gyorsulásmérő által mért adatokat az Arduino továbbítja soros porton a Raspberrynek.

A Raspberryn egy, a 6. ábrán látható python 3 szkript került megírásra, amely rögzíti a termisztor és a gyorsulásmérő adatait. Ez a skript automatikus elindul, ha bekapcsoljuk a Raspberryt.

A program soros porton keresztül elsőnek létrehoz egy adatlistát, amely a beérkező adatokat 4 külön csoportba bontja. A csoportok elemeit aszerint választja ki, hogy hányadik sorban érkeznek, ezért arra, hogy a szenzorok mérése definiálásra kerüljön, kell egy get Values() funkció, amely sensor_data néven lementi a soros porton olvasott adatokat a ser.readline paranccsal. A létrehozott 4 elemű adatlista hozzá lett rendelve a 4 számozott data-változóhoz és a for loopnak köszönhetően egyesével lépkedve olvassák le a bejövő csomagokat. A számozatlan data változó a teljes listát

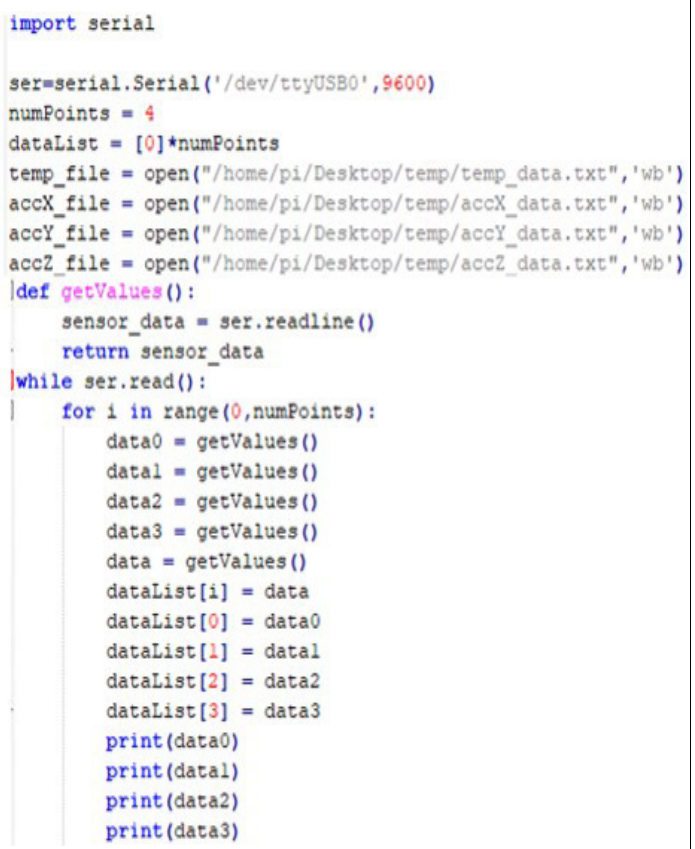

6. ábra. A szenzor adatokat kezelö python program 


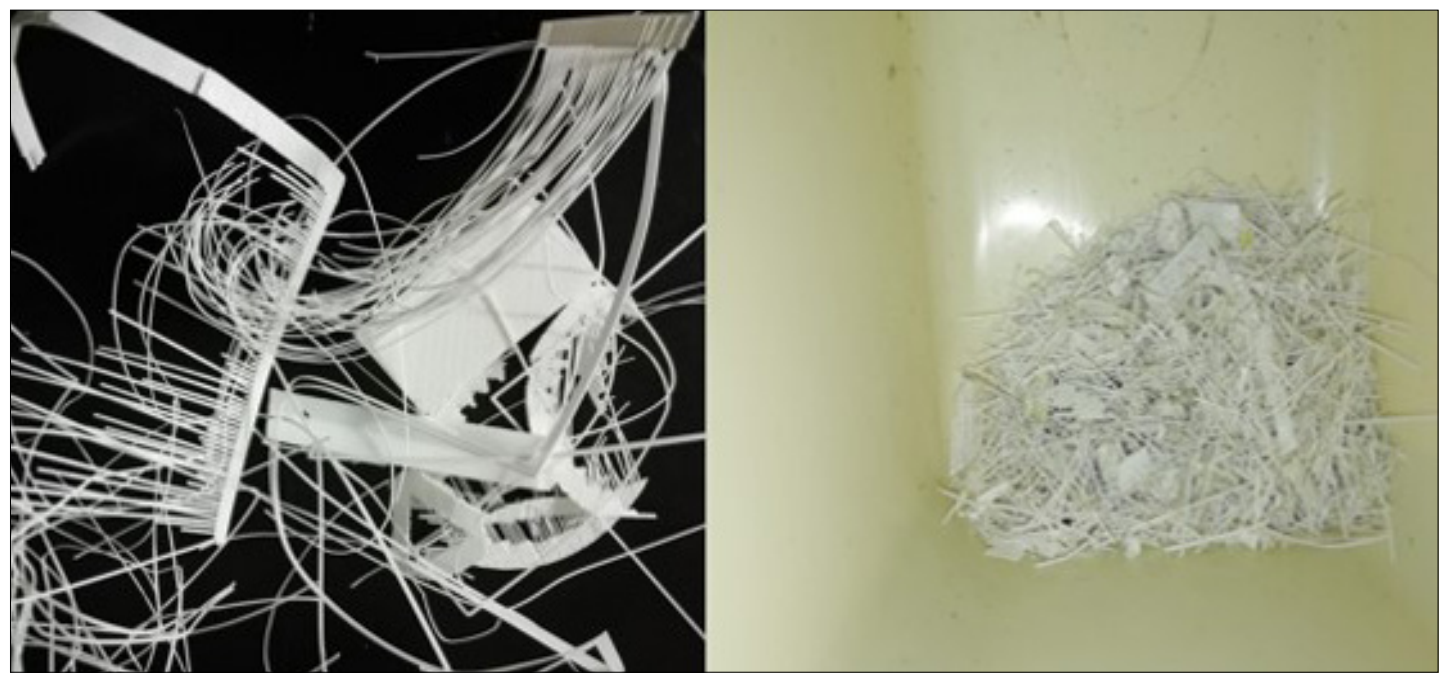

7. ábra. Aprítás eredménye

tartalmazza, amit bármikor lekérdezve látható a teljes lista tartalma, ezzel lehet hibát keresni, ha az adatok összekeverednek.

A külön változókba rendezett adatokat le kell menteni a létrehozott szöveges fájlokba. Ezt a funkciót a .write() és a .flush() paranccsal lehet megtenni. A flush parancsra azért van szükség, hogy a belső pufferből a fájlba közvetlenül ezáltal elkerülhető az adatvesztés, amely akkor történne, ha csak a.write() utasítást lenne használva.

Az eredeti weblap html-kódjához hozzáadva egy javascriptet, és egy php-kód megírásával képesek vagyunk arra, hogy a weblapon megjelenítsünk egy adatot, amely meghatározott időközönként frissül, úgy, hogy a weblapot nem kell újra tölteni.

\section{Ipari ABS aprítása}

A programozási feladatok és a kapcsolás megvalósítása után elvégezésre került egy aprítási teszt. A fent balra látható elemet 2,16 perc alatt aprította össze a gép. Az előre lefektetett minőségi feltételeknek pedig megfelelt a végeredmény. A végső eredmény a 7. ábrán látható.

\section{Következtetések}

A projekt során kitűzött célok teljesültek, és ezek a projektbeszámolóban kifejtésre kerültek. Az aprító rendelkezik távolról vezérléssel, a felügyeleti rendszer beépítése megtörtént, és az aprítási tesztet is sikeresen teljesítette.

\section{Köszönetnyilvánítás}

Ezúton szeretném megköszönni Husi Géza segítőkész hozzáállását, aki bármilyen probléma felmerülése esetén segítségemre sietett. Emellett megköszönöm a Debreceni Egyetem Műszaki Karának a szükséges feltételek biztosítását a projekt elkészültéhez. A kutatást a Debreceni Egyetem Informatikai Tudományok Doktori Iskola támogatta.

\section{Szakirodalmi hivatkozások}

[1] T. I. Erdei, Zs. Molnár, N. C. Obinna, G. Husi: Cyber physical systems in mechatronic research centre. MATEC Web Conf. Volume 126, 2017.

[2] Kacz K.: Aprítógépek (darálók) felépitése, müködése. In: Állattartás műszaki ismeretei. (2011) (2019.11.20).

https://www.tankonyvtar.hu/hu/tartalom/tamop425/0010_1A_Book_14_Az_allattartasi_muszaki_ismeretek/ch04s02.html

[3] Agisys MS 803-4 (2019.11.21)

https://agisys.hu/up/docs/agisys-motor-katalogus. pdf

[4] Arduino Nano (2019.11.21)

https://www.arduino.cc/en/Guide/ArduinoNano

[5] Raspberry Pi 1 Model B+ (2019.11.23)

https://malnapc.hu/raspberry-pi-1-model-b

[6] GNU Nano (2019.10.20)

https://www.nano-editor.org/

[7] Raspbian Lite (2019.11.23)

https://www.raspberrypi.org/downloads/raspbian/

[8] Apache 2 HTTP Server (2019.11.23)

https://httpd.apache.org/

[9] Specifications for NTC Thermistor (2019.11.25) https://www.tme.com/Document/f9d2f5e38227fc1c7d979e546ff51768/NTCM-100K-B3950.pdf. 


\title{
MƯANYAGOK SZAKÍTÓSZILÁRDSÁGÁNAK VIZSGÁLATÁRA ALKALMAS BERENDEZÉS TERVEZÉSE ÉS KIVITELEZÉSE
}

\section{DESIGN AND IMPLEMENTATION OF A TENSILE TESTING MACHINE}

\author{
Fábián Hunor, ${ }^{1}$ Gergely Attila ${ }^{2}$ \\ ${ }^{1}$ Sapientia Erdélyi Magyar Tudományegyetem, Marosvásárhelyi Kar, Mechatronika Szak, Marosvásárhely, \\ Románia, fabianhunor2@gmail.com \\ ${ }^{2}$ Sapientia Erdélyi Magyar Tudományegyetem, Marosvásárhelyi Kar, Gépészmérnöki Tanszék, Marosvá- \\ sárhely, Románia, agergely@ms.sapientia.ro
}

\begin{abstract}
The aim of this paper is to present the design and manufacturing process of a tensile testing machine capable of measuring the tensile strength of polymeric materials. The structure of the instrument is similar to that used in the industry; however, it is budget friendly. The instrument consists of a frame, and two screws which are driven by two stepper motors. An Arduino is used to control the mechanical part of the instrument and to connect it to the software.
\end{abstract}

Keywords: tensile properties, elongation, design, polymer, control.

\section{Összefoglalás}

A dolgozat célja egy, a polimerek uniaxiális szakítóvizsgálatára alkalmas berendezés tervezése és kivitelezése. A berendezés felépítése az iparban használt szakítógépek felépítéséhez hasonló, viszont egy költséghatékony megvalósítás. A berendezés felépítésében helyet kapott egy váz, két csavarorsó, melyek léptetőmotorokkal vannak meghajtva. A mechanikus részt egy Arduino egység vezérli és kapcsolja a számítógépen található kezelői felülethez.

Kulcsszavak: szakitószilárdság, megnyúlás, tervezés, polimer, vezérlés.

\section{Bevezetés}

A szakítóvizsgálatot mint anyagtudományi eljárást elsők között Leonardo Da Vinci végezte el, amelyet mai értelemben is nevezhetünk szakítóvizsgálatnak, hiszen számszerüen meghatározhatta az általa vizsgált huzal teherbírását. Maga az eljárás egyszerű volt: egy huzal végére egy kosarat erősített, amelybe homokot engedett, amíg az el nem szakadt. A mai tesztberendezéseknek az elve is ugyanaz, addig terhelik a próbatestet, amíg az tönkre nem megy. [1, 2]

A szakítóvizsgálat lényege, hogy meg tudjuk határozni az anyagok rugalmasságát, alakváltozó képességét, szilárdságát, anyagi mérőszámát, ezen tudás ismerete elengedhetetlen egy mérnök számára, aki egy új alkatrészt szeretne tervezni. [2]

A szakítószilárdság az anyagnak csak az állandó terheléssel szembeni szilárdságára ad rálátást, dinamikus igénybevétel esetén jóval kisebb erőnek tud ellenállni. A szakítószilárdságot a hőmérséklet növekedésével, általában csökkenő tendenciát mutat. A szakítóvizsgálat megállapítására az adott anyagból szabvány szerint elkészített próbatesten statikus szakítóvizsgálatot végzünk, ami azt jelenti, hogy lassan növeljük a húzóerőt, és közben a berendezés felveszi a feszültség-alakváltozás diagramját. A próbatest állandó terhelése közben két fontos feszültséget veszünk figyelembe: [3] 
- Folyáshatár $\left(R_{e}\right)$ - melyet a darab maradandó alakváltozás nélkül elvisel.

- Szakítószilárdság $\left(R_{m}\right)$ - törés nélkül kibírt legnagyobb feszültség.

A szakítóvizsgálat hitelességét és pontosságát maga a tesztberendezés határozza meg. Az iparban erre a célra használt legelterjedtebb gépek egy tengely mentén terhelik a munkadarabot. Ugyancsak ezen az elven müködik az általam tervezett és kivitelezett berendezés is, amely tartalmaz egy vázszerkezetet. Ez egyben biztosítja az egy tengely mentén történő elmozdulást és megfelelően masszív a berendezésre ható erők legyőzésére, két befogószerkezetet, amely segítségével rögzíteni lehet a próbatestet, egy erőmérő szenzort, egy elektromechanikus hajtást, amely a próbatestre ható terhelő erőt szolgáltatja, és nem utolsósorban egy vezérlést.

\section{A szakítógép bemutatása}

\subsection{A tervezési feladat bemenő adatai}

A tervezett berendezés müködésének elve nagyban hasonlít az iparban használatos szakítógépek működési elvéhez. A cél a berendezés megvalósításával az, hogy a Sapientia Erdélyi Magyar Tudományegyetem Marosvásárhelyi Karának Polimer laboratóriumi eszköztárát bővítse.

A tesztberendezés tervezésének alapjául a polietilén-tereftalát (PET) műanyag szakítószilárdsága szolgált. [4] Ez az érték az ISO-527-1 alapján fröccsöntési eljárással előállított, és $40 \mathrm{~mm}^{2}$ keresztmetszetű próbatesten 132 MPa. A szakításhoz szükséges húzóerő kiszámítható a keresztmetszet és a szakítószilárdság szorzataként, ami $5280 \mathrm{~N}$. Egy 1.2-es biztonsági tényezővel beszorozva határozható meg a gép által maximálisan kifejtetendő erő nagysága, 6336 N. 6500 N-ra történt a kerekítés. A meghajtás elektromechanikusan van kivitelezve, ami két léptetőmotorból és két csavarorsós erőátvitelből épül fel. Ebből következik, hogy a végső erőnek csak a fele terheli az egyik motort és csavarorsót, ezért egyszerü csavarorsós emelőre redukálódtak a számítások.

\subsection{A gép felépítése}

\subsubsection{Vázszerkezet}

A gép alapját egy $15 \mathrm{~mm}$ vastag OL50-anyagú lemez alkotja, amelyre két $20 \mathrm{~mm}$ átmérőjü rozsdamentes acélrúd van rögzítve. Az acélrudakon két lineáris csapágy kapott helyet, amelyek az egy tengely mentén történő elmozdulást biztosítják.

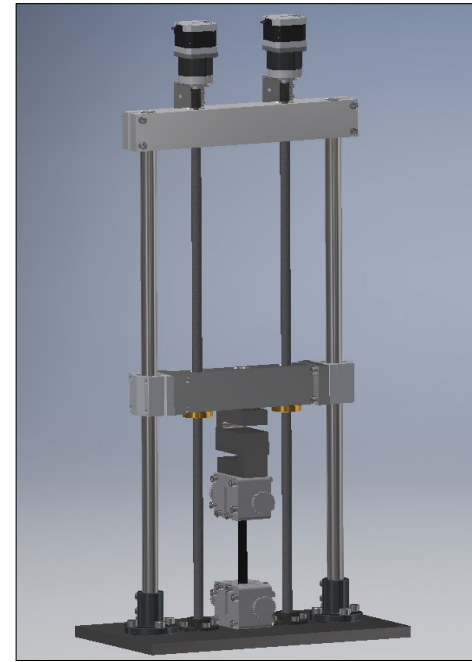

1. ábra. A tervezett szakítógép $3 D$ modellje

Ezáltal a tartórudak egyszerre több szerepet is betöltenek, tartják a motorokat, ezáltal felveszik az erőt, és megvezetik a középen elhelyezkedő mozgó keresztszánt. Fent található egy 6061-es típusú alumíniumból készült kötődarab, amelyen elhelyezkednek a motorok, és tartalmazza a csavarorsók csapágyazását.

\subsubsection{Csavarorsók}

A fentiekben megadott maximális erő értékéből kiszámítható a minimális orsó magátmérő, ez 6500 $\mathrm{N}$ felével egyenlő. Az orsó anyaga OLC45.

Az orsó magátmérőjének meghatározása:

$$
d_{2} \geq \sqrt{\frac{F}{\pi * \psi_{H} * \psi_{m} * \sigma_{m e g}}}=7,54 \mathrm{~mm}
$$

A képletben szereplő mennyiségek értelme a következő:

$\sigma_{m e g}-$ folyáshatár acél-bronz esetén,

$F$ - erő,

$d_{2}$ - mag átmérő,

$\Psi_{H}$ - csavarorsó menetprofil-magassági tényező, $\Psi_{m}$ - anya magassági tényezője.

Ezek az adatok következtében egy Tr12x3 trapézmenetes orsóra került a választás, ami $8 \mathrm{~mm}$-es magátmérővel rendelkezik, és hozzá bronzból készült anyák, az optimálisabb súrlódás érdekében

\subsubsection{Hajtás}

A berendezés működtetését két Nema 17-es léptetőmotor végzi, melyek egy i= 13,7 áttételi arányú fordulatszámcsökkentővel hajtják az orsókat [5]. Az erő értékéből és az orsó adataiból kiszámítható a szükséges forgatónyomaték értéke. 
A kívánt erő kifejtéséhez szükséges forgatónyomaték:

$M_{f}=F * \frac{d_{2}}{2} * \operatorname{tg}(\propto+\rho)=2.95 \mathrm{Nm}$

A képletben szereplő mennyiségek értelme a következő:

$M_{f} \quad$ - forgatónyomaték.

F - erő,

$d_{2} \quad$ - középátmérő.

a - trapézmenet dőlésszöge.

$\rho \quad$ - redukált súrlódási szög. [6]

A léptetőmotor folyamatos forgatónyomatéka $3 \mathrm{Nm}$, és pillanatnyilag $5 \mathrm{Nm}$-t is le tud adni, ezért erre esett a választás ebből a szempontból is. Másik és egyben fontosabb szempont a vezérlés részéről volt meghatározó, hisz a megnyúlás mérésére nem alkalmazunk külön szenzort, hanem programból figyeljük, vagyis a motor által megtett lépések számával egyenlő a megnyúlás, figyelembe véve az orsó menetemelkedését és a fordulatszám-csökkentő áttételi arányát. A motor 200 lépés megtétele után tesz meg egy teljes kört, az áttételi arány 13,7 és a menet emelkedése $3 \mathrm{~mm}$. Ezek segítségével megkapjuk, hogy 913 lépés megtétele után halad 1 mm-t a középső szán.

\subsubsection{Befogószerkezetek}

A próbatest úgy van kialakítva hogy a két szélén jóval szélesebb, ezt a méretet az ISO-527-1 írja elő, ami ebben az esetben $20 \mathrm{~mm}$. Erre a méretre lett tervezve a befogószerkezet, két mozgó pofával rendelkező csavarorsós satu. A satuk 6061-es típusú alumíniumból készültek CNC-vezérlésű marógépen.

A befogószerkezet (2. ábra.) három főbb alegységből tevődik össze, a külső szerkezetből, amely M6-os csavarokkal van összefogatva és két mozgó pofából, amelyek összeszorítják a próbatest szélét.

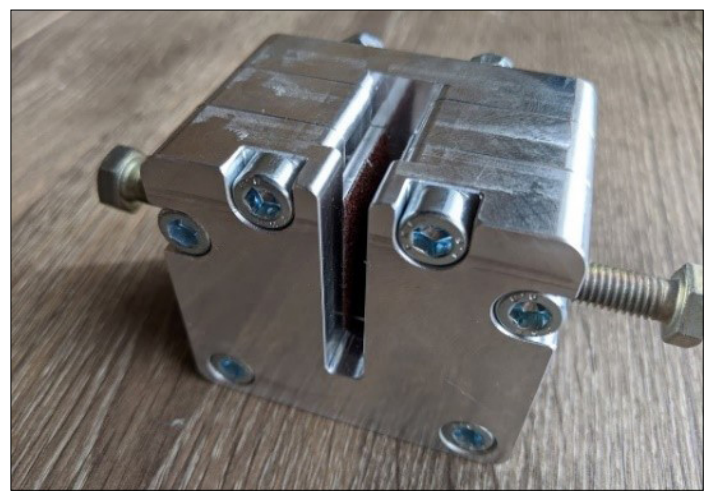

2. ábra. A befogószerkezet
A pofák felületére 80-as érdességű csiszolópapír van ragasztva, amely növeli a súrlódást a darab és a pofák közt. Két M8-as csavar a pofák mozgatását hivatott megoldani. A pofákban radiál-axiál csapágyak kaptak helyet, ezek felveszik a tengelyirányú erőket. A ház két szélébe M8-as menet van kialakítva.

\subsubsection{Csapágyazás}

A berendezésben két fajta csapágy kapott helyet, az első típus a lineáris csapágy, amely a megvezetőrudakon található, és lehetővé teszi a középső szán haladását. Ez golyós lineáris csapágy, amit az iparban előszeretettel használnak, egyszerűsége és költséghatékonysága miatt. Könnyen szerelhető, ebben az esetben M6-os csavarokkal van a középső szánhoz rögzítve. A másik típusú csapágy az axiál-radiál csapágy (3. ábra). Erre a típusra az orsóknál és a befogószerkezeteknél volt szükség, hiszen a csavarorsó által kifejtett húzó igénybevételnek és a pofákra ható szorítóerőnek is ellen kell, hogy álljanak. Az orsók esetében SKF-típusú golyós axiál-radiál csapágyak vannak használva 8 mm-es belső és 24 mm-es külső átmérővel, nem találtunk a piacon erre a típusú csapágyra gyártott csapágyházat, így a felső összekötő alumínium részében alakítottunk ki két csapágyházat. A szorítópofáknál ugyancsak SKF-típusú axiál-radiál csapágyak vannak alkalmazva, $4 \mathrm{~mm}$-es belső, illetve 13 mm-es külső átmerővel rendelkeznek. Ebben az esetben nem volt szükség külön csapágyházak alkalmazására, mivel magába a pofákba volt kialakítva a helyük, és a csavarosok is csapágyméretre vannak esztergálva.

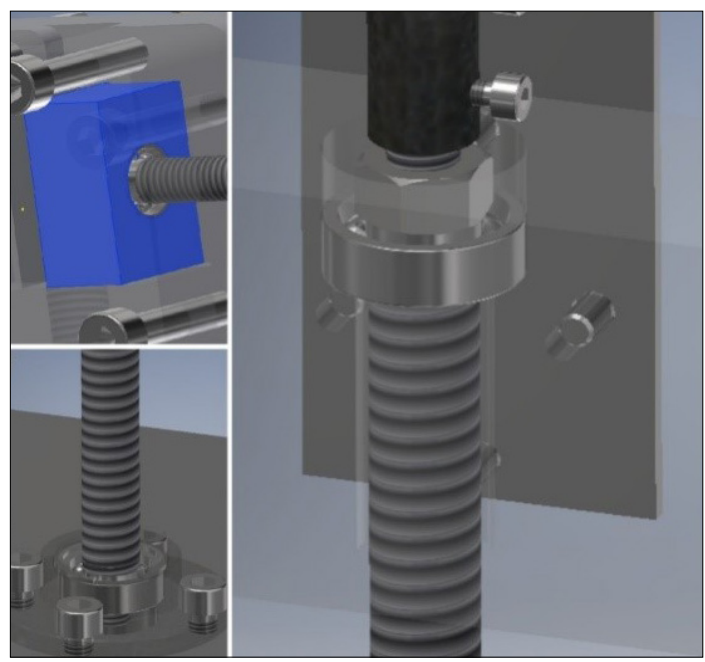

3. ábra. Radiál-axiál csapágyak,csapágyházastól 


\subsubsection{Erőmérő cella}

A próbatest elszakításához szükséges erő nagyságát egy STA-3-típusú analóg erőcella méri, melynek teherbírása $1000 \mathrm{~kg}$. [7] Ez a cella analóg jelet, vagyis feszültséget állít elő, amely egyenesen arányos az általa mért erő nagyságával. A cella által kibocsátott feszültség értéke $0-2 \mathrm{~V}$ között mozog. A tápellátását egy 12 voltos egyenáramú táp szolgáltatja. A befogószerkezet és a középső mozgószán között foglal majd helyet, és két darab M12-es csavarral lesz rögzítve a befogóhoz is, és a szánhoz is. Az általa kibocsátott feszültség értékét egy programozható mikrokontroller dolgozza fel, amely ebben az esetben egy Arduino Mega 2560.[8]

\subsubsection{Vezérlés}

A léptetőmotorok vezérlését egy DM33T-típusú digitális léptetőmotor-vezérlő végzi, amelyet a fentebb említett programozható mikrokontroller irányít. Az Arduinóban írt program utasításokat hajt végre, így vezérli a motrok forgásirányát és szögsebességét. Azért esett erre a típusú vezérlőre a választás, mert ipari felhasználásra van tervezve, megbízható és viszonylag könnyü programozni.

A bipoláris léptetőmotorok párhuzamosan bekötődnek megfelelően felcímkézett csatlakozókra. Az Arduino digitális pinjeire rákötődik a „PUL”-csatlakozó, amely a lépésekért felel, a „DIR”-csatlakozó, amely a forgásirányért felelős, és az „ENA”-csatlakozó, amely az 5 V-ba csatlakozik.

\subsubsection{Felhasználói felület}

A berendezés paraméterezését, mérési procedúrájának beállítását egy számítógépen futó szoftveres program végzi. Ez a felület egy Java-forráskódú, Eclipse fejlesztői környezetben valósult meg. A szoftver egy főablakkal indul, amelyben kiválaszthatjuk azt a soros portot, amelyen keresztül kommunikációt létesítünk az eszközünkkel. Miután kiválasztottuk ezt a beállítási lehetőséget, megjelenik a következő ablak, ahol manuálisan pozicionálhatjuk a befogószerkezetet, a nekünk megfelelő helyzetbe, a szakításra szánt próbatest méreteire. Továbbá lehetőségünkben áll kiválasztani a szakítási sebesség értékét, amelyet mm/percben adunk meg. Ha megtörtént a pozicionálás és a sebesség kiválasztása, nincs más dolgunk, mint elindítani a mérést a megfelelő gomb lenyomásával. Amíg a mérés folyamata tart, a harmadik ablak jeleníti meg online módon a szakítási diagramot. A mérés elvégzése után a felhasználónak lehetősége adódik a mérési adatok kimentésére egy .xlsx kiterjesztésű fájlba.

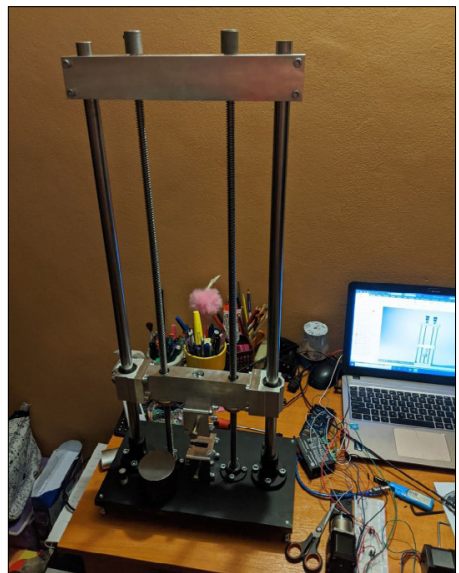

4. ábra. A berendezés megvalósított része

\section{Következtetések}

Következtetésként elmondhatjuk, hogy megterveztünk és részben megvalósítottunk (4. ábra) egy, a polimerek szakítóvizsgálatára alkalmas berendezést. A berendezés laboreszközként lesz használva a Sapientia Egyetem Marosvásárhelyi Karának Gépészmérnöki Tanszékén.

\section{Szakirodalmi hivatkozások}

[1]Tóth L., Rossmanith P.: A töréstechnika és az anyagvizsgálat története. Miskolci Egyetem, Miskolc, 1999. 4-10.

[2] Bitay E.: Anyagtudományi laboratórium I.: Tulajdonságminősítő vizsgálatok. Erdélyi Múzeum-Egyesület, 2011. https://doi.org/10.36242/mtf-11

[3] EN ISO 527: Plastics. Determination of tensile properties. 1994.

[4] Shimadzu Scientific Instruments, Columbia, MD: Testing the Tensile Properties of Rigid and Semirigid Plastics (ASTM D638 and ISO 527) (letöltve: 2020. február 20)

https://www.slideshare.net/ShimadzuSSI/testingthe-tensile-properties-of-rigid-and-semirigidplastics-astm-d638-and-iso-527

[5] Stepper Online: Nema 17 Stepper motor bipolar 17HS19-1684S-PG14 Datasheet. (letöltve 2020. február 20)

https://www.omc-stepperonline.com/download/17HS19-1684S-PG14.pdf

[6] Tolvaly-Roșca F.: Gépelemek. EME, 2019.

[7] OLCM Systems: STA-3 Alloy Steel S-Type Tension and Compression Load Cell. (letöltve 2020 feb. 20.) https://www.lcmsystems.com/sta-3-alloy-steel-stype-tension-and-compression-load-cell

[8] Arduino: Arduino Mega 2650. (letöltve 2020. február 20)

https://www.arduino.cc/en/pmwiki.php?n=Main/ arduinoBoardMega2560 


\title{
IOT-ALAPÚ SMART METEOROLÓGIAI ÁLLOMÁS ADATGYÜJTŐ RENDSZERÉNEK TERVEZÉSE ÉS MÉRÉSEKELVÉGZÉSE KIBERFIZIKAI ROBOTLABORBAN
}

\section{DESIGN OF AN IOT SMART METEOROLOGICAL STATION COMPLETE WITH DATA ACQUISITION AND REALIZING TEST MEASUREMENTS IN CYBER-PHYSICAL ROBOTICS LAB}

\author{
Faragó István, ${ }^{1}$ Erdei Timotei István, ${ }^{2}$ Zolnai Sándor, ${ }^{3}$ Husi Géza ${ }^{4}$ \\ Debreceni Egyetem, Müszaki Kar, Debrecen, Magyarország \\ ${ }^{1}$ istu.fg@gmail.com \\ ${ }^{2}$ timoteierdei@eng.unideb.hu \\ ${ }^{3}$ zsanyi007@gmail.com \\ ${ }^{4}$ husigeza@eng.unideb.hu
}

\begin{abstract}
The presented project was completed using modern, widely used IoT based devices. These include the ESP-01 microcontroller, which is programmable using the Arduino IDE (with its integrated ESP8266 interpreter), and a Raspberry Pi Zero W single board computer, which requires a Raspbian Linux distribution. In this project, an original meteorological station was created (complete with data acquisition), employing various sensors.
\end{abstract}

Keywords: IoT, ESP, Raspberry Pi, data acquisition, Linux.

\section{Összefoglalás}

A jelenlegi fejlesztést modern, széles körben alkalmazott IoT-alapú eszközökkel valósítottuk meg. Ezek között szerepel az ESP-01 mikrokontroller, amely Arduino-keretrendszerbe épített ESP8266-fordítókörnyezettel programozható, valamint egy Raspberry Pi Zero W egykártyás számítógép, melynek működéséhez, illetve programok írásához Raspbian Linux-disztribúció szükséges. A projekt keretein belül egy egyedileg megvalósított meteorológiai állomás és adatgyűjtő rendszere került legyártásra, amihez különböző szenzorok társulnak.

Kulcsszavak: IoT, ESP, Raspberry Pi, adatgyüjtö rendszer, Linux.

\section{Bevezető}

Az Épületmechatronika kutatóközpontjában található, kiberfizikai robotlaborban folynak a fejlesztések és a kutatások, a robotika és az adatgyüjtő rendszerek téma körében. A soron következő feladat szintén a kutatórészlegben került megtervezésre és legyártásra [1].

Az IoT-hálózatok legfontosabb részét alkotják a szenzorok, melyek segítségével képet kapunk a körülöttünk lévő mérhető változásokról. Ezeket a változásokat továbbíthatjuk, tárolhatjuk és feldolgozhatjuk a nekünk szükséges módon. Ennek az adatkommunikációnak a jelentősége a mai világgazdaságban folyamatosan növekszik.

Fontos, hogy ezek a szenzorok és a küldéshez szükséges perifériák kis energiaigényűek legyenek, nem kapcsolódnak elektromos hálózathoz, csak saját akkumulátorokról működhetnek. Ugyanígy fontos a vezeték nélküli technológia az adatok gyűjtéséhez. Az elkészült állomás az 1. ábrán látható. 


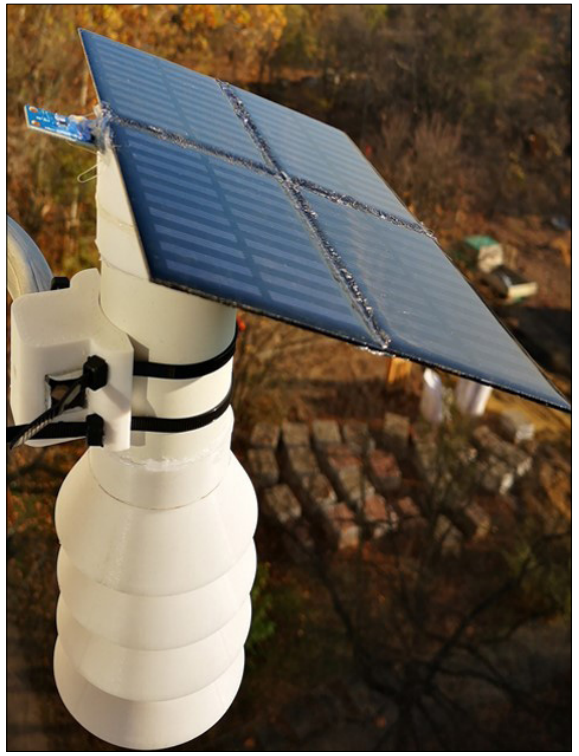

1. ábra. Az elkészített meteorológiaállomás

\section{IoT alapú távoli elérés}

Fontos, hogy a szükséges adatokat bármikor és bárhonnan elérhessük, akár a világ más pontjáról is, erről a feladatról az internet gondoskodik számunkra. A web segítségével egy távfelügyeleti adatgyüjtő berendezést valósíthatunk meg és üzemeltethetjük.

A távfelügyeleti adatgyüjtő rendszer bármilyen eszközről elérhető, ha csatlakozva van az internethez, és támogatja a webböngészést. Ezen rendszer megvalósításához Apache-webszervert használtuk, amelyen egy PHP-ban írt weboldal fut MySQL-adatbáziskezelővel. A Raspberryn futó Linux SSH (Secure Shell) protokoll segítségével érhető el. Windowson kliensprogrammal (pl.: Putty) tudunk csatlakozni ehhez az SSH-szerverhez. A megfelelő parancsok begépelésével telepíthetjük a szükséges programokat, ezután a vezérlő IP (Internet Protocol) címével és a kijelölt felhasználónév, jelszó megadásával elérhetjük a webszervert.

\section{Raspberry Pi \& ESP 8266}

\subsection{A Raspberry Pi}

A 2017. év elején, a Raspberry Pi 5. születésnapja alkalmából adták ki az 1 GHz-es egymagos BCM2835 ARM-típusú processzorral és 512 MB RAM-mal felszerelt Raspberry Pi Zero W modellt, elődjéhez képest beépített WIFI és BLUETOOTH 4.1-et tartalmaz, valamint az integrált áramkörbe

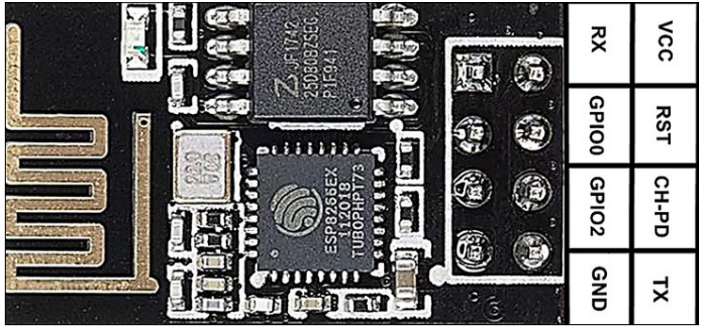

2. ábra. ESP8266-01

épített, rádiófrekvenciás antennát. A GPIO portjainak mennyisége megegyezik a nagyobb társaival, és ugyanúgy támogatja a soros, IIC- és SPI-interfészeket. Grafikus felületü, Linux-disztribúcióval közvetlenül programozható az egység [2].

A Projekt adatgyűjtő rendszere erre az eszközre épül. A készüléken Raspbian operációs rendszer fut, amely a Debian Raspberry Pi-re optimalizált változata. A Debian rendszerek jelenleg Linux vagy FreeBSD kernelt használnak [3].

\subsection{ESP8266}

A projekthez a legelső modellt, az ESP-01-et választottuk. Ugyan alaphelyzetben csak két kimenettel rendelkezik, de forrasztás segítségével több port is használhatóvá válik [4].

Az eszköz és annak portjai a 2. ábrán láthatók.

\section{Szenzorok}

\subsection{BME280}

A BME280 sokoldalú szenzor, alacsony áramfogyasztással, magas linearitással és mérési pontossággal rendelkezik. Támogatja az SPI, valamint interfészt, így tetszőlegesen kommunikálhat a szenzor a mikrokontrollerrel. Ez, és a továbbiak tárgyalt más szenzorok a 3. ábrán láthatók

A szenzor általános jellemzői:

-SPI-interfészek

- háromféle beépített szenzor

-ipari hőmérséklet-tartomány $-40 \ldots+85{ }^{\circ} \mathrm{C}$

\subsection{GY-30 (BH1750)}

A GY-30 precíziósmegvilágítás-szenzor a BME280-hoz hasonlóan rendelkezik buszinterfésszel, valamint analóg kimeneti jellel. Színképérzékenysége nagyjából az emberi szemmel egyezik meg, nagy mérési tartomány és magas felbontás jellemezi az alvó állapotú, alacsony áramfelvétel mellett.

A szenzor általános jellemzői:

- interfész,

- 50/60 Hz zajszürési funkció,

- ipari hőmérséklet tartomány $-40{ }^{\circ} \mathrm{C} . . .+85^{\circ} \mathrm{C}$ 


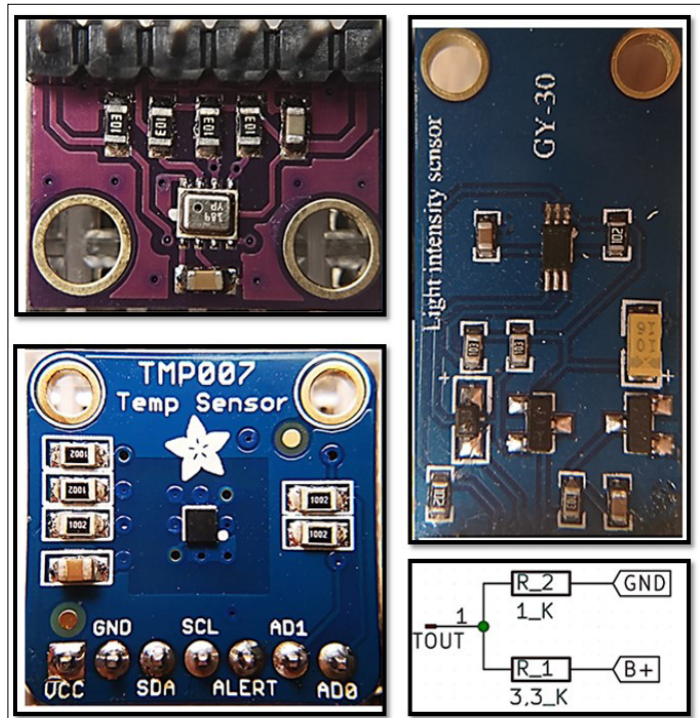

3. ábra. GY-30 szenzor, BME280, TMP007 szenzor, feszültségosztó

\subsection{TMP 007 kontaktusmentes hőmérő}

A TMP007 a Texas Instruments legújabb kontaktusmentes hőmérsékletmérő szenzorja és a TMP006 továbbfejlesztett verziója. A belső matematikai egység elvégzi az összes hőmérsékleti számítást, így az IIC-interfész által könnyen kiolvashatók az adatok. A szenzor képes mérni kontaktusmentesen egy tárgy hőmérsékletét, illetve a szenzorcellában lévő hőmérsékletet.

A szenzor általános jellemzői:

- IIC interfész,

- 14-Bit $\left(0,03125^{\circ} \mathrm{C}\right)$ felbontás,

- ipari hőmérséklet-tartomány $-40 \ldots+125^{\circ} \mathrm{C}$,

- alacsony áramfelvétel,

- kisméretű DSBGA-tokozás.

\section{Harmatpont és hőérzet számítása}

A BME280 szenzor által mért adatoknak köszönhetően lehetőségünk van a harmatpont-hőmérséklet számítására. Egy egyszerűbb összefüggés segítségével a relatív páratartalom és a léghőmérséklet ismeretében kb. 1\%-os pontossággal (30\% relatív páratartalom felett) számolható a harmatpont hőmérséklet.

A készülék megfelelő elhelyezésével lehetséges az épületszerkezeti elemek kritikus pontjainak felderítése, illetve hőhidak következtében harmatpont alá történő hőmérsékletcsökkenés [5].

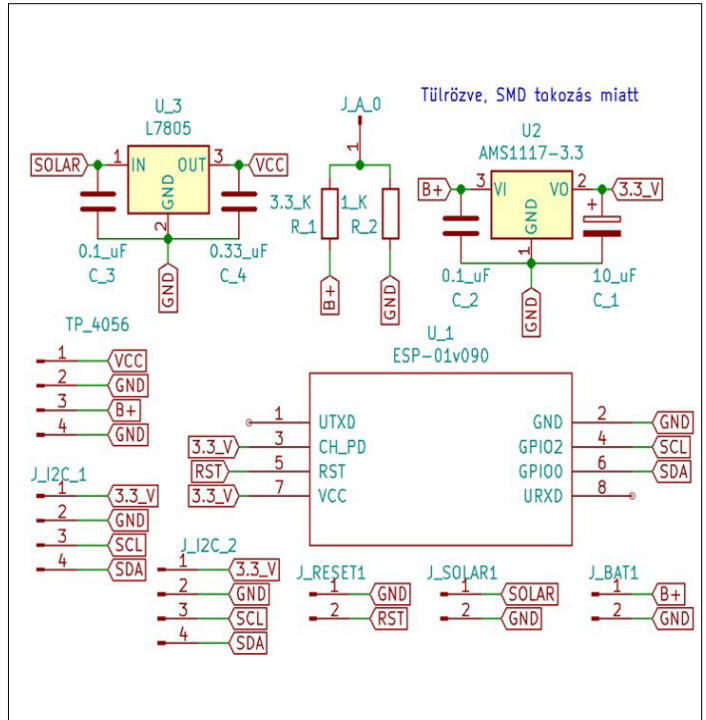

4. ábra. Sematikus kapcsolás

\section{Bekötések}

A BME280-, TMP007- és a GY-30-szenzort az SDA/SCL pinekre [GPIO 0, GPIO 2] kell kötni, és 3,3 V-os feszültségről kell üzemeltetni. A két sorosan kötött ellenállás csatlakozási pontját a TOUT portra. Az egész rendszer egy 18650-es lítiumion akkumulátorról müködik, amelyet egy $10 \mathrm{~V}, 1 \mathrm{~W}$ napelem tölt.

A rendszer egy TS1117-feszültségszabályozó által folyamatos 3,3 V feszültséget kap. Alap esetben az ESP8266-01-es modellben XPD_DCDC pin nem csatlakozik a RESET pinhez, így nem tudjuk alkalmazni a "deep sleep” funkciót, ám a pinek öszszeforrasztásával ez a hiba is kiküszöbölhető. Az említett pinek bekötése a 4. ábrán figyelhető meg.

A kapcsolásban található még egy TP4056 nevü lítiumionakkumulátor-töltő, amely a megfelelő töltőfeszültséget és túláramvédelmet biztosítja. Ez az eszköz érzékeny a bemenő feszültségre, ezért egy LM7805 LDO alkalmazása szükséges, amely csökkenti $10 \mathrm{~V}$-os panel feszültséget stabil 5 V-ra. Mert a TP4056 modul maximum 5,5 V töltőáramot bír el.

\section{Nyomtatott áramkör elkészítése}

A sematikus ábra megvalósítása után elkészült a NYÁK-terv is, mindkettő egy KiCad nevü, nyílt forrású, integrált programcsomagban készült, ami kapcsolási rajzokhoz és NYÁK-elrendezéshez használható. Az elrendezésnél törekedtem a kis 
méretre és az alkatrészek megfelelő elrendezésére, ahogyan az 5. ábrán is látható.

A program lehetővé teszi az elkészített elrendezés 3D-s megjelenítését, így lehetőség van az esetleges hibák feltárására.

Az áramkör szubtraktív (fóliamaratásos) módszerrel készült, lényege, hogy a rézfóliával borított lemez azon felületeit, amelyek az áramkört fogják alkotni, marásálló védőréteggel vonják be, majd a szabadon maradt rezet vegyi úton eltávolítják. Fontos, hogy a kimaratott lapkát védőréteggel vonják be, ez lehet erre specializált lakk vagy kémiai ónozó segítségével lefedhető. A kémiai ónozó előnye még, hogy valamennyivel növeli a vezetőképességet, de ezenfelül érdemes még lakkozni is, mert jobban véd a pára következtében fellépő esetleges áram átkúszások ellen. A végleges nyák a 6. ábrán látható.

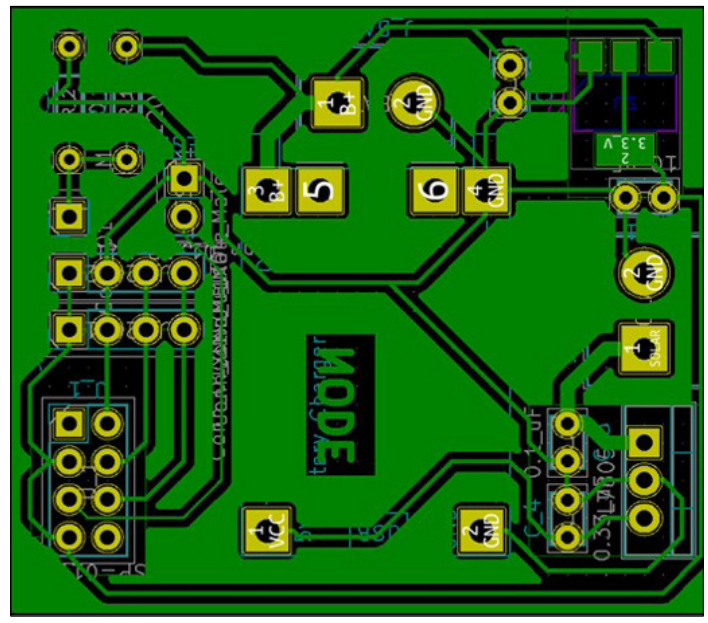

5. ábra. NYÁK-terv

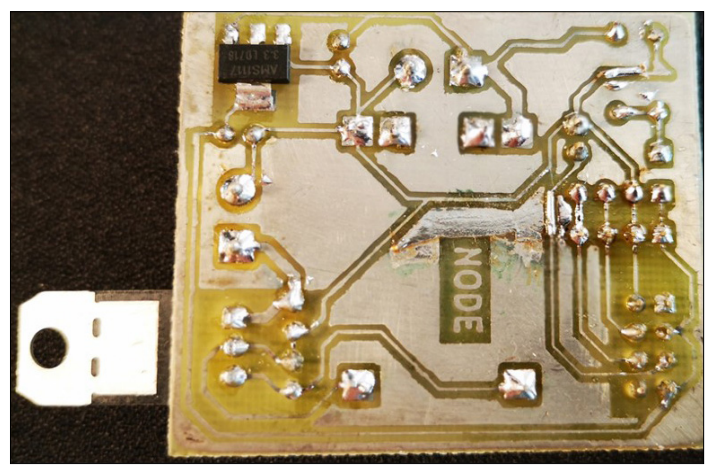

6. ábra. Kimart, ónozott áramkör

\section{Programok}

$\mathrm{Az}$ általam megvalósított feladat vezérlésprogramját Arduino Ide (1.6.11) fejlesztőkörnyezetben C/C++-alapú programozási nyelven írtam meg. A Raspberry Pi-ra készített PHP-programot pedig Notepad++-szövegszerkesztőben.

A meteorológiai állomás programja úgy van megírva, hogy beállított időközönként a szenzorok által mért adatokkal az ESP POST kéréseket küld a szervernek, melyben megadja egyszer az API-kulcsot (biztonsági kód) és a szenzoradatokat.

Ha az API-kulcs megegyezik a PHP-kódba "beégetett" változóéval, akkor feltölti az adatbázis egy meghatározott táblájára (INSERT parancs). Ezt a MySQL-kiterjesztés beépített függvényeivel hajtja végre a PHP-program. Későbbiekben a PhpMyAdmin nevű webes felületű kliens segítségével elérhető az adatbázis.

A POST-adatot a böngészők nem jelenítik meg a címsorban, ellentétben a GET-kérésekkel. Habár nem sokkal biztonságosabb ez, mert a csomagokat le lehet fülelni a szenzor hálózatán (ahol az Raspberryhez csatlakozik az ESP).

Az adatbázis elérése helyi hálózaton teljesen felhasználóbarát, csupán a szerver IP-címét kell begépelnünk egy webböngészőbe. Így megnyílik a bejelentkezési ablak, felhasználónév és jelszó begépelésével beléphetünk, és itt elérhetjük a táblákat. Az adatok ID alapján, a küldés időpontjától függően rendszerezve vannak, ezeket lehet törölni, a táblákat módosítani. Letöltés az adatbázisból több formában is megtörténhet (pl. .csv, .clsx fájlformátum). Az adatbázis bejegyzéseiből később kimutatá-sok készíthetők, mint ahogyan a 7. ábrán is látható.

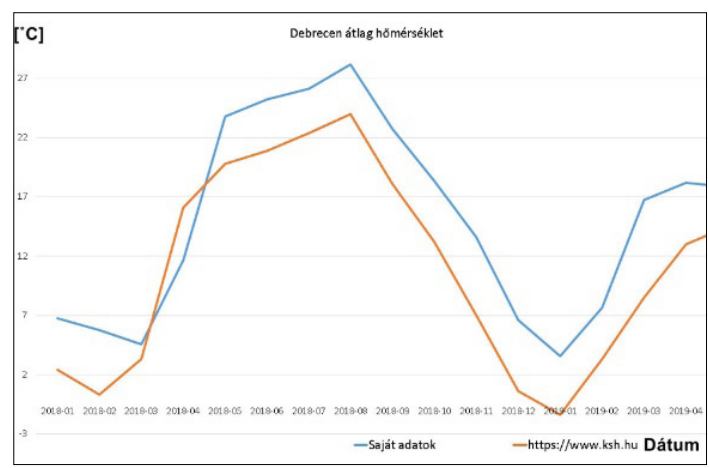

7. ábra. Mért adatok összehasonlítása [6] 


\section{Dobozolás}

A kiértékelt adatokat összehasonlítottuk a ksh.hu által megosztott adatokkal, így arra következtettem, hogy a tendenciák alapján a szenzor hőmérsékletmérése jó, viszont a rossz kialakítás miatt sokkal magasabb hőmérsékleti értékek keletkeztek.

Az akkumulátor töltése sem volt kielégítő, főleg a hidegebb hónapokban folyamatosan alacsony volt a feszültség értéke, ez látható az elküldött adatok mennyiségében is. Az alacsony akkumulátor szint elkerülése érdekében az előzőleg használt 6 V-os napelemcellát lecseréltem egy maximálisan 10 V-ot leadó panelre.

Számos más kialakítás és elemzése után méretarányosan elkészítettük a 3D-terveket, amelyeket Fusion 360 tervezőprogramban megrajzoltam, a dobozolás elemeit próbáltam úgy kialakítani, hogy a 3D-nyomtatással való előállítás menete megvalósítható legyen. Az alkatrészek elkészítése után megtörtént az összeszerelés és az elhelyezés. A külső egységet az épülettől távolabb helyeztem el, fehér színe miatt csak kismértékben történik energiafelvétel a nap sugarai által, így a szenzor pontosabb értékeket mér. Belső egység kialakítása teljesen más, a beszerelt áramkör alatt található TMP007-szenzor, és egy ablakon keresztül mérhetjük a síkfelületek hőmérsékletét. A BME280 a dobozban helyezkedik el, megfelelő szellőztetés miatt a fedél rácsos szerkezetű, ahogyan a 8. ábrán is látható.

\section{0. Összefoglalás}

A meteorológiai állomás és adatgyűjtő rendszerének megépítése, a program megírása és vezetékezése megtörtént. Az IoT-alapú hálózati kommunikáció szempontjainak a kialakított rendszer eleget tesz, a távfelügyeleti mód megfelel az elvárásainknak.

A Linux-alapokon működő periféria alacsony hardvertulajdonságai ellenére kielégíti az adat-

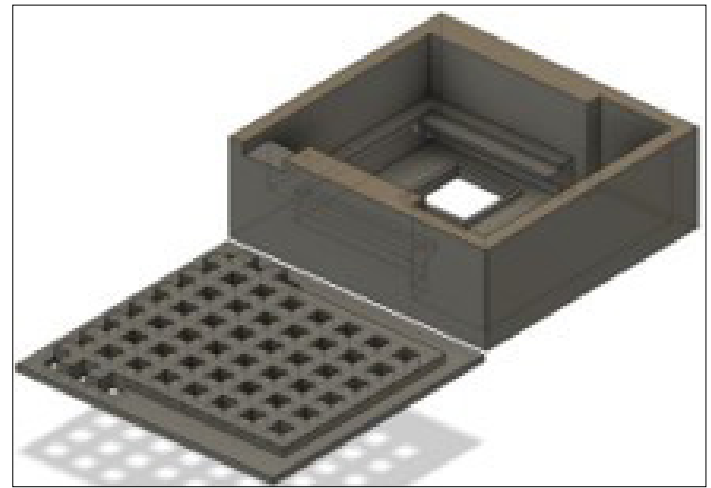

8. ábra. Megtervezett belső egység képe

bázis igényeit, tesztelés és üzemeltetés alatt nem észleltem fagyást, hálózati kapcsolat megszakadását. Az adatok lekérdezése PC-n és mobiltelefonon is megtörtént, a megjelenítés lehetségessé vált. A későbbiekben a rendszer bővíthető pl. rádióantennával, a rugalmasság növelése érdekében.

\section{Köszönetnyilvánítás}

A kutatást a Debreceni Egyetem Informatikai Tudományok Doktori Iskola támogatta.

\section{Szakirodalmi hivatkozások}

[1] T. I. Erdei, Zs. Molnár, N. C. Obinna, G. Husi: Cyber physical systems in mechatronic research centre. MATEC Web Conf. Volume 126, 2017.

[2] Raspberry Pi Family (letöltve: 2019.11.20) https://www.raspberrypi.org/blog/raspberry-pi-zero-w-joins-family/

[3] Linux Debian (letöltve: 2019.11.21) https://www.debian.org/intro/about

[4] ESP8266 (letöltve: 2019.11.23) https://butykoltem.blog.hu/2016/07/27/csinald_ magad_iot_esp8266

[5] Szász G., Tőke L.: Meteorológia mezőgazdáknak, kertészeknek, erdészeknek. Mezőgazda Kiadó, Budapest, 1997.

[6] KSH (letöltve: 2019.11.23) https://www.ksh.hu/docs/hun/xstadat/xstadat_ evkozi/e_met002.html 


\title{
KORRÓZIÓÁLLÓ VASTAG LEMEZ EGY OLDALRÓL TÖRTÉNŐ HEGESZTÉSE
}

\section{STAINLESS STEEL PLATE ONE SIDE WELDING}

Felvári Bálint, ${ }^{1}$ Dunavölgyi Dávid, ${ }^{2}$ Kuti János ${ }^{3}$

Óbudai Egyetem, Bánki Donát Gépész és Biztonságtechnikai Mérnöki Kar, Gépészeti és Biztonságtudományi, Budapest, Magyarország

${ }^{1}$ felvari.balint@bgk.uni-obuda.hu

${ }^{2}$ dunavolgyi.david@bgk.uni-obuda.hu

${ }^{3}$ kuti.janos@bgk.uni-obuda.hu

\begin{abstract}
The authors in this research investigated a cost-effective welding setup for stainless steel following the industrial trends. Ajustments, movements and tests can be avoided during plate welding by welding the piece from one side. During the research, the applied layout is investigated, any deformities that may be caused, and whether it can maintain the inter-row temperature.
\end{abstract}

Keywords: welding, plate, stainless steel.

\section{Összefoglalás}

Kutatásukban a szerzők az ipari trendeket követve egy költséghatékony hegesztési elrendezést vizsgáltak meg, korrózióálló acél esetén. A vastag lemezek hegesztése során felmerülő beállítások, mozgatások, hegesztés közbeni vizsgálatokat kerüljük el azzal, hogy egy oldalról hegesztjük a darabot. A kutatás során az alkalmazott elrendezésnek a hatásait vizsgálták meg, milyen deformációkat okoz, tartható-e a sorközi hőmérsékletet?

Kulcsszavak: hegesztés, vastag lemez, korrózióálló acél.

\section{A kutatás célkitűzése}

Kutatásunkban azt vizsgáltuk, hogy egy ausztenites korrózióálló vastag lemezt meg lehet-e hegeszteni kielégítő módon szűkített V-varrattal egy oldalról. Az egyoldali hegesztéseknek számos előnye van, ugyanakkor a kisterületen bevitt nagy energia miatt nagy deformációt okoz [1, 2].

\section{Kísérlet elrendezése, kivitelezése}

\subsection{Darabok megmunkálása}

A minták valamilyen termikus vágási eljárással kerültek kimunkálásra, így az oldaluk utómunkálatokra szorult. A munkálatok megkezdése előtt tisztázni kellett a hegesztés kialakításához szükséges geometriákat, illetve az azt vizsgáló folya- matok segédmegmunkálásait (gondolok itt a termoelemek elhelyezésére). A szabvány által előírt, szűkített V-varrat kiképzését lemezenként $15^{\circ}$-ra készítettük el egy gyalu segítségével.

\subsection{Termoelemek elhelyezése, furatok elkészítése}

A termoelemes mérés segítségével meghatározható a hőterjedés, illetve a varrat közvetlen közelében mért hőmérsékletek, és ezáltal akár a metallurgiai folyamatok [3]. Ebből kifolyólag nagyon nagy szerepe van annak, hogy a mérőegységeket hova és hogyan helyezzük el a darabon. A mi fő célunk a termoelemek elhelyezésével a sorközi hőmérsékletek pontos meghatározása volt, illetve hogy a jövőben tudjunk egy komoly hőterjedési modellt alkotni $[4,5]$. 


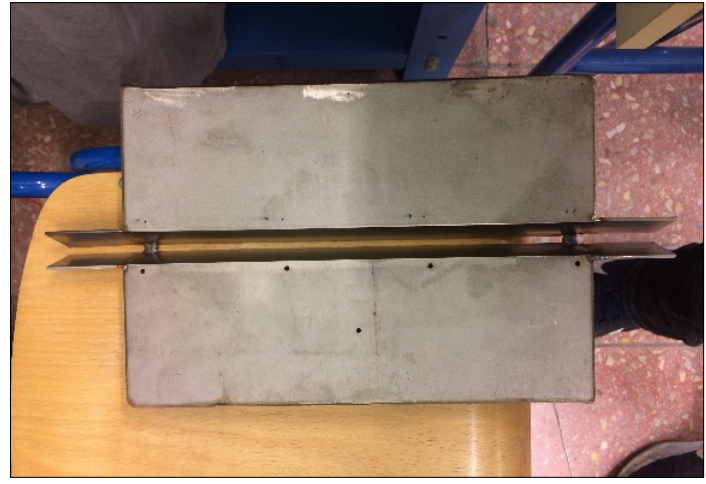

1. ábra. A hegesztési próbatest előkészítve összefüzve

\section{3. Összeállítás}

A darabok leélezése és kifúrása után az összeállítás maradt hátra. A két darabot a leélezésnél egymásnak fordítva, öt milliméter hézagot hagyva a kettő között, két füzővarrattal rögzítettük (1. ábra). A darabok két végén kifutást és befutást alkalmaztunk. Ennek főbb oka, hogy a hegesztési ív már a segédlemezeken létrejöjjön az ömledékkel együtt, és az alapanyagba belépve már stabilan haladjon. A gyökvarrat folytonos kihegesztését kerámiatámasszal segítettük.

\subsection{Hegesztőautomata összeállítása és konfigurálása}

A referenciamérést egy egyedi roboton végeztük el, melyet az egyetemen fejlesztettünk. A hegesztő automatánk kezelőfelülettel, a végálláskapcsolók pozicionálásával és a hegesztőfejet befogadó berendezés beállításával segíti a pontos, reprodukálható hegesztési helyzetet. Az automata és az EVM hegesztőgép összekötetését egy átalakított munkakábellel oldottuk meg. A robot vezérlőegységébe belekötöttük a kábel nyomógombját, ami így aktiválta az áramforrást az adott időpillanatban, és le is állította azt, amikor kellett. A robot kezelőfelülete egy arduinó segítségével működött. A panelon nyomógombok segítségével állítható a hegesztés sebessége $\mathrm{cm} /$ méter léptékben. A felkonfigurálás után csak a végálláskapcsolókat kellett pozícióba hozni a munkadarabhoz képest, ezt követte a hegesztő áramforrás beállítása és felszerszámozása [6].

A hegesztőgép egy EVM Taurus Synergic-típusú berendezés, amely kiválóan alkalmas „komplikált” folyamatok lebonyolítására [7]. A gép elektronikája tartalmaz úgynevezett JOB-okat, amelyek a gyártó által felprogramozott tartományokban tartják a hegesztési paramétereket, így nekünk a gép katalógusából kellett kiválasztani a hegesztőeljárás típusát, esetünkben MIG (Metal Inert Gas - semleges védőgázas, huzalelektródás ívhegesztés), a hegeszteni kívánt anyagminőséget (ausztenites korrózióálló acél) és a JOB-ot. A gép elektronikus beállítása részben megtörtént, innentől kezdve csak az áramerősség növelését vagy csökkentését kellett állítanunk a beolvadás és varratok, varratképek szerint. A hegesztéshez kevert gázt választottunk, a Linde Corgon gázkeverékét. A corgon egy fantázianév, ez az öszszetétel $18 \% \mathrm{CO}_{2}$ és $82 \%$ Ar-t tartalmaz, szabvány megnevezése „ISO 14175 -M21 - Arc - 18”. A gázt egy reduktoron keresztül kötöttük a gépbe, habár a gép és reduktor segítségével be lehet állítani a gáz áramlási mennyiségét, a valós értéket a hegesztőpisztoly végéhez illesztett rotaméterrel állítottuk be.

Mikor a hegesztés menetét manuálisan végigpróbáltuk, sajnos, észrevettük, hogy a gázterelő nem fér be a lemez kimunkált területébe, ezáltal nagyon hosszú ívhosszt kellene tartanunk, ami az ívzárás folytonosságát, ezáltal a gondtalan ömledékképződés és hegesztési varrat kialakulását hátráltatná, megakadályozná. Emiatt módosításokat hajtottunk végre a gázterelőn. Továbbá a fröcskölésből és gázokból adódó „szennyeződések” letapadását a gázterelőben megakadályozva, kerámiabevonattal láttuk el a komponenst. A kísérlet során a varratsorok hủlése közben ezt a kerámiaréteget többször pótoltuk, illetve tisztítottuk, a gáz gondtalan áramlása és az állandó mennyiség érdekében.

\subsection{Termoelemek bekötése, kalibrálása}

A kísérletet termoelemekkel követtük nyomon, melyeket egy központi adatfeldolgozóba kötött, amelyet csatlakoztattunk egy notebookhoz (2. ábra).

A hegesztést olyan módon hajtottuk végre, hogy minden sor egyre rövidebb lett, $20 \mathrm{~mm}$-re így minden egyes sorból tudtunk egy csiszolatot

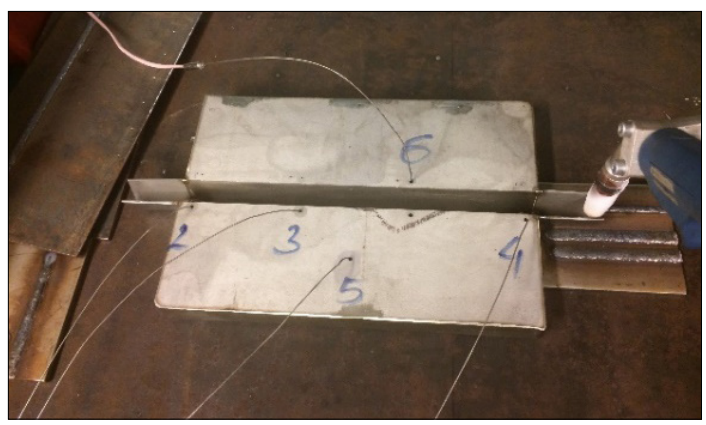

2. ábra. Összeállított próbatest 
készíteni, és megközelítően soronként vizsgálni a hőövezeti zónát és a hegesztési varratokat (a 3. ábra szerint történt a minták kimunkálása).

A metszetek elkészítését egy szalagfürésszel végeztük el, biztosítva a folyamatos hűtést.

\subsection{Minták felülettisztázása}

A ledarabolt szegmensek különböző méretűek és felületi érdességüek voltak, ahhoz, hogy mikroszkóppal a szövetképet elemezni tudjuk, a felületet síkköszörün tovább finomítottuk, majd a csiszolással és polírozással előkészítettük.

A minták maratását KALLING maratószerrel végeztük, amelynek összetétele a következő: $\mathrm{CuCL}_{2}$ $5 \mathrm{~g}$, sósav $100 \mathrm{ml}$, etanol $100 \mathrm{ml}$.

A 4. ábrán látható csiszolaton jól kivehető a varratsorok egymásra épülése, illetve az is, hogy a gyöksor, az alapanyag és a második sor találkozásánál egy gázzárvány található. A legelső sort, azaz a gyököt leszámítva, jól látszik a varratsorok szimmetriája és egyenletessége. A gyökből kivehető, hogy az ív a bal oldali alapanyag felé húzott, így a beolvadás teljesen aszimmetrikus. Továbbá látszik az állandó előtolás és áramerősség is, hiszen a gyökhézag növekedésével a varratmagasság csökkent. Ideális esetben, ez a két érték exponenciálisan nő.

$\mathrm{Az}$ 5. ábra bal oldalán a varratot láthatjuk, amelyben fekete csíkokként megjelenik a delta ferrit. Az oszloposság a hő leadásiránya felé terjed. A varrat és az alapanyag széle között $10 \mu \mathrm{m}$ szélességben kivehető a hőhatásövezet.

A szemcsedurvulás nem jelentős, de a határaikon Cr-karbid kiválás fedezhető fel (6. ábra).

Az alakítás iránya jól kivehető az alapanyagban (7. ábra), ennek oka a bekövetkező mikrodúsulások. Dermedés kezdetén ekviaxiálisak a szemcsék, a sor szélein finomabbak, beljebb durvábbak/nagyobbak. A varratra jellemző az oszlopos és homogén struktúra.

Továbbá érdekesség, hogy a mikrofelvételeken nem, de a keménységmérő mikroszkópjában igen jól látszik a varrat külső és belső szerkezete között a különbség. Kívül durvább, míg beljebb finomabb a szerkezet (8. és 9. ábra).

\subsection{Mért keménységek}

A keménységmérést egy Vickers mikrokeménység-mérővel végeztük el. A mérést $0,2 \mathrm{~kg}$ terheléssel hajtottuk végre. A mintát soronként osztottuk fel, és a következőket mértük: minden sorban háromszor mértük meg az alapanyag és a varrat keménységét. Továbbá szintén háromszor mértük a hőhatásövezetet minden egyes sorban (10. ábra).

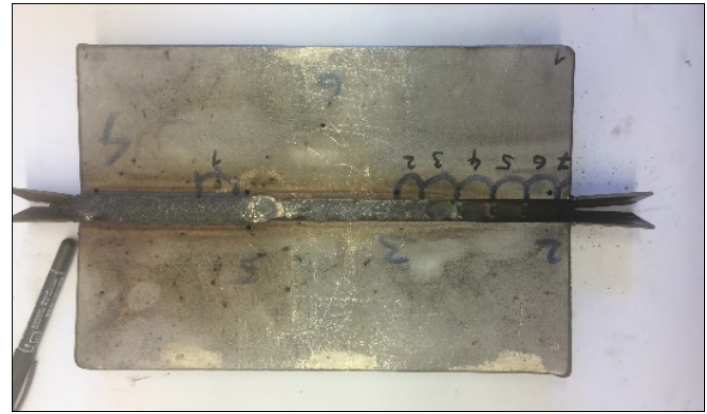

3. ábra. Szelvények kijelölése

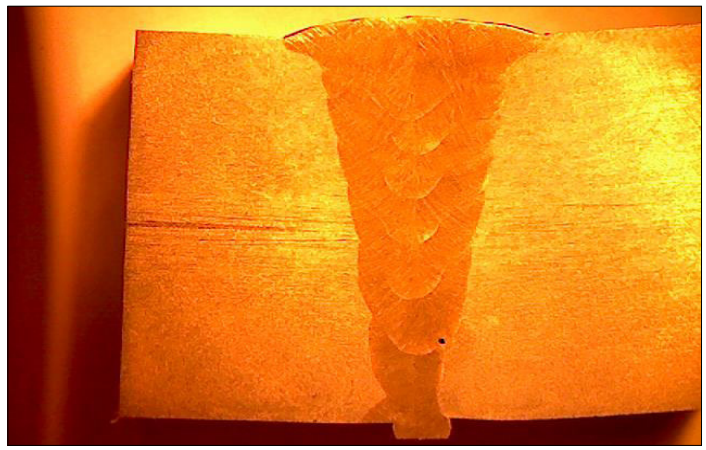

4. ábra. Teljes varratmetszet

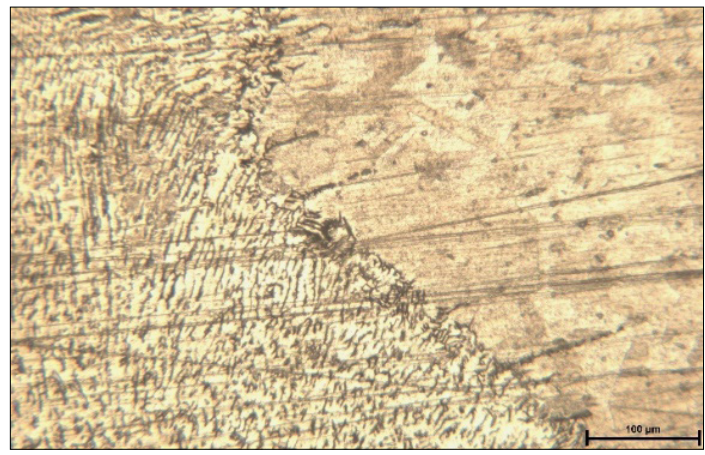

5. ábra. A varrat és az alapanyag

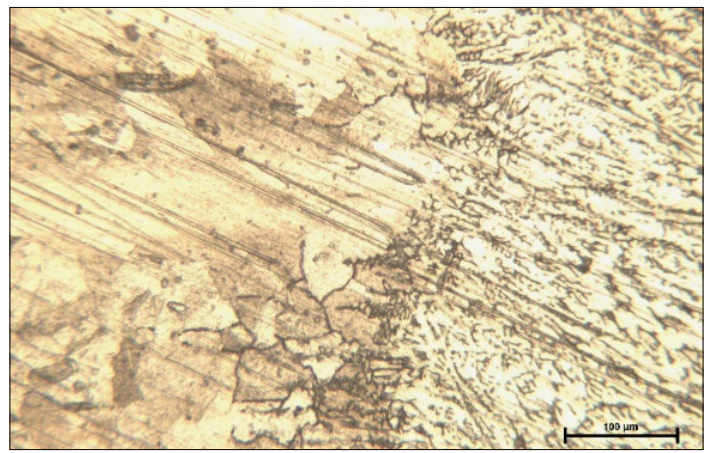

6. ábra. Varrat határán lévö minimális szemcsedurvulás 


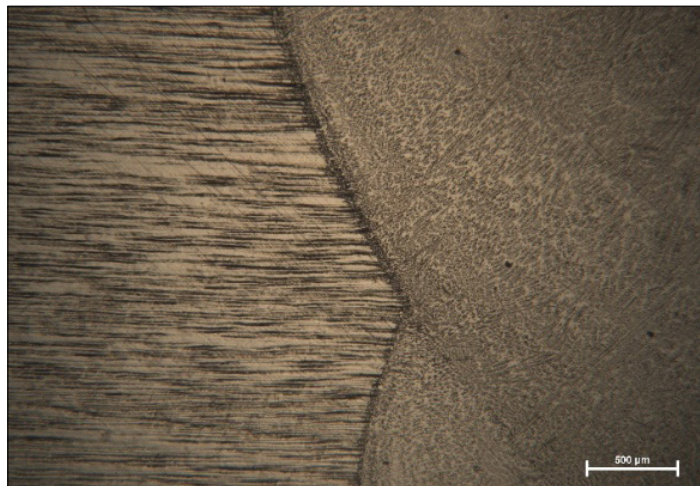

7. ábra. Alakított alapanyag

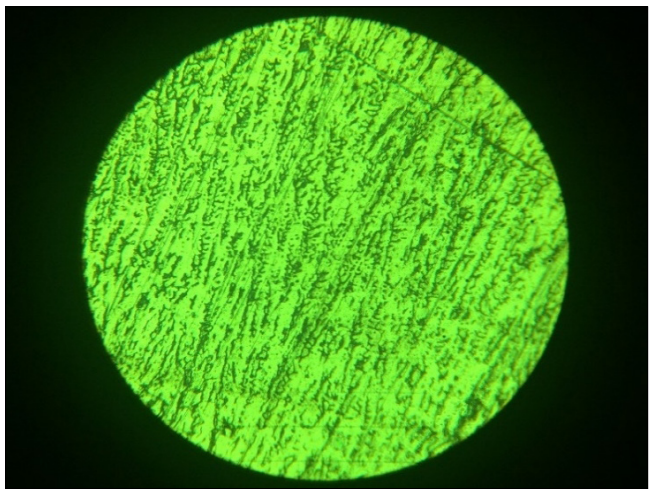

8. ábra. Varrat széle

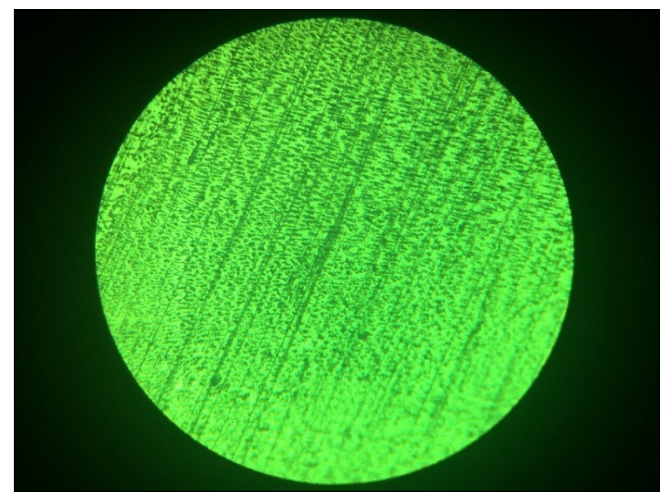

9. ábra. Varrat közepe

\section{3. Összefoglalás}

Mind a keménységmérési eredményekből, mind a szövetszerkezet-vizsgálati eredményekből megállapítható, hogy az egy oldalról történő, szűkített V-varrat hegesztése sikeresen lett végrehajtva. Ugyanakkor a hegesztés hatására a darab jelentősen vetemedett. A kutatás folytatásaként ezt kell kiküszöbölnünk, előfeszítéssel, illetve kisebb energiabevitelü hegesztési eljárásokkal.

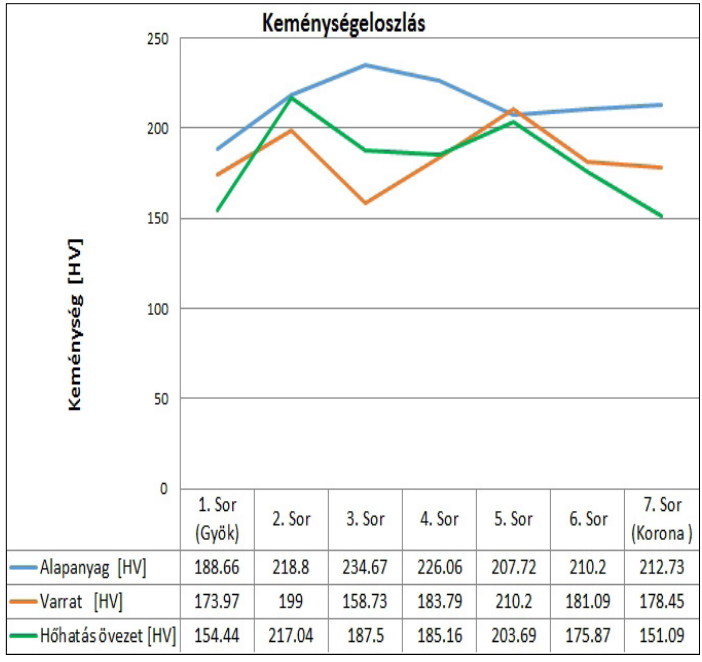

10. ábra. Keménységértékek

\section{Köszönetnyilvánítás}

Szeretnénk köszönetet mondani a magyar államnak és az Európai Uniónak az EFOP 3.6.1.-16.-2016-00010 számú projekt támogatásáért.

\section{Szakirodalomi hivatkozások}

[1] Gáti J.: Hegesztési Zsebkönyv. Cokom, 2003 .

[2] Bagyinszki Gy., Bitay E.: Hegesztéstechnika I. Eljárások és gépesítés. Műszaki Tudományos Füzetek 9., EME, Kolozsvár, 2010.

https://doi.org/10.36242/mtf-09

[3] Bagyinszki Gy., Bitay E.: Hegesztéstechnika II. Berendezések és mérések. Műszaki Tudományos Füzetek 10., EME, Kolozsvár, 2010.

https://doi.org/10.36242/mtf-10

[4] Cloos: Rapid Weld - That's what efficiency looks like! (letöltve: 2017.04.11)

https://www.cloos.de/de-en/processes/details/ rapid-weld/

[5] Biszku G.: Vastaglemezek hegesztése. Miskolci Egyetem. (letöltve: 2017.04.11)

http://docplayer.hu/15987490-Vastaglemezek-hegesztese.html/

[6] Kuti J.: Vastaglemez X varratos kötésének kiváltása szükített $V$ varrattal.

[7] Tóth L., Haraszti F., Kovács T.: A felületi érdesség hatása a hegesztett rozsdamentes acél korróziós ellenállására/Surface Roughness Effect in the Case of Welded Stainless Steel Corrosion Resistance. Acta Materialia Transylvanica 1/1. (2018) 53-56. https://doi.org/10.2478/amt-2018-0018 https://doi.org/10.2478/amt-2018-0017 


\title{
ÖNTÉSZETI SZERSZÁM TERVEZÉSE ÉS SZÁMÍTÓGÉPPEL SEGÍTETT GYÁRTÁSA
}

\section{CASTING TOOL DESIGN AND COMPUTER-AIDED MANUFACTURING}

\author{
Géresi Zoltán Gergő, ${ }^{1}$ Gábora András ${ }^{2}$ \\ Debreceni Egyetem, Müszaki Kar, Debrecen, Magyarország \\ ${ }^{1}$ zoltan.geresi@eng.unideb.hu \\ ${ }^{2}$ andras.gabora@eng.unideb.hu
}

\begin{abstract}
Designing a casting tool and choosing materials technology parameters calls for special requirements both for workpiece and tool side. After designing the technological steps and procedures I select the cutting tools. Industrial developments take priority in cloud system engineering. I used this system in the casting tool manufacturing process. It is not easy to make a comprehensive and detailed design following technological steps. The allowances and joints were made on the M2L CNC milling machine. The CAM program was made with EdgeCam software. Defining the casting parameters accurately is still a challenge, but in our major it is not the most important. For the future we are planning a most complicated casting tool.
\end{abstract}

Keywords: casting, tool, design, CNC, manufacturing.

\section{Összefoglalás}

Egy öntészeti szerszám tervezésénél nagyon fontos követelmény az anyagtechnológiai paraméterek helyes megválasztása mind a munkadarab-, mind a szerszámoldalról. A technológiai sorrend és az adott műveletek megtervezése után a szerszámválasztás következett. Az ipar folyamatos fejlődésével egyre nagyobb a hangsúly a felhőalapú gyártáson. Ezt az újdonságot alkalmaztam az öntőszerszám megvalósítása során. Nehezítő körülmény az átfogó és megfelelő részletességű tervezés és technológiai sorrend végiggondolása. A türéseket és illesztéseket az M2L CNC-marógépen munkáltam meg. A CAM-program az EdgeCam szoftverrel készült. Az öntési paraméterek pontos meghatározása még nagy kihívás, de jelenlegi szakunk tanulmányaiban ez hiányos. Szeretnénk a közeljövőben egy bonyolultabb, nagyobb geometriájú szerszámot készíteni.

Kulcsszavak: öntés, szerszám, tervezés, CNC, gyártás.

\section{1. Öntészeti szerszám tervezése}

Az öntés a fémből készült tárgyak alakadásának legősibb módja. Időszámításunk előtt három évezreddel már öntöttek bronztárgyakat. Az öntéstechnológia legfőbb jellemzője az öntendő tárgy alakadásának nagy szabadsága, amely a legbonyolultabb formájú alkatrészek előállítását is lehetővé teszi. Az eljárás előnye, hogy rideg, tehát képlékenyen nem alakítható anyagokból is lehet tárgyakat készíteni. Egyedi és tömeggyártásban egyaránt alkalmazható. Az adott termék tervezésénél elengedhetetlen, az ergonómia, a jó használhatóság és a tartósság. Számos szempont figyelembevételével szükséges megtervezni egy adott végfelhasználói eszközt.

Egy öntészeti szerszám tervezésénél nagyon fontos követelmény az anyagtechnológiai paraméterek helyes megválasztása mind a munkadarab-, mind a szerszámoldalról. A méretezés során a térfogatigény és zsugorodási tényező is elengedhetetlen a munkadarab szerszámformában elfoglalt helyét illetően. 
A technológiai sorrend és az adott múveletek megtervezése után a szerszámválasztás következik. A katalógusértékek alapján kiszámítva a technológiai paramétereket többféle szerszámra vonatkoztatva, a megfelelő szerszám kerül a szerszámgépekbe.

\subsection{PLM-módszer}

A tervezést a modern informatikai megoldások segítségével szerettem volna végrehajtani. Minden ipari formatervezést, amely előzetesen szabadkézi rajzból indul ki, egy élőképernyős monitoron hajtanak végre, hogy a megálmodott szabadkézi rajz visszaadja az elképzeléseket.

\section{Késztermék tervezése}

A tervezés során az Onshape felhőalapú, díjmentes online szoftvert használtam. A felhőalapú gyártás az ipar 4.0 vívmánya. Az ipari digitalizáció felváltja a papíralapú tervezést. A 3D-tervezés és a gyártástechnológiatervezés- (CAD/CAM) rendszerek kiváltják a papíralapú tervezést, és minimálisra szűkítik a gyártáshoz szükséges papíralapú dokumentációt.

Az ipari vállalatoknál első kézből értesülhet bármely vezető akár utazás közben is a gyárban zajló folyamatokról, ezáltal időt megtakarítva a vállalat számára. Nem szükséges az üzemben tartózkodnia ahhoz, hogy tisztában legyen a folyamatokkal, állásokkal vagy épp átállásokkal, készletekkel stb. Az Onshape esetében nem kizárólag számítógépen érhető el, hanem mobilapplikációban is. Ezáltal néhány szabad perc alatt áttekinthető a tervezés vagy a gyártás folyamata.

A kész termék ergonómiailag megfelelő kell, hogy legyen, így a sketchből kihúzással elért sarkos formát el kellett látni lekerekítésekkel. Az éles sarkok a felhasználó kezét felsérthetik, ha erősen megszorítja vagy kicsúszik a kezéből. Erre azt a megoldást találtam ki, bár a formája miatt stabil megfogást tesz lehetővé, hogy a külső éleket lekerekítéssel látom el. Először azt láttam megfelelőnek, hogy $3 \mathrm{~mm}$-es sugarú lekerekítést alkalmazok, de technológiai szempontból figyelembe

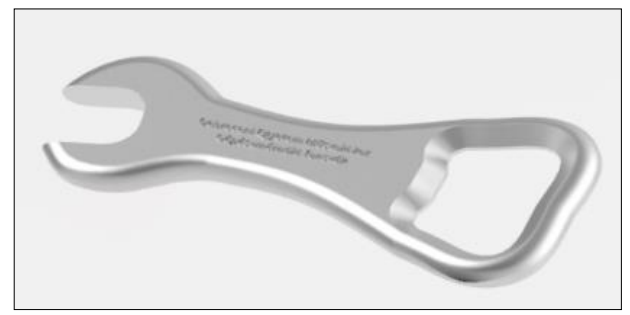

1. ábra. Kész termék (forrás: saját szerk.) kellett vennem, mi történik, ha negatív vagy pozitív irányban eltér a tűréstől a szerszám formamélysége. Ha pozitív irányban tér majd el, tehát nagyobb lesz, akkor marad egy érintetlen sáv az öntött mintában, amely nem okoz esztétikai problémát, és sérüléshez sem vezet. Ezzel szemben, ha negatívan tér el a forma mélysége, akkor, mivel összefut a két rádiusz, a lehetőség fennáll, hogy kialakuljon egy éles perem, amelyet utómunkálással el kell távolítani. Arra a döntésre jutottam, hogy 2,5 mm-re veszem a lekerekítési sugarat, és ezzel elkerülöm a gyártásból származó hibákat.

\section{3. Öntészeti szerszám tervezése}

A koncepcióm egy egyszerű gravitációs öntési technológiához alkalmas szerszám készítése volt, olyan beömlőnyílással, amely jól látható és hordozható bárki számára.

A célszerszámon a megrendelő neve is helyet kapott. Az ergonómiai szempontokat figyelembe véve, az éles, sarkos vagy letörésmenti éleket kerülni kell az eszköz tervezésénél. A termék kialakításánál törekedni kell arra, hogy az öntőformából minél könnyebben kivehető legyen a félkész termék, ezért az öntőszerszám általában 1-3ํk kúpossággal rendelkezik [1]. Az általam tervezett öntőforma oldalfalán szükséges kúpos felületeket 2,5 mm-es rádiuszos lekerekítéssel helyettesítettem, így az öntvényt könnyü eltávolítani a formából [2]. A beömlő tölcsért és a felöntés helyét is a tervezés fázisában kell meghatározni úgy, hogy az öntéskor zárványok ne keletkezhessenek, a formában lévő levegő el tudjon távozni az öntés közben. Jelen esetben a késztermék villáskulcs felőli oldalára helyeztem el mindkettőt. A szerszámforma felületminőségét is elő kell írni, $\mathrm{Rz}=3,16$ érdességet határoztam meg. A 1. ábrán látható a kész termék modellje, a 2. ábrán pedig az abból képezett háromformás öntőszerszám. A szerszámfelek összeszorítását két darab M8-csavarral biztosítottam. A szerszámok pozicionálását pedig két darab csappal oldottam meg, mely az egyik szerszámfélbe H7/m6-, míg a másik szerszámfélbe H7/f6-illesztéssel került beépítésre.

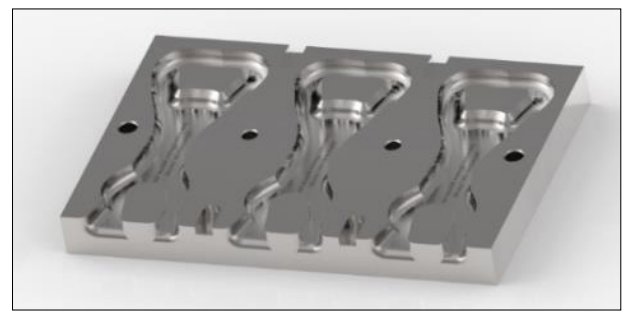

2. ábra. A szerszám modellje (forrás: saját szerk.) 
Az öntés befejeztével a szerszámfelek szétválasztásának megkönnyítését négy darab horony elhelyezésével oldottam meg, amelybe feszítésre alkalmas szerszám befér.

Mivel prototípusgyártásról van szó, a szerszámot ötvözetlen acélból készítettem (St52-1, DIN-anyagszám: 1.0052), az anyagköltséget így minimálisra szorítva. A gyártás során az erősen ötvözött acélok megkívánják a speciális szerszámokat. Ezáltal a gyártási költségek nőnek.

A szerszám konvertálása Onshape-ből parasolid-fájlként történt, amely magában hordozza az összes felületet spline-mentesen, így megszüntetve az utómunkát, azaz a spline-ok átkonvertálását. A munkadarabnullpont a munkadarab tetejeközepe volt. A biztonsági távolságot $20 \mathrm{~mm}$-re jelöltem ki, és innen indult minden munkafolyamat.

A megmunkálás beállításaiban határvonalakat kellett képezni: ezeket a program piros színnel jelöli (3. ábra). A megmunkálás teljes mélységen zajlott. A szerszámgép viselkedése feltűnően jó volt. A szerszámgép nem produkált túlzottan komoly rezgéseket, bár a burkolat kissé zajos volt. A simítás csak az oldalfalra terjedt ki, mert időközben kiderült, hogy praktikussági okokból a hullámformaminta tapadófelületként viselkedik, és kiválóan segíti a szerszám használatát. A simításhoz felületi érdességet kellett számolni, mert a nagyolt felület felületi hibáiba befolyhat az alumínium, és meggátolja az eltávolíthatóságot. A szerszám felületminőségét illetően a nagyolási technológia után durva felület marad.[3]

Elméleti felületi érdesség számítása:

$$
R_{t h}=\sqrt{\frac{d_{1}{ }^{2}-b_{r}{ }^{2}}{2}}
$$

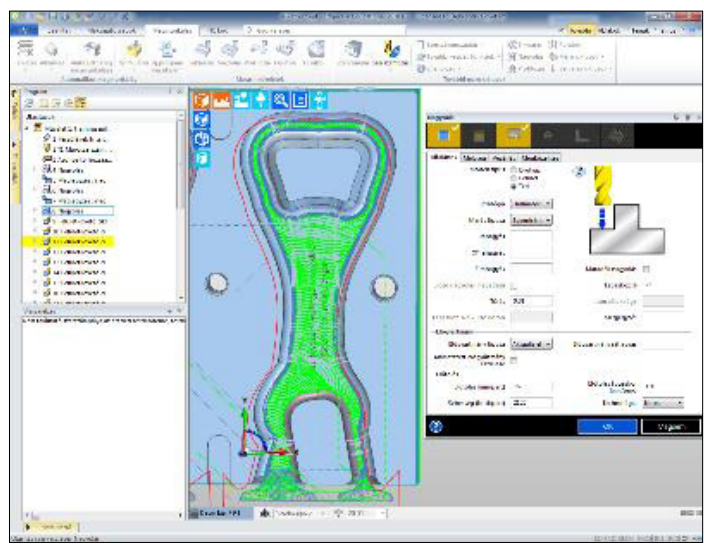

3. ábra. Hullámforma marással (forrás: saját szerk.)

$$
\begin{aligned}
b_{r} & =2 \cdot \sqrt{R_{t h} \cdot\left(d_{1}-R_{t h}\right)}= \\
& =2 \cdot \sqrt{0,0008 \cdot(6-0,0008)}=0,1385[\mathrm{~mm}]
\end{aligned}
$$

Az irányadó oldalra lépési értéket (4. ábra) használtuk fel a simításhoz generált pályához. Az így kapott eredmény egy nagyon szép, egyenletes felület. A szerszámiparban bevett szokás, hogy síkfelület-megmunkálás után egyszerűen lefektetik a szerszámgép asztalára, és speciális egyedi megfogást alkalmazva, úgynevezett papucsokkal szorítják az asztalhoz. Ennek a hátránya, hogy nagy erő hatására elmozdulhat marás közben. Mivel a gép felépítéséből adódóan nem szabott ilyen korlátot, így biztosan nem mozdíthatta ki a darabot a helyéről. A papucsokat viszonylag közel helyeztem a maráshoz, hogy maráskor ne érje nagy erőkar a munkadarabot, és így ne fordíthassa el. Program szerint a következő sorrendben történt a megmunkálás:

- beömlők marása,

- villáskulcs rész,

- eszköztest,

- zárófedél eltávolító rész,

- 2,5 × 45ํ-os élletörés 3 részből.

Megfigyelhető a csipkézett szél a formaszerszámon (5. ábra). Ez a maró kopásának tudható be. Ilyenkor kialakul egy nyomott rész és a forgácsot nem dolgozza ki a mart résznél, hanem kissé felgyüri, ezt nevezzük sorjának. Ez éles és könnyen okozhat sérülést a szabad bőrfelületen.

Ezt követően a szerszámformát megtisztítottam, majd kézzel sorjátlanítottam.

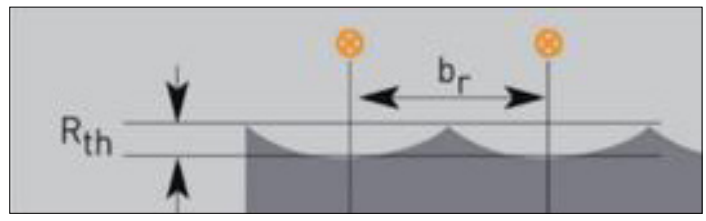

4. ábra. Elméleti felületi érdesség számítása simításhoz

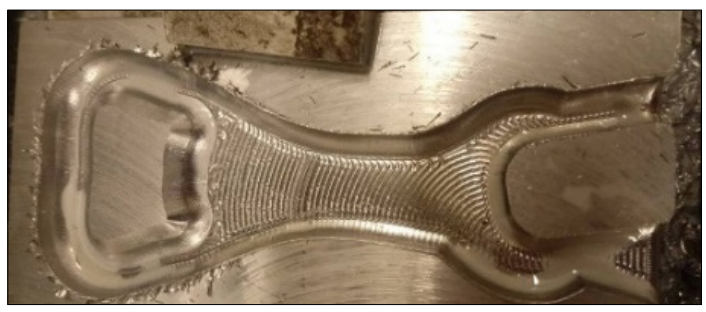

5. ábra. Kész munkadarab (forrás saját szerkesztés) 


\section{Kísérletek}

Első vizsgálatunk alapján az ömledék nem fekszi meg teljes mértékben a nagyolt formarészt. Enyhe beszívódás található a sörnyitó felőli oldalon (6. ábra). A beszívódás keletkezése a közvetkezőképpen zajlik. A termék külső síkjai a kedvezőtlen hütés következtében nem elég stabilak, a belső réteg hűlés közben behúzza. Esetünkben a 6 mm falvastagságból következik. Továbbá a beszívódás következhet a túl lassú hütésből adódóan is. A termék felső öntésű és gravitációs technológiából adódóan a hideg szerszámfalon fut végig. Látható, hogy a beömlő csatorna helyétől távolabb alakul ki.

Második vizsgálatunk alapján melegrepedés található a szerszám több részén (7. ábra). Ezesetben alapvetően metallurgiai problémáról beszélhetünk elsőként. A főbb oka a kristályosodási repedés kialakulásának, hogy az elsődleges kristályosodás során az ömledék megszilárdulása miatti feszültségek okozta alakváltozás meghaladja az alumíniumtermék alakváltozó képességét.

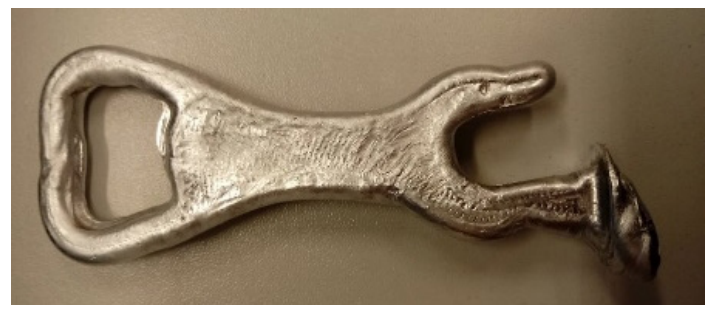

6. ábra. Kész termék öntve (forrás saját szerk.)

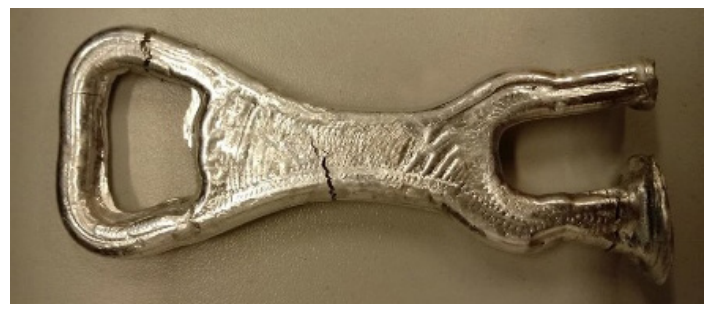

7. ábra. Repedés a készterméken (forrás: saját szerk.)

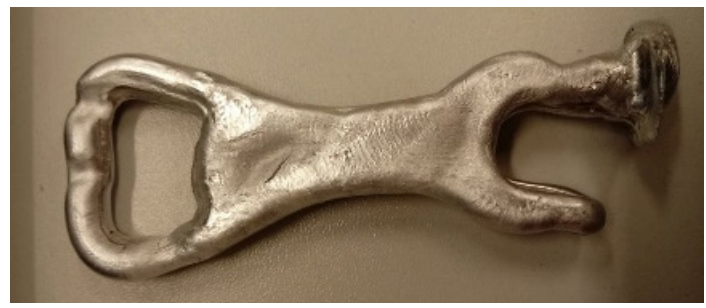

8. ábra. Beszívódás és melegrepedés (saját szerk.)
Harmadik vizsgálatunk alapján az ömledék nem tölti meg teljes mértékben a nagyolt formarészt. Enyhe beszívódás található a sörnyitó felőli nyakrészen, valamint a beszívódás területén melegrepedés. Erős beszívódás található a nyitó rész felfekvő felületén is (8. ábra).

Negyedik vizsgálatunk alapján repedést észleltünk, és töretet képeztünk, hogy lássuk a repedés terjedését. A töretből azt állapítottuk meg, hogy a repedés az anyag teljes keresztmetszetén jelen van, különböző mértékben (9. ábra).

Az ilyen jellegü ötvözetekre általánosan is jellemző, hogy a nagy szolidusz-likvidusz hőköz miatt - az ömledékállapotból történő lehűlés során - lényegesen több ideje marad a különböző alacsony olvadáspontú eutektikumok létrejöttének, s így a melegrepedés kialakulásának. Ezt a problémát könnyen orvosolhatjuk célszerüen választott hegesztőanyaggal, illetve már tervezési fázisban könnyebben hegeszthető ötvözet választásával [4]. A szerszámelőmelegítés mindkét oldalt egyenlő kell, hogy legyen ahhoz, hogy megfelelő öntvényt állítsunk elő.

Az ötödik kísérletünk alapján, az öntés eredményeként egy használható célszerszámot kaptunk, amely megfelel az elvárásainknak. A képen látszik, hogyan tölti ki a szerszámformát az ömledék, és hogyan veszi fel a nagyolt felület formáját.

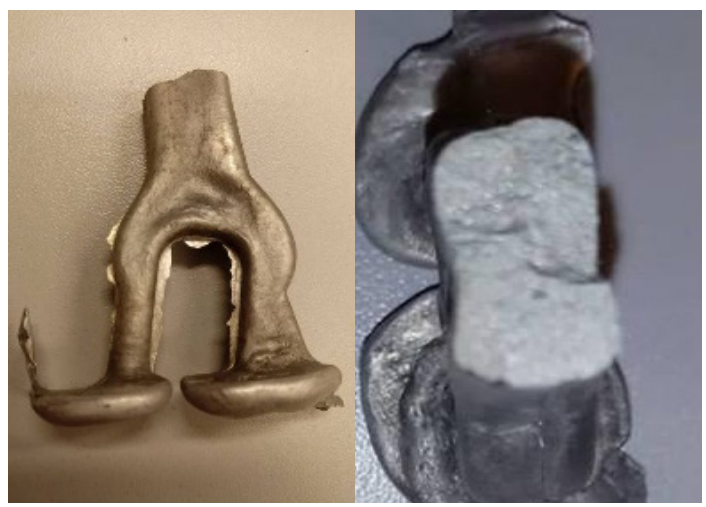

9. ábra. Repedés és töret (forrás: saját szerk.)

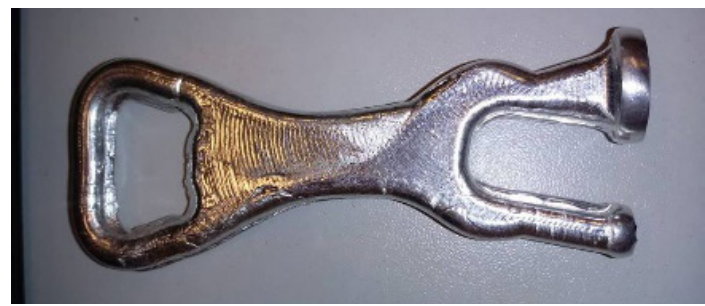

10. ábra. Megfelelő késztermék (forrás: saját szerk.) 


\section{Következtetések}

Teljesen behatárolt és minden peremfeltételnek megfelelő, gyártásra alkalmas szerszámot gyártottunk. Több kísérletet végeztünk különböző öntési paraméterek beállításával. Végül sikerült használható célszerszámot kiöntenünk. Az öntési paraméterek pontos meghatározása még nagy kihívás, de jelenlegi szakunk tanulmányaiban ez nem központi téma. Szeretnénk a közeljövőben egy bonyolultabb, nagyobb geometriájú szerszámot készíteni.

\section{Köszönetnyílvánítás}

A szerzők köszönetüket fejezik ki a Ceratizit Magyarország Kft.-nek a gyártáshoz szükséges szerszámok biztosításáért.

\section{Szakirodalmi hivatkozások}

[1] Varga F. (szerk.): Öntészeti kézikönyv. Műszaki Könyvkiadó, Budapest, 1964.

[2] G. T. Smith: CNC Machining Technology. Springer Verlag, 1993.

[3] Boza P., Burunyi P.: CNC forgácsolás 2. NMHSZFI, 2013.

[4] Fodorné Cserépi M., Pósalaky D.: Nagyszilárdságú acél és alumínium ötvözetek. Miskolc/Győr/Kecskemét, 2013. 


\title{
A TERMOGRÁFIA MÉRÉSTECHNIKAI NEHÉZSÉGEINEK ELEMZÉSE
}

\section{A REVIEW OF DIFFICULTIES IN THE MEASURING TECHNOLOGIES OF THERMOGRAPHY}

\author{
Haraszti Ferenc \\ Óbudai Egyetem, Bánki Donát Gépész és Biztonságtechnikai Mérnöki Kar, Gépészeti és Biztonságtudományi, \\ Budapest, Magyarország, haraszti.ferenc@bgk.uni-obuda.hu
}

\begin{abstract}
Thermography, a non-contact measuring technology for determining temperature, is becoming more and more widespread nowadays. The use of this imaging method assumes simple usage, but for the declaration of appropriate and correct temperature values, a complex measurement routine and in-depth theoretical knowledge are essential. In my articles I will draw attention to the most important factors influencing measurement, both from a theoretical and practical point of view.
\end{abstract}

Keywords: thermography, thermographic camera, measuring technology.

\section{Összefoglalás}

A termográfia mint érintésmentes hőmérséklet-meghatározó módszer napjaink elterjedőben lévő méréstechnikája. E képalkotó rendszer használata ma már egyszerü használatot feltételez, de a megfelelően és helyesen meghatározott hőmérsékletértékek deklarálásához nagy mérési rutin és az elméleti tudás nélkülözhetetlen. Cikkemben a legfontosabb mérést befolyásoló tényezőkre kívánom felhívni a figyelmet elméleti és gyakorlati szempontból egyaránt.

Kulcsszavak: termográfia, hökamera, méréstechnika.

\section{Bevezetés}

A mai modern műszaki diagnosztikai vizsgálatok elképzelhetetlenek érintés nélküli hőmérsékletmérés nélkül. A nagy intenzitással folyó kutatások, a sorozatgyártás nagyságrendekkel elérhetőbbé tette a termokamera jelenlétét az időszakos állapotvizsgálatok terén. A felhasználóbarát kezelhetőség, a könnyen állítható mérési paraméterek rendkívül egyszerü mérési metódusokat sugallnak az átlagfelhasználó számára. Azonban a termográfia mint képalkotó mérési eljárás megfelelően elsajátított elméleti és gyakorlati tudás hiányában szinte minden esetben rossz, kiértékelhetetlen, hibás hőmérsékleti eredményeket produkál. Biztonságtechnikai, munkavédelmi szempontból ez élet- és közveszélyes állapotokat generál.

\section{A termográfia alapjai}

Az infrasugárzáson alapuló hőmérsékletmérés, illetve a hőkamerás mérési módszer a testek hősugárzó képességétől függ. A hőmérsékleti sugárzás az a folyamat, amely az anyag hőmozgása miatt elektromágneses hullámokat bocsát ki magából. Ennek az energiának a nagy része másik testre átvetülve emittálódhat vagy reflektálódhat, továbbá transzmittálódhat is [1, 2]. Ha a vizsgált darabra érkező sugárzást az maradék nélkül elnyeli, akkor abszolút fekete testről beszélhetünk. Amennyiben teljes mértékben visszaverődik, akkor abszolút tükröződő testről, és hogyha a testen teljes mértékben áthalad, akkor átlátszó anyagról beszélhetünk. Az energiamegmaradás törvényének szemszögéből vizsgálva a sugárzási paramétereket, az alábbi összefüggést állapíthatjuk meg: 


$$
\varepsilon_{\lambda}+\rho_{\lambda}+\tau_{\lambda}=1
$$

ahol:

$\varepsilon_{\lambda}$ - emissziós tényező;

$\rho_{\lambda}$-reflexiós tényező;

$\tau_{\lambda}$ - transzmissziós tényező.

1. táblázat. Anyagok fizikai jellemzői

\begin{tabular}{|l|c|c|}
\hline \multicolumn{1}{|c|}{ Anyag } & Tényező & Összefüggés \\
\hline Fekete test & $\varepsilon=1$ & $\tau=0, \rho=0$ \\
\hline Tökéletes tükör & $\rho=1$ & $\varepsilon=0, \tau=0$ \\
\hline Tökéletes ablak & $\tau=1$ & $\varepsilon=0, \rho=0$ \\
\hline Nem átlátszó test & $\tau=0$ & $\varepsilon^{+} \rho=1$ \\
\hline
\end{tabular}

A táblázatból (1. táblázat) ) levonható gyakorlati következtetés szerint a tökéletes tükör és a tökéletes ablak hődetektoros technikával nem mérhető, hiszen számottevő sugárzást nem bocsátanak ki magukból. Anyagi minőségük nem teszi lehetővé felületük hőmérsékletének termográfiás meghatározását. Ezek az anyagok viszont a méréstechnikában a fenti tulajdonságaiknak köszönhetően széles körben alkalmazásra kerülnek.

\subsection{A sugárzás alaptörvénye}

A hősugárzásnak mint elektromágneses hullámterjedésnek közvetítő közegre nincs szüksége. A hősugárzás alaptörvénye a Stefan-Boltzmann-törvény [3]:

$$
E_{(f)}(T)=\sigma \times T^{4}
$$

ahol:

$E_{(f)} \quad$ - fekete test emissziós képessége;

$\sigma$ - Stefan-Boltzmann-féle állandó $5,6710^{-8} \mathrm{~J} / \mathrm{m}^{2} \mathrm{~K}^{4}$;

$T$ - hőmérséklet [K].

A törvény szerint a $T$-hőmérsékletű fekete test egységnyi felülete által egységnyi idő alatt kisugárzott teljes energia arányos a test hőmérsékletének negyedik hatványával. Látható tehát, hogy idealizált esetben csak a fekete test képes az öszszes hőenergiát elnyelni és azt kisugározni. Ilyen a valóságban azonban nincs. A különböző anyagok más és más mértékben képesek az energiát emittálni. Minél inkább hasonlítanak az ideális fekete test tulajdonságaihoz, annál pontosabb mérést tesznek lehetővé. Ellenkező esetben korrigálnunk kell a mérési eredményünket.

\section{A mérést befolyásoló tényezők}

Méréseinket valós környezetben az ideálistól eltérve végezzük. A valódi testek hőkibocsátó (sugárzási) kapacitása, a mérés körülményei minden esetben befolyásolják termográfiai analízisünket. A legfontosabb paraméterek a következők:

- emissziós tényező, $\varepsilon<1$;

- mérőeszköz hullámhosssza

- mérési útszakasz jellemzői.

Ezek közül a legfontosabb az emissziós tényező. Helytelen megválasztása akár nagyságrendi hőmérséklet különbséget is okozhat. Feketeségi foknak is nevezik, és egyszerűen fogalmazva, a tárgy felületének sugárzási képességét fejezi ki. Mértéke az ideális sugárzótól való eltérést mutatja. Minden esetben függ a mérendő objektum felületének anyagától, érdességétől, a mérőeszköz (hőkamera) és a tárgy által bezárt szögtől [4, 5]. Befolyásolja hőmérsékletmérésünket a háttérés tárgyhőmérséklet is. Sokan a hődetektálást végzők közül nem veszik figyelembe a mérendő objektum környezetében elhelyezkedő tárgyak által sugárzott hő nagyságát. Ez a hő reflektálódik a tárgyunkon, megváltoztatva a termokamerába jutó infravörös sugárzás valódi mennyiségét. Ha az emissziós tényezőt is pontatlanul adtuk meg, a két hiba erősíti egymást. Az 1, 2. ábrákon villamosszekrény behúzótekercsének hibás hőmérséklet meghatározása látható. A háttérhőmérséklet $20^{\circ} \mathrm{C}$-al való eltérése és a fémes felület emissziójának alulbecsült (25\%) értéke $20,2^{\circ} \mathrm{C}$-os eltérést eredményezett.

Fémek esetén a hőmérséklet függvényében változó kristályszerkezet az, ami más és más emissziós tényezőt jelenthet [6, 7]. A 3. ábrán különböző fémek specifikus emissziós tényezőjét láthatjuk a tárgyfelület hőmérsékletének függvényében [8, 9].

A grafikonból jól látható, hogy az emissziós tényező változása csak magasabb hőmérsékleten számottevő. Ebben a tartományban viszont figye-

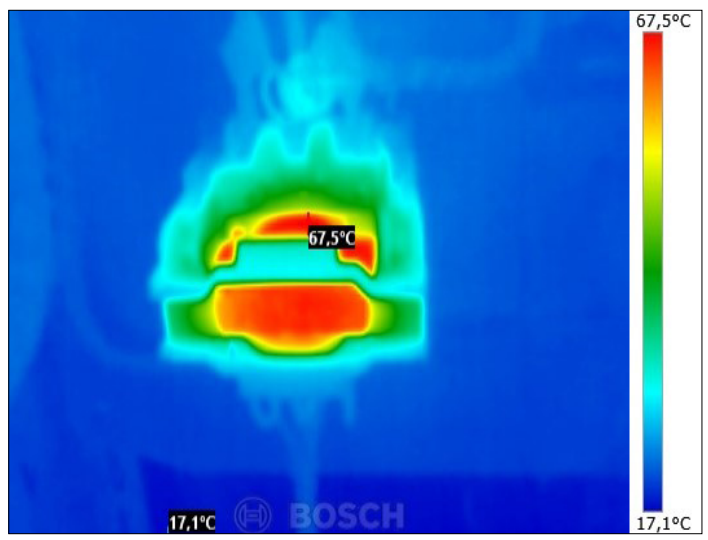

1. ábra. Behúzótekercs hőképe 


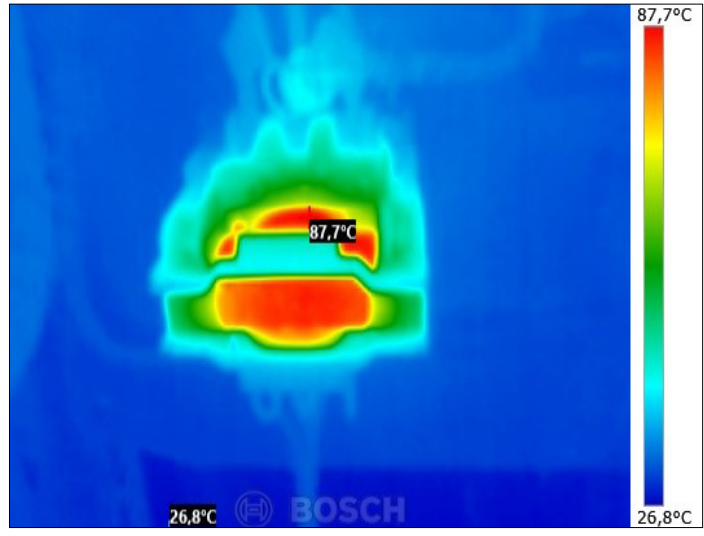

2. ábra. Behúzótekercs hőképe

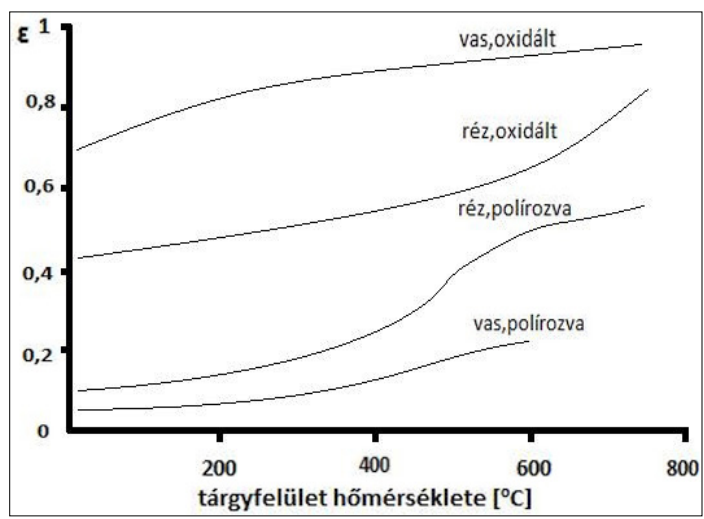

3. ábra. Különféle fémek emissziójának hőmérsékletfüggése

lembe kell vennünk a minél pontosabb hőanalízis miatt.

\subsection{Mérőeszköz hullámhossza}

Az érintés nélküli hőmeghatározás kivitelezése legfőképp a levegőn keresztül történik. Ez fizikai sajátságokat vet fel a mérőműszer kialakításában és a mérés folyamán. Többnyire három spektrális tartomány használata alakult ki. Beszélhetünk hosszú hullámú (8-14 $\mu \mathrm{m})$, középhullámú (3-5 $\mu \mathrm{m})$ és speciális esetekben rövidhullámú (1-2 $\mu \mathrm{m})$ hőkamerákról. A termográfiával foglalkozó szakember feladata eldönteni, melyik a legmegfelelőbb az adott feladat elvégzésére. Helytelenül választott méréstartomány hatást gyakorol a mérési eredményre. A gyakorlat azt mutatja, hogy a középhullámú mérőeszköz érzéketlen az alacsony hőmérsékletekre, viszont a magasabb $\left(400{ }^{\circ} \mathrm{C}\right)$ tartományban pontosabb mérést tesz lehetővé. Alacsony hőmérsékletek esetén célszerübb hosszú hullámú kamerát használni. Az ipari gyakorlatban azonban univerzálisan elterjedt hullámhossztartomány szintén a hosszú hullámú termokamera, alacsony és magas hőmérsékletek detektálására egyaránt. Kisebb korrekcióval megfelelően pontos eredményt kaphatunk például a villamosipar nem kívánatos melegedései terén. Speciális esetekben, amikor figyelembe kell vennünk a mérendő tárgy spektrális emisszióját, használhatjuk a rövidhullámon mérő hőkamerákat igen nagy hőmérsékleteken.

\subsection{Mérési útszakasz jellemzői}

Méréseinket - sok egyéb változó mellett - befolyásolja az infravörös sugárzás tárgytól a mérőműszerig megtett útja is. Ez az út, néhány kivételtől eltekintve, (vákuum) legtöbbször a levegő. A benne található szennyező anyagok: por, korom, füst, különféle vegyi anyagok hátrányosan befolyásolhatják méréseinket. Szintén hatással van az atmoszférában jelen lévő vízpára, oxigén, szén-dioxid, nitrogén, különféle szénhidrogének jelenléte. Torzíthatják eredményünket a zavaró sugárforrások, a levegő hőmérséklete is. Ezek a hátráltató tényezők már pár méterről is hátrányosan módosíthatják az átbocsátó képességet. Végül figyelembe kell vennünk a levegő fizikai sajátosságait, átviteli paramétereit is. Nem minden hullámhossztartományban van mód maximális intenzitású infravörös sugárzás detektálására. Számolt és kísérleti úton úgynevezett meghatározott atmoszferikus ablakhelyek alakulnak ki a légkörben, melyek jó átviteli tulajdonságokkal rendelkeznek. A gyártók ezekhez az ablakokhoz igazítják a különféle hullámhosszon előállított mérőberendezéseiket.

\section{Következtetések}

Cikkemben igyekeztem bemutatni a termográfiás hőmérséklet-meghatározás legalapvetőbb nehézségeit a teljesség igénye nélkül. A felhasználóbarát alkalmazhatóság, a látszólag triviális kezelhetőség mögött egy komplex és széles körü tudásbázist igénylő méréstechnikai eljárásról van szó. Pontos diagnosztikai vizsgálatokat csak hőtanfizikai felkészültség és évekig tartó üzemi méréstapasztalat útján lehet elsajátítani. Ma már az élet számos területén létjogosultságot nyert ez a technológia a villamosipartól kezdve katonai alkalmazásokon át az egészségügyig. Fontos tehát a termográfiás méréstechnika eredményét befolyásoló tényezők alapos ismerete. 


\section{Szakirodalmi hivatkozások}

[1] Haraszti F.: The bases of corrosion's investigation. In: A XXI. Fiatal műszakiak tudományos ülésszak előadásai, Kolozsvár, Románia, Műszaki Tudományos Közlemények 5. (2016) 185-188. https://doi.org/10.33895/mtk-2016.05.37

[2] Budó Á.: Kísérleti Fizika II. Tankönyvkiadó, Budapest, 1971.

[3] Wellons M.: The Stefan-Boltzmann Law. Physics Department, The College of Wooster, Wooster, Ohio 44691, USA (Dated: May 9, 2007)

[4] Professzionális Ipari Méréstechnika, (2017.02.15.) http://www.pim-kft.hu (2017.02.15.)
[5] Villanyszerelők Lapja, (2017.02.22.) www.villanylap.hu

[6] Haraszti F.: Corrosion investigation of steel samples. In: A XXI. Fiatal műszakiak tudományos ülésszak előadásai, Kolozsvár, Románia, Műszaki Tudományos Közlemények 5. (2016) 189-192. https://doi.org/10.33895/mtk-2016.05.38

[7] Kovács K.: Korróziós alapfogalmak. Műszaki Könyvkiadó, Budapest, 1965.

[8] Kovács-Coskun T., Völgyi B., Sikari-Nágl I.: Kontaktkorróziós jelenség tanulmányozása acél alumínium párosításánál. EME kiadó, Kolozsvár, 2013, 201-204.

[9] Rachne E.: Termográfia elmélet és gyakorlati méréstechnika. Invest-Marketing Bt., 2018. 


\title{
TÁRCSÁS ELEKTROSZTATIKUS SZÁLKÉPZŐ-BERENDEZÉS TERVEZÉSE ÉS KIVITELEZÉSE
}

\section{THE DESIGN AND IMPLEMENTATION OF A DISK ELECTROSPINNING DEVICE}

\author{
Hodgyai Norbert, ${ }^{1}$ Farmos Rudolf László, ${ }^{2}$ Gergely Attila ${ }^{3}$ \\ Sapientia Erdélyi Magyar Tudományegyetem, Marosvásárhelyi Kar, Gépészmérnöki Tanszék, \\ Marosvásárhely, Románia \\ ${ }^{1}$ hodgyai@ms.sapientia.ro \\ ${ }^{2}$ farmos_rudolf@ms.sapientia.ro \\ 3 agergely@ms.sapientia.ro
}

\begin{abstract}
The electrospinning procedure is a relatively simple and fast way of producing polymer fibers with diameters in the micrometer range. The one needle setup is commonly used due to its flexible design and effectiveness; however, this procedure has one major shortcoming; it has low productivity. The disk electrospinning design presented here combines the advantages of the corona and needleless electrospinning setups, namely the small solution surface area and high productivity. We used $33 \mathrm{wt} \%$ polyvinylpyrrolidone (PVP) solution to produce PVP fibers with the new design. The average fiber diameter of the produced PVP fibers was $\mathrm{d}=446 \pm 116 \mathrm{~nm}$, which is $\sim 25 \%$ larger compared to fibers produced with the one needle method.
\end{abstract}

Keywords: needleless electrospinning, disk electrospinning, polymer fibers, PVP, device design.

\section{Összefoglalás}

Az elektrosztatikus eljárás egy relatíve egyszerű és hatékony módja mikrométer nagyságrendủ átmérővel rendelkező polimerszálak előállításának. A szakirodalomban előszeretettel használt egy tűvel rendelkező variáns egyszerű és hatékony, viszont a termelékenysége alacsony. A bemutatott tárcsás elektrosztatikus berendezés ötvözi a korona és a tű nélküli elektrosztatikus berendezések előnyeit, vagyis kis oldatfelszín és nagy termelékenység. A tervezett berendezéssel sikeresen gyártottunk szálas szerkezetet 33\%-os polivinil-pirolidon- (PVP) oldatot használva. A keletkezett PVP-szálak átmérője d = 446 $1116 \mathrm{~nm}$, mely 25\%-kal nagyobb az egytűs módszerrel előállított PVP-szálak átlagos átmérőjénél.

Kulcsszavak: elektrosztatikus szálképzés, polimer szálak, PVP, tü nélküli elektrosztatikus szálképzés, tervezés.

\section{Bevezetés}

A mikrométer alatti szálátmérővel rendelkező polimerszálak előállítása elektrosztatikus eljárással nagy figyelmet kapott az elmúlt pár évtizedben. Az egyszerű gyártási eljárás, ill. nagy felület-térfogat arány miatt számos alkalmazási lehetőség felmerül. [1] Ezen hálók gyártása az esetek nagy részében egy egytűs elektrosztatikus szálképző eljárással készül, mely termelékenysége alacsony, és nem alkalmas nagyobb volumenű gyártás alkalmazására. A probléma megoldására több megoldás született, melyet a szakirodalom tárgyal. Ezen megoldások, korona-elektrosztatikus szálképző eljárást leszámítva [2-7], egy nagy oldatfelületet feltételeznek, ami alacsony forrásponttal rendelkező oldószer esetén párolgáshoz vezet, ami nem kívánatos. 
A dolgozat célja egy tű nélküli, tárcsás, elektrosztatikus szálképző berendezés tervezése és kivitelezése, amely kis oldatfelület használatával csökkentheti az oldatpárolgást.

\subsection{Egytüs elektrosztatikus szálképző eljá- rás bemutatása}

$\mathrm{Az}$ 1. ábra $\mathrm{az}$ egytűs elektrosztatikus szálképző berendezés vázát mutatja. A berendezésnek a következő alkotóelemei vannak: egy egyenáramú, nagyfeszültségű tápegység, egy tartály, mely a polimeroldatot tartalmazza, egy tủ, mely a tartállyal csővezeték segítségével kapcsolódik, valamint egy kollektor, mely a polimerszálak felfogására szolgál.

A polimeroldatot tartalmazó tartályból, amely az esetek nagy többségében egy fecskendő, egy csővezetéken keresztül jut el az oldat a fecskendő végén található tübe. A tű pozitív, míg a kollektor negatív vagy földpotenciálra van kapcsolva. A polimeroldatban a pozitív potenciál hatására pozitív töltések jelennek meg. A pozitív töltések a polimeroldatban taszítják egymást. A feszültség növelésével a pozitív töltések közti taszítóerő tovább növekszik. A folyadéksugár létrejön, amikor a töltések közti taszítóerő meghaladja az oldat felületi feszültségét a tü hegyén található folyadékcsepp felszínén. Az 1. ábra mutatja az ún. Taylor-kúpot is, mely a tű végén alakul ki [8]. Amíg a polimeroldat a tü hegyétől a kollektorig elér, az oldószer nagy része elpárolog, és a szál megnyúlik, így képezve az akár nanométer nagyságrendű átmérőt. [1, 9].

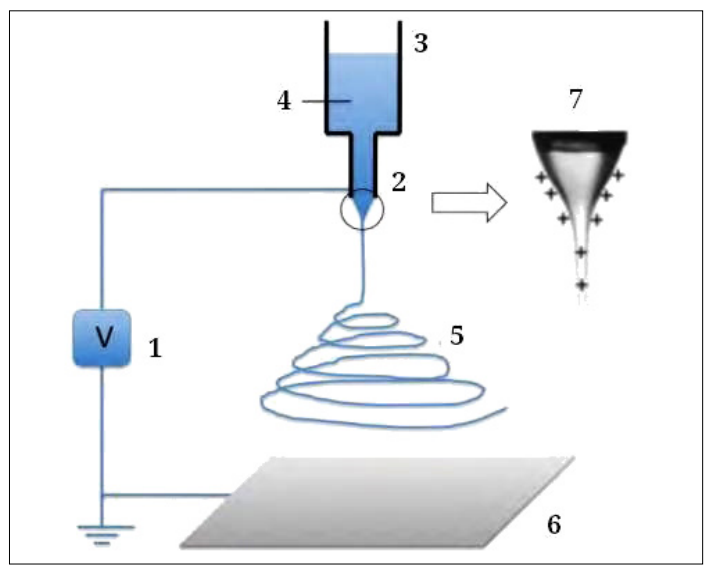

1. ábra. Polimerszálak előállítása elektrosztatikuszszálképzéssel polimeroldatból [11]. 1: nagyfeszültségütápegység, 2: szálképző elektróda(kapilláris), 3: oldatadagoló, 4: szálképzésifolyadék, 5: szálképzési térrész, 6: szálgyüjtö(földelt), 7: Taylor-kúp, vagyis a kapillárisbólkilépő folyadék deformált alakja

\subsection{Nagy teljesítményü elektrosztatikus szálképzési eljárások}

Az elektrosztatikus szálképzés teljesítménynövelésének legegyszerübb megoldása a kapillárisok számának növelése lenne, mely, habár a termelékenységet növeli, viszont a müködtetése problémás, és karbantartása nehézkes. [9, 10] A termelékenység növelése érdekében a kutatók kiküszöbölték a kapillárist a rendszerből, és egy folyadékfelszínt használtak. A polimeroldatban vezető mágneses részecskéket, hengereket, korongokat, fémhuzalokat vagy gömböket helyezve, ill. mozgatva vagy forgatva a felszínén, több Taylor-kúp kialakulásával több polimeroldat-sugár képződik, és így a termelékenység növekszik. [12] Ezen megoldások feltételezik egy folyadékfelszín létrehozását, ami magával vonja a használt oldószer elpárolgásának veszélyét, ill. a környezetből történő nedvességfelvételt. A koncentráció- és kompozícióváltozás negatív hatással lehet az elektrosztatikus szálképzési folyamatra. [13]

Molnár Kolos és társai egy olyan elektrosztatikus szálképzési technológiát fejlesztettek ki, mely nagy termelékenységgel képes polimerszálakat létrehozni, viszont nem használ nagy oldatfelszínt, így kiküszöböli a fent említett tűmentes megoldások hiányosságát. A szerkezet a 2. ábrán látható, melyet korona elektrosztatikus szálképzési eljárásnak neveztek el. [14]

A 3. ábrán látható berendezés egy vékony polimeroldat-réteget hoz létre a 2-es és 5-os egység közt, mely elősegíti több Tylor-kúp kialakulását, [8] és ezáltal megnöveli a termelékenységet, illetve megakadályozza az oldószer nagymértékű elpárolgását.

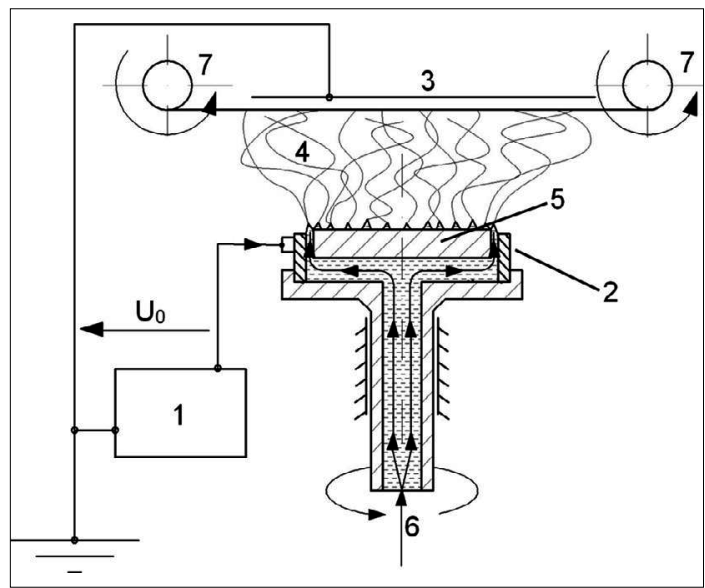

2. ábra. A tü nélküli elektrosztatikus szálképző berendezés vázlata [14] 


\section{Módszertan}

\subsection{Elektrosztatikus szálképzés}

Az elektrosztatikus szálképző eljáráshoz 33 tömeg \%-os PVP-oldatot használtunk, 75:25 (tömeg: tömeg) etanol:víz oldószerrendszerben. A tűs elektrosztatikus szálképző eljárás esetén $V=15 \mathrm{kV}$ potenciálkülönbséget, $F=0,7 \mathrm{~mL} / \mathrm{h}$ térfogatáramot és $D=10 \mathrm{~cm}$ tü-kollektor közti távolságot használtunk. A tárcsát $80 \mathrm{rpm}$, míg a futószalagot $100 \mathrm{rpm}$ fordulatszámon használtuk, $V=20 \mathrm{kV}$ és $D=10 \mathrm{~cm}$ mellett. Az oldatot az erre a célra kialakított üregbe fecskendeztük.

\subsection{Pásztázó elektron-mikroszkópos vizsgálat}

A pásztázó elektron-mikroszkópos vizsgálat egy JEOL JSM-5200-berendezésen volt kivitelezve. A mintákat $15 \mathrm{kV}$ feszültségen vizsgáltuk. A polimerszálak átmérőjének meghatározására az ImageJ programot használtuk.

\section{Eredmények}

\subsection{A tervezett berendezés bemutatása}

A tervezett berendezés kombinálja a tárcsás és a korona-elektrosztatikus eljárások pozitív tulajdonságait: a tárcsás felépítés egyszerü, míg a korona-elektrosztatikus eljárás kis folyadékfelszínt használ. A 3. és 4. ábrán látható berendezés müködési elve a következő: a tárcsa a forgómozgás következtében a palást felületére felhordja egy, erre a célra kialakított üregből az oldatot. A tárcsa felületén található oldatból a tárcsa sarkainál Taylor-kúpok alakulnak ki, és elkezdődik a szálképzés. Az üreg méretét a szerkezettel szemben állított elvárásoknak megfelelően minimalizáltuk, a párolgás csökkentése érdekében, viszont a szerkezetet úgy terveztük, hogy flexibilisen változtatható és viszonylag egyszerű legyen a tisztítása. Az ábrán látható, hogy egyszerre két tárcsát is használhatunk, mely a két különböző oldatból generál polimerszálakat, így kompozitszálas szerkezetet létrehozva. A tárcsa fordulatszámát egy potenciométerrel lehet változtatni.

A kollektor egy változtatható dőlésszögű futószalag, amely lehetővé teszi a termelékenység megnövelését és a keletkezett minta egyenletes vastagságát. A futószalag sebességét szintén egy potenciométer segítségével tudjuk változtatni.

\subsection{A PVP-hálok vizsgálata}

Az első lépésben a PVP-szálak generálásához az egytűs elektrosztatikus szálképző berendezést

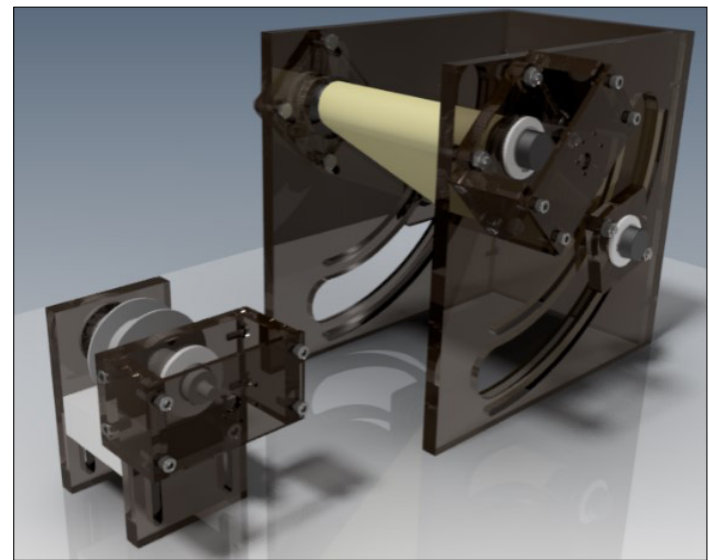

3. ábra. A tervezett tárcsás elektrosztatikus szálképző berendezés

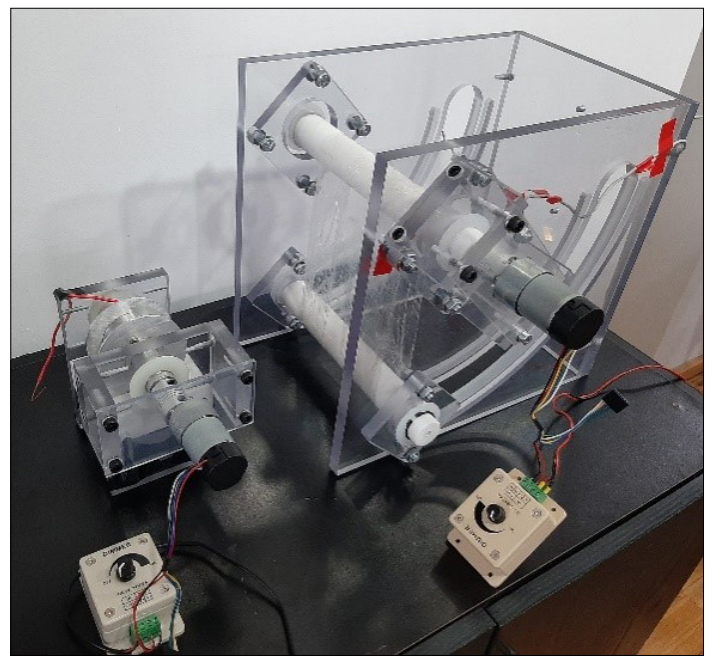

4. ábra. A megvalósított tárcsás szálképző berendezés.

használtuk, melynek felépítését részletesebben korábban közöltük. [15]. A PVP-szálak generálásához a tű és kollektor közti távolságot, $D, 10 \mathrm{~cm}$-re, illetve a térfogatáramot, $F, 0,7 \mathrm{~mL} / \mathrm{h}$-ra állítottuk. Ezen paraméterek mellett fokozatosan növeltük az alkalmazott potenciálkülönbséget, addig amíg beindult a szálképzési folyamat. Ebben az esetben ez 15 kV-nál következett be. Az 5. ábra mutatja a keletkezett szálas szerkezetet

$\mathrm{Az}$ 5.a. ábra SEM-felvételt megvizsgálva láthatjuk, hogy a szálas szerkezeten megjelentek gömbök, melyek a PVP-szálak mentén alakultak ki. Korábbi tapasztalatok alapján a gömbök 40\% oldatnál már nem jelentkeznek, így kialakulásuk nagy valószínűséggel a viszonylag alacsony koncentrációnak tudható be. Az 5.b. ábrán bemuta- 

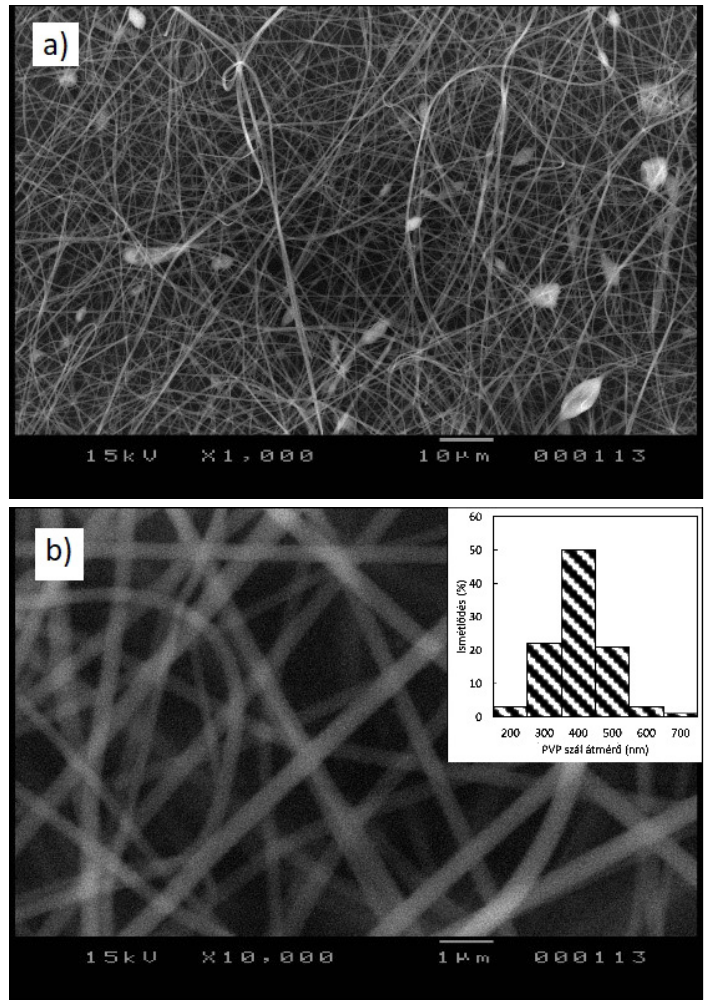

5. ábra. Az egytüs elektrosztatikus szálképzési berendezéssel generált szálas szerkezet a) x1000 és b) x10000 nagyításban készült SEM-felvétele

tott SEM-kép egy x10000 nagyítást mutat a keletkezett PVP-szálakról. Az eredmények feldolgozása $d=350 \mathrm{~nm}$ átlagos szálátmérő (1. táblázat) és $\sigma=86$ nm, szórást eredményezett. Az 5.b. ábrán a szálak átmérőjének hisztogramját is láthatjuk, amelynek vizsgálatából, illetbe a $\sigma$ értékből kiderül, hogy a keletkezett szálak átmérőjének szórása viszonylag alacsony.

A 6.a. ábrán látható SEM-felvétel azt a szálas szerkezet mutatja, melyet a tárcsával rendelkező elektrosztatikus szálképző eljárással állítottunk elő. A felvétel hasonló az 5.a. ábrához, miszerint göbök jelennek meg úgy az egytűs, mind a tárcsás előállítási eljárások esetén. A 6.b. ábrán a szálas szerkezet x5000 nagyításban látható. A keletkezett szálak sima felszínnel rendelkeznek, akárcsak az 5.b. ábra esetén. A hisztogram és a szálátmérők vizsgálata a tárcsás módszer esetén $d=446 \mathrm{~nm}$ és $\sigma=116$ nm-t eredményez. A szálátmérőértékekből látható, hogy a tárcsás módszerrel előállított PVP-szálak, az adott paraméterek mellett, átlagosan 100 nm nagyobb átmérővel rendelkeznek a
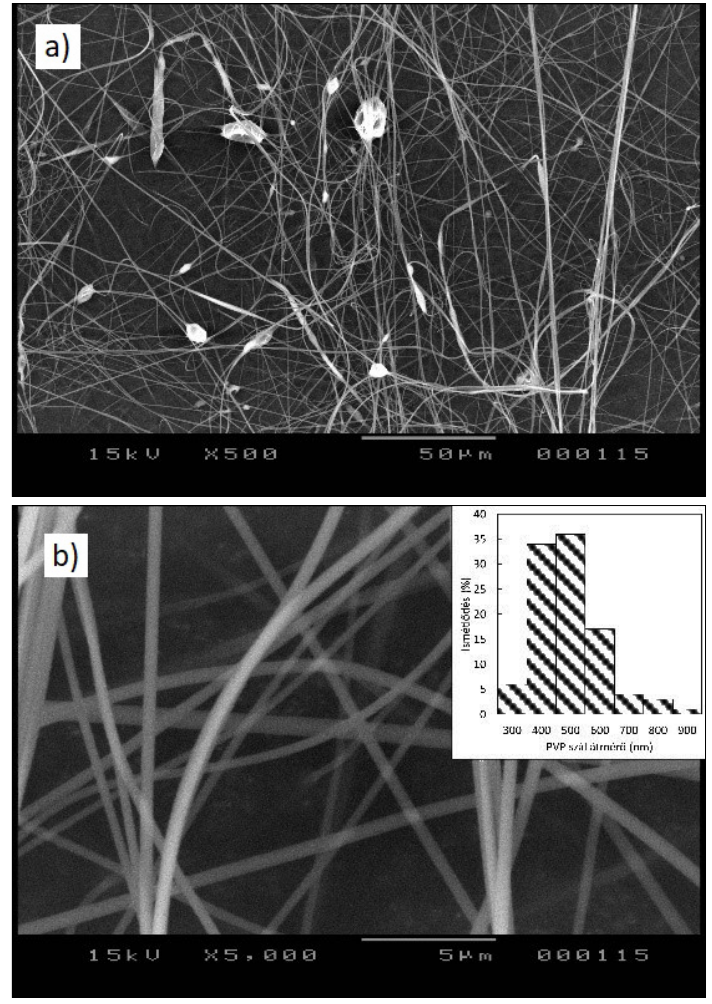

6. ábra. A tárcsával rendelkező elektrosztatikus szálképző berendezésen generált szálas szerkezet a) x500 és b) x5000 nagyításban készült SEM-felvétele.

tűs módszerhez képest. A szórási érték mindkét módszer esetén $25 \%$-a a $d$-nek.

A fentiekből levonhatjuk a következtetést, hogy a használt paraméterek mellett, a tárcsás módszerrel előállított szálas szerkezetek hasonló morfológiával rendelkeznek, mint az egytűs módszer, míg a keletkezett szálak átmérői nagyobbak 27 \%-kal. Mindkét módszer esetén a szórás értéke 25 \%-a a $d$-nek.

\section{Következtetések}

A bemutatott projekt keretében sikeresen megterveztünk és kiviteleztünk egy tárcsával rendelkező elektrosztatikus szálképző berendezést. A berendezés a termelékenységet hivatott növelni.

1. táblázat. PVP szál átmérők és szórás.

\begin{tabular}{|c|c|c|}
\hline & $\begin{array}{c}\text { Egytús } \\
\text { módszer }\end{array}$ & $\begin{array}{c}\text { Tárcsás } \\
\text { módszer }\end{array}$ \\
\hline $\mathrm{d}(\mathrm{nm})$ & 349 & 446 \\
\hline$\sigma(\mathrm{nm})$ & 86 & 116 \\
\hline
\end{tabular}


A tárcsás módszert a jól ismert egytűs módszerhez hasonlítottuk. Az eredmények alapján a két módszerrel hasonló morfológiájú szálas szerkezetet sikerült előállítani, míg a PVP-szálak átmérője a tárcsás módszer estén átlagosan 100 nm-rel nagyobb a tűs módszerrel előállított mintákhoz képest.

\section{Szakirodalmi hivatkozások}

[1] Huang Z.-M., Zhang Y.-Z., Kotaki M., Ramakrishna S.: A review on polymer nanofibers by electro-spinning applications in nanocomposites. Composites Science and Technology, 63/15. (2003) 2223-2253. https://doi.org/10.1016/S0266-3538(03)00178-7

[2] Yarin A. L. , Zussman E.: Upward Needleless Electrospinning of Multiple Nanofibres. Polymer, 2004, 45, 2977-2980. https://doi.org/10.1016/j.polymer.2004.02.066

[3] Jirsák O., Sanetrnik F., Lukas D., Kotek V., Martinova L., Chaloupek J.: US Patent W02005024101, 2005.

[4] Li J, Gao F, Liu L.Q., Zhang Z.: Needleless electro-spun nanofibers used for filtration of small particles. Express Polymer Letters, 7/8. (2013) 683-689.

https://10.3144/expresspolymlett.2013.65

[5] Jentzsch E., Gül Ö., Öznergiz E.: A comprehensive electric field analysis of a multifunctional electrospinning platform. Journal of Electrostatics, 71/3. (2013) 294-298.

https://doi.org/10.1016/j.elstat.2012.12.007

[6] Forward K. M., Flores A., Rutledge G. C.: Production of core/shell fibers by electrospinning from a free surface. Chemical Engineering Science, 104. (2013) 250-259.

[7] Niu H., Wang X., Lin T.: Needleless electrospinning: Influences of fibre generator geometry. Journal of the Textile Institute 103/7. (2012) 787-794. https://doi.org/10.1080/00405000.2011.608498
[8] Taylor G. I.: Electrically driven jets. Proceedings of Royal Society A, 313/1515. (1969) 453-475.

https://doi.org/10.1098/rspa.1969.0205

[9] Athira K., Sanpui P., Chatterjee K.: Fabrication of Poly (Caprolactone) Nanofibers by Electrospinning. Journal of Polymer and Biopolymer Physics Chemistry, 2/4. (2014) 62-66.

[10] Reneker D. H., Yarin A. L.: Electrospinning jets and polymer nanofibers. Polymer, 49/10. (2008) 2387-2425.

https://doi.org/10.1016/j.polymer.2008.02.002

[11] Theron S. A., Yarin A. L., Zussmann E., Kroll E.: Multiple jets in electrospinning: experiment and modeling. Polymer, 46/9. (2005) 2889-2899.

[12] E. Hirsch, P. Vass, B. Démuth, Zs. Pethő, E. Bitay, S. K. Andersen, T. Vigh, G. Verreck, K. Molnár, Zs. K. Nagy, Gy. Marosi: Electrospinning scale-up and formulation development of PVA nanofibers aiming oral delivery of biopharmaceuticals. Express Polymer Letters, 13/7. (2019) 590-603.

https://doi.org/10.3144/expresspolymlett.2019.50

[13] Kim G. H., Cho Y.-S., Kim W. D.: Stability analysis for multi-jets electrospinning process modified with a cylindrical electrode. European Polymer Journal, 42/9. (2006) 2031-2038.

https://doi.org/10.1016/j.eurpolymj.2006.01.026

[14] Molnar K., Nagy Z. K.: Corona-electrospinning: Needleless method for high-throughput continuous nanofiber production. European Polymer Journal, 74. (2016) 279-286.

https://doi.org/10.1016/j.eurpolymj.2015.11.028

[15] Gergley A., Kantor J., Bitay E., Biro D.: Electrospinning of Polymer Fibres Using Recycled PET. Acta Materialia Transylvanica 2/1. (2019) 19-26. https://doi.org/10.33924/amt-2019-01-04 


\title{
AZ ÁRVÍZVÉDELMI FELADATOK ELLÁTÁSÁHOZ A KÖTIVIZIG-NÉL RENDELKEZÉSRE ÁLLÓ ÉS A KÜLSŐ SZERVEZETEKTŐL BEVONHATÓ GÉPI ERŐFORRÁSOK
}

\section{MECHANICAL RESOURCES AVAILABLE AT MIDDLE TISZA DISTRICT WATER DIRECTORATE FOR EXTERNAL FLOOD PROTECTION AND OUTSOURCING}

\author{
Horváth Lajos
}

Közép-Tisza-vidéki Vízügyi Igazgatóság. Szolnok, Magyarország, horvath.lajos@kotivizig.hu

\begin{abstract}
After 1998, the flood waves of the Tisza, Zagyva and Hármas-Körös rivers reached record levels in the area of operation of MTDWD requiring significant mechanical resources from the Water Directorate and participating external organizations in order to perform the protection tasks. In this article, the author describes the volume of mechanical resources used in the management of the MTDWD and the volume of those provided by external organizations during the flood control of the Tisza River in 2000, 2006 and 2010. It proves that in the event of flood defenses exceeding the order level, the Directorate's own machinery resources are not sufficient, and that therefore, external machinery capacities are indispensable to meet future requirements.
\end{abstract}

Keywords: flood protection, mechanical resource, defense intervention, damage prevention, external forces.

\section{Összefoglalás}

Az 1998. évet követően a KÖTIVIZIG működési területét érintően a Tiszán, a Zagyván és a Hármas-Körös folyókon levonuló árhullámok több esetben rekordszintet döntöttek. A védelmi feladatok ellátása a vízügyi igazgatóságtól és a közreműködő külső szervezetektől jelentős gépi erőforrást igényelt. A cikkben a szerző ismerteti a 2000., 2006. és 2010. évi tiszai árvízvédekezés során az igazgatóság védekezési területén igénybe vett, a KÖTIVIZIG vagyonkezelésében lévő, valamint a külső szervezetek által biztosított gépi erőforrások volumenét. Bizonyítja, hogy az elrendelési fokozatot meghaladó árvízvédekezések alkalmával az igazgatóság saját gépi erőforrása a szükséges mértékben nem áll rendelkezésre, ezért a feladatok maradéktalan elvégzése érdekében elengedhetetlen a külső gépi kapacitások igénybevétele.

Kulcsszavak: árvízvédelem, gépi erőforrás, védelmi beavatkozás, kárelhárítás, külső erők.

\section{Bevezetés}

Az árvízvédelmi feladatokat ellátó vízügyi igazgatóságok a 90’-es éveket követően jelentős szervezeti átalakuláson mentek keresztül. A szervezethez tartozó építési és kivitelezési részlegek megszüntetésre vagy átszervezésre kerültek. Ebből adódóan az igazgatóság gépi kapacitása jelentősen lecsökkent, és jelenleg már nem rendelke- zik megfelelő mennyiségű és minőségű technikai eszközökkel a vízkárelhárítási tevékenység teljes körű ellátásához. A hiányzó gépi erőforrás biztosításához elengedhetetlen olyan külső szervezetek bevonása, amelyek rendelkeznek a szükséges technikai eszközökkel. (Például: a katasztrófavédelem, a honvédség, a rendvédelmi szervek, kivitelezői cégek, egyéni vállalkozók, szolgáltatók stb.) 
A téma aktualitását bizonyítja, hogy az elmúlt évtizedek árvízvédekezései során minden esetben jelentős mennyiségben kellett bevonni külső gépi erőforrásokat, mert az érintett igazgatóságok nem rendelkeztek a védekezéshez szükséges elegendő technikai gépekkel, eszközökkel.

Számolni kell azzal a lehetőséggel, hogy a Tiszán az elmúlt évtizedekben kialakult árhullámoknál magasabb árhullámok is levonulhatnak [1], ezért fel kell készülni ezek kivédésére és a lakosság árvízbiztonságát megteremtő beavatkozások elvégzésére.

A hazai szakirodalomban gyakran jelennek meg hazánk árvízi védekezésének helyzetével foglalkozó publikációk, azonban ezek nem vizsgálják a vízügyi ágazat gépi erőforrásának helyzetét, nem kutatják és tárják fel a védekezés során felmerülő gépi és technikai eszközök hiányának külső erőforrásokból történő pótlásának lehetőségét, mértékét.

Ebben a cikkben bemutatom a KÖTIVIZIG területén a 2000., 2006. és 2010. években levonult árhullámok esetében az árvízvédekezési munkák során alkalmazott gépi erőforrásokat, továbbá vizsgálom és bemutatom, hogy a mértékadó árvízszint (továbbiakban: MÁSZ), valamint a legnagyobb vízszint (továbbiakban: LNV) esetén milyen gépi erőforrás-szükséglettel kell számolni. A cikk megírásának célja, hogy bizonyítsam és egyben felhívjam a figyelmet arra, hogy az elmúlt árvízvédekezések során és egy prognosztizált, jövőbeli árhullám esetében, a vízügyi igazgatóság belső gépi erőforrása a védekezési munkákhoz nem elegendő. Eddig is szükség volt, és fejlesztések nélkül a jövőben is számolni kell azzal, hogy a hiányt külső szervezetek gépi és technikai eszközeinek igénybevételével lehet és kell pótolni.

A felkészülési időszakban elengedhetetlen az erőforrás-szükségletek felmérése, esetleges előretörténő lebiztosítása előszerződések és együttműködési megállapodások megkötésével. A szükséges erőforrás biztosításához elengedhetetlen az „Erőforrás-igénybevételi terv” elkészítése és évenkénti aktualizálása, melynek tartalmaznia kell a külső erők esetében rendelkezésre álló gépeket, valamint a kapcsolattartói elérhetőséget is. A védekezési munkák megkezdésekor sem idő, sem személyi kapacitás nem áll majd rendelkezésre ahhoz, hogy akkor kerüljön felmérésre és megszervezésre a szükséges gépi rendelkezésre állás.

\section{Az árvízvédekezési feladatok ellá- tásához szükséges gépi erőforrás igények a KÖTIVIZIG területén}

Az árvízvédekezési munkák végrehajtása során a humán erőforrás mellett számos munkagép, gépjármű, tehergépkocsi, speciális szállítójármü, vízi jármű és az ezekhez szükséges egyéb eszközök kerülnek igénybevételre. Főként a védekezéshez szükséges anyag mozgatásához és a nagyszámú fizikai munkás beavatkozási helyekre történő szállítása a legnagyobb volumenű, megoldandó logisztikai feladat. Nehezítő körülmény, hogy az észlelt árvízi jelenségek helyei és így a beavatkozási helyszínek területileg eltérőek. A KÖTIVIZIG esetében a kijelölt elsőrendű árvízvédelmi fővédvonal hossza összesen 707,114 km. A figyelőszolgálat által észlelt árvízi jelenségek (pl. buzgár, csurgás, talpszivárgás, rézsűcsúszás stb.) műszaki minősítését követően, a szakasz védelemvezetője döntést hoz a beavatkozás módjáról és megkezdéséről. Amennyiben azonnali beavatkozásra van szükség, meg kell kezdeni a fizikai munkások mozgósítását, valamint a védelmi anyagok helyszínre szállítását.

A védelmi munkák ellátásához rendelkezésre álló, a vízügyi igazgatóság saját állományú gépparkja 2020. január 1-én a következő:

-86 db terepjáró képességű 3,5 t össztömeg alat-

ti személy- és tehergépjármű;

- 67 db mezőgazdasági vontató;

- 5 db építőipari munkagép;

- 31 db vízi jármű (hajó, csónak, rocsó).

A vízügyi igazgatóság a működési területére vonatkozóan minden év február 28-ig, védelmi szakaszonként, elkészíti a felkészülési tervét. A felkészülési terv tartalmazza az előre meghatározott árhullámszintekre történő beavatkozási feladatokat, valamint azok humán, gépi és védelmianyag-igényeit.

Az 1. táblázat a 2019. évi felkészülési terv [2] alapján az árvízvédekezési beavatkozásokhoz szükséges gépek számát mutatja három különféle tetőző árhullámszint bekövetkezése esetén

A kijelölt tetőző árhullámszintek a szolnoki vízmércén a következők: „régi” MÁSZ: 974 cm, LNV: $1041 \mathrm{~cm}$ és MÁSZ: $1085 \mathrm{~cm}$. Ezen vízszintek azért kerültek kijelölésre, mert az árvízvédekezések során felkészülési tervezési szintnek és egyben mértékadónak tekinthetőek. A „régi” MÁSZ vízszintje a 74/2014. (XII. 23.) BM-rendelet a folyók mértékadó árvízszintje [3] érvénybe lépése előtti érték. 
1. táblázat. Az árvízvédekezéshez szükséges gépi eröforrások a tetőző árhullám szintjének függvényében a KÖTIVIZIG területén.

\begin{tabular}{|c|c|c|c|}
\hline $\begin{array}{c}\text { Géptípusok } \\
\text { [db] }\end{array}$ & $\begin{array}{l}\text { „régi” } \\
\text { MÁSZ }\end{array}$ & LNV & $\begin{array}{l}\text { „új”” } \\
\text { MÁSZ }\end{array}$ \\
\hline Munkagép & 232 & 330 & 1114 \\
\hline Autó, daru & 5 & 22 & 57 \\
\hline Tehergépkocsi & 1426 & 2071 & 6630 \\
\hline Mg-i vontató & 163 & 217 & 137 \\
\hline Vizi jármű & 21 & 24 & 27 \\
\hline Egyéb jármű & 6 & 6 & 7 \\
\hline
\end{tabular}

Az „új” MÁSZ 1\%-os valószínűséggel várható vízállásértékének meghatározása a vízhozamidősorok statisztikai elemzésével az 1\%-os valószínűséggel számított vízhozamból indult ki, amelyhez a legutóbbi árvizek adatait is magában foglaló, hosszú távú idősorok szolgáltattak alapadatokat..

$\mathrm{Az}$ 1. táblázatban szereplő gépigény mennyiségéből látható, hogy a vízügyi igazgatóság saját állományú gépparkja tekintetében csak a vízi járművek esetében rendelkezik kellő mértékű kapacitással. A rendelkezésére álló 86 db személy- és tehergépjármű az irányítási feladatok ellátására sem elegendő, hiszen III. fokozatú árhullám esetén már 100 fő feletti védekezésirányítói létszám részére kell biztosítani jármüvet.

$\mathrm{Az}$ árvízvédelmi készültségi fokozatok elrendelési szintjei a Tisza szolnoki vízmércéjén („0” pont: 78,78 mBf) mért vízállásai alapján a következőek: I. fok: $650 \mathrm{~cm}$; II. fok: $750 \mathrm{~cm}$; III. fok: 800 $\mathrm{cm}$.

Az 1. táblázatban jól látható, hogy a közúti járművek (tehergépkocsik) az árvízvédekezéshez szükséges gépek legnagyobb részét, 77-83\%-át teszik ki, ezért rendelkezésre állásuk alapvető feltétele a sikeres árvízvédekezésnek.

A felkészülési tervben szereplő gépigény és a vízügyi igazgatóság saját gépi állománya ismeretében kijelenthető, hogy a védekezési feladatok ellátására külső erők gépi erőforrásának bevonása szükséges, mivel a vízügyi igazgatóság saját kapacitása nem elegendő.

\section{A 2000., 2006. és 2010. évi tiszai árvíz- védekezések során alkalmazott gépi erőforrások}

A fejezetben az árvízvédekezési jelentésekből [4] származó napi és összegzett gépek mennyiségi adatait táblázatokba rendezve mutatom be, és vizsgálom a külső erők által biztosított gépi erőforrások, valamint a KÖTIVIZIG saját képességének arányát a 2000., 2006., 2010. árvízvédekezések alkalmával. A külső erők gépi mennyiségi adatai az igazgatósággal előszerződött és együttmüködési megállapodást kötött külső szervezetek gépi állományára vonatkoznak.

A 2. táblázatban kimutatott adatok alapján megállapítható, hogy a 2000. évi árvízvédekezés idején volt bevonva a legnagyobb gépi erőforrás (27 $963 \mathrm{db}$ ) és legnagyobb arányban (93\%) a külső erők gépi kapacitása. A három árhullám közül a 2000. évi tetőzött a legmagasabb, $1041 \mathrm{~cm}$ szinten Szolnoknál (2006: 1013 cm, 2010: $954 \mathrm{~cm}$ ).

2. táblázat. A 2000., 2006. és 2010. évi árvízvédekezésekben alkalmazott gépi erőforrások teljes védekezés idejére összegzett adatai a KÖTIVIZIG területén.

\begin{tabular}{|c|c|c|c|}
\hline Gépek & $\mathbf{2 0 0 0 .}$ & $\mathbf{2 0 0 6 .}$ & $\mathbf{2 0 1 0 .}$ \\
\hline $\begin{array}{c}\text { KÖTIVIZIG } \\
\text { [db] }\end{array}$ & $\begin{array}{c}2022 \\
\mathbf{( 7 \% )}\end{array}$ & $\begin{array}{c}2684 \\
\mathbf{( 1 5 \% )}\end{array}$ & $\begin{array}{c}2310 \\
\mathbf{( 1 8 \% )}\end{array}$ \\
\hline $\begin{array}{c}\text { Külső erők } \\
\text { [db] }\end{array}$ & $\begin{array}{c}25941 \\
(93 \%)\end{array}$ & $\begin{array}{c}14837 \\
\mathbf{( 8 5 \% )}\end{array}$ & $\begin{array}{c}10790 \\
(82 \%)\end{array}$ \\
\hline $\begin{array}{c}\text { Összesen } \\
\text { [db] }\end{array}$ & 27963 & 17521 & 13100 \\
\hline
\end{tabular}

A kijelölt árvízvédelmi fővédvonalakon a védelmi munkák ellátását minden esetben a területileg illetékes vízügyi igazgatóság szervezi és irányítja. A szükséges többletkapacitást az előre tervezett módon használja fel, és gondoskodik annak biztosításáról, valamint az ágazaton belüli átvezényléseket az Országos Műszaki Irányító Törzsön keresztül kérelmezi. A társszervezetek bevonását (pl.: honvédség, rendvédelmi szervek) a Megyei Védelmi Bizottságokon keresztül lehet igényelni.

A 3. táblázatban feltüntetett napi maximális adatokból is jól látható a külső erők által biztosított gépek jelentős aránya.

3. táblázat. A 2000., 2006. és 2010. évi árvízvédekezésekben alkalmazott gépi eröforrások napi maximális adatai a KÖTIVIZIG területén.

\begin{tabular}{|l|c|c|c|}
\hline Gépek & $\mathbf{2 0 0 0 .}$ & $\mathbf{2 0 0 6 .}$ & $\mathbf{2 0 1 0 .}$ \\
\hline KÖTIVIZIG & 05.01. & 04.28. & 06.03. \\
[db] & 59 & 78 & 56 \\
\hline Külső erők & 04.18. & 04.09. & 06.11. \\
[db] & 1181 & 601 & 602 \\
\hline Összesen & 04.18. & 04.09. & 06.11. \\
[db] & 1233 & 654 & 650 \\
\hline
\end{tabular}

$\mathrm{Az}$ 1. ábra szemlélteti a védekezések során igénybe vett külső szervezetek által biztosított gé- 


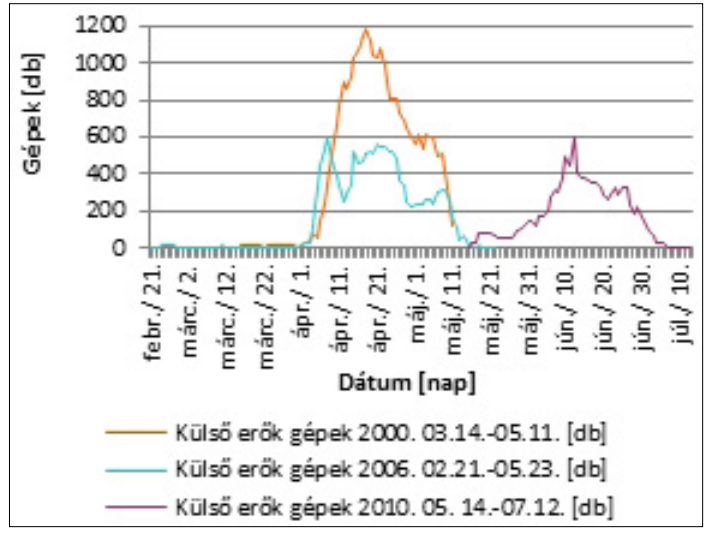

1. ábra. A 2000., 2006. és 2010. évek árvízvédekezésében alkalmazott külső erők gépeinek napi mennyiségi adatai

pek számát, melynek maximuma 2000-ben megközelítette az 1200 darabot.

A védekezés során igénybe vett gépek kimagasló számának hirtelen emelkedése az árhullám emelkedésével egyenes arányban változott, mert a meredeken emelkedő vízállás következtében a figyelőszolgálat nagy számban észlelt káros árvízi jelenségeket, melyek elhárításához védelmi beavatkozásokra került sor. Ezért több szállítójárműre volt szükség a védelmi anyagok és a fizikai munkaerő helyszínre szállítása érdekében.

\section{Következtetések}

Megállapítható, hogy a KÖTIVIZIG a rendelkezésére álló saját állományú gépi kapacitásával az árvízvédelmi munkákat magasabb fokozatú árvízszintet meghaladó árhullámok esetében nem képes ellátni.

A rendkívüli árhullámok levonulása esetén a sikeres árvízvédekezés, valamint a lakosság árvízbiztonságának megteremtése érdekében a vízügyi ágazatba jelentős számú külső gépi erőforrás bevonására van szükség.
A KÖTIVIZIG a védelmi munkák irányítása és ellátása mellett párhuzamosan végzi a normál „békebeli” igazgatási, üzemeltetési, szakfelügyeleti stb. alapfeladatát is, melyhez szintén kapcsolódik gépjárműigény, ezért nem vonható be teljes mértékben az igazgatóság gépjárműparkja a védelmi feladatok végrehajtásába.

A három vizsgált árhullám esetében a vízügyi igazgatóság és a külső erők gépi erőforrásainak aránya a tetőző vízállás függvényében változik. A Tisza szolnoki vízmércéjén mért, $1000 \mathrm{~cm}-\mathrm{t}$ meghaladó tetőző vízállása esetében $80-95 \%$ a külső erők gépierőforrás-aránya. Ez egyben azt jelenti, hogy az árvízvédekezési munkák sikeressége jelentősen függ a külső erők által biztosított erőforrásoktól. Amennyiben az igényelt gépek és technikai eszközök nem állnak kellő számban vagy időben rendelkezésre, az rontani fogja az árvízvédekezési munkák hatékonyságát és eredményességét.

A fenti helyzetek kialakulásának elkerülése érdekében javaslom, hogy a jövőben az erőforrás-igénybevételi tervben szereplő gépi igények tervezése az LNV-szintre történjen, valamint nevesíteni kell azokat a külső szervezeteket (erőket), akik szükség esetén ezeket a technikai eszközöket biztosítani tudják.

Javaslom továbbá, hogy az erőforrás-igénybevételi tervek, valamint az alapjául szolgáló előszerződések, együttműködési megállapodások aktualizálása éves rendszerességgel történjen.

\section{Szakirodalmi hivatkozások}

[1] Kovács S., Lovas A., Gombás K.: Magyarország árvízvédelme az integrált vízgazdálkodásban a Tisza folyó példáján. Hidrológiai Közlöny, 96/4. (2016) 6-19.

[2] KÖTIVIZIG: Felkészülési terv. Szolnok, 2019.

[3] Jogtár, 74/2014. (XII. 23.) BM rendelet a folyók mértékadó árvízszintjeiröl. (letöltve: 2019. 11. 30.) https://net.jogtar.hu/jogszabaly?docid=a1400074. bm

[4] KÖTIVIZIG: Árvízvédekezési napi jelentések. Szolnok, 2000., 2006., 2010. 


\title{
ELEKTRONCSÖVES ÉS FÉLVEZETŐS FESZÜLTSÉGSTABILIZÁLT ERŐSÍTŐ ÁRAMKÖRÖK KIVITELEZÉSE
}

\section{DESIGN OF ELECTRON TUBE AND SEMICONDUCTOR- BASED AND VOLTAGE STABILISED AMPLIFIER CIRCUITS}

\author{
Hrámcov István, ${ }^{1}$ Erdei Timotei István, ${ }^{2}$ Décsei Roland, ${ }^{3}$ Husi Géza ${ }^{4}$ \\ Debreceni Egyetem, Müszaki Kar, Debrecen, Magyarország \\ ${ }^{1}$ hristvan99@gmail.com \\ ${ }^{2}$ timoteierdei@eng.unideb.hu \\ ${ }^{3}$ roland.decsei@gmail.com \\ ${ }^{4}$ husigeza@eng.unideb.hu
}

\begin{abstract}
In this project, an electron tube circuit consisting of a voltage stabiliser, pre-amplifier, and final stage amplifier circuit was designed. One of the main aims was to reuse as many components and materials as possible, thereby decreasing the project's ecological footprint. The result is a hybrid electron tube amplifier. The function of the circuits was subsequently measured and analysed using various tests.
\end{abstract}

Keywords: electron tube, transformer, voltage stabilizer, amplifier, circuit, PL82, integrated circuit.

\section{Összefoglalás}

A projekt megvalósítása során egy elektroncsöves áramkörön alapuló feszültségstabilizáló, illetve erősítő áramkör került megalkotásra. Az eszköz elkészítésénél az egyik fő kritérium az alkatrész és a nyersanyag újrahasznosítása volt. Ezeket a még használható alkatrészeket tönkrement elektronikai eszközökből használtuk fel, ezzel is csökkentve a projekt költségeit és az ökológiai lábnyomot. A projekt megvalósításának eredményeként egy hibrid elektroncsöves erősítő került megtervezésre és megépítésre. Az áramkörök müködését ezt követően vizsgáltuk mérések és tesztek elvégzésével.

Kulcsszavak: elektroncső, transzformátor, feszültségstabilizátor, erősítő, áramkör, PL82, integrált áramkör.

\section{Bevezető}

$\mathrm{Az}$ elektroncsövek használata visszaszorult a XX. század 80-as éveinek elejére, sok területen a mai napig elengedhetetlenek ezen komponensek. Elektroncsöveket olyan helyen alkalmazunk, ahol magasfeszültséget, nagy áramfelvételt vagy akár kilowattos erősítést kívánunk elérni. Ezek az igények, habár a modern félvezetős technológiákkal kivitelezhetők, azok fenntartási költségei egekbe szökően magasak. Hőtermelésük pedig komplex és drága hűtőberendezéseket kíván. Az ipar mel-

lett az elektroncsövek a háztartásokban is megtalálhatóak. Legismertebb talán az elektroncsöves erősítő. Mely ismét térhódítást nyert az úgynevezett „csöves hangzás” miatt [1]. mikrohullámú sütők szintén nagy teljesítményü elektroncsővel, a magnetronnal generálják a mikrohullámokat. $\mathrm{Az}$ elektroncsövek rendelkeznek hátrányokkal, azokat kompenzálni tudjuk félvezetőkkel, így egy hibrid áramkört létrehozva, mely mind az elektroncsöves, mind a félvezetős technológiák előnyeit kihasználja. 


\section{Hibrid erősítő áramkör}

A hibrid erősítő elkészítése során nagyrészt újrahasznosított alkatrészek kerültek alkalmazásra. A váz, az elektroncsövek, a végfok részei és sok más alkatrész mind elektromos hulladékból kimentett komponensek voltak. Ennek nagy jelentősége van abban, hogy környezetünk szenynyezését csökkentsük, hogy az elkészítéshez szükséges költségeket is alacsonyan tartsuk. A projekt egyik célja, hogy ezzel kapcsolatban is támpontot szolgáltatunk.

\subsection{Előerősítő}

Az előerősítő (1. ábra) E83F-típusú pentódákat használ SE (single ended) A-osztályú üzemmódban. Az E83F képes $1 \mathrm{~W}$ [2] RMS teljesítményre $10 \%$ torzítás mellett, ami előerősítésnél bár nem szükséges, ez is jelzi az elektroncső rugalmasságát. A maximális anódteljesítmény 2,1 W [3]. Az előerősítők esetében triódákat alkalmaztunk, mivel a pentódák nagyobb zajszintet visznek a jelbe [4].

A jel egy 470-560 k $\Omega$-os logaritmikus potméteren keresztül eljut az első fontos elágazásba. Itt két ellenállás, R7 és R6, található.

Az R7 ellenállás az úgynevezett rácsszivárogtató ellenállás. Feladata, mint nevéből adódik, a jelnek a földre szivárogtatása. Ez az ellenállás állítja be az erősítő érzékenységét. Értéke pár száz k $\Omega$-tól egészen $1 \mathrm{M} \Omega$-ig terjedhet.

Az R6 ellenállás a rácsmegállító ellenállás. Erre azért van szükség, mivel magas frekvenciák kerülhetnek az elektroncsőbe. Ennek elkerülése végett az alul áteresztő szűrő elvágja a $20 \mathrm{kHz}$ feletti frekvenciákat. Az elektroncső munkapontbeállítását az R4 ellenállás végzi 180 ohmos értéken. Ez az ellenállás határozza meg az elektroncső üresjárati üzemét, mivel „A” osztályban működik. A

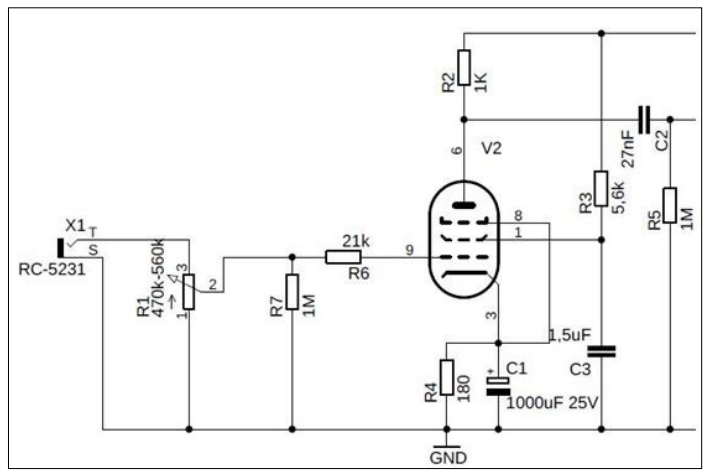

1. ábra. Az előerősítő kapcsolásirajza (részlet)
C1-kondenzátorral növelhető a cső érzékenysége (gain). Értéke $33 \mu \mathrm{F}$-tól akár $1000 \mu \mathrm{F}$-ig terjedhet.

\section{Tervezési szempontok}

Annak érdekében, hogy az elektroncsöves áramkörök vizsgálatát el tudjuk végezni, egy olyan áramkört kellett terveznünk, mely kielégíti a mérési feltételeket. Az áramkörök optimalizált alapáramkörökből lettek megtervezve annak érdekében, hogy optimálisan működjenek.

\section{A feszültségstabilizált erősítő felépí- tése}

Az eszköz dobozaként egy tönkrement mérőműszer dobozát választottuk. Mivel a műszer elektroncsöves volt, ezért a benne lévő transzformátor ideális volt számunkra. Ezenkívül elég helyet tudott biztosítani az áramkörök, illetve audis-transzformátorok számára.

Az erősítő (2. ábra) alkalmaz félvezető diódákat, melyek kis helyfoglalásuk és nagyobb hatásfokuk miatt lettek alkalmazva. BY238-típusú diódából 4 darab a nagyfeszültség egyenirányítását végzi, illetve egy helyet kapott a feszültségstabilizátor-áramkörben mint feszültségvisszafolyás-meggátló dióda. A KBL06-típusú egyenirányító híd a végfokot látja el egyenárammal. 1N4003-típusú diódák látják el a fütőszálakat egyenárammal. Az eszköz 3 fő részből épül fel: tápegység, előerősítő, végfok. A tápegység (3. ábra) transzformátort használ, melynek több kimenete van, illetve változtatható a bemeneti feszültség 110-127 és 220 V üzemre. A tápegység magában foglal egy feszültségstabilizátort, mely az előerősítő érzékeny áramkörét látja el terheléstől és bemeneti feszültségtől függetlenül 188 V-os feszültséggel. Ez a feszültség bizonyult optimálisnak az előerősítő és fázisfordító csövek számára, ezek ugyanis

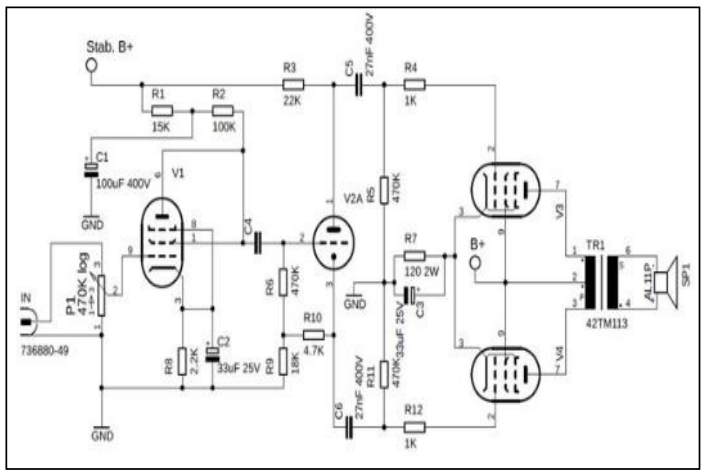

2. ábra. Az erösítő kapcsolásirajza (részlet) 


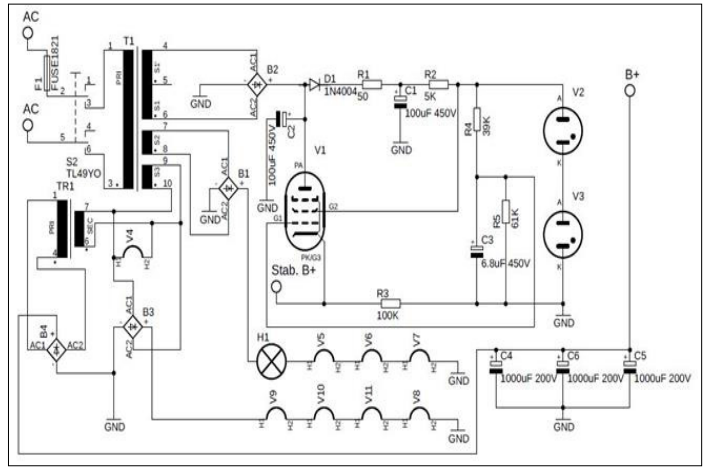

3. ábra. Tápegység

150-200 V [5, 6] üzemi feszültségen működhetnek károsodás nélkül a stabil tápegység mellett. A végfok egy egyszerü kapcsolást alkalmaz. A transzformátor 10V-os szekunder kimenetére egy másik transzformátor szekunder tekercsét kötöttük, az így kapott feszültség a második transzformátor primer tekercselésén $180 \mathrm{~V}$ AC lett. Egyenirányítás után és terhelés alatt a tápellátás $120 \mathrm{~V}$ DC lett, ez tökéletesen megfelel a PL82-típusú elektroncsöveknek. (A gyártó által ajánlott érték 170V [7].) Ez az áramkör nem igényel stabil bemenetet kapcsolásából adódóan.

\subsection{Feszültségstabilizátor működése}

A feszültségstabilizátor-áramkör stabil feszültséget szolgáltat függetlenül a terheléstől és a hálózati feszültség ingadozásától. Ez az áramkör 3 elektroncsövet használ: egy sugárpentódát és két feszültségreferencia-csövet. A 85AT2-típusú referenciacsövek egyenként $85 \mathrm{~V}$ feszültséget adnak referenciaként [8], sorosan kötve 170V. A $170 \mathrm{~V}$ mindaddig jelen lesz, amíg a feszültség nem esik a referenciacsövek nyitófeszültsége alá. Ha a terhelés hatására vagy a hálózati ingadozás hatására a feszültség eltér a referenciától, a sugárpentóda jobban kinyit, ezzel visszahozva a kívánt feszültség értékét a kimeneten [9]. Az áramkör a projekt esetében 188 V DC feszültséget ad ki.

\subsection{Az erősítő müködése}

Az erősítő három főbb részből épül fel: előerősítő, fázisfordító áramkör, push-pull konfigurációjú végfok. A jel az előerősítőbe fut be, ahol EF86-típusú pentódát alkalmaztunk trióda módban. Ha trióda módban üzemeltetjük az elektroncsövet, a zajszint jelentősen lecsökken, így megfelelővé válva alacsony jelszinteknél [5]. A jel ezek után a következő fokozat felé megy, a fázisfordító áramkörhöz. Mivel az elektroncsövek fordított polaritásban nem tudnak működni, egy fázisfordító áramkörre van szükségünk, hogy a push-pull konfigurációba elrendezett végokcsövek negatív amplitúdóért felelős ága működni tudjon. Ezt a funkciót egy PCC88-típusú elektroncső látja el. Ez egy dupla trióda [6]. A trióda anódja a pushpull pozitív ágának a vezérlőrácsát vezérli, míg a trióda katódja a negatív ág vezérlőrácsát. Ezzel a megoldással a végfok képes negatív amplitúdójú hullámot létrehozni. Mivel az elektroncsövek nagy feszültségen és alacsony áramerősségen üzemelnek, a hangszórót, mely magas áramerősségigényü alacsony feszültségen, nem lehet direktben vezérelni. Ennek megoldására audio-transzformátort kell alkalmazni.

\section{A kapcsolás megvalósítása}

Az áramkört Autodesk EAGLE-ben terveztük [10]. A tápegység és az erősítő áramkör kapcsolási rajza külön került elkészítésre az átláthatóság érdekében. A 4. ábrán látható a tápegység, mely magában foglalja a feszültségstabilizátort és a fütések számára fenntartott áramköröket is.

A fütéseket sorosan kapcsoltuk. Ennek biztonsági és tervezési okai vannak. Mivel a transzformá-
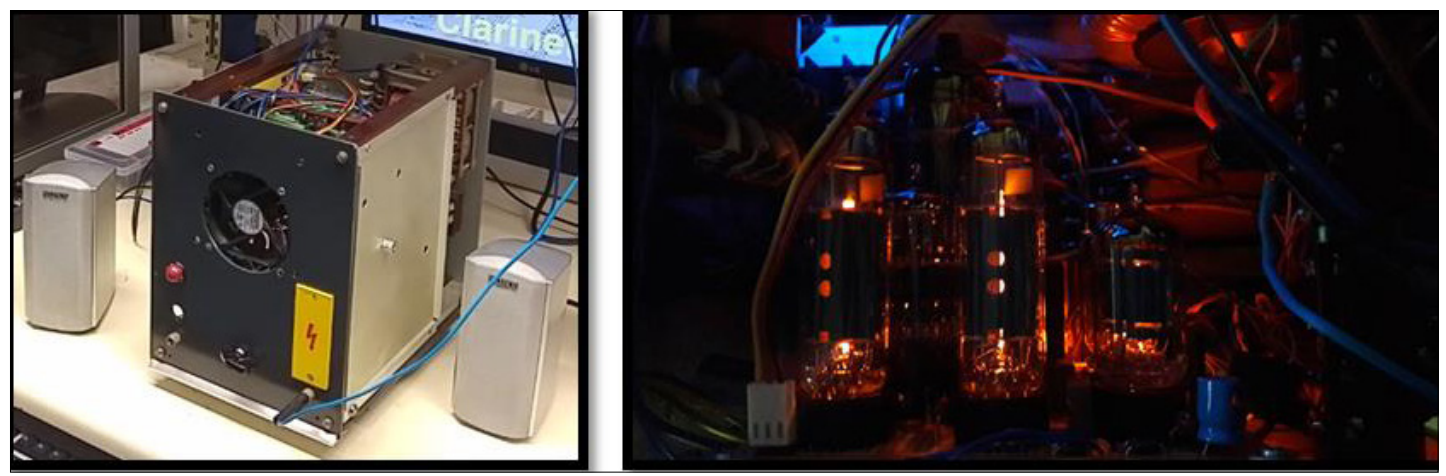

4. ábra. Az elkészült erősítő 
tort gyárilag soros fütésfüzérre tervezték, ezért a magas feszültséget soros kapcsolással elosztva megkaphatjuk a kívánt feszültséget.

A sugárpentóda, mivel $25 \mathrm{~V}$ [11] fütőfeszültséget igényel, ezért azt direktben lehet vezérelni a transzformátor fütésre kivezetett tekercséről. A 4 darab PL82-típusú pentóda a következőképpen bekötve: 2 elektroncső sorosan, majd ezzel a kapcsolással párhuzamosan a másik két elektroncső. Ezek az egyenirányítás utáni 30V-ról így megfelelően képesek üzemelni. Az előerősítő áramkörben található kettő darab EF86-, illetve PCC88-típusú csövek fütése 6,3 [5] és 7 [6] voltot igényelnek, azonban a 30 V-os feszültség miatt az áramkörhöz kellett adni sorosan egy $6.3 \mathrm{~V}$ izzót, mely a megfelelő feszültségre hozza a fütőszálakra eső feszültséget.

Az elektroncsövek erősítőknél nem igényelnek komplex áramköröket, ugyanis a tranzisztorokkal ellentétben lineárisan üzemelnek.

\section{Mérési eredmények}

\subsection{Az erősítő müködése}

Az elkészült erősítő áramkör $3 \mathrm{~W}$ teljesítményre képes, csatornánként $4 \Omega$-os terhelés mellett. $\mathrm{Az}$ erősítő áramkörök frekvencia-visszaadását speciális mérőfunkcióval rendelkező, Rhode\& Schwarz RTB2004-típusú digitális oszcilloszkóppal végeztem. A mérési tartomány $20 \mathrm{~Hz}$-től 20 kHz-i terjedt 2 Vp-p (peak to peak) jelfeszültség mellett. A beépített függvénygenerátort használtam ezen frekvenciák generálására.
A mérés előkészítéséhez egy 1 kHz frekvenciájú 2 Vp-p szinusz jelet tápláltam az előerősítő-bemenetre. Ekkor a végfok kimenetét figyelve, addig emeltem a hangerőt, míg $1 \mathrm{~W}$ teljesítményt kaptam. A teszt $20 \mathrm{~Hz}-$ ről logaritmikusan emelkedő frekvenciákkal halad $20 \mathrm{kHz}$-ig. Ideális esetben egy lineáris Bode-diagramot kapunk, azonban az erősítőben több olyan komponens is megtalálható, amely befolyásolja a görbe formáját. Többek között a jel irányába lévő kondenzátorok.

A diagramon (5. ábra) narancssárga színnel látható a gain, míg narancssárga kékkel a fázis. Megfigyelhetjük, hogy a frekvencia-visszaadás relatíve egyenes. Letörést tapasztalhatunk $40 \mathrm{~Hz}$ környékén, ami teljes mértékben elfogadható és normálisnak tekinthető. $10 \mathrm{kHz}$ felett szintén letörést tapasztalunk. Ennek oka az integrált áramkör korlátozottsága. Magas frekvenciákon nem képes megfelelő teljesítményt nyújtani torzítás nélkül. Ezért az IC kiegészítő áramköreivel korlátozni kellett a frekvencia-tartomány felső szegmensét $10 \mathrm{kHz}$ felett. Ez a lépés szükséges ennél az IC-családnál.

A jobb csatorna diagramja nagyon kis eltérést mutat a balhoz képest. Egy kisebb lefelé görbülés figyelhető meg $1 \mathrm{kHz}$ és $6 \mathrm{kHz}$ között. Ennek oka lehet a kondenzátorok és ellenállások tűrési értékével bevezetett értékkülönbség. Ennek ellenére ez a görbület emberi fül számára nem észrevehető a hangképben, és mivel nagyon hasonlóak a Bode-diagramok, ezért a sztereóhangkép kialakul a hallgató számára.

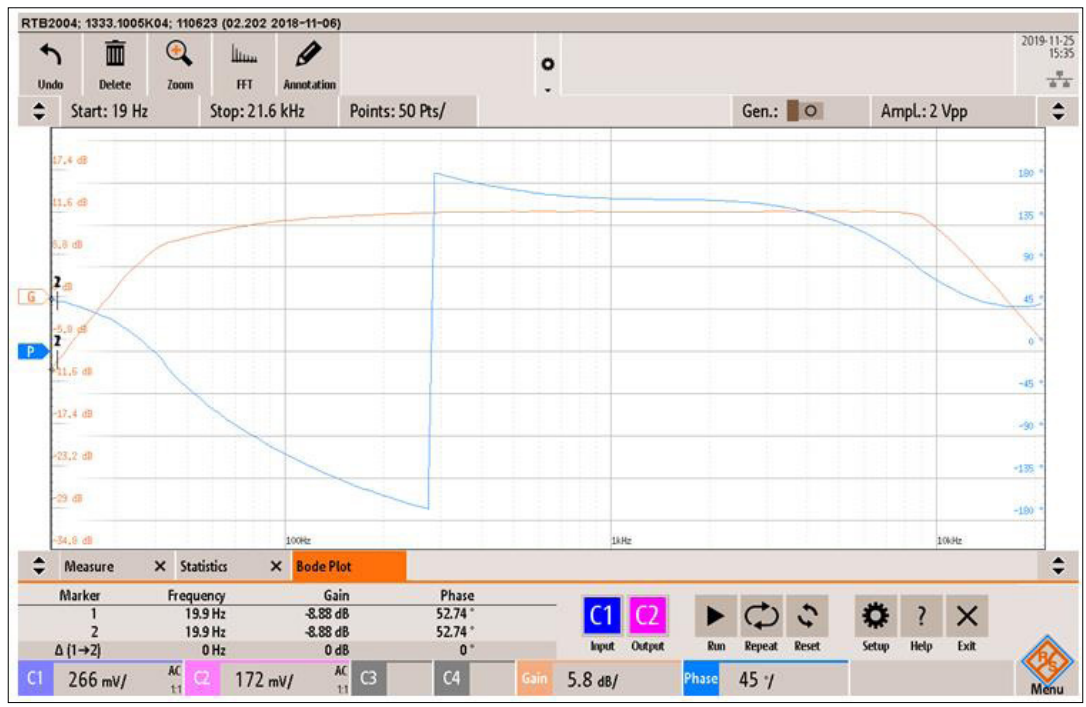

5. ábra. A bal csatorna Bode-diagramja 


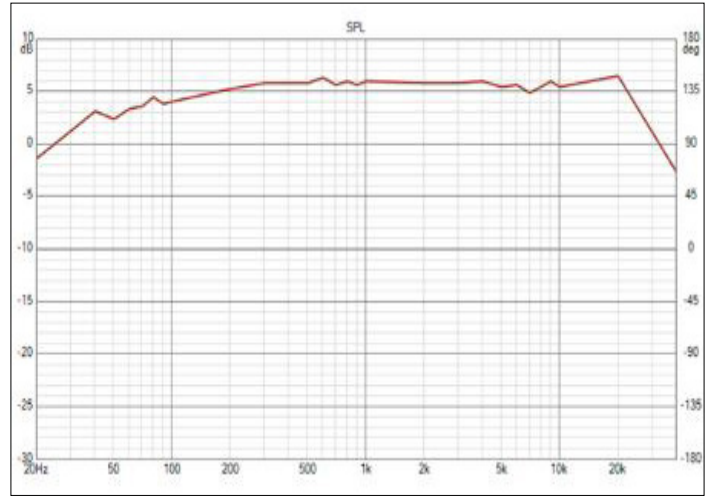

6. ábra. Bal csatorna frekvencia visszaadása hibás transzformátorral

\subsection{Elektroncsöves erősítő}

Az elektroncsövek erősítési mértékét az (1) képlet segítségével tudjuk kiszámolni:

$$
\text { Erősítés }=\frac{\mu * R(L)}{R(L)+r(p)}
$$

ahol $\mu$ az elektroncső erősítési tényezője, $\mathrm{R}(\mathrm{L}) \mathrm{a}$ terhelési ellenállás ohmban megadva, r(p) anódellenállás $\Omega$-ban megadva [12].

Az erősítő áramkör frekvencia-visszaadó képességét függvénygenerátorral (Metex MXG-9802A), digitális oszcilloszkóppal (Hantek MSO5102D) és multiméterrel (AXIO AX-588B) határoztam meg. A mérési tartományt $20 \mathrm{~Hz}$-től $20 \mathrm{kHz}$-ig végeztem.

A kapott eredményeket a VituxCAD [13] nevü szoftver segítségével grafikon formájában tüntettem fel csatornánként. (6. ábra)

Mivel ez az erősítő nem audio-transzformátort, hanem hálózati transzformátort használ a kimeneten, ezért észrevehető a frekvencia-visszaadás nonlinearitása. Ez egyszerüen abból adódik, hogy a hálózati transzformátor nem hangfrekvenciákra van méretezve.

A jobb csatorna hasonlóan teljesített, mint a bal csatorna. A sztereókép kialakul a hallgató számára, mivel a két csatorna azonos hangerővel és frekvencia-visszaadással rendelkezik.

\section{7. Összegzés, fejlesztési lehetőségek}

Az elektroncsöves és hibrid feszültségszabályozó és erősítő áramkör megépítésre került. Ezen az áramkörön méréseket végeztünk, az stabil működésre nézve. Továbbá ezen áramkörök modern felhasználási lehetőségére világítottak rá a félvezetős eszközök mellett. A projekt jövőbeli továbbfejlesztési potenciált tartalmaz magában. A transzformátoros fütőáramkör lecserélhető hatékonyabb kapcsolóüzemű tápegységre. Az audio-transzformátorok cseréjével javítható a frekvencia-visszaadás linearitása.

\section{Köszönetnyilvánítás}

Szeretném megköszönni Husi Géza tanár úrnak, hogy elvállalta a konzulensi szerepet, szakmai tudásával segített. A projekt a Debreceni Egyetem Müszaki Karán a Cyber-Physical \& Intelligent Robot Systems laborjában készült. A kutatást a Debreceni Egyetem, Informatikai Tudományok Doktori Iskola támogatta.

\section{Szakirodalmi hivatkozások}

[1] History of the Audio Amplifier, [Online]. https://sciencing.com/varactor-diode-5124911. html [Hozzáférés dátuma: 2019-11-26].

[2] E83F Datasheet, [Online]. https://frank.pocnet.net/sheets/009/e/E83F.pdf [Hozzáférés dátuma: 2019-11-26].

[3] М. Рашковский, Б. Пилипенко, В. Цирулников, Ф. Хмельницкий, Электричество в быту, Odessza, 1973

[4] TBA 790 Datasheet, [Online]. https://www.radiomuseum.org/tubes/tube_ tba790.html [Hozzáférés Dátuma: 2019-11-26].

[5] EF86 Datasheet, [Online]. https://frank.pocnet.net/sheets/010/e/EF86.pdf [Hozzáférés fátuma: 2019-11-26].

[6] PCC88 Datasheet, [Online]. https://frank.pocnet.net/sheets/010/p/PCC88.pdf [Hozzáférés dátuma: 2019-11-26].

[7] PL82 Datasheet, [Online]. https://frank.pocnet.net/sheets/030/p/PL82.pdf [Hozzáférés dátuma: 2019-11-26].

[8] 85A2T Datasheet, [Online]. https://frank.pocnet.net/sheets/190/8/85A2.pdf [Hozzáférés dátuma: 2019-11-26].

[9] Steve Bench: Tube Based Voltage Regulators. USA, 2000.

[10] T. I. Erdei, Zs. Molnár, N. C. Obinna, G. Husi: Cyber physical systems in mechatronic research centre. MATEC Web Conf. Volume 126, 2017.

[11] PL36 Datasheet, [Online]. https://frank.pocnet.net/sheets/010/p/PL36.pdf [Hozzáférés dátuma: 2019-11-26].

[12] EZ80 Datasheet, [Online]. https://frank.pocnet.net/sheets/010/e/EZ80.pdf [Hozzáférés dátuma: 2019-11-26].

[13] VituxCAD, [Online]. https://kimmosaunisto.net/Software/Software. html [Hozzáférés dátuma: 2019-11-26]. 


\title{
A V4-EK BIZTONSÁG- ÉS VÉDELEMPOLITIKÁJA - NEMZETI ÉS SZÖVETSÉGESI KIHÍVÁSOK A TAGORSZÁGOKBAN
}

\section{V4 SECURITY AND DEFENSE POLICY - NATIONAL AND ALLIED CHALLENGES IN MEMBER STATES}

\author{
Hronyecz Erika
}

Nemzeti Közszolgálati Egyetem - Budapest, Magyarország, hronyecz.erika@gmail.com

\begin{abstract}
Making the common European security and defense policy more effective starts at the state level. It is of paramount importance that the member states of the respective federations can able to demonstrate modern forces with high level of compatibility and qualification and along with that the use of these national forces at allied level should be possible without major obstacles. In this publication, the author presents the main historical points of the defense policy of the Visegrad Cooperation (V4) countries, and in this context the steps and efforts of the force to respond to new types of security challenges.
\end{abstract}

Keywords: Visegrad Group, security policy, defense policy, alliance, challenges.

\section{Összefoglalás}

A közös európai biztonság és a védelempolitika hatékonyabbá tétele az államok szintjén kezdődik. Kiemelten fontos, hogy az adott szövetségek tagországai olyan modern, kompatibilitás és képzettség tekintetében magas szinten teljesítő haderőt tudjanak felmutatni, melyek alkalmazása nemzetközi szintű összefogást igénylő probléma megoldása, illetve elhárítása esetén nem jelenti akadályát a hatékony fellépésnek. Jelen közleményben a szerző a visegrádi együttműködés (V4) országainak védelempolitikájának főbb történelmi pontjait, illetve ezzel összefüggésben az új típusú biztonsági kihívásokra adott haderőfejlesztési lépéseit, erőfeszítéseit mutatja b.

Kulcsszavak: Visegrádi Csoport, biztonságpolitika, védelempolitika, szövetség, kihívások.

\section{A biztonsági tényezők és a védelem- politika alakulása a visegrádi csoport fennállása óta}

A rendszerváltás után a kelet-közép-európai térség államai számára a gazdasági és szociális biztonság alapvető fontossággal bírt, és ennek reformálásra, fejlesztésére, hosszú távon történő stabilizálására elsődleges megoldásként az Európai Unióhoz mint gazdasági és értékközösséghez történő csatlakozást látták. De mindezen tényezők mellett nem lehetett figyelmen kívül hagyni a katonai biztonságot sem, mely szintén szenzitív állapotban volt a korábbi szocialista rendszer felbomlása után. A varsói szerződés 1991-ben történt felszámolását követően a tagországok egységesen arra törekedtek, hogy teljesítsenek minden olyan feltételt, amely hozzájárul ahhoz, hogy a lehető legrövidebb időn belül csatlakozhassanak az Észak-atlanti Szerződés Szervezetéhez. Ebben az esetben nemcsak a Nyugat felé való nyitás ösztönözte az államokat. A régió országai tudatában voltak annak, hogy egy adott külső támadás esetén önállóan nem lennének képesek megvédeni területüket, nemzetüket, szükségszerű a szövetségesi szintű szerveződés megléte. Nyolc évvel a VSZ megszűnése után, 1999. március 12-én Lengyelország, Csehország és Magyarország a NATO tagja lett, 2004-ben pedig - 
más kelet-európai volt szocialista országok mellett - Szlovákia is belépett a szervezetbe.

A '90-es években az euroatlanti integrációs folyamat müködtetése mellett, illetve annak felgyorsítása és a lehetőségekhez mérten zökkenőmentes végbemenetelének érdekében Lengyelország, Csehország, Szlovákia (1993. január 1-ig Csehszlovákia) és Magyarország együttesen szükségét érezte egy szűkebb, régión belüli összefogásnak, melyet a Visegrádi Együttműködés keretén belül valósítottak meg.

A visegrádi csoport közel 30 éves fennállása alatt több fázison is átesett az együttműködést tekintve. A kezdeti sikereket és lendületet hamar felváltották a kudarcok, a széthúzás és az egymással való versengés az euroatlanti integrációért folytatott küzdelemben, így a '90-es évek végéig stagnált a csoport aktivitása [1] Miután 2004-re mind a négy állam sikerrel abszolválta mind a NATO-hoz, mind az EU-hoz való csatlakozást, a tagállamok új alapokra helyezték V4-ek partnerségi tevékenységét. A négy ország miniszterelnökei Kroměříž városában zajló V4-es csúcstalálkozón egy új nyilatkozatot fogadtak el, mely felváltotta a csoport létrehozásáról szóló 1991-es dokumentumot. A V4-ek képviselői bejelentették, hogy elérték a korábban megfogalmazott célkitűzéseiket és kinyilvánították, hogy immár a NATO és az EU tagjaiként is eltökéltek az együttműködés folytatásában és elmélyítésében, és további összefogást gyakorolva elősegítik a régió fejlődését és érdekérvényesítő képességét. A 2010-es évek elejéig a miniszteri értekezletek és csúcstalálkozók témája elsősorban az Unió közös kül- és biztonságpolitikája, valamint a keleti bővítés volt. A visegrádi országok közös védelempolitikájával kapcsolatos, annak kezdeményezéséről szóló tárgyalások a 2010-es évek elején kezdődtek. A 2013. október 14-én Budapesten tartott csúcstalálkozó kiemelkedő jelentőséggel bírt, ugyanis először itt rögzítették nyilatkozat formájában, hogy az Észak-Atlanti Szövetség és az Európai Unió törekvéseivel összhangban a V4-ek közös védelempolitika megvalósítását tüzik ki célul, mely védelmi együttműködés aktívvá tételének érdekében a tagországok miniszterelnökei konkrét utasításokat fogalmaztak meg védelmi minisztereik felé, melyek tartalmi kivonatát a következő pontok alkotják:

- hosszú távú jövőkép felvázolása a közös védelmi együttműködési stratégiákról;

- kooperáció megerősítése a tagországok fegyveres erőinek kiképzése során és a gyakorlatok területén; -megerősített védelmi tervezési együttműködés kereteinek V4 szinten történő meghatározása, új védelmi együttműködési területekazonosítása. [2]

A budapesti csúcstalálkozót követő pár hónapon belül, 2015 márciusában a négy ország védelmi minisztere a V4-ek a közös védelempolitikai stratégia megerősítésére két dokumentumot is aláírt. A „Long Term Vision of the Visegrad Countries on Deepening their Defence Cooperation” címet viselő irat a tagországok hosszú távú elképzelését fogalmazza meg védelmi együttműködésük fokozásáról. Ennek alapján szükségesnek tekintik a védelmi ipar, a közös képességek fejlesztését, többnemzeti alakulatok létrehozását, közös védelmi célokat szolgáló eszközök, rendszerek beszerzését, az interoperabilitás kiszélesítését a közös oktatás, képzések és gyakorlatok által.

A másik dokumentum a „Framework for Enhanced Visegrad Defence Planning Cooperation” címet viselte, melyben megfogalmazzák azokat irányokat és tevékenységeket, melyek területén megvalósulhatnak a közös védelmi célokat szolgáló beszerzések és fejlesztések.

A fenti megállapodások és intenzív védelmi témájú találkozók eredményeit tekintve sikerek és kudarcok egyaránt elkönyvelhetők a tagországok ilyen téren való együttműködését illetően. Ami mindenképpen sikeresnek nyilvánítható az a többnemzeti alakulatok létrehozása, hiszen a V4 harccsoport 2019. július 1-től december 31-ig tartó intervallumban másodjára lépett készenlétbe. Szintén elismerésre méltó az oktatás és képzés területén történt aktív szerepvállalás. A közös kutatás-fejlesztési elképzelésekkel és beszerzésekkel kapcsolatos koncepciók eredménytelennek bizonyultak. Ezeken a területen a legnehezebb a kooperáció, mert vitális nemzeti védelemgazdasági érdekeket érint. [3]

\section{Haderőfejlesztési törekvések a V4 tagállamaiban a védelmi kiadások mértékének tekintetében}

Az elmúlt évtized második felétől a négy tagországban komoly lépéseket tettek a haderő fejlesztésének területén mind tárgyalások szintjén, mind már konkrét beszerzéseket illetően, ezenfelül a katonai kiképzés és oktatás területén is számos változást, változtatást irányoztak elő. A V4 államai többek között a hasonló történelmi, gazdasági és társadalmi múltból kifolyólag közel azonos problémákkal küzdenek a honvédelmi helyzetük, feladataik, katonai kötelezettségeik tekintetében mind 
saját nemzetük felé, mind pedig a NATO felé. Viszont eltérő nemzeti érdekeik miatt a biztonsággal kapcsolatos elképzeléseik fontossági skálája merőben más sorrendet mutat.

A visegrádi csoport államai közülterületre, gazdaságra, népességszámra vonatkozó adatait tekintve Lengyelország a legnagyobb. Az ország területe stratégiailag kiemelt jelentőségű, az EU és a NATO határállama, ebből kifolyólag a geopolitikai gondolkodás Lengyelország esetében a legmeghatározóbb. Lengyelország abból a szempontból szerencsés helyzetben van, hogy a rendszerváltás utáni időszakban, a NATO-hoz és EU-hoz történt csatlakozást követően ugyan jelentősen csökkentette a haderőfejlesztésre szánt összegeket, de nem építette le teljes mértékben a hadseregét, ezáltal sikerült viszonylag gyors ütemben újjáépíteni és modernizálni haderejét, mely folyamat még jelenleg is aktív státuszban van. A megújulás és fejlesztés, azok intenzitásának növelése ezen a területen már a Krím-félsziget Oroszország által történt 2014-ben lezajlott bekebelezése előtt is napirenden volt. Lengyelország 2009-óta átfogó védelmi reformot hajt végre, és az elmúlt évek során ennek megfelelően egyenletesen magasan - a GDP 2\%-a körül - tartotta védelmi kiadásait, de az orosz annexió után ez a folyamat érthető módon felgyorsult. 2030-ra a bruttó hazai termék 2,5\%-át tüzte ki célul honvédelmi kiadásokra fordítani. Napjainkra Lengyelország a hadsereg létszámát, felépítését tekintve egyértelműen a közép-kelet-európai régió vezető katonai hatalmává vált.

Szlovákia szintén az EU és a NATO perifériáján fekszik, így kiemelten fontos számára Ukrajna biztonsága. A NATO-elvárásoknak megfelelően Szlovákia is vállalta, hogy a költségvetés $2 \%$-át védelmi célokra fordítja, de ez az elmúlt évek során nem valósult meg. 2014 óta viszont folyamatosan növekvő tendenciát mutat a védelmi kiadásokra fordított összeg mértéke. A rendelkezésre álló adatok alapján 2014-ben a katonai költségvetés a GDP 1\%át tette ki, ez az arány a 2019. évre már 1,74\%-ra emelkedett. Csehország is komoly többletráfordítást irányoz elő az elkövetkezendő években a honvédelmi költségvetés területén, melyet az is alátámaszt, hogy az elmúlt fél évtizedben éves lebontásban nézve - a 2014-es 0,91\%-os értéket alapul véve -konzekvensen magasabb értéket mutatnak az erre irányuló kimutatások. 2019-ben már elérte a 1,19 \%-ot. [4] A cél Csehország esetében is, hogy a bruttó hazai termék kétszázalékos összegét tudják védelmi kiadásokra fordítani.

A történelmi múltat tekintve Magyarország előtt is még komoly feladatteljesítés áll a haderőfejlesz- tés területén. A '90-es évektől kezdve beindult egy permanens, hosszan tartó amortizációs folyamat a Magyar Honvédség haditechnikai eszközeit illetően, melynek eredményeképpen a 2000-es évek végére a magyar haderő teljesen elavult felszereléssel és fegyverzettel bírt, melyek jelentős része még a szovjet „örökség” volt. Ebben az időintervallumban a leépülés nemcsak a honvédség technikai felszereltségére vonatkozott, komolyan érintette a személyi állományt is. A 106/2007. (XII.6.) számú országgyülési határozat alapján az MH létszáma maximalizálva lett: 2007. december 31. után a honvédség létszáma nem haladhatta meg a 23950 föt, mely számmal az MH költségvetési létszáma elérte mélypontját. [5]

A 2010-es évektől ugyan mutatkozott erőfeszítés a modernizálás tekintetében, komolyabb eredmények mégis inkább csak az elmúlt három év során mutatkoztak. Az évtized második felétől növekvő tendenciát mutat a fejlesztés és az ebbe fektetett összeg mértéke mind a haditechnikai eszközállományt, mind pedig a katonai képességfejlesztést illetően. A „Zrínyi 2026” elnevezésű honvédelmi és haderőfejlesztési programot 2017 elején jelentették be, melynek keretén belül egy 10 éves periódust felölelve fogják a Magyar Honvédség teljes eszközparkját korszerűsíteni, a professzionális képzést erősíteni. A program megvalósulásával a kormány célja, hogy az MH a térség meghatározó haderejévé váljon.

2020-ban várható több olyan modern és professzionális technika megjelenése a honvédség eszközállományában, melyek beszerzését már korábbi tárgyalások útján rögzítette és jóváhagyta a magyar állam. Magyarország 2019. évi védelmi költségvetése 513 milliárd forint volt, a 2020. évre 103 milliárd forinttal többet, 616 milliárd forintot irányoztak elő, melyből 216 milliárd forint költhető fejlesztésekre. [6] Ez az összeg a GDP 1,17\%-a, mely még így is jelentősen elmarad a NATO által elvárt minimum 2\%-os aránytól, melynek teljesítésére a 2024. év lett célul kitüzve.

$\mathrm{Az}$ 1. ábra alapján látható a négy ország egymáshoz, illetve más NATO-tagállamokhoz viszonyított helyzete annak tekintetében, hogy az egyes államok védelmi költségvetése a nemzetek bruttó hazai termék hány százalékát tette ki a 2014. és a 2018-as évek összehasonlításában. A négy tagország eddigi haderőfejlesztési tevékenységeit és a védelmi célokra fordított összeg arányát tekintve megállapítható, hogy Lengyelország jelentősen kiemelkedik ezen a területen a másik három tagállamhoz viszonyítva. A védelmi kiadások az alábbi négy alapvető csoportra bonthatók: 


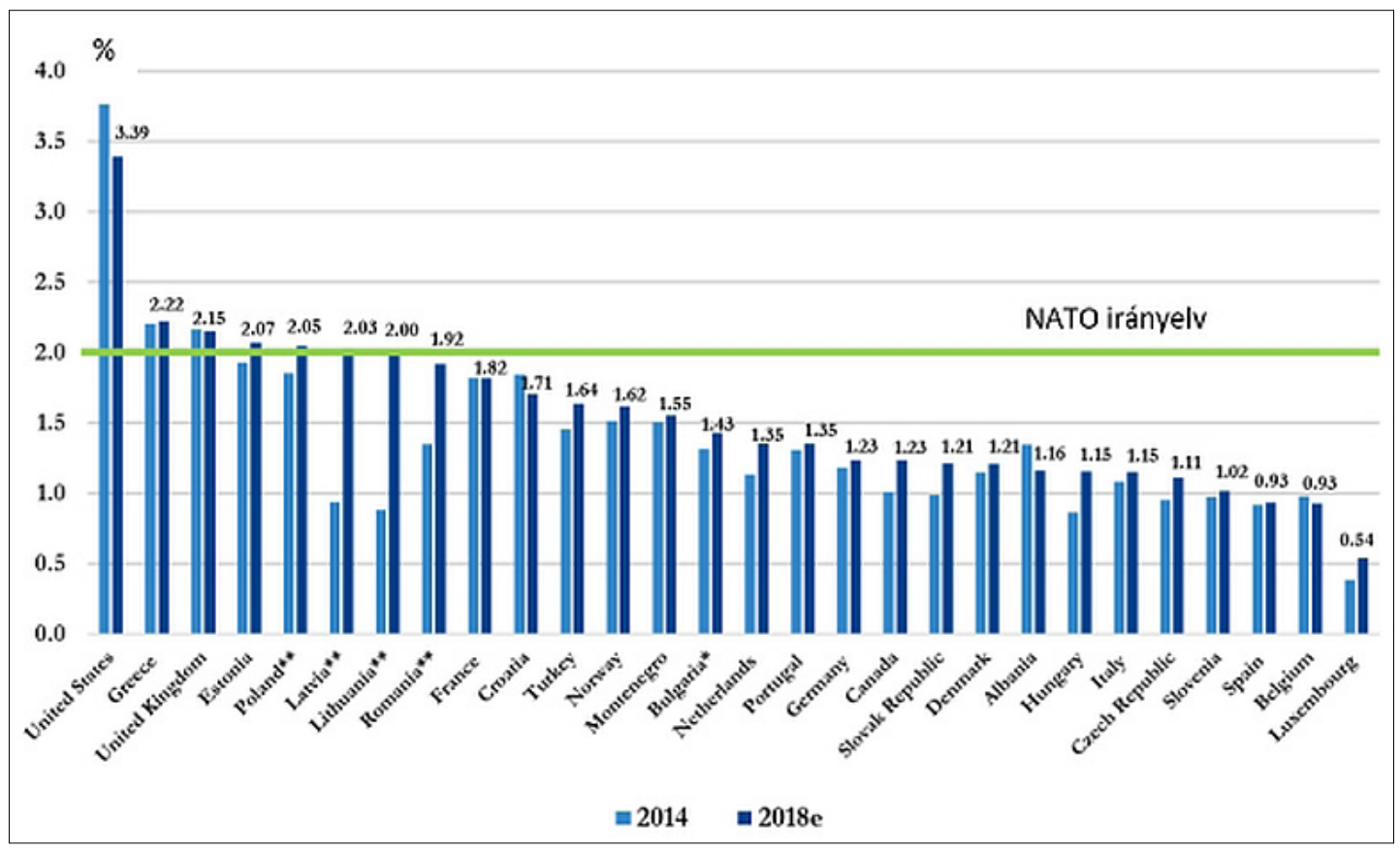

1. ábra. Védelmi kiadások a GDP arányában [7]

- haditechnikai eszközök

- személyi vonatkozású költségek

- infrastrukturális kiadások

- egyéb költségek. [8]

Kérdés azonban, hogy az adott államok milyen arányban hajtják végre a modernizáció részterületeit.

A katonai képességeket, illetve a haderő helyzetét, adottságait figyelembe véve a négy ország egymáshoz viszonyított helyzetéről a Global Firepower 2020-as [9] értékelése átfogó képet nyújt.

A rangsorban a 8 fő kategórián - emberi erőforrás, légierő, gépesített haderő, haditengerészet, természeti erőforrások, logisztika és földrajz - belül 45 egyedi tényezőt vesznek figyelembe az adott nemzet PowerIndex-pontszámának meghatározására. A legfrissebb adatok alapján a visegrádi csoport országai közül Lengyelország a 21. helyen szerepel, őt követi Csehország a 34. helyen, míg Magyarország az 54., Szlovákia pedig az 58. a listán szereplő 138 ország közül.

Többek között ezen adatok is alátámasztják, hogy a közös történelmi múlt ellenére a négy ország eltérő helyzetű haderővel rendelkezik. Eltérést mutat haderőinek nagysága, illetve különbözőséget mutat finanszírozásuk és fejlesztésük mértéke is. Ami viszont osztatlan célként detektálható mind a négy tagállam esetében, az a régi, szovjet haditech- nikai eszközök lecserélése. A NATO tekintetében a kompatibilitási és interoperabilitási képesség továbbra is garantált, arra azonban - figyelembe véve az adott országok ipari, gazdasági és politikai helyzetét - nincs lehetőség, hogy ezen fejlesztések során egységes felszereléseket, illetve gépparkot állítsanak fel a V4-ek. A haderőfejlesztésre irányuló védelmi kiadások jelentős eltérést mutatnak az egyes országok között, de az irányvonalat tekintve megállapítható, hogy az adott országok ilyen jellegű kiadásainak emelése kiemelt fontosságú.

\section{Következtetések}

Az új típusú biztonsági kihívásokat már csak modern, korszerü eszközökkel felszerelt, professzionálisan képzett állománnyal rendelkező haderő képes hatékonyan kezelni. A V4-ek tagországai az elmúlt évek során kiemelt hangsúlyt helyeztek a haderő-, illetve a képességfejlesztésre. A vizsgált négy állam - önmagához viszonyítva - a rendszerváltás óta talán napjainkban van a legmagasabb szinten hadereje fejlettségének és fejlesztésének mértékét illetően, és a jelenleg futó korszerüsítéssel kapcsolatos programok és tervek alapján ezt a folyamatot a 2030-as évek elejére tervezik lezárni. Jelen helyzetben az a kérdés, hogy az egyes tagállamok -az elkövetkezendő években a hazai és regionális politikai, illetve gazdasági életben bekövet- 
kezendő változások függvényében -milyen módon tudják fenntartani és betartani a fejlesztési programokban lefektetett és előirányzott terveket. A megváltozott biztonsági környezet nemcsak nemzeti, nemzetközi szintű erőfeszítéseket és összefogást is igényel. Az új típusú biztonsági kihívások kezelése új szemléletet, új hozzáállást, új megoldásokat és módszereket követel. A tömeghadsereg alkalmazása helyett a modern technológiai eszközök, azok szakszerű alkalmazása kerül előtérbe, ebből kifolyólag a katonák kiképzettsége, professzionalizmusa megkérdőjelezhetetlen fontossággal bír. A 21. század egyik jellegzetessége a haderők nemzetközi feladatokra történő felhasználásának korábban nem ismert felerősödése. [10] A V4-tagországok ennek tudatában viszik véghez a többéves ütemtervben meghatározott haderőfejlesztési folyamatokat, melyek megvalósítását elsősorban a nemzeti érdekek, a belső gazdasági és politikai helyzet és adottságok diktálta tényezők befolyásolják, de emellett érzékelhető, hogy a tagállamok odafigyelnek az egymás közötti együttmüködés egyensúlyának fenntartására a közép-kelet-európai térség stabil biztonságának érdekében.

\section{Köszönetnyilvánítás}

Az Innovációs és Technológiai Minisztérium ÚNKP19-3-III-NKE-47 kódszámú Új Nemzeti Kiválóság Programjának szakmai támogatásával készült.

\section{Szakirodalmi hivatkozások}

[1] Fodor M.: A visegrádi védelempolitika fejlödése, Biztonságpolitikai szakportál 2019.

https://biztonsagpolitika.hu/egyeb/a-visegradi-vedelempolitika-fejlodese (letöltve: 2020. március 1.).
[2] Visegrad Group, Budapest Joint Statement of the Visegrad Group Heads of Government On Strengthening the V4 Security and Defence Cooperation

http://www.visegradgroup.eu/calendar/2013/ budapest-joint-statement-140929 (letöltve: 2020.02.23.)

[3] Szenes Z.: Cél vagy eszköz? A visegrádi védelempolitika fejlődése (2). Honvédségi Szemle 2017/1. 3-23.

[4] Basic Data of the State Budget in Chapter of the Ministry of Defence in 1993-2018

http://www.army.cz/en/facts-file/defence-budget/ defence-budget-130198/ (letöltve: 2020.02.26.)

[5] Végh F.: Honvédségünk a rendszerváltástól napjainkig (2.). Honvédségi Szemle 2018/4. 3-18.

[6] Rekordnagyságú lesz a honvédelmi költségvetés 2020-ban

https://honvedelem.hu/cikk/rekordnagysagu-lesz-a-honvedelmi-koltsegvetes-2020-ban/ (letöltve: 2020.03.01.)

[7] Farkas T.: A védelmi tevékenységeket támogató MH Kormányzati Célú Elkülönült Hírközlő Hálózat fejlesztési lehetőségeinek vizsgálata a honvédelmi és haderőfejlesztési program (Zrínyi 2026) tükrében - Hazai/nemzetközi szakirodalmi összefoglaló. Hadtudományi Szemle 2019/4. 10.

[8] Farkas T.: A védelmi tevékenységeket támogató MH Kormányzati Célú Elkülönült Hírközlő Hálózat fejlesztési lehetőségeinek vizsgálata a honvédelmi és haderőfejlesztési program (Zrínyi 2026) tükrében - Hazai/nemzetközi szakirodalmi összefoglaló. Hadtudományi Szemle 2019/4. 5-16.

[9] 2020 Military Strength Ranking https://www.globalfirepower.com/countries-listing.asp (letöltve: 2020.03.01.)

[10] Gazdag F., Remek É.: A biztonsági tanulmányok alapjai. Dialóg Campus Kiadó, Budapest, 2018. 


\title{
HÁZTARTÁSI MOSÓVIZEK, MINT ALTERNATÍV VÍZFORRÁSOK ELEMZÉSE
}

\section{INVESTIGATION OF HOUSEHOLD LAUNDRY WATER AS AN ALTERNATIVE WATER SOURCE}

\author{
Kelemen Orsolya, ${ }^{1}$ Izbékiné Szabolcsik Andrea, ${ }^{2}$ Bodnár Ildikó ${ }^{3}$ \\ Debreceni Egyetem, Müszaki Kar, Környezetmérnöki Tanszék, Debrecen, Magyarország \\ ${ }^{1}$ kelemen727@gmail.com \\ ${ }^{2}$ szabolcsikandi@eng.unideb.hu \\ 33bodnari@eng.unideb.hu
}

\begin{abstract}
The goal of our research is to study the potential treatment options for the relatively contaminated greywater fraction from washing, in order to use this fraction as an alternative water source. During the research to compare the purification efficiency of different greywater treatment solutions we have created a constant composition synthetic laundry greywater, based on tap water, which represents the real laundry water in the terms of quality. As greywater treatment solutions, in terms of physical pre-treatment procedure we used a sand filtering method, and in terms of chemical processes we used coagulation and oxidation. Based on treatment efficiencies, we can say that the treatment procedures can achieve significant quality improvements, but none of the methods can achieve the required cleaning efficiency by itself. In order to reach the optimum quality parameters, the use of combined methods is required.
\end{abstract}

Keywords: greywater, laundry water, reuse, sustainability.

\section{Összefoglalás}

Kutatásunk célja a mosásból származó, viszonylag terhelt szürkevízfrakció potenciális kezelési lehetőségeinek tanulmányozása fenntartható vízhasználat biztosítása céljából. A kutatás során a különböző szürkevízkezelési megoldások tisztítási hatásfokának összehasonlíthatósága érdekében egy állandó összetételű, ivóvízalapú szintetikus mosóvizet készítettünk el, mely minőségi szempontból jól reprezentálja a valós mosóvizeket. A szürkevízkezelési megoldások közül mint fizikai előkezelési eljárást a szürést, illetve mint kémiai eljárást a koagulálást és az oxidációt alkalmaztuk. A kezelési hatásfokok alapján elmondható, hogy a kezelési eljárásokkal jelentős minőségi javulást lehet elérni, de önmagában egyik módszerrel sem érhető el a megfelelő tisztítási hatásfok. Kombinált módszerek használata szükséges az optimális minőségi paraméterek eléréshez.

Kulcsszavak: szürkevíz, mosóvíz, újrahasználat, fenntarthatóság.

\section{Bevezető}

A víz alapvető forrás a túléléshez minden élő szervezet számára. A rés az igényelt és az elérhető vízkészlet között napról napra növekszik. Napjainkban jelentős figyelmet kell fordítanunk a fenntartható vízgazdálkodásra, ezáltal a szennyvizek és a háztartásonként keletkezett szürkevizek újrahasznosítása egyre fontosabbá válhat. Ezen vizek gyüjtésével és kezelésével olyan kezelt vízhez juthatunk, amelyet újrahasználhatunk háztartási szinten olyan tevékenységek során, melyek nem igényelnek ivóvíz-minőségű vizet, pl.: WC-öblítésre, öntözésre vagy akár autómosására is. 


\section{A szürkevizekről}

Szürkevíznek nevezzük a mosogatásból, fürdésből és mosásból származó szennyvizet, mely nem tartalmazza a WC öblítésére használt vizet, tehát olyan, háztartásból származó szennyvíz, amely nem érintkezik a WC vízöblítése során keletkezett vízzel. A kutatásunkban kifejezetten vizsgált, mosásból (laundry greywater) származó szürkevízfrakció nagy koncentrációban tartalmaz felületaktív anyagokat a mosóporokból, öblítőkből, fehérítőkből, valamint ruhákból szöveteket, továbbá elhalt emberi hámsejteket és hajszálakat is [1]. A szürkevizekben a detergensek jelenléte mellett számolnunk kell a vizek mikro- és makroelem-tartalmának növekedésével, mivel a háztartásokban keletkező használt vizekben viszonylag nagy koncentrációban találhatóak nyomelemek és nehézfémek is, melyek az újrahasználat esetén jelentős terhelést gyakorolhatnak az ökoszisztémára.

\subsection{Detergensek}

Mosás során a szennyeződések eltávolítására felületaktív anyagokat, detergenseket használunk, így a szürkevizekben nagy mennyiségü felületaktív anyag található, amelyek a háztartási szennyvízzel kikerülhetnek a felszíni vizekbe, ahol annak felszínén vékony habréteget képezve csökken a víz által felvehető oxigén mennyisége, illetve az öntisztulási folyamat hatásfoka, beindulhat az algavirágzás. Ezért újrahasználat előtt a szürkevizeket fontos ezektől a felületaktív anyagoktól és egyéb szennyezőktől is megtisztítani [2].

\section{Kezelési eljárások}

A szürkevíz kezelésére többféle eljárást alkalmazhatunk. Ezek fizikai, kémiai, fiziko-kémiai és biológiai módszerek lehetnek.

Fizikai eljárások kiemelt műveleti megoldásai a szűrés, illetve az ülepítés. A szűrés általában önmagában nem elegendő, így ezt előkezelésként is alkalmazzák. Célja a lebegő és egyéb szuszpendált részecskék eltávolítása [3].

A kémiai kezelési eljárások meghatározó művelete a szürkevizek kezelésében a koagulálás [4]. A koaguláció a kolloid részecskék destabilizálását jelenti, amely a részecskék közötti taszítóerő csökkenésének, ill. megszűnésének hatására következik be. A részecskék destabilizálása megvalósítható például speciálisan szorbeálódó vegyületekkel. Leggyakrabban vas(III)- és alumíniumsókat alkalmaznak, melyek hatására ún. mikropelyhek keletkeznek. Ezek a pelyhek magukhoz kötnek az adott mérethatárnál kisebb kolloid részecskéket is, azokat mintegy kiszűrik, derítik a vizes fázisból. Ez a pelyhes lebegőanyag már gyorsabban elválasztható az ülepítőkben vagy flotálókban a vizes fázistól [5].

Kémiai kezelési eljárás lehet továbbá oxidatív megoldás, melynek hatására végbemegy a szerves szennyezők lebontása, fertőtlenítő hatásának köszönhetően csökkenhet a toxicitás, valamint a színés szaganyagok degradációja is megtörténik [6].

Nemzetközi szakirodalmak érhetőek csak el a kezelt szürkevizek minőségére vonatkozóan, melyek a minősítési paraméterek közül kettőt kiemelve, a biológiai oxigényigény $\left(\mathrm{BOD}_{5}\right)$ értékét $10 \mathrm{mg} / \mathrm{l}$ koncentrációban, illetve a zavarosságot 2 NTU értékben javasolják maximalizálni az újrahasználat feltételeként [7].

\section{Szintetikus szürkevíz}

A különböző szürkevízkezelési műveletek tisztítási hatásfokának összehasonlítása érdekében egy állandó összetételű, ivóvízalapú mosóvizet állítottunk elő, amely minőségi szempontból jól reprezentálja a valós, mosásból származó szürkevízfrakciót. A valós minták összetétele nagyon változó, így a korrekt kezelési hatásfokok nyomon követésére szükséges a kezelendő víz összetételének állandósága, mely szintetikusan, adott receptúra alapján kidolgozható és később biztosítható a vizsgálatokhoz. A szintetikus mosóvíz előállításakor az elérendő minőségi paraméterek iránymutatójául a Környezetmérnöki Tanszék korábbi kutatásai alkalmával meghatározott minőségi összetétel szolgált [8]. A minták alkotó komponensei mosószer és öblítő, valamint a szennyeződések reprezentálása érdekében növényi olaj és természetes eredetű szerves tápanyag voltak. A szintetikus mosóvíz előállítása során szisztematikus komponensadagolás mellett követtük a minta összetételét jellemző vízanalitikai paraméterek változását. Minősítési lépésként párhuzamos mérésekben vizsgáltuk a minták pH-, zavarosság-, fajlagos elektromosvezető-képesség-, biológiai oxigénigény-, oldott, szerves széntartalom- és zétapotenciál-értékeit.

\section{Kezelésmódszerek tanulmányozása}

Első lépésben a mechanikai kezelésben a szűrés hatásfokát tanulmányoztuk. A szűrési eljárás során egy kvarchomok szürőközeget alkalmaztunk. Ahogyan az 1. táblázatban látható, a mért para- 
méterek elemzése alapján megállapítható, hogy a szűrés a pH-értékekben csökkenést eredményezett a kicsapódott és kiszürt detergensek miatt. A kezelés hatására mind a biológiailag bontható szervesanyag-tartalom, mind az oldott formában lévő szervesanyag-tartalom mennyisége, valamint a zavarosság értéke is jelentősen csökkent.

1. táblázat. Homokszüréssel kezelt minta vízanalitikai paraméterei

\begin{tabular}{|l|c|c|c|}
\hline & & $\begin{array}{c}\text { Szintetikus } \\
\text { mosóvíz }\end{array}$ & $\begin{array}{c}\text { Homokszürt } \\
\text { minta }\end{array}$ \\
\hline pH & - & $7,87-8,16$ & $7,66-7,68$ \\
\hline Vezetőképesség & $\mathrm{mS} / \mathrm{cm}$ & $1,18-1,28$ & $1,02-1,27$ \\
\hline Zéta-potenciál & $\mathrm{mV}$ & $-37,2-(-28,3)$ & $-30-(-22,1)$ \\
\hline Zavarosság & $\mathrm{NTU}$ & $97,76-175,05$ & $43,88-133,04$ \\
\hline DOC & $\mathrm{mg} / \mathrm{l}$ & $283,2-514,55$ & $107,09-144,05$ \\
\hline BOD & $\mathrm{mg} / \mathrm{l}$ & $360-666,67$ & $183,67-235$ \\
\hline
\end{tabular}

Ezt követően kémiai kezelési eljárásokat vizsgáltunk. Koaguláció során koagulálószerként vas(III)kloridot használtunk, melyet oldat formájában különböző koncentrációban adagoltunk a vízmintához.

Folyamatosan mértük a zétapotenciál változását, és az eredményekből megállapítottuk a megfelelő vegyszermennyiséget az optimális $0 \pm 5 \mathrm{mV}$ közötti zétapotenciál eléréséhez. A megfelelő zétapotenciál-értéket minimum 46, de maximum $60 \mathrm{~g} / \mathrm{l} \mathrm{FeCl}_{3}$ adagolásával értük el. A kezelés hatékonyságát a 2 . táblázat szemlélteti.

2. táblázat. Optimális $\mathrm{FeCl}_{3}$-dózissal kezelt minta vízanalitikai paraméterei

\begin{tabular}{|l|c|c|c|}
\hline & & $\begin{array}{c}\text { Szintetikus } \\
\text { mosóvíz }\end{array}$ & $\begin{array}{c}\text { Koagulált } \\
\text { minta }\end{array}$ \\
\hline pH & - & $7,87-8,16$ & $2,99-3,95$ \\
\hline Vezetőképesség & $\mathrm{mS} / \mathrm{cm}$ & $1,18-1,28$ & $1,45-2,17$ \\
\hline Zéta-potenciál & $\mathrm{mV}$ & $-37,2-(-28,3)$ & $-4,45-4,22$ \\
\hline Zavarosság & $\mathrm{NTU}$ & $97,76-175,05$ & $392,31-504,31$ \\
\hline DOC & $\mathrm{mg} / \mathrm{l}$ & $283,2-514,55$ & $139,85-154,45$ \\
\hline
\end{tabular}

A kiindulási szintetikus mosóvízminta jellemzőihez viszonyítva látható, hogy a $\mathrm{pH}$ igen savas tartományba mozdult el a koagulálószer $\left(\mathrm{FeCl}_{3}\right)$ jelenlétének hatására. A flokkulálódott részecskéknek köszönhetően növekedett a fajlagos elektromos vezetőképesség és a zavarosság értéke is. A kezelés célja a szerves szennyeződések eltávolítása, melyeket az összes szerves széntartalom
(DOC) mérésével követhetünk nyomon. A kezelés után ez az érték majdnem 60\%-kal csökkent a kiindulási állapothoz viszonyítva.

Egy másik kémiai kezelési eljárást is vizsgáltunk, az oxidációt. Oxidáció során kezelőszerként különböző mennyiségben hidrogén-peroxidot $\left(\mathrm{H}_{2} \mathrm{O}_{2}\right)$ adagoltunk a mintához. A kezelés hatására pH-növekedést valamint kismértékben a zavarosság, a vezetőképesség és az oldott formában lévő szervesanyagtartalom-értékek csökkenését tapasztaltuk.

\section{Következtetések}

A kezelési hatásfokok tanulmányozása alapján elmondható, hogy szűréssel, illetve koagulálással jelentős minőségi javulást lehet elérni, de önmagában egyik módszer sem ér el elegendő tisztítási hatásfokot. Az oxidációval sem értünk el jelentős változást a szintetikus mosóvízminták minőségi paramétereit tekintve.

Az eredményességet különféle vízanalitikai paraméterek mérésén keresztül követtük figyelemmel, ezek a pH, zavarosság, fajlagos elektromos vezetőképesség és a zétapotenciál. Továbbá a szervesanyag-tartalom mennyiségi meghatározására vizsgáltuk a minták biológiai oxigénigényét és oldott szerves széntartalmát is. A kezelések hatásfokát százalékosan a 3. táblázat mutatja be, mely a kezeletlen minta minőségi paramétereiben bekövetkező változások mértékeit szemlélteti.

\section{3. táblázat. Kezelési hatásfokok}

\begin{tabular}{|c|c|c|c|}
\hline & $\begin{array}{l}\text { Homok- } \\
\text { szürés }\end{array}$ & Koagulálás & Oxidáció \\
\hline pH & $\begin{array}{c}\begin{array}{c}5,31 \% \\
\text { csökkenés }\end{array}\end{array}$ & $\begin{array}{c}\begin{array}{l}57,33 \% \\
\text { csökkenés }\end{array}\end{array}$ & $\begin{array}{c}2,93 \% \\
\text { emelkedés }\end{array}$ \\
\hline $\begin{array}{l}\text { Fajlagos } \\
\text { elektromos } \\
\text { vezetőké- } \\
\text { pesség }\end{array}$ & $\begin{array}{c}\text { 7,44\% } \\
\text { csökkenés }\end{array}$ & $\begin{array}{l}\text { 43,6\% emel- } \\
\text { kedés }\end{array}$ & $\begin{array}{c}\text { 10,32\% } \\
\text { csökkenés }\end{array}$ \\
\hline $\begin{array}{l}\text { Zéta-poten- } \\
\text { ciál }\end{array}$ & $\begin{array}{c}27 \% \\
\text { csökkenés }\end{array}$ & $\begin{array}{c}\text { 99,5\% } \\
\text { csökkenés }\end{array}$ & $\begin{array}{c}\text { 9,31\% } \\
\text { csökkenés }\end{array}$ \\
\hline Zavarosság & $\begin{array}{c}50 \% \\
\text { csökkenés }\end{array}$ & $\begin{array}{c}\text { 242,9\% } \\
\text { emelkedés }\end{array}$ & $\begin{array}{c}\text { 30,59\% } \\
\text { csökkenés }\end{array}$ \\
\hline BOD $_{5}$ & $\begin{array}{c}56,7 \% \\
\text { csökkenés }\end{array}$ & - & - \\
\hline DOC & $\begin{array}{c}\quad 64,4 \% \\
\text { csökkenés }\end{array}$ & $\begin{array}{c}59,15 \% \\
\text { csökkenés }\end{array}$ & $\begin{array}{c}20,35 \% \\
\text { csökkenés }\end{array}$ \\
\hline
\end{tabular}


A 3. táblázat adatait elemezve, a homokszűrés kapcsán összességében elmondható, hogy minden vízminőségi paraméterben javulás látható, leginkább a szerves anyagok mennyiségének tekintetében történt csökkenés, illetve a zavarosságérték vonatkozásában 50 \%-os javulás érhető el.

Koagulálás során az optimális dózissal történő kezelés hatására a zétapotenciál-érték esetében közel $0 \mathrm{mV}$ értéket lehet elérni, vagyis a hatásfok így igen magas, illetve az összes szerves széntartalom is közel $60 \%$-al csökkenthető ezzel a módszerrel. Azonban a koagulálószer $\left(\mathrm{FeCl}_{3}\right)$ jelenléte miatt a $\mathrm{pH}$ jelentősen savas irányba mozdul el, valamint a zavarosság értéke is a pehelyképződés hatására nagyon magas volt.

Az oxidatív kezelés kapcsán a pH tekintetében növekedés figyelhető meg, azonban a többi paramétert vizsgálva kismértékű csökkenés, vagyis minőségi javulás mutatkozik. Ezek alapján megállapítható, hogy mindhárom kezeléssel minőségi javulást lehet elérni, de önmagában egyik módszer sem ér el a nemzetközi ajánlások alapján elegendő tisztítási hatásfokot. Tapasztalataink alapján kombinált kezelési módszerek használata szükséges az optimális minőségi paraméterek eléréséhez. Végső célunk a kezelési lépések hatékony öszszeillesztése és eredményesen kezelt mosóvíz előállítása, mely alkalmazható háztartási szinten, például WC-öblítésre vagy öntözésre.

\section{Szakirodalmi hivatkozások}

[1] Ghaitidak D. M., Yadav K. D.: Characteristics and treatment of grey-water. A review. Environmental Science and Pollution Research, 20/5. (2013) 2795-2809.

[2] Juhász É., Erős M. L. I: Felületaktív anyagok zsebkönyve. Műszaki Könyvkiadó, Budapest, 1979.

[3] Y. P. V. K., A. M. Boyjoo: A review of grey-water characteristics and treatment processes. Water Science and Technology, 67/7. (2013) 1403-1424.

[4] M. Pidou, F. A. Memon, T. Stephenson, B. Jefferson, P. Jeffrey: Greywater recycling: treatment options and applications. Engineering Sustainability, 2007.

[5] Kárpáti Á. (Szerk.): Vízgazdálkodás - Szennyvíztisztítás. Környezetmérnöki Tudástár, Veszprém, 2011.

[6] W. H. Chin, F. A. Roddick, J. L. Harris: Greywater treatment by $\mathrm{UVC} / \mathrm{H}_{2} \mathrm{O}_{2}$. Water Research, 43. (2009) 3940-3947.

[7] Guidelines for water reuse. Office of Wastewater Management, EPA/600/R-12/618, U.S. Enviromental Protection Agency, Washington, 2012.

[8] Bodnár I., Szabolcsik A., Baranyai E., Üveges A., Boros N.: Qualitative characterization of household greywater in the northern great plain region of Hungary. Environmental Engineering and Management Journal, 13/11. (2014) 2717-2724. 


\title{
ÖVES LÉGRUGÓTERMÉKEK GYÁRTÁSÁNAK FEJLESZTÉSE
}

\section{DEVELOPMENT IN MANUFACTURING OF BELTED AIR SPRING}

\author{
Kiss Gábor József, ${ }^{1}$ Szigeti Ferenc, ${ }^{2}$ Gergely Dezső ${ }^{3}$ \\ Nyíregyházi Egyetem, Müszaki és Agrártudományi Intézet, Müszaki Alapozó, Fizika és Gépgyártástechno- \\ lógia Tanszék, Nyíregyháza, Magyarország \\ ${ }^{1}$ kissgaborjozsef97@gmail.com \\ ${ }^{2}$ szigeti.ferenc@nye.hu \\ ${ }^{3}$ dezso.gergely@nye.hu
}

\begin{abstract}
Nowadays, due to increasing environmental regulations, public transport is developing rapidly. Therefore, the companies who manufacture railway fittings have to keep up. As a result, factories need to develop and expand their capacity by modernizing existing machines and installing new machines. The author is involved in this capacity expansion, at ContiTech Hungary Ltd, where production of the rail belted air spring had to be increased. In order to do this, improvements were made to the structure drum to build the carcass, for which two suggestions were made regarding the fold back unit. Other goals are the improvement of the air spring and the development of ergonomics.
\end{abstract}

Keywords: train air spring, bellow production, capacitive improvement.

\section{Összefoglalás}

Az egyre szigorodó környezetvédelmi szabályok miatt a tömegközlekedés rohamos léptekben fejlődik, ezért a vasúti szerelvényeket gyártó cégeknek is újabb fejlesztéseket kell bevezetniük. Ennek következtében a jármüipari beszállítóknak a meglévő gépek korszerűsítésével és új gépek beüzemelésével kell fejleszteniük a kapacitásaikat. Egy ilyen kapacitásbővítésben vettem én is részt a ContiTech Magyarország Kft.-nél, ahol az öves vasúti légrugó gyártásának kapacitását kellett növelni. Ennek érdekében a karkasz felépítéséhez szükséges félépítődobra készítettem el fejlesztéseket. Két javaslatot dolgoztam ki a berendezés visszahajtó egységén. A fejlesztéssel további céljaim között szerepelt a légrugó minőségének javítása és az operátorok fizikai terhelésének csökkentése.

Kulcsszavak: vasúti légrugó, membrán gyártás, kapacitásbővítés.

\section{Bevezető}

Vasúti légrugókkal a nagy vízszintes irányú erőhatásokat és rándulásokat csillapítjuk. A légrugó utazás közben elnyeli a pálya egyenletlenségeiből adódóan fellépő rezgéseket, mérsékli a dinamikus erőhatásokat, ezáltal nő az utazási komfortérzet. Függőleges irányú mozgása elhanyagolható, erre a célra még megmaradtak a hagyományos spirálrugók. Ezen rendszerek összeépítéséből áll össze egy korszerü forgóalváz (1. ábra).

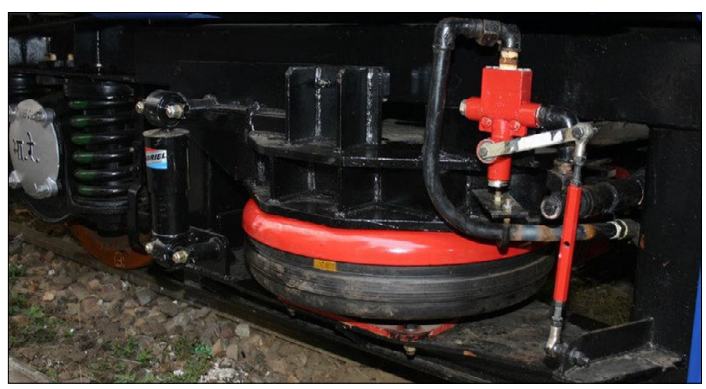

1. ábra. Spirál és öves vasúti légrugóval szerelt vasúti kocsi forgóváza [1] 


\section{Felépítődob bemutatása}

A gyártási kapacitás bővítésének igénye az öves vasúti légrugó termékcsaládnál merült fel, ezért a fejlesztéseket ennek a típusnak a gyártásához szükséges felépítődobokra vonatkozóan végeztem el (2. ábra).

A felépítődob működése: a felépítődob egy kónuszos adapterrel rögzíthető a felépítőgéphez. Rögzítés során oda kell figyelni a levegőcsatlakozók helyzetére, amelyek a felépítőgép adaptertengelyében és a felépítőgép rögzítőtárcsáján helyezkednek el. Ha megfelelően rögzítettük a dobot, akkor a felépítőgép kezelőfelületén keresztül tudjuk szabályozni a két levegőtáplálást. Az egyik csatlakozással a szegmensnyitó balgot tudjuk müködtetni (lásd a 3. ábrán), a másik táplálással pedig a karkasz két szélét tudjuk visszahajtani (lásd a 4. ábrán).

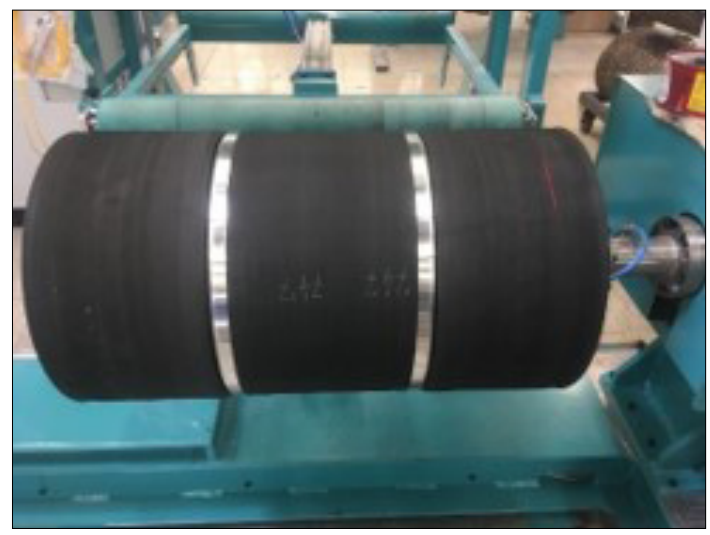

2. ábra. Felépítődob

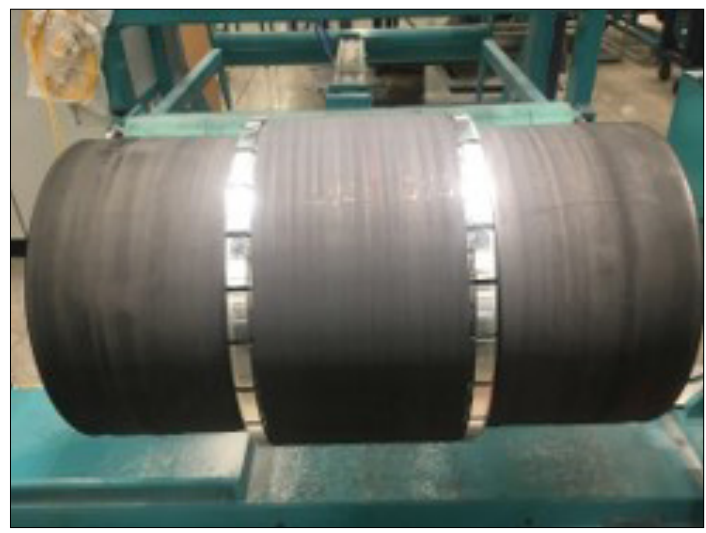

3. ábra. Nyitott állapotú szegmens

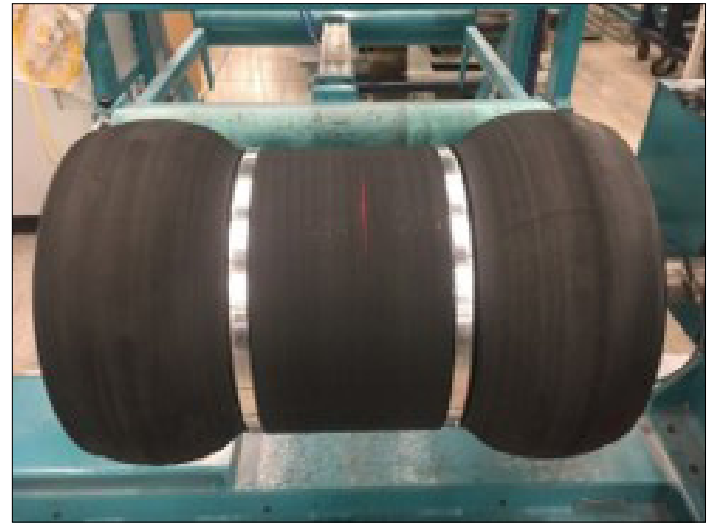

4. ábra. Karkasz szél visszahajtás

\subsection{Jelenlegi karkaszszél-visszahajtás be- mutatása}

A gyártási kapacitás növelése érdekében optimalizálnom kellett a gyártási időket. A felépítés során a membrán szélének a visszahajtása volt a legkritikusabb pont. Jelenleg két egykamrás balgot használnak a visszahajtásra, ezt fejlesztettem úgy, hogy a lehető legkevesebb emberi munkára legyen szükség, és ezáltal a gyártási folyamat gyorsabb legyen.

A 5. ábrán látható, hogy jelenleg milyen mértékben tudjuk visszahajtani a meglévő visszahajtó egységgel a karkasz szélét. A 6. ábrán pedig látható, hogy a dolgozó két kezével tudja csak teljesen visszahajtani a membrán szélét, ami egy műszak alatt eléggé megterheli az operátor ujjait

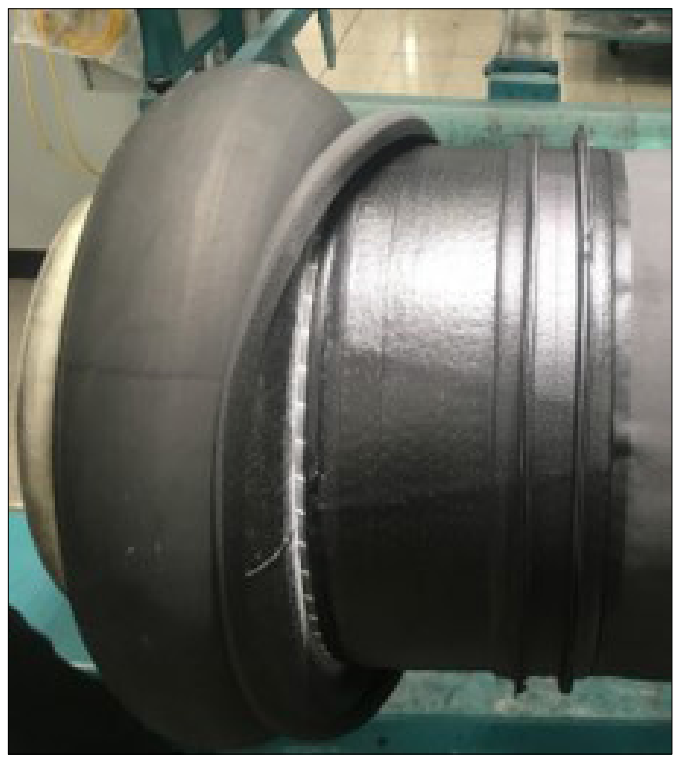

5. ábra. Előhajtás balggal 


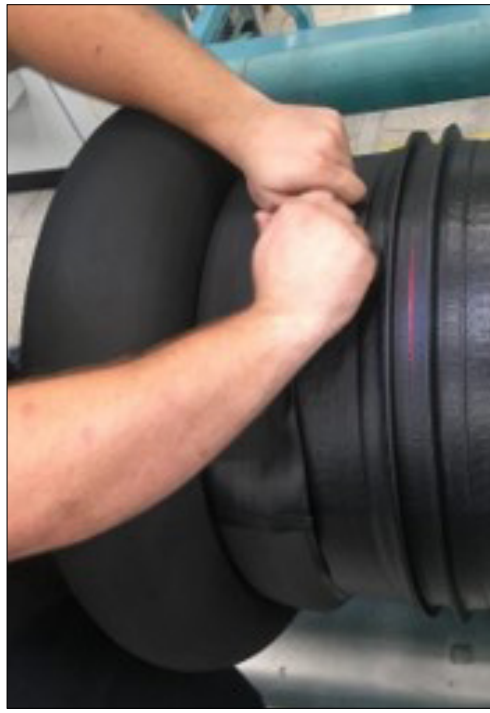

6. ábra. Visszahajtás kézzel

\section{Duplabalgos verzió}

Ebben a fejezetben bemutatom a duplabalgos egység szerkezetét, felvázolom a működtetéséhez szükséges energiaellátást, majd ismertetem a gumielemek gyártásához szükséges felépítődobokat és a rajtuk felépített balgokat.

Az 7. ábrán látható a duplabalgos verzió háromdimenziós modellje. A könnyebb szemléltetés érdekében minden alkatrésznek különböző színt adtam, a két visszahajtó balgot kivéve

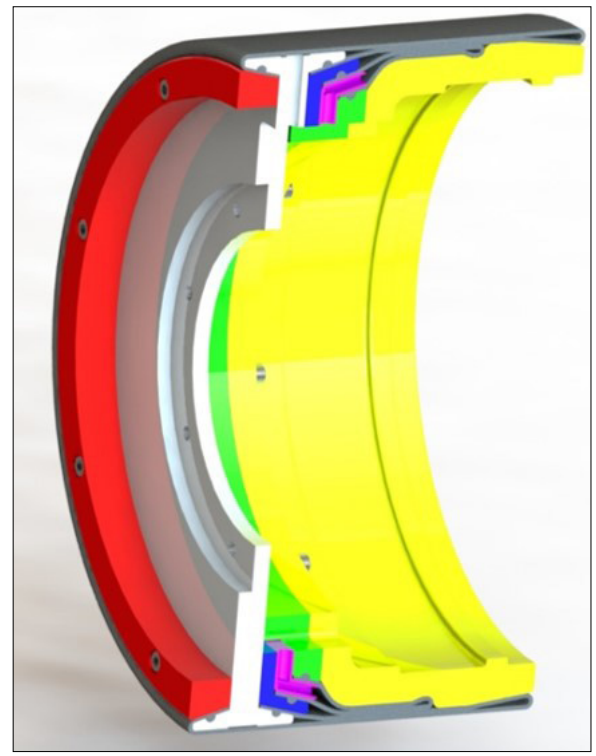

7. ábra. Duplabalgos visszahajtó egység

\subsection{Duplabalgos visszahajtó egység szerke- zete}

Az 8. ábrán látható, szürkével jelölt munkadarab a központi alkatrész. A pirossal, kékkel, lilával és zölddel jelölt alkatrészek a kúpos balgszorítók. Sárgával pedig a danamid adaptert jelöltem.

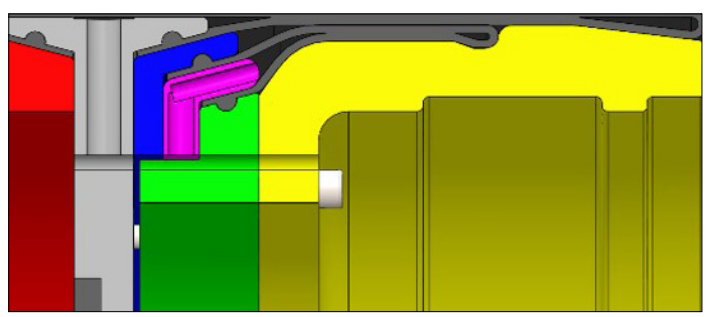

8. ábra. Duplabalgos visszahajtó egység szerkezete

A tervezés során figyelembe vettem az alkatrészek funkcióját, így egyedül a központi alkatrész anyaga lett acél, amely közvetlenül kapcsolódik a felépítődob tengelyén elhelyezett kúpos szorítóhoz. Ezen alkatrészhez kapcsolódnak a kúpos balgszorítók és az általuk közrefogott balgok, továbbá a danamid adapter. A kúpos balgszorító adapterek anyaga alumínium, mivel funkciójukat teljes mértékben ellátják, és ezzel súlyt tudunk csökkenteni, ami nagyon fontos a felépítődoboknál azért, hogy ne terheljék túl a felépítőgépet. Az alumínium hátránya viszont az, hogy a szorítókban elhelyezett menetek hamar károsodnának szerelés során, ezért az összes alkarészt a központi elemen rögzítem [2].

Tervezés során szintén nagy figyelmet kell fordítani a visszahajtó egység külső átmérőjére, amely nem lehet nagyobb 440 mm-nél, mivel akkor a karkaszt nehezen vagy egyáltalán nem lehetne eltávolítani a dobról. Az ábrán látható balgoknál megfigyelhető, hogy a visszahajtás tövénél egy légüres tér képződik, ezt szándékosan ábrázoltam így, mert a már meglévő dobok alapján ez egy tapasztalt viselkedése a balgoknak. Ezt a danamid adapter kikönnyítésével tudjuk kompenzálni.

\subsection{Energiaellátás}

A kapacitásbővítés során telepítésre került egy új felépítőgép, amely lehetővé teszi, hogy 2-nél több levegőtáplálást használjunk a felépítődobok működtetéséhez. Jelen esetben 3 csatlakozást kellene igénybe venni, melyből kettőt az új verzió igényelne. Ahhoz, hogy 3 db táplálást tudjunk használni, a már meglévő felépítőgép-adaptert 
kellene átalakítani vagy egy újat gyártani, ami növelné az üzembe helyezés költségét.

Amennyiben ezt a verziót alkalmazzuk, elveszítjük a gépek közötti átállások lehetőségét esetleges meghibásodás esetén, így ezt a dobot nem tudnánk megfelelően használni a többi felépítőgépen, ha valamilyen okból kifolyólag a legújabb felépítőgép meghibásodna.

A 8. ábrán megfigyelhető, hogy a nagyobb balg a központi adapternél kapja a sürített levegőt, a kisebbik balg pedig a lila színnel jelölt kúpos balgszorítón keresztül.

\subsection{Balg}

A balgoknak két típusát különböztetjük meg. Az egyik típusa a vulkanizáláshoz használt alakítóbalg, amely anyagának köszönhetően nem vulkanizálódik ki soha, csak öregedik. Szerkezetileg csak ezt a különleges gumit tartalmazza [3, 4].

Másik típusa a balgoknak a segédfunkciókra alkalmazott gumielemek. Felépítésük hasonló a légrugókéhoz, ugyanúgy légzáró-borító rétegekből és szövetből épülnek fel. A különbség csak az, hogy a segédbalgok mindig az adott feladatra vannak kialakítva, így a formája minden egyes darabnak teljesen eltérő.

A duplabalgos verzióhoz két segédbalg szükséges. Szerkezetük teljesen megegyezik, csak geometriai méretekben különböznek egymástól.

\subsection{Balg felépítődob}

A balgok felépítéséhez két darab dobra van szükségünk. A 8. ábrán látható, hogy a balgperem átmérői nem egyeznek meg. Felépítésüket csak kúpos és egy hengeres dobon tudnánk elvégezni. A kúpos dob gyártása nagymértékben megnövelné a költségeket.

\section{Ikerbalgos megoldás}

Ebben a fejezetben a második fejlesztési javaslatomat ismertetem, ami a 9. ábrán látható.

\subsection{Az ikerbalgos egység szerkezete}

Az ikerbalgos megoldás müködtetéséhez szükséges alkatrészek kevésbé bonyolultak, mint az előző verzióban, és kevesebb alkatrész szükséges az összeállításához, mivel csak két helyen kell rögzíteni a balgot az egységhez.

Továbbá csökkentettem a visszahajtó egység hosszát $40 \mathrm{~mm}$-el, így anyagot tudunk megspórolni úgy, hogy a szerkezet még elég stabil marad. Ezenkívül a felépítéshez is elegendő hely marad,

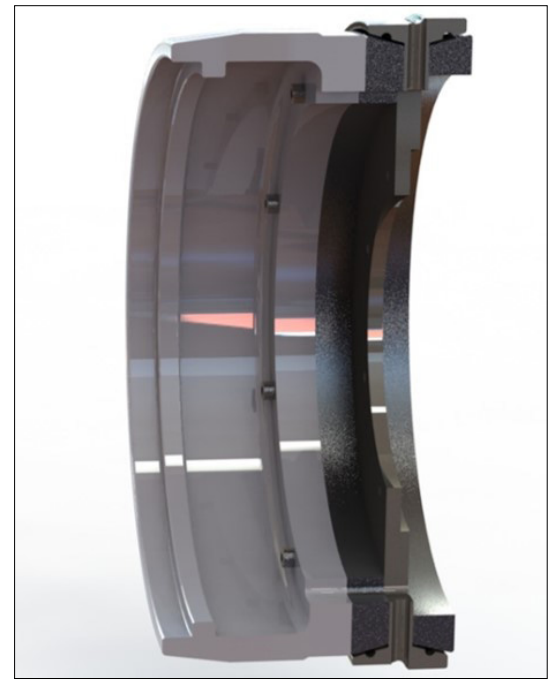

9. ábra. Ikerbalgos megoldás

és ezzel a módosítással még súlyt is tudunk csökkenteni. Mindezeken felül, a balgok élettartamát is növeljük, mivel így kisebb az esélye annak, hogy a dolgozók kiszúrják azt.

\subsection{Az ikerbalgos megoldás előnyei}

A visszahajtó egység fejlesztésével célom a gyártási idő csökkentése. Jelenleg kézzel kell visszahajtani külön-külön mindkét oldalt, ami időigényes. Azzal, hogy balgokkal hajtanánk vissza a membrán szélét, időt tudnánk spórolni.

Továbbá, ha egységesen minden karkasz szélét a visszahajtó balgokkal hajtanánk vissza, akkor elérnénk, hogy minden egyes visszahajtás mindenhol egységes lenne. Ezzel javulna a membránok minősége, hiszen sokkal szorosabban lenne visszahajtva, és nem maradna a peremkarikáknál levegő. Sőt, az ergonómia is javulna a mostanihoz képest, mivel a dolgozónak nem kellene nagy erőt kifejteni az ujjaival.

\subsection{Balg}

A balg szerkezete a duplabalgos verzióhoz képest sokkal bonyolultabb. Elkészítésekor az alapbalgra még egy balg került felépítésre. A 10. ábrán látható, hogy a második balg lapolása hova és milyen szélességben fog kerülni. A két lapolás (talpalás) között fog elhelyezkedni a lyukasztás, amely biztosítja a két balg közötti levegőáramlást.

A balg felépítése ezen rajz alapján történik. A balgok felépítéséhez egyetlen dobra van szükség. A dob készítésekor két fő méretre kell koncentrálni, az átmérőjére és a peremkarikák tá- 


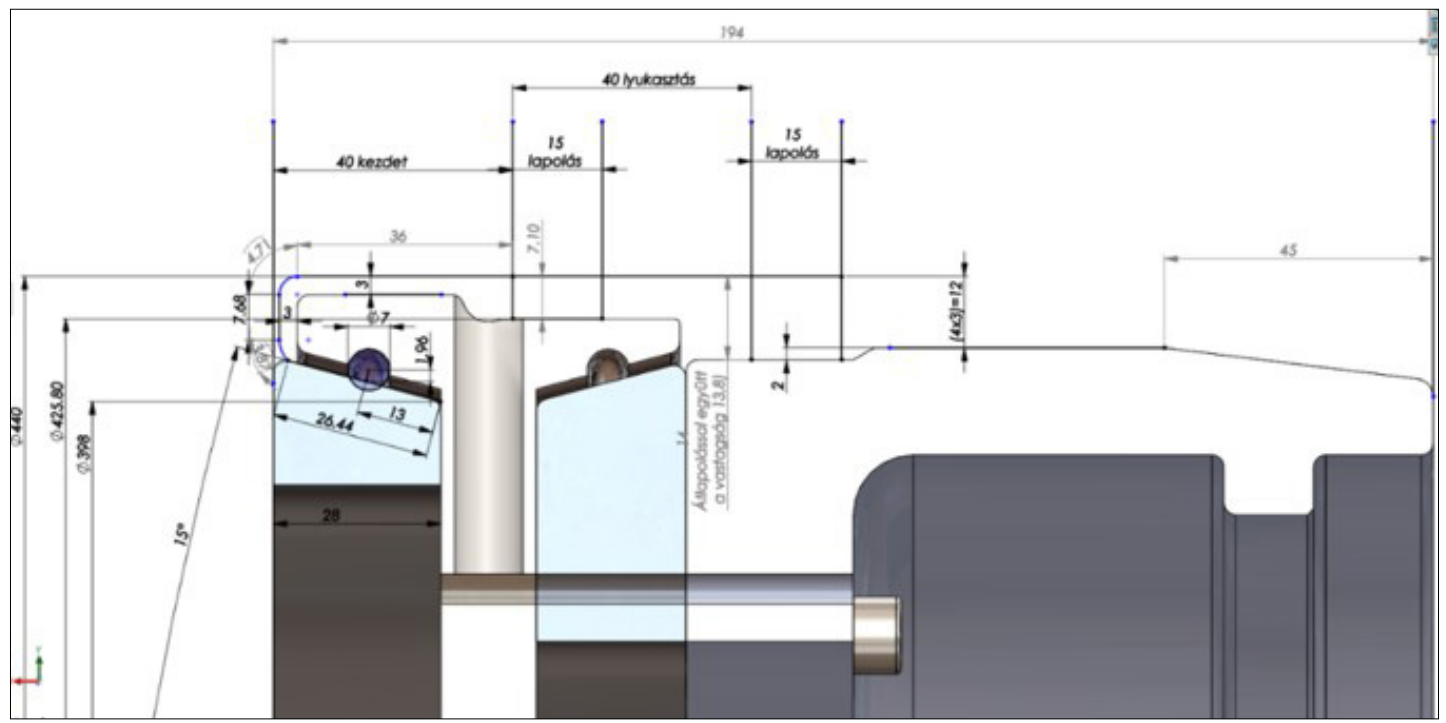

10. ábra. Balg felépítési útmutató

volságára. Ezen méretek meghatározhatók a rajz alapján. Ezenfelül figyelembe kell venni egy 3\%os zsugorodási tényezőt, amelyet még pluszban hozzá kell adni a méretekhez.

\section{A membránszél visszahajtási kísérle- te ikerbalgos egységgel}

Az öveslégrugó-felépítő dob kialakításának köszönhetően lehetőségünk volt végrehajtani egy kísérletet, amelyben teszteltük az ikerbalgos viszszahajtó egység működését, funkcióját.

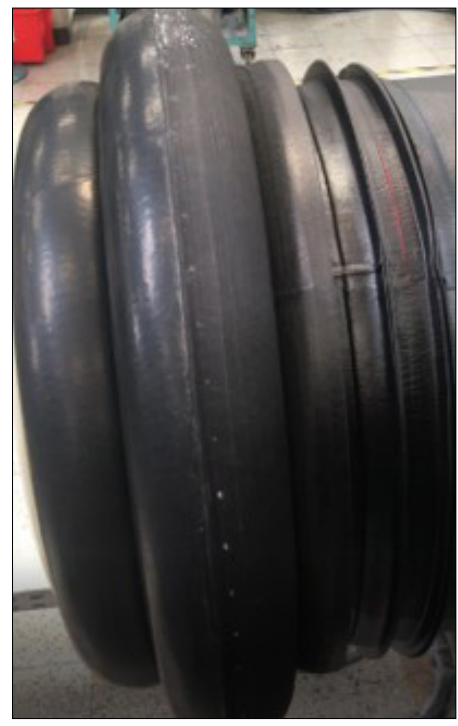

11. ábra. Visszahajtás balggal
A 11. ábrán látható, hogy a karkasz szélvisszahajtása az ikerbalggal történik. Megfigyelhető az ábrán, hogy ezzel az új technikával szinte teljesen vissza tudjuk hajtani a membránok szélét.

Továbbá, a visszahajtások minősége érezhetően jobb, mivel nem marad levegő a visszahajtás tövében. Ez annak köszönhető, hogy a balg teljesen a peremkarika tövétől feszíti a karkaszt a szegmensek szélének, így egy sokkal szorosabb viszszahajtást idéz elő. A 12. ábrán látható, hogy az operátornak már csak rá kell simítania a karkasz szélét.

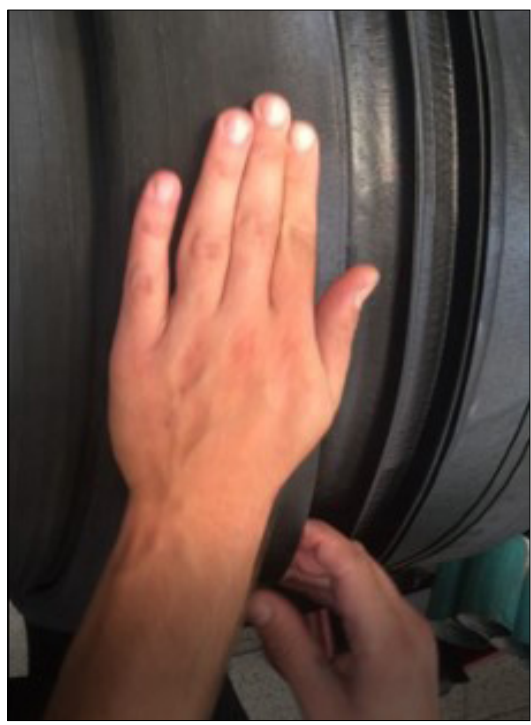

12. ábra. Simítás 


\section{Fejlesztések összehasonlítása}

A megfelelő fejlesztés kiválasztása előtt készítettem a főbb szempontok alapján egy összehasonlítást, amely a 1. táblázatban látható.

A fejlesztések közül az ikerbalgos megoldásra esett a választás kedvezőbb feltételeinek köszönhetően. Az üzem területén már 3 darab felépítődob átalakítása megtörtént, és további dobok kerülnek majd átalakításra.

1. táblázat. Fejlesztések összehasonlítása

\begin{tabular}{|c|c|c|c|}
\hline \multicolumn{2}{|c|}{ Duplabalgos fejlesztés } & \multicolumn{2}{|c|}{ Ikerbalgos fejlesztés } \\
\hline Előnyök & Hátrányok & Előnyök & Hátrányok \\
\hline $\begin{array}{l}\text { Egyszerű } \\
\text { gumielemek }\end{array}$ & $\begin{array}{l}\text { Bonyolult } \\
\text { szerkezet } \\
\text { Nagyobb } \\
\text { tömeg } \\
\text { Bonyolult- } \\
\text { abb szerelés } \\
\text { Két balg } \\
\text { felépítődob } \\
\text { szükséges }\end{array}$ & $\begin{array}{l}\text { Egyszerü } \\
\text { szerkezet } \\
\text { Kisebb tömeg } \\
\text { Egyszerűb- } \\
\text { ben szerel- } \\
\text { hető } \\
\text { Egy balg } \\
\text { felépítődob } \\
\text { szükséges }\end{array}$ & $\begin{array}{l}\text { Bonyolult } \\
\text { gumielem }\end{array}$ \\
\hline
\end{tabular}

\section{7. Összefoglalás}

A vasúti légrugók gyártásának kapacitásbővítése érdekében fejlesztéseket végeztem a felépítéshez szükséges felépítődob karkaszvisszahajtó egységén. Két megoldást dolgoztam ki, amelyek közül az ikerbalgos verzióra esett a választás. Ezzel a megoldással a már elvégzett kísérletek alapján növelni tudom a visszahajtás hatékonyságát, minőségét és mindezek mellett csökkenteni lehet a manuális munkát. Az eredmények láttán további felépítődobok is átalakításra fognak kerülni.

\section{Szakifejezések magyarázata}

A dolgozatomban használok néhány speciális gumiipari szakkifejezést, ezeket szeretném röviden elmagyarázni [3, 4].

Karkasz: A felépített nyers termék vulkanizálás előtti állapota.

Felépítés: a termék konfekcionálása, egy hengeres felületre feltekerve a nyers gumit és a szilárdsághordozó szövetet, majd az így kapott cső mindkét oldalát visszahajtjuk, rugalmas vagy fix drótból készült karikára. A felépítés lehet egyvagy kétfázisú.

Egyfázisúnál a terméket komplettre építjük, kétfázisúnál először egy csövet építünk, majd egy másik gépen tesszük fel a peremkarikákat a megfelelő pozícióba. A felépített gumielem: Légzáró (belső gumiréteg (14. ábra)) - Szilárdsághordozó (2 vagy több gumizott szövetréteg (13. ábra)) - Borító (külső gumiréteg (14. ábra)) - Peremdrótok.

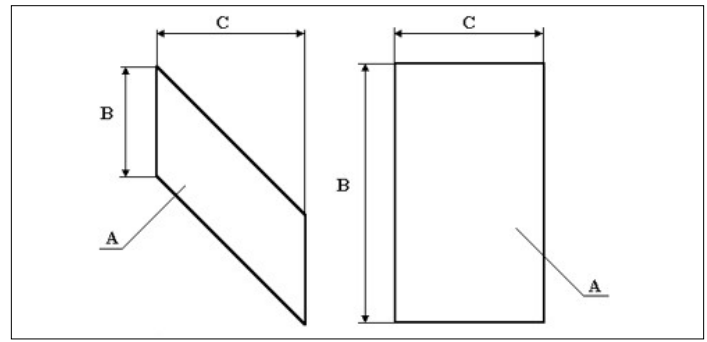

13. ábra. Szövetbetét

14. ábra. Légzáró és borító betét

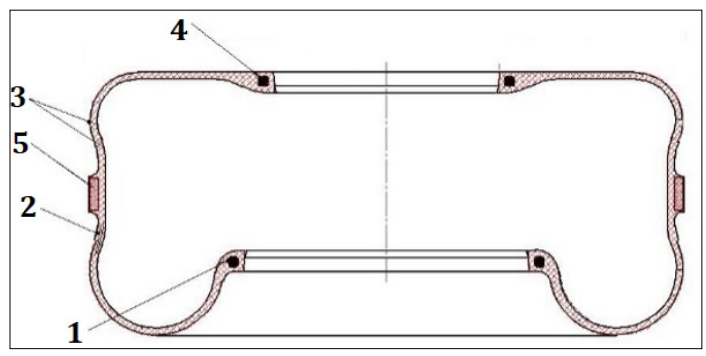

15. ábra. 1. Nagyperemdrót; 2. Szövetek; 3. Légzáró-borító; 4. Kisperem drót; 5. Gumirozott övdrót

Felépítődob: Hengeres eszköz, amire a nyers félkész terméket feltekerjük.

Balg (zsák): két fajtája van:

Vulkanizáló balg: Nyúlásra képes gumitermék, 4-10 mm falvastagsággal, több méretben készül, nehezen vulkanizáló kaucsukból (bróm-butil) így több termék kivulkanizálására alkalmas. Funkciója, hogy a terméket belülről a forma falához nyomja, ezzel biztosítva a vulkanizáláshoz szükséges nyomást.

Felépítő balg: Nyúlásra képes textil-gumi kombináció, amit a felépítődob végére szerelve segít a karkasz végének visszahajtásában.

Vulkanizálás: Vulkanizálásnak nevezzük mindazokat a folyamatokat, amelyekben a képlékeny, viszkoelasztikus viselkedésű kaucsukkeveréket elasztikus gumivá alakítjuk át.

Öves vasúti légrugó: A membrán közepe dróttal erősített, így nagyobb terhelést képes felvenni, helyigény növekedés nélkül (15. ábra).

\section{Szakirodalmi hivatkozások}

[1] https://indiarailinfo.com/blog/post/489191/16 Letöltés: 2019.11.21

[2] Fenyvessy T., Fuchs R., Gürtler M., Plósz A.: Múszaki Táblázatok. TCS Media Kft, Budapest, 2015.

[3] Bartha Z.: Gumiipari kézikönyv. I. Taurus-OMIKK, Budapest, 1988.

[4] Bartha Z.: Gumiipari kézikönyv. II. Taurus-OMIKK, Budapest, 1989. 


\title{
SDMN-ARCHITEKTÚRA AZ 5G-BEN
}

\section{SDMN ARCHITECTURE IN 5G}

\author{
Kovács Márk, ${ }^{1}$ Agg Péter András, ${ }^{2}$ Johanyák Zsolt Csaba ${ }^{3}$ \\ Neumann János Egyetem, GAMF Müszaki és Informatikai Kar, Kecskemét, Magyarország \\ ${ }^{1}$ kovacs.mark@gamf.uni-neumann.hu \\ 2 agg.peter@gamf.uni-neumann.hu \\ 3 johanyak.csaba@gamf.uni-neumann.hu
}

\begin{abstract}
Due to the exponentially growing number of mobile devices connected to the Internet the current 4G LTE-A mobile network will no longer be able to serve the nearly 5 billion mobile devices. With the advent of the fifth generation, however, the number of cybercrimes may increase. This requires building an architecture that can adequately protect against these attacks. For wired networks, the SDN-type architecture has been introduced for some time. As a result, a similar design concept has emerged, which is called Software Defined Mobile Networks (SDMN). This article describes this technology to help preventing DoS, DDoS attacks, and IP source spoofing.
\end{abstract}

Keywords: $S D N, 5 G, N F V, S D M N$, security.

\section{Összefoglalás}

Az exponenciálisán növekvő internetre csatlakoztatott mobileszközök száma miatt a jelenlegi 4G LTE-A mobilhálózat már nem lesz képes kiszolgálni a már közel 5 milliárd mobileszközt. Az ötödik generáció megjelenésével azonban még nagyobbra nőhet a kiberbűnözés mértéke. Ezen kockázat ellensúlyozásaként egy olyan architektúra felépítése szükséges, amely kellőképpen ki tudja védeni ezeket a támadásokat. A vezetékes hálózatoknál már egy ideje bevezetésre került az SDN-típusú felépítés. Ennek nyomán próbálnak egy hasonló kialakítást megvalósítani az 5G-hálózatoknál is, aminek eredményeképpen megszületett a Software Defined Mobile Networks z (SDMN) fogalma. Cikkünk ezt a technológiát mutatja be annak érdekében, hogy könnyebben kivédhetők legyenek a DoS-, DdoS-támadások, illetve az IP-forráscím-hamisítások.

Kulcsszavak: $S D N, 5 G, N F V, S D M N$, biztonság.

\section{Szoftver által definiált hálózatok (SDN)}

Napjaink az egyik legelterjedtebb és leghatékonyabb hálózati megoldása a szoftver által definiált hálózatok (Software Defined Networks, SDN) [1]. Az SDN legnagyobb újítása a hagyományos hálózatokkal szemben, hogy elválasztja a vezérlősíkot (controlplane) az adatsíktól (dataplane). Ezen módszer segítségével fontos szerepet kap a központosított vezérlés. Az SDN-hálózatoknál három fő réteget különböztetünk meg: az adatsíkot, vezérlősíkot, és az alkalmazási síkot.
Az SDN adatsíkjában gyakorlatilag a kapcsolók és forgalomirányítók találhatóak (közös nevükön SDN-kapcsolók), melyeknek feladatuk csak a csomagok eljuttatása a célcímig felsőbb utasítás alapján, melyet a vezérlősíktól kapnak. Ezek az eszközök az úgynevezett déli interfészen (SouthboundInterface) keresztül kapják meg az utasításokat, és végrehajtásukhoz szükségük van arra, hogy OpenFlow [2] protokoll-kompatibilisek legyenek.

A vezérlősík biztosítja az itt használt programok segítségével a hálózat automatikus konfigurálását, a dinamikus hozzáférést és vezérlést az igények- 
nek megfelelően. Egyik legfontosabb rétege ennek a síknak a virtualizáció, amely azonban nem keverendő össze a hálózati funkciók virtualizációjával (NFV [3], Network Function virtualization). (Az SDN és az NFV kapcsolatáról a következő részben beszélünk.) Ebben a síkban található a hálózati operációs rendszer is (Network Operating System), amely az esetlegesen felmerülő hálózatmenedzsmenti problémák kezelésére szolgáltat megoldásokat. A vezérlősík közvetlen kapcsolatban van az SDN harmadik síkjával, az úgynevezett alkalmazási síkkal. A köztük lévő kommunikációért az északi interfész (NorthboundInterface) felel.

Az SDN harmadik síkja az alkalmazási sík, melyben három alréteg található: a nyelvalapú virtualizáció (Language-basedvirtualization), a programozási nyelvek (Programminglanguage) és a hálózati alkalmazások (Network Applications). Feladatuk a megfelelő utasítások kiadása a vezérlés felé, melyek biztosítják a gyors és megbízható kommunikációt központi felügyelet mellett.

\section{SDN és NFV}

A hálózati virtualizációnál nagyon sokszor emlegetik az SDN-t és NFV-t együtt, bár ezek nem függenek egymástól. A két megoldásnak van kapcsolata, úgyis mondhatnánk, hogy kiegészítik egymást.

Az SDN a hálózati eszközöket virtualizálja (kapcsolók, forgalomirányítók), a hagyományos továbbító eszközök helyett használ olcsóbb, gyorsabb, központilag vezérelhető hardverelemeket, illetve természetesen egy vagy több vezérlőkontrollert, amelyek segítségével biztosíthatja a megfelelő központosított védelmet, adminisztrálhatóságot, illetve a gyors reagálást a felhasználói igényeknek megfelelően.

Az NFV a hálózati funkciók virtualizálását tekinti elsődleges feladatnak. Az NFV-virtualizáció segítségével gyors telepíthetőséget, költségcsökkentést, rugalmasságot biztosít. Segítségével olyan szolgáltatásokat tudunk szoftveresen igénybe venni, amelyeket korábban hardverben valósítottak meg (pl. hálózati címfordítás (NAT), tűzfalszolgáltatások, DHCP). Fontos megjegyezni, hogy az NFV-szolgáltatások megvalósításának nem feltétele az SDN-hálózat megléte.

\section{Jelenlegi mobilhálózatok hiányosságai}

A mobilkommunikáció az 1980-as években kezdődött el, ami kezdetben csak és kizárólag hanghívásokra volt használható mindössze 56 kbps adatátviteli sebességgel. Napjainkban azonban ez

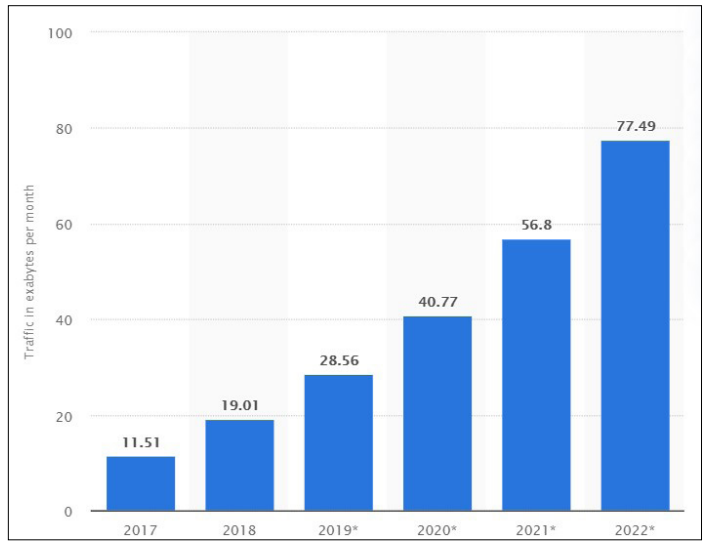

1. ábra. Globális mobil adatforgalom 2017 és 2022 között [4]

a kezdetleges szolgáltatás kinőtte magát egy külön nagy hálózattá, amely képes kapcsolódni a világhálóra, és ennek köszönhetően a hanghívásokon kívül videóhívásokra, nagy felbontású online videók átvitelére, online játékokra is használható [5].

A jelenleg használt mobilhálózatokat több hiányosság is jellemzi:

- Megfelelő skálázhatóság hiánya: a forgalom gyorsan növekszik az új nagy sávszélességet igénylő mobilszolgáltatások miatt, és a jelenlegi statikus hálózatok túl rugalmatlanok, ezért jövőbeni mủködésük túl költséges lesz.

- Komplex hálózati menedzsment: a fizikai hálózati eszközökhöz nincs biztosítva egy közös vezérlő interfész, ezért még egy kisebb feladathoz is nagy szakértelem szükséges, ami a legtöbb rendszerleállási hiba forrása is egyben.

- Komplex és drága hálózati eszközök: néhány eszköznek túl sok feladatot kell elvégeznie (pl. forgalomfigyelés, számlázás, QoS vagy éppen a szülői felügyelet), ami növeli az eszköz összetettségét és költségét.

- Magas költségek: az üzemeltetők nem tudják összeegyeztetni a különböző olcsóbb gyártók eszközeit, ami növeli a költségeket, illetve a kézi beállítás és rugalmatlanság miatt magas az üzemeltetési költség is.

- Rugalmatlanság: a szabványosítási hosszú folyamat miatt sokáig elhúzódik egy új szolgáltatás bevezetése.

\section{Szoftver által definiált mobilhálóza- tok (SDMN)}

$\mathrm{Az}$ SDN eredetileg vezetékes hálózatokhoz lett tervezve, azonban a fejlesztők észrevették a lehe- 


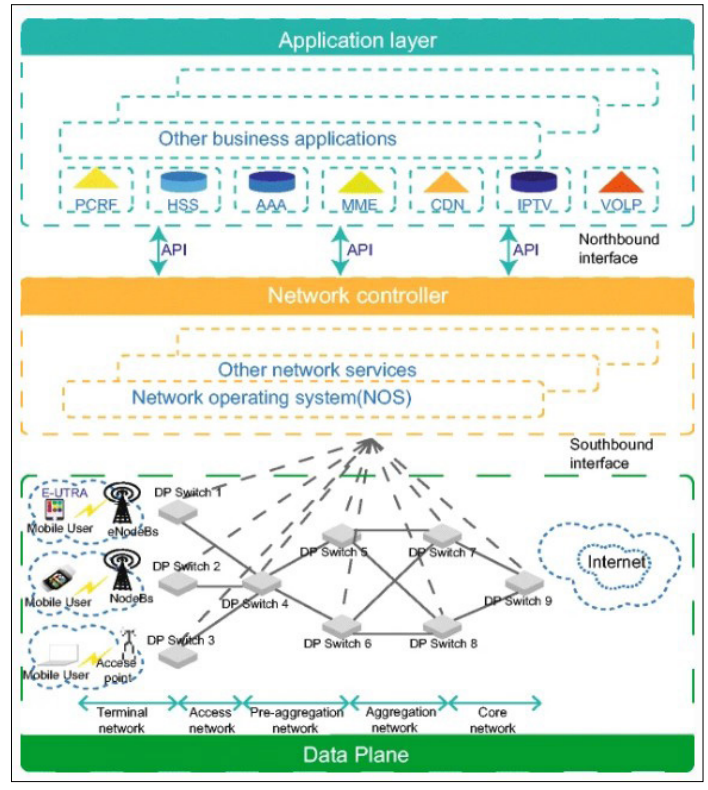

2. ábra. SDMN architektúra [6]

tőséget, hogy ez a megoldás működhet vezeték nélküli környezetben is.

Az SDMN egy programozható, rugalmas és forgalomközpontú hálózati konstrukció, amely az SDN-t, NFV-t és felhőalapú számolás kombinációjából áll. A jelenleg működő mobilhálózatoktól annyiban tér el, hogy a forgalomközpontú modell segítségével integrálják a drága hardveres eszközöket, és központosított logikai vezérlőt helyeznek az optimális működés érdekében.

Az SDN-hez hasonlóan az SDMN is három részből áll: adatsíkból, vezérlősíkból és az alkalmazási síkból.

Bár az SDN-koncepció sajnos nem oldja meg az előző fejezetben említett összes problémát, de növeli a rugalmasságot, skálázhatóságot és ezáltal a teljesítményt is. A jelenlegi mobilhálózatot egy forgalomközpontú modell felé irányítja, melynek segítségével olcsó hardvert és logikailag központosított vezérlőt alkalmaz. Az SDN-kompatibilis kapcsolók, útválasztók és átjárók az SDN-vezérlőn és a hálózati operációs rendszeren (NOS) keresztül vezérelhetők. A vezérlősík virtuális összetevőként telepíthető egy operátorfelhőben. Az 2. ábra a SDMN felépítését szemlélteti [7].

\subsection{DP réteg}

Infrastrukturális rétegnek is szokás nevezni, ahol a hálózati eszközök találhatóak, mint a kapcsolók és forgalomirányítók. A bázisállomások határkapcsoló adatsík kapcsolóihoz vannak csatlakoztatva.
Az internethez kapcsolódnak a másik oldal határkapcsolói.

\subsection{Hálózati vezérlő}

A logikailag központosított vezérlő segítségével lehet a DP eszközeit konfigurálni, vezérelni. Egy vezérlőprotokollt használ (pl. OpenFlow) a DP-elemek eléréséhez, illetve az forgalomszabályozások telepítéséhez. A hálózativezérlő- és a DP-réteget az SDN-architektúrához hasonlóan a déli irányú API köti össze. A vezérlőn fut a NOS, a vezérlési szolgáltatások támogatásához.

\subsection{Alkalmazási réteg}

Itt található meg az összes vezérlő- és üzleti alkalmazás, mint a házirend, előfizetői szerver, azonosítás, jogosultságkezelés, könyvelés. Az alkalmazási réteg és a hálózati vezérlő között az északi határú API biztosítja a kapcsolatot.

\section{Biztonsági hiányosságok}

Az SDN-ből származó biztonsági rések itt is megtalálhatók:

-A központosított felügyelet integrálja a hálózati konfigurációt, a hálózati szolgáltatás-hozzáférés vezérlését és a szolgáltatás telepítését a vezérlőrétegen. Ha a támadó sikeresen megszerzi az irányítást az SDN-ben, akkor a hálózati szolgáltatás megbénul, és ez az egész hálózatot érinti [8].

- Az SDN programozhatóságának főbb problémája a harmadik féltől származó alkalmazásokon és vezérlőn alapuló bizalom. A rosszindulatú alkalmazások kockázatát hordozza magában, ezért meg kell erősíteni a hitelesítési eljárást az alkalmazás és a vezérlőrétegek között a vezérlő védelme érdekében.

- Az NFV és az SDN kombinációja biztonsági problémák sorozatát jelentheti. Példaul az OpenFlow,

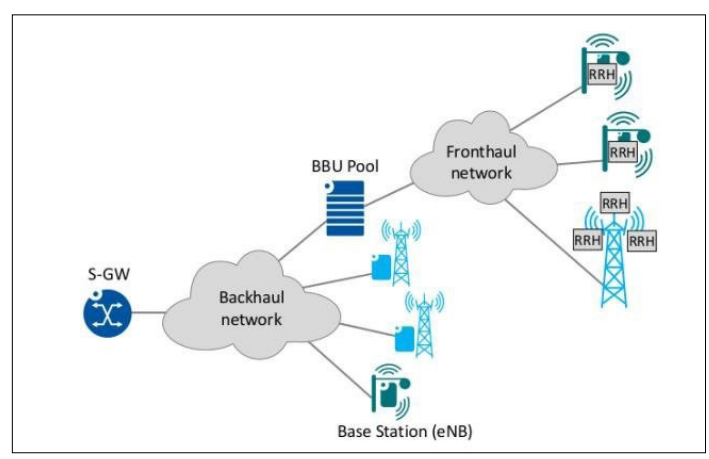

3. ábra. Backhaul és Fronthaul hálózatok közötti kapcsolat [9] 
az NFV, a szoftver által definiált Fronthaul hálózati biztonsági problémák és a terminálproblémák stb. A szoftver által definiált fronthaul esetében a virtualizált támadás veszélyt jelent.

- A szoftver által meghatározott Fronthaul-, (SDF) vezeték nélküli programok szempontjából az SDMN-biztonságot fenyegető veszély lehet a MAC-hamisítás és a rosszindulatú RF-interferencia is. [10]

\section{Összegzés}

A növekvő forgalom miatt egyre nagyobb igény van egy jól megtervezett hálózati architektúrára a mobilhálózatok terén is. Ennek nyomán számos kutatás folyik az új generáció technológiájának jól kialakított, azonban biztonságos kialakítására.

\section{Köszönetnyilvánítás}

Köszönettel tartozunk a kutatás támogatásáért, amely az EFOP-3.6.1-16-2016-00006 „A kutatási potenciál fejlesztése és bővítése a Neumann János Egyetemen” pályázat keretében valósult meg. A projekt a Magyar Állam és az Európai Unió támogatásával, az Európai Szociális Alap társfinanszírozásával, a Széchenyi 2020 program keretében valósul meg.

\section{Szakirodalmi hivatkozasok}

[1] Ramos F. M. V., Kreutz D., Verissimo P.: Software-defined networks: On the road to the softwarization of networking. Agile Product Management \& Software Engineering Excellence, Business Technology \& Digital Transformation Strategies Cutter Business Technology Journal, 28. (2015) 6-13.
[2] Lara A., Kolasani A., Ramamurthy B.: Network innovation using OpenFlow: A survey. IEEE Communications Surveys \& Tutorials, 16/1 (2014), 493-512.

[3] Bo Han, Vijay Gopalakrishnan, Lusheng Ji, Seungjoon Lee: Network function virtualization: Challenges and opportunities for innovations. IEEE Communications Magazine 53/2. (2015) 90-97. DOI: 10.1109/MCOM.2015.7045396

[4] Statista: Global mobile data traffic from 2017 to 2022. (letöltve: 2020. február 20).

https://www.statista.com/statistics/271405/global-mobile-data-traffic-forecast/

[5] Militano L., Araniti G., Condoluci M., Farris I., Iera A.: Device-to-Device Communications for $5 G$ Internet of Things. EAI Endorsed Transactions on Internet of Things 1/1. (2015) 150598. https://doi.org/10.4108/eai.26-10-2015.150598

[6] Chen, M., Qian, Y., Mao, S. et al. Software-Defined Mobile Networks Security. Mobile Netw Appl 21, 729-743 (2016). https://doi.org/10.1007/s11036-015-0665-5

[7] Liyanage M., Gurtov A., Ylianttila M.: Software Defined Mobile networks (SDMN) Beyond LTE network architecture. Wiley, 2015.

[8] Ji, X., Huang, K., Jin, L. et al.: Overview of $5 G$ security technology. Sci. China Inf. Sci. 61, 081301 (2018). https://doi.org/10.1007/s11432-017-9426-4

[9] Hailu D. H., lema G. G., Bjørnstad S.: Performance Evaluation of Ethernet Network for Mobile Fronthual Networks. IJEESC 7/1. (2017) 287-298.

[10] Liyanage M. et al.: Enhancing Security of Software Defined Mobile Networks. IEEE Access, 5 (2017) 9422-9438. 


\title{
A RAPID WELD TECHNOLÓGIA KÖLTSÉGHATÉKONY KONFIGURÁCIÓJÁNAK KUTATÁSA
}

\section{A COST EFFECTIVE RAPID WELD TECHNOLOGY CONFIGURATION}

\author{
Laki Márk ${ }^{1}$, Kuti János² \\ Óbudai Egyetem, Bánki Donát Gépész és Biztonságtechnikai Mérnöki Kar, Budapest, Magyarország \\ 1 laki.mark.lm@gmail.com \\ ${ }^{2}$ kuti.janos@bgk.uni-obuda.hu
}

\begin{abstract}
The research focuses on determining the application parameters of a new process developed by Cloos. With the use of Cloos Rapid Weld technology (metal active gas welding), the authors carried out welding experiments on S235JR steel sheets ( $6 \mathrm{~mm}$ and $8 \mathrm{~mm}$ thick). The results of the welding experiments were verified by hardness measurement [1-3]. The goal is to establish one side one row suitable welded joint by the used technology.
\end{abstract}

Keywords: Rapid weld, Cloos, hardness.

\section{Összefoglalás}

A kutatás egy Cloos által fejlesztett új eljárásváltozat alkalmazási paramétereinek meghatározására koncentrál. Az alkalmazott Cloos Rapid Weld technológiával (huzalelektródás védőgázas ívhegesztés) S235JR-acéllemezek (6mm és $8 \mathrm{~mm}$ vastag) hegesztési kísérleteit végezték a szerzők. A hegesztési kísérletek eredményeit keménységméréssel ellenőrizték [1-3]. A cél az alkalmazott technológiával az adott lemezeken egy oldalról egy sorban varratot létrehozni, mely eleget tesz a követelményeknek.

Kulcsszavak: rapid weld, Cloos, keménység.

\section{Bevezetés}

A hegesztéstechnológia, beleértve az eljárásokat és az áramforrásokat, az elmúlt évtizedekben rohamosan fejlődni kezdett. Az ipar nagy teljesítményt, reprodukálhatóságot és jó minőséget követel meg a hegesztett szerkezetek gyártása során. A különböző cégek az új eljárásokat saját márkanévvel jelölik, mely inkább csak utal a technológia sajátosságaira. Számos új megnevezéssel találkozhatunk ennek következtében. Az egyes eljárások alkalmazható paramétereit azonban nem minden esetben közli a gyártó. Mérésekkel meghatározhatók az egyes áramforrások, eljárások, sőt paraméter-együttesek korlátai.

\section{Rapid Weld és a T.I.M.E. technológia}

A Cloos Rapid Weld technológiája a T.I.M.E. (Transferd Ionoized Molten Energy) eljárások közé tartozik [4]. Jellemzően az ívhegesztés teljesítményének növelésével emelik a gyártás volumenét, illetve a huzalelőtolási sebesség növelésével csökkenthető az anyagátvitel zavar okozta hibák száma.

A Rapid Weld technológia a szabad huzalhoszsz függvényében szabályozza az áramerősséget. Az így létrejött varrat teljes hosszában egyenletes beolvadást mutat, még megnövelt szabad huzalhossz esetén is. Ezt az eljárásváltozatot jellemzi a nagy teljesítmény, a huzalelőtolási sebesség, 
amely $14 \mathrm{~m} /$ perc és $34 \mathrm{~m} /$ perc közötti értéket is felvehet, miközben az áramerősség jellemzően 400-tól 550 A-os tartományban mozog.

Főként acéllemezek hegesztésére használják ma az iparban, főként daruelemek és nyomástartó edények gyártása során [5].

Az 1. ábra a Rapid Weld technológia során az áramerősség és az ívfeszültség alakulását mutatja be.

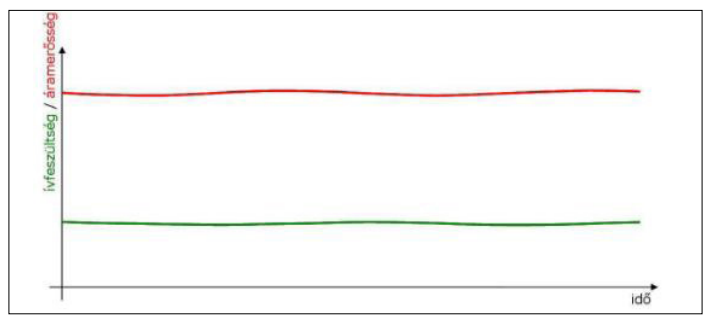

1. ábra. Rapid Weld-áramerösség/-ívfeszültség alakulása

\section{Felhasználási lehetőségek kutatása}

A kutatásban arra kerestük a választ, lehetséges-e a technológiát közepesen vastag lemez hegesztésére alkalmazni azzal a céllal, hogy csökkentsük a gyártáshoz szükséges időt, az ívhegesztési eljárások során alkalmazható paraméter beállítások alkalmazásával [6-8].

A vizsgálatokat $6 \mathrm{~mm}$ és $8 \mathrm{~mm}$ vastag S235 JR-acéllemezeken végeztük. Azzal a szándékkal végeztük a kísérleteket, hogy egy oldalról, egy sorból hozzunk létre elfogadható minőségű varratot. A vizsgálathoz M21-es védőgázkeveréket használtunk. A Linde által gyártott Corgon-összetétel 18\% $\mathrm{CO}_{2}$-t és $82 \%$ Ar-t tartalmaz, a szabvány megnevezése „ISO 14175 -M21 - Arc - 18”.

\subsection{Kísérletek}

A próbák során S235 JR általános rendeltetésű acélt használtunk, a lemezvastagság $(8 \mathrm{~mm})$. A kitűzött cél az elfogadható minőségű varrat létrehozása egy oldalról egy sor alkalmazásával [9-11]. A 2018-as tapasztalatainkból kiindulva a megszokottnál rövidebb, 100x150 (mm)-es lemezt alkalmaztunk, mivel a termikus terhelés miatt hosszabb jó minőségű varratok stabil készítése nagyon nehéznek bizonyult, illetve a próbadarabok korlátozott száma miatt próbáltuk a lehető legtöbb próbát kialakítani a meglévő anyagmenynyiségből.

A próbák során a fő változó a lemezek leélezése volt. 0-ától $45^{\circ}$-os leélezésig vizsgáltuk a lehetőségeket. $0^{\circ}$-os, $15^{\circ}$-os, $30^{\circ}$-os és $45^{\circ}$-os darabokból
5-5 db készült előkészítésre. A leélezéseket gyalu segítségével hoztuk létre, valamint a felső oxidréteget eltávolítottuk a fém felszínéről, közvetlenül a hegesztés előtt pedig megtisztítottuk a próbadarabokat, hogy szennyeződés ne befolyásolja a végeredményt.

Három próbahegesztést végeztünk a hegesztőberendezés kalibrálásához, mielőtt megkezdtük a munkát a próbadarabokon. Az elvégzett teszt alapján áramerősség tekintetében a 345-365 A közötti zónában dolgoztunk, feszültség tekintetében 40-43 V-os értékkel dolgoztunk.

Minden esetben az azonos leélezésű szöggel rendelkező darabok közül 2 db-ot hézag nélkül hegesztettünk, $2 \mathrm{db}$-ot $1 \mathrm{~mm}$-es hézaggal, míg $1 \mathrm{db}$ ot $2 \mathrm{~mm}$-es hézaggal. Ezzel az volt a célunk, hogy legyen tapasztalatunk, hogy az eljárás mennyire érzékeny a pontos beállításra. A 2. ábra egy nem megfelelő koronaoldalú kísérleti mintát mutat be.

Az 1. táblázatban összefoglaltuk, hogy milyen különböző beállításokkal készítettük el a hegesztési próbákat, illetve hogy szemrevételezés alapján melyeket tartottuk megfelelőknek.

\section{1. táblázat. Kísérleti paraméterek összefoglalása}

\begin{tabular}{|c|c|c|c|}
\hline $\begin{array}{l}\text { Leélezés } \\
\text { szöge } \\
\left({ }^{\circ}\right)\end{array}$ & $\begin{array}{l}\text { Hézag } \\
\text { mérete } \\
\text { (mm) }\end{array}$ & $\begin{array}{c}\text { Élszalag } \\
\text { (i/n) }\end{array}$ & $\begin{array}{c}\text { Megfelelőség } \\
\text { (i/n) }\end{array}$ \\
\hline 0 & 0 & & nem felelt meg \\
\hline 15 & 0 & & megfelelt \\
\hline 15 & 0 & $\mathrm{x}$ & megfelelt \\
\hline 30 & 0 & & megfelelt \\
\hline 30 & 0 & $\mathrm{x}$ & megfelelt \\
\hline 45 & 0 & & nem felelt meg \\
\hline 45 & 0 & $\mathrm{x}$ & nem felelt meg \\
\hline 0 & 1 & & nem felelt meg \\
\hline 15 & 1 & & megfelet \\
\hline 15 & 1 & $\mathrm{x}$ & megfelet \\
\hline 30 & 1 & & nem felelt meg \\
\hline 30 & 1 & $\mathrm{x}$ & nem felelt meg \\
\hline 45 & 1 & & nem felelt meg \\
\hline 45 & 1 & $\mathrm{x}$ & nem felelt meg \\
\hline 0 & 2 & & nem felelt meg \\
\hline 15 & 2 & & nem felelt meg \\
\hline 30 & 2 & & nem felelt meg \\
\hline 45 & 2 & & nem felelt meg \\
\hline
\end{tabular}




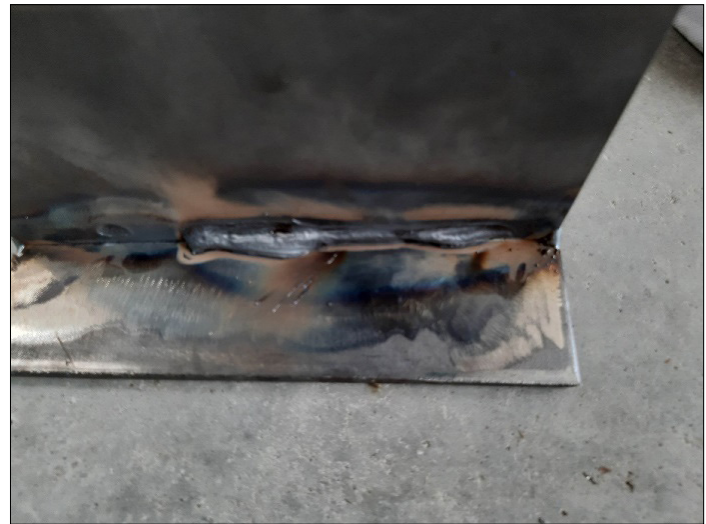

2. ábra. Nem megfelelö koronaoldal

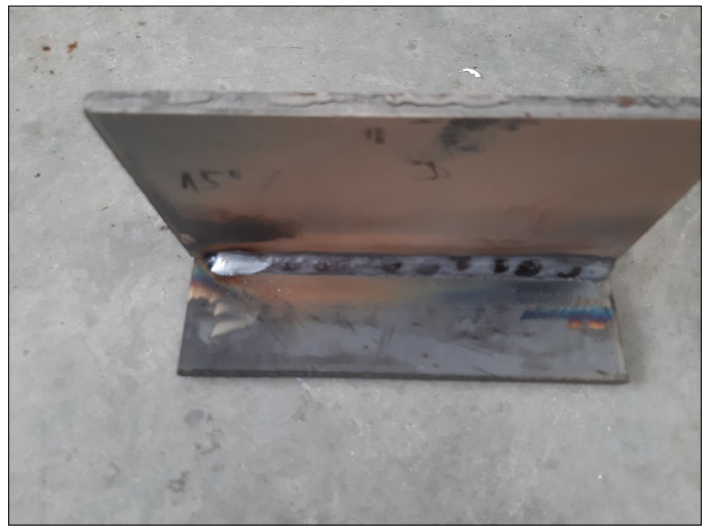

3. ábra. Sikeres $15^{\circ}$-os varrat

Az élszalag esetünkben egy vékony, $1 \mathrm{~mm}$-es, $45^{\circ}$-os letörést jelent, melyet sarokcsiszoló segítségével, kézzel készítettünk a leélezett darabokra.

Szemrevételezés eredményeképpen azt állapítottuk meg, hogy a $15^{\circ}$-os leélezés és $1 \mathrm{~mm}$ hézag beállításával alakíthatunk ki legjobb varratot (3. ábra).

A $2 \mathrm{~mm}$ hézag olyan nagy volt, hogy egyszerüen átfújta rajta a nagy áramerősség hatására a hozaganyagot a védőgáz. $0 \mathrm{~mm}$ hézag alkalmazása mellett a $15^{\circ}$-os és a $30^{\circ}$-os leélezéssel is megfelelő varratot tudtunk létrehozni (3. ábra). A kísérletekből az kitűnt, hogy amit eredetileg célul tüztünk ki, hogy leélezés nélkül valósítsuk meg a hegesztést, az nem valósult meg.

\section{Darabolás, csiszolás, polírozás}

A darabok beolvadását és a varrat megfelelőségét keménységméréssel és a metallográfiai vizsgálatokkal ellenőriztük. Ezekhez a vizsgálatokhoz az alábbi módon készítettük elő a darabokat.
A daraboláshoz egy Bomar STG 230 G-fürészt használtunk, amelynek a segítségével folyamatos hütés mellett tudtuk elvégezni a vágást, így nem befolyásoltuk a kialakult szövetszerkezetet.

A csiszolást és polírozást egy Struers LaboForce-50-es berendezésen végeztük el. Struers Waterproof SiC-csiszolópapír használatával fokozatosan növelve a csiszolás finomságát $60 ; 120 ; 250$; 500; 800; 1200-as papírt használva készítettük elő a darabokat. A csiszolás végeztével elsőként $3 \mu \mathrm{m}$-es érdességen majd $1 \mu \mathrm{m}$-es érdességen végeztük el a polírozást. Nital 3-típusú, savas kémhatású anyaggal marattuk a minták felszínét. Az így előkészített darabokat vizsgáltuk meg fénymikroszkóp segítségével [12-14].

Az elkészült kötések nem mutatták a martenzit megjelenését. A várt ferrit-perlites szövet látható az elkészült képeken. A hőhatásövezet kiterjedése jól mutatja, hogy megfelelő sebességű hegesztés során a közepesen vastag lemez sincs kitéve túl magas termikus terhelésnek.

A $2 \mathrm{~mm}$ hézag olyan nagy volt, hogy egyszerűen átfújta rajta a nagy áramerősség hatására a hozaganyagot a védőgáz. $0 \mathrm{~mm}$ hézag alkalmazása mellett a $15^{\circ}$-os és a $30^{\circ}$-os leélezéssel is megfelelő varratot tudtunk létrehozni. A kísérletekből az kitűnt, hogy amit eredetileg célul tűztünk ki, hogy leélezés nélkül valósítsuk meg a hegesztést, az nem valósult meg.

A csiszolatokról készült képen jól látható, hogy megfelelő beolvadási mélységgel sikerült létrehozni a varratokat. Mind a $15^{\circ}$-os, mind a $30^{\circ}$-os leélezésnél megfelelőek lettek a hegesztési kötések.

A mintáim szövetszerkezetét miután megvizsgáltam mikroszkóppal, microVickers-kemény-

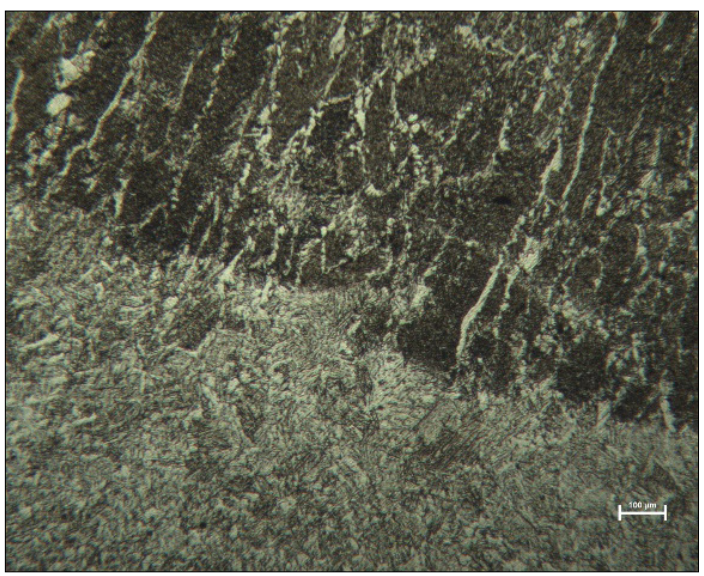

4. ábra. $15^{\circ}$-os, leélezés, $1 \mathrm{~mm}$ hézag $4 \times 20$-as nagyitás a varrat és a hőhatásövezet 


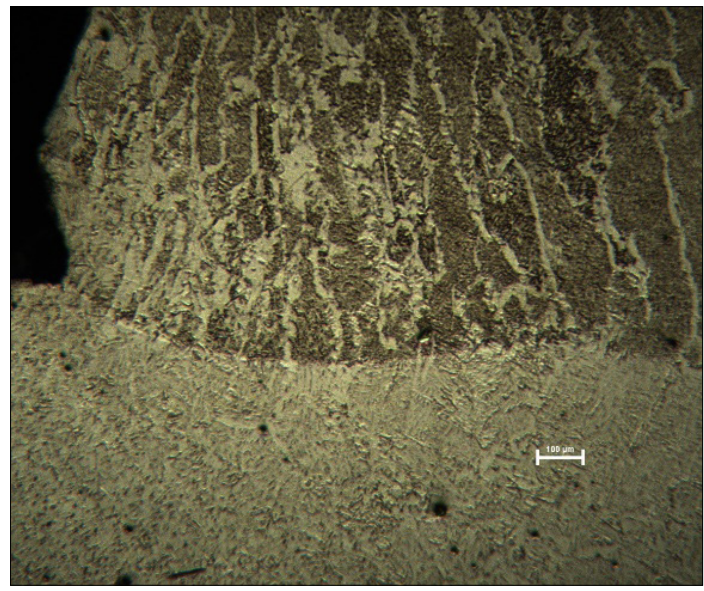

5. ábra. $30^{\circ}$-os leélezés, 0 hézag 4x20-as nagyítás

ségmérést hajtottam végre. Vickers-eljárás esetén egy $136^{\circ}$-os csúcsszöggel rendelkező gyémántgúla a szúrószerszámunk, microVickers-eljárás esetén a darab felületén egy apró, csak mikroszkóppal látható lenyomatot készítünk. A lenyomat felülete arányos a keménységgel, a két átló átlagából ezért következtethetünk az anyag keménységére.

A két minta ömledékzónájában, a hőhatásövezetben és az alapanyagban mértem $200 \mathrm{~g}$ terheléssel a keménységet, azzal a céllal, hogy igazoljam a mikroszkópon látott szövetszerkezetet [15-18]. Az egyes zónákban 3-3 mérést hajtottam végre, majd ezek eredményét értékeltem ki.

Az egyes minta ömledékzónájában HV 130, hőhatásövezetében HV 103, alapanyagában HV 116 keménységet mértem. A második minta ömledékzónájában HV 105, hőhatásövezetében HV 125, alapanyagában HV 121 értéket kaptam. A kapott eredmények igazolják a várakozásainkat.

\section{Konklúzió}

A vizsgálatok összefoglalásaként a kitűzött célt sikerült elérni. Közepesen vastag lemezt $(8 \mathrm{~mm})$ sikerült a Rapid Weld technológiával egy oldalról egy sorból hegeszteni, és elfogadható minőségű varratot létrehozni. Az eredmények értékelése alapján egyértelműen a $15^{\circ}$-os leélezés és 1 mm-es hézag hozta a legjobb eredményt (4. ábra). A $15^{\circ}$-os és $30^{\circ}$-os (5. ábra) leélezéssel hézag használata nélkül készült darabokon látható hogy a sarokvarrat vízszintes lemezébe kisebb a beolvadás mértéke, de még így is elfogadható minőségű varratok hozhatók létre. Ugyanakkor az is megállapítható, hogy a leélezés nélküli darabok ebben az anyagvastagságban nem lettek megfelelőek.
Az eljárásra jellemző nagy sugár- és hőterhelés miatt javallott az automatizálás, amellyel tovább javítható a varrat minősége, így a hézag nélkül történő hegesztés bizonyulhat a legjobb megoldásnak jobb költséghatékonysága miatt.

Végül a varrat minőségének javítására alkalmazhatunk három- vagy négykomponensű gázkeveréket, ezek az ívstabilitás javításával jobb szélbeolvadást biztosíthatnak.

A kísérletet lehet folytatni még olyan irányba, hogy a hegesztés automatizált, illetve ha az élelőkészítéseket lángvágással vagy plazmavágással végezzük el.

\section{Köszönetnyilvánítás}

A szerzők köszönetet kívánnak mondani a magyar államnak és az Európai Uniónak az EFOP-3.6.1-162016-00010. számú projekt keretében nyújtott támogatásért.

\section{Szakirodalmi hivatkozások}

[1] Balogh A.: Hegesztő szakmérnöki jegyzet. Miskolci Egyetem

[2] Szunyogh L., Artinger I., Romvári P.: Hegesztés és rokontechnológiák. Gépipari Tudományos Egyesület

[3] Béres L., Gáti J., Gremsperger G., Komócsin M., Kovács M.: Hegesztési Zsebkönyv. 2003

[4] Cloos: Rapid Weld - That's what efficiency looks like! (2019.11.05)

https://www.cloos.de/de-en/processes/details/ rapid-weld/

[5] Biszku G.: Vastaglemezek hegesztése. Miskolci Egyetem.

[6] Bagyinszki Gy., Bitay E.: Hegesztéstechnika I. Eljárások és gépesítés. Müszaki Tudományos Füzetek 9., EME, Kolozsvár, 2010. https://doi.org/10.36242/mtf-09

[7] Bagyinszki Gy., Bitay E.: Hegesztéstechnika II. Berendezésekés mérések. Műszaki Tudományos Füzetek 10., EME, Kolozsvár, 2010. https://doi.org/10.36242/mtf-10

[8] Bitay E., Bagyinszki Gy.: Ívhegesztési eljárásváltozatok fejlesztései. XXII. FMTÜ. Műszaki Tudományos Közlemények 7., EME, Kolozsvár, 2017. 99-102.

https://doi.org/10.33895/mtk-2017.07.17

[9] Kuti J.: Vastaglemez $X$ varratos kötésének kiváltása szükített $V$ varrattal. Szakdolgozat, Óbudai Egyetem, Budapest 2017.

[10] Gyura L., Fehérvári G., Balogh D.: Szabályozott anyagátvitelü fogyóelektródás védőgázos hegesztések vizsgálata. In: 25. Jubileumi Hegesztési Konferencia, Budapest, 2010. május 19-21. http://hegkonf2010.uni-obuda.hu/17_Gyura_Fehervari_Balogh_Hegkonf2010.pdf 
[11] Kristóf Cs.: Korszerü MIG/MAG eljárásváltozatok minőségirányitási értékelése. Messer Hungarogáz Kft.

h t t p s: / / w w w. m e s s e r. h u / d o c u ments/20598/464486/Cikk_KCS_MIG-MAG-eljarasok-ertekelese_Hegesztetechnika-2015_4_-szam. pdf/10cc0d0d-bb94-46eb-a984-7f17a9435d45 2019.11.05.

[12] Réger M., Füredi E., Tóth L: Relationship between the conditions of solidification and the primary microstructure in the case of steels In: Conference on Heat Treating, 1992, 70-73.

[13] Réger M., Tóth L.: A primer dendrittávolság meghatározási lehetőségei. Kohászati Lapok 127/6. (1994) 237-240.

[14] Tóth L.: Examination of the Properties and Structure of Tool Steel En 1.2379 Due to Different Heat Treatments. European Journal Of Materials Science And Engineering 3/3. (2018) 165-170.
[15] Dima A., Tóth L., Minea A: Some aspects of computer-aided planning of the heating process during heat treatment and hot forming. In: Euromat ' 94. Topical Conference, 1994. 1286-1290.

[16] Tóth L., Erdélyi Á.: Programming of Computerized System for In Situ Investigations of transformations in Metal and Alloys. Bulletin of the Polytechnic Institute of Jassy XLII/3-4. (1996) 591-592.

[17] Réti T., Felde I.,Tóth L.: Computer Simulation of Steel Quenching, In: Druga L., Kolozsváry Z., Vermesan G.,; Kocsis Baán M., Bolos V. (szerk.) 12-th National Heat Treating Conference Marosvásárhely, Románia, 1997. 89-95.

[18] Dima A., Tóth L., Badarau Gh., Minea A. A.,Vizureanu P.: Experimental Determination of Optimum Size of the Austenitic Grain by Means of the Heat Treatment Cycles in Laboratory Conditions. Institutul Politehnic Iasi, Buletinul Secția Știința și Ingineria Materialelor 44/1-4. (1998) 125-133. 


\title{
KERÁMIA GÖMBHÉJJAL TÖLTÖTT, ALUMÍNIUMMÁTRIXÚ, BIMODÁLIS FÉMHABOK VIZSGÁLATA
}

\section{INVESTIGATION OF BIMODAL ALUMINIUM MATRIX SYNTACTIC FOAMS FILLED WITH CERAMIC HOLLOW SPHERES}

\author{
Leveles Borbála, ${ }^{1,2, a}$ Kemény Alexandra, ${ }^{1,2, b}$ Orbulov Imre Norbert 1,2,c \\ ${ }^{1}$ Budapesti Műszaki és Gazdaságtudományi Egyetem, Gépészmérnöki Kar, Anyagtudomány és Technológia \\ Tanszék, Budapest, Magyarország \\ ${ }^{2}$ MTA-BME Lendület Kompozit Fémhabok Kutatócsoport, Budapest, Magyarország \\ a borbala.leveles@edu.bme.hu, ${ }^{b}$ alexa@eik.bme.hu, ${ }^{c}$ orbulov@eik.bme.hu
}

\begin{abstract}
In this study bimodal A413 matrix syntactic foams filled with ceramic hollow spheres (CHSs) were produced and examined by computer tomography (CT) and quasi-static mechanical testing to determine the mixing properties of the hollow spheres and the strength of the metal foam. Two hollow spheres of different nominal diameters $\left(\mathrm{d}_{1}=2.4 \mathrm{~mm}\right.$ and $\left.\mathrm{d}_{2}=7.0 \mathrm{~mm}\right)$ were used in equal volume ratio. The produced metal foams have a density of $1.61 \pm 0.03 \mathrm{~g} / \mathrm{cm}^{3}$, with smaller inclusions and some defective hollow spheres in the structure. The foams have an average compressive strength of $120 \mathrm{MPa}$ and a specific mechanical energy absorbing capacity of $43.5 \mathrm{~J} / \mathrm{cm}^{3}$. As a result of the upsetting tests, the matrix material is separated from the CHSs, breaking the connection between them
\end{abstract}

Keywords: bimodal metal foams, mechanical testing, ceramic hollow spheres.

\section{Összefoglalás}

Kutatásunk során A413-mátrixú, kerámia gömbhéjjal töltött, bimodális fémhabok gyártását és makroszerkezeti, valamint kvázi-statikus mechanikai vizsgálatát végeztük el a gömbhéjak keveredésének és a fémhab szilárdságának meghatározása érdekében. A gyártás során két különböző névleges átmérőjü gömbhéjat alkalmaztunk $\left(\mathrm{d}_{1}=2,4 \mathrm{~mm}\right.$ és $\left.\mathrm{d}_{2}=7,0 \mathrm{~mm}\right)$ azonos térfogatarányban. Az így előállított fémhabok sürüsége $1,61 \pm 0,03 \mathrm{~g} / \mathrm{cm}^{3}$, szerkezetében előfordulnak kisebb a zárványok és néhány hibás gömbhéj is. A minák átlagos törőszilárdsága $120 \mathrm{MPa}$, fajlagos energiaelnyelő képessége pedig 43,5 J/cm³. A zömítés hatására a mátrixanyag elválik a gömbhéjaktól, közöttük a kapcsolat több helyen megszűnik.

Kulcsszavak: bimodális fémhabok, mechanikai anyagvizsgálat, kerámia gömbhéjak.

\section{Bevezetés}

A cellás anyagok rendkívül nagy fajlagos szilárdsággal és energiaelnyelő képességgel rendelkeznek kis sűrűségük mellé társuló különleges szerkezetüknek köszönhetően. Éppen ezért napjainkban mesterséges módon is törekszünk az ilyen anyagok létrehozására különböző teherviselő és ütkö- zőelemekben. Fémhabok gyártásával ez a cél megvalósíthatóvá válik [1].

Fémhabokat jellemzően valamilyen könnyüfém alapanyagból készítenek. Elterjedt ezek közül az Al és Mg mátrixanyag, de Fe, Zn és más fémek is sikeresen alkalmazhatók [2-5]. A cellákat a sürüségcsökkentés céljából valamilyen gáz tölti ki, amelyek hatására a kialakuló fémhabok struktúrájuk 
alapján csoportosíthatók nyílt- vagy zártcellás habokra. A szilárdság és a tervezhetőség javítása érdekében gyakran úgynevezett szintaktikus fémhabokat (angolul metal matrix syntactic foams, MMSFs) állítanak elő, amelyek jellemzője, hogy a cellákat valamilyen egyenletes eloszlású és azonos méretű üreges vagy habosított második fázis egyenletes eloszlásban hozza létre. A legelterjedtebb ilyen töltőanyagok a kerámia gömbhéjak, ezek mellett vas gömbhéjakat és alacsony költségü habosított anyagokat is használnak fémhabok előállítására [6-9].

A szintaktikus fémhabok gömb alakú töltőanyagának térkitöltési tényezője véletlenszerü sűrü illeszkedés esetén (angolul random close packing, RCP) $64 \%$. Ennek a tényezónek a növelésével tovább csökkenthető a szerkezet sürüsége. Ezt eltérő méretű töltőanyagok véletlenszerű elrendeződésével értük el. Amennyiben két töltőanyagtípus egyetlen tulajdonságán, mégpedig a méretén kívül mindenben megegyezik, azt bimodálisnak nevezzük. A szintaktikus fémhabok bimodalitását az átmérőbeli eltérés alapján definiáljuk [10].

Tao és munkatársai bimodális kerámia mikrogömbhéjakkal (75-125 $\mu \mathrm{m}$ és 250-500 $\mu \mathrm{m}$ ) töltött, Al6082-mátrixú szintaktikus habokat vizsgáltak. Az általuk gyártott bimodális fémhabok teljes porozitása $10 \%$-kal nagyobb volt, mint a szintaktikus fémhaboké, kezdeti alakváltozásuk pedig 8\%kal volt nagyobb [11].

Orbulov és kutatócsoportja bimodális (150 $\mu \mathrm{m}$ és $1425 \mu \mathrm{m}$ ) Globocer-gömbhéjakkal töltött, AlSi12mátrixú szintaktikus habok nyomótulajdonságait vizsgálták. Kimutatták, hogy a bimodális fémhabok nyomószilárdsága megbízhatóan megbecsülhető a csak kisebb és csak nagyobb gömbhéjat tartalmazó fémhabok tulajdonságaiból keverékszabály alkalmazásával [12].

\section{Eszközök és módszerek}

Kutatásunkban A413-öntészeti alumínium mátrixanyagot alkalmaztunk, amelynek kémiai összetétele szabvány alapján: 11,0-13,0 t\% Si; max. 1,3 t\% Fe; 1,0 t\% Cu; max. 0,5 t\% Ni; 0,35 t\% Mn; max. 0,15 t\% Sn; 0,1 t\% Mg és a maradék Al.

Töltőanyagként nagy tisztaságú $\mathrm{Al}_{2} \mathrm{O}_{3}$-gömbhéjakat alkalmaztunk, amelyek névleges átmérői $\mathrm{d}_{1}=2,4 \mathrm{~mm}$ és $\mathrm{d}_{2}=7,0 \mathrm{~mm}$. A gömbhéjak tulajdonságait részletesen egy korábbi kutatás során részletezte kutatócsoportunk [13].

A bimodális fémhabokat kisnyomásos infiltrálással állítottuk elő. A technológiai változókat az 1. táblázat tartalmazza. A paraméterek a gömbhéjak előhevítési hőmérséklete $\left(\mathrm{T}_{\text {elô }}\right)$ és ideje $\left(\mathrm{t}_{\mathrm{elô}}\right)$,
1. táblázat. Az infiltrálási változók

\begin{tabular}{|c|c|c|c|c|}
\hline $\begin{array}{c}\mathbf{T}_{\text {eló }} \\
\left({ }^{\circ} \mathbf{C}\right)\end{array}$ & $\begin{array}{c}\mathbf{t}_{\text {elö }} \\
(\mathbf{m i n})\end{array}$ & $\begin{array}{c}\mathbf{p}_{\text {inf }} \\
(\mathbf{k P a})\end{array}$ & $\begin{array}{c}\mathbf{t}_{\text {inf }} \\
(\mathbf{s})\end{array}$ & $\mathbf{T}_{\text {mátrix }}$ \\
\hline 500 & 45 & 300 & 5 & 650 \\
\hline
\end{tabular}

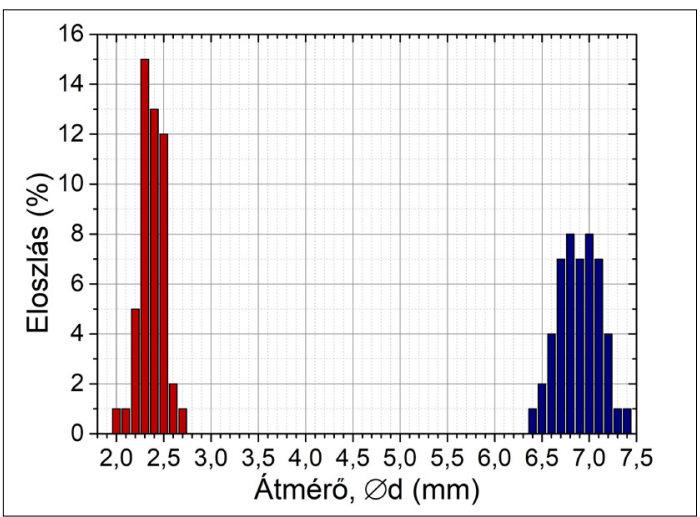

1. ábra. A felhasznált gömbhéjak átmérő szerinti eloszlása azonos térfogatarányban történő felhasználáskor

az infiltrálási nyomás $\left(\mathrm{p}_{\text {inf }}\right)$ és idő $\left(\mathrm{t}_{\text {inf }}\right)$, valamint a mátrix olvadék-hőmérséklete $\left(\mathrm{T}_{\text {mátrix }}\right.$ ). Az alumínium hevítését IND IF-10 indukciós kemencében végeztük. Az infiltráláshoz argongázt alkalmaztunk, amelyet egy szigetelt pipán keresztül vezettünk az olvadékhoz.

Jelen kutatásunk során egyenlő térfogatú kis és nagy gömbhéjakból gyártottunk bimodális fémhabokat. Az elméleti térkitöltés matematikai modell alapján 72,8 \% [10]. Ez két diszkrét átmérőértékre és pontosan gömb alakú elemekre vonatkozik, tehát a számított érték hibával terhelt. A töltőanyag méretbeli eloszlását mutatja az 1. ábra, a két gömbhéj azonos térfogataránya esetén (1:1).

A mérések során meghatároztuk a minták sürűségét, valamint CT-felvételeket készítettünk YXLON Y.CT Modular berendezéssel. A mechanikai tulajdonságok meghatározásához zömítővizsgálatokat végeztünk $5 \mathrm{~mm} /$ perc keresztfejsebességgel egy Instron 5989 univerzális elektromechanikus anyagvizsgáló berendezésen 600 kN-os erőmérő cellával. Az eredményeket az ISO 13314:2011 szabvány alapján értékeltük ki [14].

\section{Eredmények}

A gyártott bimodális fémhabok sűrűsége tömegmérés és geometriai mérések alapján 1,61 $\pm 0,03$ g/cm³ értékre adódtak. Az A413 mátrix- 
anyag sürűségéhez képest $\left(2,66 \mathrm{~g} / \mathrm{cm}^{3}\right)$ ez jelentős csökkenést mutat, azonban fontos megjegyezni, hogy az elméleti térkitöltéssel számolva $1,4 \mathrm{~g} / \mathrm{cm}^{3}$ sürüségértéket kapunk, amelytől valamelyest eltér a valós mért érték. Ennek az oka könnyen belátható, hiszen már a gömbhéjak átmérői sem két diszkrét értéket vesznek fel, körkörösségük pedig átlagban 6-8\%-os hibával terhelt [13].

A számítógépes tomográfiás (angolul computer tomography, CT) felvételek betekintést adnak az anyag belsejébe, a benne előforduló hibákra és anyaghiányosságokra is vizuális visszajelzést adnak (2. ábra). Látható, hogy néhány gömbhéjba alumínium szivárgott be, amely növeli a teljes szerkezet sűrűségét. Továbbá megfigyelhető, hogy az olvadék zsugorodásából adódóan néhány zárvány is megjelenik a mátrixanyagon belül, ezt nem kívánt porozitásnak nevezzük. Az eloszlás számszerüsítéséhez további mérésekre van szükség.

A zömítővizsgálatok során felvett adatokból készített nyomógörbéket mutatja a 3. ábra. A diagramon megfigyelhető a mérési eredmények szórási sávja, illetve a mérési eredmények számtani átlaga szaggatott vonallal. Látható, hogy a kompozitokra jellemző plató jelentősen eltér az Al1050 mátrixanyaggal kapott jellegzetes görbétől mivel nem monoton [7].

A szabvány alapján kiértékelt mérőszámokat tartalmazza a 2. táblázat. A maximális feszültséget (törőszilárdság) és a hozzá tartozó alakváltozást, valamint munkát „c” indexszel jelöltük. A többi feltüntetett érték szabványos jelölésű [14]. zömítővizsgálatok során a fémhabok szétestek, a mátrixanyag és a gömbhéjak kapcsolata a tönkremenetel során megszűnt. Ezt a jelenséget mutatja be a 4. ábra.

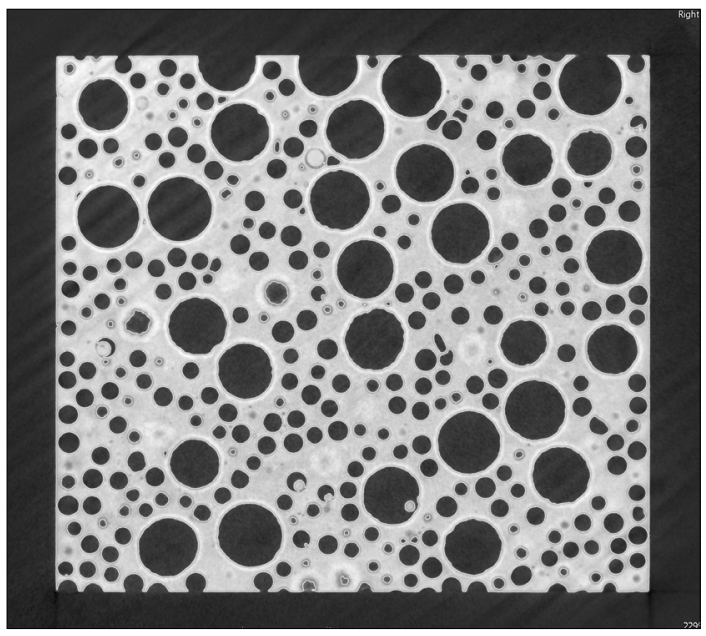

2. ábra. CT-s felvétel egy $2 D$-s szelete
2. táblázat. A zömítővizsgálatok eredményei

\begin{tabular}{|l|c|c|}
\hline Mérőszám & Érték & Szórás \\
\hline$\sigma_{\mathrm{c}}(\mathrm{MPa})$ & 120 & 29 \\
\hline$\varepsilon_{\mathrm{c}}(\%)$ & 5,39 & 0,80 \\
\hline $\mathrm{W}_{\mathrm{c}}\left(\mathrm{J} / \mathrm{cm}^{3}\right)$ & 3,23 & 1,33 \\
\hline$\sigma_{\mathrm{pl}}(\mathrm{MPa})$ & 77 & 18 \\
\hline$\varepsilon_{\mathrm{ple}}(\%)$ & 54,31 & 0,86 \\
\hline $\mathrm{W}\left(\mathrm{J} / \mathrm{cm}^{3}\right)$ & 43,50 & 16,82 \\
\hline $\mathrm{W}_{\mathrm{e}}(\%)$ & 64,22 & 0,96 \\
\hline
\end{tabular}

\section{Következtetések}

Összességében megállapítható, hogy a vizsgált bimodális fémhabok tulajdonságai fontos információt szolgáltatnak a fémhabok tudományterületének. Kutatásunk során a következő megfigyeléseket tettük:

- a térkitöltés elméleti modellezése hibával terhelt a valódi anyag tökéletlenségei miatt;

- a gyártott bimodális fémhabok átlagosan

$1,62 \mathrm{~g} / \mathrm{cm}^{3}$ sürüséggel rendelkeznek;

-a vizsgált minták törőszilárdsága átlagosan

$120 \mathrm{MPa}$, platófeszültsége $77 \mathrm{MPa}$;

- az elnyelt fajlagos törési munka 43,50 J/ $\mathrm{cm}^{3}$;

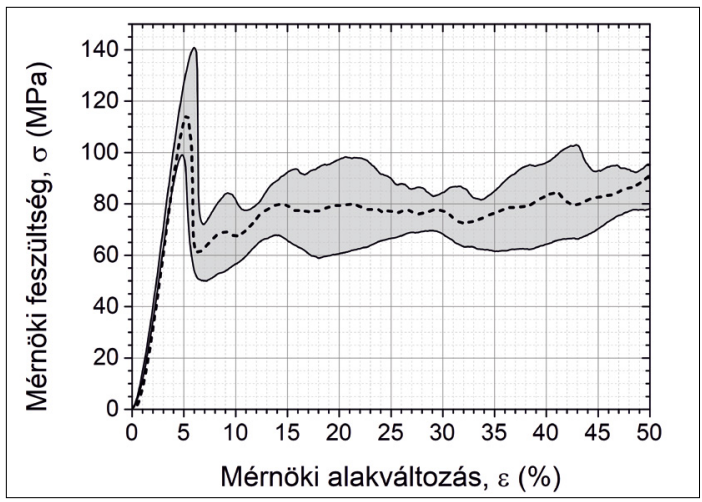

3. ábra. A mérési eredmények szórási sávja, jelölve a számtani átlagot

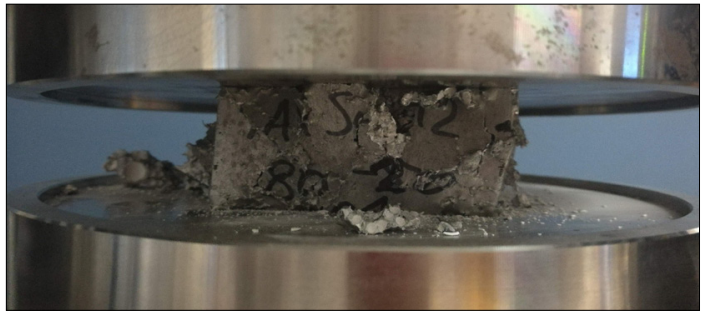

4. ábra. A vizsgált fémhabok tönkremenetele zömítés során 
- a zömítővizsgálatok eredményei jelentős szórást mutatnak. Ennek oka a fémhabok egyediségében keresendő a véletlenszerü sűrü illeszkedés miatt. Pontosabb eredményekhez további mérésekre van szükség;

- a fémhabok zömítés során szétesnek, a mátrix anyag kapcsolata a gömbhéjakkal megszűnik.

\section{Köszönetnyilvánítás}

A publikáció az Innovációs és Technológiai Minisztérium NTP-SZKOLL-19-006 kódszámú Nemzeti Tehetség Program pályázatának támogatásával valósult meg. A kutatás publikálásában anyagi segítséget nyújtott a Gépészmérnökképzésért Alapítvány.

\section{Szakirodalmi hivatkozások}

[1] Gupta N., Rohatgi P. K.: 4.15 Metal Matrix Syntactic Foams. In: Comprehensive Composite Materials II. Elsevier, Oxford, 2018. 364-385. doi.org/10.1016/B978-0-12-803581-8.09971-9

[2] Orbulov I.N., Szlancsik A.: On the Mechanical Properties of Aluminum Matrix Syntactic Foams. Advanced Engineering Materials, 20/5. (2018) 1-12.

doi.org/10.1002/adem.201700980

[3] Anbuchezhiyan G., Muthuramalingam T., Mohan B.: Effect of Process Parameters on Mechanical Properties of Hollow Glass Microsphere Reinforced Magnesium Alloy Syntactic Foams Under Vacuum Die Casting. Archives of Civil and Mechanical Engineering, 18/4. (2018) 1645-1650. doi.org/10.1016/j.acme.2018.07.008

[4] Park H., Hong K., Kang J. S., Um T., Knapek M., Minárik P., Sung Y. E., Máthis K., Yamamoto A., Kim H. K., Choe H.: Acoustic Emission Analysis of the Compressive Deformation of Iron Foams and their Biocompatibility Study. Materials Science and Engineering: C, 97. (2019) 367-376. doi.org/10.1016/j.msec.2018.12.035

[5] Linul E., Lell D., Movahedi N., Codrean C., Fiedler T.: Compressive Properties of Zinc Syntactic Foams at Elevated Temperatures. Composites Part B: Engineering, 167. (2019) 122-134.

\section{doi.org/10.1016/j.compositesb.2018.12.019}

[6] Orbulov I. N.: Metal Matrix Syntactic Foams Produced by Pressure Infiltration - The effect of Infiltration Parameters. Materials Science and Engineering: A, 583. (2013) 11-19.

doi.org/10.1016/j.msea.2013.06.066

[7] Szlancsik A., Katona B., Májlinger K., Orbulov I. N.: Compressive Behavior and Microstructural Characteristics of Iron Hollow Sphere Filled Aluminum Matrix Syntactic Foams. Materials 8/11. (2015) 7926-7937.

doi.org/10.3390/ma8115432

[8] Szlancsik A., Katona B., Kemény A., Károly D.: On the Filler Materials of Metal Matrix Syntactic foams. Materials 12/12. (2019) 2023. doi.org/10.3390/ma12122023

[9] Taherishargh M., Katona B., Fiedler T., Orbulov I. N.: Fatigue Properties of Expanded Perlite/Aluminum Syntactic Foams. Journal of Composite Materials, 51/6. (2017) 773-781.

doi.org/10.1177/0021998316654305

[10] Brouwers H. J. H.: Random Packing Fraction of Bimodal Spheres: An Analytical Expression. Physical Review E, 87. (2013) 1-8.

doi.org/10.1103/PhysRevE.87.032202

[11] Tao X. F., Zhang L. P., Zhao Y. Y.: Al Matrix Syntactic Foam Fabricated with Bimodal Ceramic Microspheres. Materials \& Design, 30/7. (2009) 2732-2736. doi.org/10.1016/j.matdes.2008.11.005

[12] Orbulov I. N., Kemény A., Filep Á., Gácsi Z.: Compressive Characteristics of Bimodal Aluminium Matrix Syntactic Foams. Composites Part A: Applied Science and Manufacturing, 124. (2019) 105479.

doi.org/10.1016/j.compositesa.2019.105479

[13] Kemény A., Károly D.: Mechanical and Microstructural Features of Ceramic Hollow Spheres. Acta Materialia Transylvanica 2/1. (2019) 27-31. doi.org/10.33924/amt-2019-01-05

[14] ISO 13314:2011 Mechanical testing of metals Ductility testing - Compression test for porous and cellular materials. 


\title{
SZÜRKEVIZEK HATÉKONY KEZELÉSÉT TÁMOGATÓ DETERGENS- ÉS FÉMANALITIKAI VIZSGÁLATOK
}

\section{INVESTIGATIONS OF DETERGENTS AND METAL COMPONENTS FOR SUPPORTING THE EFFECTIVE TREATMENT OF GREYWATER}

\author{
Lós Réka ${ }^{1}$, Izbékiné Szabolcsik Andrea ${ }^{2}$, Bodnár Ildikó ${ }^{3}$ \\ Debreceni Egyetem, Müszaki Kar, Környezetmérnöki Tanszék, Debrecen, Magyarország \\ ${ }^{1}$ losrekaaa@gmail.com \\ ${ }^{2}$ szabolcsikandi@eng.unideb.hu \\ ${ }^{3}$ bodnari@eng.unideb.hu
}

\begin{abstract}
The aim of our research was to investigate the detergent content and several micro and macro elements in greywater samples, a necessary step in determining the water quality for the further reuse of the greywater. We determined the anionic detergent content of synthetic greywater with a two-phased titration method prepared in laboratory conditions. The current study leads to a new suggestion for a more accurate and reliable titrimetric method for determination of anionic detergent content of synthetic greywater samples. Following these investigations, we also examined the metal content of synthetic bath water. We wanted to highlight how detergents in greywater influence the micro and macro element content of the given synthetic bath water samples.
\end{abstract}

Keywords: greywater, detergents, micro and macro elements.

\section{Összefoglalás}

Kutatásunk célja a szürkevizekben található detergenstartalom és számos mikro- és makroelem vizsgálata, melyek meghatározása a szürkevizekben további újrahasználat miatt szükségszerü. Laboratóriumi körülmények között előállított szintetikus fürdővizek anionaktívdetergens-tartalmát vizsgáltuk kétfázisú titrimetriás módszerrel. A korábbi módszerfejlesztéseinken túl jelen tanulmányban további fejlesztéseket javaslunk a módszer pontosabb és megbízhatóbb használata érdekében. Ezen vizsgálatainkat követően a szintetikus fürdővizek fémtartalmát is vizsgáltuk, a vizsgálatok során arra szerettünk volna rávilágítani, hogy a detergensek milyen mértékben befolyásolják az adott szintetikus fürdővíz mikro- és makroelem-tartalmát.

Kulcsszavak: szürkevizek, detergens, mikro- és makro elemek.

\section{Bevezető}

Vizeink mennyiségének csökkenése, illetve az egyre növekvő vízigények jelentős problémákat okozhatnak a megfelelő minőségű víz biztosításában. Ezért alternatívákat kell kidolgoznunk, hogy csökkentsük a nagymértékű vízhasználatot. Egy lehetséges alternatíva, ha a háztartásokban például WC-öblítésre, öntözésre vagy autómosás- ra szürkevizet használunk ivóvíz helyett [1, 2]. Szürkevizeknek tekinthetők a háztartásokban mosogatás, mosás, kézmosás, fürdés során keletkező szennyvizek, melyekhez nem soroljuk a vízöblítéses WC-k vizeit [1, 2]. A szürkevizekben nagy mennyiségű felületaktív anyag található, amelyet felhasználás vagy vízbázisokba történő kijuttatás előtt szükségszerű eltávolítani, ugyan- 
is ezek az anyagok habréteget képezhetnek a víz felszínén, ezzel csökkentve a vízben oldott oxigén mennyiségét és az öntisztulási folyamatokat. Emulgeáló hatásukból adódóan gátolják az oldhatatlan szennyezők kiülepedését, így költségesebbé teszik az ivóvíz előállítását felszíni vizekből [2]. A detergenseket kémiai szerkezetük szerint 4 csoportba sorolhatjuk, eszerint megkülönböztetünk anionaktív, kationaktív, nemionos és amfoter detergenseket [3, 4]. A detergensek antropogén eredetű környezetbe jutása káros lehet, mivel meggátolják az oxigén diffúzióját a vizekben, illetve algavirágzást okozhatnak [2]. Zavarják a szennyvíztisztítást, az ivóvíztisztítást, rontják a felszíni víz öntisztulásának a hatásfokát. A szintetikus fürdővizek változatos összetételűek, ez a különbözőség a víz fémtartalmára is jellemző. A detergensek jelenléte mellett számolnunk kell a használt vizek mikro- és makroelem-tartalmának növekedésével, mivel nagy koncentrációban találhatóak nyomelemek és nehézfémek is ezen frakciókban, melyek újrahasználat esetén jelentős terhelést gyakorolhatnak az ökoszisztémára [1, 5, 6]. Vizsgálataink során a szürkevizekben található különböző makro- és mikroelem-koncentrációkat is vizsgáltuk, hogy megállapíthassuk, a szürkevizekben található detergensek hogyan befolyásolják ezen elemek koncentrációit.

\section{Anyag és módszer}

A Környezetmérnöki Tanszéken évek óta folyó kutatások során adekvát mérésekkel is sikerült bebizonyítani, hogy a szürkevizek minősége (öszszetétele) nagyon változó. Ezért kidolgoztak egy szintetikus szürkevízreceptet, mely jól reprezentálja a régióban keletkező átlagos fürdővízmintákat. Az így fejlesztett állandó összetételű szintetikus szürkevízzel többek között a detergenstartalom meghatározására szolgáló módszerfejlesztési kísérleteink eredményei is jól összehasonlíthatók egymással. Kutatásunk célja a szürkevizek detergenstartalmának meghatározására szolgáló módszer alkalmazhatóságának vizsgálata, fejlesztése volt, mely segítségével olyan egyedi módszert dolgozzunk ki, mellyel a szürkevizek detergenstartalma gyorsabban, pontosabban és kevésbé környezetszennyező eljárással mérhető legyen egy egyszerű titrimetriás vizsgálat segítségével. A vizsgálatok alkalmával csak az anionaktív detergensek (röviden ANA-tartalom) meghatározását tűztük ki célul, melyeket az ISO 2271:1989 nemzetközi szabvány segítségével végeztünk el. Vizsgálataink során 5 méréssorozat eredményeit

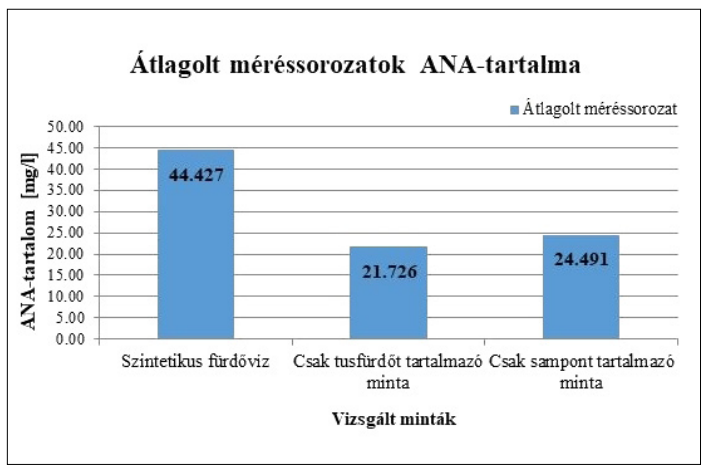

1. ábra. Szintetikus fürdővíz minták anionaktív detergenstartalma

átlagoltuk. Detergenstartalom meghatározására 3 vízmintát készítettünk, elsőként a laboratóriumilag előállított fürdővizet vizsgáltuk, melynek ANA-tartalma $44,427 \pm 1,59 \mathrm{mg} / \mathrm{L}$, a csak tusfürdőt tartalmazó vízminta esetén az ANA-tartalom $21,726 \pm 0,39 \mathrm{mg} / \mathrm{L}$, a csak sampont tartalmazó vízminta ANA-tartalma 24,491 22,00 mg/L-nek adódott, melyet az 1 . ábra szemléltet.

Megállapítottuk, hogy a csak tusfürdőt és csak sampont tartalmazó minták ANA-értékeit összeadva megközelítőleg megkaptuk a szintetikus fürdővíz ANA-tartalmát, ami azt mutatja meg, hogy a háztartásokban főként a kozmetikai szerekből, tusfürdőkből és samponokból származik a fürdővíz ilyen jellegű detergenstartalma. Fémanalitikai mérések során mikrohullámúplazmaatom-emiszsziós spektrometriát, röviden MP-AES mérőmüszert használtunk, mely méréseket a Debreceni Egyetem Szervetlen és Analitikai Kémiai Tanszékén található Agilent 4210 MP-AES-készülékkel végezhettünk el. Ezen méréstechnika alkalmazása során az elemeket egymást követően tudjuk mérni [7]. A készülékben az elemek mérése egy mintából egymás után történik, hullámhossz szerint növekvő sorrendben. A nagyszámú hullámhossz-adatbázis lehetővé teszi a megfelelő hullámhossz kiválasztását, ezzel minimalizálva a spektrális zavaró hatásokat.

\section{Eredmények és értékelésük}

Kutatásunk során vizsgáltuk a szintetikusan előállított fürdővizek mikro- és makroelem-tartalmát. Célunk az volt, hogy megvizsgáljuk a detergensek milyen mértékben változtatják meg az adott elemek koncentrációértékeit. A mérések alkalmával kontrollként a minták készítéséhez használt ivóvíz mikro- és makroelem-tartalmát is mértük, ugyanis a későbbiekben ezen eredmé- 
nyeket is összehasonlítottuk a szintetikus fürdővízmintákra kapott eredményeinkkel.

A 2. ábra a bárium-, réz-, stroncium- és cinktartalmat szemlélteti.

A 3. ábrán az az alumínium-, kadmium-, krómés vastartalmak láthatóak.

A lítium, mangán, nikkel és ólom-koncentrációkra vonatkozó adatokat pedig a 4. ábra mutatja

Mikroelemek vizsgálatai során megállapíthatjuk, hogy a réz-, cink- és nikkelelemek koncentrációemelkedéséért jelentős mértékben felelősek a detergensek. Ólom esetén azt tapasztaltuk, hogy a detergensek mellett a szintetikus fürdővízhez szükséges egyéb alkotók is befolyásolják ezen mikroelem-koncentráció növekedését. A vas, alumínium és lítium mikroelemek esetében elmondhatjuk, hogy a szintetikus fürdővíz egyéb alkotói okozhatják a koncentrációváltozásokat. Stroncium-, bárium-, kadmium- és mangántartalom már jellemzően az ivóvízmintákban is megtalálható, tehát ezen elemek mennyiségét nem befolyásolja a detergensek jelenléte. A krómtartalomra vonatkozó vizsgálatok minden esetben méréshatár alatti elemtartalmat jeleztek, vagyis a minták krómtartalma 0,1 $\mu \mathrm{g} / \mathrm{L}$ alatti értéknek adódtak, mivel az alkalmazott készülék kimutatási határa krómra vonatkozóan 0,1 $\mu \mathrm{g} / \mathrm{L}$ volt. Az 5. ábrán láthatók a vizsgált makroelem-tartalmak (kálcium, kálium, magnézium és nátrium).

Makroelemek vizsgálata során megállapíthattuk, hogy a vártnak megfelelően a kalcium és magnézium jelenléte már az ivóvízben is jelentős, azaz ezeknek az elemeknek a jelenlétét nem a detergensek okozzák, hanem az ivóvíz keménységéből származnak. A megemelkedett kálium- és nátriumkoncentrációk kapcsán elmondhatjuk, hogy a fürdővizekben található detergensek befolyásolják ezen elemek mennyiségét. Mindezek alapján az elemkoncentrációk alakulásáért is nagymértékben felelősek lehetnek a detergensek, melyek változatos tisztító-, mosó- vagy kozmetikai szerek használata miatt jutnak a szürkevizekbe.

\section{4. Összefoglalás}

Vizsgálataink során a detergenstartalom meghatározását tűztük ki célul az ISO 2272: 1989-es nemzetközi szabvány segítségével. A szintetikus fürdővíz ANA-tartalmát megállapítva azt tapasztaltuk, hogy a csak tusfürdőt és csak sampont tartalmazó ANA-értékeket összeadva megközelítőleg megkaptuk a szintetikus fürdővíz ANA-tartalmát. Megállapítottuk, hogy a háztartásokban főként a kozmetikai szerekből, tusfürdőkből és sampo-

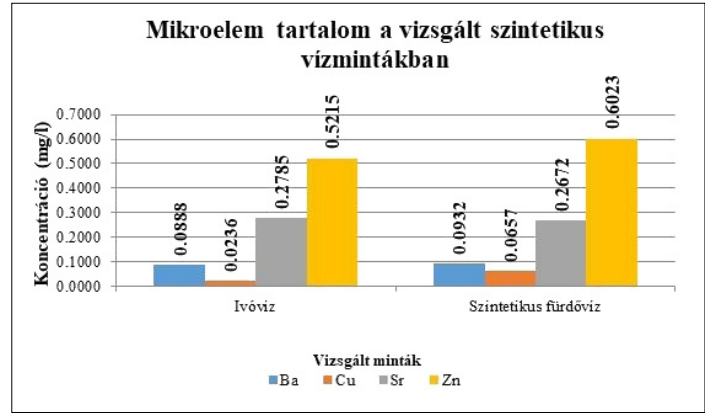

2. ábra. Vizsgált vízminták bárium-, réz-, stronciumés cinktartalma

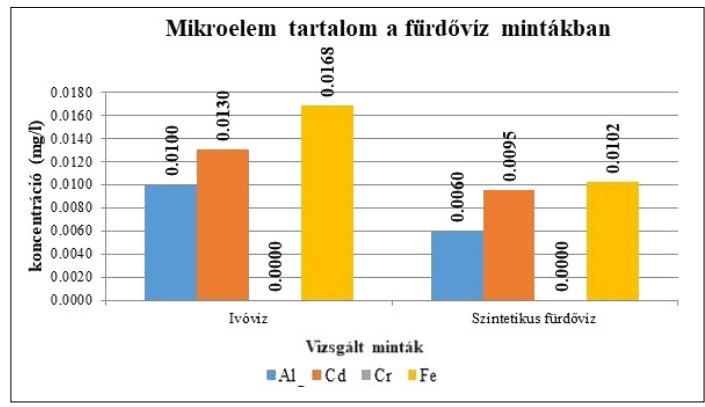

3. ábra. Alumínium-, kadmium-, króm-, vastartalom a szintetikus fürdővízmintákban

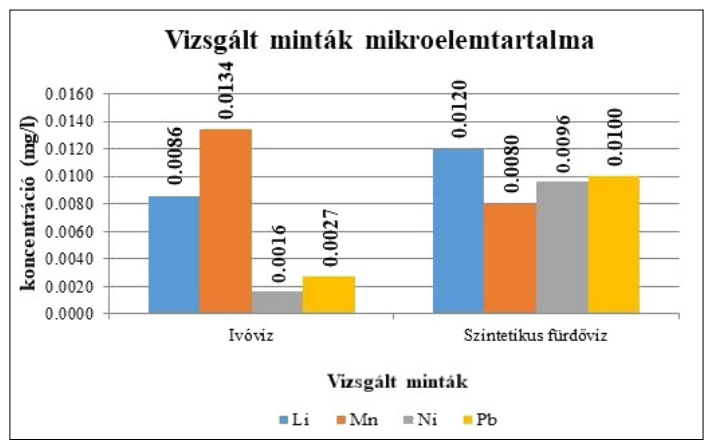

4. ábra. Lítium-, mangán-, nikkel- és ólomtartalom a vizsgált fürdővízmintákban

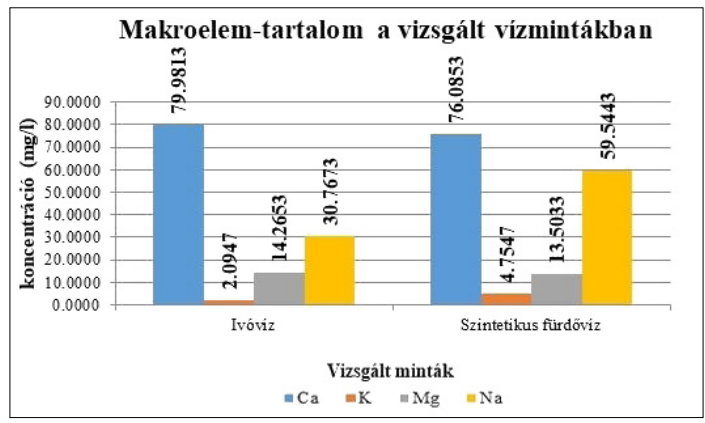

5. ábra. Makroelem-tartalom a szintetikus fürdővízmintákban 
nokból származik a fürdővíz detergenstartalma. Mikroelemek esetén a cink-, réz-, nikkel- és ólomelemek koncentrációiban okozott a detergensjelenlét elemkoncentráció-növekedést. Cink esetében teljes mértékben, réznél kb. 80\%-ban, míg nikkel és ólom esetén kb. 30\%-ban okozták a detergensek az elemnövekedéseket. Makroelemek vizsgálata során a nátrium- és káliumelemek koncentrációi változtak a detergenshasználattal. Nátriumtartalom alapján 30\%-ban, kálium esetén 60\%-ban a detergensek felelősek a megnövekedett elemkoncentrációkért.

\section{Szakirodalmi hivatkozások}

[1] Ghaitidak D. M., Yadav K. D.: Characteristics and treatment of greywater. A review. Environmental Science and Pollution Research, 20/5. (2013) 2795-2809.

[2] Lós R., Izbékiné Szabolcsik A., Bodnár I.: Szürkevizek detergens tartalmának meghatározására alkalmas analitikai módszerek fejlesztése. International Journal of Engineering and Management Sciences (IJEMS), 3/2. (2018).
[3] Juhász É, Lelkesné Erős M.: Felületaktív anyagok zsebkönyve. Müszaki Könyvkiadó, 1979.

[4] Ketola A.: Determination of surfactants in industrial waters of paper-and board mills. (2016). DOI: 10.13140/RG.2.2.36735.41124

[5] Bodnar I., Szabolcsik A., Baranyai E., Uveges A., Boros N.: Qualitative characterization of household greywater in the Northern great plain region of Hungary. Environmental Engineering and Management Journal, 13/11. (2014) 2717-2724.

[6] Bodnár I., Boros N., Baranyai E., Fórián S., Izbékiné Szabolcsik A., Jolánkái G., Keczánné Üveges A., Kocsis D.: Épületek csapadékvizeinek és szürkevizeinek vizsgálata az Észak-Alföld régióban környezetbarát és energiahatékony hasznosítás céljából. In: F. Kálmár (szerk.) Fenntartható energetika megújuló energiaforrások optimalizált integrálásával, Akadémiai Kiadó, 2014, 167-201.

[7] Baranyai. E.: Mikrohullámú plazma atomemissziós spektrometria, Debreceni Egyetem, Szervetlen és Analitikai Kémiai Tanszék, 2015. 


\title{
A GYÁRTÁS KÖZBEN ALKALMAZOTT HƯTÉS HATÁSA HŐÁLLÓ PLA-ALAPANYAGRA
}

\section{THE IMPACT OF ACTIVE COOLING ON HEAT RESISTANT PLA}

\author{
Lukács Norbert László, ${ }^{1}$ Ficzere Péter, ${ }^{2}$ Szebényi Gábor ${ }^{3}$ \\ Budapesti Müszaki és Gazdaságtudományi Egyetem, Budapest, Magyarország \\ ${ }^{1}$ lukacsnorbert98@gmail.com \\ 2ficzere@kge.bme.hu \\ ${ }^{3}$ szebenyi@pt.bme.hu
}

\begin{abstract}
In this study the properties of HT-PLA were determined with tensile tests. The influence of cooling was determined and influence of manufacturing environment shown to be predictable. Heat resistant 3D printing materials can be widely used in the manufacturing process but these materials are relatively expensive. HTPLA is one of the cheapest materials with these parameters.
\end{abstract}

Keywords: FDM, high temperature PLA, additive manufacturing, 3D printing, cooling.

\section{Összefoglalás}

Ezen tanulmányban a HT-PLA fantázianevű hőálló PLA-anyag tulajdonságait vizsgáltuk hagyományos szakítóvizsgálattal. A vizsgálat segítségével megismertük a tárgyhűtés hatását az alkatrész tulajdonságaira, és következtetéseket tudtunk levonni a környezet hatásáról a munkadarabra. A hőálló filamentek széles körben használhatóak a gyártási folyamatok során, azonban gyakran nagyon magas ár jellemzi őket. A HT-PLA az egyik legolcsóbb olyan anyag, amely elméletileg akár $100^{\circ} \mathrm{C}$ elviselésére is képes.

Kulcsszavak: FDM, additív gyártástechnológiák, 3D nyomtatás, hőálló alapanyagok, hütés.

\section{Bevezető}

Az FDM-technológia terjedésével a felhasználási területek is változnak, egyre több ilyen módon gyártott alkatrész kerül közvetlen felhasználásra [1]. Mára már számtalan típusú alapanyag áll rendelkezésünkre, van köztük hőálló, flexibilis, UV-álló is. Az alapanyagok egy új fajtája a hőkezelhető filamentek csoportja, mely könnyebbé teszi a gyártást és számunkra megfelelő anyagtulajdonságokat biztosít, azonban az utólagos hőkezelés egyéb várható kellemetlenségeket okozhat, köztük a vetemedést, illetve méretváltozást is. Ebben a tanulmányban a gyártás során alkalmazott hütés hatását tárgyaljuk, azonban a jövőben a hőkezelés hatásait is vizsgáljuk.

\section{Módszer}

„A HT-001-ből nyomtatott alkatrészek eleve a hagyományos PLA-nál magasabb hőállósággal rendelkeznek (65-70 ${ }^{\circ} \mathrm{C}$ HDT érték E2092 szabvány szerint). Ezt az értéket könnyen $100^{\circ} \mathrm{C}$ fölé növelhetjük egy rövid hőkezelés elvégzésével:

A kinyomtatott tárgyat helyezzük előmelegített kemencébe (sütőbe) 20 perc időtartamra, 80-100 ${ }^{\circ} \mathrm{C}$-os hőmérséklet mellett, majd óvatosan hagyjuk lehülni. A polimerszerkezet az eljárás során kristályrácsba rendeződik, mely magasabb hőállóságot és szilárdságot eredményez [2].”

A gyártáshoz egy CrealityEnder 3 nyomtatót használtunk fel, mely egy egyszerü, kereskedel- 
mi forgalomban kapható, bárki számára elérhető áru FDM (FFF) 3D-nyomtató.

A próbatesteket fekvő, valamint álló helyzetben is kinyomtattuk hütés alkalmazásával, majd anélkül is (1. ábra). A gyártási paraméterek:

$-215^{\circ} \mathrm{C}$-os fej-, illetve $60{ }^{\circ} \mathrm{C}-$ os asztalhőmérséklet; $-40 \mathrm{~mm} / \mathrm{s}-$ os sebesség;

-100\%-os belső kitöltöttség;

- a rétegvastagság $0,2 \mathrm{~mm}$.

Ezeket az adatokat több korábbi tanulmány is a legmegfelelőbb általános paramétereknek jelölte meg PLA-nyomtatás során [3, 4, 5]. A próbatestek szakítóvizsgálata a BME Polimertechnika tanszék Zwick Z005-ös berendezésén történt (2. ábra).

Minden esetben 5-5 szabványos próbatestet vizsgáltunk. A szakítási sebesség szabvány szerint $5 \mathrm{~mm} / \mathrm{s}$ volt (3. ábra).

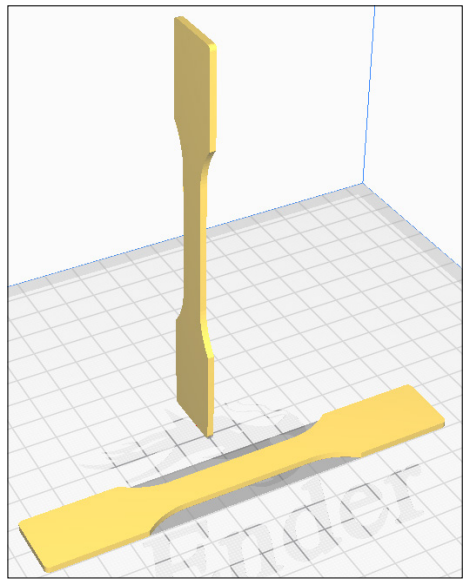

1. ábra. Szabványos próbatestek

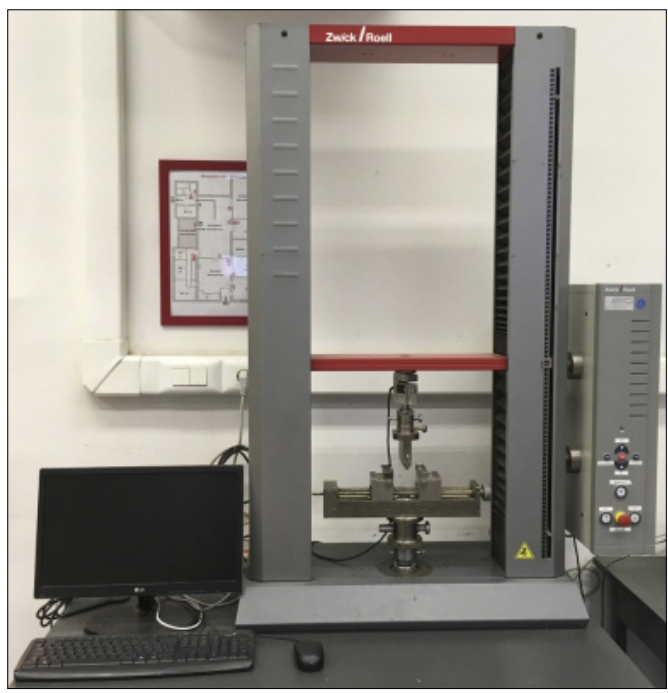

2. ábra. Zwick Z005 mérőberendezés

\section{Eredmények}

A fekvő helyzetben nyomtatott próbatestek szakítóvizsgálatainak eredményeit a következő diagramok szemléltetik. Mint látható, a hűtés nélkül gyártott próbatestek szakítószilárdsága átlagosan körülbelül $45 \mathrm{MPa}$ (4. ábra) volt, ami jelentősen eltér a gyártó által megadott $66 \mathrm{MPa}$ értéktől. Ez önmagában adódhat a nyomtatás során alkalmazott kitöltés irányából [6], valamint a nem megfelelő szálak közti tapadásból [4]. A gyártó nem ad meg irányfüggést.

Az aktív hűtéssel gyártott próbatestek szakítószilárdsága jelentősen csökkent a hűtés nélkül gyártott próbatestekéhez képest (5. ábra). Mint látható, a szakítószilárdságuk nem sokkal nőtt 35 MPa fölé.

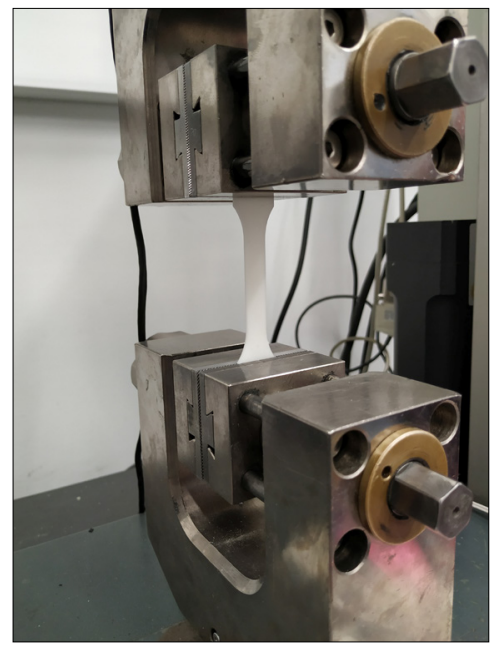

3. ábra. Próbatestek vizsgálata

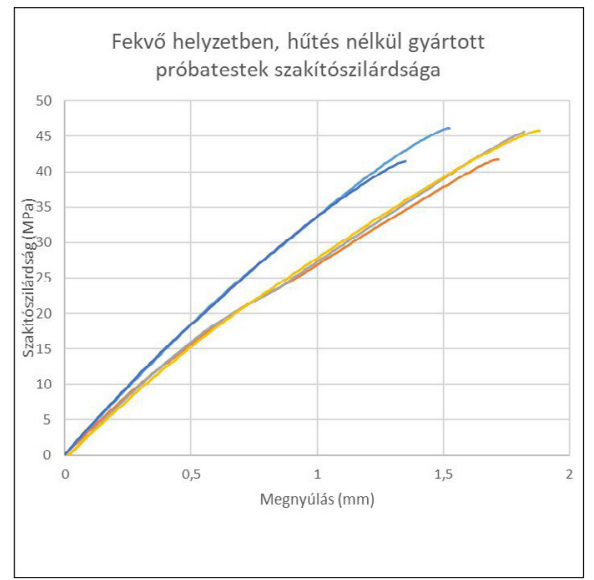

4. ábra. Fekvő helyzetben, hütés nélkül gyártott próbatestek szakítószilárdsága 


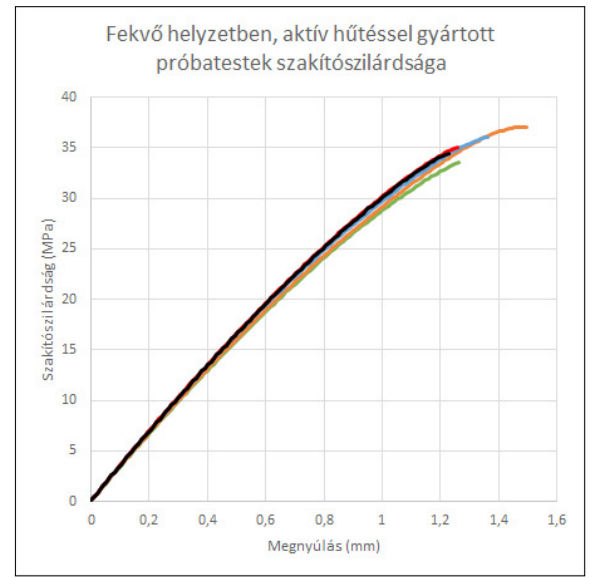

5. ábra. Fekvő helyzetben, aktív hütéssel gyártott próbatestek szakítószilárdsága

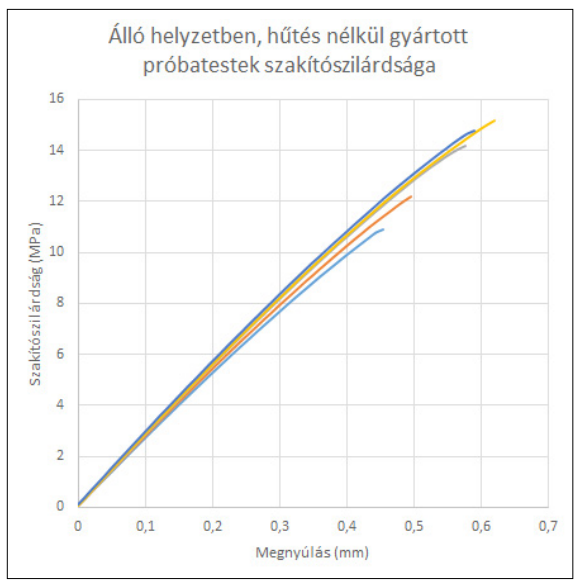

6. ábra. Álló helyzetben, hütés nélkül gyártott próbatestek szakítószilárdsága

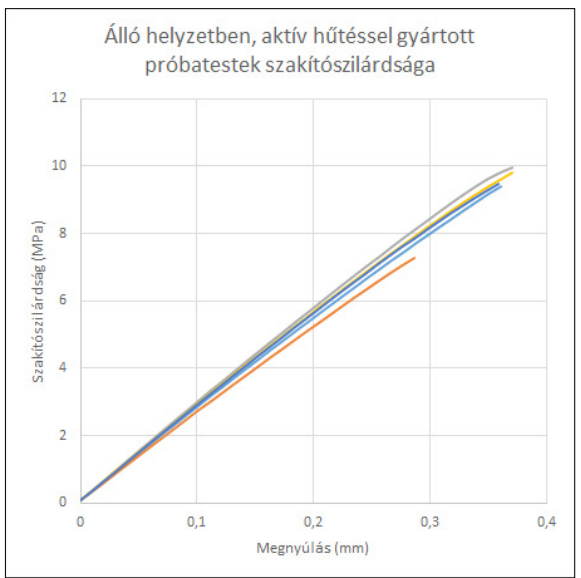

7. ábra. Álló helyzetben, aktív hütéssel gyártott próbatestek szakítószilárdsága
A hűtés alkalmazása sok esetben elengedhetetlen az FDM-nyomtatás során, különösen a nagy túllógásokkal tűzdelt alkatrészek esetében, ahol szükséges az anyag mielőbbi megszilárdulása a megfelelő felületminőség eléréséhez.

Az álló helyzetben gyártott próbatestek mechanikai tulajdonságai nem érték el a korábbi eredmények alapján várt értékeket [7], azonban az aktív hűtés nélkül gyártott próbatestek ebben az esetben is jobb tulajdonságokat mutattak.

Az aktív hütéssel gyártott, állított próbatestek szakítódiagramjai a 7. ábrán figyelhetők meg.

Az eredmények táblázatos formában:

1. táblázat. A próbatestek átlagos szakítószilárdságai

\begin{tabular}{|l|c|}
\hline \multicolumn{1}{|c|}{ Próbatest típusa } & $\begin{array}{c}\text { Átlagos szakítószilárdsága } \\
\text { (MPa) }\end{array}$ \\
\hline Fekvő, hűtéssel & 35,21 \\
\hline Fekvő, hűtés nélkül & 44,23 \\
\hline Álló, hűtéssel & 9,18 \\
\hline Álló, hűtés nélkül & 13,44 \\
\hline
\end{tabular}

\section{Következtetések}

A vizsgálatok alapján elmondható, hogy a hütés hatására jelentősen csökkent a próbatestek szakítószilárdsága - az átlagos 44 MPa-ról körülbelül 35 MPa-ra, ami körülbelül 20\%-os csökkenést jelent - így az FDM-technológiával előállítani kívánt alkatrészeket ajánlott úgy megtervezni, hogy azok ne igényeljenek hűtést. Ezt a jelenséget magyarázhatja az, hogy hűtés hatására a fúvóká-

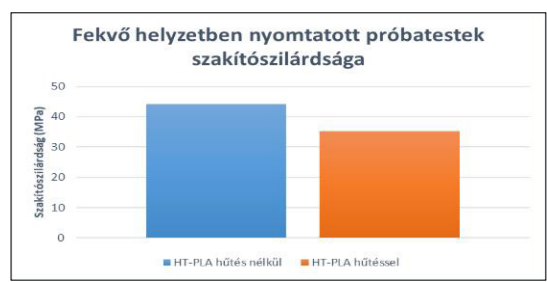

8. ábra. A fekvő helyzetben gyártott próbatestek összehasonlítása

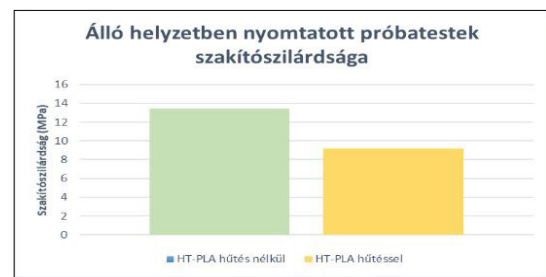

9. ábra. Az álló helyzetben gyártott próbatestek összehasonlítása 
ból kiáramló anyag már azelőtt elkezd megszilárdulni, hogy összeolvadna az előző rétegekkel (8. ábra).

Az álló próbatestek esetében ez az arány tovább romlott, itt már körülbelül 30\%-ra tehető a különbség a hütve, illetve a hütés nélkül gyártott darabok esetében (9. ábra).

\section{5. Összefoglalás}

A kapott eredmények alapján könnyen megállapíthatjuk a tárgyhütés negatív hatását az FDM-technológiával gyártott alkatrészek mechanikai tulajdonságaira. Az eredmények ismeretében fontos az így készítendő tárgyakat, alkatrészeket úgy tervezni, hogy azok ne igényeljenek hűtést a nyomtatás során. A jövőbeni felhasználás előtt a hőkezelés anyagra gyakorolt hatásait, valamint az alkatrész formai követelményeire gyakorolt hatásait is szükséges megvizsgálni.

\section{Köszönetnyilvánítás}

Ez a tanulmány nem jöhetett volna létre Dr. Török Ádám közreműködése nélkül. Köszönjük a munkáját!

\section{Szakirodalmi hivatkozások}

[1] Gerendás P., Károly D., Pammer D., Kiss R. M.: Egyedi kézrögzítő fejlesztés és gyártása $3 D$ nyomtatással. Biomechanica Hungarica XI/2., 23-30.

[2] 3DEE Store Budapest (letöltve: 2020.01.28.) https://3dee.hu/termek/ht-pla-001/

[3] Lukács N. L., Ficzere P., Temesi T.: Gyártási paraméterektől függö rétegközi hibák vizsgálata $C A D$ szoftverekkel. GÉP, LXX/3, 54-57.

[4] Ogjan L. et all.: Impact of processing parameters on tensile stength in-process crysallinity and mesostructure in FDM-fabricated PLA specimens. Rapid Prototyping Journal 25/8. (2019) 1398-1410

[5] Ficzere P., Lukács N. L.: Evaluation opportunities of SEM pictures by CAD software. Design of Machines And Structures 9/2. (2019) 20-24.

[6] K. Álvarez C., Lagos R. F., Aizpun M. : Investigating the influence of infill percentage on the mechanical properties of fused deposition modelled ABS parts. Ingeniería e Investigación 36/3. (2016) 110-116. https://doi.org/10.15446/ing.investig.v36n3.56610

[7] Ficzere P., Borbas L., Falk Gy., Szebenyi G.: Experimental determination of material model of machine parts produced by Selective laser sintering (SLS) technology. Materials Today: Proceedings, 5/13. Part 2, (2018) 26489-26494. https://doi.org/10.1016/j.matpr.2018.08.104. 


\title{
LÉZERES FELMÉRŐESZKÖZ ÉS FELMÉRÉSI MÓDSZERTAN KÖZVETLEN ÉPÍTÉSZETI TERVEZŐSZOFTVER- KAPCSOLATTAL
}

\section{LASER SURVEY TOOL AND SURVEY METHODOLOGY FOR DIRECT ARCHITECTURAL CAD SOFTWARE CONNECTION}

\author{
Máder Patrik Márk, ${ }^{1}$ Szilágyi Dorottya, ${ }^{2}$ Rák Olivér, ${ }^{3}$ Háber István Ervin ${ }^{4}$ \\ Pécsi Tudományegyetem Müszaki és Informatikai Kar, Pécs, Magyarország \\ ${ }^{1}$ patrik.mader@mik.pte.hu \\ 2szdo95@gmail.com \\ ${ }^{3}$ rakoliver90@gmail.com \\ ${ }^{4}$ ihaber@mik.pte.hu
}

\begin{abstract}
Building Information Modeling (BIM) has been the fastest growing methodology in architectural design, construction, preliminary works and in several other engineering activities in the past few years. It is mostly implemented in the fields of design, construction and building operation, however, there are still unexploited possibilities in further areas - such as building surveys. Many tools are available today to produce detailed and accurate 3D survey data, but specialists and custom software usually have to be involved in the process. Transforming this information into BIM models is also a time-consuming task, as their direct architectural design software integration is limited. The following article introduces a possible solution in order to improve communication and the modeling process.
\end{abstract}

Keywords: building survey, algorithm, building information modeling, 3D printing.

\section{Összefoglalás}

Az épületinformációs modellezés (BIM) az építészeti tervezés, kivitelezés, műszaki előkészítés és egyéb mérnöki tevékenységek esetén is az elmúlt évek legnagyobb ütemben fejlődő módszertana. Integrációja talán leginkább a tervezés, a kivitelezés és az üzemeltetés területein valósult meg, azonban még számos terület, például az építészeti felmérés is biztosít lehetőségeket. Jelenleg is számtalan eszközzel készíthető részletes és pontos 3D-felmérési állomány, azonban ezek feldolgozása többnyire egyedi szoftverekben és specialisták bevonásával valósul meg. BIM-modellé alakításuk is időigényes manuális feladat, mivel közvetlen építészeti tervezőszoftver-integrációjuk nagyon korlátozott. A cikk egy lehetséges megoldást mutat be a hatékony kommunikáció megteremtése és a modellezési folyamat tovább fejlesztése érdekében.

Kulcsszavak: épületfelmérés, algoritmus, épületinformációs modellezés, 3D nyomtatás.

\section{Bevezető}

Építészeti felmérésre a tervezés-előkészítő felméréstől kezdve, az építés közben elvégzett ellenőrző méréseken és az aktuális állapotok rögzítésén keresztül, egy egyszerű belső tér falainak átfestéséhez szükséges anyagmennyiség-meghatározásig minden esetben sor kerül.

A hosszú ideje alkalmazott hagyományos eszközök (pl.: mérőszalag, lézeres távolságmérő) mellett manapság korszerű technológiák (pl.: lézerszkennerek, fotogrammetriai elven müködő 
eszközök) is támogatják a mérnöki munkát [1]. A modern eszközöknek köszönhetően jelenleg minden eddiginél pontosabb és részletgazdagabb 3 dimenziós állományok előállítására és megjelenítésére nyílik lehetőség.

A folyamat hatékonysága azonban csak a felmérés céljának megfelelően kiválasztott felmérőeszköz és módszertan esetén biztosítható. Több gyártó kínál szinte minden elérhető funkciót egy eszközben vagy ráépülő eszközkörnyezetben felsorakoztató termékeket (pl. Leica RTC360 lézerszkenner és LeicaCyclone szoftver, vagy Leica BLK360 lézerszkenner [2] és OrthoGraph szoftver [3]), azonban ezek használata és az előállított állományok utófeldolgozása magas szakértelmet kíván, beszerzési áruk pedig magas tartományban mozog. Ezzel szemben sok eszköz rendelkezik ezekhez képest korlátozott funkcionalitással (pl.: LeicaDisto professzionális lézeres távolságmérő termékcsalád [2]), amelyhez alacsonyabb felhasználói kompetenciaigény és ár társul.

Kijelenthető, hogy mindkét esetben kompromisszumok megkötése szükséges, viszont véleményünk szerint a két kategória közelíthető egymáshoz, és a saját szoftverkörnyezet helyett a magasabb funkcionalitást biztosító építészeti tervezőszoftverekkel történő szoros együttmüködés is biztosítható.

\section{Koncepció, kialakítás, felépítés}

Az eszközfejlesztési alapkoncepció megfogalmazása során a bevezetőben röviden feltárt tényezők és szempontok kerültek figyelembevételre. A cél egy olyan eszköz kialakítása, amely a gyakorlatias felhasználás, a 3D-építészeti felújítás és továbbtervezés lehetőségének megteremtését kívánja kiszolgálni egyszerü eszközkezelés és a felmérési adatok automatizált utófeldolgozásának segítségével. A felmérési adatok algoritmus segítségével 3D-épületmodellekké, épületrészmodellekké állnak össze a tervezőszoftverek natív környezetében. A műszer kialakítása tulajdonképpen a földi lézerszkennerek (TLS) [4] müködési elvén alapul, annak egyszerűsített megvalósításával. Egy lézermodul segítségével felületenként vagy élek mentén néhány pont mérését követően egy „ultraritka pontfelhő” állítható elő, amely egy feldolgozó algoritmus segítségével építészeti tervezőszoftverekben is értelmezhető modellelemekké konvertálható.

A fejlesztési tevékenység jelenleg a második változat megvalósításánál tart. Korábban az Emberi Erőforrások Minisztériuma, Emberi Erőforrás Tá- mogatáskezelő „NTP-NFTÖ-18” azonosítójú „Nemzet Fiatal Tehetségeiért Ösztöndíj” című pályázata lehetőséget biztosított az elképzelés létjogosultságának tesztelésére és az első termékverzió elkészítésére. A fejlesztési folyamat során azonban felmerültek módosítható, javítható részletek, melyek a jelenlegi munkafázisban kerülhettek kidolgozásra.

A fejlesztési fázis a korábbi folyamat során elkészült eszközváz, vezérlőelektronika és a funkcionalitásért felelős programsorok felülvizsgálatával kezdődött. A vizsgálat rávilágított arra, hogy a meglévő részletek javítása nem eredményezi az elvárt előrelépést, így a teljes projekt a korábbi tapasztalatokat felhasználva újra tervezésre került. A korábbi hardveralkotók (motorok, szenzorok, modulok) teljes körű cseréje, az eszközváz áttervezése és 3D-nyomtatása, valamint a programsorok újraírása is megtörtént.

A vezérlőelektronika alapegységét továbbra is az Arduino-környezet [5] biztosítja. Hardvere azonban a korábbi Arduino Uno R3-eszközt felváltva egy speciális (RobotDyn) Arduino Mega2560-alaplap, amely integrált ESP8266 Wi-Fi-modullal rendelkezik. (2. ábra - „A”) Ez a konstrukció lehetőséget biztosít Wi-Fi-protokollon keresztüli vezetéknélküli kommunikációra, a lézermodul és minden egyéb kiegészítőegység kezelésére, valamint a motorvezérlő modul (2. ábra - „B”) csatlakoztatását követően a léptetőmotorok szabályozására is (1. ábra).

A léptetőmotorok (2. ábra - „C”) hagyományos, alacsony áramerősség-igényű (0,4 A), NEMA 17-típusú egységek, amelyek az XY tengely körüli 360 fokos forgatásért és YZ tengely-irányú lézermodul mozgatásért felelősek. Utóbbi esetében a hasznosítható tartomány lefedésére 98 fok elfordulás elegendő, így forgástartománya szoftveresen korlátozott.

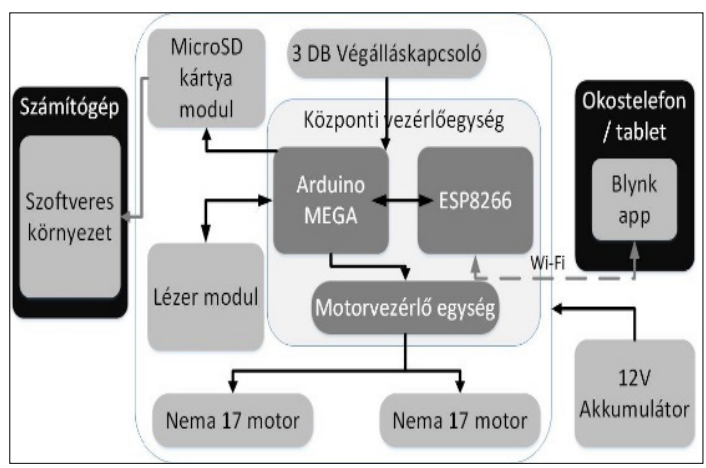

1. ábra. A kialakítás logikai vázrajza 


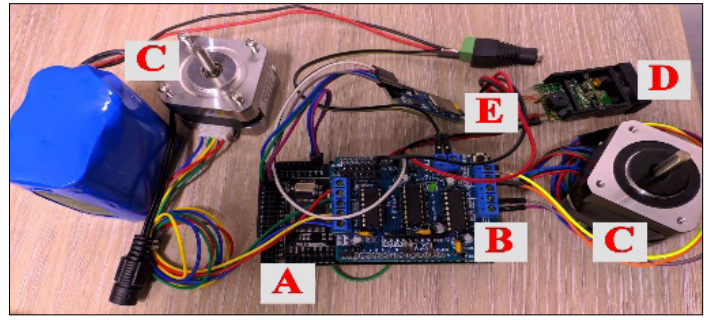

2. ábra. A rendszer fizikai felépítése

A beépített lézeregység (2. ábra - „D”) hagyományos lézeres távolságmérőkben is megtalálható típusokkal egyenértékü. (2. ábra) Vezérlése kommunikációs portjain keresztül, egyszerü karakteres utasítások segítségével lehetséges. Ilyen például a „D”, amely parancs kiadása esetén a modul egy mérést végez, vagy az „S”, amelyet követően kiolvassa a feszültség- és aktuálishőmérséklet-adatokat. Az Arduino alaplappal történő kommunikáció során is ezek segítségével valósul meg az utasítások kezelése.

\section{Müködési mechanizmus}

A mérési folyamat okostelefon vagy tablet segítségével végrehajtott pozicionálással kezdődik. Mobilapplikáció [6] segítségével létrehozható a vezérlést és a visszajelzést biztosító környezet (3. ábra), amely Wi-Fi-protokoll segítségével kapcsolódik a felmérőegységhez, és küldi számára az utasításokat. A műszer lehelyezését követően a felmérni kívánt pont pozícióját beállítva kiválasztandó a felmérendő épületszerkezet típusa, majd aktiválható a lézermodul, és elvégezhető a mérés. A felületről visszaverődő lézersugár segítségével megállapítható az egység és a felmért pont távolsága. A mért érték megjelenik az applikációban, és tárolásra kerül az eszközbe helyezett microSD (2. ábra - „E”) kártyán is. Egybefüggő sík felületek esetén az eddig ismertetett folyamat még legalább két alkalommal hajtandó végre, ezzel biztosítva, hogy minden felületről minimum 3 db mérési pont álljon rendelkezésre, amely már

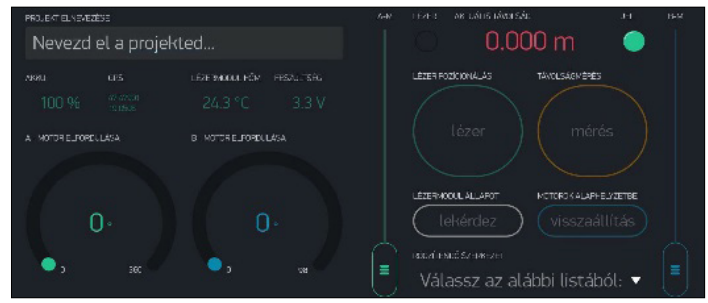

3. ábra. Az irányítópult felépítése egyértelműen meghatározza a síkokat. Amennyiben nem felületi, hanem alaki mérést szeretnénk elvégezni, a megírt programsorok erre is biztosítanak lehetőséget. Alaki mérés alatt a szerkezetek és tárgyak befoglaló geometriájának rögzítése értendő a jellemző pontjaik felmérése által.

A mért távolságokat és egyéb kiegészítő, valamint egyedi azonosító információkat az eszköz folyamatosan microSD kártyára is rögzíti. Az adatok struktúrájának kialakítása során egyszerű váz megalkotása volt a cél, amely a későbbi felhasználást teljes egészében ki tudja szolgálni, és megfelelő alapot biztosít a koordinátaszámítás műveleteihez.

$\mathrm{Az}$ adatmenedzsment folyamatához tartozik a mérés során keletkező adatokból a mért pontok koordinátáinak számítása és csoportosítása is. Ennek környezete jelenleg egy komplex táblázatban biztosított. A műveletek során az eszköz pozíciója tekinthető az alappontnak $(0,0,0)$, amelyhez viszonyítva egy relatív koordinátarendszerben kerülnek rögzítésre a felmért pontok. Mivel ez esetben a távolság, az elfordulásértékek és az alappont („origó”) mindhárom koordinátája ismert, $(0,0,0)$ trigonometrikus függvények, szögfüggvények segítségével meghatározható a másik pont térbeli helyzete. A pontok térbeli pozíciója az algoritmusalapú feldolgozás alapja, így a számítás helyessége létfontosságú. Ennek érdekében minden mérést követően a 2 db (P1, P2) térbeli pont távolságának meghatározására [7] alkalmas képlet visszaellenőrzési céllal felhasználásra kerül (1).

$$
d\left(P_{1}, P_{2}\right)=\sqrt{(x 2-x 1)^{2}+(y 2-y 1)^{2}+(z 2-z 1)^{2}}
$$

A koordinátaszámítást követő utolsó lépésben a tervezőszoftverek számára is értelmezhető geometriák előállítása történik. Az elkészített algoritmus Autodesk Revit tervezőszoftver Dynamo-kiegészítőjében került összeállításra. Az algoritmus a koordinátaszámítást végző táblázat releváns adatainak felhasználásával a felmérés eredményének vizualizálását és a pontok által alkotott felületek épületszerkezeteknek (falak, födémek, ablakok, ajtók, stb.) való megfeleltetését végzi el. A programsorok az adatok feldolgozása során felmérési típusazonosító alapján megkülönböztetik az információkat, így például a nyílászárókat $4 \mathrm{db}$ sarokpontjuk felhasználásával képezik le, míg az egyszerü falak és födémek minimum $3 \mathrm{db}$ mérési pontra feszített síkon kerülnek elhelyezésre.

A teljes folyamat automatikus, és a végtermékek a tervezőszoftver számára natív modellele- 
mekként azonosított, információtartalommal is bíró BIM-entitások, amelyek a programfunkciókat kihasználva a későbbiekben módosíthatók is (4. ábra).

Több helyiség felmérése vagy több álláspont esetén az egymáshoz illesztés minden esetben $3 \mathrm{db}$ segédpont felhasználásával lehetséges. Ezeket a referenciapontokat a szerkezetek azonosításával megegyező módon egyedi azonosítóval rögzítjük.

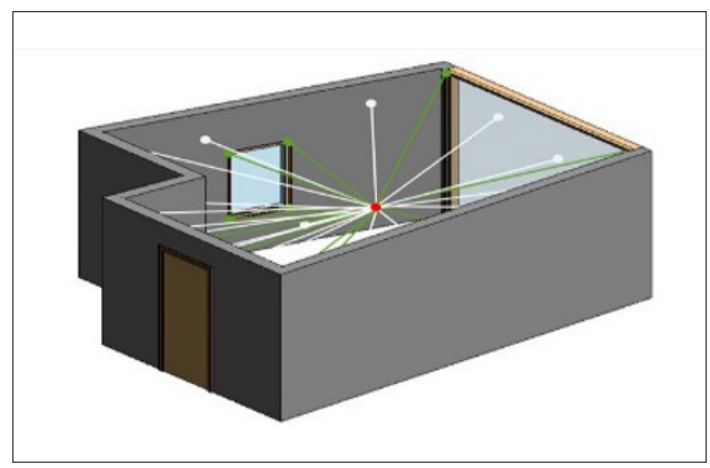

4. ábra. Az algoritmus által generált 3D-modell

\section{Eszközváz}

A prototípusgyártás fontos részét képezi a külső burok megtervezése és gyártása is. A vázmodellek és az alkotórészek előállítása 3D modellező szoftverekben történik, melyek ezt követően Polylactic Acid (PLA) anyagból 3D nyomtató segítségével készültek el. Ezzel a munkafolyamattal a koncepcióvázlatok rövid idő alatt újra tervezhetők, módosíthatók és előállíthatók (5. ábra).

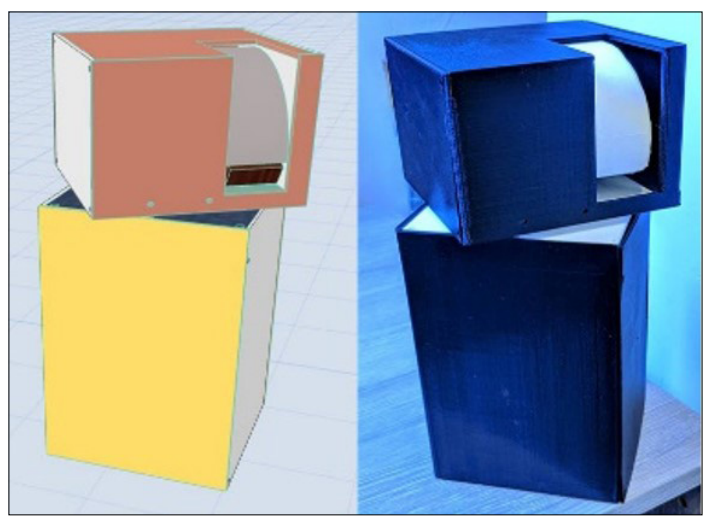

5. ábra. A modell és az összeszerelt mérőmüszer

\section{Következtetések}

A felmérőeszköz és a módszertan is egyaránt teljesíti az előirányzott elképzeléseket, így a kutatásfejlesztési tevékenység eredményei pozitívnak és biztatónak nevezhetők. A tervezőszoftverrel való közvetlen kapcsolata növeli a müszer felhasználóinak körét, és hatékonyabb, gazdaságosabb folyamatokat eredményez. Akár amatőr felhasználók is elvégezhetik épületük egyszerüsített belső felmérését. Az ennek során előállított állományok pedig az építészek számára biztosítanak kiindulási 3D-modellt, amely a tovább tervezés alapjaként felhasználható. Ezek alapján indokoltnak tartjuk a műszer további optimalizációját és bővített funkcionalitására irányuló jövőbeli fejlesztési lehetőségek megvalósítását. Többek között a mérési folyamat automatizálása, az adatok mobileszközön történő azonnali vizualizációja és más tervezőszoftverekbe történő integrációja számos kihívást tartogat még.

\section{Köszönetnyilvánítás}

Az Innovációs és Technológiai Minisztérium ÚNKP19-3 kódszámú Új Nemzeti Kiválóság Programjának szakmai támogatásával készült.

\section{Szakirodalmi hivatkozások}

[1] Bayyati A.: Modern Surveying Technology: availability and suitability for Heritage Building Surveying and Heritage Building Information Models (HerBIM). London South Bank University, (2017) 2-7.

[2] Leica Geosystems, Termékek (letöltve: 2020. február 2.).

https://leica-geosystems.com/hu-hu/products

[3] OrthoGraph Enterprise (letöltve: 2020. január 20.) https://www.orthograph.com/

[4] Petrie G., Toth K. C.: Terrestrial Laser Scanners. In: Topographic Laser Ranging and Scanning, Principles and Processing. (Szerk.: Shan J., Toth K. C.). Taylor \& Francis, CRC Press, 2009. 87-92.

[5] Arduino: What is Arduino? (letöltve: 2020. január 20.).

https://www.arduino.cc/en/Guide/Introduction

[6] Blynk: Miből áll és hogyan is müködik a Blynk? (letöltve: 2020. január 20.).

http://docs.blynk.cc/\#intro

[7] Soo T.: Coordinate Systems and Vectors in 3-Space. In: Single Variable Calculus: Early Transcendentals. $1^{\text {st }}$ Edition (Szerk.: Soo T.), Cengage Learning, 2010. 911. 


\title{
SZÖVETTEKERCSELŐ EGYSÉG TERVEZÉSE
}

\section{DESIGN OF A FABRIC WINDING UP UNIT}

\author{
Márton László1, Szigeti Ferenc, ${ }^{2}$ Gergely Dezső ${ }^{3}$ \\ Nyíregyházi Egyetem, Müszaki és Agrártudományi Intézet, Müszaki Alapozó, Fizika és Gépgyártástechno- \\ lógia Tanszék. Nyíregyháza, Magyarország \\ 1 lacuko97@gmail.com \\ ${ }^{2}$ szigeti.ferenc@nye.hu \\ ${ }^{3}$ dezso.gergely@nye.hu
}

\begin{abstract}
For air-spring production the fabric winding is what prepares the semi-finished materials. The rubber body, that we called the membrane is made from using several layers of fabric and rubber. Building together these layers defines the mechanical properties. During the winding up, we prepare the cut rubber or fabric layers in rolls. Quality of rolling and the performance to make the semi-finished material, depend on the machine which is used for the winding. To satisfy the higher production capacity it was necessary to create a modern construction using automated systems. To assure the ergonomic expectations was a main viewpoint too. My thesis main goal is to explain, in detail, my design and to prove the device structural solutions using finite element analysis.
\end{abstract}

Keywords: air-spring production, fabric winding, automated systems, finite element test, tool designing.

\section{Összefoglalás}

A szövettekercselés a légrugógyártás folyamatára készíti elő a félkész anyagot. A légrugók gumieleme több gumirétegből épül fel, melyek megfelelő egymásra építése az előírt rétegrendben határozza meg a vulkanizálást követő mechanikai tulajdonságokat. A szövettekercselés során a vágott gumielemet készítjük elő tekercsekben. A tekercselés minősége és teljesítménye alapvetően befolyásolja a gyártás kapacitását. A megnövekedett gyártási igények kielégítése érdekében szükséges volt egy korszerü, automatizált rendszerrel ellátott szövettekercselő egység kialakítására, amely ugyanakkor lehetővé teszi az ergonómiai feltételek javítását is. A dolgozatom célja ennek a berendezésnek a részletes megtervezése, valamint véges elemes szimulációkkal a szerkezeti megoldások ellenőrzése.

Kulcsszavak: légrugógyártás, szövettekercselés, automatizált rendszer, végeselemes szimuláció, készüléktervezés.

\section{Bevezető}

Az egyetemi tanulmányaimat a duális képzés keretében folytattam a nyíregyházi Continental ContiTech Magyarország Kft.-nél. A gyakorlati időm alatt megismerkedtem a közlekedési és ipari termékek gyártására fókuszáló gumiipari termékek gyártási folyamataival, illetve azok gyakorlati felhasználásával [1].

Az üzemben jelenleg alkalmazott szövettekercselő egység elavult, a tekercsek minősége a mai követelményeknek már nem felel meg, ezért üzemi feladatként megbízást kaptam egy új szövettekercselő egység kifejlesztésére.

Elsőként bemutatom a légrugógyártáshoz szükséges folyamatokat, meghatározom a szövettekercselő egység gyártási folyamatban történő elhelyezkedését. Ezt követően a fejlesztés során alkalmazott szerkezeti megoldások magyarázata következik. A váz, a kiegészítő berendezések és segédrendszerek szerepét, funkcióját, illetve a keletkező terhelésekkel szembeni ellenállását 
vizsgálom. A fejlesztés célja az elavult szerkezet korszerüsítése, a növekvő vevői igények, illetve a cég által megadott szempontok figyelembevételével. A szerkezeti megoldások kidolgozása után elkészítettem a gyártáshoz szükséges műszaki dokumentációt.

\section{A korábban alkalmazott szövetteker- cselő egység bemutatása}

A folyamat elején a kalanderezett tekercset a gépbe helyezik, melynek szövetelemeit még előzőleg a felhasználási területnek megfelelően szögbe és méretre vágják. Ez a megmunkált gumilap hevederen érkezik az operátorhoz, akinek a feladata a vágott szövet egyesítése (végtelenítése). A dolgozó átlapolással egymásra helyezi a lapokat, melyeket a szögben elhelyezett heveder a tekercselőegységhez szállítja (1. ábra). A végtelenített lapokat itt egy ún. kísérőszövetbe tekerik, mely elválasztórétegként funkcionálva meggátolja a gumifilm, valamint a szintén itt készülő szövetre felpréselt gumifilm összetapadását. Így készülnek el a felhasználásra kész tekercsek. A tekercselőegység működésétől függ a termelés kapacitása, a tekercsek minősége (gumilapok, szövetlapok gyűrődése nem megengedett!).

\section{A korábban alkalmazott berendezés jellemző hibái}

Az első hiba a tekercselésben a gép csapágyazásából ered. A tekercs tengelye két oldalról van csapágyazva. A tengelyt ki- és be kell helyezni a tekercselés végén és annak kezdetén. Erre a célra egy olyan tengelycsatlakozás van kialakítva, melyben egy pneumatikus munkahenger villás

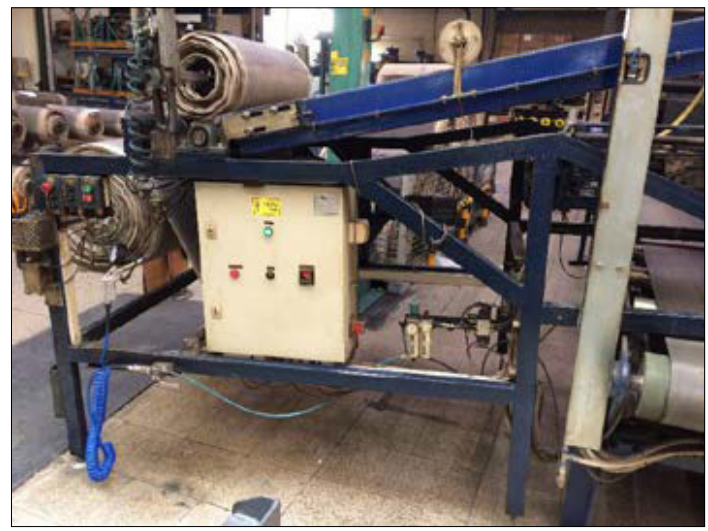

1. ábra. Régi szövettekercselő egység vége egy ellenrugóval biztosított nyitófüles reteszt old ki (2. ábra).

E megoldásnak köszönhetően a tekercsek tengelyének ki- és behelyezése egyszerű, viszont a tengelynek szabad játéka van a csatlakozókban, melynek következtében a tekercselés nem lesz megfelelő minőségű. A tengelyirányú holtjáték következtében megszűnik az egytengelyűség és a tekercsben található szövet gyűrődött lesz, vagy esetenként a szövetlapok elcsúsznak egymáshoz képest, ill. szétválnak.

A tekercselés folyamán, ahogy növekszik a feltekercselt anyag, úgy a tekercs átmérője is növekszik, ezért biztosítani kell a csapágyház és a csatlakozás lineáris elmozdulását. Ennek megoldására egy úgynevezett hornyos oszlop található. Maguk a csatlakozó tengelyvégek 2 darab egysorú mélyhornyú golyóscsapágy segítségével a nekik megfelelően kialakított hornyokban (3. ábra) képesek elvégezni a lineáris mozgást. Az üzemi tapasztalatok szerint a csapágyak a hornyokban gyakran megragadtak, ami a tekercsben kárt okozott.

Problémát jelentett a kész tekercs ki- és behelyezése is. A feltekercselt szövet súlya esetenként meghaladja az 50 kg-ot, az érvényes munkavédelmi szabályok szerint ezt a súlyt már emberi erővel nem szabad mozgatni. Erre a célra a gép mellett található egy daru, mely a tekercs kivételére szolgál. A daru használatával a tekercs már kivehető a gépből, azonban a daru emelőkarjának a tekercshez való pozicionálása, biztonságos beállítása nehézkes és időigényes folyamat

$\mathrm{Az}$ ismertetett hibajelenségek, illetve a jelenlegi egység gyakori karbantartási igénye miatt felmerült a szükségessége egy új szerkezet, illetve konstrukció kidolgozásának, mely korszerűbb és megbízhatóbban müködik.

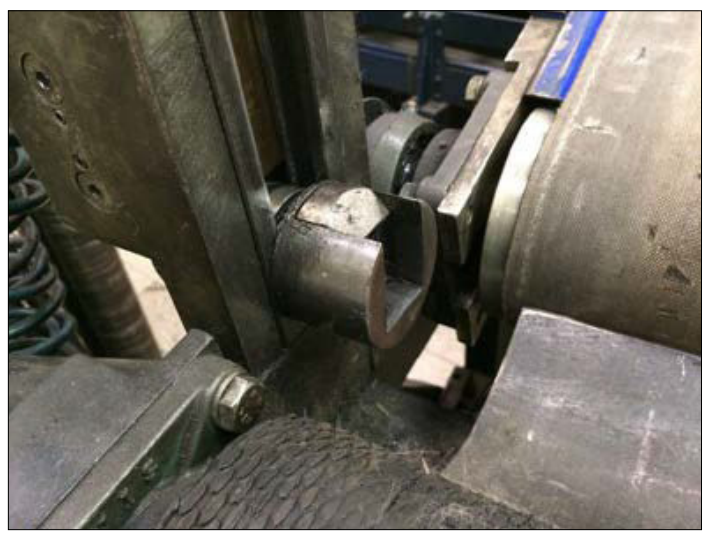

2. ábra. Tengelycsatlakozás a géphez 


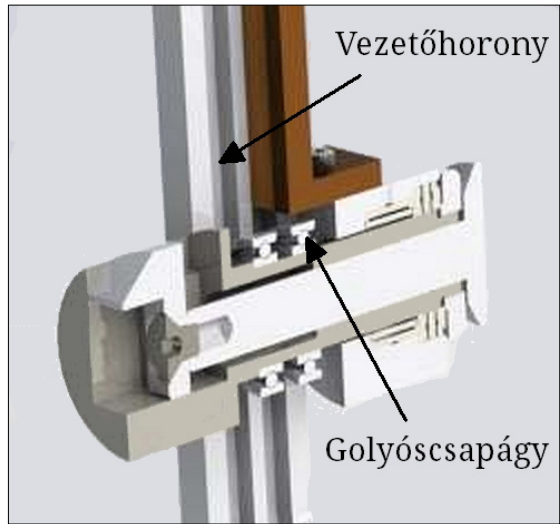

3. ábra. Tekercselőoszlop metszete

\section{Fejlesztési javaslatok a tekercselő- egység korszerüsítésre}

A feladat megfogalmazását követően két különböző működési elvű konstrukció tervét készítettem el. Mindkét verzió a legfontosabb követelmények szem előtt tartásával készült el, azonban szerkezeti megoldásaik, illetve működésük is jelentősen eltér egymástól.

\subsection{Billenőkaros változat}

Az első változat, a „Billenőkaros tekercselő berendezés” (4. ábra) kiemelendő előnye, hogy a szerkezete egyszerü, ugyanakkor működtetése automatizált.

Müködése: A folyamat indításakor az operátor az üres tekercsdobot a tengellyel együtt behelyezi a gép karjaiban található csatlakozóelemekbe, melyet a gép villamos motorok segítségével a tekercsasztal hevederére helyez. A tekercsek kialakítását a heveder biztosítja, az átmérőkülönbség kiküszöbölését a szabadon mozgó karok teszik lehetővé. A tekercselési folyamat végeztével a szerkezet kiemeli az asztalról az elkészült tekercset, melyet a berendezés az operátor munkaszintjére szállít, majd a folyamat ismétli önmagát.

\subsection{Oszlopos tekercselőegység}

A második fejlesztési változat az ún. „Oszlopos szövettekercselő egység” (5. ábra). Főbb jellemzői: magasfokú automatizáltság, ergonómiai szempontoknak való teljes körű megfelelőség. A szerkezet kialakítása komplex, az egyedileg gyártott alkatrészek kialakítása bonyolult, azonban CNC-vezérlésű megmunkáló berendezéseken a megmunkálás megvalósítható. Jelentős előnyt jelent, hogy az alkatrészek 80\%-a a kereskedelmi forgalomban beszerezhető, így meghibásodás esetén a javítás gyorsan elvégezhető.

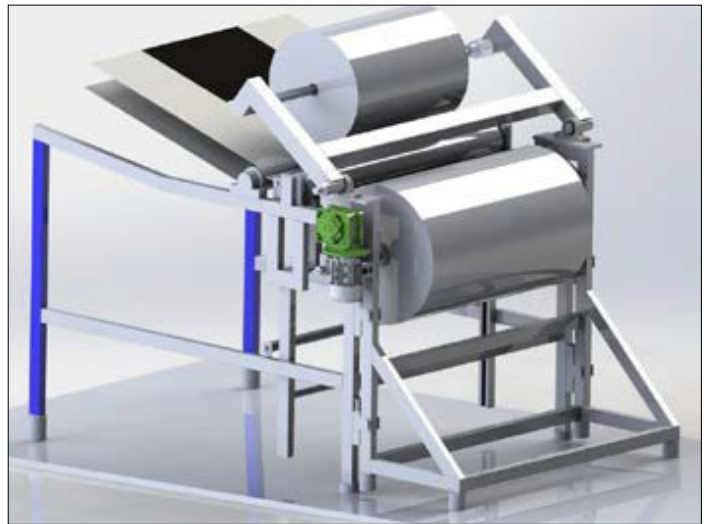

4. ábra. Billenőkaros tekercselőegység

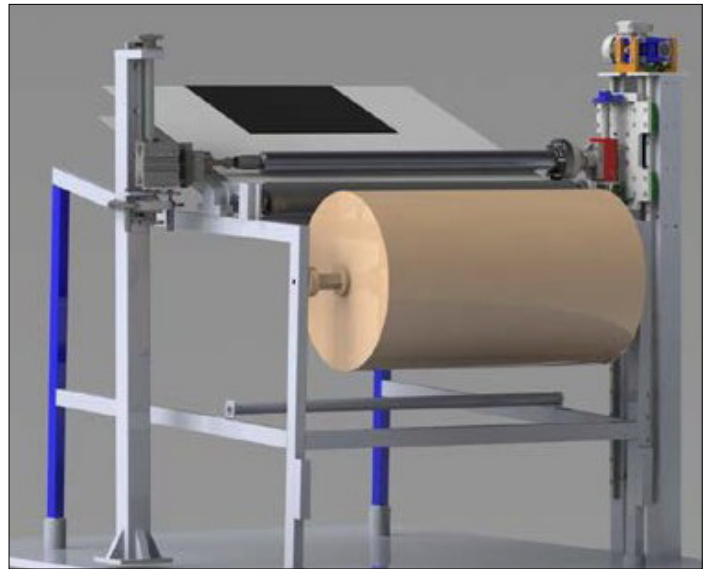

5. ábra. Oszlopos szövettekercselő egység

\subsection{Választott konstrukció}

A két változat elvi kidolgozását követően üzemi megbeszélést indítottunk, amelyen a berendezéssel dolgozó operátorokkal, illetve üzemvezetőkkel együtt kiválasztottuk a cég számára legmegfelelőbb megoldást.

Az oszlopos tekercselőegységet (6. ábra) tartottuk minden szempontból a számunkra legmegfelelőbbnek. Így következhetett a szerkezet komplex kidolgozása.

\section{Az oszlopos szövettekercselő egység föbb jellemzői}

Alapvetően a berendezés két fő egységre különíthető el. A következőkben a fő részeket bal oldali felépítményként és jobb oldali felépítményként mutatom be. Ezek összehangolt működtetése biztosítja a félkész anyag gyártásához szükséges működési feltételeket. 


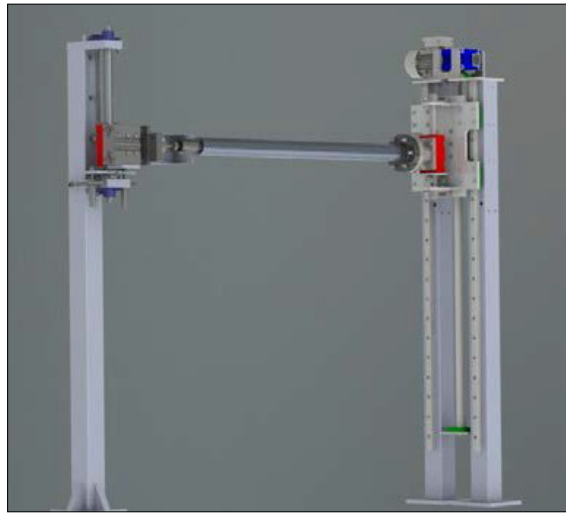

6.ábra. Az oszlopos szövettekercselö egység váz-szerkezete

\subsection{Bal oldali felépítmény}

A berendezés ezen részének elsődleges feladata a pneumatikus megfogótengely központosítása, továbbá a párhuzamosság biztosítása a hevederasztallal. Ezeket a funkciókat a 7. ábrán látható elemek biztosítják.

Működése: Egy pneumatikus munkahenger csapágyazással ellátott forgo, központosító kúpot nyit és zár. Ez a megoldás biztosítja a megfogó tengely központosítását. Szükség volt az átmérőkülönbség növekedéséből adódó méretkülönbség kompenzálására, melyet egy függőleges irányú elmozdulást végző lineáris tengely, illetve csapágyház biztosít. A pneumatikus munkahenger alatt található két csillapító munkahenger, melyek feladata a tekercselés végeztével a kúp oldását követő visszacsúszás csillapítása, illetve e berendezés alaphelyzetbe történő állítása. A lineáris tengelyek a tengelyre merőleges irányú állíthatósággal rendelkeznek, mely a beszerelést teszi egyszerüvé, illetve lehetővé teszik a vázszerkezet elhelyezéséből adódó nehézségek kiküszöbölését.

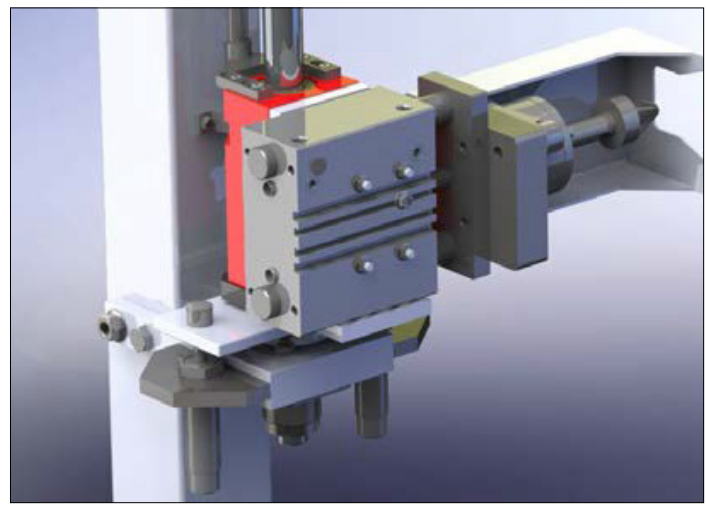

7. ábra. Bal oldali felépítmény fóbb szerelvényei

\subsection{Jobb oldali felépítmény}

A jobb oldali felépítmény a tekercselő egység (8. ábra) legkomplexebb egysége. Feladata a tekercselés optimalizálása, a keletkező terhelések felvétele, a kész tekercs mozgatása. Az elkészült tekercs súlyát (átlagosan $50 \mathrm{~kg}$ ) és a segédberendezések összeadódó tömegét a szerkezetnek alakváltozás nélkül kell viselnie, illetve mozgatnia.

A felépítménnyel szemben 3 fő követelményt támasztunk: a folyamatos és jó minőségű tekercsek kialakítása, a félkész anyag biztonságos mozgatása, valamint hogy mindezeket a feladatokat a felépítmény automatizált rendszerrel hajtsa végre. $\mathrm{Az}$ oszlopszerkezeten található 1-1 sínpár, amelyen a segédberendezést tartó lapra erősített lineáris kocsik biztosítják a függőleges mozgást. Az oszlopok között egy trapézmenetes orsó van elhelyezve, melyet a szerkezet tetején található villanymotor hajt meg a szükséges irányban. A tartólapon egy lineáris tengely [2] található, amely már az előzőekben részletezett átmérőkülönbség kompenzálását szolgálja. Az operátornak a tekercselés végén kézzel kell kinyitnia (biztosítási funkció) az egységet. Erre a célra a lineáris csapágyház alatt egy forgótárcsa került elhelyezésre, amely lehetővé teszi a könnyü nyitást, illetve zárást.

A 9. ábrán bemutatott metszeten láthatók a szerkezet főbb elemei. Az ábra bal oldalán talál-

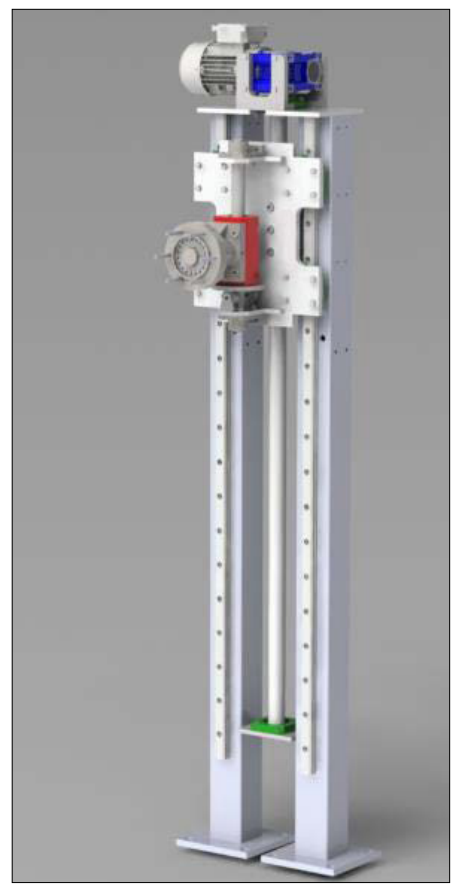

8. ábra. Jobb oldali felépítmény 


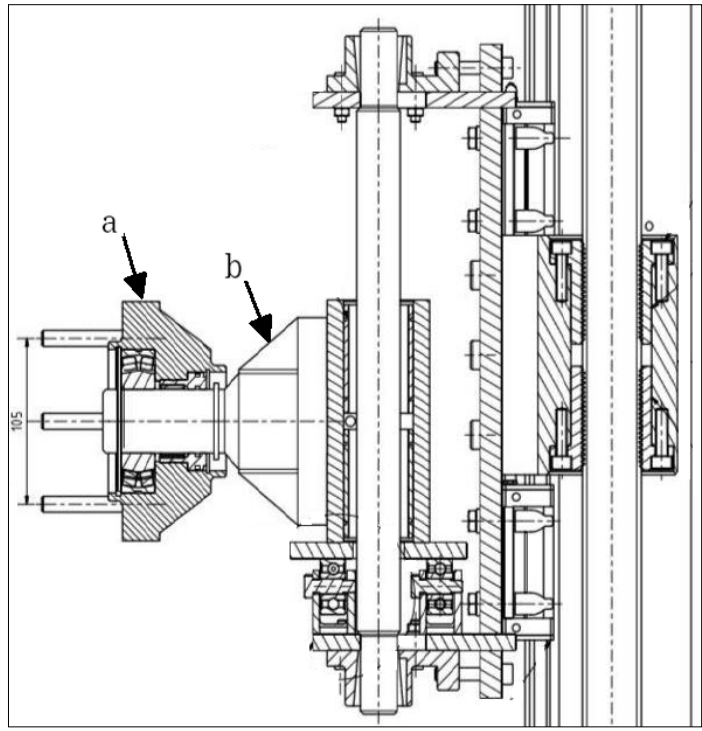

9. ábra. Segédberendezések metszete

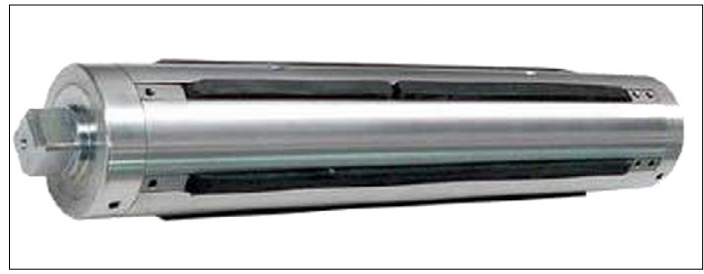

10. ábra. Pneumatikus rögzítőtengely

ható a két, egyedi gyártással készítendő alkatrész, melyek szerkezeti kialakítását a következőkben mutatom be. A tekercseket rögzítő tengely legygyakrabban a papír, illetve a szövetgyártásban alkalmazott (10. ábra). Megnevezése: pneumatikus megfogótengely. Müködési elve: a tengelyen található gumipofák nyomás hatására szorítóerőt fejtenek ki a ráhelyezett elemekre, jelen esetben a tekercsek dobjára, amelyet pozicionálni és rögzíteni szükséges.

\section{Végeselem-vizsgálatok}

A tekercselőegység tervének elkészítését követően 3 dimenziós modellek segítségével megvalósíthatóvá vált a végelem-analízis. A Solidworks szoftver [3] végeselem-moduljának felhasználásával elvégeztem a fontosabb szerkezeti elemek szilárdsági ellenőrzését.

Kiemelt feladatnak tekintettem a legnagyobb terheléseknek kitett szerkezeti egységek ellenőrzését, a tekercs súlyát hordó elemek vizsgálatát. $\mathrm{Az}$ ellenőrzést minden részegységre végrehajtottam helyettesítő modellek segítségével.

\subsection{A csatlakozótárcsa vizsgálata}

Az első egyedileg készített alkatrész a tekercs tengelyét tartó csatlakozótárcsa. A tárcsára (9. ábra „a” jelű alkatrész) a tekercs súlyából adódó erők és nyomatékok hatnak.

Hat darab tőcsavar rögzíti egymáshoz a tárcsát, illetve a tengelyt. Ezen a hat csavaron adódik át a terhelés. A szimulációt bemutató 11. ábrán jól látható, hogy a csavarokban ébrednek a legnagyobb feszültségek. A csatlakozótárcsa igénybevételeit az 1. táblázatban tüntettük fel. A méretezés helyességét igazolta, hogy a feszültségek és deformációk minden esetben az anyagra megengedett értékeknél kisebbek voltak.

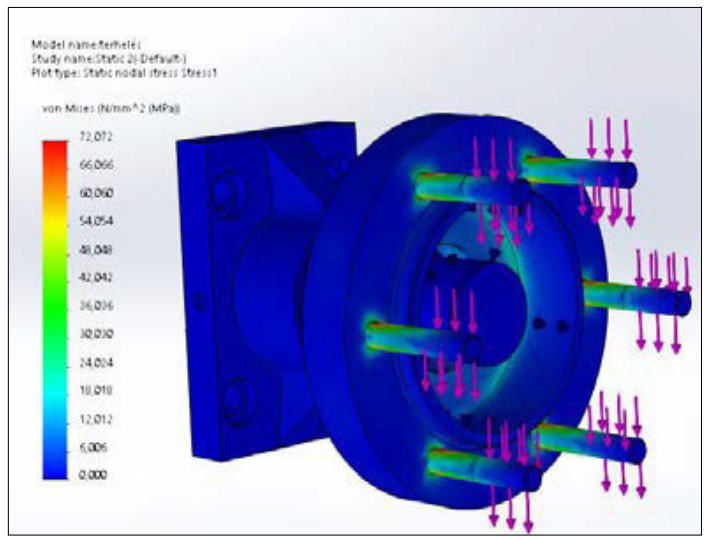

11. ábra. Csatlakozótárcsa VEM-vizsgálata

1. táblázat. Csatlakozótárcsa igénybevételei

\begin{tabular}{|l|c|}
\hline Igénybevétel típusa & Maximum \\
\hline Ekvivalens feszültség: $\sigma_{e q}$ & $72,1 \mathrm{MPa}$ \\
\hline Elmozdulás, kihajlás & $0,19 \mathrm{~mm}$ \\
\hline
\end{tabular}

\subsection{Csatlakozó tengelycsonk}

A csatlakozótárcsa szintén egyedi gyártással készülő szerkezeti elem (9. ábra „b” jelű alkatrész). Ezen helyezkedik el az előző pontban bemutatott csatlakozótárcsa. A tengelycsonk felülete köszörült a csapágyak megfelelő illeszkedése miatt. A tengelycsonk négy csavarral csatlakozik a lineáris csapágyházhoz.

A 12. ábrán megfigyelhető, hogy a legnagyobb feszültség a váll felülete mögött, a kúpos felületen ébred. A váll a csapágy megtámasztása érdekében szükséges. A legnagyobb ébredő feszültség 13,5 MPa, amely nem haladja meg az anyagra megengedett maximális értéket. Az anyagra jellemző megengedett $\sigma_{\text {red }}=512 \mathrm{MPa}$. 


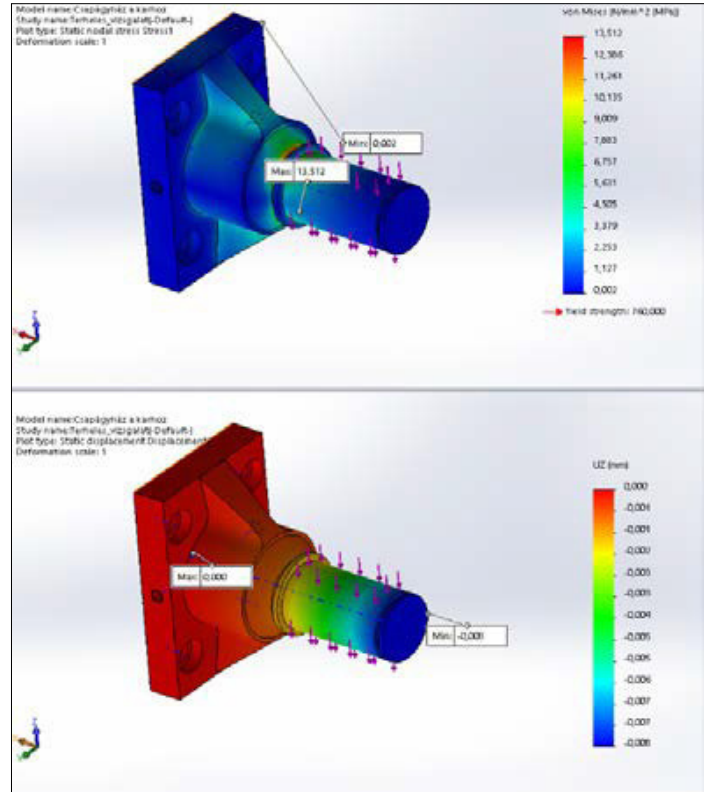

12. ábra. Csatlakozó tengelycsonk VEM-vizsgálat

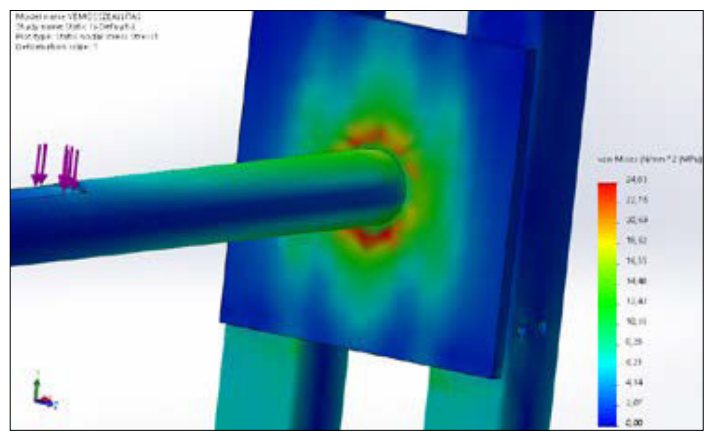

13. ábra. A tartólapban ébredő feszültségek

\subsection{A tartószerkezet vizsgálata VEM-mód- szerrel}

A tartószerkezetekre is elvégeztem az ellenőrző vizsgálatot. Az alkatrészek jelentős száma és bonyolultsága miatt indokolt volt helyettesítő modellek használata. A vizsgálati eredmények és a feszültséggyűjtő helyek a 13. és 14. ábrán lathatók. Az ébredő feszültségek egyik helyen sem haladják meg a megengedett értéket.

\section{Technológiai tervek készítése az egye- di alkatrészek gyártásához}

A szövettekercselő egység legnagyobb terhelésnek kitett alkatrészei bonyolultságuk, illetve kialakításuk miatt 5 tengelyes CNC-vezérlésű szerszámgépen gyárthatók le.

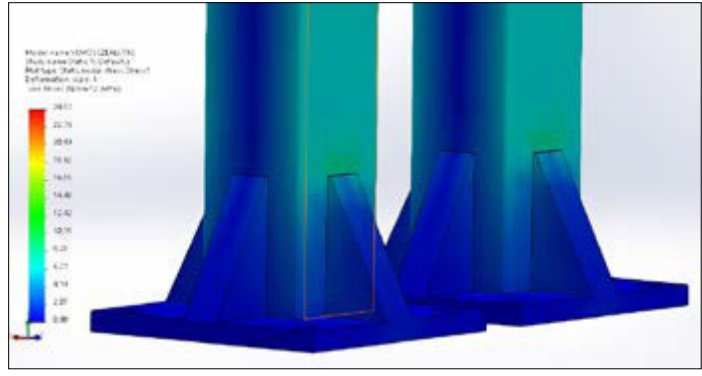

14. ábra. A talpakban ébredő feszültségek

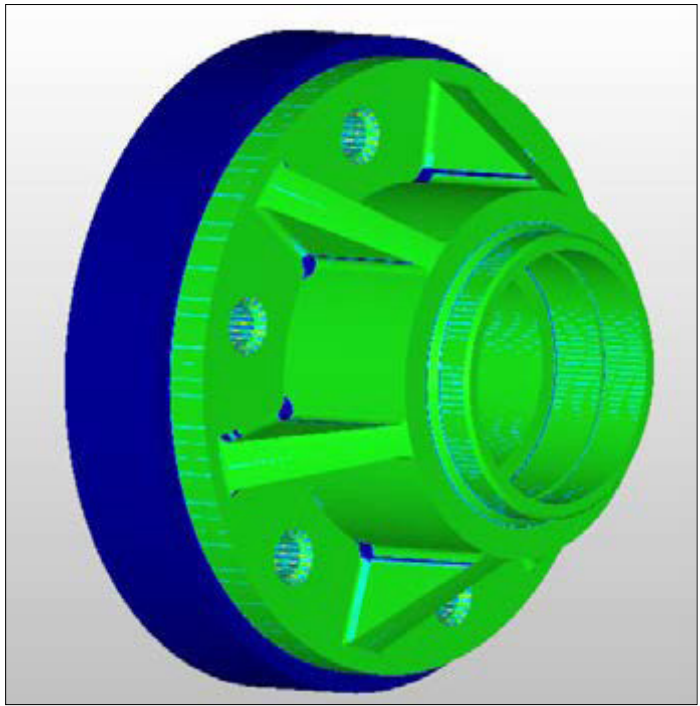

15. ábra. Csatlakozótárcsa megmunkált felületei

Ehhez EdgeCAM [4] szoftverrel elkészítettem az alkatrészek CNC-megmunkálási programját és szimulációt is készítettem a megmunkáláshoz. A 15. ábrán látható a szimuláció végén kialakult felület, zöld színnel jelöltem a megmunkált felületeket.

Látható, hogy a csatlakozótárcsa a megmunkálás befejeztével még rendelkezik (kékkel jelölt) nem pontosan megmunkált, ráhagyást tartalmazó felületekkel. A pontos, rajz szerinti megmunkáláshoz a merevítő bordák közelében igen kis méretű szerszámot kellene alkalmazni, amely jelentősen növelné a megmunkálási időket. A jelölt felületeken maradó ráhagyás nem befolyásolja a megfelelő müködést.

A csatlakozó tengelycsonk (16. ábra) megmunkálása körülményesebb és nagyobb szerszámozottságot igényel, egy felfogásból nem készíthető el. A második felfogást követő megmunkálás után a tengelycsonk hátfelülete egyetlen marad, ezért külön megmunkálást igényel. 


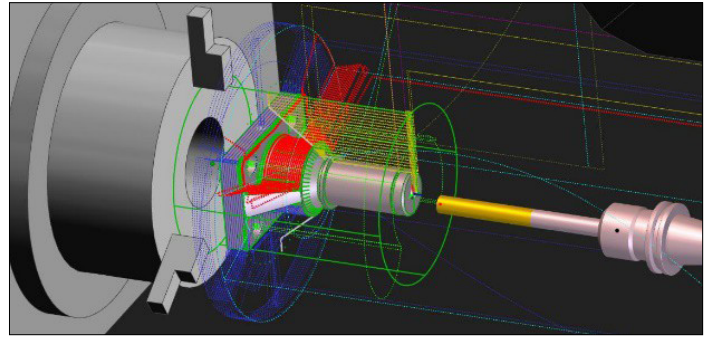

16. ábra. Tengelycsonk felfogási vázlata

\section{Fúrótárcsás készülék}

A csatlakozó tárcsa gyártásához nem indokolt a készülék használata, ha CNC-vezérlésű szerszámgéppel történik a gyártás. Amennyiben azonban a müködő felületek előállítása hagyományos szerszámgépen történik, indokolt a megmunkálás pontosságát növelő készülék használata. Ezért, sorozatgyártást feltételezve, megterveztem a gyártás megfelelő pontosságát biztosító fúrókészüléket (17. ábra).

A készülék használatával a megmunkálás automatizálttá válik. A furatok osztását léptetőmotor hajtja végre, a pontos méretű és helyzetű furatok elkészítését a fúrólapba rögzített fúróperselyek biztosítják. A furatmegmunkálás során egy pneumatikus megfogó egység rögzíti az alkatrészt elmozdulás ellen.

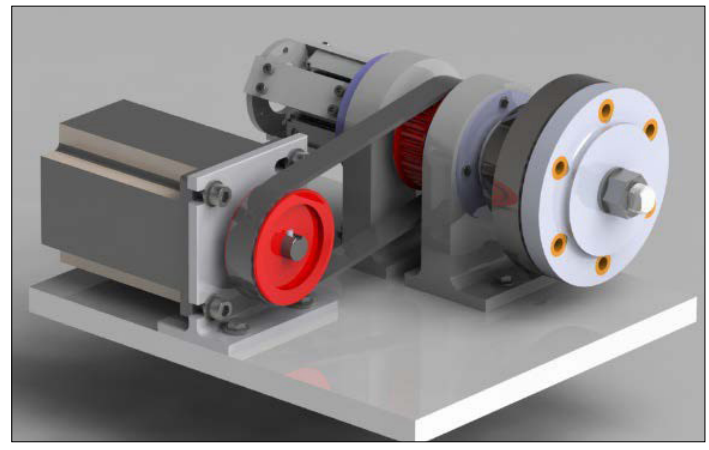

17. ábra. Automata fúrótárcsás készülék

\section{9. Összefoglalás}

A dolgozatban bemutattam a szövettekercselő egység tervezésének, ellenőrzésének folyamatát, a berendezés fontosabb elemeinek gyártástechnológiáját. A fejlesztés gyakorlati megvalósításáról, a gyártási költségek pontos meghatározását követően, az üzem vezetősége fog dönteni.

\section{Szakirodalmi hivatkozások}

[1]Bartha Z.: Gumiipari kézikönyv. Taurus-Omikk, Budapest, 1985.

[2] Herczeg A.: Szerkesztési atlasz. Műszaki Könyvkiadó, Budapest, 1980.

[3] www.solidworks.com

[4] www.egdecam.com 


\title{
VÉKONYLEMEZ HENGERÍTÉSI FOLYAMATÁNAK NUMERIKUS MODELLEZÉSE
}

\section{NUMERICAL MODELLING OF THE THREE-ROLL BENDING PROCESS OF A THIN PLATE}

\author{
Máté Péter, ${ }^{1}$ Szekrényes András ${ }^{2}$ \\ Budapesti Müszaki és Gazdaságtudományi Egyetem, Budapest, Magyarország \\ 1 matepeter95@gmail.com \\ 2szeki@mm.bme.hu
}

\begin{abstract}
The three-roll bending process is a simple procedure, commonly used in the industry, through which a cylindrical surface can be produced from a sheet plate. This process is mainly controlled through experience and it is described with the finite element method, except for a very few numerical and analytical investigations. The topic of this article is to present a numerical method, through which the curvature function along the rolling direction can be calculated. This article presents the proposed numerical method and its verification with the finite element method. The results of the two numerical methods are in good agreement.
\end{abstract}

Keywords: sheet metal, three-roll bending, metal forming, residual curvature.

\section{Összefoglalás}

A lemezhengerítés egy, az iparban gyakran használt, viszonylag egyszerű eljárás, amely segítségével sík lemezből hengerpalást állítható elő. A folyamatot leginkább tapasztalati úton kezelik, leírására pedig,kevés kivétellel, legtöbbször véges elemes modellek születtek. A cikk témája egy olyan saját numerikus eljárás bemutatása, amely segítségével kiszámítható a lemezgörbület lefutása adott paraméterek mellett. A cikkben bemutatom a nemlineáris numerikus eljárást, illetve ennek a végeselem-módszerrel történő ellenőrzését. A végeselem-módszer eredményei megfelelő pontossággal követik az algoritmus által számolt értékeket.

Kulcsszavak: lemez, hengerítés, képlékeny alakítás, maradó görbület.

\section{Bevezető}

A hengerítési folyamat maga gyakorlatilag egy olyan hárompontos hajlítás, amelyen áttoljuk a lemezt, így annak minden pontja hajlítást szenved el. A berendezés két alsó és egy felső görgőből áll, úgy, hogy a felső görgő az alsó kettő között helyezkedik el. A lemezt behelyezzük a három görgő közé, majd a középső görgő függőleges elmozdításával terheljük a lemezt a 1 . ábra szerint. Az alsó görgők együttes forgatásával mozgásra kényszerítjük a lemezt, bár extrémebb esetben a felső görgő hajtása is indokolt lehet. A folyamatos eltolással a lemez minden pontját meggörbítjük, ezáltal hengerfelületet hozva létre.

\section{Lemez modellezése}

A modellezéshez választott rugalmas-képlékeny anyagmodell a rugalmas-lineárisan izotróp keményedő, más néven Von Mises-féle bilineáris modell. Ennek a húzógörbéje az 2. ábrán található. Ez a modell jól alkalmazható kis alakváltozások és viszonylag egyenes plasztikus karakterisztikájú anyagok esetén, illetve az erre való alapozással a számítási algoritmus könnyen kiegészíthető egy multilineáris anyagmodell adoptálására. 


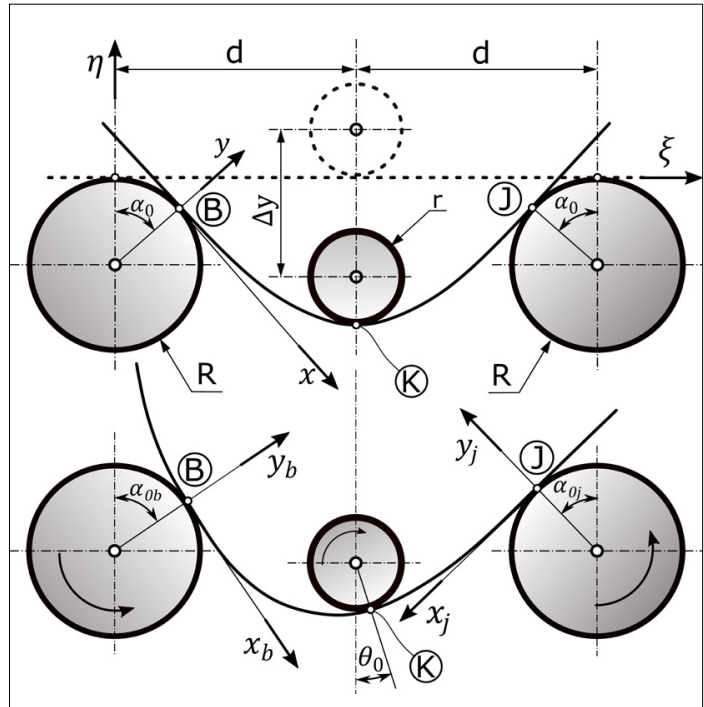

1. ábra. A szerkezet bemutatása: első terhelés (felül) és eltolás (alul)

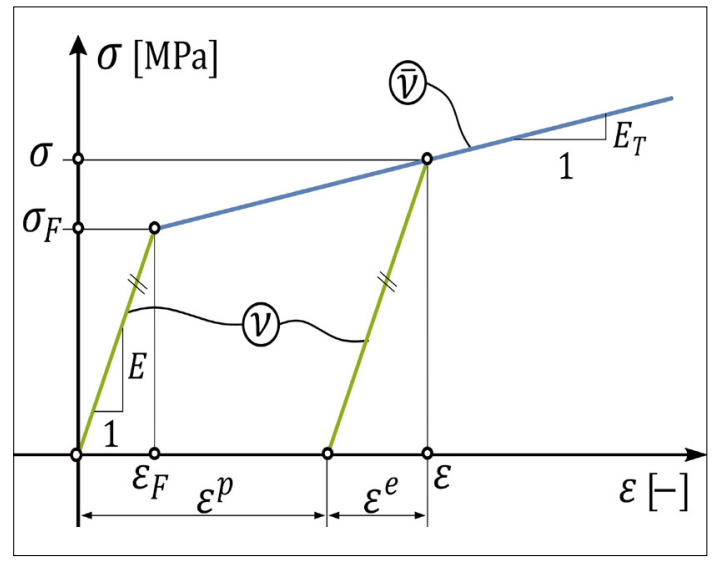

2. ábra. A bilineáris modell húzógörbéje

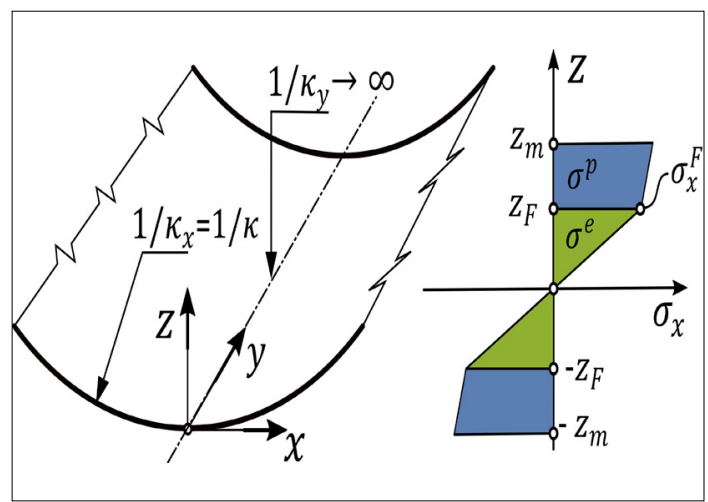

3. ábra. Lemezhajlítás és feszültségeloszlás
A rugalmas tartománybeli feszültség és alakváltozás összefüggését az (1) egyenletben található Hooke-törvény adja meg, amelyet a (2) egyenlet szerint adaptáltam a képlékeny tartományra, a kezdőpont $\left(\sigma_{F} ; \varepsilon_{F}\right)$ pontba való eltolásával. A továbbiakban a Kirchhoff-féle lemezmodellt használom. A konstitutív egyenletben szereplő feszültség- és alakváltozási paraméterek a lemez középsíkjához kötött lokális koordinátarendszerben vannak leírva. A lemezt kizárólag hajlítás terheli, ennek vázlata a 3 . ábrán látható.

A lemezben az $x$ irányú fajlagos nyúlás az $\varepsilon_{X}=\kappa \cdot z$ képlet szerint alakul.

$$
\begin{aligned}
\boldsymbol{\sigma}^{e} & =\left[\begin{array}{l}
\sigma_{x}^{e} \\
\sigma_{y}^{e}
\end{array}\right]=+\frac{E}{1-v^{2}} \cdot \kappa \cdot z\left[\frac{1}{v}\right] \\
\boldsymbol{\sigma}^{\mathbf{p}} & =\left[\begin{array}{c}
\sigma_{x}^{p} \\
\sigma_{y}^{p}
\end{array}\right]=\left[\begin{array}{l}
\sigma_{x}^{F} \\
\sigma_{y}^{F}
\end{array}\right]+\frac{E_{T}}{1-(\bar{v})^{2}} \cdot \kappa \cdot\left(z-z_{F}\right)\left[\frac{1}{\bar{v}}\right]
\end{aligned}
$$

A folyási határ paramétereihez Huber-MisesHencky-féle egyenértékű feszültséget használom fel. A rugalmas zóna határán fennálló feszültségállapot a (3) képlet szerint alakul.

$$
\boldsymbol{\sigma}^{\mathbf{F}}=\left[\begin{array}{c}
\sigma_{x}^{F} \\
\sigma_{x}^{F}
\end{array}\right]=\frac{\sigma^{F}}{\sqrt{1-v+v^{2}}} \cdot\left[\begin{array}{l}
1 \\
v
\end{array}\right]
$$

Fontos továbbá ismerni a lemezen belüli rugalmas és rugalmas-képlékeny zónák határát, illetve, hogy milyen terhelésnél jelentkezik folyás. Ehhez definiálom a határgörbületet és a lemezvastagság mentén a zónahatárt az (4) és (5) egyenletek szerint.

$$
\begin{aligned}
& \kappa_{H}=\frac{\sigma^{F}}{z_{m}} \cdot \frac{1}{E} \cdot \frac{1-v^{2}}{\sqrt{1-v+v^{2}}} \\
& z_{F}=\frac{\sigma^{F}}{\kappa} \cdot \frac{1}{E} \cdot \frac{1-v^{2}}{\sqrt{1-v+v^{2}}}
\end{aligned}
$$

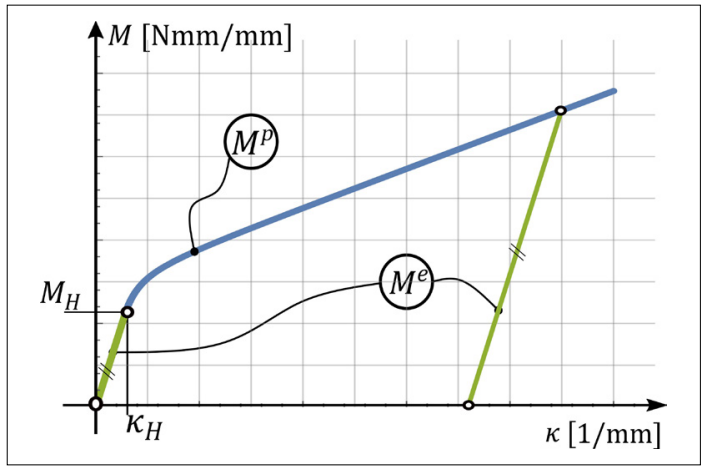

4. ábra. A lemez hajlítógörbéje 
A lemez hajlításához szükséges élnyomaték a feszültségmező integrálásából adódik. Az elasztikus $\left(M^{e}\right)$ és a már megfolyt $\left(M^{p}\right)$ állapotban szükséges nyomatékok összefüggései a (6) és (7) képletek szerint alakulnak , a görbülettől való függésük a 4. ábrán látható.

$$
\begin{aligned}
& M^{e}(\kappa)=\lambda \cdot \kappa \\
& M^{p}(\kappa)=a+\frac{b}{\kappa^{2}}+c \cdot \kappa
\end{aligned}
$$

Az $a, b, c, \lambda$ anyag- és geometriafüggő konstansok, a (8)-(11) egyenletek szerint.

$$
\begin{aligned}
& \lambda=\frac{2}{3} \cdot \frac{E}{1-v^{2}} \cdot z_{m}{ }^{3} \\
& a=\frac{z_{m}{ }^{2} \cdot \sigma^{F}}{\sqrt{1-v+v^{2}}} \cdot\left(1-\frac{E_{T} \cdot\left(1-v^{2}\right)}{E \cdot\left(1-\bar{v}^{2}\right)}\right) \\
& b=\frac{\sigma_{F}{ }^{3} \cdot\left(v^{2}-1\right)^{2} \cdot\left(E+E_{T} \cdot\left(v^{2}-1\right)-\bar{v}^{2} \cdot E\right)}{3 \cdot E^{2} \cdot\left(1-v+v^{2}\right)^{\frac{3}{2}} \cdot\left(\bar{v}^{2}-1\right)} \\
& c=\frac{2 \cdot E_{T} \cdot z_{m}{ }^{3}}{3 \cdot\left(1-\bar{v}^{2}\right)}
\end{aligned}
$$

\subsection{A plasztikus Poisson-tényező}

A plasztikus tartományban elfogadott a feltételezés, hogy az alakváltozás képlékeny komponense nem okoz dilatációt [1]. Ha ezt alkalmazom a bilineáris anyagmodellre, a (12) egyenlet adódik. Az összefüggés levezetése az egytengelyű húzásra történt, de feltételezem, hogy a kapott Poisson-tényező $\left(v_{p}\right)$ bármilyen alakváltozási állapotra érvényes.

$v_{p}\left(\varepsilon_{x}\right)=\frac{1}{2}-\left(\frac{1}{2}-v\right) \cdot\left[\frac{\varepsilon_{F}}{\varepsilon_{x}}+\frac{E_{T}}{E} \cdot\left(1-\frac{\varepsilon_{F}}{\varepsilon_{x}}\right)\right]$

Arra való tekintettel, hogy a konstitutív egyenletben szereplő Poisson-tényező csak a folyáshatár utáni tartományra vonatkozik, definiálom a $\bar{v}$-t a (13) egyenlet segítségével.

$$
\bar{v}=\frac{\varepsilon_{y}-\varepsilon_{y}^{F}}{\varepsilon_{x}-\varepsilon_{x}^{F}}=\frac{1}{2}-\left(\frac{1}{2}-v\right) \cdot \frac{E_{T}}{E}
$$

\section{Numerikus modell}

\subsection{Modellezési eszközök}

Mivel a lemeznek csak az egyik irányban létezik zérustól különböző görbülete, ezért az jellemezhető a középsíkjának a hengerek tengelye menti vetületével az 5 . ábra szerint. A lemezt hosszában véges számú, $\Delta s$-hosszúságú elemből építem fel, ahol az egyes csomópontokhoz tartozó paraméterek numerikus integrálás eredményei. A lemezt továbbá jobb és bal oldali részre osztom, majd addig iterálom a lemezre ható erőket amíg a két lemezrész megfelelő közelítéssel egy másodrendben folytonos görbét alkot, úgy, hogy közben ugyanazon, $\boldsymbol{K}$ pontban érintői a középső görgőnek. Az érintkezési csomópont indexe mindig „ $i_{0}$. Az első terhelésnél elegendő az egyik oldali lemezrész számítása a szimmetria miatt. Eltolás esetén megbomlik a szimmetria, így külön vizsgálni kell a két alsó görgőn ébredő erőt. Az egyes csomópontokra a rekurziót a (14)-(18) képletekkel adom meg.

A folyamatot az alsó görgőkön ébredő erő vezérli, így indirekt módon adódik az összefüggés a középső henger elmozdulása és a görbületfüggvény között. Az eltolást a lemez újbóli, adott számú csomóponttal áthelyezett terhelésével modellezem [2]. A terhelés és az érintkezési pont eltolódása csak a $\boldsymbol{B}$ pontra van kikötve, a többi kiadódik a számításból.

$$
\begin{aligned}
& M_{i}=\left(x_{i-1}+\Delta s \cdot \cos \left(\varphi_{i-1}\right)\right) \cdot|\mathbf{f}| \\
& \kappa=\left\{\kappa^{*} \mid M_{i}=M\left(\kappa^{*}\right)\right\} \\
& \varphi_{i}=\varphi_{i-1}+\Delta s \cdot \frac{\kappa_{i}+\kappa_{i-1}}{2} \\
& x_{i}=x_{i-1}+\Delta s \cdot \cos \left(\frac{\varphi_{i}+\varphi_{i-1}}{2}\right) \\
& y_{i}=y_{i-1}+\Delta s \cdot \sin \left(\frac{\varphi_{i}+\varphi_{i-1}}{2}\right)
\end{aligned}
$$

A (15) egyenletben a görbület a megfelelő (6) vagy (7) képletből számítandó. A szögelfordulás megfelelő numerikus integrálásához legalább másodfokú parabolát kell illeszteni szakaszonként a görbületfüggvényre, majd végül a parabolát integrálni.

\subsection{Kontaktpont keresése}

Első terhelésnél a szimmetria kihasználása miatt az 5. ábrán látható $\theta_{0}$ eltűnik, és a kontaktpontban $\alpha_{0}^{\prime}=\varphi_{i_{0}}$. Így elég azt a csomópontot keresni, ahol a (19) egyenlet teljesül.

$$
d=\left(R+y_{i_{0}}\right) \cdot \sin \left(\varphi_{i_{0}}\right)+x_{i_{0}} \cdot \cos \left(\varphi_{i_{0}}\right)
$$

Eltolás esetén a megbomlott szimmetria miatt a középső görgőn elmozdul a $\boldsymbol{K}$ pont $\theta_{0}$ szöggel. $\mathrm{Az}$ 5. ábrán látható $\boldsymbol{\rho}$ vektor már konstansnak számít, és a $\xi-\eta$ rendszerben adott. A feladat itt 
az $\alpha_{0}{ }^{\prime}$ szög keresése. A megoldáshoz a (20) egyenlet szerint számoljuk az $\alpha_{0}^{\prime}$ szög szinuszát és koszinuszát. Megoldás ott van, ahol ezek megfelelő pontossággal kielégítik a Pitagorasz-tételt.

$$
\left(\begin{array}{c}
\cos \left(\alpha_{0}^{\prime}\right) \\
\sin \left(\alpha_{0}^{\prime}\right)
\end{array}\right)=\left(\begin{array}{cc}
\rho_{\xi} & -\rho_{\eta} \\
\rho_{\eta} & \rho_{\xi}
\end{array}\right)^{-1} \cdot\left(\left(\begin{array}{l}
x_{i_{0}} \\
y_{i_{0}}
\end{array}\right)-\mathbf{r}_{1}-\mathbf{r}_{2}\right)
$$

\section{Következtetések}

Azonos anyagi és gépi paraméterek mellett, négy csomópontos síkelemekkel végzett szimuláció eredményei összehasonlítva a numerikus eljárással a 6. ábrán láthatóak. A véges elemhez használt elemek síkfeszültségi állapotban vannak. A vastagság mentén a felbontáshoz 8 elemet alkalmaztam, A. Ktari et al. [3] alapján. Itt a görbületet három szomszédos, a középfelületen található csomópont köré írható kör sugara adja.

A 6. ábrán egy hozzávetőlegesen 35 mm-es eltolás után észlelhető görbületeloszlás van ábrázolva, a lemez gépből való eltávolítása nélkül, az ívhossz függvényében. A függvényen jelölt $\boldsymbol{B}, \boldsymbol{K}, \boldsymbol{J}$ pontok a 1. ábra szerinti érintkezési pontok helyei a folyamat leállítása pillanatában, míg a $\boldsymbol{K}^{0}$ jelű pont a legelső terhelésnél a középső görgővel való érintkezési pontot jelöli. Látható, hogy ott a legnagyobb a görbület, utána pedig egy exponenciálisan csökkenő harmonikus függvényhez hasonló alakot vesz fel.

A számításokhoz használt adatok az 1. és 2. táblázatban találhatóak.

A 6. ábrán szereplő függvények közötti relatív eltérés maximuma 3,2\%, így az eljárás megbízhatónak minősül további kutatáshoz.

\section{1. táblázat. Tesztadatok}

\begin{tabular}{|c|c|c|c|c|}
\hline $\begin{array}{c}\mathbf{E} \\
\text { [GPa] }\end{array}$ & $\begin{array}{c}\mathbf{E}_{\mathbf{T}} \\
\text { [GPa] }\end{array}$ & $\boldsymbol{v}$ & $\begin{array}{c}\mathbf{\sigma}_{\mathbf{F}} \\
\text { [MPa] }\end{array}$ & $\begin{array}{c}\mathbf{z m} \\
\text { [mm] }\end{array}$ \\
\hline 210 & 21 & 0.3 & 230 & 0.08 \\
\hline
\end{tabular}

2. táblázat. Tesztadatok

\begin{tabular}{|c|c|c|c|c|}
\hline $\begin{array}{c}\mathbf{R} \\
{[\mathbf{m m}]}\end{array}$ & $\begin{array}{c}\mathbf{r} \\
{[\mathbf{m m}]}\end{array}$ & $\begin{array}{c}\Delta \mathbf{y} \\
{[\mathbf{m m}]}\end{array}$ & $\begin{array}{c}\mathbf{d} \\
{[\mathbf{m m}]}\end{array}$ & $\begin{array}{c}\mathbf{\Delta s} \\
{[\mathbf{m m}]}\end{array}$ \\
\hline 7.5 & 4 & 4 & 13.5 & 0.001 \\
\hline
\end{tabular}

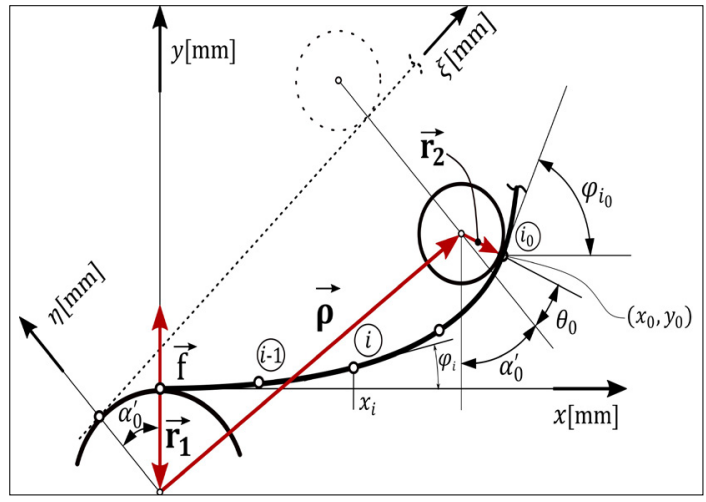

5. ábra. A lemez mechanikai ábrája

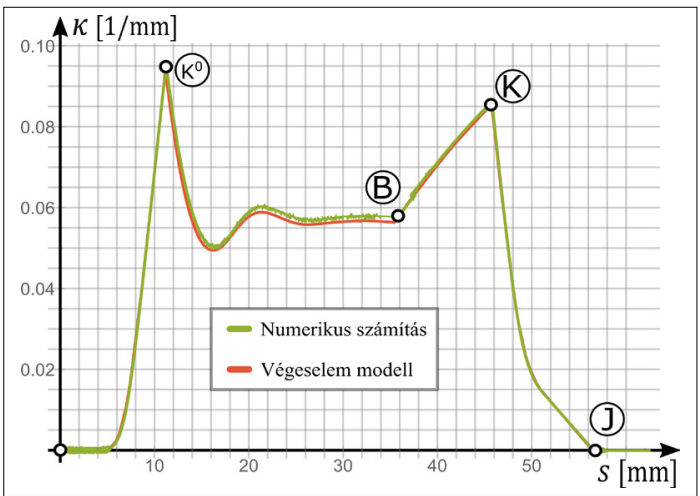

6. ábra. A numerikus eljárás összehasonlítása végeselem-módszerrel

\section{Szakirodalmi hivatkozások}

[1] Shin J. G., Lee J. H., Kim Y. I., Yim H.: Mechanicsbased determination of the center roller displacement in three-roll bending for smoothly curved rectangular plates. KSME International Journal, 15/12 (2001) 1655-1663. https://doi.org/10.1007/BF03185120

[2] NASA Technical Reports Server, A Study of Poisson's Ratio in the Yield Region. 1952. (letöltve: 2020. február 26.).

https://ntrs.nasa.gov/archive/nasa/casi.ntrs.nasa. gov/19930083272.pdf

[3] Ktari A., Antar Z., Haddar N., Elleuch K.: Modeling and computation of the three-roller bending process of steel sheets. Journal of Mechanical Science and Technology, 26 (2012) 123-128.

https://doi.org/10.1007/s12206-011-0936-4 


\title{
KITERJESZTETT PROJEKTÜTEMEZÉSI FELADATOK MEGOLDÁSA
}

\section{SOLVING EXTENDED PROJECT SCHEDULING PROBLEMS}

\author{
Mihály Krisztián, ${ }^{1}$ Kulcsár Gyula ${ }^{2}$ \\ Miskolci Egyetem Alkalmazott Informatikai Intézeti Tanszék, Miskolc, Magyarország \\ 1 altmihaly@uni-miskolc.hu \\ 2 iitkgy@uni-miskolc.hu
}

\begin{abstract}
Project based planning and execution is used in various phases of a product lifecycle, starting from the conceptual idea and design through to the manufacturing and maintenance. It is common, that an enterprise or an organization executes more than one project in parallel. These projects may share the same resources and may have differing goals. Based on experience the order of task execution is a key factor, having a major impact on the key performance indicators. Our paper presents an extended model and a scheduling method for resource constrained project scheduling problems.
\end{abstract}

Keywords: project scheduling, generation scheme, multi-objective, multi-project, extended RCPSP.

\section{Összefoglalás}

A projektalapú tervezés és végrehajtás egy termék életciklusának különböző fázisaiban jelenthet meg, kezdve a koncepcionális elképzeléstől és tervezéstől egészen a gyártásig és karbantartásig. Általánosságban elmondható, hogy egy vállalat vagy szervezeti egység egynél több projektet hajt végre párhuzamosan. Ezek a projektek közös erőforrásokon osztozhatnak, és különböző célokat szeretnének megvalósítani. Gyakorlati tapasztalatok alapján az elvégzendő feladatok végrehajtási sorrendjének kulcsszerepe van,és alapvető hatást gyakorolnak a teljesítménymutatókra. Cikkünkben az erőforráskorlátosprojekt-ütemezési probléma egy kiterjesztett modelljét és ütemezési módszerét mutatjuk be.

Kulcsszavak: projektütemezés, generálási séma, többcélúság, párhuzamos projekt, kiterjesztett RCPSP.

\section{Projektütemezés}

A projektalapú feladat-végrehajtás napjainkban nagyon sok üzleti és ipari területen megtalálható. Projektelven lehet megszervezni például egy egyedi termékfejlesztést, egy sportesemény megszervezését vagy egy projektalapú gyártást. A projektütemezés témaköre nagy múltra tekint vissza, és a felhalmozott ismeretanyag ellenére egy továbbra is aktívan kutatott terület, mivel- a speciális eseteket most nem tekintve - az NP nehéz feladatok körébe soroljuk [1].

Kutatásunkban egy ismert erőforráskorlátosprojekt-ütemezési feladattípust új szempontokkal egészítettünk ki, melyre keresünk hatékony leíró modellt és projektütemező eljárásokat. Kidolgoztunk egy új megoldási koncepciót, melyben reaktív szabályalapú módszereket, keresési technikát és szimulációs módszereket kombináltan használunk

\section{Erőforráskorlátosprojekt-ütemezési probléma}

Az erőforráskorlátosprojekt-ütemezési (RCPSP) feladatot az alábbiak szerint adhatjuk meg [2]:

Adott az elvégzendő feladatok egy előre ismert halmaza $\mathrm{T}=\{1,2,3, \ldots, \mathrm{n}\}$. 
Adottak előre ismert erőforrástípusok $\mathrm{K}=\{1,2,3, \ldots, \mathrm{m}\}$. Az erőforrástípusok kapacitása korlátozott, azaz nem végtelen mennyiségben állnak rendelkezésre az erőforrástípusokhoz tartozó erőforrások. Emiatt előfordulhat, hogy adott időpillanatban a feladatok párhuzamos végrehajtásához nem áll rendelkezésre megfelelő mennyiségű erőforrás. Az erőforrások kapacitása előre ismert, melyet a kezdeti ismert állapotból származtatva bármely ütemtervtől függő időpillanatban determinisztikusan meg tudunk határozni. Ezt a kapacitást $\mathrm{R}_{\mathrm{k}}$, $\mathrm{k} \in \mathrm{K}$-módon jelöljük. $\mathrm{Az}$ erőforrástípusokat megújulónak tekintjük, azaz bármely feladat végrehajtása után a feladat végrehajtásához szükséges kapacitás újra rendelkezésre áll (pl. személyek, gépek, eszközök stb.).

A probléma definiálásakor két korlátozó típusú feltételt adhatunk meg. Minden feladat esetén ismert az elkezdéshez szükséges feladatok halmaza, melyet $\mathrm{P}_{\mathrm{i}}$-vel jelölünk. Egy $\mathrm{i} \in \mathrm{T}$ feladat akkor végezhető el, ha minden $\mathrm{j} \in \mathrm{P}_{\mathrm{i}}$ feladat végrehajtásra került. Egy feladat végrehajtásához szükség lehet egy vagy több erőforrástípusból egyedileg előre meghatározott kapacitásra. A feladat akkor hajtható végre, ha a végrehajtáshoz szükséges kapacitásszükséglet minden erőforrástípusból egyszerre kielégíthető.

Az ütemezési feladat megoldása egy olyan feladat-végrehajtási-sorrendmegtervezését jelenti, melyet a végrehajtás során követve, a kapacitáskorlátokat nem sértjük meg, és az előzési relációk teljesülnek. Ezt végrehajtható projektütemezésnek (röviden ütemezésnek) nevezzük. Amennyiben több végrehajtható ütemezés is létezik, akkor az ütemezési feladat célfüggvény megadásával specializálható. Az ütemezési feladat megoldása során arra törekszünk, hogy a célfüggvény figyelembevételével a lehető legjobb végrehajtható ütemezést állítsuk elő.

\section{Kiterjesztett modell}

A második fejezetben bemutatott feladatot az alábbi szempontok figyelembevételével terjesztettük ki.

\subsection{Több célfüggvény együttes alkalmazása}

Két végrehajtható ütemezés közül azt tekintjük egy minimalizálandó célfüggvény szempontjából jobbnak, amely megoldás esetében a kapott függvény-érték kisebb. Maximalizálandó célfüggvény esetében a nagyobb célfüggvényérték jelenti a jobb megoldást. Ismert és gyakran használt minimalizálandó célfüggvény például a legkésőbbi feladat befejezési ideje $\left(C_{\max }\right)$, a késéssel befejezett munkák száma és a legnagyobb késés $\left(\mathrm{L}_{\max }\right)$. Maximalizálandó célfüggvényre példa az erőforrástípusok átlagos kihasználtságának mértéke. Valós példák alapján egy ütemezés beváltságának kifejezése nehezen fogalmazható meg egyetlen célfüggvénnyel.

Ekkor egy lehetséges módszer az, hogy egy új, több szempontot figyelembe vevő célfüggvényt alakítunk ki. Ez történhet egy új teljesítménymutató bevezetésével, melyre célfüggvényt lehet definiálni, vagy - praktikusan - egy új összetett célfüggvény kialakításával, melyet az ismert célfüggvények súlyozásával definiálunk.

A kidolgozott megoldási stratégiánkban a célfüggvényértékek relatív változásainak súlyozási módszerét használjuk. Ennek lényege, hogy mindig két lehetséges ütemezést hasonlítunk össze. Több célfüggvény szerint kiszámítjuk a két megoldás értékeit. Adott célfüggvény esetében az értékek különbségét elosztjuk a nagyobb értékkel, így megkapjuk a relatív változás előjeles értékét. Ezt elvégezve minden célfüggvény esetében, majd az elemi relatív változásokat összegezve megkapjuk a változások eredőjét. Ha a célfüggvények nem egyformán fontosak, akkor súlyfaktorok hozzárendelésével fejezzük ki azok fontosságát. Végül az elemi relatív változások súlyozott összege mutatja meg a két vizsgált megoldás egymáshoz viszonyított hatékonyságát. Ez a módszer tetszőleges számú és típusú célfüggvényre alkalmazható.

\subsection{Párhuzamosan futó projektek}

Az RCPSP-feladat egy projektet és az ahhoz tartozó feladatokat és megkötéseket írja le. Ennek kiterjesztéseként modellezzük azt az esetet, amikor az erőforrásokat nem egyetlen projekt feladataihoz kell hozzárendelnünk, hanem több, párhuzamosan futó projekt feladataihoz. Az egyes projektek egymástól nemcsak a végrehajtandó feladatokban és korlátozó feltételekben térnek el, hanem eltérő célfüggvényekkel is rendelkezhetnek.

Egy lehetséges módszer, hogy a feladatok halmazához hozzáadunk két új feladatot az alábbiak szerint:

- egy virtuális, globális GS-projekt-kezdőfeladatot, GS $\in$ T. A GS-feladat minden eredeti projekt, minden előfeltétel nélküli feladatának megelőző feladataként vezetjük be;

- egy virtuális, globális GT-projektzárófeladatot, GT $\in$ T. A GT feladatnak előfeltétele lesz minden olyan feladat, amely az eredeti definíció szerint nem előfeltétele más feladatnak. 
Ezzel a modellezéssel a párhuzamosan futó feladatok problémája egy egyprojektes ütemezési feladattá redukálható, azonban a projektek közötti eltérő célfüggvények miatt egy új, egyesített célfüggvény létrehozása szükséges. Ez a gyakorlatban sokszor nehézségbe ütközik.

\section{Alkalmazott modell}

A kiterjesztett feladat modellezése során az RCPSP-probléma alapelemeiből indultunk ki. Így értelmezzük a feladatokat, a projekteket, az erőforrástípusokat. Egy projekt megadásakor a projekt azonosító adatain és a projekthez rendelt feladatokon kívül a projekthez tartozó célfüggvények súlyát lehet megadni. A lehetséges célfüggvények listája a jelenlegi implementációban előre megadott, de az alkalmazott szoftverarchitektúra lehetővé teszi később saját célfüggvények implementálását.

A rendelkezésre álló erőforrástípusokat projektektől függetlenül lehet megadni. Egy erőforrástípust az azonosítóján kívül a kapacitását leíró függvénnyel lehet megadni. Jelenlegi megvalósításban egy erőforrástípus kapacitáskorlátja konstans függvénnyel írható le, de a kialakított architektúra lehetővé teszi időben változó kapacitáskorlát modellezését is.

A végrehajtandó feladatokat, a feladatok erőforrástípusonként szükséges kapacitásigényét, valamint a feladatok közötti megelőzési relációt feladatonként lehet megadni.

\section{Alkalmazott ütemező}

Az alkalmazott ütemezőalgoritmus két fő komponensből áll: egy generálási sémán alapuló ütemterv készítőt, illetve egy heurisztikus keresőt integrál.

A generálási séma elvén alapuló projektütemező működését tekintve egy üres ütemtervből indul ki, és minden iterációban a még nem ütemezett feladatok listájából egy feladatot ad a projektütemtervhez. Az iterációban a következő ütemezendő feladat választásakor a megadott korlátokat mindig figyelembe veszi, azaz csak olyan feladatot tekint végrehajthatónak, melynek minden előfeltétele teljesült, és a szükséges erőforrásigénye egyszerre kielégíthető. A végrehajtható feladatok meghatározását tekintve megkülönböztetünk soros és párhuzamos generálási sémát. A soros ütemezési séma elsődlegesen az előfeltételek teljesülését veszi figyelembe. A döntési halmazba azok a feladatok kerülnek, amelyeknek minden előfeltétele teljesült. Ezek közül az aktuális pillanatnak megfelelően a legnagyobb prioritású (összességében a legfontosabbnak tűnő) feladat kerül kiválasztásra. Ezt a feladatot ütemezi be az algoritmus úgy, hogy az erőforrástípusokból igényelt kapacitások együttállása szempontjából a lehető legkorábbi kezdési időponttal rögzíti az ütemezésben.

A párhuzamos generálási séma elsődlegesen a feladatok legkorábbi indíthatóságára helyezi a hangsúlyt. Egy közbenső állapotban a döntési halmazt úgy állítja elő, hogy meghatározza a legkorábban indítható feladatok listáját. A soros generálási sémától eltérő módon, itt nem az összes indítható munkát veszi alapul a döntési halmaz meghatározásához. A döntési halmazból viszont ugyanazzal a prioritásalapú módszerrel választ jelöltet, amelyiket a soros séma is használja.

Amennyiben több feladat is megfelel a kritériumoknak, (azonos prioritásúak) úgy a generálási séma az ilyen feladatok közül véletlenszerűen választ.

Megközelítésünkben a véletlenszerü választás helyett egy determinisztikus kiegészítést alkalmaztunk, hasonlóan más publikált kiegészítésekhez. Egyetlen heurisztikus módszer helyett azonban több feladatkiválasztási heurisztikát együttesen alkalmazunk, melyek súlyát a felhasználó által megadott paraméterek alapján vesszük figyelembe. A generálási séma működése így közvetlenül a felhasználó által megadott paraméterek szerint befolyásolható.

A generálási sémát szimulációs modulként tekintve, egy heurisztikus keresőt is implementáltunk, mely során a heurisztikus kereső feladata a feladatkiválasztási heurisztikák súlyának iteratív módosítása.

\section{Megvalósítás}

A kiterjesztett probléma megoldására egy új ütemező szoftvert fejlesztettünk ki, melynek fő moduljait szemlélteti az 1. ábra.

Minden modul objektumorientált ABAP felhasználásával került kialakításra. Az egyes modulok egymástól ABAP-interfészek használatával elkülönítettek. Az alkalmazott interfészek célja a modulok szeparált funkcionális tesztautomatizálásának lehetősége és az implementációs alternatívák rugalmasságának elősegítése.

Az egyes modulok által megvalósított funkciók és a modulok felelősségi körei: 


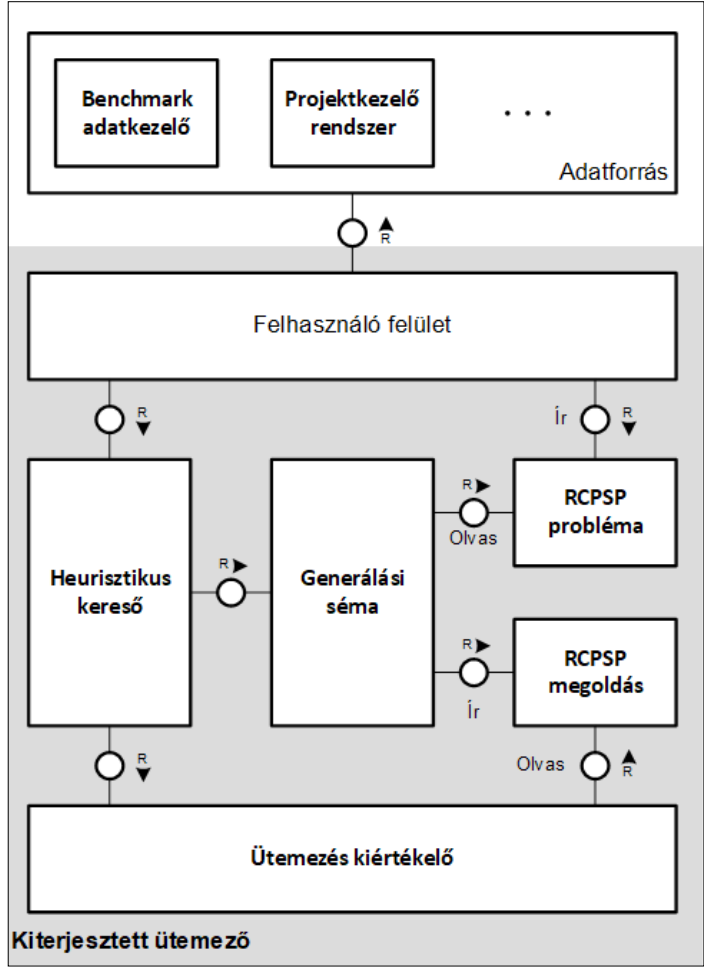

1. ábra. Kiterjesztett ütemező moduláris felépítése

- RCPSP-probléma

Feladata a kiterjesztett modell adatainak futásidejü tárolása. Modellezett írási és olvasási interfésszel rendelkezik. A modellezett interfészek célja, hogy a használati viszony más modulokkal jól szeparált legyen;

- RCPSP-megoldás

Feladata a kiterjesztett modell egy megvalósítható ütemezésének reprezentálása. Tárolja az egyes feladatok hozzárendelésének sorrendjét és ütemezési idejét a különböző erőforrástípusokhoz. Modellezett írási és olvasási interfésszel rendelkezik;

\section{- Generálási séma}

Feladata a kiterjesztett RCPSP-probléma soros generálásiséma-alapú megoldása, melyhez bemenetként az RCPSP problémaolvasási interfészét, valamint a választási lépést befolyásoló szelekciós heurisztikai paramétereket és súlyokat leíró adatát használja. A generálási séma a determinisztikusan kialakított megoldást az RCPSP-megoldás-író interfészén keresztül tárolja el;

- Heurisztikus kereső

A heurisztikus kereső a felhasználó által megadott célfüggvények, a korábban generált RCPSP megoldás(ok) alapján módosít a heurisztikus vezérlőparamétereken, majd újabb RCPSP megoldás(oka)t generál;

- Ütemezés kiértékelő

Az ütemezési kiértékelő a végrehajtható ütemezést értékeli ki a felhasználó által megadott projek célfüggvények alapján;

\section{- Adatforrás}

Több adatforrás-illesztő áll rendelkezésre, melyek különböző céllal rendelkeznek. A benchmark adatkezelő feladata, hogy ismert és más módon leírt ütemezési feladatokat a kiterjesztett modell szerinti leírásra készítsen. A projektkezelő rendszerillesztő feladata, hogy SAP PM-modul által leírt projektek adatait a kiterjesztett ütemező által elvárt formátumra képezze. További lehetséges adatforrás a példafeladatok adatbázisa, mely szerepe az implementáció helyességének ellenőrzése integrációs teszteken keresztül.

\section{Eredmények}

A kiterjesztett modellt és a megtervezett ütemezőt implementáltuk a tanszéken telepített SAP Netweaver 7.50fejlesztői tesztkörnyezetben. A modell- és az algoritmusimplementáció nem tartalmaz SAP-specifikus elemeket, azok más, objektumorientált nyelvre leképezhetőek. Választásunk oka, hogy SAP PM-modullal történő integráció SAP-platformon lehessen megvalósítható a későbbiekben.

Az elkészült új implementációt összevetettük ismert alapproblémákra ismert megoldásokkal, mely során két módszert alkalmaztunk.

Az elsőben a kiterjesztett modellre képeztünk olyan speciális megkötésekkel rendelkező ütemezési feladatokat, amelyekre létezik ismert, optimumot szolgáltató ütemező algoritmus. Ismeretes, hogy a kétgépes, előzés nélküli Flow Shop-ütemezési feladatra a Johnson-algoritmus optimális megoldást ad $\mathrm{C}_{\max }$ célfüggvény esetén [3]. A keresési eljáráson alapuló modellünk kis problémák esetén nagy valószínűséggel (>95\%) megtalálta az optimumot.

Második esetben az alap-RCPSP-problémát képeztük le a kiterjesztett modellre, és $C_{\text {max }}$ célfüggvény szerint publikált legjobb eredményekkel vetettük össze [4], [5]. A benchmark feladatokra futtatva az ütemezőt összehasonlítottuk az ismert legjobb eredményekkel. Azt tapasztaltuk, hogy kisméretű problémák esetén döntő többségben (>70\%) az ismert legjobb megoldást megtalálta az ütemezőrendszerünk. 


\section{Következtetések}

Cikkünkben összefoglaltuk a kiterjesztett, erőforrás-korlátos, többprojektes, többcélú ütemező modellünk legfontosabb jellemzőit.

A kiterjesztett modell alkalmas a már korábban ismert feladatok kezelésére. Figyelembe véve a rugalmasságból adódó eltérést, a specializált algoritmusok jobb teljesítményt mutatnak.

$\mathrm{Az}$ általunk javasolt megoldási koncepció lehetővé teszi nagyon sokféle ütemezési feladat megoldását. Ez az implementált szoftver segítségével tudtuk igazolni. A klasszikus ütemezési feladatok jelentős része megfogalmazható a kiterjesztett feladat egy speciális eseteként. Ezáltal a szoftver támogatja az ilyes feladatok megoldását. Ez a gyakorlat szempontjából nagyon fontos. A különböző cégek számára egy ilyen alkalmazás nem igényel egyedi fejlesztést, nem kell a rendszerbe forráskódszinten újabb elemeket hozzáadni.

Az elért eredmények alapján folytatjuk a megoldási algoritmusok és az implementáció fejlesztését.

A továbbfejlesztés egyik fő iránya az, hogy újabb generálási sémát dolgozunk ki az ütemezési stratégia finomítása érdekében. Egy másik tervezett irány az, hogy a megoldás előállításának vezérfonalát jelentő, heurisztikus algoritmust kiegé- szítjük új módosító operátorokkal. A fejlesztési irányok közé tartozik továbbá az is, hogy az ütemezendő projektelem kiválasztásakor új összehasonlító algoritmust fejlesztünk ki.

\section{Szakirodalmi hivatkozások}

[1] Garey M. R., Johnson D. S.: Computers and Intractability; A Guide to the Theory of NP-Completeness. 1st Edition, Series of Books in the Mathematical Sciences, W. H. Freeman; 1979.

[2] Kolisch R, Hartmann S.: Heuristic Algorithms for Solving the Resource-Constrained Project Scheduling Problem: Classification and Computational Analysis. In: Weglarz J. (ed) Project scheduling. Recent Models, Algorithms and Applications. International Series in Operations Research \& Management Science 14., Springer, 1999, 147-78.

[3] Johnson, D. B.: Efficient Algorithms for Shortest Paths in Sparse Networks. Journal of the ACM, 24/1. (1977) 1-13. https://doi.org/10.1145/321992.321993

[4] Kolisch R., Sprecher A.: PSPLIB - A project scheduling problem library: OR Software - ORSEP Operations Research Software Exchange Program. European Journal of Operational Research, 96/1. (1996). 205-216. https://doi.org/10.1016/S0377-2217(96)00170-1

[5] Project Scheduling Problem Library - PSPLIB: Datasets. . (letöltve: 2019. december 1.) http://www.om-db.wi.tum.de/psplib/data.html 


\title{
AZ OTTHONTEREMTÉS JÖVŐJÉNEK KATALÓGUSA
}

\section{THE CATALOG FOR OUR FUTURE HOME}

\author{
Molnár Eszter, ${ }^{1}$ Borsos Ágnes ${ }^{2}$ \\ Pécsi Tudományegyetem Müszaki és Informatikai Kar, Pécs, Magyarország \\ ${ }^{1}$ meszter.arch@gmail.com \\ 2 agnesborsos@mik.pte.hu
}

\begin{abstract}
Today's continuously growing society has a strong influence on efficiency within the construction industry. The need to build new homes in a shorter period of time increases. Finding the solution to this problem is a key element in today's world. In connection with this there was a defining initiation in the 1900s with the development of „type design”, which even today has a significant role in architecture. These „type design” buildings used parts which were prefabricated, making certain phases of construction quicker. At the end of the XX. century the appearance of these plans seemed to be insufficient for the expected result. In the XXI. century there is an attempt to create another plan sample catalogue which can reflect building to productivity and try to minimalize the time for home development.
\end{abstract}

Keywords: home, future, catalog, type design, prefabrication.

\section{Összefoglalás}

A folyamatosan növekvő társadalom a mindennapok rohanásában az építőipar hatékonyságát jelentős mértékben befolyásolja. Egyre nagyobb az igény újabb és újabb otthonok létrehozása iránt minél rövidebb idő alatt. Ennek megoldása napjaink egyik kiemelkedő feladatává vált. Ezzel kapcsolatban már az 1900-as években megjelent egy fontos kezdeményezés a típustervek létrehozásával, melyek közül megannyi jelenleg is meghatározó szerepet tölt be. Ezek az épületek már magukban hordozták az előregyártás különféle elemeit, mellyel a különféle munkafázisokra fordított időtartamot sikerült csökkenteni. A XX. század végén azonban ezeknek a terveknek a megjelenése csekély volt, és nem hozták meg a kívánt eredményt. A XXI. században újabb kísérletet tesznek egy mintaterv-katalógus létrehozására, mely reflektálhat az építőipar termelékenységére, és egy otthon létrehozásához szükséges időt csökkentheti.

Kulcsszavak: otthon, típusterv, katalógus, elöre gyártás, jövő.

\section{Bevezetés}

Az otthonteremtés napjaink egyik kiemelkedő megoldásra váró feladata. Jelenkori törekvések is ezt igazolják, hiszen egyre több otthonteremtési támogatást hoznak létre annak érdekében, hogy mindenki igényét kiszolgálják. A támogatások megjelenése azonban nem minden szempontból jelent megoldást. Az építőipar megterhelése növekvő tendenciát mutat, melynek köszönhetően egyre kevésbé lesz képes ellátni időben a ráháruló feladatokat. Az egyik legnagyobb jelenlevő probléma az építőanyagok és a jó munkaerő hiánya, melyekből folyamatos késlekedések és többletköltségek alakulhatnak ki egy kivitelezés során. Ezek a gondok már a XX. században jelen voltak, és erre minduntalan igyekeztek megoldást találni. Ennek a problémának napjainkig nem sikerült a végére járni, azonban megjelent egy komolyabb próbálkozás egy új mintaterv-katalógus létrehozására. A mintaterv-katalógus magában foglal 
számos korszerü és régi korokat megidéző típusterveket. Ezek olyan ötletek és tervek, melyek ismételhetők, sokszorosíthatók, többször is felhasználhatók különféle területeken és telepítési helyzetekben. Ezek az épületek azonban az alapkoncepciót megtartva, az adott helyszínre adaptálva minden egyes alkalommal egyedi értéket fognak képviselni. A mintatervek a kiviteli szintű tervek mellett egy BIM-modellt is tartalmaznak, melyek helyszíni megtekintésre is alkalmazhatók egy-egy ellenőrzés vagy fennakadás esetén, illetve már a tervezés során felmerülő akadályok kiküszöbölésére is alkalmasak.

\section{A XX. század típustervei}

Európa lakosságának száma az 1950-es évek óta napjainkig közel 200 millió fővel növekedett [1]. Az építőipar ezzel a folyamatosan gyarapodó népességgel és az újonnan megjelenő igényekkel próbálja tartani a lépést. A XX. században végbemenő ipari forradalomnak köszönhetően számos technológia alakult ki, melynek köszönhetően az építéstechnológia folyamatosan fejlődött. A megjelenő eszközök nemcsak a technológiákat alakí-

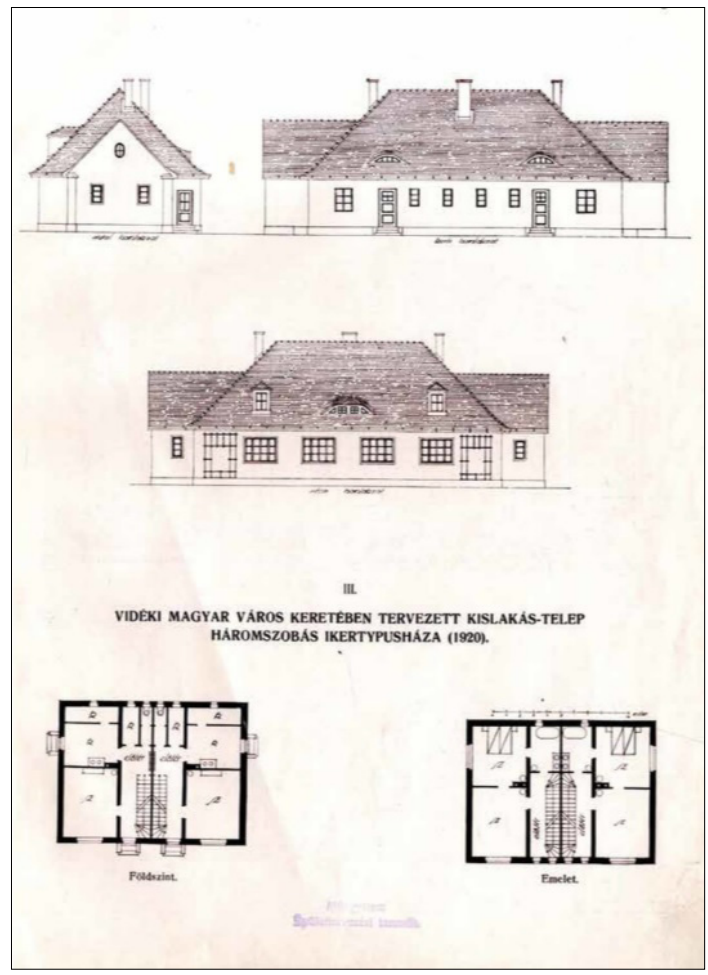

1. ábra. Vidéki magyar város keretében tervezett kislakás-telep háromszobás ikertípusháza, 1920. [2] - 1/18-as kép tották át, hanem a mindennapi élethez szükséges funkciókban is meghatározó szerepet töltöttek be (1. ábra). A városok fejlesztése a népesség gyarapodásával növekvő tendenciát mutatott, míg a falvak folyamatos elszegényedést és elhagyatottságot mutattak. Közel 507 olyan zsáktelepülés alakult ki, melyek csupán egy útvonallal kapcsolódnak a fő tengelyekhez. Ezeknek a településeknek a gazdasági helyzete a XX. században meginduló urbanizáció hatására redukálódott, és1970-2011 között a vizsgált települések népessége 71\%-kal csökkent [2]. Annak érdekében, hogy a települések ne váljanak semmivé, már az 1900-as évek első ütemében olyan törekvések jelentek meg, melyek az otthonok hiányos helyzetének megoldására és az eltűnések megelőzésére adhatnak választ. Az első lépések között volt Darányi Ignác segélyezési indítványozása, melyet a minisztérium lépései követtek. Ezeknek a lényege egy mintaház-akció meghirdetése volt, melyek közül számos épület tekinthető a század első mintaházpéldájának.

Ezt követte Lechner Ödön újabb pályázata, mellyel egy időben jelentek meg hitelekkel kapcsolatos támogatási programok. 1927-ben a Falusi Kislakásépítő Szövetkezetek által került meghirdetésre az első ilyen program, melynek köszönhetően közel 43000 embernek adtak kölcsönt kizárólag lakásépítés céljából. 1940-ben hozták létre az Országos Nép- és Családvédelmi Alapot. A programnak köszönhetően, több, mint 12000 típuslakást építettek fel a rászoruló nagycsaládok részére. Ezeket a terveket a mintaterveknek megfelelően kivitelezték, amit a különböző tájegységek épületei inspiráltak. 1948-ban létrehoztak egy mintaterveket összefoglaló kötetet, mely az egy évvel korábban meghirdetett pályázati anyagokat tartalmazta. Ebben a pályázati anyagban három csoportot különböztettek meg: a gazdálkodó-lakóház, munkáscsalád-lakóház és a szellemi foglalkozásúak számára tervezett házak csoportját. A kötetnek megjelenésével egy időben megjelent egy rendelet, amely megfogalmazta, hogy a tervekhez tartozó engedélyek díjmentesek legyenek. A II. világháborút követő időszakban a központilag épített lakóépületek és a falusi otthonok kerültek előtérbe. A lakóépületek a növekvő munkaerő elszállásolására voltak alkalmasak a telephelyekhez közel, ezzel is növelve a munkásosztály kiszolgálását. A népességnövekedés és a városokban megjelenő kedvező kínálatok a városok felé meginduló tömeget eredményezték. 1956 után szüntették meg az államosítást, mely a magánlakás-építések újraindítását tette lehetővé. 
Több mint 700000 elavult és elhagyatott lakás megszüntetését tűzték ki célul. Az 1966. évi törvényben fogalmazták meg: „A lakásviszonyok javítására 300 ezer lakás építését kell biztosítani, állami lakás ebből 100 ezer legyen. Hiteltámogatással, megfelelő anyagellátással és építőipari kapacitással elő kell segíteni 200 ezer lakás magánerőből történő magánépítését”. Továbbá azt is megfogalmazták, hogy „10 milliárd forint hosszú lejáratú hitellel, típustervekkel segítsék a lakosságot”. Az 1960-as évek végén meghirdettek egy országos szintű pályázatot, melynek hatására megépítették Bitó János tervét, amely később a mintaházak elemeként szolgált. A terveknél figyelembe kellett venni az akkoriban jelen levő építőanyagokat és technológiákat is a kivitelezhetőség érdekében. Az 1970-es évek végén megjelent egy hasonló tervpályázat, mely 135 tervet tartalmazott, és 2 katalógus is készült belőle: Magánlakás-építés ajánlott tervei és a családi házak. Ebben az időszakban ezek a típustervek nagy hírnévre tettek szert (2. ábra). 10 év alatt több mint 100 ezer tervet értékesítettek. A típustervek folyamatos fejlesztése mellett megjelent az igény a melléképületek létrehozá-

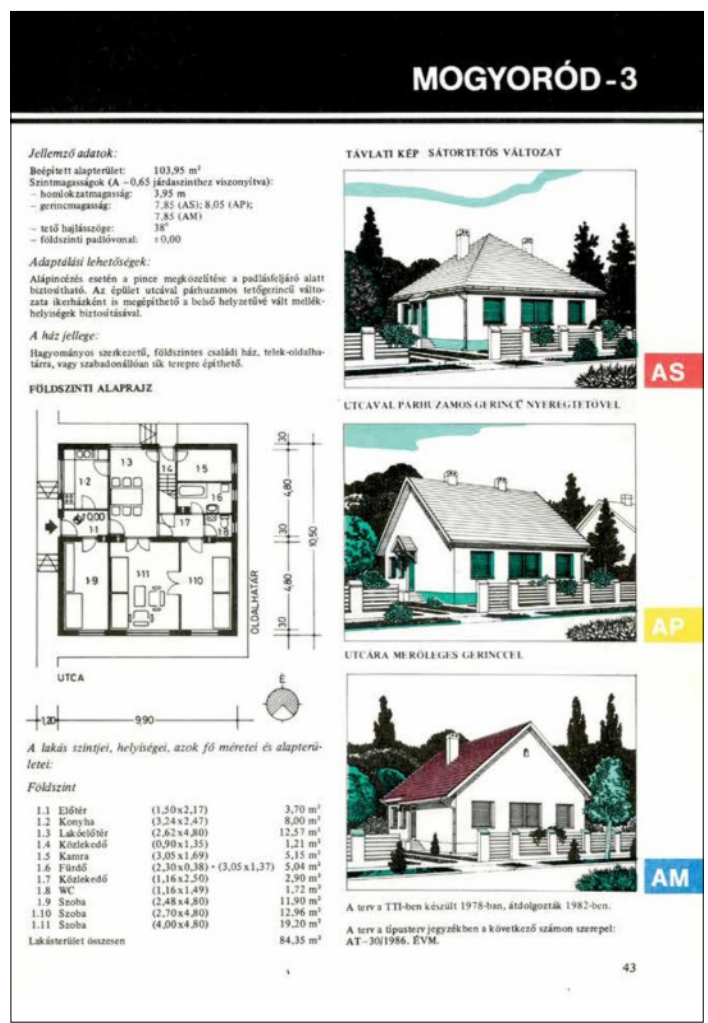

2. ábra. A magánerős lakásépítés ajánlott tervei, 1988, [3] - 10/18-as kép sára és a tetőterek beépítésére. 1990-től a cégek által ajánlott típustervek kezdték uralni a piacot. Ennek a következménye egy nehezen átlátható kínálat lett az építtetők számára. Ezzel az indíttatással egy időben megjelent a magánérdek felértékelődése, és a magánépítészek vették át az irányítást a mintaházak felett [4].

\section{A XXI. század típustervei}

A XXI. századra kialakult magánérdekek előtérbe helyezésének végeredménye a mintaházak számának csekély számban való megjelenése lett. A 2015-2016-os években létrehoztak egy kormányrendeletet a Családok otthonteremtési kedvezménye néven, amely anyagi segítséget nyújthat azoknak, akik saját ingatlant szeretnének. A Lechner Tudásközpont által létrehozott statisztikai adatok megmutatják, hogy a városok lélektani száma milyen mértékben növekedett 2001-től 2011-ig [5]. Ezt a kialakuló urbanizálást a városok által nyújtott kedvező életkörülmények váltották ki. Nagyobb a választék a munkahelyek, a beiskoláztatás és a lakókörülmények között is. Ez a megoldás egyszerübbnek kínálkozik, mint a falvakból való bejárás a városközpontokba. A Lechner Tudásközpont létrehozott egy Zsáktelepüléseink kétarcúsága elnevezésű interaktív térképet, mely megmutatja hogyan változik napról napra az alacsony lélekszámú települések aránya [6]. Egy további térkép, melyet szintén a Lechner Tudásközpont hozott létre, pedig megmutatja, hogy különböző életszakaszokban miként változtak a különböző lakhatásra szolgáló épületek számai. A legnagyobb építési százalék jól láthatóan 1971-1980 közé integrálódott elszórtan az ország teljes területén. 2011-2014 között az a százalék már Budapestre és környékére korlátozódott, illetve csekély mértékben még egy-két nagyvárosra és környezetére [7]. Ezek az adatok is azt igazolják, hogy egyre többen keresnek lakhatást a nagyvárosokban akár szülőfalvakat, településeket is elhagyva ezzel. Ennek megelőzésére 2019-ben létrehozták a Falusi családok otthonteremtési kedvezményét, mely kimondottan a programban részt vevő falvakban ad anyagi támogatást a betelepülőknek. A falvakban egy családi ház egy nagyvárosi kislakáshoz képest jutányos áron kínálkozhat az érdeklődők számára. Ezek az adatok azonban tájegységenként változnak, a nagyvárosokhoz közeledve növekedhetnek. Számolva azzal, hogy a kedvező családtámogatási programoknak köszönhetően a lélektani arány gyarapodik a községekben, a Lechner Tudásközpont 2019 
áprilisában kiadott egy országos ötletpályázatot egy új mintaterv-katalógus létrehozására, melynek kiadását 2020-ra ütemezik. A 273 beérkezett tervből 93 mintaház került megvásárlásra. Ennél a pályázatnál is megjelenik a hármas csoportosítás, mint az 1948-ban létrehozott ötletpályázatban. Ezek a kategóriákat a mindennapok igényeinek megfelelően hirdették meg: a Kádár-kockák újragondolása, a kalákában megépítendő családi házak és az okosotthonok formájában.

Ezeknek az objektumoknak a megtervezésénél figyelembe kellett venni a mobilitást a különböző beépítési módokhoz és terepviszonyokhoz való alkalmazhatóság okán. A cél, hogy az ingatlanok létrehozása során a tervezéstől kezdődően a kivitelezésig minden gördülékeny legyen, és az időtartam ne növekedjen jelentős mértékben a kialakuló hiányok és problémák miatt. Ebből kifolyólag ezek a tervek már rendelkeznek a szükséges számú engedélyekkel, illetve előregyártott elemekből készülnek. Az üzemekben előkészített szerkezetek és az adott elemekhez tartozó cégek által biztosított munkaerő hatására minimalizálható a késedelmi fázisok aránya, és ezzel együtt a halmozódó többletköltségek aránya is. A megvásárolt épületek között jobbnál jobb és különféle frappáns megoldások találhatók, azonban mindegyik terv tükrözi a falvakban megjelenő formavilágokat valamilyen jelképként. Ezzel az új mintaterv-katalógussal egy újabb korszak kezdődhet el a községek fejlesztésének életében. Ezekkel a létesítményekkel a kívülálló, elnéptelenedő falvakban megjelenhet a modernizáció, a technológiai fejlődések maradandó nyoma, és ezáltal vonzóbbá válhatnak a társadalmi rétegek számára, mely népességnövekedést eredményezhet az elnéptelenedő településeken. A 2020-ban megjelenő mintaterv-katalógus elődjeinek tapasztalataiból merítettek ihletet egy korszerü összefoglalás megalkotására, mely a tervek szerint minimum

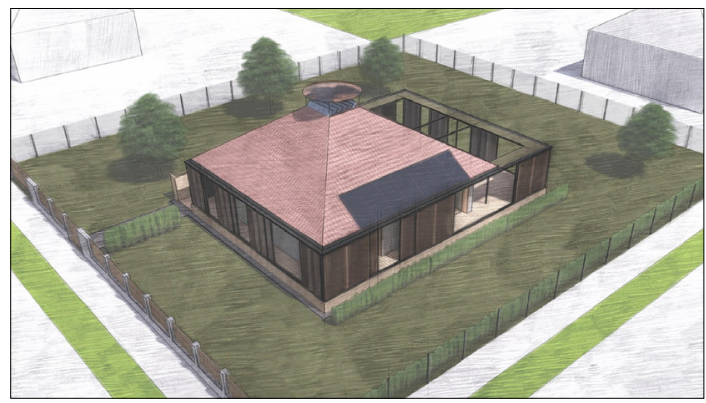

3. ábra. Lechner-mintaterv-katalógus: Kockaház-átalakitás, Hegedüs Csilla terve. [8]
50 évig kiszolgálhatja az építtetőket és tervezőket is egyaránt (3. ábra). Ezek a mintaterv-katalógusok ugyanis nem csak azok számára kínálnak megoldást, akik saját otthont szeretnének teremteni, hanem egyfajta útmutatást is adhatnak a tervezőknek, akik inspirációt szerezhetnek egy-egy stílusirányzatból, és ezáltal fejleszthetik és tágíthatják saját látásmódjukat. A mintatervek lényege a szerkezetek teljes mértékű előregyártása és helyszíni összeszerelése. Ezek a megoldások az ábrán is látható mértékben befolyásolják az átlagos otthonok létrehozásához képest az építési ciklusra. A bevezetésben már szó volt a BIM-modell létrehozásáról, mely újdonságként szerepel a mintatervek életében, hiszen a XX. században ezzel még nem tudtak szolgálni. Ezeket a terveket a helyszínen tabletek vagy különböző hordozható eszközök segítségével megnyitva, egyszerűen áttekinthetővé válik az épület szerkezetileg és esztétikailag is. Ezek a tervek egy általános otthon létrehozásával szemben nem tartalmaznak rejtett költségeket, hiszen előre meghatározott ütemterv készül hozzájuk. Ezzel reagálhatnak arra a problémára, mely a különféle építkezések során létrejövő többletköltségekkel járhatnak, illetve a kivitelezést is meggyorsíthatják az előregyártott elemek és a kivitelezést megelőző gördülékeny tervadaptációk is egyaránt. A diagramon jól látható a különbség, mely mindegyik esetben a legrosszabb és legköltségesebb helyzeteket feltételezi (4. ábra).

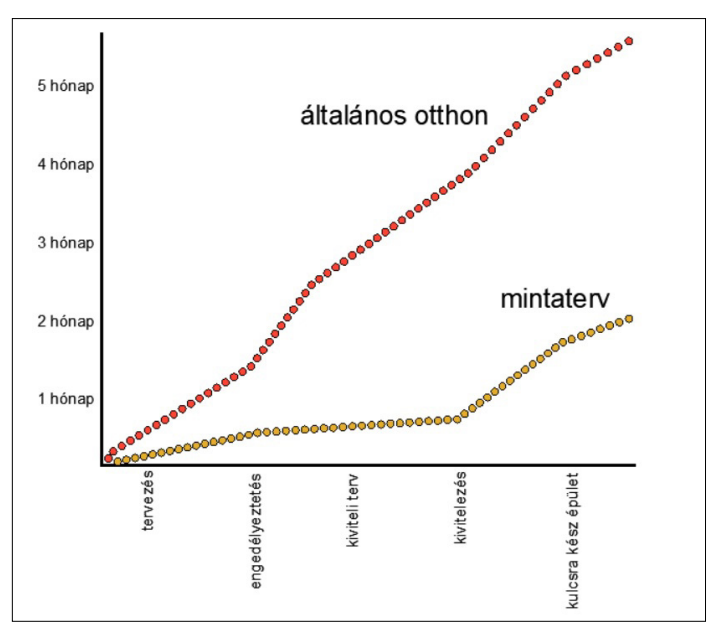

4. ábra. A mintatervek és általános otthonok létrehozásának ciklusai (saját ábra) 


\section{Okosotthon}

Ebben a fejezetben a típustervpályázatra készített tervemet, annak koncepcióját és konklúzióját fogom bemutatni. A terv létrehozásában a [9-19] voltak az inspirációim. Az általam választott okosotthon-kategória kiemelkedő részét képezi az elöregedő települések fejlődésében, hiszen az ott megépülő létesítmények korszerüsítése napjainkban elengedhetetlenné válik. Az alaprajzi elrendezésnél figyelembe vettem a különböző helyiségek egymáshoz való viszonyait és kapcsolatait a különböző társadalmi változások figyelembe vételével. Napjainkban előtérbe kerülnek az amerikai típusú konyhák, így tervemben is hasonlóképpen került kialakításra a konyha. Az egybenyitott terek egyre inkább praktikussá és esztétikailag elhanyagolhatatlanná válnak. A földszinti és emeleti elrendezésben is egyaránt érvényesül az egybenyitott terek növelése optikai hatások eszközének segítségével (5. ábra). Az épületen elhelyezett nagyméretű nyílászárók megfelelő elhelyezése csak erősíti az optikailag megnövelt térérzetet (6. ábra). A funkciók úgy kerültek kialakításra, hogy a különböző telekhelyzeteknél megjelenő tájolásoknál alkalmazhatók legyenek. A helyiségek kialakításánál a tájoláson kívül az otthonteremtési programokban meghatározott négyzetméterarányok is meghatározó szerepet képviseltek. A terv egy négyfős család számára készült, így három hálószoba helyezkedik el az emeleten. Az otthonok megtervezésénél egyik

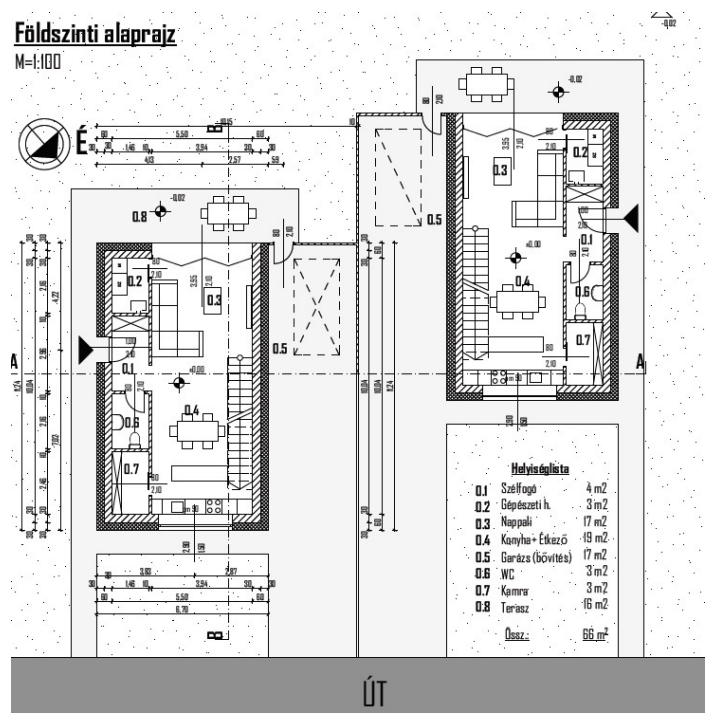

5. ábra. Lechner Mintaterv Katalógus-tervpályázatára készült ikerház beépítéses családi ház (saját terv)

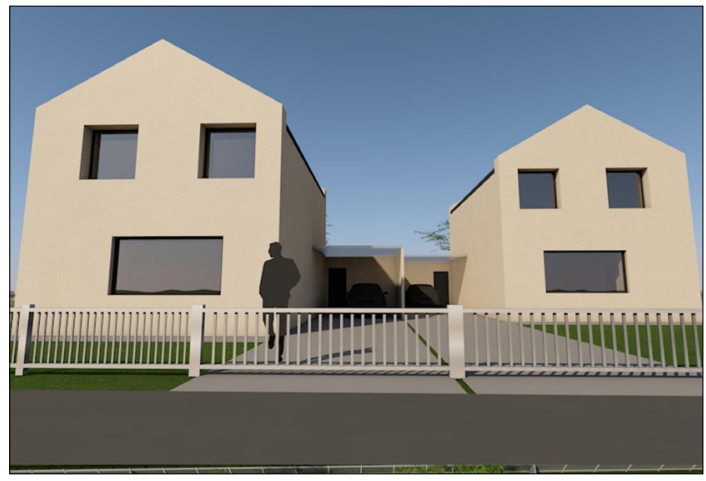

6. ábra. Lechner Mintaterv Katalógus-tervpályázatára készült saját tervezésü okosotthon látványterve (saját terv)

kritérium a későbbi bővíthetőség volt, melyet egy adott helyiséggel vagy külső kertkapcsolattal kellett elérni.

Az okosotthon kategóriában a különböző természeti elemek hasznosítását tǔztem ki célul, ezért a tetőburkolaton megjelennek napelemmel rendelkező cserepek, melyek ellátják az épület energiakészletét. Elektromos fütés, illetve légkondicionálás került kialakításra és olyan szellőztetőberendezések, melyek nem igényelnek számottevő energiafelhasználást. Az épület szerkezete előregyártott elemekből lenne kivitelezhető, mely gördülékennyé tenné az építkezést.

\section{Következtetések}

A mintaterv-katalógusok kihívása továbbra is a fennmaradásuk és a mindennapi életbe való integrálódásuk. A Lechner által létrehozott katalógust fél évszázadra tervezik, mely egy kísérleti fázisként is felfogható, hogy hogyan tudnak érvényesülni ezek a tervek. A jelen katalógusban szereplő tervekben érvényesülnek a kortárs építészeti kifejezések és a régmúlt idők fortélyait felölelő elemek is, tökéletes egységet alkotva együtt. Az általam készített terv is ennek szellemében formálódott, és további fejlesztéseken megy keresztül, hogy minél élhetőbb és kivitelezhetőbb megoldás valósulhasson meg, mely megfelel a különböző társadalmi rétegekben megjelenő igényeknek, mint a napjainkban egyre fontosabbá váló környezettudatos életmód. A naponta újuló technológiákkal kísérletezve, a szerkezeti megoldások is nyomon követhetők lesznek annak érdekében, hogy az épület részletesen értelmezhető legyen. Ezt is segítheti a BIM- vagy más információs modellek felhasználása. Az előregyártásnak és a modern tervfeldolgozásnak köszönhetően 
komoly esélyekkel rendelkezik a típusterv annak érdekében, hogy a mindennapok építészetében figyelemre méltó szerepet tölthessenek be ezek az ismétlődő, de mégis egyedi érdekeket képviselő otthonok.

\section{Szakirodalmi hivatkozások}

[1] Központi Statisztikai Hivatal: A világ népessége kontinensek szerint, 1950-2100. Grafikon.

https://www.ksh.hu/interaktiv/grafikonok/ vilag_nepessege.html?fbclid=IwAR0Z93Apc6Nl1nlPcHnkS1hEyzp1SeFWZTBIP74m7lEMjE5HBAtMfMljevY

[2] Lechner Tudásközpont, Zsáktelepülések kétarcúsága, 2017. március 1.

http://lechnerkozpont.hu/cikk/zsaktelepuleseink-ketarcusaga

[3] Perényi T.: Mintaházak történeti áttekintése, Építész Forum, 2016.07.26.

https://epiteszforum.hu/mintahazak-torteneti-attekintese

[4] BME Lakóépületek tervezési tanszék: Családi házak katalógusa: Ajánlott tervek (letöltve 2019. október 09.)

[5] Lechner Tudásközpont: Lakónépesség változása 2001-2011.

http://portal.lechnerkozpont.hu/arcgisportal/apps/webappviewer/index.html?id=04ca645cf4794d3ab06eb15e0e59009a

[6] Lechner Tudásközpont: Zsáktelepülések statisztikai adatai

http://portal.lechnerkozpont.hu/arcgisportal/ apps/webappviewer/index.html?id=20352668bc1040439b9a09101ceb8aaf

[7] Lechner Tudásközpont: Lakásépítések leggyakoribb időszaka

http://webmap.lechnerkozpont.hu/webappbuilder/apps/foldgomb1701/
[8] Lechner Tudásközpont: Nemzeti mintaterv katalógus 2020.

http://nmtk.lechnerkozpont.hu/terv/nmtk070

[9] A modern építészet elemei-50 kortárs épület értelmezése. Terc, Budapest, 2014.

[10] Építésügyi ás városfejlesztési minisztérium: $L a-$ kás és lakókörnyezet 1983-85.

[11] Szövetkezeti láncházak, sorházak, Budapest, 1977.

[12] Építésügyi és Városfejlesztési Minisztérium: Tervpályázat'79 - magánerős lakóépületek panelos építéstechnológiával.

[13] Branczik M., Keller M.: Korszerü lakás, az óbudai kísérlet. 1960, Terc Kft, 2011

[14] Központi Statisztikai Hivatal: Települések a lét határán, Erősen fogyó népességü törpefalvak Magyarországon, 2014. április.

http://www.ksh.hu/docs/hun/xftp/idoszaki/regiok/fogyonep.pdf

[15] Perényi Tamás: Mintaházak történeti áttekintése, Budapest, 2015. november.

https://epiteszforum.hu/mintahazak-torteneti-attekintese

[16] Hornyik Sándor: A posztkommunista „magyar kocka”, 2014. április.

http://meonline.hu/archivum/a-posztkommunista-magyar-kocka/

[17] A magánlakásépítés ajánlott tervei: Családi házak. Építésügyi Tájékoztatási Központ, Budapest, 1986.

[18] Körner Zs., Nagy M.: Az európai és magyar telepszerü lakásépítés története 1945-től napjainkig. TERC Kft, Budapest, 2007.

[19] Kortárs magyar épitészet, Többlakásos házak. TERC Kft., Budapest, 2012. 


\title{
GÉPI TANULÁSBAN ALKALMAZOTT DIMENZIÓSZÁM- CSÖKKENTŐ MÓDSZEREK
}

\section{DIMENSIONALITY REDUCTION METHODS USED IN MACHINE LEARNING}

\author{
Muhi Kristóf, ${ }^{1}$ Johanyák Zsolt Csaba ${ }^{2}$ \\ Neumann János Egyetem, GAMF Müszaki és Informatikai Kar, Kecskemét, Magyarország \\ 1 muhi.kristof@gamf.uni-neumann.hu \\ 2 johanyak.csaba@gamf.uni-neumann.hu
}

\begin{abstract}
In most cases, a dataset obtained through observation, measurement, etc. cannot be directly used for the training of a machine learning based system due to the unavoidable existence of missing data, inconsistencies and high dimensional feature space. Additionally, the individual features can contain quite different data types and ranges. For this reason, a data preprocessing step is nearly always necessary before the data can be used. This paper gives a short review of the typical methods applicable in the preprocessing and dimensionality reduction of raw data.
\end{abstract}

Keywords: machine learning, dimension reduction, data processing, big data.

\section{Összefoglalás}

A megfigyelésekből szerzett nagy mennyiségű adat legtöbb esetben nem alkalmazható azonnal közvetlenül egy számítási intelligencián alapuló modell tanítására, mivel a gyakorlatban szinte elkerülhetetlen az, hogy hibás, inkonzisztens vagy hiányos adatokat tartalmazzon az adathalmaz. Emellett a különböző jellemzők értékei nagyon eltérő típusúak vagy nagyságrendűek lehetnek, ami különböző átalakításokat tehet szükségessé. A cikkben áttekintjük az adatfeldolgozás tipikus lépéseit.

Kulcsszavak: gépi tanulás, dimenzió csökkentés, adatfeldolgozás.

\section{Adatok előfeldolgozása}

\subsection{Adatok tisztítása}

A mintaadatok alapján történő tanításnál a rendelkezésre álló adathalmaz ún. minták sokasága. Minden mintát egy rekord vagy vektor ír le, azaz egy értéksor, amely különböző jellemzők értékeit tartalmazza az adott minta esetében. Például a KDD Cup 99 [1] adatbázis esetében 41 megfigyelt jellemző van, és 4898431 adatrekord.

Az adattisztítás során kiszürjük azokat a rekordokat, ahol valamely tulajdonságnál nem a megengedett típusú érték áll (pl. hibás protokollazonosító). Emellett az adattisztítás feladata lehet az ismétlődések eltávolítása, mivel a duplán tárolt adatok hibás, félrevezető statisztikákat eredményezhetnek.

\subsection{Hiányzó adatok}

Az adatgyűjtés eredményeként előálló adathalmaz egyes rekordjai hiányosak lehetnek (pl. egy vagy több jellemző értéke nem lett rögzítve). Ilyen esetekben az alábbi stratégiák közül választhatunk.

\subsubsection{Az érintett rekordok (vektorok) elhagyása}

Ez a legegyszerübb megoldás. Ha egy többezres mintahalmazban néhány rekord hiányos (pl. 1\% alatt van az érintett rekordok száma), általában 
különösebb kockázat nélkül elhagyhatjuk az érintett rekordokat. Mielőtt ezen opció mellett döntenénk, érdemes azt is megfontolni, hogy nincs-e jelzésértéke az adott attribútum értékhiányának, pl. hálózati forgalomnál nem lehetséges-e, hogy pont egy támadás eredményeképpen nem sikerült rögzíteni az érintett adatot.

\subsubsection{A hiányzó adatok helyettesítése az adott attribútum átlagértékével}

Ez egy egyszerü megoldás, amely viszonylag könnyen megvalósítható, azonban cserébe nagy lehet annak a kockázata, hogy a kapott adathalmazból teljesen hibás következtetéseket vonunk le.

\subsubsection{A hiányzó adatok pótlása egyesével, emberi munkával}

A megoldás néhány tíz érintett rekord esetében még reális lehet, azonban nagyon költséges és időigényes. Megvalósításának előfeltétele az, hogy valamilyen a priori ismerettel rendelkezzünk a vizsgálat tárgyára vonatkozóan.

\subsubsection{A hiányzó adatok pótlása regressziós/ interpolációs technika segítségével}

A módszer olyan esetben alkalmazható, ha valamilyen szabályosság (pl. lineáris változás) figyelhető meg az adott attribútum egymás utáni rekordokban megfigyelt értékei között vagy az érintett attribútum ún. „függő jellemző", azaz aktuális értéke valamely más attribútum vagy attribútumok értékeiből következik. Amennyiben sikerül egy függő jellemzőt azonosítani, akkor az esetek többségében nem érdemes túl sok energiát áldozni a jellemző hiányzó értékeinek pótlására, ugyanis a dimenziószám-csökkentés során ettől az attribútumtól úgyis megfogunk válni.

\subsection{Függő attribútumok}

Függőnek nevezünk egy attribútumot akkor, ha értéke egyértelműen származtatható egy vagy több másik jellemző értékéből. A függő attribútum értéke egy redundáns adat, amely csak növeli a kezelendő adatmennyiséget, és ezáltal a számítások idő- és tárigényét, azaz költségét. A dimenziószám-csökkentés során egyebek között a függő attribútumok kiszürésére is törekszünk.

\section{4. Átalakítás numerikus alakká}

A minták hasonlóságának értékeléséhez és különböző statisztikák számításához numerikus adatokra van szükségünk. Abban az esetben, ha a címkék/kategóriák/különböző szöveges adatok értékeinél egyértelmű a sorrend és az egymástól való távolság (pl. egyenletes), akkor a feladat könnyen megoldható. Például tegyük fel, hogy három lehetséges címkeértékünk van. Ezek a kicsi, közepes és a nagy. A sorrend egyértelmü, és feltételezhetjük, hogy az egymást követő értékek azonos távolságra vannak. Ilyenkor a három címke előfordulásait 1, 2, és 3-as értékekre cseréljük.

\subsection{Számosságcsökkentés}

Adatok alapján történő modellépítésnél gyakori probléma, hogy nagyon nagy mennyiségű adattal kell dolgoznunk. A nagy mennyiségü adat rendelkezésre állása hasznos, viszont túlzottan megnövelheti a modell felépítéséhez szükséges időt, ezért sok esetben arra kell törekednünk, hogy egyfajta optimumpontra állítsuk be a felhasznált adatmennyiséget úgy, hogy a lehető legkisebb rekordszám mellett a lehető legtöbb információt őrizzük meg az eredeti adathalmazból, azaz a kiválasztott részhalmaz legyen reprezentatív [2].

\section{Dimenziószám-csökkentés}

A modellfelállítás során a rendelkezésre álló adatrekordok gyakran nagyszámú jellemzőt tartalmaznak, ami részben arra is visszavezethető, hogy az adatgyüjtés megtervezésekor még nem rendelkeztek elegendő információval a megfigyelt jelenségre vonatkozóan, így minden elképzelhető, rögzíthető adatot gyűjtenek annak érdekében, hogy minél teljesebb képet kapjunk, és nehogy valami fontos kimaradjon.

A sok jellemző azonban nagy memória- és számításigényt is jelent, ami akár megoldhatatlanná is teheti a feladatot. Ezért törekednünk kell arra, hogy a feladat dimenzionalitását csökkentsük. A dimenziószám-csökkentő módszerek célja az, hogy az eredetileg $m$ dimenziós adatpontokat úgy képezzük le egy $k$ dimenziós térbe (ahol $k<m$ ), hogy [3]

-minél jobban megőrizzük a pontok osztályozhatóságát, azaz az egy osztályba/kategóriába tartozó pontok minél jobban elkülönüljenek a többi osztályba/kategóriába tartozó pontoktól második;

-minimális legyen az információ veszteség.

Számos módszer kínálkozik a feladatra. Elsőként nézzük meg azokat, amelyek nem járnak információvesztéssel, azaz a redundáns adatok kiszűrését célozzák meg. 


\subsection{Információvesztés nélküli dimenzió- szám-csökkentés}

Azoknál az adathalmazoknál, amelyek a „mindent gyüjtünk" elv alapján keletkeztek, könnyen előfordulhat, hogy egy jellemző értéke minden rekordban azonos. Ilyenkor ezt a jellemzőt (vagy oszlopot, ha egy táblázatban/mátrixban gondolkodunk) minden további nélkül eltávolíthatjuk adatbázisunkból. Bár ez egy triviális megoldásnak tűnik, de a gyakorlatban könnyen előfordulhat (ld. az NLS-KDD [4] adatbázis 20\%-os mintanagyságú tanító adatbázisa).

\subsection{Dimenziószám-csökkentés főkompo- nens elemzéssel}

A legtöbb gyakorlati feladatnál kismértékű információvesztés elfogadható kockázatot jelent, ha cserébe jelentős mértékű dimenziószám-csökkenést lehet elérni. Tekintsünk a rendelkezésünkre álló mintaadatokra mint pontokra egy sokdimenziós térben. Ekkor a mintaadatrekord minden egyes eleme a pont egy koordinátáját jelenti ebben a térben. Számos feladatnál ezek a pontok nem véletlenszerűen helyezkednek el a térben, hanem valamilyen szabályosságot követnek, vagy a pontok változékonysága nem minden irányban egyforma.

Például az 1. ábrán a pontok közelítőleg egy egyenes mentén helyezkednek el. Ha felrajzoljuk ezt a képzeletbeli egyenest egy koordinátatengelyként ( $\mathrm{c}_{1}$ az 1 . ábrán) és a rá merőleges koordinátatengelyt is berajzoljuk, akkor megfigyelhetjük, hogy a pontok nagy változékonyságot mutatnak a $c_{1}$ tengely mentén, és viszonylag kicsi a változékonyságuk az arra merőleges $\mathrm{c}_{2}$ irányban.

Amennyiben a pontok merőleges vetületeit képezzük a $c_{1}$ tengelyre, akkor egy olyan pontsort

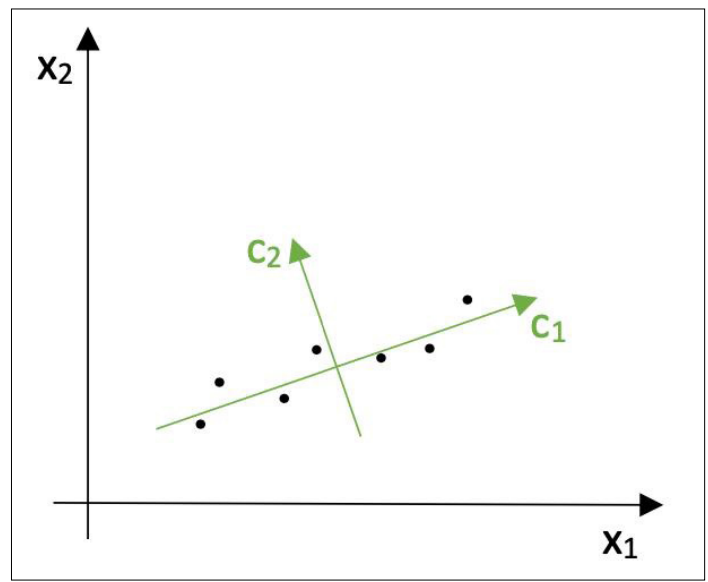

1. ábra. Ponthalmaz új koordináta tengelyekkel kapunk, amely a tengelyen helyezkedik el (piros pontok a 2. ábrán). Ezek a pontok csak kismértékben térnek el az eredeti pontoktól, viszont helyzetük egyetlen koordinátával leírható a c $c_{1}$ tengely mentén. Amennyiben a továbbiakban ezekkel a pontokkal dolgozunk az eredetiek helyett, akkor az eredetileg kétdimenziós adathalmaz dimenziószámát eggyel csökkentettük kismértékű adatvesztéssel.

A főkomponens-elemzés célja ezen tengelyek beazonosítása, majd a pontok koordinátáinak meghatározása az új koordinátarendszerben egy lineáris transzformáció segítségével.

\subsection{Információnyereség-alapú dimenzió- szám-csökkentés}

Az információnyereség- (Information Gain - IG) alapú dimenziószám-csökkentés módszerének alapgondolata a döntési fák elméletéhez (pl. ID 3, C4.5, C5.0 algoritmusok [5]) kapcsolódik, ahol jellemzőkként haladva a kiválasztott jellemző értékei szerint minden döntésnél részhalmazokra bontja a kezdeti halmazt. Az algoritmus alapja az entrópiaszámítás. Az $S$ halmaz entrópiája

$$
E(S)=-\sum_{k=1}^{N} p_{k} \log _{2} p_{k}
$$

a halmaz "szennyezettségét" (inhomogenitását), azaz változékonyságát jellemzi. Itt $\mathrm{N}$ a halmazban előforduló értékek száma és $p_{k}$ az egyes értékek relatív gyakorisága, amit a

$$
p_{k}=\frac{n_{k}}{n}
$$

képlettel számítunk, ahol $n$ az összes halmazelem, $n_{k}$ a $k$. címkével rendelkező halmazelemek száma.

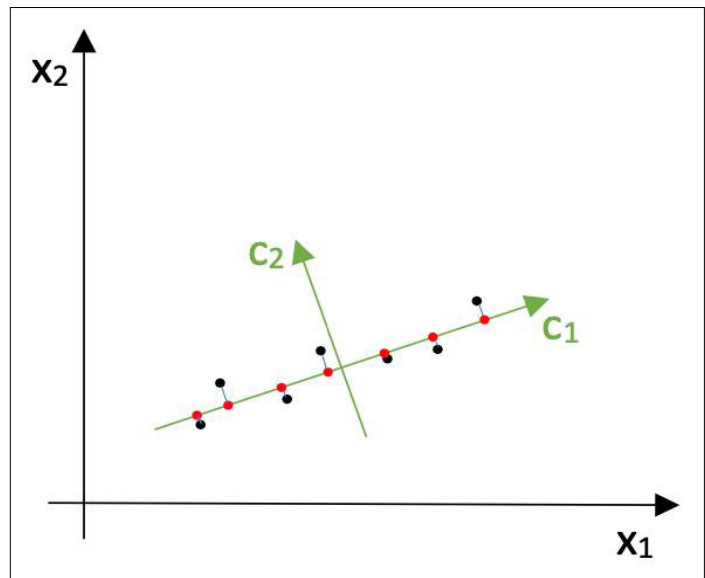

2. ábra. Vetítés a c tengelyre 


\subsection{Véletlen projekciók (Random Projection)}

Az eljárás a pontokat az eredeti $m$ dimenziós térből egy alacsonyabb $r$ dimenziószámú térbe vetíti véletlenszerü lineáris projekciót alkalmazva. A vetítés úgy történik, hogy egy véletlen számokból előállított mátrixxal megszorozzuk a jellemzők mátrixát.

$T=X \cdot R P$, ahol $T \in \mathbb{R}^{n x r}, X \in \mathbb{R}^{n x m}, R P \in \mathbb{R}^{m x r}$ és $R P$ minden sora egység nagyságú vektor

$\left\|R P_{i}\right\|^{2}=1, j=1 . . m$.

A véletlen számok Gauss-eloszlását követik. A módszer jól megőrzi a pontok közötti távolságot, és számításigénye kisebb a PCA-nál. A transzformáció minősége a pontok számától és $\mathrm{r}$ értékétől függ. A 3. ábra az NSL-KDD 20\%-os tanító adathalmaz egy 3D-s véletlen projekcióját mutatja be. A pontok színei a forgalomtípusokra utalnak.

\subsection{T-eloszlású sztochasztikus szomszéd beágyazás (t-Distributed Stochastic Neigh- bor Embedding)}

A t-DSNE eljárás a dimenziószám-csökkentés során arra törekszik, hogy a hasonló pontokat egymáshoz közel tartsa, míg az eltérőket egymástól távol [3]. Az eredeti pontokat úgy modellezi, mintha azok normál eloszlásból származnának, a beágyazott pontokat pedig úgy, mintha azok egy Student(t) eloszlásból származnának. Legtöbbször pontcsoportok (klaszterek) két- vagy háromdimenziós vizualizációjára használják. Az eljárás hátránya, hogy eredményeképpen nem keletkezik egy mátrix vagy képlet, amely lehetővé tenné azt, hogy további (pl. teszt, validációs stb.) adatokat ugyanabba a térbe transzformáljunk az eredeti $m$ dimenziós térből. A 4. ábra bemutatja a t-DSNE-transzformáció eredményét a NSL-KDD

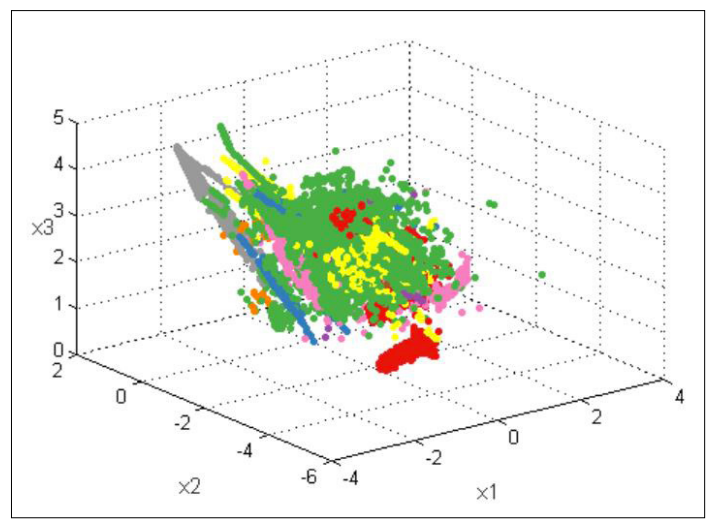

3. ábra. Az NSL-KDD 20\%-os tanító adathalmaz egy véletlen projekciója a háromdimenziós térbe

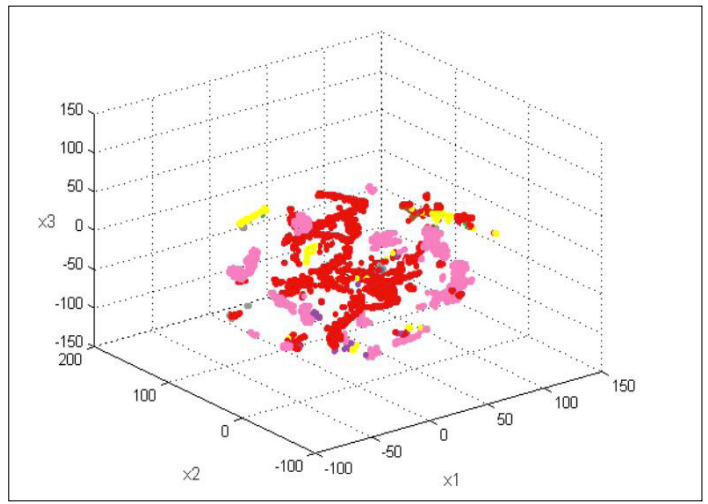

4. ábra. Az NSL-KDD 20\%-os tanító adathalmazból véletlenszerüen kiválasztott 10000 minta t-DSNE-transzformációja a háromdimenziós térbe Chebysev-távolságokat alkalmazva

20\%-os tanító adathalmazból véletlenszerüen kiválasztott 10000 minta esetére.

\section{Összegzés}

A gépi tanulás során felhasználni kívánt nyers mA gépi tanulás során felhasználni kívánt nyers mintaadatok legtöbbször egy előfeldolgozási lépésen kell, hogy átessenek a tényleges felhasználást megelőzően. Ez a lépés magában foglalja a hiányzó adatok problémájának kezelését, a számosság és a dimenzionalitás csökkentését. Cikkünkben röviden áttekintettük az ilyen esetekben leggyakrabban alkalmazott megoldásokat.

\section{Köszönet}

Köszönettel tartozunk a kutatás támogatásáért, amely az EFOP-3.6.1-16-2016-00006 „A kutatási potenciál fejlesztése és bővítése a Neumann János Egyetemen” pályázat keretében valósult meg. A projekt a Magyar Állam és az Európai Unió támogatásával, az Európai Szociális Alap társfinanszírozásával, a Széchenyi 2020 program keretében valósul meg.

\section{Szakirodalmi hivatkozások}

[1] KDD Cup 1999 Data http://kdd.ics.uci.edu/databases/kddcup99/kddcup99.html

[2] Ősz R., Holik I.: Pedagógiai kutatásmódszertan, Óbudai Egyetem, 2015.

[3] Géron A.: Hands-on Machine Learning with ScikitLearn, Keras, and TensorFlow. Concepts, Tools, and Techniques to Build Intelligent Systems, O’Reilly, 2019. ISBN 978-1-492-03264-9

[4] NSL-KDD dataset, https://www.unb.ca/cic/datasets/nsl.html

[5] Mitchell T. M.: Machine learning. McGraw-Hill Science/Engineering/Math, 1997. 


\title{
TÖMÖRÍTÉSI EGYÜTTHATÓ BEFOLYÁSA A HÁROMTENGELYÜ GEORÁCSOKKAL MEGERŐSÍTETT ÚTSZERKEZETEK TARTÓKÉPESSÉGÉRE
}

\section{INFLUENCE OF THE DEGREE OF COMPACTION ON THE BEARING CAPACITY OF A ROAD STRUCTURE REINFORCED WITH TRIAXIAL GEOGRIDS}

\author{
Nagy Andor-Csongor, ${ }^{1}$ Hajdó Harmat, ${ }^{2}$ Kis Ádám, ${ }^{3}$ Moldovan Dorin-Vasile ${ }^{4}$ \\ Kolozsvári Müszaki Egyetem, Epitőmérnöki kar, Tartószerkezet tanszék, Kolozsvár, Románia \\ 1 andor.nagy@yahoo.com \\ ${ }^{2}$ harmat.hajdo@gmail.com \\ 317sadam@gmail.com
}

\begin{abstract}
The degree of compaction for a crashed stone roadbed is one of the most important technical characteristic in road construction works. An insufficient compaction can have significant effects on the resulting bearing capacity, even if the road structure is reinforced with geosynthetic mate-rials. The present study concernes the utility of using geosynthetic reinforcement in the base layer of a road structure, while varying the degree of compaction on 1:1 scale models.
\end{abstract}

Keywords: triaxial geogrid, degree of compaction, bearing capacity of a road structure.

\section{Összefoglalás}

A tömörítési együttható meghatározó műszaki jellemzője az útépítési munkálatoknak. Egy sikertelen tömörítésnek számos olyan hatása van, amely befolyásolja az adott talajszerkezet így kapott teherbíró képességét, még geoszintetikus anyagokkal megerősített töltések esetében is. A tanulmány megvizsgálta a geoszintetikus megerősítésnek az úttöltés alaprétegébe történő elhelyezésének hasznosságát, mindezt a teherbíró képesség vizsgálatával, georács-megerősítéssel, valamint geoszintetikus anyag nélkül, variálva a különböző tömörítési fokokat.

Kulcsszavak: háromtengelyü georácsok, tömörítési együttható, útszerkezetek tartóképessége.

\section{Bevezetés.}

A jelenlegi kutatás kéttípusú 1:1 méretarányú modell fejlesztését foglalta magában. Az egyik egy közúti töltés, amelynek alaprétegét megerősítettük egy triaxiális georáccsal, valamint egy geoszintézis nélküli modellt hoztunk létre. A tanulmányozott szerkezeti modellt egy dobozban valosítottuk meg, amelynek a következőek a tér- beli méretei: $(\mathrm{b} \times \mathrm{L} \times \mathrm{h}) 1,50 \times 2,00 \times 1,00 \mathrm{~m}$, létrehozva a hosszanti nyitással (L) középen egy kihúzható fiókot, amelynek a következőek a méretei: $0,50 \times 1,70 \times 0,25 \mathrm{~m}$, ahogy mindez 1 . ábrán is szemléltetve van.

A fiók eltávolítását követően a vizsgált talajszerkezetet kb. 20 órán át állni hagytuk, amely idő alatt a saját súlya alatt konszolidálódott. Ezt a folyamatot a további kísérletek során is beiktattuk. 


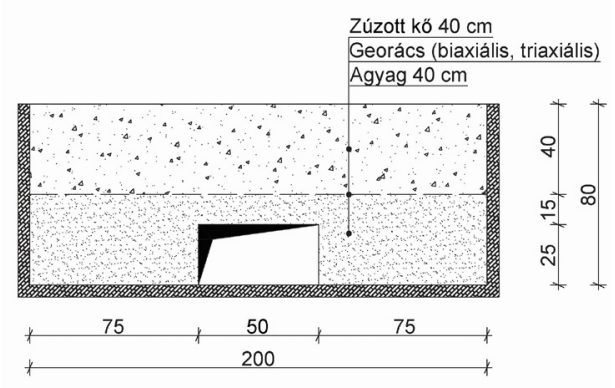

1. ábra. A használt útszerkezet vázlata (a megerősítetlen modell esetében a georácsot elhagyták)

A kísérletek folyamán használt georács típusa TriAx TX140, 40 mm-es háromszögnyílásokkal, illetve a radiális merevségének mértéke $225 \mathrm{kN} / \mathrm{m}$.

Az alsó réteg agyagos növényi talajból, míg a létrehozott közúti alapréteg 0-63-as optimális keverésű zúzott kőből áll. Mindkét réteg $40 \mathrm{~cm}$ vastagságú.

A teherbíró képesség megállapítására használt kísérleti eszköz a Lucas-lemez volt, a kísérlet folyamán a modell statikus terhelését a létrehozott hézag irányába hajtottuk végre, amíg a vizsgált talajszerkezet beomlott. A kísérlet folyamán megfigyeltük a rés deformációit, a használt triaxiális georács csomópontjának eltolódását, amelyek a rés közepén helyezkedtek el, illetve annak szélein.

\section{A modellek megvalósítása}

A tömörítés a GE-026-97 [1] előírásoknak megfelelően történt. Az optimális tömörítési értéket laboratóriumi körülmények közt, normál Proctorteszt segítségével határoztuk meg, úgy, hogy a zúzott kő felső rétegének kiszámítottuk a száraz térfogatsűrűségét (“vizes zacskós módszerrel”, a STAS 1913-15/75 [2] előírásoknak megfelelően), összehasonlítva azt a vizsgált talaj száraz maximális térfogatsűrűségével, mindezt optimális nedvességtartalommal összemérve. A geoszintetikus rács nélküli, valamint az első megerősített modell esetében megfelelő tömörítési eljárást alkalmaztunk, vagyis a két réteget két szakaszban tömörítettük (mindegyik réteget 20 cm-es vastagságúra), többszörös áthaladással, és legalább 4 ütést applikálva mindegyik nyomra. A második megerősített modellben a zúzottkő-réteg nem megfelelően volt tömörítve, mindössze 2 sorozattal, és ennek hatására csak 81\%-os tömörítési együtthatót értünk el ennél a modellnél. Összehasonlítva mindezt az előző modellekhez képest, a különbség számottevő (93-95\% - az előző két modell alkalmával).

\section{A teherbíró képesség vizsgálatának folyamata}

\subsection{Triaxiális georáccsal megerősített modell - optimális tömörítés}

Az első kísérlet alkalmával a teherbíró képesség megállapítása egy triaxiális georáccsal megerősített szerkezeti modellen volt alkalmazva, megfelelő tömörítési együttható alkalmazásával. A statikus terhelés Lucas-lemez felhasználásával valósult meg, amelynek átmérője $300 \mathrm{~mm}$, központi elhelyezkedésü, vagyis a fiók által kialakított hézagra helyezve. A terhelési lépések a STAS 2914/4-89 [3] előírásainak felelnek meg, pontosabban a közúti szerkezeti rendszereknek megfelelően egy $50 \mathrm{kPa}$-os terhelésnövekedéssel, 0.05 mm-es stabilizációs határértékkel, 5 percenként egy-egy mérést követően. Ezt a tesztet addig végeztük, amíg a kísérleti modell szerkezete beomlott [4]. Az első kísérlet alkalmával feljegyzett süllyedések a következőek: $1 \mathrm{~mm} 100 \mathrm{kPa}$ alkalmazásával, $1.5 \mathrm{~mm} 150 \mathrm{kPa}$ terhelés alatt, valamint $3 \mathrm{~mm} 200 \mathrm{kPa}$ terhelés alatt . Az első üreg körüli észrevehető deformáció 10 perc utáni 200 $\mathrm{kPa}$-os terhelést követően volt megfigyelhető, az üreg mennyezete $2 \mathrm{~mm}$ deformálódott. A tanulmányozott szerkezet konszolidációs ideje gyors volt, 15 perc az $50 \mathrm{kPa}$-os terhelési lépésben, 15 perc a $100 \mathrm{kPa}$-os terhelés alkalmával, 20 perc a $150 \mathrm{kPa}-$ os terhelés alkalmával, valamint 15 perc a $200 \mathrm{kPa}$-os terhelési lépésben. A $250 \mathrm{kPa}-\mathrm{os}$ terhelési lépés alkalmával történt az első közepes méretű földdarabka lehullása (2. ábra).

Megállapítottuk, hogy a teljes deformációnak nem volt jelentős növekedése, a 25 perc eltelte utáni mérés $4 \mathrm{~mm}$ nagyságú elváltozást mutatott. A fejlődés hasonló volt a következő terhelési lépésben is, $300 \mathrm{kPa}$ terhelés alatt, továbbra is meg-

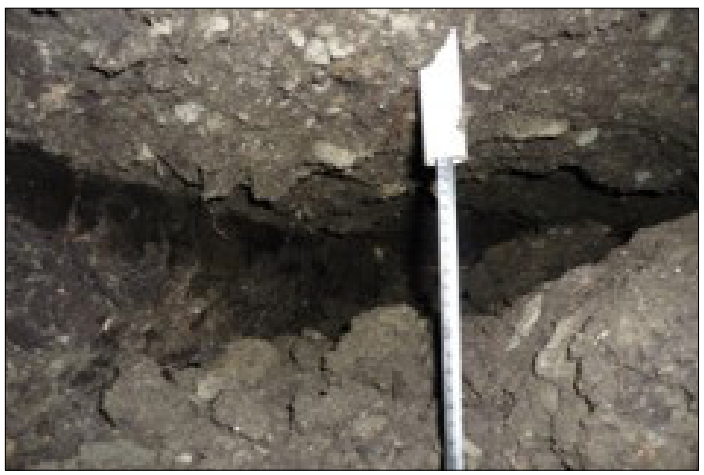

2. ábra. Statikus terhelések következtében az üreg összeomlik 
figyelhető volt a földdarabkák fokozatos leomlása, valamint a stabilizációs határértéket kb. 20 perc elteltével értük el, 5,5 mm-es elváltozással.

A 350 kPa-os terhelés alatt az üreg felső részének nagy felülete beomlott. Egyidejüleg megfigyelhettük a kitöltési ív létrejöttét, amely eloszlatta az üreg közepére mért nyomást az oldalfalak területére. A megerősített szerkezet viselkedésén $400 \mathrm{kPa}$-os terhelés mellett észrevettük, hogy a deformációk csak 25 perc után stabilizálódtak. A vizsgált szerkezet gyorsan konszolidálódott a $450 \mathrm{kPa}$-os terhelés alatt, 20 perc után mérhető volt a deformáció $3 \mathrm{~mm}$-es növekedése (7,0 mm ről 7,3 mm-re). Még az 500 kPa-os terhelési fokra való átváltás sem okozott jelentős deformációkat, az elmozdulások kezdetben $1 \mathrm{~mm}$-t mutattak, majd a vizsgált talajszerkezet stabilizálódásának alkalmával (35 perc terhelést követően) az összelmozdulás értéke $5 \mathrm{~mm}$ volt $(8,0 \mathrm{~mm}$-ről 8,5 mm-re). A triaxiális georáccsal megerősített vizsgált talajszerkezet az $550 \mathrm{kPa}$-os terhelés hatására nagyobb, mint 10 mm-es deformációkat szenvedett el. A konszolidációs időtartamok állandóságát a következő két terhelési szakaszban is megőriztük, 600, valamint $650 \mathrm{kPa}$ terhelés alatt, mindezt 45 perc elteltével. A közúti szerkezet viszonylag keveset deformálódott, $600 \mathrm{kPa}$ terhelés következtében leolvashattunk egy 12,2 mm nagyságú középértéket, valamint 15 mm-t a 650 kPa-os terhelés alkalmával. A zúzottkő-réteg felületén a repedések $700 \mathrm{kPa}$ terhelés alatt jelentkeztek. A következő terhelési szakaszban $(750 \mathrm{kPa})$ egy 2 mm-es konstans értékủ elváltozás volt megfigyelhető olvasási intervallumonként. A 35 perces időintervallumban rögzítettük a belső csomópont első elmozdulását. Ebben a terhelési szakaszban az elmozdulás kissé megnőtt, 15 percet követően elérte a 6,5 mm-es értéket.

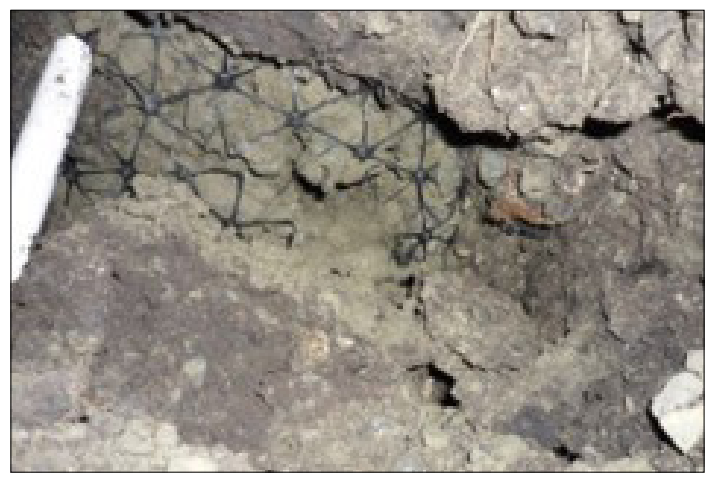

3. ábra. A föld összeomlása eredményeképpen a georács megrongálódik
A következőkben 800 kPa-os erőhatás következtében a vizsgált szerkezet 5 perc után összeomlott. Az üreg körüli földréteg összeomlását követően megfigyelhető volt, ahogy a zúzott kő megragad a georácshálóban, illetve ahogy a triaxiális georács elszakad (3. ábra).

A zúzottkő-réteg és a triaxiális georács eltávolítását követően megállpítható volt, hogy a repedés a nyomáskúp kerületének egy részén történt.

\subsection{Triaxiális georáccsal megerősített modell - sikertelen tömörítés}

Sikertelen tömörítés alkalmával (alacsony tömörítési együttható) a szerkezetnél megfigyelhettük, hogy a 200 kPa-os terhelés alatt a deformációk megnövekedtek, észrevehető már az első mérési lépés alkalmával, deformáció $211 \mathrm{~mm}$ az üreg központi részén, valamint $585 \mathrm{~mm}$ annak szélein. Jól érzékelhető deformációk mutatkoztak meg a 25 perc elteltével végrehajtott mérés alkalmával, számszerűsítve mindezt $210 \mathrm{~mm}$, azonban az üreg mennyezetének hosszirányú repedései is hangsúlyt kaptak. A földréteg ezen szintje alatt 40 percet követően megszilárdult, és a eltolódás csúcsértéke 5,5 mm volt. A következő terhelés alkalmával (250 kPa) az eltolódások láthtóan megugrottak, az üreg eldeformálódott, ezáltal létrehozva az üreg új 208 mm-es központi magasságát, valamint 586 mm-es szélein lévő magasságot. Formai és méretbeli változásokon ment át, elérve a 205 mm-es értéket 55 perc elteltével.

A vizsgált talajszerkezet konstans konszolidációs értékét 65 perc terhelés után kaptuk meg, az utolsó mérési intervallumban az elmozdulás értéke 10,5 mm volt. A 300 kPa mértékű terhelés felgyorsította az elmozdulást az első 20 percben, elérve a 3 mm különbségű elmozduláshoz az alsó terhelési lépcsőhöz képest, majd az elmozdulási értékek konstans módon kezdtek el növekedni, kb. hat tizedmilliméterrel. Ennek a terhelésnek az alkalmával az üreg mennyezete leereszkedett $5 \mathrm{~mm}$ - $\mathrm{t}$ az első mérési adatokhoz képest, és ez a tendencia arra engedett következtetni, hogy 40 perc elteltével a mérések 197 mm-t mutattak a központi elhelyezésű mérőrúdon, és összehasonlítva ezt az első mérési eredménnyel, $215 \mathrm{~mm}$, létrejött egy közel 20 mm-es deformáció. A deformáció továbbítódott az üreg teljes felületén, a mérőrúd ez alkalommal az üreg szélén elhelyezve 589, 590, valamint $591 \mathrm{~mm}$ mértékủ eredményeket mutatott. Tehát a mérőeszközön leolvasott deformációk mértéke konstans növekedést mutatott hat tizedmiliméter értékkel, a vizsgált talajszerkezet 100 
és 110 perc időintervallumban szilárdult meg. Az összelmozdulási érték kb. 22 mm volt.

Az utolsó terhelési lépésben alkalmazott erő, $350 \mathrm{kPa}$, hatására a szerkezet leomlása késleltetve volt az 5 perces időintervallum eléréséig (4. ábra). Ettől a ponttól a szerkezet alsó részének boltozathatása megszűnt, a deformációkat csak a georács megnyúlása vette át.

$\mathrm{Az}$ 5. ábrán megfigyelhető a zúzott kőnek a georácsba való beágyazása, valamint annak kitüremkedése a georács résein. Ettől a pillanattól kezdve az elmozdulások gyors növekedést mutattak, számszerüsítve $3 \mathrm{~mm} /$ perc, valamint az üreg falai összeomlottak.

A triaxiális georács belső csomópontja, fleximéterrel követve, $1 \mathrm{~mm}$-t mozdult el percenként. A $350 \mathrm{kPa}$-os terhelés hatására a georács 12 perc után bomlott meg. Az összeomlás pillanatában 51,6 mm-es elmozdulás volt mérhető a mérőlemez alatt. A törési kúp falai kb. 45 fokos szöget zártak a vízszintes iránnyal. A zúzottkő-réteg, valamint a georács eltávolítása után megmértük a törési kúp

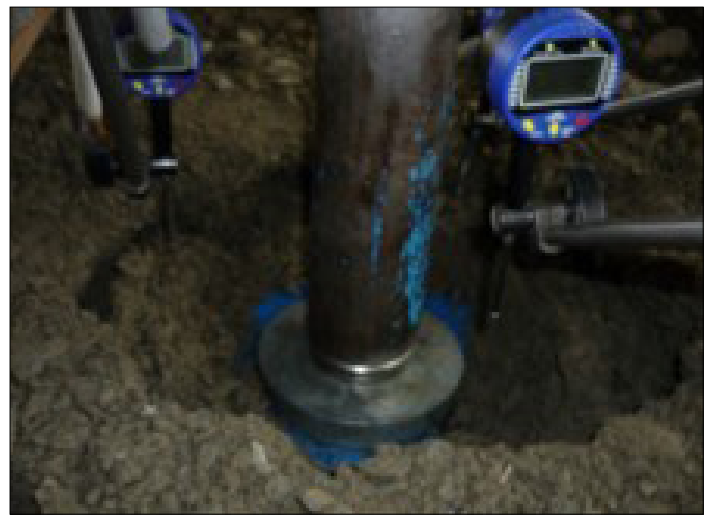

4. ábra. 350 kPa terhelés alatt összeomlik a szerkezet

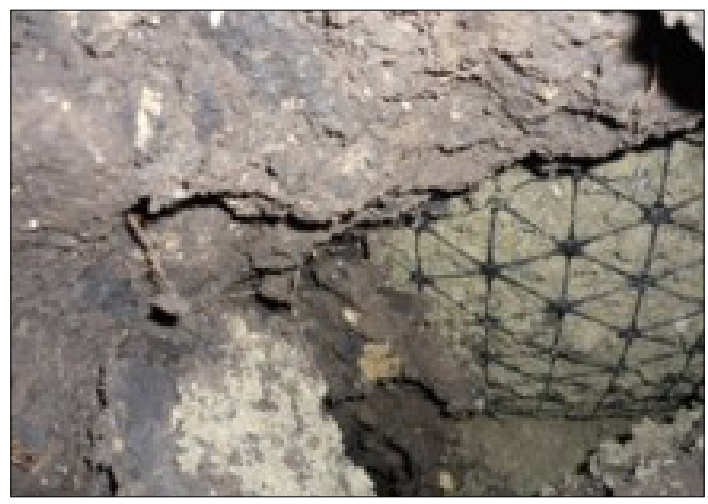

5. ábra. A szerkezet beomlása nyomán láthatóvá válik a beágyazás lenyomatát, amely $105 \mathrm{~cm}$ volt. A zúzottkő-réteg eltávolításának alkalmával felfedeztünk a georácson egy szakadási pontot (6. ábra), majd a teljes feltárást követően még két hasonló szakadási pont jelenlétét állapítottuk meg (7. ábra), a terhelési felülettel ellentétes oldalon.

Ez a jelenség kizárta a beágyazási folyamat jótékony hatását, és lehetővé tette a zúzottkő-réteg kisebb mértékű összeomlását az üregen belül, azonban a külső csomópontban már nem voltak mozgósítva a nyújtási erők a rácson belül, így ennek irányában az értéke nulla maradt.

\subsection{Geoszintetikus rács nélküli modell}

Ahhoz, hogy meg lehessen határozni a georácsos megerősítés hatásainak mértékét, egy harmadik megerősítés nélküli modellt is létrehoztunk, amely ez alkalommal georácsot nem tartalmazott.

$\mathrm{Az}$ szerkezet létrehozása a fentiekben hasonlóan történt, a fiók eltávolítását követően a vizsgált talajszerkezetet kb. 20 órán át állni hagytuk, amely idő alatt a saját súlya alatt megszilárdult. A georácsos szerkezetektől eltérően, ez a szerkezeti

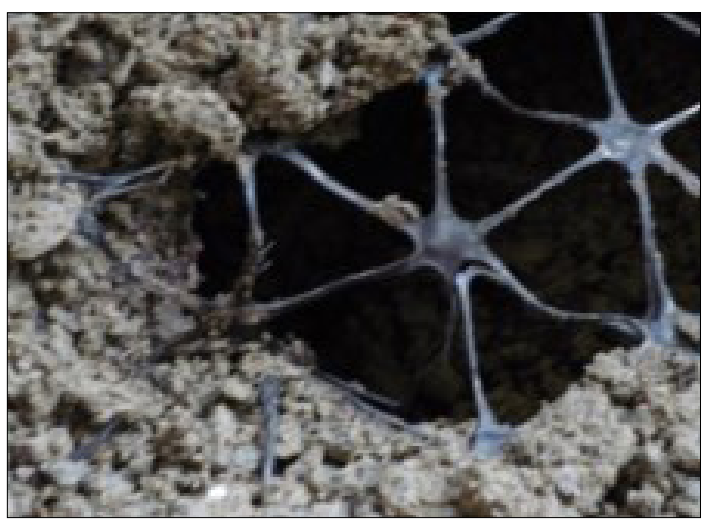

6. ábra. Omlás a triaxiális georács mentén

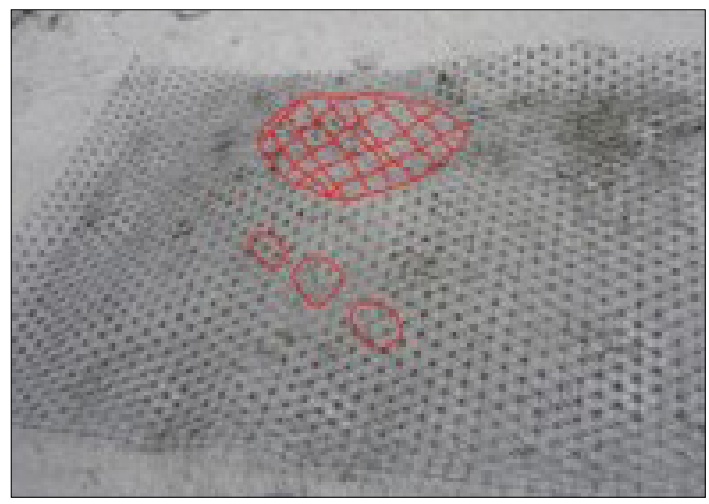

7. ábra. A nyomáskúp, valamint a három átlósan elhelyezkedő szakadási pont 
modell a saját súlya alatt történő konszolidáció következtében a lyuk közepére helyezett mérőrúd 24 óra után mutatott értéke $210 \mathrm{~mm}$ volt, öszszehasonlítva a kezdeti 215 mm-hez.

Az első terhelési szakaszt követően, $50 \mathrm{kPa}$ hatására nem következtek be jelentős deformációk a szerkezetben, az összelmozdulási érték két tized miliméter alatt voltak a konszolidáció pillanatában. A 100 kPa-os terhelési szakasz 10 percig tartott, amely két leolvasási ciklusnak felel meg, megadva a 0,6 mm-es elmozdulást a tesztlemez alatt. Az üreg központi része még a harmadik terhelési szakaszt követően sem szenvedett méretbeli változásokat $(150 \mathrm{kPa})$. Csak a 20 . percet követően lépett érvénybe egy $2 \mathrm{~mm}$ nagyságú elváltozás, amelyet az üreg szélén elhelyezett mérőrúdon olvashattunk le, amely jelezte a talajmozgást az üreg szélétől, hogy átvegye a terhelést a boltozathatáson keresztül. Az eredmény olvasásával egyidejűleg érvénybe lépett a vizsgált talaj konszolidációja, valamint továbbléptünk a következő terhelési szakaszba, 200 kPa értékkel. A 15 perc elteltével való eredményolvasás megmutatta az első deformációt, amely $2 \mathrm{~mm}$ volt. A mérőrúd az üreg szélén $2 \mathrm{~mm}$-t leereszkedett, elérve így az 577 mm-es értéket. A talaj konszolidációja 30 perc elteltével lépett érvénybe. A $250 \mathrm{kPa}$-os terhelési szakasz alkalmával kisebb méretű talajdarabkák omlottak le. Mivel a nyomás nem csökkent, ezért csak a tesztlemez alatt koncentrálódott az, így csak ott léptek érvénybe omlások. Az üreges mennyezet kisebb méretű talajdarabka-omlása mellett az oldalfalakban nem jöttek létre további repedések. Ez alatt a terhelési erő alatt a talaj 25 perc után érte el a konszolidációs küszöböt. A $300 \mathrm{kPa}$-os terhelésre való váltást követően meghatározható volt az olvasási ciklusonkénti 2 mm-es változási érték, az üreg mennyezetének a deformációja folytatódott, a központi elhelyezésű mérőrúd pedig $196 \mathrm{~mm}$-es értéket mutatott, a doboz aljától mérve. Az üreg szélén elhelyezve a mérőrudat, 579 mm-es mérhető érték volt, amely azt jelenti, hogy az üreg oldalsó falai is eldeformálódtak. Az összelmozdulás ebben a terhelési szakaszban elérte a 4,5 mm-es értéket 40 perc elteltével, amely 8 mérési ciklusnak felel meg. A következő terhelési szakaszban, $350 \mathrm{kPa}$, bekövetkezett az üreg mennyezetének beomlása a mérőrúd irányába (8. ábra).

Az elmozdulások kihangsúlyozódtak, az első mérést követően leolvashattunk egy 1,5 mm-es ugrást az alsó betöltési mérési lépéssel szemben. $\mathrm{Az}$ üreg továbbra is eldeformálódott, ez a tendencia különösen azért volt észrevehető, mert a

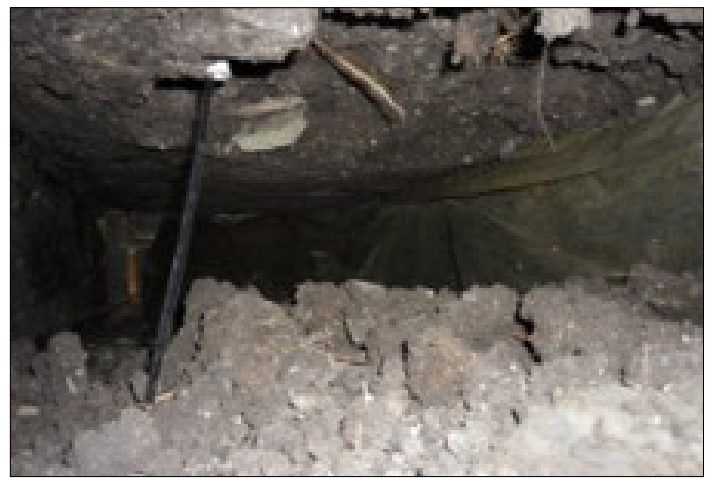

8. ábra. Az üreges mennyezetből származó nagyobb földdarabkák beomlanak a 350 kPa-os terhelés hatására

az üreg mennyezetének oldalsó részén kihangsúlyozódtak a repedések. Megjelentek az oldalsó falakon is kisebb beomlások, amelyet az üreg szélén lévő mérőrúd is jelzett. 45 perc elteltével mérhető volt a maximális elmozdulás, $7 \mathrm{~mm}$, lehetővé téve a leolvasások közötti különbséget, valamint a nagyobb terhelési fokra való váltást. A 400 kPa-os terhelés alkalmával az 1 cm-es deformációt is átléptük, az elmozdulások állandó növekedést mutattak, leolvasási intervallumonként kb. 0,2 mm-es értékkel. Ez alatt a terhelési lépés alatt a vizsgált talajszerkezet 65 perc után stabilizálódott. A következő terhelési szakaszban bekövetkezett közepes méretű földdarabkák leomlása, jelezve az összeomlás közeledtét. 35 percet követően 450 kPa-os terhelés kíséretében megmértük az üreges mennyezet deformációját, amelynek mértéke $1 \mathrm{~cm}$ volt, amely megfelel a tesztpanel mikrokomparatív óráin mért kalibrációnak. Geoszintetikus megerősítés nélkül elmondhatjuk, hogy a törtkő rétegrésze egyidejüleg deformálódik el a vizsgált talajjal. A talajkonszolidációt 40 perc alatt, $450 \mathrm{kPa}$-os terhelés alatt regisztráltuk. A következő terhelés további omlásokat eredményezett. Az üreg deformációja 20 és 90 perces időközönként regisztráltuk, a központi elhelyezésű mérőrúdon leolvasható értékek pedig $187 \mathrm{~mm}$, valamint $183 \mathrm{~mm}$ voltak. 110 perc után rögzítettük az elmozdulási értékeket, amelyek a talaj szilárdulását eredményezték, egy $3 \mathrm{~cm}$-es deformáció kíséretében. A következő terhelési szakaszban, 550 kPa-os terhelés hatására megvalósult a föld beomlása az üregbe (9. ábra), a deformációk kihangsúlyozódtak, $3 \mathrm{~cm}$-ről elérve egy $5 \mathrm{~cm}$-es értéket, mindezt 5 perc alatt, amelyet követően a tesztlemez elsüllyedt a saját súlya alatt és a hidraulikus emelő nyomására. 


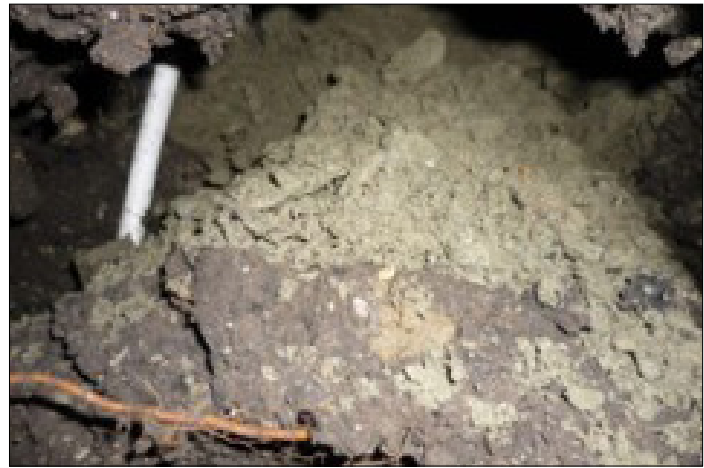

9. ábra. Az üreg összeomlott az 550 kPa-os terhelési nyomás alatt

Tekintettel arra, hogy a deformációk megengedett értékeinek elérése rövid volt, elmodhatjuk, hogy a létrejött összeomlás hirtelen jellegű volt. A törtkő felső rétegének egy része átfolyt a szerkezetben eredetileg kialakított üregbe. Az öszszeomlást követően kialakult kúp átmérője $45 \mathrm{~cm}$. A törtkő-réteg eltávolítását követően megfigyelhető volt az így létrejött kúp alsó részének alakja, valamint méretei mérhetőek voltak: $120 \mathrm{~cm}$ hoszszú, 85 cm széles. Az összeomlott felület megerősítette a kezdeti feltételezéseinket, miszerint ez csak egy lokális beomlás.

1. táblázat. Terhelési szintek értelmezése a teherbírás mértéke alapján

\begin{tabular}{|c|c|c|c|}
\hline $\begin{array}{l}\text { Terhelési } \\
\text { lépés }\end{array}$ & $\begin{array}{c}\text { Ekvivalens } \\
\text { koncentrált } \\
\text { erő }\end{array}$ & $\begin{array}{l}\text { Nyomás } \\
\text { érték }\end{array}$ & $\begin{array}{c}\text { Lemez } \\
\text { alatti } \\
\text { nyomás }\end{array}$ \\
\hline$[\mathrm{kPa}]$ & {$[\mathrm{kN}]$} & {$[\mathrm{tf}] / \mathrm{m}^{2}$} & [tf] \\
\hline 50 & 3,55 & 5,100 & 0,362 \\
\hline 100 & 7,10 & 10,200 & 0,724 \\
\hline 150 & 10,65 & 15,300 & 1,086 \\
\hline 200 & 14,20 & 20,400 & 1,448 \\
\hline 250 & 17,76 & 25,500 & 1,811 \\
\hline 300 & 21,31 & 30,600 & 2,173 \\
\hline 350 & 24,86 & 35,700 & 2,535 \\
\hline 400 & 28,41 & 40,800 & 2,897 \\
\hline 450 & 31,96 & 45,900 & 3,259 \\
\hline 500 & 35,51 & 51,000 & 3,621 \\
\hline 550 & 39,06 & 56,100 & 3,983 \\
\hline 600 & 42,61 & 61,200 & 4,345 \\
\hline 650 & 46,16 & 66,300 & 4,707 \\
\hline 700 & 49,71 & 71,400 & 5,069 \\
\hline 750 & 53,27 & 76,500 & 5,432 \\
\hline 800 & 56,82 & 81,600 & 5,794 \\
\hline
\end{tabular}

\section{Következtetések}

Az általunk tanulmányozott talajszerkezetek teherbírása tehát kifejezhető a következőképpen: $1 \mathrm{kPa}=101,972 \mathrm{kgf} / \mathrm{m}^{2}=0,102 \mathrm{tf} / \mathrm{m}^{2}$.

A kísérletben használt tesztlemez felülete $\phi 300 \mathrm{~mm}$, amely négyzetméterben kifejezve 0,071 $\left(0,071 \mathrm{~m}^{2}\right)$, mindez számszerüleg nagyon közel áll a forgalmi terhek kiszámításához használt kéttengelyü lemezlenyomathoz.

A gyengén tömörített szerkezet alacsonyabb terhelési értéket adott, mint a megerősítés nélküli szerkezet. A különbség a két átviteli lépés között 36\%-os volt (350 kPa şi $550 \mathrm{kPa}$ ). Összehasonlítva a $800 \mathrm{kPa}$-os értéket, hasonló talajszerkezeti esetet vizsgálva, viszont megfelelően tömörítve azt, a különbség számottevőbb, vagyis 56\%-os, és a teherbírás tényleges értéke több mint a duplájára nőtt.

Ezek az eredmények arra engednek következtetni, hogy a georács használata hiábavaló abban az esetben, ha az útrétegek megfelelő tömörítési foka nem valósul meg előzetesen [5, 6, 7, 8].

\section{Szakirodalmi hivatkozások}

[1] GE-026-97. Ghid pentru execuţia compactării în plan orizontal şi înclinat a terasamentelor

[2] STAS 1913-15/75. Teren de fundare. Determinarea greutăţii volumice pe teren.

[3] STAS 2914/4-89. Teren de fundare. Determinarea modulului de deformaţie liniară prin încercări pe teren cu placa.

[4] Moldovan D. V., Nagy A. Cs., Muntean L. E., Fărcaş V. S., Coţ R.: A comparative study of the failure mode of conventional road structures and of road structures reinforced with polypropylene rectangular mesh geogrids. $14^{\text {th }}$ International Multidisciplinary Scientific Geoconference SGEM2014, Albena, Bulgaria, 11-15.

[5] Agaiby Sherif W., Jones Colin J. F. P.: Design of reinforced fill systems to support footings overlying cavities. Geotextiles and Geomembranes, 14. (1996) 57-72.

[6] Asakereh A., Ghazavin M., Tafreshi S. N. Moghaddas: Cyclic response of footing on geogrid-reinforced sand with void. Soils and Foundations, 53/3. (2013) 363-374.

[7] Briançon L., Villard P.: Design of geosynthetic-reinforced platforms spanning localized sinkholes. Geotextiles and Geomembranes, 26. (2008) 416-428.

[8] Giroud J. P., Bonaparte R., Beech J. F., Gross B. A.: Design of soil layer-geosynthetic systems overlying voids. Geotextiles and Geomembranes, 9. (1990) 11-50. 


\title{
SZABAD DIETANOL-AMIN-TARTALOM MEGHATÁROZÁSA
}

\section{DETERMINATION OF FREE DIETHANOLAMINE CONTENT}

\author{
Nagy Roland, ${ }^{1}$ Hartyányi Máté, ${ }^{2}$ Nagy Bianka, ${ }^{3}$ Varga Csilla ${ }^{4}$ \\ Pannon Egyetem, MOL- Ásványolaj- és Széntechnológiai Intézeti Tanszék, Veszprém, Magyarország \\ ${ }^{1}$ nroland@almos.uni-pannon.hu \\ ${ }^{2}$ mate.hartyanyi@gmail.com \\ ${ }^{3}$ nagy.bianka@mk.uni-pannon.hu \\ ${ }^{4}$ vcsilla@almos.uni-pannon.hu
}

\begin{abstract}
Quantification of alkanolamines is imperative for health and chemical safety risk reasons. A fast method that requires less equipment has been developed for the determination of free diethanolamine in different types of additives. Repeatability tests were carried out. The free diethanolamine content of commercially available additives has been determined. We have recommended industrial applicability.
\end{abstract}

Keywords: DEA, additives, method, development.

\section{Összefoglalás}

Az alkanol-aminok mennyiségének meghatározása egészségügyi és kémiai biztonsági kockázati okokból rendkívül fontos. Gyors és kisebb eszközigényü módszert dolgoztunk ki, mellyel a szabad dietanol-amin különböző adalékokban meghatározható. Ismételhetőségi vizsgálatokat végeztünk. Kereskedelmi forgalomban is kapható adalékok szabad dietanol-amin tartalmát határoztuk meg. Ajánlást tettünk ipari alkalmazhatóságra.

Kulcsszavak: DEA, adalék, módszerfejlesztés.

\section{Bevezetés}

Napjainkban elengedhetetlen a hatékony módszer az alkanol, és az alkil-aminok mennyiségének meghatározására, azok lehetséges egészségügyi és kémiai biztonsági kockázatai miatt. A dietil-, illetve a trietil-amint reagensként használják fel számos gyógyszerészeti összetevő, például az oxibutinin-hidroklorid vagy a trazodon-hidroklorid gyártási folyamatában [1]. A kozmetikumokban és testápolási termékekben megtalálható dietanol-amin mennyisége korlátozott, mivel a dietanol-amin-maradványok reakcióba léphetnek más speciális összetevőkkel, melynek eredményeképpen rendkívül erős karcinogén tulajdonsággal rendelkező nitrozo-dietanol-amin képződik [2]. Ebből adódóan az említett komponensek kvalitatív és kvantitatív meghatározása nélkülöz- hetetlen feladat. Az alkanol-aminok elemzésére rendelkezésre álló módszerek közül agáz-kromatográfiát vagy a folyadék-kromatográfiát alkalmazó technikák kapják a legnagyobb figyelmet. A korszerübb eljárások a kromatográfiás elválasztást tömeg-spektroszkópiás módszerrel ötvözik. A kromatográfiás elválasztás és detektálás javításának érdekében az alkanol-aminok származékképzését valósítják meg, melynek célja az analit elemzésre alkalmasabb formába történő átalakítása [2]. A származékképzés legegyszerübb módja egy olyan reagens használata, mely képes reagálni az analitok jellegzetes csoportjával, és azzal „származékot” képezni. A folyadék-kromatográfiával végzett analitikai alkalmazásokra vonatkozóan a derivatizáció kétféle módon hajtható végre: vagy oszlop előtti vagy oszlop utáni derivatizációval (PCD) [3]. A dietanol-amin-tartalom meghatáro- 
zására gyors és egyszerű a GC-MS-módszer, azonban a megbízható mennyiségi meghatározáshoz a mintának minimum $1000 \mathrm{mg} / \mathrm{kg}$ DEA-tartalommal kell rendelkeznie [2]. A DEA (dietanol-amin) és TEA (trietanol-amin) kvantitatív meghatározásához a mintához történő nátrium-hidroxid hozzáadagolását követően dimetil-szulfoxidban szükséges feloldani. Mivel az oldatban ionos kötés nem lehetséges, a DEA ésa TEA könnyen kinyerhető és mennyiségileg meghatározható, gőztér-mintaadagoló gáz-kromatográfiás módszer alkalmazásával [1].

Szakirodalmi közleményeket áttekintve, DEA-tartalom meghatározására csak többlépcsős, műszeres analitikai módszer lehetséges. Célunk egyszerű, gyors és kis eszközigényű módszer kidolgozása.

\section{Felhasznált anyagok}

Méréseinkhez DEA és PEG (polietilén-glikol), illetve kókuszzsírsav reakciótermékeket használtunk fel.

1. táblázat. A felhasznált anyagok tulajdonságai

\begin{tabular}{|l|l|l|}
\hline & \multicolumn{1}{|c|}{ DEA } & \multicolumn{1}{c|}{ PEG-300 } \\
\hline Molekulatömeg $(\mathrm{g} / \mathrm{mol})$ & 105,14 & $285-315$ \\
\hline Forráspont $\left({ }^{\circ} \mathrm{C}\right)$ & 268 & $>220$ bomlik \\
\hline Dermedéspont $\left({ }^{\circ} \mathrm{C}\right)$ & 28 & -15 és -8 között \\
\hline Sürüség $\left(\mathrm{g} / \mathrm{cm}^{3}\right)$ & 1,09 & 1,125 \\
\hline
\end{tabular}

A DEA és PEG-300-at tulajdonságai alapján alkalmasnak találtuk a vizsgálatok elvégzésére.

2. táblázat. Zsírsav-DEA-reakciótermékek tulajdonságai

\begin{tabular}{|l|l|l|l|}
\hline & \multicolumn{1}{|c|}{ Coco-DEA } & \multicolumn{1}{|c|}{ Coco-DEA } & $\begin{array}{l}\text { Zsírsav } \\
\text { DEA }\end{array}$ \\
\hline Gyártó & $\begin{array}{l}\text { Alpha Chem- } \\
\text { ical }\end{array}$ & $\begin{array}{l}\text { Kelemen és } \\
\text { Társa }\end{array}$ & $\begin{array}{l}\text { (MOL } \\
\text { Lub Kft.) }\end{array}$ \\
\hline pH & $5,5-7,5$ & $5,6-7,5$ & $6-8$ \\
\hline szín & világos sárga & világos sárga & $\begin{array}{l}\text { világos } \\
\text { sárga }\end{array}$ \\
\hline $\begin{array}{l}\text { Szabad } \\
\text { zsírsav, w\% }\end{array}$ & max 1,5 & max 1,0 & max 1,0 \\
\hline $\begin{array}{l}\text { Vízben való } \\
\text { oldhatóság, } \\
\text { 20C-on }\end{array}$ & $\begin{array}{l}\text { teljes oldódás, } \\
\text { pH 9,0-10,5 }\end{array}$ & $\begin{array}{l}\text { teljes oldódás, } \\
\text { pH 9,0-10,5 }\end{array}$ & \\
\hline
\end{tabular}

A vizsgált zsírsav-DEA reakciótermékek tulajdonságai szűk tartományban mozogtak.

\section{Módszerkidolgozás}

Munkánk során egy új, egyszerű és gyors kísérleti módszer kidolgozását végeztük el, amelynek segítségével különböző adalékok, készítmények szabad amintartalmát lehet meghatározni. A módszer segítségével jellemezhető az alapanyagok konverziója. A szabad amintartalom ismeretében a készítmény minőségellenőrzése is szélesebb körü lehet [4]. A módszer kidolgozása során a ITM-40-006-jelü szabvány volt a kiindulópont [5].

\section{A vizsgálat végrehajtása}

- 1 g vizsgálandó anyag bemérése

- az elegy feloldása 10 ml metanolban

- 100 ml IPA/víz hozzáadása az oldathoz

- az így kapott elegy titrálása $0,1 \mathrm{M} \mathrm{HCl}$ oldattal

\section{1 liter IPA/víz készítése}

- 7,5 g káliumklorid bemérése

- a bemért káliumklorid feloldása $330 \mathrm{ml}$ desztillált vízben

-670 ml izopropil-alkohol hozzáadása az oldathoz

\section{Titrálás}

-az elegy Erlenmayer-lombikba történő bemérése

- egy csepp metilvörös indikátor hozzáadása

- az átcsapási szín megjelenéséig való titrálás

A szabad amintartalom meghatározásához alkalmazott egyenlet a következő:

$$
w t \%=\frac{V_{f} * f * K * C_{H C l}}{m}
$$

ahol:

$V_{f} \quad-$ a $0,1 \mathrm{M}$ sósav fogyása $\mathrm{cm}^{3}$-ben

$f \quad$ - a sósav faktora (értéke 1 , mivel dedikált sósavval titráltam)

$K$ - titer szám

$C_{H C l}$ - a sósav koncentrációja

$m$ - a bemért minta tömege g-ban.

Elvégeztük a módszer ismételhetőségének vizsgálatát, amelynek eredményeit a 3. táblázat tartalmazza.

Az ismételhetőségvizsgálatok (RSD-érték kisebb, mint 5\%) alapján megállapítottuk, hogy a kidolgozott módszer megbízhatóan ismételhető. Ezek alapján a módszerrel további vizsgálatokat végeztünk. 
3. táblázat. Ismételhetőségi vizsgálatok eredményei

\begin{tabular}{|l|c|}
\hline & $\begin{array}{c}\text { Szabad amin tarta- } \\
\text { lom }\end{array}$ \\
\hline Coco-DEA reakciótermék 1 & 14,2 \\
\hline Coco-DEA reakciótermék 2 & 14,1 \\
\hline Coco-DEA reakciótermék 3 & 14,1 \\
\hline Coco-DEA reakciótermék 4 & 13,9 \\
\hline Coco-DEA reakciótermék 5 & 14,0 \\
\hline Átlag & 14,1 \\
\hline Szórás & 0,14 \\
\hline RSD\% & 0,98 \\
\hline
\end{tabular}

\section{Eredmények}

A vizsgálatokat különböző arányú DEA/PEG 300 keverékének szabad amintartalmának meghatározásával kezdtük. A mérési eredményeket a 4. táblázat tartalmazza.

4. táblázat. Különböző DEA-tartalmú termékek vizsgálata

\begin{tabular}{|l|c|c|c|c|c|c|c|}
\hline \multicolumn{1}{|c|}{$\begin{array}{c}\text { Minta } \\
\text { sorszáma }\end{array}$} & $\mathbf{1 .}$ & $\mathbf{2 .}$ & $\mathbf{3 .}$ & $\mathbf{4 .}$ & $\mathbf{5 .}$ & $\mathbf{6 .}$ & $\mathbf{7 .}$ \\
\hline $\begin{array}{l}\text { Bemérés } \\
\text { alapján } \\
\text { DEA-tartalom } \\
\text { W\% }\end{array}$ & 1,00 & 5,20 & $\mathbf{9 , 9}$ & 15,10 & 20,15 & 25,05 & 50,10 \\
\hline $\begin{array}{l}\text { Titrimetriás } \\
\text { módszerrel } \\
\text { meghatáro- } \\
\text { zott DEA-tar- } \\
\text { talom w\% }\end{array}$ & 1,11 & 4,98 & 10,05 & 15,08 & 20,12 & 24,99 & 49,91 \\
\hline
\end{tabular}

Megállapítottuk, hogy az új módszerrel meghatározott, szabad DEA-tartalom a bemérési adatokkal jól korrelál, melyet az 1 . ábra szemléltet.

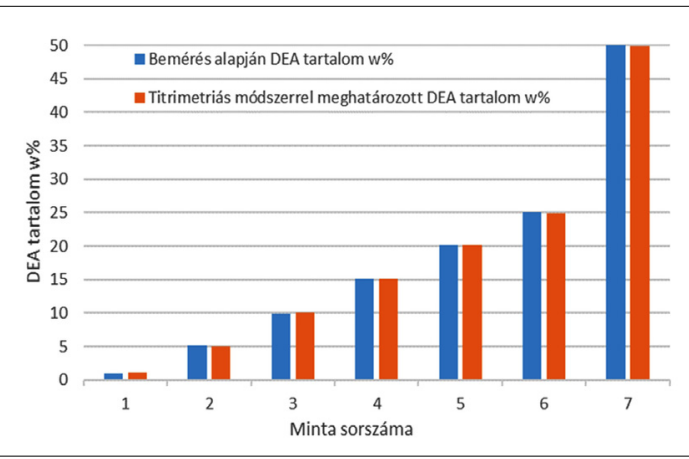

1. ábra. Különböző DEA-tartalmú termékek vizsgálata
A vizsgálatokat különböző gyártó által gyártott DEA-tartalmú termékek szabad amintartalmának meghatározásával folytattuk. A mérési eredményeket az 5. táblázat tartalmazza.

5. táblázat. Kereskedelmi tenzidek DEA-tartalma

\begin{tabular}{|c|c|c|}
\hline Minta jele & $\begin{array}{c}\text { Titrimetriás } \\
\text { módszerrel } \\
\text { meghatározott } \\
\text { DEA-tartalom } \\
\text { w\% }\end{array}$ & $\begin{array}{c}\text { Gyártó által } \\
\text { megadott } \\
\text { DEA-tartalom } \\
\text { w\% }\end{array}$ \\
\hline $\begin{array}{c}\text { Coco DEA } \\
\text { (Alpha Chemical) }\end{array}$ & 14,05 & 14,20 \\
\hline $\begin{array}{c}\text { Coco DEA } \\
\text { (Kelemen \& Társa } \\
\text { Kft.) }\end{array}$ & 12,80 & 12,80 \\
\hline $\begin{array}{c}\text { Zsírsav DEA } \\
\text { (MOL Lub Kft.) }\end{array}$ & 14,45 & 14,50 \\
\hline
\end{tabular}

Megállapítottuk, hogy az új módszerrel meghatározott szabad DEA-tartalom a gyártó által megadott adatokkal jól korrelál, melyet a 2 . ábra szemléltet.

Méréseink jól tükrözik, hogy a bemutatott módszerrel pontosan meghatározható a DEA-tartalom, mind beméréssel ellenőrizve, mind pedig a gyártó által megadott DEA-értékekhez viszonyítva.

\section{Következtetések}

Vizsgálataink során az alábbi megállapításokat nyertük:

- sikerült gyors, kis eszközigényü DEA-tartalom meghatározására alkalmas módszert kidolgozni,

- a módszer megbízhatósága adódott,

-a kidolgozott módszer alkalmas késztermékek DEA-tartalmának meghatározására.

A kidolgozott módszer egyszerüsége miatt a DEA-tartalmú készítmények gyártása során az üzem területén is alkalmazható.

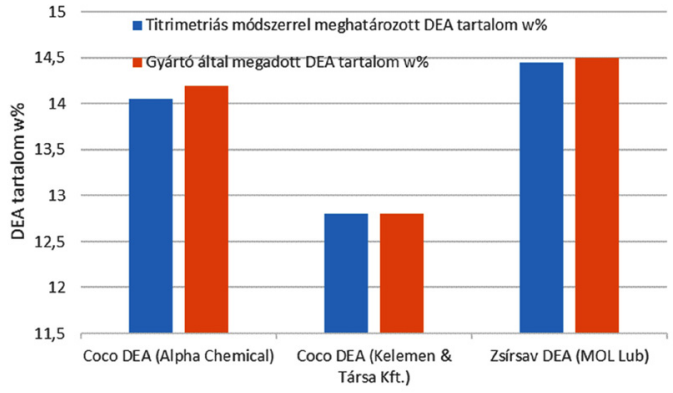

2. ábra. Különbözö gyártók DEA-tartalmú adalékoknak vizsgálata 


\section{Szakirodalomi hivatkozások}

[1] Ashish R. Deshpande, Ganesh Ramachandran, Ramesh S. Yamgar: Determination of diethylamine and triethylamine quantitatively using GC-headspace chromatography. Eurasian Journal of Analytical Chemistry, 7/1. (2012) 43-48.

[2] EN ISO 18818: Cosmetics, Analytical method, Detection and quantitative determination of Diethanolamine (DEA) by GC/MS, 2017.

[3] Zacharis C. K., Tzanavaras P. D.: Liquid Chromatography coupled to on-line post column deri- vatization for the determination of organic compounds: a review on instrumentation and chemistries, Analytica Chimica Acta, 798/10. (2013) 1-24, https://doi.org/10.1016/j.aca.2013.07.032

[4] Longman G. F. : The Analysis of Detergents and Detergent Products. First Edition. John Wiley \& Sons Ltd., 1975, 276-344.

[5] ITM-40-006. Free Amine in PIB-MALA Amine Dispersants: Potentiometric Titration Method. 2002 (szeptember 18.). 


\title{
A HATÉKONY KÖRNYEZETTUDATOS NEVELÉS KRITÉRIUMAI
}

\section{CRITERIA FOR AN EFFECTIVE ENVIRONMENTAL EDUCATION}

\author{
Novák János \\ Óbudai Egyetem, Kollégium, Keleti Károly Gazdasági Kar Vállalkozásmenedzsment Intézet, \\ Biztonságtudományi Doktori Iskola,novak.janos@koll.uni-obuda.hu
}

\begin{abstract}
Environmental awareness could also be called environment management, since it is necessary to organize, or rather manage any activities performed in order to protect the environment. A person who cares about their environment in their own household performs organizational tasks that are far more complex than people living in households who don't care, or care less about their environment. Consider how much extra energy it takes to selectively collect plastic PET bottles, or to properly dispose of used batteries, compared to those who just dispose of these together with municipal waste, out of negligence or laziness. Many think that the activities of the average person don't matter since there are so many of us on Earth that a single person's efforts won't change anything. Man, as a living being, is not capable of making decisions that would solve problems emerging in the next 20, 30 or 40 years; we usually start dealing with issues that we think will matter within the next 2-3 years: but we have admit that 2-3 years are not enough to solve global environmental protection and climate change problems. This way of thinking can easily lead to the decline of humanity in the future.
\end{abstract}

Keywords: environmental awareness, education, future, sustainability.

\section{Összefoglalás}

A környezettudatosságot akár környezetmenedzsmentnek is hívhatjuk, hiszen a környezet megóvására organizált tevékenységeket úgymond menedzselni, szervezni szükséges. Egy olyan ember, aki törődik a környezetével a saját háztartásában, egy olyan szervezési feladatot lát el, amely sokkal komplexebb, mint az olyan háztartásban élők életvitele, akik környezetükre nem vagy csak kevésbé figyelnek. Gondoljunk csak bele, hogy mennyi plusz energiabefektetést jelent akár a műanyag PET-palackok különgyüjtése vagy az elhasznált elemek, rossz akkumulátorok megfelelő gyüjtése és leadása azzal szemben, akik ezeket hanyagságból vagy lustaságból a kommunális szeméttel együtt gyűjtik. Nagyon sokan úgy gondolják, hogy egy átlagos ember tevékenysége nem számít, hisz olyan sokan vagyunk a Földön, hogy nem változtat semmin, ha csak egy ember elkezdi óvni a környezetét. Az ember mint élőlény nem képes olyan döntéseket hozni, amelyek 20-40 év múlva bekövetkező problémákat oldanának meg, általában 2-3 éven belül bekövetkező problémákkal kezdünk el foglalkozni, de lássuk be, egy globális környezetvédelmi és klímaváltozási probléma megoldására 2-3 év nem elegendő. Ez a gondolkodásmód könnyen vezethet a jövőben az emberiség hanyatlásához.

Kulcsszavak: környezettudatosság, nevelés, oktatás, jövő, fenntarthatóság. 


\section{Bevezetés}

A környezettudatosság a XX. század végétől van leginkább jelen, amióta komolyabb figyelmet kapott az emberek és az azok által kifejlesztett technológiák miatt bekövetkezett, egyre növekvő ökológiai katasztrófa veszélye. 2020-ra az emberiség ökológiai lábnyoma már komolyan mérhető formát öltött, amely főleg a melegebb hónapok átlaghőmérsékletén látszik. Már az elmúlt pár hónap is megmutatta, hogy a bolygónk átlaghőmérséklete a korábbi évekhez képest rohamos ütemben növekszik.

Lehet szó a brutális méreteket öltő brazil erdőkitermelésekről és erdőtüzekről vagy a folyamatos légszennyezésről, amelynek legnagyobb okozói pont a legfejlettebb és legnépesebb országok. Muszáj realizálnunk, hogy a bolygónk és az emberiség megélhetése érdekében a jelenlegi megszokásaink és munkafolyamataink a fenntartható jövő szempontjából sem reálisak. Gyermekkorunkra visszaemlékezve, mindig voltak figyelmeztetések, hogy iparosodott és fejlődő társadalmunk milyen kihatásokkal lehet bolygónk ökológiai egészségére, azonban akkor még számunkra - ahogy másoknak is - ezek csak riogatásnak tűntek. Ennek fő oka, hogy maga a környezettudatosság mint alapvető ,jellem” nem volt szerves része a 90-es és 2000-es évek közoktatásának hazánkban, sem pedig külföldön, bár Európa területén már a 70es évektől indultak törekvések a közös környezetvédelemi politika irányába. 1972-ben megállapí- tották a közös környezetvédelmi politika szükségességét. 1987-ben jött létre az egységes európai okmány új, „Környezet” elnevezésű címe, amely a közös környezetpolitika első jogalapjaként funkcionált. A jelenkor Európájában, a folyamatosan erősödő és teret nyerő „zöld pártok” támogatottsága is azt mutatja, hogy a környezettudatosság és az arra való igény jelentős mértékben növekedett az elmúlt évekhez, sőt évtizedekhez képest a választópolgárok körében. Ez a tendencia arra enged következtetni, hogy társadalmunk körében egyre nő azok száma, akik érdekeltek egy fenntartható és környezetbarát jövő kialakításában. Véleményem szerint, az emberiségnek jelenlegi technikai tudásával képesnek kell lennie arra, hogy egy olyan jövőt kivitelezzen a következő generációk számára, amely környezeti és energetikai szempontból élhetőbb lesz a jelenleginél. Ennek a célnak az eléréséhez azonban több alapvető dolgon fejleszteni és újítani kell, például az oktatásban; legyen szó akár a felnövő vagy a már felnőtt generációkról.

\section{Környezettudatos magatartásforma és a nevelés}

Magát a környezettudatos gondolkodásmódot több csatornán és több fázisban lehet a gyerekek számára egy alapvető elvvé, értékké formálni az oktatáson keresztül. Sajnos, jelenleg a klíma- és környezetvédelmet szinte alig vagy egyáltalán nem oktatják az általános, illetve középiskolák-

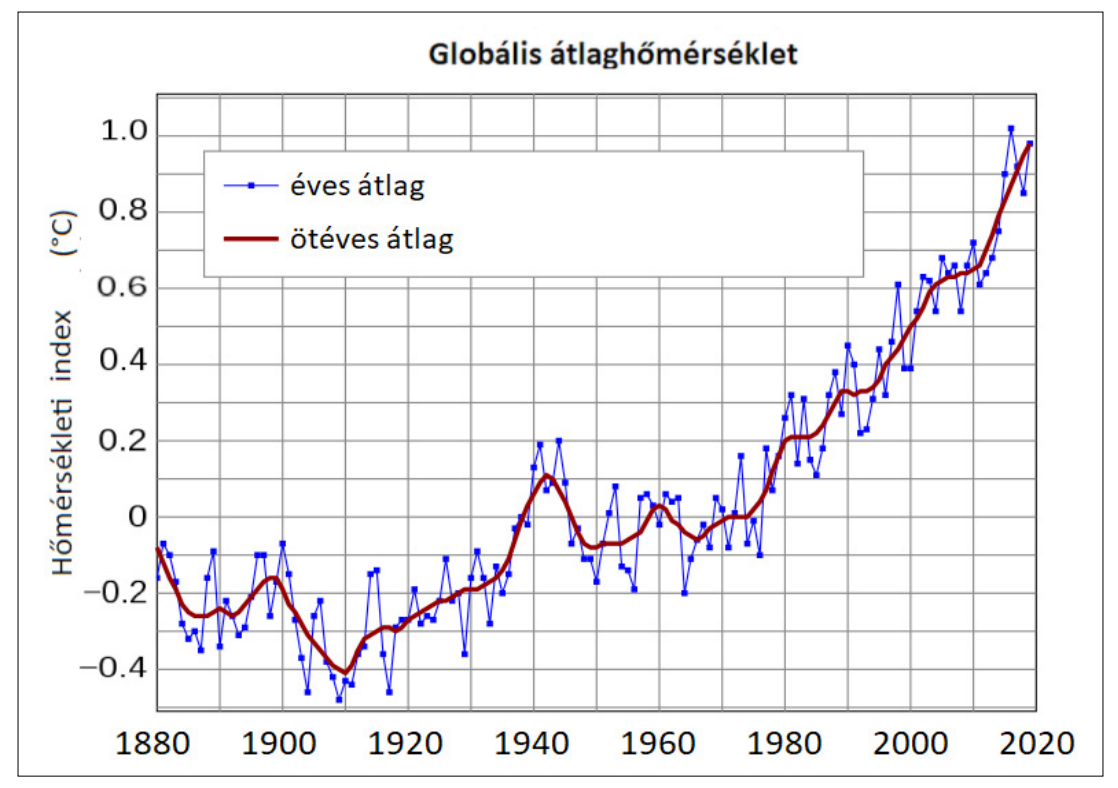

1. ábra. Hőmérsékleti index 1880-tól napjainkig [1] 
ban, gimnáziumokban. Ezen a vonalon, a világon elsőként, Olaszországban sikerült forradalmasítani az oktatás ilyen irányú hiányosságát, ahol hivatalosan is bekerült a tananyagba a „klímaváltozás” elnevezésű tantárgy, az állami iskolai tananyagban jövőre már szerepelni fog a klímaváltozás és a fenntartható fejlődés tudatos oktatása. Az olasz oktatásügyi miniszter, Lorenzo Fioramonti elmondta, hogy „az iskolások a következő tanévben 33 órában kötelezően foglalkoznak majd a klímaváltozás hatásaival”. A miniszter hangsúlyozta, kezdeményezése arra irányul, hogy a tanulók következő generációja megismerkedjen a klímaváltozás okaival, kockázataival és hatásaival [2]. Fontos már fiatalon egy olyan gondolkodásmódot kiépíteni a gyerekekben, amely nemcsak célravezető és produktív, hanem a környezettudatosság által képes új és alternatív módokon értékeket teremteni. Ezért, a másik fő csatornán, a közoktatáson kívül a család és az azonbelül folyó tudatos nevelés a környezettudatosságra a másik fontos tényező. Ennek eszközei lehetnek olyan „apróságok”, mint a szelektív hulladékgyűjtés vagy az arra alkalmas dolgok otthoni (házi) újrahasznosítása. Számíthat a későbbiekben egy olyan ökológia énkép kialakítása, amely kapcsán a gyermek érezheti, hogy majd a felnőttkori élete, illetve munkája milyen ökológiai lábnyomot hagyhat maga után. Ezáltal a későbbi iskolai oktatásban szereplő tananyag egy fontos kiegészítő szerepet és jelentést is elnyerhet. A jelenkorunk környezetvédelemmel foglalkozó oktatásának másik fő kihívása a már dolgozó emberek kész mechanizmusokkal operáló munkafolyamatainak, „zöldebb” átgondolásának motiválása, főleg a kis- és középvállalkozásokban. Saját munkahelyemen is megfigyelhetően tapasztalom a „régi, de működik” elv fennállását, amely által néha már-már irreális mennyiségű irodai (papír-, műanyag) hulladék keletkezik. Ezeket többnyire már vagy a technika, vagy egyéb, zöldebb megoldás felválthatná, ha az adott cégen belül egy külön szemponttá válna a profiton kívül is a jövő fenntarthatósága. Ennek a már kialakult problémának megoldása lehetne egy úgynevezett környezeti és fenntarthatósági továbbképzés elterjesztése, amely által a dolgozók is átformálhatnák a már kialakult gondolkodásmódjukat, és akár új (zöldebb, olcsóbb) megoldásokat is felfedezhetnének, később beépítve ezeket a mindennapjaikba. 14-16 éves korban már szellemileg és érzelmileg is nagyon fogékonyak a környezeti gondokra a fiatalok. Ekkor kezdik átlátni a világot, érzékelik és értik a fonák helyzeteket, érzelmileg és értelmileg is nagyon nyitottak [3].
Fontos, hogy a környezeti nevelés a környezetvédelem-gazdaság-társadalom viszonyrendszerében készítse fel a gyermeket az összefüggések és sokszor, sajnos, az egymást gátoló célrendszerek felismerésére, ebben a korlátozott döntési térben pedig a legoptimálisabb és etikus döntések meghozatalára (például növekedés és munkahelyteremtés kontra környezetszennyezés viszonya). A környezeti nevelés azáltal válik teljessé (holisztikussá), hogy kiterjed a mentálhigiéniás egészség területére, a pszichés egyensúly és harmónia létrejöttének nevelési lehetőségeire. A környezeti nevelés a jövőre irányul, a jövő kihívásaira való felkészítés a jelen nehéz körülményei között [4].

A környezeti nevelés céljai, feladatai (a teljesség igénye nélkül):

-ismeretterjesztés (természet, földrajz, élővilág, biológia);

-készségalakítás és képességfejlesztés (harmóniára való törekvés, problémamegoldó gondolkodás, döntés képesség fejlesztése);

- tudatformálás (ökológiai szemlélet és szépérzék, holisztikus szemléletmód);

- értékközvetítés (legfontosabb elve, hogy a következő generációk számára is csodálatos hely maradjon a Föld).

\section{Hiányosságok az elemi oktatásban}

Magyarországon a környezeti nevelés egy olyan téma, amely folyamatosan foglalkoztatja a magyar pedagógusokat és a szerveződés honlapján ofi.hu - a mai napig folyamatosan friss kutatások kerülnek fel a téma nemzetközi és magyar vonatkozásában. Ezek kiterjednek az új alkalmazható módszerekre és ezek hatékonyságára egyaránt. A magyar környezeti nevelés egyik legnagyobb hiányosságai közé tartozik, hogy a megelőzés nem kap kellően nagy hangsúlyt az oktatásban. A témának magyar pedagóguskörökben egy elég konzervatív értelmezése van elterjedve, ami a hagyományos módszerekre korlátozódik, mint például a szelektív hulladékgyűjtés vagy a kreatív újrahasznosítás. Ezenkívül a „környezet” kifejezést sokszor korlátozzuk a természetben található környezetre, míg a városi környezet szóba sem kerül. A magyar oktatási rendszer egyik legnagyobb hibája, hogy az oktatás egy 45 percre szabdalt mintát követ, és így elsikkadhatnak a fontos összefüggések. A rendszerszemlélet nélkül pedig nemcsak a környezeti nevelés elveinek átültetése, hanem más dolgok oktatása is nehezebbé válik. Hazánkban is nagy számban találhatóak már a kisóvodásokat is környezettudatos nevelésben részesítő öko- és zöldóvodák és általános iskolák, 
továbbá a környezettudatos nevelésnek komoly pedagógiai eszköztára és szakirodalma jött létre. Ezek közé tartozik a szociálpszichológusok, cselekvéspedagógusok, frontális oktatásban résztvevők kompetenciái, tudásbázisa. Az Ökoiskola-program jó dolog, viszont ez azt is jelenti, hogy a környezettudatosság még mindig egy olyan dolognak minősül, amelyet nem érez minden oktatási intézmény magáénak. A másik hangsúlyosabb probléma a megközelítésben rejlik. A gyermekek elsősorban a problémákkal találkoznak, amelyek már régen túl nőttek rajtuk - például a globális felmelegedés -, ráadásul azokat nem ők okozták, hanem az előző generációk. Fontosabb lenne arra rámutatni, hogy mit tehetnek ők a környezetükért. Ezekre a hiányosságokra kínál megoldást több program és szakképzés is, amelyek a pedagógusok környezeti neveléssel kapcsolatos ismereteit célozzák. Ezek nagy része költségekkel jár, mert független akkreditált egyesületek szervezik azokat. Állami intézményekben is fellelhető néhány hasonló továbbképzés. Szintén az elemi oktatás hiányosságainak rovására írhatók a későbbi fejlődés során kialakult ún. észlelési hibák, hiszen az oktatás kezdeti szakasza nagy részben befolyásolja a közép- és felsőoktatásban a tanulási mechanizmusokat.

\subsection{A környezettudatos magatartást érintő észlelési hibák}

Érdekes megfigyelni, hogy a környezettudatos tevékenységben, a döntéshozatalban mennyire jelen vannak és kézzelfoghatóak a tudás és a döntés szubjektivitását igazoló észlelési hibák:

-sztereotípiák és kategorizálások - az atomerőmű és az atomenergia zöldenergia, a hibrid autó az környezetkímélő;

- Halo effektus - a kis kocsi, az keveset fogyaszt;

- negatív torzítás - a diesel üzemű gépkocsi, az mind nagyon környezetszennyező;

- projekció - a zöldszervezetek (pl. a Greenpeace) azok erőszakosak;

- szelektív érzékelés - a bálnavadászat nem érdekel, nem érint, nem jut el a tudatomig;

- okság és korreláció - a globális felmelegedésnek semmi köze az emberi tevékenységekhez, sőt, nincs is globális felmelegedés;

- okság - a környezetvédelem drága és munkahelyet veszélyeztet.

\section{4. Összegzés}

Léteznek már olyan gazdaságfejlődési modellek, amelyek képesek megőrizni a természeti erőforrásokat a következő generációk számára is. Ehhez viszont szükséges a megújuló erőforrások használata, a pazarlás nélküli fogyasztói magatartás, illetve az anyag- és energiatakarékos termelés. Ezekben a modellekben a világ nemzetei többnyire olyan formában jelennek meg, melyben a növekvő létszámú emberiség oly módon használja a rendelkezésre álló forrásokat, hogy az elérhető maradjon az elkövetkező nemzedékek számára is [5].

Olyan mértékű az emberi rombolás, hogy néhány száz éven belül a Földünk lakhatatlanná válik. Hatalmas lesz a hőség és szárazság, a levegő pedig lélegezhetetlen lesz. Hawking szerint 2600ra a bolygónk a Vénuszhoz hasonló tűzgolyóvá válik majd. Ebből is látszik, hogy egyáltalán nem elég, ha csak a környezetvédőkre, illetve az államra bízzuk a környezetet, a polgároknak is meg kell érteniük az ügy súlyosságát, és el kell kezdeniük környezettudatosan élni, nemcsak a saját, hanem gyermekeik, unokáik jövőjének biztosítására is. Ahogy a Föld népessége növekszik, úgy egyre nagyobb nyomást gyakorlunk a környezetre. Ha ez a fajta nyomás meghaladja a környezet regeneráló, illetve megújító folyamatait, komoly következményeket von maga után. Ez okból, napjainkban sokkal nagyobb figyelmet kell fordítani környezetünk védelmére, mint eddig bármikor.

„Te légy a változás, ha látni akarod a világ változását." (Mahatma Gandhi)

\section{Szakirodalomi hivatkozások}

[1] https://stq.m.wikipedia.org/wiki/Bielde:Global_ Temperature_Anomaly.svg (letöltve: 2020.03.01)

[2] Magyar Nemzet: Elsőként a világon az olasz iskolai tananyagba kerül be a klímaváltozás 2019. november 06. (letöltve: 2020.03.02)

https://magyarnemzet.hu/kulfold/elsokent-a-vilagon-az-olasz-iskolai-tananyagbakerul-be-a-klimavaltozas-7466894/

[3] Magyar Közlöny, 2003/43/II. szám. 434.o.

[4] Havas P.: A biológia tanítása és a környezeti nevelés. (letöltve: 2020.03.03)

http://korlanc.uw.hu/download/cikk4.htm

[5] Barbier E. B., Markandya A.: A New Blueprint for a Green Economy. Routledge, 2013. 


\title{
SOROSGERJESZTÉSÛ EGYENÁRAMÚ MOTOR MODELLEZÉSI ELJÁRÁSAINAK ÁTTEKINTÉSE
}

\section{REVIEW OF THE MODELLING METHODS OF SERIES WOUND DC MOTORS}

\author{
Szántó Attila, ${ }^{1}$ Szántó András, ${ }^{2}$ Sziki Gusztáv Áron ${ }^{3}$ \\ Debreceni Egyetem, Informatikai Tudományok Doktori Iskola. Debrecen, Magyarország \\ ${ }^{1}$ szanto.attila93@gmail.com \\ 2 andras.szanto.0503@gmail.com \\ ${ }^{3}$ szikig@eng.unideb.hu
}

\begin{abstract}
Thanks to technological development and ever-increasing environmental regulations, electric and hybrid vehicles are playing an increasingly important role in road transport. An important part of these vehicles is the electric motor, several different types of which are utilized in modern vehicles. One of these types is the series wound DC motor. In this publication, we review the different modelling methods of the above motor type. On the basis of the models we can perform the simulation in MATLAB/Simulink environment. We also present the technical parameters and characteristics that are needed to run the simulation, and the measurement procedure for determining them. Finally, we present the measurement system we have developed for the measurement and testing the motors.
\end{abstract}

Keywords: series wound DC motor, modelling, simulation, MATLAB/Simulink.

\section{Összefoglalás}

A technológia fejlődésének, valamint az egyre szigorodó környezetvédelmi előírásoknak köszönhetően az elektromos és hibrid járművek egyre szélesebb körben terjednek el a közúti közlekedésben. A járművek egyik fő alkotórésze a villanymotor, amelynek számos típusa létezik, és teljesít szolgálatot a modern járművekben. A jelen publikációban az elektromos járművek hajtására kifejlesztett soros gerjesztésű egyenáramú motor modellezési eljárásait tekintjük át. A modellek alapján -MATLAB/Simulink környezetben - elkészíthető a motor szimulációja. A továbbiakban bemutatjuk, hogy a szimulációs program futtatásához milyen bemenő paraméterek és karakterisztikák szükségesek, valamint ismertetjük a meghatározásukhoz alkalmazott kísérleti eljárásokat, megadva a részletes leírásukat tartalmazó irodalmi forrást. Végül bemutatjuk az általunk kifejlesztett mérőrendszert, amellyel a mérések elvégezhetők.

Kulcsszavak: soros gerjesztésü DC motor, modellezés, szimuláció, MATLAB/Simulink.

\section{Bevezetés}

Napjainkban a közúti közlekedésben egyre szélesebb körben terjednek el a különböző alternatív hajtású járművek. Ennek okai egyrészt a klímaváltozás miatt szigorodó kormányzati előírások, jogszabályok, másrészt a rohamosan fejlődő technológia. A különböző alternatív hajtások közül leginkább az elektromos és hibrid hajtások terjedtek el, köszönhetően az akkumulátorok, valamint az elektromos és hibrid rendszerek gyors fejlődésének.

Mivel a hibrid és elektromos rendszerü hajtásokban található valamilyen villanymotor, ebből adódóan az elektromos motorokkal kapcsolatos 
kutatások egyre hangsúlyosabbak. A Debreceni Egyetem Műszaki Karán a hallgatói csapatok - saját fejlesztésű és kivitelezésű járművekkel - rendszeres résztvevői alternatív hajtású járművek számára hirdetett versenyeknek (Shell ECO Marathon, MVM Futam, Pneumobil és Elektromobil versenyek). A tudatosabb tervezés és eredményesebb versenyzés érdekében Matlab/Simulink-környezetben [1] kifejlesztettünk egy járműdinamikai szimulációs programot, amely a jármű müszaki adataiból előállítja a jármű menetdinamikai függvényeit. A programot felhasználva optimalizálhatjuk a jármü, illetve a hajtáslánc műszaki jellemzőit egy adott versenyfeladathoz.

A szimulációs program fontos része a jármű hajtásláncának, ezenbelül motorjának szimulációja. Kutatásaink során a Debreceni egyetem Műszaki Karán tervezett és kivitelezett elektromos hajtású versenyautó soros gerjesztésű egyenáramú motorját modelleztük.

A modellünk alapján MATLAB/Simulink-környezetben elkészítettük a motor szimulációját [2]. Emellett a motort saját fejlesztésű mérőrendszeren teszteltük, és a teszt eredményeit összehasonlítottuk a mérési eredményekkel [2].

A szakirodalomban soros gerjesztésű egyenáramú motorra több, részben eltérő modell fellelhető. Ezek a modellek különböző műszaki adatokból, karakterisztikákból számolnak, amelyek vagy megtalálhatóak a motor katalógusában, vagy kísérleti úton kell őket meghatározni. A jelen közlemény célja, hogy áttekintse a soros gerjesztésű, egyenáramú motorokra ismert modelleket, valamint bemutassa, hogy a különböző modellek milyen műszaki adatokból, karakterisztikákból számolnak. Emellett bemutassa azokat az eljárásokat - megadva a részletes leírásukat tartalmazó irodalmi forrásokat -, amelyekkel a fenti adatok, karakterisztikák kísérleti úton meghatározhatók. Végül röviden bemutatjuk a saját, villanymotorok tesztelésére kifejlesztett mérőrendszerünket.

\section{Modellek soros gerjesztésű egyená- ramú motorra}

Az elektromos járművek hajtására alkalmazott villanymotorok közül egy a soros gerjesztésű, egyenáramú motor. A fenti motortípusnál az álló és a forgórész is tekercselt, és azok egymással sorba vannak kötve. Az álló és forgórész közötti elektromos kapcsolatot szénkefék biztosítják. A fenti motor modellezése egy elektromágneses és egy dinamikai egyenleten alapul, ezeket a továbbiakban ismertetjük.

\subsection{Elektromágneses egyenlet}

\subsubsection{Az egyenlet általános alakja}

A Kirchhoff-féle huroktörvény alapján a soros gerjesztésű egyenáramú motorra felírható az alábbi egyenlet:

$$
U=\left(R_{s}+R_{r}\right) \cdot i+\varepsilon_{s}+\varepsilon_{r}+\varepsilon_{s r}+U_{k e f e}
$$

ahol

$$
\begin{aligned}
& \text { U - a motor tápfeszültsége, } \\
& R_{s} \text { és } R_{r}-\text { az álló és forgó rész tekercseinek } \\
& \text { elektromos ellenállása, } \\
& \text { i - a motoron átfolyó áram erőssége, } \\
& \varepsilon_{s} \text { és } \varepsilon_{r}-\text { az önindukció során az álló és forgó } \\
& \text { részben, } \\
& \varepsilon_{s r} \quad-\text { a kölcsönös indukció során a forgó } \\
& U_{\text {kefe }} \quad-\text { a kefefeszültség. }
\end{aligned}
$$

$\mathrm{Az} \varepsilon_{s}$ és $\varepsilon_{r}$ elektromotoros erők számítására a [3, $4,5,6,7,8,9,10]$ szakirodalmakban egységesen a következő összefüggéseket használják:

$$
\begin{aligned}
& \varepsilon_{s}=L_{s}(i) \cdot \frac{d i}{d t} \\
& \varepsilon_{r}=L_{r}(i) \cdot \frac{d i}{d t}
\end{aligned}
$$

ahol $L_{s}(i)$ és $L_{r}(i)$ az álló- és forgórész öninduktivitása.

Mint látható, általános esetben az öninduktivitás függ a tekercseken átfolyó áram erősségétől. Az Ls(i) és Lr(i) karakterisztikák kísérleti meghatározására a $[2,10]$ forrásokban találunk eljárást.

$\mathrm{Az} \varepsilon_{s r}$ elektromotoros erő számítására alapvetően két megközelítés létezik. Az egyik [2, 3, 4, 5, 6] szerint:

$$
\varepsilon_{s r}=L_{s r}(i) \cdot \omega \cdot i
$$

ahol

$$
\begin{aligned}
& L_{s r}(i) \text { - az álló és forgórész kölcsönös induktivi- } \\
& \text { tása, } \\
& \omega \quad \text { - a forgórész szögsebessége. }
\end{aligned}
$$

Az $L_{s r}(i)$ karakterisztika kísérleti meghatározására a [2, 3] forrásban találunk eljárást.

A másik megközelítésben [8, 9, 10] az elektromotoros erőt az állórész mágneses fluxusából $\left(\Psi_{s}(i)\right)$ számolják:

$$
\varepsilon_{s r}=K_{e} \cdot \Psi_{s}(i) \cdot \omega
$$

ahol $K_{e}$ konstans, amely a névleges értékekből meghatározható.

Ehhez az (1) összefüggést kell felírni a motor állandósult állapotú működésére. Állandósult állapotban teljesül, hogy: 


$$
\varepsilon_{s}=L_{s}(i) \cdot \frac{d i}{d t}=0,(6) \quad \varepsilon_{r}=L_{r}(i) \cdot \frac{d i}{d t}=0
$$

Tehát:

$$
k_{e}=\frac{U_{N}-\left(R_{S}+R_{r}\right) \cdot i_{N}-U_{k e f e}}{\Psi_{S N} \cdot \omega_{N}}
$$

A $\Psi_{s}(i)$ karakterisztika kísérleti meghatározására a [2, 3] forrásokban találunk eljárást.

\subsubsection{Lineáris és nemlineáris közelítés}

A modellezési eljárás során egyaránt alkalmazhatunk lineáris és nemlineáris közelítést. A lineáris közelítés esetén feltételezzük, hogy az álló és forgó rész mágneses fluxusa, továbbá az álló rész által a forgórészben keltett mágneses fluxus egyenesen arányos a motoron átfolyó áram erősségével:

$$
\Psi(i)=L \cdot i \Rightarrow L=\frac{\Psi(i)}{i}=\text { állandó }
$$

Azaz, ebben az esetben az álló és forgó rész öninduktivitása, valamint a kölcsönös induktivitás állandó, amelyek meghatározhatók a névleges értékekből [10].

A nemlineáris közelítés esetében két esetet különböztetnek meg. Az első esetben statikus induktivitásokat alkalmaznak, amelyeket a mágneses fluxus és áramerősség hányadosaként értelmeznek. Ebben az esetben azonban a fenti hányados, így az induktivitás nem állandó, hanem függ az áramerősségtől:

$$
L(i)=\frac{\Psi(i)}{i} \neq \text { állandó }
$$

A második esetben dinamikus induktivitásokat használnak, amelyet az alábbi összefüggés értelmez:

$$
L(i)=\frac{d \Psi(i)}{d i}
$$

Meg kell jegyezni, hogy a lineáris közelítés csak a motor állandósult állapotú működése esetén ad pontos közelítést, dinamikus esetben (például, ha a motor felpörög) elég pontatlan. Az utóbbi esetben a dinamikus induktivitások használata ajánlott, amelyekkel minden esetben megvalósítható a pontos modellezés. Itt meg kell jegyezni, hogy a pontosság tovább növelhető a Jill Atherton-modell alkalmazásával, amely a mágneses nemlinearitások mellett a vasmaggal kapcsolatos veszteségeket is figyelembe veszi.

\subsection{Dinamikai egyenlet}

A motor forgó részére felírható az alábbi mozgásegyenlet:

$$
J \cdot \frac{d \omega}{d t}=T_{e l m}-T_{\text {ter } h}-T_{\text {súrl }}
$$

ahol

$T_{e l m}$ - az elektromágneses nyomaték,

$T_{\text {terh }}$ - a terhelő nyomaték,

$T_{\text {súrl }}$ - az ellenállási nyomaték,

$J$ - a forgórész tehetetlenségi nyomatéka.

Az elektromágneses nyomaték - az állórész mágneses fluxusából - a következő összefüggéssel számítható:

$$
T_{e l m}=k_{m} \cdot \Psi_{s}(i) \cdot i \cdot \eta_{m}(i)
$$

ahol

$k_{m}$-állandó,

$\eta_{m}(i)$ - a motor hatásfoka, amely függ a motoron átfolyó áram erősségétől.

A $k_{m}$-állandó a névleges értékekből meghatározható:

$$
\begin{aligned}
& k_{m}=\frac{T_{e l m N}}{\Psi_{s N} \cdot i_{N} \cdot \eta_{m N}} \\
& T_{e l m N}=\frac{P_{N}}{\omega_{N}}
\end{aligned}
$$

A fenti összefüggésben $P_{N}$ a motor névleges teljesítménye. A $\eta_{m}(i)$ karakterisztika általában szerepel a motor katalógusában.

Az elektromágneses nyomatékot a kölcsönös induktivitás ismertében a következő összefüggéssel számíthatjuk:

$$
T_{e l m}=L_{s r}(i) \cdot i^{2}
$$

Az ellenállási nyomaték magában foglalja a csapágyak, valamint a kommutátorokon súrlódó szénkefék dinamikai ellenállását, valamint a légellenállást. Az ellenállási nyomaték számítására hagyományosan a következő összefüggést alkalmazzák:

$$
T_{\text {súrl }}=k_{f} \cdot \omega
$$

ahol $k_{f}$ állandó.

Itt meg kell jegyezni, hogy a fenti lineáris kapcsolat csak nagyobb fordulatszámok esetén ad jó közelítést. Pontosabb szimulációhoz az ellenállási nyomatékot ki kell mérni a fordulatszám függvényében. Erre a [2, 3] forrásokban található eljárás. A terhelő nyomatékot mindig a motor adott alkalmazása határozza meg. Egy jármű esetében például a jármű hajtásából adódik a terhelő nyomaték. 


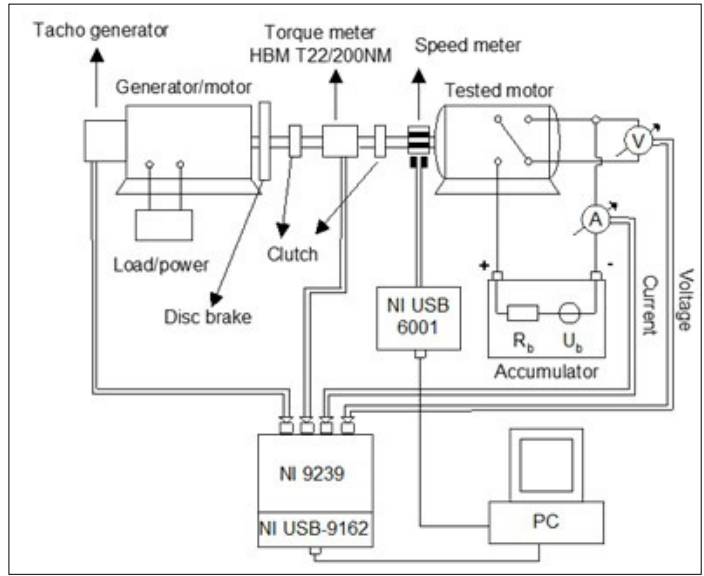

1. ábra. A mérörendszer

\section{Mérőrendszer a motoradatok és karakterisztikák kísérleti meghatáro- zásához}

$\mathrm{Az}$ 1. ábra a motoradatok és karakterisztikák méréséhez, valamint a tesztmérések elvégzéséhez kifejlesztett mérőrendszert mutatja. A mérőrendszer részletes leírását a [10] forrás tartalmazza.

\section{Következtetések}

Jelen közleményben áttekintettük a soros gerjesztésű egyenáramú motorok modellezésére a lehetséges eljárásokat. Mivel a modellek különböző motor paraméterekből épülnek fel, így eltérések lehetnek az egyes modellek alapján elkészített szimulációs programok eredményei között. A későbbiekben tervezzük megvizsgálni, hogy a modelleknél alkalmazott egyszerüsítések milyen eltéréseket okoznak a szimulációs eredmények pontosságában.

\section{Köszönetnyilvánítás}

A kutatást az „Integrált kutatói utánpótlás-képzési program az informatika és számítástudomány diszciplináris területein” (EFOP-3.6.3-VEKOP-16-2017-00002) című projekt támogatta. A projekt az Európai Unió támogatásával, az Európai Szociális Alap társfinanszírozásával valósult meg.

\section{Szakirodalmi hivatkozások}

[1] Szántó A., Sziki G. Á., Hajdú S., Gábora A., Sipos K. B.: Jármüdinamikai szimuláció és optimalizáció. In: A XXIII. Fiatal műszakiak tudományos ülésszak előadásai/Proceedings of the $23^{\text {th }}$ international scientific conference of youngth engineers, Kolozsvár/Cluj, Románia, Müszaki Tudományos Közlemények 9. (2018) 219-222.

https://doi.org/10.33894/mtk-2018.09.50

[2] Sziki G. Á., Sarvajcz K., Kiss J., Gála T., Szántó A., Gábora A., Husi G.: Experimental investigation of a series wound DC motor for modeling purpose in electric vehicles and mechatronics systems. Measurement, 109. (2017) 111-118.

https://doi.org/10.1016/j.measurement.2017.05.055

[3] Hadziselimovic M., Blaznic M., Štumberger B., Zagradišnik I.: Magnetically Nonlinear Dynamic Model of a Series Wound DC Motor. Przeglad Elektrotechniczny 87/12b. (2011) 60-64.

[4] FFarhan A. Salem: Dynamic Modeling, Simulation and Control of Electric Machines for Mechatronics Applications. International Journal of Control, Automation and Systems, 1/2. (2013).

[5] Liceaga-Castro J. U., Siller-Alcalá I. I., JaimesPonce J., Alcántara-Ramírez R.: Series DC Motor Modeling and Identification. 2017 International Conference on Control, Artificial Intelligence, Robotics \& Optimization (ICCAIRO). https://doi.org/10.1109/ICCAIRO.2017.54

[6] Záskalický P.: Modelling of a Serial Wound DC Motor Supplied by a Semi-Controlled Rectifier. Advances in Electrical and Electronic Engineering. 5/1. (2006) 110-113.

[7] Valdez Martínez J. S., Guevara Lopez P., Medel Juarez J. J.: Series Wound DC Motor Modelling and Simulation, Considering Magnetic, Mechanical and Electric Power Losses. 52 ${ }^{\text {nd }}$ IEEE International Midwest Symposium on Circuits and Systems, 2009.

https://doi.org/10.1109/MWSCAS.2009.5235954

[8] Santana J., Naredo J. L., Sandoval F., Grout I., Argueta O. J.: Simulation and construction of a speed control for a DC series motor. Mechatronics, 12/9-10. (2002) 1145-1156.

https://doi.org/10.1016/S0957-4158(02)00019-3

[9] Bitar Z., AlJabi S., Khamis I.: Modeling and Simulation of Series DC Motors in Electric Car. Energy Procedia, 50. (2014) 460-470.

https://doi.org/10.1016/j.egypro.2014.06.056

[10] Barna G.: Simulation Model of a Series DC Motor for Traction Rail Vehicles. $21^{\text {st }}$ International Conference on Methods and Models in Automation and Robotics (MMAR), 2016.

https://doi.org/10.1109/MMAR.2016.7575192 


\title{
SZERSZÁMACÉLOK FELÜLETI KOPÁSÁLLÓSÁGÁNAK NÖVELÉSE FELÜLETKEZELÉSSEL
}

\section{TOOL STEELS SURFACE WEAR RESISTANCE INCREASING BY SURFACE TREATMENT}

\author{
Tóth László, ${ }^{1}$ Nyikes Zoltán, ${ }^{2}$ Mhatre Umesh ${ }^{3}$ \\ 1,2 Óbudai Egyetem, Bánki Donát Gépész és Biztonságtechnikai Mérnöki Kar. Budapest, Magyarország, \\ toth.laszlo@bgk.uni-obuda.hu,nyikes.zoltan@phd.uni-obuda.hu \\ ${ }^{3}$ Surface Modification Technologies Pvt. Ltd. Mombai, India, umhatre.smtpl@gmail.com
}

\begin{abstract}
The industry is imposing increasing wear and tear requirements on tools, which can no longer be satisfied with the development of base materials (tool steels). Surface treatment technologies can provide a solution as the surface of the working tool must be suitable. It can determine a relationship between the hardness, surface roughness and the abrasion resistance of various surface treatments and the coating technologies such as PVD as a result of tool steel surface layers. These relationships form the basis for tool selection and provide a theoretical basis for the design of surface technologies.
\end{abstract}

Keywords: hardness, wear resistance, $P V D$ process, surface treatment.

\section{Összefoglalás}

Az ipar a szerszámokkal szemben egyre nagyobb kopásállósági követelményeket állít, mely az alapanyagok (szerszámacélok) fejlesztésével már nem elégíthető ki. A felületkezelési technológiák megoldást kínálhatnak, hiszen a szerszámok dolgozó felületeinek kell megfelelőnek lenniük. Megvizsgálva a keménységet, a felületi érdességet és a különböző felületkezelések és bevonatolási technológiák, mint a PVD eredményeként létrejött szerszámacél-felületi rétegek kopásállóságát, összefüggéseket lehet feltárni. Ezen összefüggések alapját képezik a szerszámkiválasztásnak, és a felületi technológiák tervezéséhez elméleti hátteret adnak.

Kulcsszavak: keménység, kopásállóság, PVD eljárás, felületkezelés.

\section{Bevezetés}

A szerszámacélokat a velük szemben támasztott követelmény, mint a nagy keménység, szívósság, kopásállóság és egyéb meghatározó mechanikai tulajdonságaik, alapján lehet minőség szerint besorolni.

Mivel az acélok fejlesztése a korlátait feszegeti, ezért a dolgozófelület keménységének és kopásállóságának a növelése lett a cél.

A felület keménysége és kopásállósága hagyományos és modern eljárásokkal is növelhető. Különböző termokémiai eljárásokkal (nitridálás, cementálás, boridálás stb.) már régóta sikeresen növelik az acélok keménységét, kopásállóságát. Újabb fejlesztések a PVD- és CVD-technológiával történő felületkezelések, amikor a szerszám felületén vékony, kemény réteget építenek fel [1, 2]. A XIX. század végén a forgácsolási technológia fejlesztése miatt a szerszámokat nagy sebességű forgácsolási munkákhoz alkalmazták, emiatt új szerszámokra volt szükség, és kifejlesztették a gyorsacélokat. Az első gyorsacéltípus 1910-ben került nyilvántartásba, T1 jellel, melyet a Crucible Steel Co. szabadalmaztatott. Az akkori volfrámhiány miatt molibdént kezdtek alkalmazni, mellyel újabb acéltípusokat fejlesztettek ki [3, 4]. 


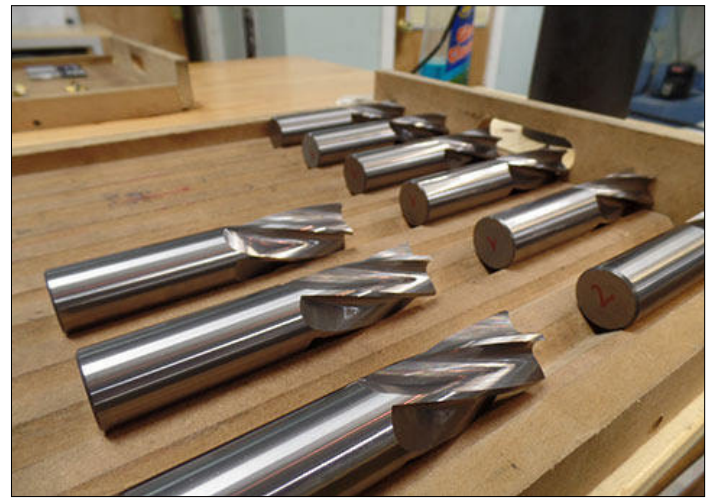

1. ábra. Bevonatolt szerszámok

A 60-as években az acélok fejlesztése, a növelt szilárdságú acélok megjelenése a piacon a szerszámanyagokkal szemben is magasabb elvárásokat támasztott. A forgácsolási követelmények teljesítésére ezért a szerszámacélok felületkezelésével válaszoltak a szerszámgyártók.

A hagyományos eljárásokat is jelentősen fejlesztették, de emellett még a bevonatolási technológiák (PVD, CVD stb.) is terjedni kezdtek. A bevonatok, a hagyományos felületkezelési eljárásokkal szemben a keménységet és kopásállóságot akár három-tízszeresére tudták növelni. Az 1. ábra PVD-bevonatolt szerszámokat mutat be.

\section{Hagyományos felületkezelési eljárások}

A felületi hőkezelések (kérgesítő eljárások) célja kemény, kopásálló felületi kéreg létrehozása az alapanyag magrésze szívósságának megtartása mellett. A hevítésnek igen gyorsan, néhány $100^{\circ} \mathrm{C} / \mathrm{s}$ sebességgel végbe kell mennie, hogy a már nemesített anyag szövetszerkezete ne módosuljon. A hagyományos felületkezelések közül a gyakorlatban a legismertebbek a felületi edzés, a betétedzés és a nitridálás [5].

\subsection{Felületi edzés}

A felületi edzés a darab hevítéséből és gyors hütéA felületi edzés a darab hevítéséből és gyors hütéséből áll. A kiinduló alapszövet a nemesítéssel létrehozott szferoidit. Ez biztosítja a mag szívósságát és szilárdságát. A kéreg keménységét és kopásállóságát pedig a martenzit adja. Martenzites átalakulásról akkor beszélünk, ha a lehűtés olyan gyors, hogy diffúzióra nincs idő, az átalakulás nem egyensúlyi. A folyamatot két ellentétes hatás befolyásolja: a túlhűtés miatt a gamma-alfa átalakulási kényszer nő, viszont a túlhűtés következtében olyan alacsony hőmérsékletet hozunk létre, amin a diffúziós átalakulás sebessége lecsökken. E két hatás eredményeképpen a gammavas rácsátbillenéssel, az atomok egyidejű együttes mozgásával változik FKK-rácsból TKK-ráccsá. Mivel azonban a TKK-rácsnak sokkal kisebb a karbonoldó képesége, az alfarácsnak egy túltelített és tetragonálissá torzult formája jön létre. Ezt hívjuk martenzitnek, ez adja a kéreg keménységét. A felületi edzés lényege tehát, hogy a hőkezelési ciklust olyan sebességgel végzik, hogy a kéregben elég idő legyen az allotrópátalakulásra és az abból való hütésre, de a munkadarab belsejének már ne legyen elég ideje az átedződésre. A felület és a mag közötti hőmérséklet-különbségekből jelentős feszültségek keletkeznek. Ezen feszültségeket $150-200^{\circ} \mathrm{C}$ közötti feszültségmentesítéssel lehet csökkenteni. A felületi edzés több módon végezhető, az eljárásokat a hevítéshez használt energiaforrások szerint csoportosíthatjuk. Eszerint létezik pl.:

- lángedzés,

- indukciós edzés,

- elektronsugaras edzés,

- lézersugaras edzés.

Lángedzéssel nagyobb kéregvastagság hozható létre (1,5-12 mm). Indukciós edzésnél a váltakozó áram frekvenciájának változtatásával szabályozható a kezelt réteg vastagsága [6, 7]. Minél nagyobb a frekvencia, annál vékonyabb réteg hevül fel, a beedzett réteg néhány tized mm-től max. 10 $\mathrm{mm}$-ig terjedhet). Indukciós hevítéssel lényegesen gyorsabban érhető el az előírt hőmérséklet a hagyományos módszerekhez képest. Más edzési eljárással szemben a legalapvetőbb különbség, hogy a hő magában a munkadarabban keletkezik az indukált örvényáramok révén [8, 9].

\subsection{Betétedzés}

A betétedzés sajátossága, hogy a kezelni kívánt alkatrész felületét karbonnal dúsítják, majd edzik. A munkadarab szívósságát az acél alacsony karbontartalma biztosítja, a kéreg keménységét pedig a diffúzióval növelt karbontartalmú réteg edzett, martenzites szövetszerkezete. A megfelelő szívósság érdekében tehát alacsony karbontartalmú, (C < 0,25\%) nem edzhető minőségeket használnak. A mag szilárdságát ötvözéssel javítják. A karbonfelületbe diffundálásának (cementálásnak) köszönhetően viszont a kéreg karbontartalma akár a szerszámacélokéval megegyező mértékűre növelhető, $(0,6 \%<C<1 \%)$ így edzhetővé válik. Ha a cementálást követően edzik a darabot, a mag az alacsony C-tartalom miatt nem tud beedződni, tehát szívós tulajdonságát megőrzi. 
A kéreg pedig a karbon- és egyéb ötvözőanyagoktól, valamint az edzéstől függően kemény, kopásálló lesz. A cementálás hőmérséklete $850-950^{\circ} \mathrm{C}$. A betétedzéssel elért kéregvastagság néhány tized mm-től kb. 2 mm-ig terjed. A betétedzés után megeresztő hőkezelésnek vetik alá a darabot, ami 180-200 ${ }^{\circ} \mathrm{C}$-on zajlik. Ezzel az eljárással 55-65 HRC felületi keménység érhető el.

\subsection{Nitridálás}

A nitridálás az acélok olyan termokémiai kezelése, amelynek célja a felület nitrogénnel történő, diffúzió általi dúsítása. A munkadarab magjának szilárdsága és szívóssága a nemesített (szferoidites) szövetszerkezetnek köszönhető. A kéreg keménységét a nitrogénnek a nitridképző ötvözőelemekkel (Al, Mo, Ti, V) létrehozott nitridvegyületei biztosítják. A nitridálhatóság tehát az ötvözőelemektől függ. Mivel nitridálással csak a felületi réteget kezeljük, a mag megfelelő szívósságát és szilárdságát még a nitridálás előtt nemesítéssel biztosítják. A nitridálást nitrogénleadó közegben (leggyakrabban ammónia) végzik. A nitrogén a felületbe diffundálva, az ötvözőkkel nitrideket képez. A nitridálási hőmérséklet kisebb, mint az acél nemesítésekor alkalmazott megeresztési hőmérséklet. Nitridálással nagyobb felületi keménység érhető el, mint betétedzéssel, (1000-1200 HV) viszont maximum 0,1-0,2 mm-es kéregvastagság érhető el $[10,11]$.

\section{Modern felületkezelési eljárások}

A gőzfázisból történő bevonatképzési módszereket alapvetően két fő csoportba oszthatjuk: fizikai gőzfázisú bevonás (Physical Vapour Deposition, vagyis PVD) és kémiai gőzfázisú bevonás (Chemical Vapour Deposition, vagyis CVD). Ezen eljárásokat soroljuk a modern bevonatolási eljárások közé [11-13].

\subsection{PVD- vagy fizikai gőzfázisú bevonatolás}

A fizikai gőzfázisú rétegleválasztás során a bevA fizikai gőzfázisú rétegleválasztás során a bevonatot képező anyagot atomos, molekuláris vagy ionos formában viszik fel a bevonandó alkatrész felületére. A bevonatot szilárd, folyékony vagy gáznemű forrásból viszik fel. A PVD-eljárások viszonylag alacsony hőmérsékleten $\left(50^{\circ} \mathrm{C} \ldots 550^{\circ} \mathrm{C}\right)$ mennek végbe. Ez azt jelenti, hogy az eljárás nem módosítja a réteg alatti hordozóanyag szövetszerkezetét, ami több szempontból is kedvező [13, 14]. Egyrészt nincs allotróp átalakulás, tehát az ebből adódó méretváltozást is elkerüljük, más-

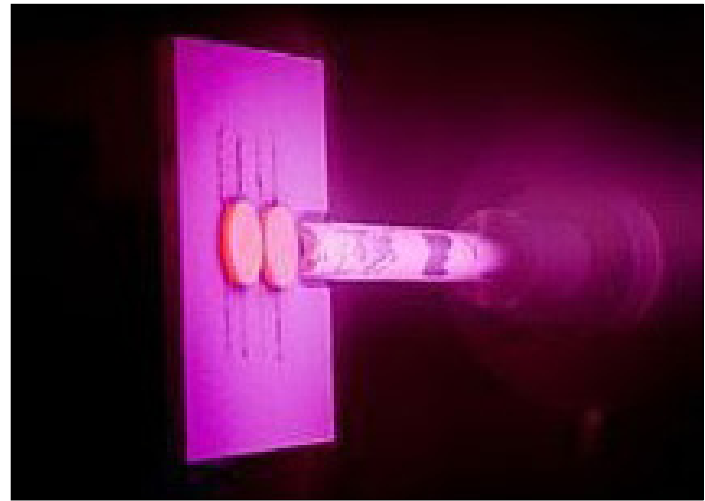

2. ábra. PVD-bevonatolás

részt tudjuk, hogy módosult szövetszerkezetben máshogy oldódnak az ötvözők és a diffúzióval bevitt bevonandó anyag. Továbbá alkalmazható edzett és megeresztett gyorsacél szerszámokon is a kilágyulás veszélye nélkül. Lehúléskor pedig több vetemedéssel és több maradó feszültséggel lehetne számolni, ami a bevonat stabilitása miatt sem előnyös és a tervezést is nehezíti.

Az elérhető keménység a felületen létrehozott réteg kémiai összetételétől függ. A 2 . ábrán a bevonatolás látható.

\subsection{CVD- vagy kémiai gőzfázisú bevonatolás}

A kémiai gőzfázisú bevonás hasonlóan sokoldalúan alkalmazható eljárás, mellyel szinte bármilyen fém és nemfémes (pl. karbon, szilícium) anyagú bevonat felvitelére lehetőség nyílik. Tehát vegyületek (nitridek, karbidok, oxidok) és sok más anyag is felvihető ezzel az eljárással. Az eljárás során két vagy több megfelelő összetételü, gázállapotú vegyületet egy reaktorkemencébe vezetnek, és termikusan, (hagyományos CVD-) vagy más módon (pl. plazmával vagy lézerrel előidézett CVD) a bevonandó tárgy felületének közelében reakcióba visznek, aminek hatására termokémiai bomlás és további reakciók játszódnak le. A keletkező reakciótermék az alkatrész felületére lecsapódva szilárd bevonatot képez, azonban itt gázfázisú melléktermék is keletkezik. Az eljárás a PVD-hez hasonlóan vákuumban történik, a hőmérséklet viszont $600-1100^{\circ} \mathrm{C}$ közötti tartományban van. A magas hőmérséklet által elősegített diffúziónak köszönhetően a CVD-eljárással egyenletes vastagságú, kis porozitású, megfelelő tapadású bevonat hozható létre, akár bonyolult alakú munkadarabon is. Amíg azonban a szinterelt karbid hordozóanyag torzulás nélkül bírja a magas hőmérsékletet, addig szerszámacélok esetében megkerülhetetlen az utólagos hőkezelés (edzés 
és megeresztés), és ezzel együtt is számolni kell bizonyos mértékű deformációval. Ezért a napjainkban zajló CVD-eljárásokhoz füződő kutatások is az alacsony hőmérsékletű eljárások kifejlesztését célozzák meg.

\section{4. Összefoglalás}

A nagy kopásnak kitett alkatrészek és szerszámok elvárt felületi keménysége és kopásállósága az ismertetett eljárásokkal, illetve ezek kombinációival valósíthatók meg. Mind a hagyományos, mind a modern felületi eljárásokat folyamatosan fejlesztik, mely tovább növelheti a kezelt munkadarabok élettartamát és hatékony alkalmazását.

\section{Köszönetnyilvánítás}

A szerzők köszönetet mondanak a támogatásért a magyar államnak és a Nemzeti Kutatási, Fejlesztési és Innovációs Hivatalnak a támogatásért a TÉT-201900093 számú projekt megvalósításában.

\section{Szakirodalmi hivatkozások}

[1] Sandvik Coromant: Forgácsolószerszám-anyagok (letöltés: 2019. október 24.)

https://www.sandvik.coromant.com/hu-hu/ knowledge/materials/pages/cutting-tool-materials.aspx

[2] Böhler S600. High Speed Steel, 2007. (Letöltés: 2020. 03. 03.)

https://www.boehler.hu/app/uploads/sites/92/ productdownloads/S600DE.pdf

[3] Böhler S600. Termékleírás. (Letöltés: 2020. 03. 03.) https://www.boehler.hu/hu/products/s600/

[4] Böhler S600, High Performance Materials for High Performance Tools. 2018. (Letöltés: 2020. 03 03.) https://www.bohler-edelstahl.com/app/uploads/ sites/92/2019/09/S000En.pdf

[5] Sebestyén A., Nagyné Halász E., Bagyinszky Gy., Bitay E.: Felületmódosítási eljárások hatása acélok kopásállóságára. XII. FMTÜ, EME, Kolozsvár, 2007. 161-169. https://doi.org/10.36243/fmtu-2007.4
[6] Bagyinszky Gy., Bitay E.: Kopásálló felületkezelt rétegek minősítése./Characterization of surface treated, wear resistant layers. XIV. FMTÜ, Kolozsvár, 2009. 13-16.

https://doi.org/10.36243/fmtu-2009.08

[7] Bitay E.: Bevonatolt gyorsacélok kopásállósága/ Coated HS steels wear resistance. XVIII. FMTÜ, EME, Kolozsvár, 2013. 73-76.

https://doi.org/10.36243/fmtu-2013.10

[8] Kovács T. A., Bitay E.: The Hardness Control in the Coated Surface Layer. Materials Science Forum, (0255-5476 1662-9752): Volume 729, (2012), pp. 415-418.

https://doi.org/10.4028/www.scientific.net/ MSF.729.415

[9] Kovács T. A.: Nano-mechanical and surface morphological properties of TiN coating produced by PVD in tool steel. Materials Science Forum, 659. (2010), 191-196.

https://doi.org/10.4028/www.scientific.net/ MSF.659.191

[10] Kovács T., Dévényi L.: Investigation of wear process by a gradient method. Materials Science Forum, 473-474. (2005), 213-218.

https://doi.org/10.4028/www.scientific.net/ MSF.473-474.213

[11] Totten G. E.: Steel Heat Treatment: Metallurgy and Technologies. CRC Press, Taylor and Francis Group, 2006 Oregon USA .

[12] Kovács-Coskun T., Bitay E.: The hardness control in the coated surface layer. Materials Science Forum, 729. (2013) 415-418.

https://doi.org/10.4028/www.scientific.net/ MSF.729.415

[13] Bagyinszki Gyula, Bitay Enikő: Felületkezelés. Műszaki Tudományos Füzetek 5., EME, Kolozsvár, 2009.

https://doi.org/10.36242/mtf-05

[14] Bitay E., Kovács T.: The effect of the laser surface treatments on the wear resistance. Materials Science Forum, 649. (2010) 107-112.

https://doi.org/10.4028/www.scientific.net/ MSF.649.107 


\title{
TANULÁSIRÁTA-MÓDSZER FULL-BATCH GRADIENS- TANULÁSRA
}

\section{A LEARNING RATE METHOD FOR FULL-BATCH GRADIENT DESCENT}

\author{
Asadi Soodabeh, ${ }^{1}$ Vogel Manfred ${ }^{2}$ \\ Institute for Data Science, University of Applied Sciences and Arts, Northwestern Switzerland \\ ${ }^{1}$ soodabeh.asadidezaki@fhnw.ch \\ 2 manfred.vogel@fhnw.ch
}

\begin{abstract}
In this paper, we present a learning rate method for gradient descent using only first order information. This method requires no manual tuning of the learning rate. We applied this method on a linear neural network built from scratch, along with the full-batch gradient descent, where we calculated the gradients for the whole dataset to perform one parameter update. We tested the method on a moderate sized dataset of housing information and compared the result with that of the Adam optimizer used with a sequential neural network model from Keras. The comparison shows that our method finds the minimum in a much fewer number of epochs than does Adam.
\end{abstract}

Keywords: machine learning, gradient descent, learning rate.

\section{Összefoglalás}

Cikkünkben egy olyan tanulásiráta-módszert mutatunk be gradienstanulásra, amely kizárólag elsőrendű információkat használ fel. Ezen módszer esetében nem szükséges a tanulási ráta manuális beállítása. Az algoritmust alkalmaztuk egy nulláról felépített lineáris neurális hálóra full-batch gradiens-módszer esetén, mikor a gradienst a teljes adathalmazra kiszámoljuk egy paraméter-aktualizálási lépésben. A módszert egy közepes méretű, szállásinformációkkal kapcsolatos adathalmazon teszteltük, a kapott eredményeket pedig összevetettük a Keras-beli Adam algoritmus által szolgáltatottakkal egy szekvenciális neurális háló esetén. Az eredmények azt mutatják, hogy az Adam algoritmushoz képest a mi módszerünk sokkal kevesebb epoch alatt megtalálja a minimumot.

Kulcsszavak: gépi tanulás, gradiens módszer, tanulási ráta.

\section{Introduction}

Machine learning methods aim at updating a set of parameters $W$ in order to optimize an objective function $f(W)$. They iteratively perform a procedure which applies changes to the parameters. Gradient Descent (GD) is one of the most popular and widely used algorithms for training machine learning models such as deep neural networks. GD attempts to optimize the objective function by following the steepest descent direction given by the negative of the gradient. There are many modifications to the GD algorithm. In fact, Keras [1] offers several other optimizers for deep learning which are actually improvements of the GD method. The GD algorithm requires the learning rate hyperparameter to be chosen. Setting the learning rate typically involves a tuning procedure. Usually, the highest possible learning rate is chosen manually. Choosing higher than this rate can cause the objective function to diverge. On the other hand, choosing it too low results in slow learning. Determining a good learning rate 
could be more of an art than a science for many problems. There have been several attempts at estimating a good learning rate at each iteration of GD. These either try to speed up learning when suitable, far from the minima, or to slow down learning near a local minima. Learning rate schedules have been proposed [2] to automatically decrease the learning rate based on how many epochs through the data have been done. These approaches typically add additional hyperparameters to control how quickly the learning rate decays. One method to accelerate the training procedure is the Momentum method [3]. This can be considered as the simplest extension to GD. Momentum strategy is based on saving the past gradient information and using it in the current iteration to update the parameters. In [4], Adagrad is introduced and significantly good results are obtained on large scale learning. The update rule in Adagrad is

$$
\Delta W^{(i)}=-\frac{\alpha}{\sqrt{\sum_{j=1}^{i} g^{(i)^{2}}}} \cdot g^{(i)}
$$

when we update the parameters as

$$
W^{(i+1)}=W^{(i)}+\Delta W^{(i)} \text {. }
$$

Here:

a - is a global learning rate,

$g(i)$ - is the gradient of the cost function with respect to the parameters.

$i$ - superindex that indicates the $i$-th iteration.

While the manually tuned global learning rate $\alpha$ appears here, each iteration has its own specific rate that grows with the inverse of the gradient magnitude. Due to the continual accumulation of squared gradients in the denominator, proportional to the inverse of the gradient, the learning rate will continue to decrease throughout training, eventually decreasing to zero and stopping training completely. In [5], with Adadelta optimizer, this deficiency was removed.

In [6], the authors proposed Adam algorithm which is based on adaptive estimates of lower-order momentums. A variant of this algorithm which is based on the infinity norm is proposed as Adamax.

Here, we propose a suitable value for the learning rate at the current iteration (epoch for the full-batch GD) which is based on estimating the scalar function of the learning rate with a parabola and choosing the minimum of the parabola as the learning rate in the current iteration. Details of our method are explained in the next section.

\section{Results}

Suppose that $X \in \mathbb{R}^{m \times n}, Y \in \mathbb{R}^{m \times 1}$ are the matrix of features and the vector of labels, respectively. We consider the cost function to be the mean squared error as

$$
f(W):=\frac{1}{m} \sum_{i=1}^{m}\left(y^{i}-\hat{y}^{i}\right)^{2}
$$

where

$y^{i}$ is the $i$-th label corresponding to $x^{i}$ the $i$-th row of features matrix $X$.

$\hat{y}^{i}=X W+b$ denotes the $i$-th predicted value, $W, b$ are the weight and the bias parameters to be optimized.

For simplicity, in the sequel, we omit $b$ and consider $W$ only. Suppose that we are in the current iteration (i). The idea of gradient descent is to step forward from the current position in the direction of the negative gradient. The step size should be chosen to reach the minimal point. Thus, the problem is to choose $\alpha$ such that

$$
h(\alpha):=f\left(W^{(i)}-\alpha \nabla f\left(W^{(i)}\right)\right),
$$

is minimal. The new approximate solution $W^{(i+1)}$ is given as:

$$
W^{(i+1)}=W^{(i)}-\alpha \nabla f\left(W^{(i)}\right) .
$$

In order to find the minimum of $h$, we should differentiate $h$ and apply some root-finding algorithms. This is often too complicated, additionally, knowing the exact minimum on the negative gradient line is not really helpful, because the optimum almost certainly does not lie on this line. Hence, it suffices to approximate $h$ by a parabola and to take the absolute minimum on this parabola as an approximation for the minimum of $h$.

Our algorithm works as follows:

- We first define $\beta_{1}=0$ and $\beta_{3}=1$, and we calculate

$$
h\left(\beta_{3}\right)=f\left(W^{(i)}-\beta_{3} \nabla f\left(W^{(i)}\right)\right) .
$$

- While $h\left(\beta_{3}\right) \geq h\left(\beta_{1}\right)=f\left(W^{(i)}\right)$, we divide $\beta_{3}$ by 2 . Note that since $\beta_{1}$ is not the minimum of $h$, there exists such a value for $\beta_{3}$.

- With $\beta_{1}=0, \beta_{3}$ and $\beta_{2}=\beta_{3} / 2$, and their corresponding function values, we can construct the parabola $P(\beta):=A \beta^{2}+B \beta+C$. The minimum $\alpha$ of $P$ in the interval $\left[\beta_{1}, \beta_{3}\right]$ is either $\alpha=-\frac{B}{2 A}$ or the boundary $\alpha=\beta_{3}$.

This gives a new approximation as the one in (4). 


\section{Implementation}

We tested our optimizer on the set of data of House Sales in King County, USA [7]. This dataset contains 21613 data points which were broken into 17384 points for train- and 4229 for validation sets. We built a linear neural network from scratch and used the above-explained idea for finding the suitable learning rate. We also used the sequential dense layers from Keras and implemented a neural network along with different optimizers from Keras. The best result was obtained for Adam. Therefore, we compared our results with those of Adam optimizer. We made our comparison in terms of the mean squared error (MSE) and the mean absolute percentage error (MAPE) defined as follows:

$$
M S E:=\frac{1}{m} \sum_{i=1}^{m}\left(y^{i}-\hat{y}^{i}\right)^{2},
$$

and

$$
M A P E:=\frac{1}{m} \sum_{i=1}^{m}\left|\frac{y^{i}-\hat{y}^{i}}{y^{i}}\right| .
$$

Figure 1 and Figure 2 illustrate how MSE and MAPE decrease over the iterations. As shown in the figures, our optimizer falls around the minimum after very few iterations while Adam does not still capture the minimum after $500 \mathrm{ep}$ ochs. After this number of epochs, our optimizer reached the MAPE error of 20.14 and 20.69 for the training and the validation sets, respectively, while Adam reached the MAPE of 39.03 and 39.76 for the training and the validation sets, respec-

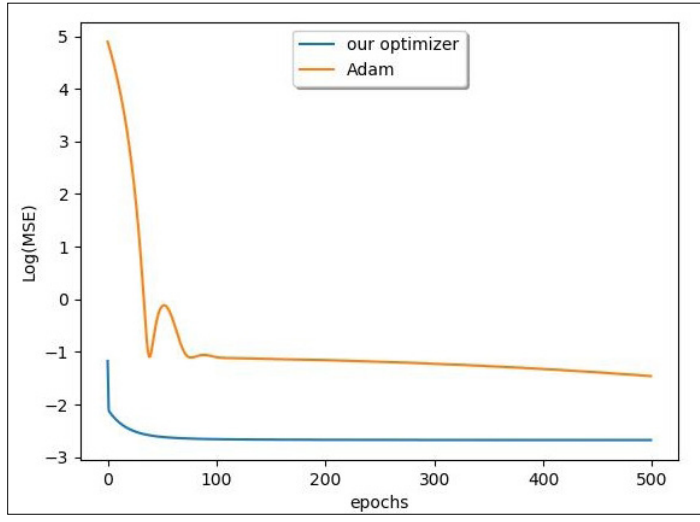

Figure 1. Logarithm of MSE over 500 epochs for the validation set. tively. The hyperparameters selected for Adam in this implementation are as follows:

- learning rate: 0.0003

- beta_1=0.9

- beta_2=0.99

- decay $=10^{-6}$

\section{Conclusions}

We presented a learning strategy for a gradient descent optimizer which estimates the scalar function of the learning rate in a typical iteration by a parabola while the parameters and the gradient with respect to the parameters are fixed. We implemented our idea on a set of housing data and compared the progress of mean squared error as well as the mean absolute percentage error with those of Adam over a certain number of epochs. This is done for a linear neural network with whole data used in the process before the parameters get updated. Under these circumstances, our idea appears to find the minimum much faster than Adam does. We have not been successful yet in obtaining satisfactory results in circumstances other than these. The idea for future work is to apply some slight modifications to enable our method to work well for any neural network and for the case of mini-batch gradient descent to fulfill the memory requirement as well.

\section{Acknowledgment}

The work of the first author is supported by the Swiss Government Excellence Scholarships grant number ESKAS-2019.0147. This author would also like to thank the support from the University of Applied Sciences and Arts, Northwestern Switzerland.

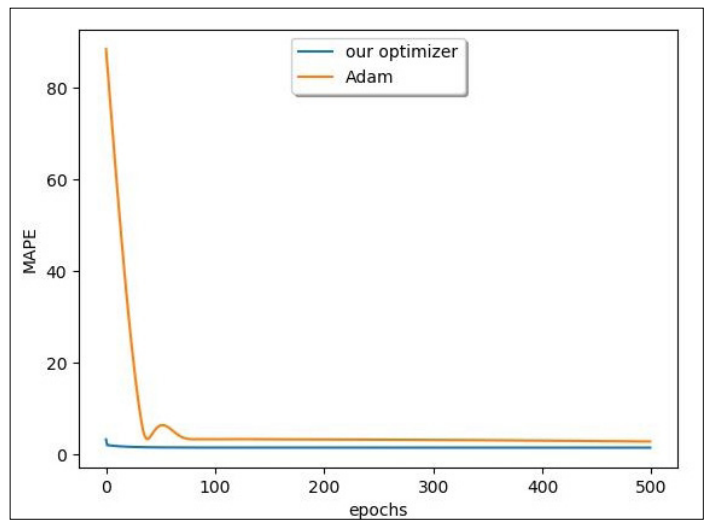

Figure 2. MAPE over 500 epochs for the validation set. 


\section{References}

[1] Keras https://keras.io/

[2] Robinds H., Monro, H.: A stochastic approximation method. Annals of Mathematical Statistics, 22. (1951) 400-407.

https://projecteuclid.org/euclid.aoms/1177729586

[3] Rumelhart D. E., Hinton G. E., Williams R. J.: Learning representations by back-propagating errors. Nature, 323. (1986) 533-536.

https://www.nature.com/articles/323533a0

[4] Duchi J., Hazan E., Singer Y.: Adaptive subgradient methods for online leaning and stochastic optimization. Journal of Machine Learning Research, 12. (2011) 2121-2159.

http://jmlr.org/papers/v12/duchi11a.html
[5] Zeiler M. D.: Adadelta: An adaptive learning rate method. arXiv preprint arXiv:1212.5701, 2012. https://arxiv.org/abs/1212.5701

[6] Kingma D., Lei Ba J.: Adam: a method for stochastic optimization. ICLR 2015. https://arxiv.org/abs/1412.6980

[7] House Sales in King County, USA: Predict house price using regression

https://www.kaggle.com/harlfoxem/housesalesprediction 


\section{SZERZŐK JEGYZÉKE LIST OF AUTHORS}

A

AGG Péter 101

ASADI Soodabeh Dezaki 174

B

BAGYINSZKI Gyula 31

BEKE Éva 36

BITAY Enikő 31

BODNÁR Ildikó 91, 114

BORSOS Ágnes 142

C

CSONGVAI Roland 40

D

DÁVID László 19

DEBRECENI Attila 45

DÉCSEI Roland 81

DUNAVÖLGYI Dávid 59

E

ERDEI Timotei István 45, 54, 81

\section{F}

FÁBIÁN Hunor 50

FARAGÓ István54

FARMOS Rudolf-László 72

FELVÁRI Bálint 59

FICZERE Péter 118

\section{G}

GALACZI László-Andor 19

GÁBORA András 63

GÉRESI Zoltán Gergő 63

GERGELY Attila Levente 50, 72

GERGELY Dezső 95, 126

GYÖRGY Katalin 19

\section{H}

HÁBER István Ervin 122

HAJDÓ Harmat 152

HARASZTI Ferenc 68

HARTYÁNYI Máté 158

HODGYAI Norbert 72

HORVÁTH Lajos 77

HRÁMCOV István 81

HRONYECZ Erika 86

HUSI Géza 45, 54, 81

I, J

IZBÉKINÉ SZABOLCSIK Andrea 91, 114

JOHANYÁK Zsolt Csaba 101, 148

K

KELEMEN Orsolya 91

KEMÉNY Alexandra 110

KIS Ádám 152

KISS Gábor József 95

KOVÁCS Márk 101

KULCSÁR Gyula 137

KUTI János 59, 105

L

LAKI Márk 105

LEVELES Borbála 110

LÓS Réka 114

LUKÁCS Norbert László 118

\section{M}

MÁDER Patrik Márk 122

MÁRTON László 126

MÁTÉ Péter 133

MHATRE Umesh 170

MIHÁLY Krisztián 137

MOLDOVAN Dorin-Vasile 152

MOLNÁR Eszter 142

MUHI Kristóf 148 
N

NAGY Andor-Csongor 152

NAGY Bianka 158

NAGY Judit

NAGY Roland 158

NOVÁK János 162

NYIKES Zoltán 170

\section{$\mathbf{O}, \mathbf{R}$}

ORBULOV Imre Norbert 110

RÁK Olivér 122

Sz

SZÁNTÓ András 166

SZÁNTÓ Attila 166

SZEBÉNYI Gábor 118
SZEKRÉNYES András 133

SZIGETI Ferenc 95, 126

SZIKI Gusztáv Áron 166

SZILÁGYI Dorottya 122

$\mathbf{T}$

TORKOS Zoltán 40

TÓTH László 170

TÓTH Szabolcs 45

V

VARGA Csilla 158

VOGEL Manfred 174

Z

ZOLNAI Sándor 54 